Universidade de São Paulo

Instituto de Biociências

JOSÉ RENATO ROSA CUSSIOL

Caracterização funcional de uma nova proteína antioxidante: Ohr (Organic Hydroperoxide Resistance Protein). Vias de redução e expressão em Xylella fastidiosa

São Paulo

2010 
Universidade de São Paulo

Instituto de Biociências

JOSÉ RENATO ROSA CUSSIOL

\section{Caracterização funcional de uma nova proteína antioxidante: Ohr (Organic Hydroperoxide Resistance Protein). Vias de redução e expressão em Xylella fastidiosa}

Tese apresentada ao Departamento de Biologia Evolutiva e Genética do Instituto de Biociências da Universidade de São Paulo para a obtenção do título de doutor em ciências na área de Biologia/Genética

Orientador: Prof. Dr. Luis Eduardo Soares Netto

São Paulo 2010 
FICHA CATALOGRÁFICA

Cussiol, José Renato Rosa

Caracterização funcional de uma nova proteína antioxidante: Ohr (Organic Hydroperoxide Resistance Protein). Vias de redução e expressão em Xylella fastidiosa

144 páginas

Tese (doutorado) - Instituto de Biociências da Universidade de São Paulo. Departamento de Genética e Biologia Evolutiva

Palavras Chave: 1. Peroxidase dependente de tiól. 2. Ohr.

3. Ácido lipóico. 4. Xylella fastidiosa 
Candidato(a): $\quad$ José Renato Rosa Cussiol

Título da tese: $\quad$ Caracterização funcional de uma nova proteína antioxidante: Ohr (Organic Hydroperoxide Resistance Protein). Vias de redução e expressão em Xylella fastidiosa

Orientador: Luis Eduardo Soares Netto

A Comissão Julgadora dos trabalhos de Defesa de Tese de Doutorado, em sessão pública realizada a considerou

\section{( ) Aprovado(a) ( )Reprovado(a)}

Examinador(a):

Assinatura:

Nome:

Instituição:

Examinador(a):

Assinatura:

Nome:

Instituição:

Examinador(a):

Assinatura:

Nome:

Instituição:

Examinador(a):

Assinatura:

Nome:

Instituição:

Presidente:

Assinatura:

Nome:

Instituição: 
Aos meus pais 


\section{Agradecimentos}

Ao Prof. Dr. Luis Eduardo Soares Netto. Pela orientação, paciência e os ensinamentos constantes, sem necessidade de hora marcada. Exemplo de cientista sério e disposto a colaborar e expandir o conhecimento para novas áreas.

Ao Dr. José Freire da Silva Neto por me ajudar em boa parte dos experimentos de regulação gênica de ohr e no cultivo de Xylella fastidiosa e à Profa Dra Marilis do Vale Marques, por me deixar utilizar as facilidades de seu laboratório de pesquisa.

Ao Dr. Luke Ignatius Szweda por disponibilizar anticorpo anti-ácido lipóico e os Profs. Drs. José Roberto Kfouri Júnior e Mariz Vainzof por ajudarem na obtenção do anticorpo anti-Ohr.

Aos Profs Drs Paolo Di Mascio e Sayuri Miyamoto por sintetizar e disponibilizar os hidroperóxidos de lipídios que utilizei em meu projeto.

À Profa Dra Gisele Monteiro. Pela amizade e pelos ensinamentos e conselhos. Por me ensinar o que é hierarquia (boa Professora!) e por contaminar a todos com a sua energia e risadas discretas!

Ao Gustavinho, pela presença constante nessa caminhada. Afinal, "amigo é que a gente seja, mas sem precisar de saber o por quê é que é".

Ao Thiago Alegria, pela constante ajuda na execução de parte dos experimentos com Ohr e pela amizade desde antes de entrar no lab.

Ao Dr. Bruno "Habib" Brasil Horta pela amizade durante esses anos de laboratório e por estar sempre de prontidão pra ajudar a todos.

Ao Prof. Dr. Marcos Antônio de Oliveira, pela colaboração nos trabalhos e pelas risadas garantidas nos congressos.

À Dra Marilene Demasi, pelos ensinamentos e orientação quando entrei no laboratório e por me deixar usar as facilidades de seu laboratório no Instituto Butantan.

Aos amigos e colegas de laboratório (Aline, Andressa, André, Daiane, Dudu, Gabriel, Gilberto, Karen, Lucas "Mica", Marcella, Marina, Rafa e Tati) e aqueles que já não estão mais (Victor "Carioca", Dani, Camila, Aninha, Rafael, Mirian, Telma, Cinthian) e à Simone Vidigal Alves pelo suporte técnico indispensável para este trabalho e para o andamento do laboratório.

Aos amigos e amigas de faculdade. Por todo esse tempo de graduação e pós-graduação. Pelas viagens, churrascos, encontros e festas. Ensino, cultura e extensão na veia!

Aos amigos de sempre: Lu, Guigo, Véio, Yuri, Rocco, Fernz, Jé, André, Junior, Vitão, Diogo, Rodrigo e muitos outros pela garantia de boas risadas a todo momento.

À família Biosal/Joga no Pagode. Pelos amigos que fiz e pelos jogos e momentos inesquecíveis que passamos.

Ao meu primo Túlio, pela ajuda na formatação da tese, pela amizade de uma vida inteira e pelas "moda de viola" que a gente insiste em tentar tocar.

Aos meus tios Isaura e Jorge e a minha prima Ana Paula, por me hospedarem e me acolherem em sua casa antes e durante o começo da escrita da tese.

À minha centagenária avó, que aparentemente tem um excelente sistema de defesa antioxidante. 
Aos meus pais, José Roberto e Sonia, pois foi através de seus esforços que cheguei até esse momento e a minha irmã Ana Júlia, pelo imenso carinho que demonstra por mim, mesmo implicando tanto por eu ser bagunceiro. Amo vocês.

À toda a "parentaia".

"Existe uma teoria que diz que, se um dia alguém descobrir exatamente pra que serve o Universo e por que ele está aqui, ele desaparecerá instantaneamente e será substituído por algo ainda mais estranho e inexplicável.

Existe uma segunda teoria que diz que isso já aconteceu."

Douglas Adams, em "O Restaurante no Fim do Universo", Ed. Sextante, 2004, p. 7. 



\section{RESUMO}

Xylella fastidiosa é uma bactéria gram-negativa, colonizadora do xilema de plantas economicamente importantes, sendo responsável por diversas patogenias como a doença de Pierce em videiras e a clorose variegada dos citros (CVC). Plantas, ao serem infectadas por patógenos, dispõem de um maquinário de defesa que inclui a geração de espécies reativas de oxigênio (ROS). Peróxidos de lipídios podem ser formados pelo ataque de ROS à membrana bacteriana ou pela ação de lipoxigenases. O sistema da AhpR (alquil hidroperóxido redutase) foi inicialmente caracterizado como o principal responsável pela defesa contra hidroperóxidos orgânicos em bactéria. Recentemente, foi descrito um gene em muitas bactérias patógenas no qual a sua deleção conferia a célula uma maior susceptibilidade a hidroperóxidos orgânicos, mas não a $\mathrm{H}_{2} \mathrm{O}_{2}$ ou a geradores de superóxido (Mongkolsuk et al., 1998 e Ochsner et al., 2001). Por esta razão, este gene foi denominado ohr (organic hydroperoxide resistance gene). O objetivo desse trabalho foi caracterizar funcionalmente a proteína Ohr de $X$. fastidiosa. Inicialmente, demonstramos que Ohr possui atividade peroxidase dependente de tiól sendo que sua capacidade de reagir com hidroperóxidos é devida á presença de um par de cisteínas conservadas em seu sítio ativo. Também mostramos que Ohr possui um enovelamento alfa/beta único, não observado nas estruturas de outras peroxidases dependentes de tiól como peroxirredoxinas e glutationa peroxidases. Análises do sítio ativo de Ohr mostraram que seus prováveis substratos são moléculas hidrofóbicas e alongadas. Corroborando esta hipótese, demonstramos que enzimas lipoiladas, classicamente relacionadas com o metabolismo intermediário, interagem física e funcionalmente com Ohr, enquanto que os sistemas tiorredoxina e glutationa, classicamente relacionados a tióis peroxidases, não sustentam a atividade peroxidásica de Ohr. Este resultado representa a primeira descrição de uma peroxidase que é diretamente reduzida por grupos lipóicos de enzimas. Também fornecemos evidências que indicam que Ohr atua na redução de hidroperóxidos derivados de ácidos graxos insaturados. De fato, 
análise cinética de estado estacionário por bi substrato mostra que Ohr decompõem hidroperóxidos orgânicos com alta eficiência $\left(k_{\text {cat }} / K_{M} \sim 10^{6} \mathrm{M}^{-1} \cdot \mathrm{s}^{-1}\right)$ através de um mecanismo ping-pong, sendo aproximadamente dez mil vezes mais eficiente do que na presença de $\mathrm{H}_{2} \mathrm{O}_{2}$. Esses dados em conjunto mostram que Ohr é central na resposta bacteriana contra o estresse induzido por hidroperóxidos orgânicos, mas não por $\mathrm{H}_{2} \mathrm{O}_{2}$ e define uma nova classe de enzimas antioxidantes com propriedade únicas: peroxidases dependentes de grupos lipóicos.

Outro objetivo desse trabalho foi estudar a via de regulação gênica de ohr em Xylella fastidiosa. Na maioria dos organismos, ohr é regulada por uma proteína repressora denominada OhrR (Sukchawalit et al., 2001), mas em algumas bactérias foi descrito que a expressão de ohr era regulada positivamente por um fator sigma alternativo $\left(\sigma^{\mathrm{E}}\right)$ de função extra citoplasmática (Gourion et al., 2008). Nossos resultados mostraram que ohr de $X$. fastidiosa não está sob controle de nenhuma dessas proteínas, sendo provavelmente expressa constitutivamente. Análises por northern blot não mostraram alterações nos níveis de ohr em células submetidas a estresse oxidativo ou etanólico. Esses resultados, ainda que preliminares, indicam que possivelmente o controle da expressão gênica de ohr em $X$. fastidiosa é distinto daqueles descritos até o momento na literatura para outras bactérias. 


\section{ABSTRACT}

Xylella fastidiosa is a gram-negative bacterium, which colonizes the xylem from economically important plants, being responsible for several diseases such as Pierce disease (PD) in gravepines and citrus variegated clorosis (CVC). Plants, when infected by pathogens, are able to defend themselves through several mechanisms which include the generation of reactive oxygen species (ROS). Lipid hydroperoxides can be generated from the attack of ROS to the bacterial membrane or by the action of lipoxygenases. The alkyl hydroperoxide reductase system (AhpR) was initially characterized as the main responsible for the detoxification of organic hydroperoxides in bacteria. Recently, it was also characterized another gene in many pathogenic bacteria, whose deletion renders cells susceptibility to organic hydroperoxide treatments but not by $\mathrm{H}_{2} \mathrm{O}_{2}$ or by superoxide generators (Mongkolsuk et al., 1998 and Ochsner et al., 2001). For this reason, it was named ohr (organic hydroperoxide resistance gene). The goal of this work was to functionally characterize Ohr, the product of ohr gene from Xylella fastidiosa. Initially, we demonstrated that Ohr possesses Cys-based thiol-dependent peroxidase activity. Later, we showed that Ohr possesses a unique alpha/beta fold not observed in the structures of other thiol peroxidases such as peroxiredoxins and glutathione peroxidases. Analyses of Ohr active site showed that its likely substrates are elongated and hydrophobic molecules. Furthermore, we showed that lipoylated enzymes, classically related with the intermediary metabolism, interacts physically and functionally with Ohr while classical thiol-dependent pathways, such as thioredoxin and glutathione, failed to support Ohr activity. This finding represents the first evidence of a peroxidase that is directly reduced by lipoyl groups of enzymes. Also, we obtained evidences indicating that Ohr acts in the detoxification of peroxides derived from unsaturated fatty acids. In fact, steady-state kinetics using bi-substrate analysis showed that Ohr decomposes organic peroxides with high efficiency $\left(k_{\text {cat }} / K_{M} \sim 10^{6} \mathrm{M}^{-1} \cdot \mathrm{s}^{-1}\right)$ through a pingpong mechanism, at least ten thousand times more efficiently than hydrogen peroxide $\left(\mathrm{H}_{2} \mathrm{O}_{2}\right)$. All these results together shows that Ohr is central in the response of bacteria to the 
stress induced by organic hydroperoxides but not by $\mathrm{H}_{2} \mathrm{O}_{2}$ and defines a new class of antioxidant enzymes with unique properties such as lipoyl-dependent peroxidase activity.

Another goal of this work was to study the regulation of ohr expression in Xylella fastidiosa. ohr expression is regulated in most bacteria by a repressor protein named OhrR (Sukchawalit et al., 2001) but, in some bacteria, ohr expression is positively regulated by an alternative sigma factor $\left(\sigma^{E}\right)$ with extracitoplasmatic function (Gourion et al., 2008). Our results showed that ohr from $X$. fastidiosa was not under the control of none of these regulators, probably being constitutively expressed. Through northern blot analysis, we did not observed any changes in ohr levels in cells submitted to oxidative or ethanolic stress. These results, indicates that ohr expression probably differs from that previously described on literature for other bacteria. 


\section{Lista de Figuras}

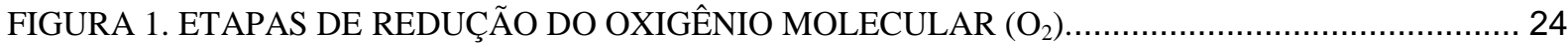

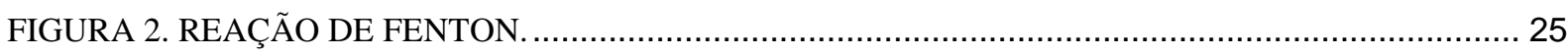

FIGURA 3. PROPAGAÇÃO DA PEROXIDAÇÃO LIPÍDICA........................................................... 27

FIGURA 4. FORMAÇÃO DE RADICAL ALCOXIL NA PRESENÇA DE ÍONS FERRO. .......................... 27

FIGURA 5. REAÇÃO DE REDUÇÃO DE PERÓXIDOS CATALISADA POR TIÓIS PEROXIDASES. ....... 33

FIGURA 6. INDUÇÃO DA EXPRESSÃO DE $O H R$ NA PRESENÇA DE ROS ........................................ 39

FIGURA 7. INDUÇÃO DA EXPRESSÃO DE OHR E AHPC POR NORTHERN BLOT EM XANTHOMONAS

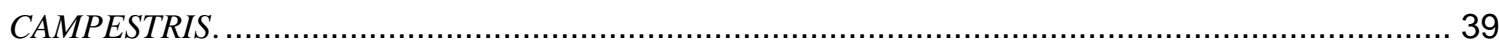

FIGURA 8. ESTRUTURA DE OHRR COMPLEXADA A REGIÃO OPERADORA DE OHRA EM BACILLUS

SUBTILLIS. ……

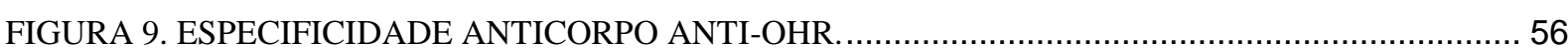

FIGURA 10. DOMÍNIOS DA PROTEÍNA OHR NO QUAL ESTÃO PRESENTES AS CISTEÍNAS

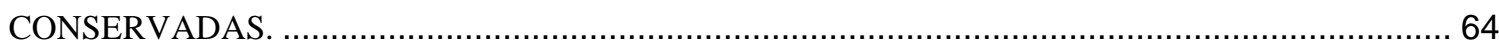

FIGURA 11. ATIVIDADE PEROXIDÁSICA DEPENDENTE DE TIÓL DE OHR....................................... 65

FIGURA 12. ESPECIFICIDADE DE TIÓL DA ATIVIDADE PEROXIDÁSICA DE OHR. ......................... 66

FIGURA 13. FORMAÇÃO DE ÁCIDO SULFÊNICO EM OHR C125S................................................... 66

FIGURA 14. ANÁLISES POR SDS-PAGE NÃO REDUTOR DA MIGRAÇÃO DE OHR RECOMBINANTE

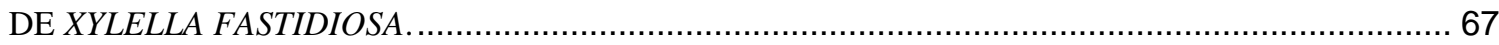

FIGURA 15. ANÁLISE DOS INTERMEDIÁRIOS DO CICLO CATALÍTICO DE OHR.............................. 68

FIGURA 16. ESTRUTURA TRIDIMENSIONAL DO HOMODÍMERO DE OHR DE XYLELLA FASTIDIOSA.

69

FIGURA 17. INTERAÇÕES POLARES ENTRE AMINOÁCIDOS DO SÍTIO ATIVO DE OHR DE XYLELLA

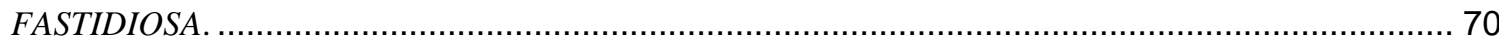

FIGURA 18. MECANISMO PROPOSTO DO CICLO CATALÍTICO DE OHR NA REDUÇÃO DE

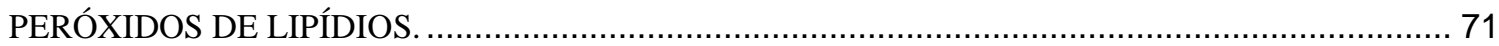

FIGURA 19. FLUXO DE ELÉTRONS NO SISTEMA LIPOAMIDA HETERÓLOGO................................. 72

FIGURA 20. PRESENÇA DE LPD RECOMBINANTE EM CORPO DE INCLUSÃO................................... 74

FIGURA 21. PURIFICAÇÃO DE LPD RECOMBINANTE DE CORPOS DE INCLUSÃO........................... 75

FIGURA 22. PURIFICAÇÃO DE LPD SOLÚVEL EM LINHAGEM AD494(DE3)................................... 76

FIGURA 23. PURIFICAÇÃO DE LPDA SOLÚVEL EM LINHAGEM AD494(DE3) .................................. 76

FIGURA 24. PURIFICAÇÃO DE SUCB SOLÚVEL EM LINHAGEM BL21(DE3). ................................. 77

FIGURA 25. PURIFICAÇÃO DE PDHB SOLÚVEL EM LINHAGEM AD494(DE3) .................................. 78

FIGURA 26. PURIFICAÇÃO DE TRXR SOLÚVEL EM LINHAGEM BL21(DE3) ................................. 79

FIGURA 27. PURIFICAÇÃO DE TSNC SOLÚVEL EM LINHAGEM AD494(DE3). ................................ 80

FIGURA 28. COMPARAÇÃO DA ATIVIDADE DISSULFETO REDUTASE DE LPD WT BOVINA E MUTANTE DE $X$. FASTIDIOSA 
FIGURA 29. TRIAGEM DE MUTAÇÕES NA SEQÜÊNCIA DE LPD RECOMBINANTE DE XYLELLA FASTIDIOSA.

FIGURA 30. AUSÊNCIA DE MUTAÇÃO NA SEQÜÊNCIA DA NOVA LPD RECOMBINANTE DE XYLELLA FASTIDIOSA 82

FIGURA 31. COMPARAÇÃO DA ATIVIDADE PEROXIDÁSICA DE OHR DEPENDENTE DE LIPOAMIDA NA PRESENÇA DE LPD BOVINA E DE X. FASTIDIOSA. 84

FIGURA 32. COMPARAÇÃO DA ATIVIDADE PEROXIDÁSICA DEPENDENTE DE LIPOAMIDA ENTRE OHR E PEROXIRREDOXINAS. 85

FIGURA 33. PLOTES DE LINEWEAVER-BURK DA ATIVIDADE PEROXIDÁSICA DE OHR DEPENDENTE DE LIPOAMIDA. 86

FIGURA 34. REPRESENTAÇÃO ESQUEMÁTICA DO MECANISMO CATALÍTICO DE OHR (BI BI PING PONG).

FIGURA 35. ATIVIDADE PEROXIDÁSICA DE OHR E A ESPECIFICIDADE POR SUBSTRATO 87 FIGURA 36. OBTENÇÃO DOS PLOTES SECUNDÁRIOS PARA CÁLCULO DOS PARÂMETROS ENZIMÁTICOS DE OHR 88

FIGURA 37. ATIVIDADE DISSULFETO REDUTASE DAS ENZIMAS LIPOILADAS. 89

FIGURA 38. ENZIMAS RECOMBINANTES LIPOILADAS DE $X$. FASTIDIOSA SUPORTAM A ATIVIDADE DE OHR. 90

FIGURA 39. CINÉTICA ENZIMÁTICA PARA OHR NA PRESENÇA DE ENZIMAS LIPOILADAS......... 91 FIGURA 40. DEPENDÊNCIA DA ATIVIDADE DE OHR EM CONCENTRAÇÕES DE LPDA.................. 92 FIGURA 41. ATIVIDADE PEROXIDÁSICA DE OHR EM CONCENTRAÇÕES CRESCENTE DE LPD. .. 93 FIGURA 42. ATIVIDADE DISSULFETO REDUTASE DO SISTEMA TIORREDOXINA DE $X$.

FASTIDIOSA. 94

FIGURA 43. ATIVIDADE PEROXIDÁSICA DE OHR E PRXQ NO SISTEMA TIORREDOXINA DE $X$.

FASTIDIOSA. 94

FIGURA 44. OHR CO-IMUNOPRECIPITA COM ENZIMAS LIPOILADAS EM XYLELLA FASTIDIOSA. . 95 FIGURA 45. IMUNODETECÇÃO DE ENZIMAS LIPOILADAS EM XYLELLA FASTIDIOSA. 96 FIGURA 46. DETECÇÃO DE OHR E ENZIMAS LIPOILADA NAS FRAÇÕES INTRA E EXTRACELULAR 97

FIGURA 47. HABILIDADE DOS IMUNODEPLETADOS DE E. COLI (EC) E X. FASTIDIOSA (XF) DE SUPORTAR A ATIVIDADE DE OHR 98

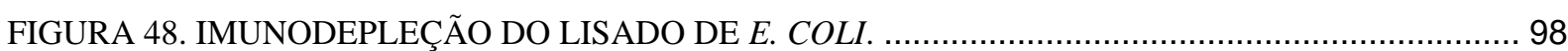
FIGURA 49. CINÉTICA ENZIMÁTICA PARA OSMC RECOMBINANTE DE E. COLI. .99 FIGURA 50. ATIVIDADE COMPARADA DE OHR E OSMC NA PRESENÇA DE ENZIMA LIPOILADAS DE X. FASTIDIOSA. 101

FIGURA 51. REDUÇÃO DE PERÓXIDO LINOLÉICO POR OHR. 102 FIGURA 52. ATIVIDADE DE REDUÇÃO DE HIDROPERÓXIDO DE ÁCIDO OLÉICO NO SISTEMA LIPOAMIDA 103

FIGURA 53. PURIFICAÇÃO DE MUTANTES DE OHR RECOMBINANTE EM GEL SDS-PAGE REDUTOR 
FIGURA 54. ATIVIDADE PEROXIDÁSICA DE OHR WT E MUTANTES NO SISTEMA LIPOAMIDA. 104 FIGURA 55. IONIZAÇÃO DO GRUPO TIÓL DA CYS 61 DE OHR. ................................................... 106

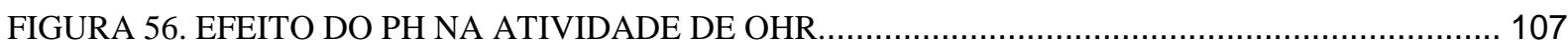

FIGURA 57. IONIZAÇÃO DO GRUPO TIÓL DA CYS 61 DE OHR.................................................... 108

FIGURA 58. WESTERN BLOT UTILIZANDO ANTICORPO ANTI-OHR........................................... 109

FIGURA 59. WESTERN BLOT UTILIZANDO ANTICORPO ANTI-OHR......................................... 110

FIGURA 60. EXPRESSÃO DE OHR EM LINHAGEM WT E MUTANTES DE XYLELLA FASTIDIOSA ... 111

FIGURA 61. ANÁLISE POR ELETROFORESE DE RNA TOTAL DE XYLELLA FASTIDIOSA ................ 112

FIGURA 62. EXPERIMENTO CONTROLE DA EXPRESSÃO DE RRNA 16S EM XYLELLA FASTIDIOSA.

FIGURA 63. EXPERIMENTO CONTROLE DA EXPRESSÃO DE $O H R$ EM LINHAGEM BL21(DE3) DE $E$.

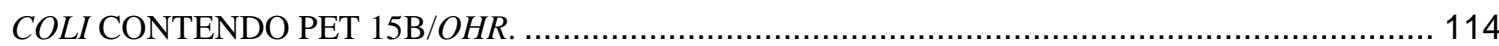

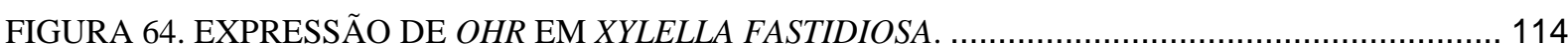

FIGURA 65. NÍVEIS DE OHR EM XYLELLA FASTIDIOSA APÓS TRATAMENTOS POR UMA SEMANA.

FIGURA 66. ESQUEMA PROPOSTO PARA A VIA DE REDUÇÃO DE OHR.............................. 120

FIGURA 67. INTERAÇÕES HIDROFÓBICAS DE RESÍDUOS DO SÍTIO ATIVO COM UMA MOLÉCULA DE PEG

FIGURA 68. ALINHAMENTO DE AMINOÁCIDOS DA PROTEÍNA OHR DE DIFERENTES BACTÉRIAS.

FIGURA 69. INTERAÇÃO E POSIÇÃO DE AMINOÁCIDOS DE X. FASTIDIOSA E P. AERUGINOSA COM

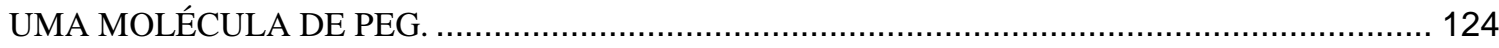

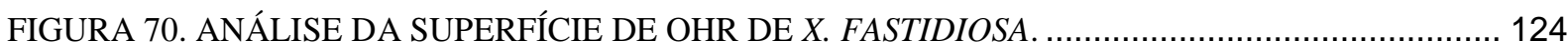

FIGURA 71. COMPARAÇÃO DO MECANISMO DE ESTABILIZAÇÃO DO TIOLATO ENTRE OHR E

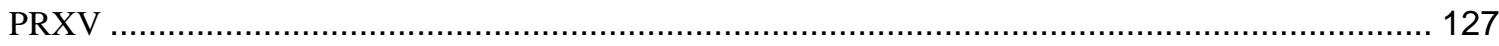

FIGURA 72. COMPARAÇÃO DAS ESTRUTURAS QUATERNÁRIAS DE TIÓIS PEROXIDASES.......... 128

FIGURA 73. ANÁLISE COMPARATIVA DA SUPERFÍCIE PROTÉICA DE TIÓIS PEROXIDASES....... 129 


\section{LISTA DE TABELAS}

TABELA 1. OLIGONUCLEOTÍDEOS UTILIZADOS PARA AMPLIFICAÇÃO DOS RESPECTIVOS

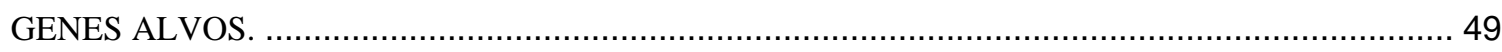

TABELA 2. CONDIÇÕES DE CLONAGEM E EXPRESSÃO DE GENES ALVOS. .................................... 50

TABELA 3. OLIGONUCLEOTÍDEOS UTILIZADOS PARA A CONSTRUÇÃO DE MUTANTES DE OHR.

TABELA 4. ANOTAÇÃO DOS GENES PERTENCENTES AOS COMPLEXOS PDH E KDH DE XYLELLA FASTIDIOSA. 73

TABELA 5. PARÂMETROS CINÉTICOS DE OHR PARA DIFERENTES SUBSTRATOS ......................... 88

TABELA 6. PARÂMETROS CINÉTICOS DE OHR PARA DIFERENTES SUBSTRATOS ........................ 92

TABELA 7. PARÂMETROS CINÉTICOS DE OSMC PARA DIFERENTES SUBSTRATOS..................... 100

TABELA 8. VALORES DE PK ${ }_{\mathrm{A}}$ DA CISTEÍNA PEROXIDÁSICA DE OHR WT E MUTANTES............. 107 


\section{LISTA DE ABREVIATURAS E SIGLAS}

\begin{tabular}{|c|c|}
\hline Ahpl & alquil hidroperóxido redutase (cTPxIII) \\
\hline AhpC & alquil hidroperóxido redutase subunidade C \\
\hline AhpF & alquil hidroperóxido redutase subunidade F \\
\hline AhpR & sistema alquil hidroperóxido redutase \\
\hline Bcp & proteína comigratória com bacterioferritina \\
\hline BSA & albumina bovina sérica \\
\hline $\mathrm{CHP}$ & hidroperóxido de cumeno \\
\hline CVC & clorose variegada dos citros \\
\hline Cys $_{p}$ & cisteína peroxidásica \\
\hline Cys & cisteína de resolução \\
\hline DHLA & ácido dihidrolipóico \\
\hline DTNB & ácido 5,5'-ditiobis(2-nitrobenzóico) \\
\hline DTT & 1,4-ditiotreitol \\
\hline Gpx & glutationa peroxidase \\
\hline Grx & glutarredoxina \\
\hline GS & glutamina sintetase \\
\hline GSH & glutationa reduzida \\
\hline GSSG & glutationa oxidada \\
\hline Hepes & ácido 4-(2-hidroxietil)piperazina-1-etano sulfônico \\
\hline HR & Resposta Hipersensitiva (Hypersensitive Response) \\
\hline $\mathrm{LAOOH}$ & hidroperóxido de ácido linoléico \\
\hline $\mathrm{LOOH}$ & hidroperóxido de lipídio \\
\hline LOX & lipoxigenase \\
\hline Lpd & dihidrolipoamida desidrogenase \\
\hline $\mathrm{NADH}$ & $\beta$-nicotinamida adenina dinucleotídeo reduzido \\
\hline NADPH & $\beta$-nicotinamida adenina dinucleotídeo 2'-fosfato reduzido \\
\hline NEM & N-etilmaleimida \\
\hline ohr & organic hydroperoxide resistance gene \\
\hline Ohr & Organic Hydroperoxide Resistance Protein \\
\hline OhrR & repressor de Ohr \\
\hline $\mathrm{OLOOH}$ & hidroperóxido de ácido oléico \\
\hline
\end{tabular}




$\begin{array}{ll}\text { osmC } & \text { osmotically inducible gene } \\ \text { OsmC } & \text { osmotically inducible protein } \\ \text { PDHB } & \text { dihidrolipoamida acetil transferase } \\ \text { PEG } & \text { polietileno glicol } \\ \text { PHGpx } & \text { glutationa peroxidase de hidroperóxido de fosfolipídio } \\ \text { PMSF } & \text { fluoreto de fenilmetilsulfonila } \\ \text { Prx } & \text { peroxirredoxina } \\ \text { PrxQ } & \text { peroxirredoxina Q } \\ \text { ROS } & \text { Espécies Reativas do Oxigênio (Reactive Oxygen Species) } \\ \text { mRNA } & \text { RNA mensageiro } \\ \text { rRNA } & \text { RNA ribossomal } \\ \text { SAR } & \text { Resistência Sistêmica Adquirida (Systemic Acquired Resistance) } \\ \text { SDS } & \text { dodecil sulfato de sódio } \\ \text { SDS-PAGE } & \text { eletroforese em gel de poliacrilamida sob condição desnaturante } \\ \text { SOD } & \text { superóxido dismutase } \\ \text { SucB } & \text { dihidrolipoamida succinil transferase } \\ t \text {-BHP } & \text { terc-butilhidroperóxido } \\ \text { TCA } & \text { ácido tricloroacético } \\ \text { Tpx } & \text { tiorredoxina peroxidase } \\ \text { Tris } & \text { tris(hidroximetil)aminometano } \\ \text { Trx } & \text { tiorredoxina } \\ \text { TrxR } & \text { tiorredoxina redutase } \\ \text { Tsa } & \text { thiol-specific antioxidant } \\ \text { WT } & \text { selvagem (wild type) } \\ \text { YBBN } & \text { tiorredoxina redutase } \\ \text { PAn } & \end{array}$




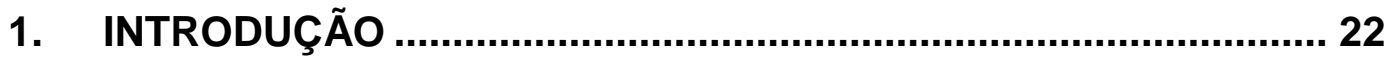

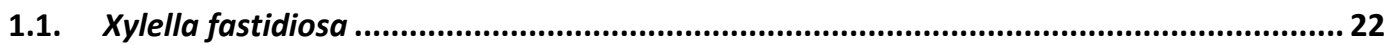

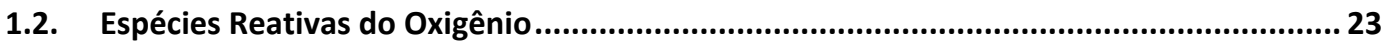

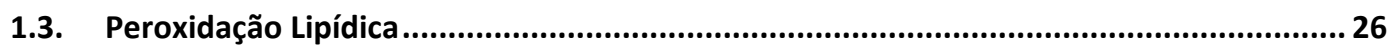

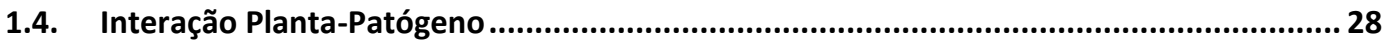

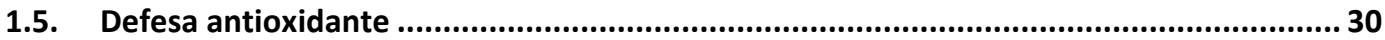

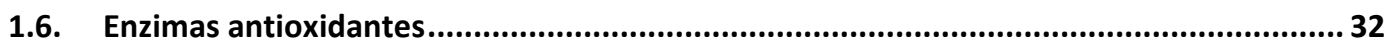

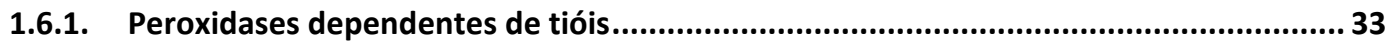

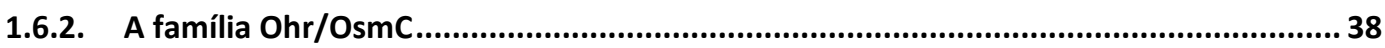

1.7. Regulação gênica modulada por mudanças REDOX em procariotos .............................. 40

1.7.1. Regulação redox de Ohr.......................................................................................... 41

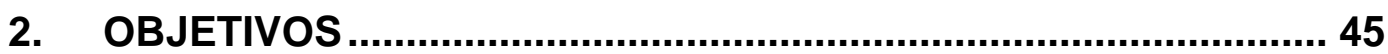

3. MATERIAIS E MÉTODOS .......................................................... 45

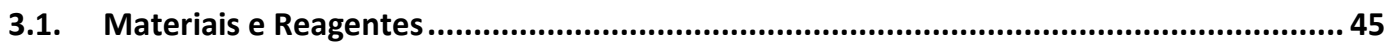

3.2. Linhagens bacterianas de clonagem e expressão .................................................. 46

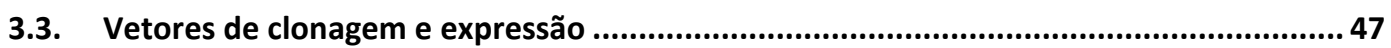

3.4. Meios e condições para cultivo de E. coli............................................................... 47

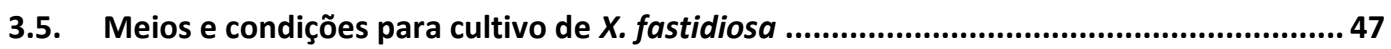

3.6. Construção de vetores de superexpressão ................................................................. 48

3.7. Transformação de bactérias eletrocompetentes por eletroporação ............................... 49

3.8. Superexpressão em $E$. coli dos genes clonados........................................................ 49 
3.9. Purificação das proteínas recombinantes por cromatografia de afinidade a metal ........ 50

3.10. Purificação de proteínas em corpos de inclusão ..................................................... 51

3.11. Mutações sítio-dirigido em Ohr de Xylella fastidiosa ...............................................52

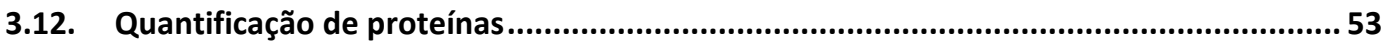

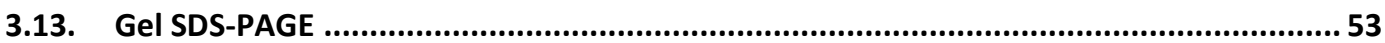

3.14. Quantificação de cisteínas livres pelo ensaio de DTNB ............................................ 53

3.15. Detecção da formação de ácido sulfênico em proteínas ........................................... 54

3.16. Redução de lipoamida por borohidreto de sódio ....................................................... 54

3.17. Solubilização de ácido lipóico pelo método do pH alcalino .........................................55

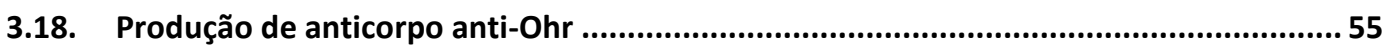

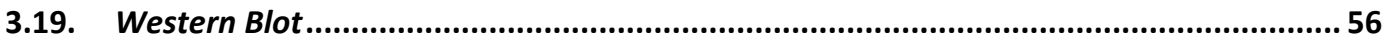

3.20. Imunoprecipitação de extrato protéico ....................................................................5

3.21. separação e detecção de proteínas da fração extracelular de xylella fastidiosa............57

3.22. Determinação da concentração de hidroperóxidos....................................................58

3.23. Ensaio FOX (Ferrous oxidation in xylenol orange assay) ...........................................58

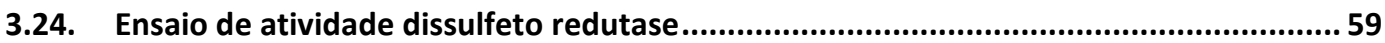

3.25. Ensaio de atividade peroxidásica da proteína Ohr pelo sistema lipoamida ...................59

3.26. Determinação do $\mathrm{pK}_{\mathrm{a}}$ de cisteínas reativas............................................................59

3.27. Preparação de RNA e Northern Bloting ...............................................................61

3.28. Marcação radioativa de DNA por oligonucleotídeos iniciadores aleatórios (Random Primed Synthesis). Obtenção de sondas

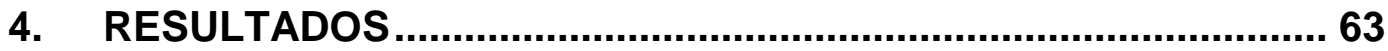

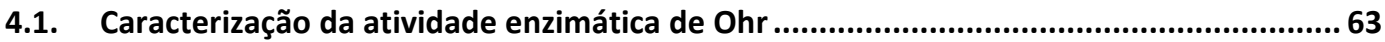


4.2. Caracterização do sistema redutor biológico de Ohr

4.2.1. Expressão e purificação de produtos de genes do metabolismo intermediário de Xylella

fastidiosa

4.2.2. Expressão e purificação de produtos de genes do sistema tiorredoxina de Xylella

fastidiosa

4.2.3. Lpd de Xylella fastidiosa sustenta a atividade peroxidásica de ohr no sistema lipoamida

4.2.4. Caracterização da atividade peroxidásica de Ohr dependente de grupos lipóicos 85

4.2.5. Ohr interage com proteínas lipoiladas in vivo 95

4.2.6. OsmC de Escherichia coli é reduzida por enzimas lipoiladas de $x$. fastidiosa. 99

4.3. Ohr é capaz de reduzir peróxidos derivados de lipídios 101

4.4. Caracterização de resíduos de aminoácidos envolvidos na catálise de ohr. 103

4.5. Regulação gênica de ohr em Xylella fastidiosa 108

5. DISCUSSÃO

6. CONCLUSÕES

7. PERSPECTIVAS

8. REFERÊNCIAS BIBLIOGRÁFICAS

9. ANEXOS 


\section{INTRODUÇÃO}

\subsection{Xylella fastidiosa}

Xylella fastidiosa é uma bactéria gram-negativa, fastidiosa, colonizadora do xilema, conhecida por causar doenças em diversas plantas monocotiledôneas e dicotiledôneas de grande importância econômica (Hopkins, 1989). A maioria dessas doenças é observada em plantas que são exóticas às Américas, enquanto várias plantas nativas são hospedeiras tolerantes, ou seja, que suportam a colonização pela bactéria não mostrando sintomas, sugerindo que $X$. fastidiosa é endêmica no continente Americano desde antes da introdução de espécies exóticas (Redak et al., 2004). As doenças causadas por este fitopatógeno incluem a doença de Pierce em videiras e a clorose variegada dos citros (CVC). A transmissão de $X$. fastidiosa é feita obrigatoriamente por insetos conhecidos popularmente como cigarrinhas ou "sharpshooter leafhoppers" (ordem Hemíptera, subordem Homóptera, família Cicadellidae, subfamília Cicadellinae). A bactéria se aloja no trato digestivo, o qual é parte do exoesqueleto do inseto composto basicamente por quitina e outros polissacarídeos derivados de quitina (Almeida et al., 2006). Aparentemente, não há especificidade entre o vetor e a cepa de $X$. fastidiosa, sendo assim, todas as espécies de vetores são capazes de transmitir todas as cepas do patógeno. A transmissão de $X$. fastidiosa do vetor para a planta é única entre os fitopatógenos, já que a bactéria pode ser transmitida sem necessitar de um período de latência no vetor. Outra característica dessa bactéria, é que ela interage com superfícies ricas em polissacarídeos de vetores e hospedeiros (Chatterjee et al., 2008). Nas plantas, Xylella fica confinada em vasos compostos de polissacarídeos como celulose e pectina. Ao contrário de outras bactérias fitopatogênicas, $X$. fastidiosa coloniza exclusivamente o xilema de plantas. Ainda não se conhece o exato mecanismo de patogenicidade das doenças causadas por $X$. fastidiosa, mas propõe-se que seja através da disfunção do sistema de condução de água ou produção de fitotoxina. A colonização do xilema da planta causa uma oclusão do vaso impedindo assim que o transporte de água ocorra naturalmente. Apesar do aumento considerável nos estudos realizados em $X$. fastidiosa, pouco se sabe ainda sobre os mecanismos de adesão, movimentação entre os vasos, translocação sistêmica e expressão dos sintomas em plantas, além do seu comportamento inseto-vetor. A doença CVC, também conhecida popularmente como amarelinho, foi primeiramente descrita em 1987 e afeta praticamente todas as variedades 
comerciais de citros. Os sintomas da doença incluem variegações (zonas de coloração) conspícuas em folhas velhas com áreas cloróticas na superfície superior e material em forma de goma na superfície inferior. Os frutos afetados são pequenos e de pouco valor comercial. A clorose variegada dos citros (CVC) tem sido considerada como a mais importante doença citrícola no Brasil, sendo o estado de São Paulo o estado de maior produção de laranja do país. Estima-se que de um total de 205 milhões de plantas no estado, aproximadamente 12 milhões estão infectadas com algum nível de sintoma de CVC (Amaro et al., 1997). As perdas anuais causadas pela doença CVC estão na ordem de US\$ 100 milhões. Como ainda não há uma forma específica de combate à Xylella fastidiosa, os citricultores devem implantar em seus pomares as estratégias de manejo da doença. Devido à importância econômica da cultura de citros para o país, o genoma dessa bactéria foi seqüenciado (Simpson et al., 2000). Através do processo de anotação gênica foi possível analisar as proteínas constituintes dessa bactéria propiciando uma importante ferramenta aos grupos de pesquisa na tentativa de elucidar os mecanismos de patogenicidade dessa bactéria.

\subsection{Espécies Reativas do Oxigênio}

Uma das primeiras hipóteses formuladas para explicar a toxicidade do oxigênio, defendia que $\mathrm{O}_{2}$ era capaz de inativar diretamente enzimas essenciais à sobrevivência dos organismos (Balentine, 1982). Entretanto, contrário a essa hipótese, sabe-se que a maior parte das enzimas em aeróbios não é afetada por $\mathrm{O}_{2}$. A hipótese mais aceita até então é de que a maioria dos danos provocados pelo $\mathrm{O}_{2}$ são devido aos seus derivados radicalares e não radicalares, comumente denominados como "Espécies reativas do oxigênio (ROS)".

As células estão continuamente sendo expostas às ROS tanto de fontes exógenas quanto de fontes endógenas. Uma das maiores fontes produtoras de ROS em eucariotos é a cadeia de transporte de elétrons mitocondrial. Normalmente, a citocromo oxidase é responsável por repassar quatro elétrons $\left(4 \mathrm{e}^{-}\right)$provenientes de quatro moléculas de citocromo c para o $\mathrm{O}_{2}$ reduzindo-o a duas moléculas de água 


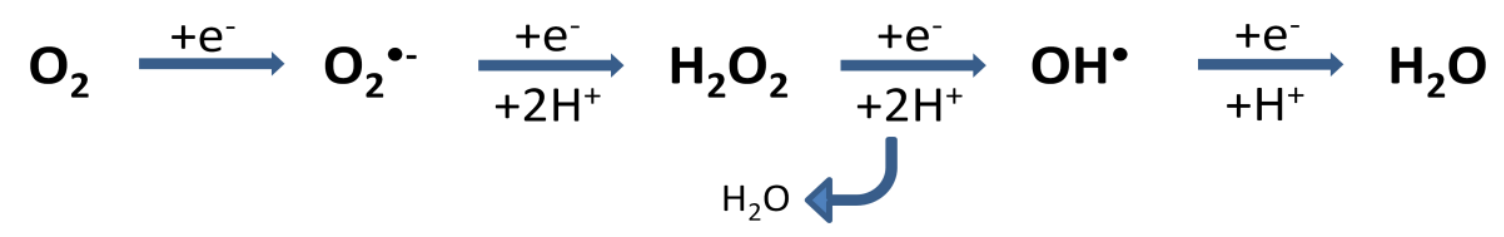

Figura 1. Etapas de redução do oxigênio molecular $\left(\mathrm{O}_{2}\right)$.

O complexo da citocromo c oxidase repassa um a um os elétrons e impede que espécies parcialmente reduzidas (ROS) escapem. Entretanto, esse vazamento pode ocorrer em uma etapa anterior em 0,1 a $0,01 \%$ das vezes, principalmente no sítio da ubiquinona gerando radical ânion superóxido $\left(\mathrm{O}_{2}{ }^{--}\right)$. Cadeias de transporte de elétrons de procariotos também são responsáveis pela formação de ROS. Dentre outros processos comumente relacionados à produção de ROS podemos incluir:

- $\quad$ radiação ionizante (UV)

- Produção por enzimas como NADPH oxidase; óxido nítrico sintetase; lipoxigenases; cicloxigenases; xantina oxidase entre outras. A produção de ROS por essas enzimas está envolvida diretamente com a sua atividade atuando em diversos processos como na defesa contra patógenos invasores de plantas e animais, resposta inflamatória, metabolismo de drogas e xenobióticos.

O balanço entre a presença de ROS e antioxidantes na célula compõe o balanço redox celular. Alterações no balanço redox com o aumento de ROS levam a eventos de sinalização que ativam genes de resposta antioxidante e de reparo. Uma alta exposição das células à ROS (estresse oxidativo) ou uma baixa presença de espécies antioxidantes pode levar a alterações críticas a constituintes da célula sendo em última instância citotóxico estando implicadas no envelhecimento celular e em uma série de patologias como câncer, doenças cardiovasculares, inflamatórias e degenerativas (Stadtman, 1990). No entanto, sabe-se que mesmo em células não expostas a condições de estresse oxidativo, ROS (como $\mathrm{H}_{2} \mathrm{O}_{2}$ e $\mathrm{NO}^{\circ}$ ) podem atuar como segundos mensageiros para receptores agonistas como fatores de crescimento e hormônios sinalizando proliferação ou mudanças metabólicas associadas a esses compostos (revisado por Winterbourne \& Hampton, 2008).

Radical hidroxila é capaz de reagir com quase todas as moléculas existentes encontradas em sua vizinhança devido ao seu alto potencial redutor $(+2.31 \mathrm{v})$, incluindo biomoléculas como DNA, proteínas e lipídios de membranas. Pode ser formado pela reação 
de Fenton (Figura 2) onde metais de transição $\left(\right.$ como $\mathrm{Fe}^{+2}$ ) são oxidados na presença de $\mathrm{H}_{2} \mathrm{O}_{2}$ ou então por reação de fissão homolítica da água promovida por luz UV. Devido a sua alta reatividade, o radical hidroxila não deve atuar como molécula sinalizadora.

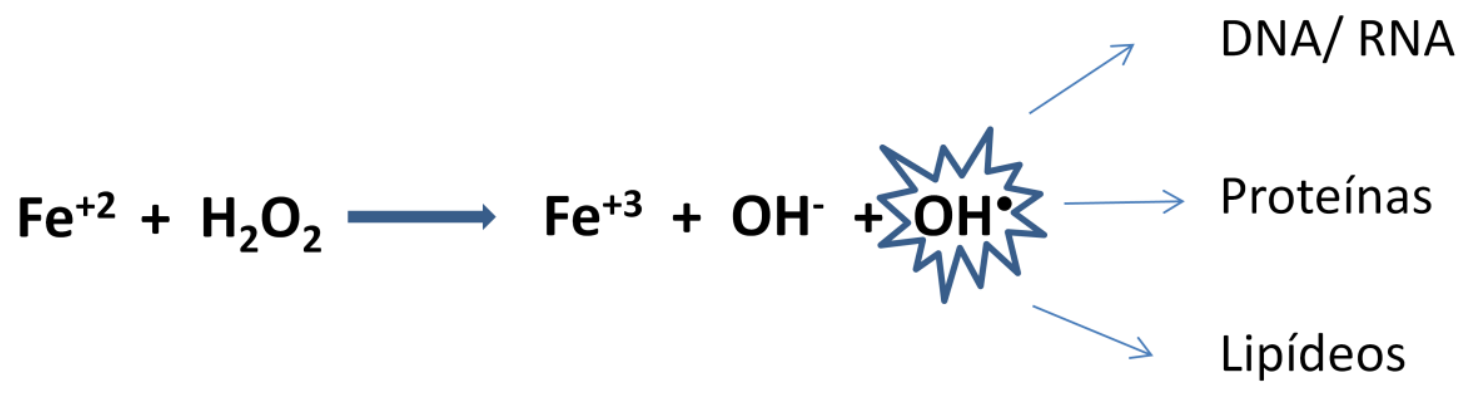

Figura 2. Reação de Fenton.

$\mathrm{O}_{2}{ }^{*-}$ é muito menos reativo que o radical hidroxila não reagindo com a maioria das moléculas biológicas em solução aquosa e pH fisiológico. No entanto, sua forma protonada, o radical hidroperóxido, além de ser mais reativo, é mais hidrofóbico que $\mathrm{O}_{2}{ }^{\bullet-}$ podendo penetrar nas membranas celulares onde pode dar início a conversão de ácidos graxos em peróxidos de lipídios muito tóxicos (Grant \& Loake, 2000). $\mathrm{O}_{2}{ }^{\bullet-}$ pode levar também a formação de peroxinitrito, uma espécie mais reativa e citotóxica, através da rápida reação de $\mathrm{O}_{2}{ }^{*-}$ com NO . Peroxinitrito é rapidamente decomposto através de isomerização a nitrato e ânion hidroxila ou, quando protonado, a radicais nitrito e hidroxila ambos mais reativos que os precursores do peroxinitrito em uma via independente de metal (Pfeiffer et al., 1997 e Coddington et al., 1999). Peroxinitrito também pode reagir rapidamente $\mathrm{com} \mathrm{CO}_{2}$ gerando uma mistura de nitrato (65\%), radical carbonato e dióxido de nitrogênio (35\%). Sabe-se que o par bicarbonato/ $\mathrm{CO}_{2}$ constitui o principal tampão fisiológico da célula estando presente em altas concentrações (na escala de milimolar). Dessa forma, radical carbonato é um oxidante com alta relevância fisiológica visto que este pode ser gerado em altas concentrações (revisado por Medinas et al., 2007).

Tanto $\mathrm{O}_{2}{ }^{\circ-}$ quanto a sua forma protonada podem ser convertidos por dismutação em $\mathrm{H}_{2} \mathrm{O}_{2}$. Essa molécula é tóxica para a maioria das células em concentrações na faixa de 10$100 \mu \mathrm{M}$. Em concentrações menores, pode atuar como molécula sinalizadora devido a sua baixa reatividade com a maioria das moléculas. Muito de seus efeitos citotóxicos observados ocorre de forma indireta. Por atravessar facilmente as membranas celulares, pode reagir com íons ferro e cobre via reação de Fenton gerando ROS mais tóxicas como radical hidroxila. Em macrófagos, $\mathrm{H}_{2} \mathrm{O}_{2}$ pode reagir com a enzima mieloperoxidase na presença de íons cloreto gerando ácido hipocloroso, um potente microbicida (revisado por Winterbourne, 
2008). Apesar de possuir um alto potencial redutor, a maioria de suas reações possui uma alta energia de ativação e são lentas. Tióis $(\mathrm{SH})$, quando presentes em sua forma desprotonada de ânion tiolato ( $\mathrm{S}^{-}$), estão entre as poucas biomoléculas capazes de reagir diretamente com $\mathrm{H}_{2} \mathrm{O}_{2}$.

Oxidação e redução de proteínas tiólicas é visto como um importante mecanismo no qual oxidantes se integram nas vias de transdução de sinal celulares. No entanto, parece haver uma hierarquia dentro da célula dentre os compostos que podem reagir diretamente com $\mathrm{H}_{2} \mathrm{O}_{2}$ levando-se em conta parâmetros cinéticos. Estudos recentes indicam que as peroxirredoxinas, uma classe de proteínas tiólicas de função peroxidásica (caracterizadas mais abaixo), provavelmente são os sensores primários de $\mathrm{H}_{2} \mathrm{O}_{2}$ na célula reagindo diretamente com essa molécula devido a sua alta reatividade e concentração. A oxidação de seu grupo tiólico facilitaria a transmissão do sinal para outras proteínas alvo menos reativas com $\mathrm{H}_{2} \mathrm{O}_{2} \mathrm{e}$, portanto, improváveis de reagir diretamente com esta molécula (revisado por Winterbourne \& Hampton, 2008).

\subsection{Peroxidação Lipídica}

Ácidos graxos insaturados são espécies que contêm ao menos uma dupla ligação em sua cadeia carbônica. São os principais alvos de peroxidação lipídica da célula por serem mais facilmente oxidados do que ácidos graxos saturados. Quanto maior o número de insaturações conjugadas no ácido graxo, maior será a sua suscetibilidade a ataques por ROS, visto que as duplas ligações enfraquecem a energia de ligação da ligação $\mathrm{C}-\mathrm{H}$. As membranas que circundam as células contêm grandes quantidades de ácidos graxos insaturados. Muitos radicais tais como hidroxila, $\mathrm{HO}_{2}{ }^{\circ}$ e radical alcoxil (RO') são capazes de oxidar esses lipídios de membrana. A iniciação da peroxidação lipídica se dá através do ataque a um lipídio que é suficientemente reativo para extrair um átomo de hidrogênio $\left(\mathrm{H}^{*}\right)$ de um lipídio insaturado ( $\mathrm{LH}$ ). O radical de lipídio centrado no carbono formado $\left(\mathrm{L}^{*}\right)$, pode reagir com $\mathrm{O}_{2}$ para formar outro radical peroxil (LOO'). Este último propaga a peroxidação lipídica abstraindo o hidrogênio de um lipídio insaturado vizinho enquanto é convertido a um hidroperóxido (LOOH) (Figura 3). 


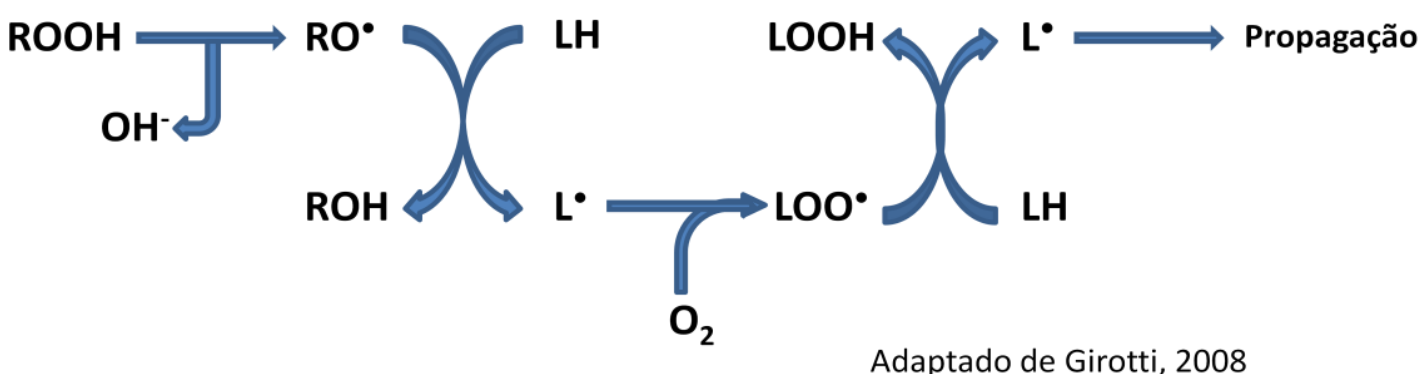

Figura 3. Propagação da peroxidação lipídica.

Hidroperóxidos de lipídios formados podem também reagir com íons de ferro ou cobre, gerando radical alcoxil de maneira semelhante à formação de radical hidroxila por $\mathrm{H}_{2} \mathrm{O}_{2}$ na reação de Fenton. $\mathrm{O}$ radical alcoxil, por sua vez, pode propagar a peroxidação lipídica para outras moléculas de ácidos graxos (Figura 4).

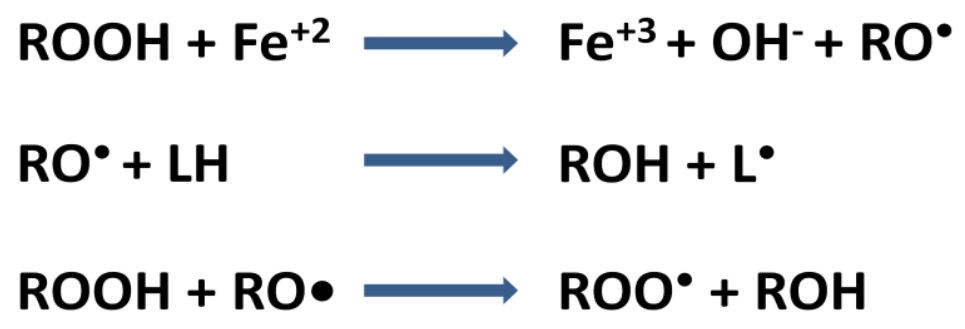

Figura 4. Formação de radical alcoxil na presença de íons ferro.

A peroxidação lipídica induzida por estresse está relacionada em muitos casos com arteriosclerose, neurodegeneração, câncer e outras desordens (Halliwell \& Gutteridge, 2007). A presença de $\mathrm{LOOH}$ em membranas altera a fluidez destas devido ao aumento em sua hidrofilicidade modificando suas propriedades físico-químicas. Na presença de agentes redutores ou íons metálicos catalíticos, hidroperóxidos de lipídios podem ser oxidados por reações de transferência de um elétron gerando radicais oxil (LO') extremamente reativos (revisado por Girotti, 2008).

Estudos demonstraram que a meia vida de hidroperóxidos de lipídios é muito maior quando comparada a precursores ou produtos de radicais livres. Essa característica em conjunto com a sua maior hidrofilicidade quando comparada a seus lipídios precursores, permite a esses peróxidos translocar rapidamente de suas membrana de origens para outros compartimentos de membrana (Vila et al., 2000). Sendo assim, hidroperóxidos de lipídios podem atuar tanto em processos de transdução de sinais como de maneira tóxica, 
podendo migrar para o núcleo das células onde o DNA genômico pode ser danificado pelos produtos radicalares desses peróxidos (Ouedraogo et al., 2003). Além da peroxidação lipídica mediada por ROS, em plantas, peroxidação de ácidos graxos pode ocorrer pela ação de lipoxigenases (LOX). Estas enzimas atuam geralmente sob ácidos graxos incorporando oxigênio molecular nas posições 9 e 13 da cadeia carbônica de ácidos graxos insaturados 18:2 e 18:3. Esses peróxidos de ácidos graxos formados podem dar origem a metabólitos secundários como oxidolipinas e ácido jasmônico importantes para o desenvolvimento da planta (Blee, 1998). Esses ácidos graxos de cadeia insaturada são gerados de fosfolipídios de membrana pela ação da enzima Fosfolipase $A_{2}$ (Gobel et al., 2001).

\subsection{Interação Planta-Patógeno}

As plantas, devido ao fato de estarem confinadas ao local onde cresceram reagem quimicamente a uma série de ameaças vindo do ambiente ao seu redor. Desta maneira, elas desenvolveram uma ampla variedade de respostas de defesa para proteção contra estresses bióticos ou abióticos. Infecções por fungos, bactérias e vírus estão entre as mais perigosas com a qual a planta tem que lidar.

Barreiras químicas e físicas pré-formadas constituem a primeira linha de defesa da planta. Dentre as estratégias empregadas pelas plantas para se defender de uma invasão temos: reforço da parede celular para impedir a entrada do patógeno, produção de fitoalexinas, proteínas microbicidas e morte celular programada limitando o estabelecimento e propagação do patógeno (revisado por Abramovitch \& Martin, 2004). A regulação espacial e temporal desses processos irá determinar o resultado da interação planta-patógeno: susceptibilidade ou resistência à doença. Em inúmeras interações não-compatíveis essas reações estão associadas com a morte de um pequeno número de células no local da infecção, conhecido como Resposta Hipersensitiva (Hypersensitive Response - HR) (Dangl et al., 1996). O desencadeamento de respostas de resistência requer o reconhecimento de moléculas sinalizadoras, produzidas tanto pelo organismo invasor como liberadas pela parede celular da planta. Essas moléculas sinalizadoras são denominadas como "elicitores", podendo ser oligossacarídeos, glicoproteínas e glicopeptídeos. Essa resistência é caracterizada pela rápida ativação do sistema de defesa da planta principalmente na superfície celular e é baseada mais na ativação de componentes pré-existentes do que no envolvimento da maquinaria biossintética da célula (Dangl et al., 1996). Dentre as respostas 
envolvidas já caracterizadas temos: aumento na permeabilidade da membrana citoplasmática, geração de ROS, mudança no potencial de membrana e no pH extracelular, fluxo iônico, mudanças no padrão de fosforilação protéica e imobilização oxidativa de proteínas da parede celular (revisado por Wojtaszek, 1997).

Uma das primeiras respostas desencadeadas durante a HR é a rápida e transiente produção de enormes quantidade de ROS no local da infecção pelo patógeno. ROS são as moléculas elicitoras mais bem estudadas na literatura e reconhecidamente responsáveis por orquestrar a HR (Levine et al., 1994). A primeira hipótese de que ROS estavam envolvidas na HR foi demonstrado em tecidos de tubérculo de batata que produziam $\mathrm{O}_{2}{ }^{*-}$ quando inoculadas com uma linhagem avirulenta de Phytophthora infestans enquanto uma linhagem virulenta não gerava a mesma produção (Doke, 1983). Estudos posteriores demonstraram que a principal enzima envolvida na produção de $\mathrm{O}_{2}{ }^{*-}$ é a NADPH oxidase (NOX) localizada na membrana plasmática em um sistema análogo ao de neutrófilos (Torres et al., 2002 e Yoshioka et al., 2003). Durante a geração de ROS, genes de defesa antioxidante da planta são inibidos aumentando assim o estresse oxidativo na área afetada levando em última instância a morte celular programada (revisado por Pitzchke et al., 2006). Peroxidases secretadas extracelularmente (POX) são outra fonte de ROS bem documentada durante a HR. A produção de ROS por essas peroxidases tem como função principal o fechamento dos estômatos, impedindo assim a entrada do patógeno por essa via (Kawano et al., 2003). $\mathrm{O}_{2}{ }^{*-}$ gerado pode ser dismutado à $\mathrm{H}_{2} \mathrm{O}_{2}$ ou gerar radical peroxil podendo levar a peroxidação lipídica. Muitos autores demonstraram que peroxidação lipídica ocorre durante HR podendo ser um dos principais eventos que levam a morte celular programada (May et al., 1996; Kenton et al., 1999).

Como visto na sessão acima a produção de peróxidos de lipídios pode acontecer por um processo não-enzimático ou enzimático devido à ação das lipoxigenases. Diferentemente de ROS, lipoxigenases abstraem o próton de insaturações específicas da cadeia carbônica de ácidos graxos insaturados. Dessa forma, foi observado que durante a HR elicitada por Xanthomonas campestris pv. malvacearum em algodão, foram encontrados peróxidos derivados de ácidos graxos gerados exclusivamente por lipoxigenases (Jalloul et al., 2002), questionando o papel das ROS como maior fonte geradora de peróxidos de lipídios. Foi ainda demonstrado que lipoxigenases têm a sua expressão aumentada durante a HR (Porta e Rocha-Sosa, 2002).

Estudos têm demonstrado que a produção de ROS pode servir não somente como uma proteção direta contra o ataque do patógeno, mas também como um sinalizador para a ativação de respostas posteriores à HR nas células infectadas (Tenhaken et al., 1995). Nessa resposta, temos o estabelecimento de uma imunidade nos tecidos sistêmicos a 
infecções secundárias denominada resistência sistêmica adquirida (SAR) (Grant \& Loake, 2000).

As plantas, por conviverem intimamente com estes produtos altamente tóxicos, dispõem de um maquinário capaz de amenizar os efeitos citotóxicos das ROS produzidas endogenamente através dos processos metabólicos ou durante a interação planta-patógeno. Os patógenos, da mesma maneira, para se defenderem dos efeitos tóxicos das ROS e de seus subprodutos, dispõem de enzimas antioxidantes capazes de ajudar o patógeno a superar a barreira oxidante imposta pela planta, possibilitando assim a infecção. Evidências mostram, por exemplo, que a ação de enzimas antioxidantes ajuda a atrasar ou prevenir HR provocada pela planta hospedeira (revisado por Mur et al., 2008).

\subsection{Defesa antioxidante}

Antioxidante pode ser definido como "qualquer substância que quando presente em concentrações menores que a de um substrato oxidável, atrasa, previne ou remove significativamente a oxidação deste" (Halliwell \& Gutteridge, 2007). Reação de remoção de ROS só é definida como protetora quando o produto da reação é menos reativo ou tóxico que a espécie inicial. Dentro dessa classificação podemos incluir:

- Substâncias que previnem a formação de ROS, diminuindo a disponibilidade de pró oxidantes como íons ferro e cobre, inibindo assim reações catalisadas por metais (reação de Fenton). Exemplos incluem quelantes de metais como a desferrosiamina e proteínas como metalotioneína e transferrina.

- Agentes que cataliticamente removem ROS como as enzimas Superóxido dismutase (SOD), catalase e tióis peroxidases.

- Agentes "sequestrantes" de ROS, isto é, capazes de reagir preferencialmente com as ROS preservando biomoléculas mais importantes. Temos como exemplos compostos de baixo peso molecular como glutationa (GSH), ascorbato (Vitamina C), a-tocoferol (Vitamina E), ácido dihidrolipóico (DHLA) e enzimas como albumina (BSA). 
- Proteínas que protegem contra as lesões oxidativas através de outros mecanismos, como chaperonas.

- Sistemas de reparo às lesões oxidativas como enzimas de reparo de DNA, proteína (metionina sulfóxido redutase) e lipídio (glutationa peroxidase) funcionando como última linha de defesa do organismo (revisado por Netto, 2001).

As definições para ROS e antioxidantes abrangem um universo de compostos, cada um com características únicas. Portanto, é inapropriado generalizar tais espécies, pois apresentam diferentes reatividades a diferentes compostos sendo que fatores termodinâmicos (a possibilidade de uma reação ocorrer) e cinéticos (a velocidade com que essa reação ocorre) entram no cômputo final (revisado por Winterbourne, 2008).

Em minha tese de doutorado, demos ênfase ao estudo do ácido lipóico e de seu derivado de amida, lipoamida, como doadores de elétrons para um sistema de defesa antioxidante envolvido na detoxificação de peróxidos orgânicos em bactérias.

Ácido lipóico e seu derivado de amida, lipoamida, são compostos redox ativos amplamente caracterizados devido a sua capacidade de servir como cofator de complexos multienzimáticos que catalisam a descarboxilação oxidativa de um a-cetoácido com a transferência do grupamento acil resultante para coenzima A com concomitante liberação de $\mathrm{CO}_{2}$. Em organismos aeróbicos, glicose e outros açúcares, ácidos graxos e a maioria dos aminoácidos são em último passo oxidados à $\mathrm{CO}_{2}$ e água no ciclo de Krebs. Antes que eles possam entrar no ciclo, os esqueletos carbônicos de açúcares e ácidos graxos devem ser degradados ao grupo acetil da acetil-CoA para entrada no ciclo de Krebs. A degradação do piruvato, derivado da glicólise, a acetil-CoA e $\mathrm{CO}_{2}$ é catalisada por um complexo enzimático composto por três enzimas denominado piruvato desidrogenase (PDH) que está localizado na mitocôndria de células eucarióticas e no citossol de procariotos. Este complexo faz parte da família multienzimática 2-oxo ácido desidrogenase que compreende também acetoglutarato desidrogenase $(\mathrm{KDH})$, pertencente ao ciclo de Krebs, e o a-cetoácido desidrogenase de cadeia lateral envolvido na degradação oxidativa de alguns aminoácidos como isoleucina, leucina e valina (revisado por Perham et al., 2002). São compostos por multímeros das subunidades E1 (piruvato/a-cetoglutarato desidrogenase), E2 (dihidrolipoamida acil transferase) e E3 (dihidrolipamida desidrogenase). A enzima E2, com atividade dihidrolipoamida acil transferase, é similar entre os complexos possuindo ao menos uma molécula de ácido lipóico covalentemente ligada a um resíduo de lisina através de uma ligação amida em seu sítio ativo. A enzima E3, com atividade dihidrolipamida 
desidrogenase, catalisa processos redox entre as enzimas E2 lipoiladas (com ácido lipóico covalentemente ligado) e NADH/NAD+ (revisado por Reed, 2001; Bunik, 2003).

Ácido lipóico livre em sua forma reduzida, ácido dihidrolipóico (DHLA), foi proposto como um seqüestrador de radicais livres e outros oxidantes. Foi visto que DHLA pode interromper a propagação em cadeia de reações radicalares iniciadas por diversas ROS (revisado por Moini et al., 2002), detoxificar peroxinitrito (Trujillo et al., 2005) e também prevenir o estresse induzido por peroxidação lipídica (Akpinar et al., 2008). Entretanto, ácido lipóico não acumula extensivamente na célula, sendo rapidamente metabolizado (Schupke et al., 2001). Como conseqüência, a disponibilidade celular de ácido lipóico livre é significantemente menor do que a de outros compostos antioxidantes de baixo peso molecular como glutationa e ascorbato que são encontrados em concentrações na faixa de milimolar. Sendo assim, tem sido questionado na literatura se DHLA livre pode funcionar como um seqüestrador de ROS in vivo.

\subsection{Enzimas antioxidantes}

Superóxido dismutase (SOD) foi uma das primeiras enzimas antioxidantes descritas. Essa enzima catalisa a reação de dismutação de $\mathrm{O}_{2}{ }^{*-}$ à $\mathrm{H}_{2} \mathrm{O}_{2}$ e $\mathrm{O}_{2}$. A descoberta de que uma enzima era capaz de remover um radical livre mostrou que estes eram importantes produtos metabólicos, pois até então eram considerados de pouca importância biológica (McCord \& Fridovich, 1969).

$\mathrm{H}_{2} \mathrm{O}_{2}$ formado por reação de dismutação, pode ser decomposto por duas classes de enzimas antioxidantes: catalases e peroxidases. Catalases catalisam a decomposição direta de $\mathrm{H}_{2} \mathrm{O}_{2}$ a $\mathrm{O}_{2}$ através de um agrupamento Heme - $\mathrm{Fe}^{+3}$ que faz parte do sítio ativo da enzima (Kirkman \& Gaetani, 1984). Peroxidases catalisam a remoção de $\mathrm{H}_{2} \mathrm{O}_{2}$ e outros peróxidos na presença de agentes redutores.

Enzimas antioxidantes, assim como outras proteínas, participam de reações redox catalisando a remoção de ROS em reações de transferência de elétrons. Para desempenhar essa função, utilizam-se de cofatores redox como NAD+, FAD, Heme, Selênio (Se), íons ferro e outros metais de transição. Em contraste, algumas proteínas utilizam aminoácidos de sua própria cadeia polipeptídica em reações de transferência de elétrons, principalmente cisteína. Cisteína é um aminoácido não essencial, hidrofóbico que tem como característica principal possuir um grupamento tiól ( $\mathrm{RSH}$ ) em sua cadeia lateral. A reatividade das cisteínas está relacionada com o $\mathrm{pK}_{\mathrm{a}}$ da sulfidrila pois sua forma desprotonada é um agente nucleófilo, capaz de participar de uma série de reações de transferência de elétrons. 
Cisteína livre possui pouca reatividade para desencadear reações redox pois seu pK $\mathrm{a}_{\mathrm{a}}$ está em torno de 8.5 (Benesch \& Benesch, 1955). O mesmo ocorre com a maioria dos resíduos de cisteínas presentes em proteínas, portanto em pH fisiológico a maior parte das sulfidrilas está na forma protonada, muito menos nucleófila do que sua forma desprotonada (ânion tiolato). Em algumas proteínas, o enovelamento protéico pode gerar regiões que favorecem a reatividade das cisteínas. Muitas proteínas envolvidas em processos redox possuem cisteínas reativas que são estabilizadas em sua forma desprotonada por um resíduo de aminoácido básico, geralmente lisina ou arginina. Cisteínas reativas estão envolvidas em uma série de reações redox como redução e formação de pontes dissulfeto, glutationilação protéica e redução de peróxidos (revisado por Netto et al., 2006 anexo III).

\subsubsection{Peroxidases dependentes de tióis}

Dentre os diversos sistemas antioxidantes conhecidos, nossos estudos estão centrados na compreensão da função biológica de uma classe de enzimas denominadas peroxidases dependente de tióis. São enzimas capazes de detoxificar diferentes peróxidos como $\mathrm{H}_{2} \mathrm{O}_{2}$ e alquil hidroperóxidos. Têm como característica, o fato de não necessitarem de cofatores e grupos prostéticos no seu ciclo catalítico. Ao invés disso, possuem um resíduo de cisteína conservado em seu sítio ativo que reage com os peróxidos detoxificando-os ao seus respectivos alcoóis (Figura 5).

\section{$2 \mathrm{R}^{1} \mathrm{SH}+\mathrm{R}^{2} \mathrm{OOH} \longrightarrow \mathrm{R}^{1} \mathrm{SSR}^{1}+\mathrm{R}^{2} \mathrm{OH}+\mathrm{H}_{2} \mathrm{O}$}

Figura 5. Reação de redução de peróxidos catalisada por tióis peroxidases.

Exemplos de peroxidases dependentes de tióis incluem as peroxirredoxinas, glutationa peroxidases e a superfamília Ohr/OsmC.

\section{Peroxirredoxinas}

As peroxirredoxinas foram descritas recentemente quando comparada a outras enzimas antioxidantes como catalase e SOD. Foi observado que extrato de $S$. cerevisiae era capaz de proteger a enzima glutamina sintetase (GS) da inativação pelo sistema 
$\mathrm{Fe}^{+3} / \mathrm{O}_{2} /$ tióis. A proteína responsável pela proteção à GS foi isolada e caracterizada como uma enzima antioxidante. (Kim et al., 1988). Devido ao fato dessa enzima somente proteger GS da inativação na presença de tióis como ditiotreitol (DTT) e glutationa (GSH) e não na presença de outros agentes redutores não-tiólicos (como ascorbato), foi denominada TSA (Thiol specific antioxidant). Estudos demonstraram que o gene codificante de TSA não apresentava homologia com nenhuma catalase, SOD ou peroxidase conhecidas (Chae et. al., 1993). Foi demonstrando que Tsa1 de S. cerevisiae era capaz de reduzir diferentes hidroperóxidos e alquilhidroperóxidos à custa de um composto tiólico, responsável por regenerar a forma oxidada dessas proteínas (Netto et al., 1996). O sistema da tiorredoxina (Trx) e tiorredoxina redutase (TrxR) foi identificado como o redutor biológico de TSA, responsável por carregar os elétrons do NADPH para a TSA oxidada. Foi observado que a atividade específica das TSA na presença do sistema Trx/TrxR/NADPH aumentava consideravelmente em comparação a outros compostos tiólicos tais como DTT e $\beta$ mercaptoetanol. Estas enzimas foram então renomeadas como tiorredoxinas peroxidases (TPx) (Chae et al., 1994a; Netto et al., 1996). São enzimas conservadas, distribuídas nos mais diversos grupos taxonômicos, como bactérias, protozoários, fungos, invertebrados, plantas e mamíferos. Desta maneira foi proposto agrupar estas enzimas em uma família denominada peroxirredoxinas (Prx) (Rhee et al., 1998). São proteínas abundantes estando entre as dez proteínas mais abundantes em Escherichia coli (Link et al., 1997). A maioria das Prxs exibe atividade tiorredoxina peroxidásica. No entanto, algumas das enzimas encontradas nesta família não funcionam no sistema TRx/TR/NADPH, não podendo desta maneira, receber esta designação.

Tiorredoxina é um polipeptídeo de aproximadamente $12 \mathrm{kDa}$, com dois grupos sulfidrilas adjacentes (duas cisteínas separadas por dois aminoácidos, CXXC) que, quando oxidados, formam uma ponte dissulfeto intramolecular. A tiorredoxina está envolvida em vários processos fisiológicos devido à sua capacidade de reduzir pontes dissulfeto em proteínas alvo (atividade dissulfeto redutase). Além das peroxirredoxinas, têm como alvos biológicos as enzimas ribonucleotídeo redutase (importante para síntese de DNA), metionina sulfóxido redutase e fatores de transcrição como p53 e NF-KB (revisado por Powis \& Montfort, 2001). As cisteínas da tiorredoxina são regeneradas a forma reduzida pela enzima tiorredoxina redutase à custa de elétrons provenientes do NADPH (Holmgren, 1985). Tiorredoxina redutase (TrxR) é um membro da família das flavoenzimas com atividade piridina nucleotídeo-dissulfeto oxidorredutases. Esta classe de enzimas incluem também glutationa redutase, lipoamida desidrogenase, NADH peroxidase entre outras. Tem como características, a presença de um centro redox composto por um par de cisteínas além de um domínio protéico responsável pela ligação covalente de uma molécula de FAD. O fluxo 
de elétrons ocorre do NADPH para a molécula de FAD, para o centro redox e finalmente para o dissulfeto da tiorredoxina (revisado por Williams, Jr., 1985)

Em bactérias, as peroxirredoxinas também podem ser reduzidas por outros sistemas sendo que um dos mais bem descritos é o sistema da alquil hidroperóxido redutase (AhpR), responsável pela redução de alquilhidroperóxidos a seus correspondentes alcoóis. Este sistema é composto de duas subunidades: (1) AhpC (alquil hidroperóxido redutase subunidade C), uma peroxirredoxina com alta similaridade à Tsa1 de $S$. cerevisiae (Storz et al., 1989); e (2) AhpF (alquil hidroperóxido redutase subunidade F), uma flavoenzima que possui domínios funcionalmente similares à tiorredoxina e tiorredoxina redutase (Chae et al., 1994b). O mecanismo catalítico do sistema AhpR de $S$. typhimurium envolve a redução do hidroperóxido pela AhpC, com subseqüente regeneração da $A h p C$ reduzida pela AhpF, à custa de elétrons provenientes do $\mathrm{NAD}(\mathrm{P}) \mathrm{H}$ (Tartaglia et al., 1990). Além de metabolizar hidroperóxidos orgânicos e $\mathrm{H}_{2} \mathrm{O}_{2}$ (Ellis \& Poole, 1997), AhpC decompõe peroxinitrito (Bryk et al., 2000). Na maioria dos organismos que não possuem AhpF, a proteína AhpC tem como doador de elétrons o sistema tiorredoxina (tiorredoxina e tiorredoxina redutase). Entretanto, recentemente foi demonstrado que AhpC de M. tuberculosis era capaz de reduzir peróxidos na presença de AhpD, uma dissulfeto redutase que possui um motivo Cys-X-X-Cys igual ao das tiorredoxinas, porém sem similaridade de seqüência com a mesma (Bryk et al., 2002). Diferentemente dos sistemas redutores propostos até o momento, foi demonstrado que a redução de $A h p D$ era acoplada às enzimas do metabolismo intermediário celular. Nesse sistema, dihidrolipoamida desidrogenase (Lpd) e dihidrolipoamida aciltransferase (SucB), componentes do complexo multienzimático da 2-oxoácido desidrogenase do metabolismo intermediário celular participam da defesa antioxidante de M.tuberculosis juntamente com AhpC e AhpD. Esses resultados mostraram pela primeira vez o papel de proteínas do metabolismo intermediário celular atuando na defesa antioxidante em uma via de redução de peróxidos (Bryk et al., 2002).

As peroxirredoxinas podem ser subdivididas em 3 diferentes grupos de acordo com o mecanismo de catálise envolvido. Todas apresentam uma cisteína na região $\mathrm{N}$-terminal, responsável direta pela atividade peroxidásica da enzima, denominada cisteína peroxidásica $\left(C_{\mathrm{p}}\right)$. Esta sulfidrila é oxidada a um ácido sulfênico havendo liberação de água, caso o peróxido envolvido seja $\mathrm{H}_{2} \mathrm{O}_{2}$ ou do álcool correspondente, no caso de um alquilhidroperóxido. As etapas seguintes são características para cada subtipo:

- 1-cys-Prx: este subtipo apresenta somente um resíduo de cisteína N-terminal conservado. $\mathrm{O}$ ácido sulfênico gerado é estabilizado pela estrutura protéica sendo então reduzido por um tiól exógeno, tal como DTT. O seu redutor biológico era até recentemente 
desconhecido para a maioria das proteínas. Estudos anteriores deram indicações de que peroxirredoxina mitocondrial de $S$. cerevisiae podia ser reduzida por uma tiorredoxina mitocondrial (Pedrajas et al., 2000). Estudos recentes de nosso grupo demonstraram que as 1-cys-Prx de diversos grupos taxonômicos também podem ser reduzidas por ascorbato, quebrando o paradigma vigente até então de que as peroxirredoxinas só podem ser reduzidas por compostos tiólicos (Monteiro et al., 2007).

- 2-cys-Prx típicas: apresentam duas cisteínas conservadas. A cisteína mais Cterminal, não envolvida diretamente na redução de peróxidos, é a cisteína de resolução (Cys ${ }_{\mathrm{r}}$ ). O ácido sulfênico gerado reage com a cisteína de resolução do outro monômero havendo a formação de um homodímero, apresentando uma ou duas pontes dissulfeto.

- 2-cys-Prx atípicas: também possuem duas cisteínas, porém o dissulfeto formado é intramolecular sem a homodimerização das cadeias polipeptídicas por interação covalente entre as cisteínas de cada monômero.

Outra classificação das Prx é baseada na estrutura primária, podendo ser divididas em 5 subgrupos (Trivelli et al., 2003)

- subgrupo A: as enzimas pertencentes a este subgrupo apresentam dois resíduos de cisteína conservados localizados em motivos VCP (Valina-Cisteína-Prolina). AhpC de $S$. typhimurium e E. coli e cTPxI de S. cerevisiae fazem parte deste subgrupo.

- subgrupo B: possuem similaridade com o subgrupo A, porém possuem somente um resíduo de cisteína conservado na região N-terminal localizado em um motivo VCT (ValinaCisteína-Treonina). A ausência do resíduo de cisteína C-terminal parece ter relação com a incapacidade de interação com a tiorredoxina (Chae et al., 1994b). Possuem atividade catalítica do tipo 1-cys-prx.

- subgrupo C: possuem também um resíduo Cys conservado na região $\mathrm{N}$-terminal, porém apresentam baixa similaridade com as enzimas dos subgrupos A e B. Foram denominadas peroxirredoxinas Q (PrxQ) ou BCP ("Bacterioferitin comigratory protein") devido ao fato de co-migrarem com bacterioferritina. Essas proteínas possuem dois resíduos de cisteína na região $\mathrm{N}$-terminal separados por poucos aminoácidos (aproximadamente quatro) e tendem a formar ponte dissulfeto intramolecular com o intermediário oxidado estável, semelhante ao mecanismo catalítico do tipo 2-cys-prx atípico. 
- subgrupo D: inicialmente caracterizadas em S. cerevisiae, as proteínas deste subgrupo são denominadas de peroxirredoxinas do tipo II (Verdoucq et al., 1999). As proteínas deste subgrupo apresentam baixa similaridade com as dos subgrupos A, B e C. A maioria das proteínas deste subgrupo possui apenas uma cisteína conservada, situada em motivos TCT (Treonina-Cisteína-Treonina) ou TCS (Treonina-Cisteína-Serina). Essas proteínas podem utilizar tiorredoxina como substrato e apresentam grande heterogeneidade funcional, podendo apresentar ciclo catalítico do tipo 1-cys-prx (bactérias ou plantas, Rouhier et al., 2002), 2-cys-prx (Ahp1 de S. cerevisiae, Jeong et al., 1999) ou 2-cys-prx atípica (prxV de mamíferos, Seo et al., 2000).

- subgrupo E: é composto de proteínas de bactérias que contêm cerca de 40 resíduos de aminoácidos entre as duas cisteínas. Possuem atividade catalítica do tipo 2-cysprx atípica.

\section{Glutationa peroxidase}

As glutationa peroxidases (Gpx) compreendem uma família de tiól peroxidases capazes de detoxificar diferentes peróxidos à custa de elétrons provenientes da glutationa (GSH), um tripeptídeo de baixa massa molecular (Gly-Cys-Glu). De maneira similar às peroxirredoxinas, o hidroperóxido é reduzido ao álcool correspondente. A maioria das GPx têm como característica peculiar a presença em seu sítio ativo de um átomo de selênio $(\mathrm{Se})$. Selênio é um elemento pertencente do grupo IV da tabela periódica e a sua química se assemelha à do enxofre (S). Está presente no sítio ativo das Gpx como selenocisteína, cisteína na qual o átomo de enxofre (R-SH) é substituído por selênio (R-SeH). A presença de selênio está relacionada com um aumento da atividade catalítica da enzima. A eficiência catalítica das Gpx que possuem selênio está em torno de $10^{8} \mathrm{M}^{-1} \cdot \mathrm{s}^{-1}$ (Hofmann et al., 2002). Além de $\mathrm{H}_{2} \mathrm{O}_{2}$, Gpx também catalisa a redução de hidroperóxidos de ácidos graxos, hidroperóxido de colesterol, hidroperóxidos de timina e outros hidroperóxidos sintéticos, como hidroperóxido de cumeno (CHP) e terc-butilhidroperóxido ( $t$-BHP). Em S. cerevisiae (Avery \& Avery, 2001) e E. coli (Fisher et al., 1999), essas enzimas não possuem uma selenocisteína em seu sítio ativo, mas sim um resíduo de cisteína conservado e aceitam como substrato hidroperóxidos de fosfolipídios. Dessa forma essas enzimas foram denominadas de glutationa peroxidase de hidroperóxidos de fosfolipídios (PHGpx). Hidroperóxidos de fosfolipídios são intermediários centrais na cadeia de reações de 
peroxidação lipídica. Portanto as PHGpx estão envolvidas no reparo de lipídios sendo geralmente reconhecidas como a principal linha de defesa do organismo contra danos oxidativos à membrana (Ursini et al., 1995).

Seu redutor fisiológico, GSH, está presente em animais, plantas e bactérias aeróbias, freqüentemente em concentrações na escala milimolar. Na sua forma oxidada (GSSG), duas moléculas de glutationa estão unidas através de uma ponte dissulfeto intermolecular entre os dois grupos sulfidrilas de suas cisteínas. Além de atuar como substrato para Gpx, têm como função vital a manutenção do balanço redox intracelular atuando com um tampão redox. Alterações no balanço redox (na razão GSH/GSSG) geram eventos de sinalização que levarão, no caso de um estresse oxidativo, a transcrição de enzimas antioxidantes. Em $\mathrm{pH}$ fisiológico, GSH está presente em grande parte na forma protonada devido ao seu $\mathrm{pK}_{\mathrm{a}}$ estar em torno de 9.2. Isso desfavorece sua reação com dissulfetos, pois a forma protonada não é um bom nucleófilo. Entretanto, as suas altas concentrações intracelulares tornam a reação favorável cineticamente. No citossol de células normais, a relação de glutationa reduzida e oxidada (GSH/GSSG) é alta. Isso se deve, em parte, à redução de GSSG para GSH pela enzima glutationa redutase $(\mathrm{GR})$, que catalisa a reação de redução de GSSG à custa da oxidação de NADPH (Halliwell \& Gutteridge, 2007).

Mais recentemente foi descrito uma proteína de função antioxidante presente somente em bactérias e que não conservava semelhança de seqüência primária com nenhuma enzima antioxidante conhecida. Essa enzima, denominada Ohr, será descrita mais detalhadamente no tópico seguinte, visto que é o objeto de trabalho de meu doutorado.

\subsubsection{A família Ohr/OsmC}

Em 1998, foi descrito um gene em Xantomonas campestris que quando deletado tornava a bactéria mais suscetível a tratamentos com hidroperóxidos orgânicos como $t$-BHP e CHP mas não a $\mathrm{H}_{2} \mathrm{O}_{2}$ e geradores de $\mathrm{O}_{2}{ }^{*-}$ como paraquat (Mongkolsuk et al., 1998). Em Pseudomonas aeruginosa, linhagens $\Delta o h r$ mostraram aumento da sensibilidade à hidroperóxidos orgânicos em ensaios de disco de inibição de crescimento (Ochsner et al., 2001). Análises de expressão gênica vieram a corroborar com esses dados visto que tratamentos com hidroperóxidos orgânicos como $t$-BHP (Mongkolsuk et al., 1998) induziam fortemente a transcrição de ohr enquanto $\mathrm{H}_{2} \mathrm{O}_{2}$ induzia fracamente e nenhuma indução era observada quando as células eram expostas a outras fontes geradoras de ROS como menadiona (Mongkolsuk et al., 1998. Figura 6). 


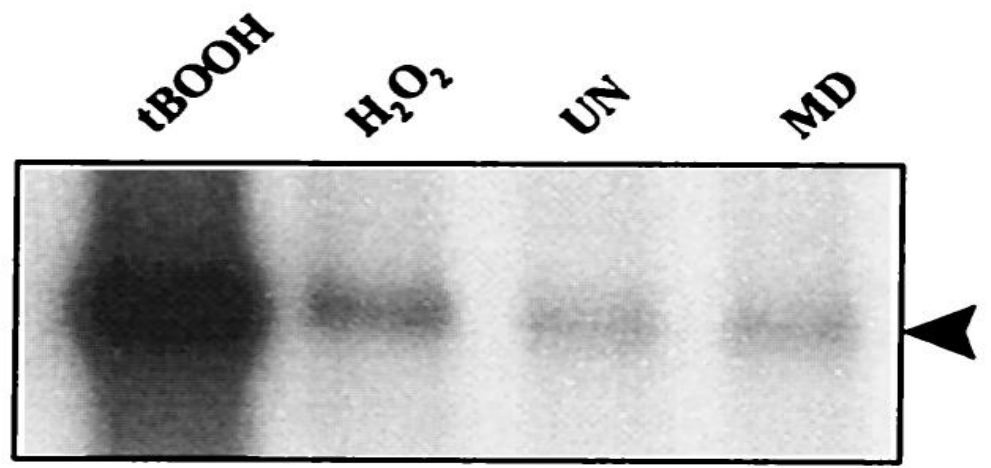

Figura 6. Indução da expressão de ohr na presença de ROS.

Análise por northern blot de RNA total isolado de Xanthomonas campestris pv phaseoli não induzida (UN) e induzida com 100 $\mu \mathrm{M}$ de menadiona (MD), $\mathrm{H}_{2} \mathrm{O}_{2}$ e $t$-BHP. Adaptado de Mongkolsuk et al., 1998.

Até então, postulava-se que o sistema da alquil hidroperóxido redutase $(\mathrm{AhpR})$ era o único sistema responsável pela redução de alquilhidroperóxidos em procariotos (Jacobson et al., 1989). Através de ensaios de complementação foi demonstrado que este novo gene restaurava a resistência de linhagem de $E$. coli $\triangle a h p C F$ a hidroperóxidos orgânicos (Mongkolsuk et al., 1998). Estudos posteriores indicaram que o produto de ohr exercia papel fundamental na resposta bacteriana a hidroperóxidos orgânicos, em especial aqueles derivados de ácidos graxos de cadeia insaturada visto que a mesma resposta não era observada em ahpC (Klomsiri et al., 2005 Figura 7).

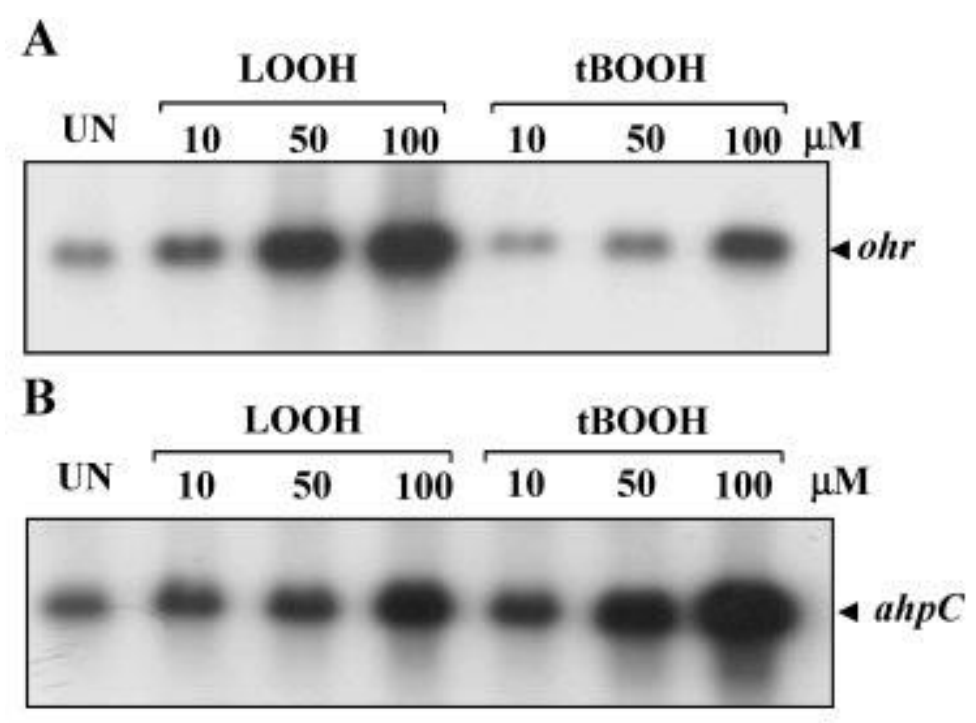

Figura 7. Indução da expressão de ohr e ahpC por northern blot em Xanthomonas campestris.

Hidroperóxido de ácido linoléico (LOOH) leva a uma maior indução de $o h r$ que $t$-BHP enquanto a mesma resposta não é observada para $\operatorname{ahpC}$. Adaptado de Klomsiri et al., 2005. 
Este gene foi denominado ohr (organic hydroperoxide resistance gene) devido à resistência que ele conferia a hidroperóxidos orgânicos. Este gene, está presente exclusivamente em bactérias sendo que a maioria desses organismos são patógenos de animais e plantas como Actinobacillus pleuropneumoniae, Bacillus subtilis, Deinococcus radiodurans, Enterococcus faecalis, Xanthomonas campestris e Xylella fastidiosa (Shea \& Mulks, 2002; Fuangthong et al., 2001; Atichartpongkul et al., 2001; Rince et al., 2001; Mongkolsuk et al., 1998 e Cussiol et al., 2003 respectivamente). Interessantemente, não foi observada similaridade de seqüência com outras proteínas procarióticas e eucarióticas conhecidas. A identidade de seqüência dentro da família Ohr, o produto do gene ohr, está entre $40-70 \%$. Além disso, Ohr possui cerca de $20 \%$ de similaridade com o gene osmC de Escherichia coli, também presente em diversas bactérias. Diferentemente de ohr, foi observado que a transcrição de osmC era induzida quando a célula era exposta a uma condição de choque osmótico (Gutierrez \& Devedjian, 1991). Análises filogenéticas mostraram que Ohr e OsmC são duas subfamílias de uma mesma família de proteínas denominada então Ohr/OsmC (Atichartpongkul et al., 2001).

No entanto, a atividade enzimática de Ohr, o produto do gene ohr, não havia sido caracterizada até o momento.

\subsection{Regulação gênica modulada por mudanças REDOX em procariotos}

Muitos fatores de transcrição exploram a química do enxofre presente em resíduos de cisteínas ou como parte de clusters metal-enxofre para mudar de um estado de oxidação para outro quando expostos a ROS (revisado por Paget \& Buttner, 2003).

OxyR foi o primeiro fator de transcrição sensível a mudanças redox caracterizado. Foi observado em $E$. coli que tratamentos com $\mathrm{H}_{2} \mathrm{O}_{2}$ ativavam um regulon que compreendia mais de vinte genes de defesa antioxidante como catalase (katG), peroxirredoxinas (sistema AhpR), glutationa redutase (gor), glutarredoxina $(g r x A)$ e tiorredoxina (trxC) (revisado por Storz \& Zheng, 2000). As bases moleculares de sua regulação redox foram elucidadas através de uma combinação de estudos estruturais, bioquímicos, fisiológicos e genéticos. OxyR é uma proteína de ligação ao DNA tetramérica, onde cada monômero possui uma cisteína reativa (Cys199 em $E$. coli) capaz de reagir com $\mathrm{H}_{2} \mathrm{O}_{2}$, formando um ácido sulfênico que rapidamente reage com outro resíduo de cisteína (Cys208 em E. coli) formando um dissulfeto intramolecular. A formação da ponte dissulfeto leva a um reenovelamento do domínio regulatório, que levam a alterações estruturais entre OxyR e o DNA. Essas 
alterações, permitem com que a RNA polimerase transcreva os genes alvos (revisado por Mongkolsuk \& Helmann, 2002).

PerR é outro fator de transcrição responsável pela resposta adaptativa à $\mathrm{H}_{2} \mathrm{O}_{2}$ em muitos organismos procariotos. Atua como repressor da transcrição em genes alvos possuindo um domínio N-terminal de ligação ao DNA e um domínio C-terminal que geralmente contém dois íons metálicos coordenados por quatro resíduos de cisteínas. Um dos íons metálicos é obrigatoriamente $\mathrm{Zn}^{+2}$, enquanto o outro sítio regulatório tende a ser mais promíscuo, porém ocupado na maioria das vezes por íon $\mathrm{Fe}^{+2}$ e em outras ocasiões por íon $\mathrm{Mn}^{+2}$. Isto acaba implicando em mudanças na regulação dos genes alvos (revisado por Paget e Buttner, 2003). PerR foi identificado como sendo o maior regulador da resposta induzida por estresse peroxidativo em $B$. subtilis e protótipo para um grupo de repressores sensíveis a hidroperóxidos relatados em bactérias gram-positivas e negativas. PerR reprime a expressão de catalase, AhpR, proteína de ligação ao DNA (MrgA), o operon de biossíntese de heme, a própria PerR assim como Fur (Ferric uptake regulator), o principal regulador da homeostase de ferro (Herbig \& Hellmann, 2002). Recentemente, foi proposto um novo mecanismo de ação para PerR. Em condições de exposição à $\mathrm{H}_{2} \mathrm{O}_{2}$, a oxidação do $\mathrm{Fe}^{+2}$ do sítio regulatório leva a formação de radical hidroxila via reação de Fenton. Esse radical, reage com dois resíduos de histidina que coordenam o cofator metálico desreprimindo a região promotora dos genes alvos. PerR oxidada é posteriormente degradada. Interessantemente, nessa hipótese não há o envolvimento dos resíduos de cisteína como sensores do peróxido.

\subsubsection{Regulação redox de Ohr}

Foi observado em Pseudomonas aeruginosa através de estudos de gene repórter, que uma linhagem $\Delta o x y R$ não alterava o padrão de expressão do promotor de ohr, indicando que a expressão gênica de Ohr não estava sobre controle de OxyR. Sabe-se que OxyR controla a expressão de diversas tióis peroxidases que são altamente induzidas por peróxidos orgânicos (Loprasert et al., 2000; Mongkolsuk et al., 1997 e Choi et al., 2001).

Foi descrito em Xanthomonas campestris que a transcrição de ohr está sobre o controle de um regulador negativo da transcrição denominado OhrR (Sukchawalit et al., 2001) cujo gene se localiza adjacente ao gene ohr. OhrR possui moderada identidade de seqüência com a família de reguladores negativos da transcrição MarR (Multiple antibiotic resistance protein regulatory family). Nesse estudo, foi mostrado que altos níveis de expressão de OhrR reprimiam a transcrição do gene ohr enquanto tratamentos com 
hidroperóxidos orgânicos levavam a ativação da transcrição de ohr, indicando que esses peróxidos orgânicos agem provavelmente inativando $\mathrm{OhrR}$, liberando assim a região promotora para transcrição de ohr. De fato, foi demonstrado em Bacillus subtillis que OhrR inibe a transcrição de ohr se ligando a duas regiões adjacentes de seqüências repetidas na região promotora de ohr e, portanto, bloqueando a transcrição gênica. Exposição a hidroperóxidos orgânicos leva a oxidação de um único resíduo de cisteína conservado na região N-terminal de OhrR a ácido sulfênico ou a estados mais elevados de oxidação, o que leva à desrepressão de OhrR e transcrição de ohr. Foi observado que mutação sítio dirigida do resíduo de cisteína por serina ou glicina não alterava a capacidade de OhrR de se ligar a região promotora do DNA, porém não havia indução da expressão de ohr em tratamentos com peróxidos orgânicos. Esses dados mostraram que a cisteína N-terminal de OhrR era fundamental para o mecanismo de desrepressão sensível a alterações redox (Fuangthong \& Helmann, 2002). Resultados similares foram obtidos em Xanthomonas campestris (Panmanee et al., 2002) e Streptomyces coelicolor (Oh et al., 2007). Estudos recentes ajudaram a elucidar o mecanismo de ação de OhrR em diferentes organismos. Primeiramente, através da estrutura de OhrR complexada a região operadora de $\mathrm{ohr}$ foi possível observar que OhrR é um homodímero de aproximadamente 17KDa que contêm dois domínios funcionais em cada subunidade: domínio de dimerização e o domínio de ligação ao DNA (Figura 8). Ao todo, aproximadamente 44 resíduos fazem cerca de 60 contatos com 22 bases do DNA. Foi observado que o $\mathrm{pK}_{\mathrm{a}}$ do resíduo de cisteína conservado está próximo de cinco, o que tornaria a sulfidrila desprotonada em pH fisiológico. Como não há resíduos básicos próximos da cisteína, o tiolato é estabilizado por ligações de hidrogênio com dois resíduos de tirosina que quando substituídos por alanina abolem a expressão de ohr. A oxidação da cisteína com a formação de uma molécula de ácido sulfênico ocasionaria um impedimento estéril na estrutura, sendo necessário um rearranjo conformacional para impedir esse fenômeno com a conseqüente liberação de OhrR do DNA (Hong et al., 2005)

Estudos posteriores demonstraram que o mecanismo de ação de OhrR é ainda mais complexo. Aparentemente, a formação do ácido sulfênico não leva a liberação de OhrR do DNA. A perda de atividade está correlacionada tanto com a formação de um dissulfeto misto, através de reações com tióis em um processo de S-tiolação, como com a ciclização do ácido sulfênico com um grupo amina da cadeia principal, formando uma molécula de sulfenamida (Lee \& Helmann, 2007). Aparentemente, o processo de S-tiolação protegeria a cisteína de processos de superoxidação enquanto, na ausência de tióis biológicos, acarretaria a formação da sulfenamida. No entanto, OhrR de muitos organismos (como Xanthomonas campestris), contêm duas cisteínas conservadas. Estas formam um dissulfeto intramolecular substituindo o fenômeno de S-tiolação documentado em Bacillus subtilis e 
outras bactérias como Oceanobacillus iheyensis, Streptomyces coelicolor, Sinorhizobium meliloti e Rhodopseudomonas palustris (Lee \& Helmann, 2007). Todavia, o mecanismo de ação geral de OhrR deve ser bastante semelhante para todos os organismos.

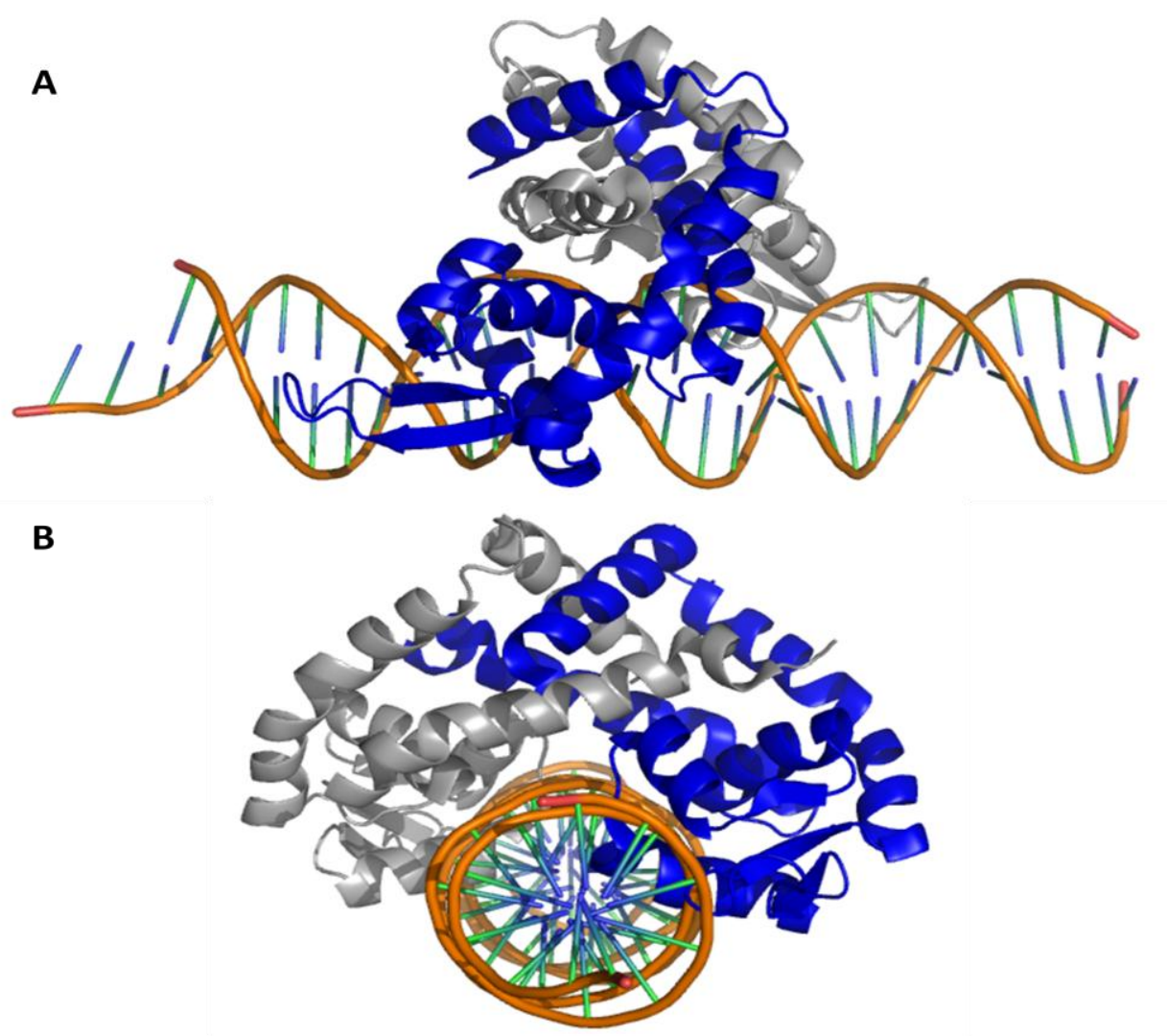

Figura 8. Estrutura de OhrR complexada a região operadora de ohrA em Bacillus subtillis. OhrR está representada como um homodímero com suas cadeias polipeptídicas nas cores azul e cinza. Figura foi gerada através do programa PyMol (PDB ID: 1Z9C).

Pouco se sabe a respeito da química envolvida no processo de superoxidação ou redução dessa molécula. Entretanto, estudos cinéticos demonstraram que o ácido sulfênico de OhrR pode ser superoxidado por hidroperóxido de ácido linoléico ( $\mathrm{LAOOH}$ ) cem vezes mais rápido do que por hidroperóxido de cumeno indicando que, dependendo do agente oxidante, OhrR pode ser reversivelmente oxidada ou funcionar como um "sacrificial regulator" (Soonsanga et al., 2008). De fato, a presença de resíduos aromáticos e apolares próximos da cisteína reativa proporciona um ambiente hidrofóbico e alongado, ideal para o ancoramento de oxidantes lipofílicos (Hong et al., 2005). No entanto, resultados obtidos em Agrobacterium tumefaciens mostram que ohr é mais induzida nesse organismo por hidroperóxido de cumeno (CHP) do que por hidroperóxido de ácido linoléico ( $\mathrm{LAOOH}$ ) indicando que a sensibilidade do sistema regulatório na resposta a diferentes hidroperóxidos 
orgânicos não é única em todos os organismos, variando de espécie para espécie (Chuchue et al., 2006).

Um fato a ser considerado, é que muitos organismos que possuem Ohr não possuem genes codificantes para OhrR, indicando que o mecanismo de regulação de Oh nesses organismos deve ser diferente. De fato, em Methylobacterium extorquens, Ohr parece ser regulada por PhyR, um ativador da transcrição de inúmeros genes de resposta a estresse que contêm no domínio N-terminal um fator sigma alternativo (RpoE) de função extra citoplasmática (Gourion et al., 2006; Gourion et al., 2008). Em Mycoplasma gallisepticum a expressão de ohr não é aumentada na presença de peróxidos orgânicos e outras ROS, mas sim na presença de estresse etanólico enquanto estresse osmótico provoca diminuição da expressão gênica. Postula-se nessa bactéria que ohr também esteja sobre controle do fator sigma alternativo $\sigma^{\mathrm{E}}$ (codificado pelo gene $r p o E$ ) baseado em similaridades de uma seqüência de bases da região promotora de ohr com a seqüência consenso do sítio de ligação de $\sigma^{\mathrm{E}}$ (Jenkins et al., 2008).

Em eubactérias, a RNA polimerase dependente de DNA é uma enzima com múltiplas subunidades responsável pela transcrição de todas as moléculas de RNA da célula (Borukhov \& Nudlery, 2003). O cerne da enzima (subunidades $\alpha_{2} \beta \beta^{\prime} \omega$ ) contem toda a maquinaria catalítica necessária para síntese de RNA, mas para iniciar a transcrição necessita associar-se à subunidade sigma $(\sigma)$, formando a holoenzima $\left(\alpha_{2} \beta \beta^{\prime} \omega \sigma\right)$. A subunidade dissociável $\sigma$ participa de todos os eventos da iniciação da transcrição, incluindo o reconhecimento de seqüências específicas da região promotora, o posicionamento da holoenzima e a abertura da dupla fita de DNA. Os elementos das regiões -10 e -35 do promotor são os principais determinantes reconhecidos por regiões altamente conservadas dos fatores sigma (Browning \& Busby, 2004). Neste processo, conhecido como ciclo do sigma, o fator sigma associa-se ao cerne da RNA polimerase para iniciação da transcrição e dissocia-se após a transcrição para o complexo de elongação. Após o término da transcrição, o cerne da RNA polimerase está livre para associar-se ao sigma e iniciar novo ciclo de transcrição. Muitas bactérias contem diferentes tipos de fatores sigma e, portanto, múltiplas holoenzimas. Entretanto, evidências recentes mostram que o fator sigma também está envolvido na regulação do processo de elongação (revisado por Mooney et al., 2005). Em E. coli, o fator sigma primário é denominado $\sigma^{70}$, sendo necessário para a transcrição da maioria dos genes, incluindo aqueles que desempenham funções essenciais como genes de housekeeping. Fatores $\sigma$ alternativos são aqueles que controlam genes de função especializada, necessários geralmente para desempenhar funções específicas (e.g. motilidade) ou sobre condições de estresse (e.g. choque térmico, estresse oxidativo). O fator $\sigma^{E}$, faz parte do grupo de fatores sigma de função extra citoplasmática responsável por 
transcrever genes capazes de manter a integridade do envelope bacteriano. Esse fator é induzido em condições de estresse que afetam a célula inteira como choque térmico, etanólico e a estresses do envelope como mutações que inativam chaperonas periplasmáticas (revisado por Paget \& Helmann, 2003). Foi observado que $\sigma^{\mathrm{E}}$ regula a expressão de muitos genes relacionados com patogenicidade (Rhodius et al., 2006). Em Streptomyces coelicolor, a oxidação do fator anti- $\sigma$ RsrA por $\mathrm{H}_{2} \mathrm{O}_{2}$ ou diamida leva à formação de ponte dissulfeto que resulta na ativação do regulon $\sigma^{R}$, resultando na indução genes alvos correspondentes (Kang et al., 1999).

Em $X$. fastidiosa, não foram encontrados genes que apresentassem similaridade com OhrR de outras bactérias. Também não foi encontrada em proteínas da família MarR de Xylella fastidiosa, a presença de cisteínas conservadas. Deste modo, podemos supor que o controle da transcrição de ohr em $X$. fastidiosa é realizado por outro mecanismo diferente do realizado pela OhrR.

\section{OBJETIVOS}

Ohr é uma das principais enzimas atuantes na resposta da bactéria à detoxificação de hidroperóxidos orgânicos. Dessa maneira, essa enzima deve desempenhar papel importante na defesa antioxidante de Xylella fastidiosa, especialmente durante a interação planta-patógeno.

O objetivo dessa tese é entender o papel fisiológico de Ohr em $X$. fastidiosa através de sua caracterização funcional, buscando elucidar suas vias de redução, oxidação e os mecanismos de regulação gênica.

\section{MATERIAIS E MÉTODOS}

\subsection{Materiais e Reagentes}

Ácido lipóico, Acrilamida, Adjuvante de Freund completo e incompleto, agarose, ampicilina, BHT (hidroxitolueno butilado), bis-acrilamida ( $N, N^{\prime}$-metilenobis-acrilamida), BSA (albumina bovina sérica), canamicina, citrato sintetase, diamida, DTNB [ácido 5,5'-ditiobis(2nitrobenzóico)], DTT (1,4-ditiotreitol), Hepes (ácido 4-(2-hidroxietil)piperazina-1- 
etanosulfônico), Lipoamida, NADH (b-nicotinamida adenina dinucleotídeo reduzido), NADPH (b-nicotinamida adenina dinucleotídeo 2'-fosfato reduzido), PMSF (fluoreto de fenilmetilsulfonila), sulfato de estreptomicina, sulfato ferroso, $t$-BHP (terc-butilhidroperóxido), TCA (ácido tricloroacético), tetraciclina, Tris (tris(hidroximetil) aminometano), uréia e xilenol orange foram obtidos da Sigma-Aldrich Co. (St. Louis, Missouri, USA). CHP (hidroperóxido de cumeno), $\mathrm{H}_{2} \mathrm{O}_{2}$ e $\beta$-mercaptoetanol foram obtidos da Merck KGaA (Darmstadt, Alemanha). Proteína A Sepharose e Full-Range Rainbow Molecular Weight Marker foi obtida da GE Healthcare (Pittsburgh, Pensilvânia, USA). Brometo de etídeo, imidazol, e SDS (dodecil sulfato de sódio) foram obtidos da USB Corporation (Cleveland, Ohio, USA). Marcadores de massa molecular (BenchMark Protein Ladder, Low DNA Mass Ladder, $1 \mathrm{~Kb}$ Plus DNA Ladder e I DNA/Hind III Fragments) foram obtidos da Invitrogen Corporation (Carlsbad, Califórnia, USA). T4 DNA ligase e as enzimas de restrição BamHI, EcoRI, HindIII, Ndel, Nhel e Xhol foram obtidas da New England BioLabs, Inc. (Ipswich, Massachusetts, USA). Taq DNA polimerase, Hi-Fidelity Taq DNA polimerase e dNTPs foram obtidos da Fermentas Inc. (Glen Burnie, Maryland, USA). Coomassie brilliant blue G-250 foi obtido da Bio-Rad Laboratories, Inc. (Hercules, Califórnia, USA). Peptona e extrato de levedura foram obtidos da Oxoid Ltd. (Basingstoke, Hampshire, Inglaterra). Todos os demais reagentes empregados eram grau analítico. Todas as soluções foram preparadas em água tratada no sistema Milli-Q (Millipore Corporate, Billerica, Massachusetts, USA).

\subsection{Linhagens bacterianas de clonagem e expressão}

- DH5 $\alpha$ : E. coli [endA1, hsdR17 $\left(r_{k}^{-} m_{k}^{+}\right)$, supE44, thi-1, recA1, gyrA (Na 1'), relA1, $\Delta$ $(\text { lacZYA-argF) })_{169}$ (m80lacZ4M15)] linhagem de clonagem (Novagen EMD Biosciences, Inc., Merck KgaA).

- XL1-Blue: E. coli recA1 endA1 gyrA96 thi-1 hsdR17 supE44 relA1 lac [F' proAB lacl ${ }^{q} Z D M 15 \operatorname{Tn} 10\left(\operatorname{Tet}^{\mathrm{R}}\right)$ ]: linhagem de clonagem (Stratagene, Agilent Technologies, Inc., Santa Clara, Califórnia, USA).

- BL21(DE3): E. coli [F', amp $T$, $h s d S_{b}\left(r_{B}^{-} m_{b}^{-}\right)$, gal, dcm (DE3)] linhagem de expressão (Novagen EMD Biosciences, Inc.).

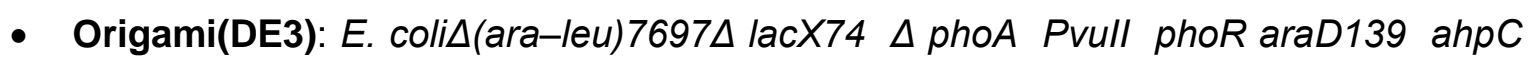

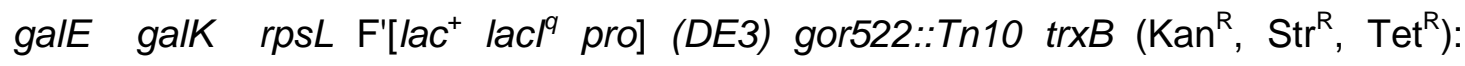
linhagem de expressão (Novagen EMD Biosciences, Inc.). 
- AD494(DE3): E. coli $\Delta$ (ara leu)7967 $\Delta$ lacX74 $\Delta$ phoA Pvull phoR $\Delta$ malF3 F'lac ${ }^{+}$ laclq pro] trxB::kan (DE3) $\left(K^{q} n^{\mathrm{R}}\right)$ : linhagem de expressão (Novagen EMD Biosciences, Inc.).

- Rosetta(DE3): E. coli [ $F^{-}$omp $T h s d S_{B}\left(r_{B}^{-} m_{B}^{-}\right)$gal dcm (DE3)] pRARE ${ }^{2}\left(\operatorname{Cam}^{R}\right)$ : linhagem de expressão (Novagen EMD Biosciences, Inc.).

\subsection{Vetores de clonagem e expressão}

- TOPO: vetor de clonagem (Invitrogen) linearizado. Possui em sua extremidade 3' um resíduo de deoxitimidina (T) na qual está ligada covalentemente a enzima topoisomerase I.

- pET15b: vetor de superexpressão (Novagen) cuja expressão do gene de interesse é controlada pelo promotor viral T7lac que é desreprimido por IPTG. Possui sítio de clonagem (com as enzimas de restrição Ndel, BamHl e Xhol) e uma seqüência de bases que codifica para uma cauda de poli histidina que será incorporada a enzima na porção $\mathrm{N}$-terminal. Possui também um sítio para clivagem por trombina caso haja necessidade de remoção posterior da cauda de histidina.

- pET28a: vetor de superexpressão (Novagen), cuja expressão do gene de interesse é controlada pelo promotor viral T7 lac que é desreprimido pelo composto IPTG. Possui um sítio de clonagem (contendo seqüências reconhecidas por várias enzimas de restrição) e uma seqüência de bases codificadoras de cauda poli histidina para a porção N e C-terminal. Também possui seqüência de bases que codificam para uma cauda T7 interna e um sítio de clivagem por trombina.

\subsection{Meios e condições para cultivo de E. coli}

LB: $1 \%$ triptona; $0.5 \%$ cloreto de sódio; $0.5 \%$ extrato de levedura e $2 \%$ ágar (quando sólido), $\mathrm{pH} 7.4$

\subsection{Meios e condições para cultivo de $X$. fastidiosa}

PWG: Fitona Peptona 4g/l; tripticase peptona $1 \mathrm{~g} / \mathrm{l}$; cloreto de hemina $0,001 \%$; $\mathrm{K}_{2} \mathrm{HPO}_{4}$ 1.2g/l; $\mathrm{MgSO}_{4} .7 \mathrm{H}_{2} \mathrm{O}$ 0.4g/l; glutamina $0,4 \%$; glicose $0,5 \%$ 
O cultivo de Xylella fastidiosa J1a12 (Monteiro et al., 2001) foi realizado em meio de cultura PW (Davis et al., 1981), sem albumina de soro bovino (BSA) e sem vermelho fenol, suplementado com $0,5 \%$ de glicose (PWG). Para manutenção das culturas foi feito cultivo em placa (PWG sólido com ágar 1.2\%). Em meio líquido, o cultivo foi feito em $50 \mathrm{ml}$ de PWG em frascos de $250 \mathrm{ml}$ a temperatura ambiente sem agitação. As linhagens mutantes rpo $\mathrm{Ne}$ $r p o E$ foram cultivadas com ampicilina $10 \mu \mathrm{g} / \mathrm{ml}$. As bactérias foram cultivadas até fase logarítmica por aproximadamente sete dias.

\subsection{Construção de vetores de superexpressão}

Os genes de interesse foram amplificados a partir de cosmídeos contendo genes de $X$. fastidiosa disponibilizados pelo Projeto Genoma deste organismo ou a partir de DNA genômico de Xylella fastidiosa das linhagens 9a5c (obtido do laboratório da $\operatorname{Prof}^{\mathrm{a}} \mathrm{Dr}^{\mathrm{a}}$ Aline Maria Silva do Instituto de Química da USP) e J1a12 (obtido do laboratório da Prof ${ }^{\mathrm{a}} \mathrm{Dr}^{\mathrm{a}}$ Marilis do Vale Marques do Instituto de Ciência Biomédicas da USP). Para a execução de todas as reações de PCR descritas utilizamos o termociclador Perkin-Elmer 9700 (Applied Biosystems) e a enzima Taq DNA polimerase. A amplificação dos genes de interesse foi confirmada por eletroforese em gel de agarose. Os oligonucleotídeos desenhados para a amplificação dos respectivos genes estão descritos na Tabela 1.

Após a amplificação, os produtos de PCR e seus respectivos vetores de superexpressão foram submetidos à digestão com enzimas de restrição. Os produtos da digestão foram submetidos à eletroforese em gel de agarose $(0.8 \%)$ e os fragmentos correspondentes foram extraídos do gel utilizando o kit Wizard SV Gel and PCR Clean-up system (Promega Corporation), segundo o protocolo do fabricante. Produto de PCR e o vetor de expressão foram ligados utilizando a enzima T4 DNA ligase e o produto da ligação foi inserido em linhagem DH5- $\alpha$ de E. coli por eletroporação. Após crescimento em meio sólido (LB) contendo os respectivos antibióticos (Ampicilina 100 $\mu \mathrm{g} / \mathrm{ml}$ para $\mathrm{pET}-15 \mathrm{~b}$ e Canamicina $15 \mu \mathrm{g} / \mathrm{ml}$ para pET-28a) transformantes foram selecionados para confirmação do inserto por reação de PCR a partir da colônia, seguido de eletroforese em gel de agarose. A colônia selecionada (na qual houve amplificação do inserto) foi crescida em meio líquido LB com o respectivo antibiótico e o produto da ligação gene/vetor de superexpressão foi isolado utilizando o kit Perfectprep-Plasmid mini (Eppendorf AG, Hamburgo, Alemanha), segundo o protocolo sugerido pelo fabricante. Após a confirmação da presença do vetor por eletroforese em gel de agarose, inserimos o vetor em linhagens bacterianas de superexpressão para a produção de proteínas recombinantes. Novamente, plaqueamos a 
transformação e algumas colônias crescidas foram selecionadas para o teste de expressão. Todas as linhagens transformadas foram estocadas em glicerol $8 \%$ à $-70^{\circ} \mathrm{C}$.

Tabela 1. Oligonucleotídeos utilizados para amplificação dos respectivos genes alvos.

\begin{tabular}{|c|c|c|c|c|}
\hline Gene & Produto & Sentido & Sequência $\left(5^{\prime} \rightarrow 3^{\prime}\right)$ & Restrição \\
\hline lpd & \multirow[t]{2}{*}{ Lpd } & Forward & GGGAATTCCATATGACGTTGC & Ndel \\
\hline Ipd & & Reverse & CCGCTCGAGTCAGTTTGCTTTATG & Xhol \\
\hline IpdA & \multirow[t]{2}{*}{ LpdA } & Forward & GGGAATTCCATATGACGGTGATTG & Ndel \\
\hline IpdA & & Reverse & CCGCTCGAGTTACTTTGCTGAAG & Xhol \\
\hline sucB & \multirow[t]{2}{*}{ SucB } & Forward & CTAGCTAGCATGACCATCGAAG & Nhel \\
\hline sucB & & Reverse & CGCGGATCCTTATAAGCC & BamHI \\
\hline pdhb & \multirow[t]{2}{*}{ PDHB } & Forward & GGGAATTCCATATGACCGAAATCAAGGAAG & Ndel \\
\hline pdhb & & Reverse & CGGGATCCTCAACGGGCCTTAC & BamHI \\
\hline tsnc & \multirow[t]{2}{*}{ Tsnc } & Forward & CCGGAATTCATGAGCGACTATGTTCTAC & EcoRI \\
\hline tsnc & & Reverse & CCCAAGCTTTGAGTCGGTGTTTGC & HindIII \\
\hline ybbn & \multirow[t]{2}{*}{ Ybbn } & Forward & CGCCATATGCATGGTTTTTACTC & Ndel \\
\hline ybbn & & Reverse & CGCGGATCCTCAAAACAAC & BamHI \\
\hline trxa & \multirow[t]{2}{*}{ TrxA } & Forward & GGAATTCCATATGCAGATCATTACCGCTACG & Ndel \\
\hline trxa & & Reverse & CGGGATCCTTAAAGATACGTCTGTACAGC & BamHI \\
\hline trxr & \multirow[t]{2}{*}{ TrxR } & Forward & CGCCATATGAGCGATTATCCTGC & Ndel \\
\hline trxr & & Reverse & CGCGGATCCTCAGTTAC & BamHI \\
\hline
\end{tabular}

\subsection{Transformação de bactérias eletrocompetentes por eletroporação}

O vetor de interesse e a bactéria eletrocompetente foram colocados numa cubeta de eletroporação e sujeitos a um pulso de voltagem no eletroporador Gene Pulser II Electroporation System (Bio-Rad Laboratories), ajustado em $2.5 \mathrm{kV}$ de voltagem e $25 \mu \mathrm{F}$ de capacitância. Após o pulso de voltagem, as células foram ressuspendidas em $1 \mathrm{ml}$ de LB sem ampicilina e deixadas sob agitação a $37^{\circ} \mathrm{C}$ por 1 hora. Após esse período, foram plaqueadas em meio sólido seletivo LB na presença do respectivo antibiótico e incubadas overnight a $37^{\circ} \mathrm{C}$, para o crescimento das bactérias transformadas com o vetor.

\subsection{Superexpressão em E. coli dos genes clonados}

As colônias transformantes foram crescidas em $50 \mathrm{ml}$ de LB na presença dos antibióticos específicos para cada linhagem superexpressante até atingir a densidade óptica desejada (entre 0.6-1.0).No passo seguinte, foi adicionado IPTG ao meio de cultura de 
modo a ativar o promotor T7 presente no vetor de expressão, desencadeando assim a transcrição dos genes alvos e conseqüente superexpressão da proteína de interesse. As condições de expressão como concentração de IPTG, temperatura, tempo de indução e concentração dos respectivos antibióticos utilizados está descrito na Tabela 2.

Tabela 2. Condições de clonagem e expressão de genes alvos.

\begin{tabular}{|c|c|c|c|c|}
\hline Gene & Vetor & Linhagem & Antibióticos & Condições de indução \\
\hline Ipd & pET-15b & AD494(DE3) & $\begin{array}{l}\text { Ampicilina }(100 \mu \mathrm{g} / \mathrm{ml}) \\
+ \text { Canamicina }(15 \mu \mathrm{g} / \mathrm{ml}\end{array}$ & $0.5 \mathrm{mM}$ IPTG, overnight, $20^{\circ} \mathrm{C}$ \\
\hline IpdA & pET-15b & AD494(DE3) & $\begin{array}{l}\text { Ampicilina }(100 \mu \mathrm{g} / \mathrm{ml}) \\
+ \text { Canamicina }(15 \mu \mathrm{g} / \mathrm{ml}\end{array}$ & $\begin{array}{l}0.1 \mathrm{mM} \text { IPTG, ácido lipóico } \\
(300 \mu \mathrm{g} / \mathrm{ml}), \text { overnight, } 20^{\circ} \mathrm{C}\end{array}$ \\
\hline sucB & pET-28a & BL21(DE3) & Canamicina $(15 \mu \mathrm{g} / \mathrm{ml})$ & $\begin{array}{l}0.1 \mathrm{mM} \text { IPTG, ácido lipóico } \\
(300 \mu \mathrm{g} / \mathrm{ml}) \text {, overnight, } 20^{\circ} \mathrm{C}\end{array}$ \\
\hline$p d h b$ & pET-15b & BL21(DE3) & Ampicilina $(100 \mu \mathrm{g} / \mathrm{ml})$ & $\begin{array}{l}0.1 \mathrm{mM} \text { IPTG, ácido lipóico } \\
(300 \mu \mathrm{g} / \mathrm{ml}) \text {, overnight, } 20^{\circ} \mathrm{C}\end{array}$ \\
\hline tsnc & pET-15b & AD494(DE3) & $\begin{array}{l}\text { Ampicilina }(100 \mu \mathrm{g} / \mathrm{ml}) \\
+ \text { Canamicina }(15 \mu \mathrm{g} / \mathrm{ml}\end{array}$ & $0.5 \mathrm{mM}$ IPTG, overnight, $20^{\circ} \mathrm{C}$ \\
\hline trr & $\mathrm{pET}-15 b$ & BL21(DE3) & Ampicilina $(100 \mu \mathrm{g} / \mathrm{ml})$ & $0.5 \mathrm{mM}$ IPTG, overnight, $20^{\circ} \mathrm{C}$ \\
\hline $\begin{array}{l}\text { ohr (WT e } \\
\text { mutantes) }\end{array}$ & pET-15b & BL21(DE3) & Ampicilina $(100 \mu \mathrm{g} / \mathrm{ml})$ & $1 \mathrm{mM}$ IPTG, $3 \mathrm{~h}, 37^{\circ} \mathrm{C}$ \\
\hline
\end{tabular}

\subsection{Purificação das proteínas recombinantes por cromatografia de afinidade a metal}

Após o período de indução, as células foram centrifugadas (5000 RPM por 10 min.), ressuspendidas em tampão de lise celular ( 20 mM tampão fosfato de sódio pH 7.4, 500 mM $\mathrm{NaCl}$ e $20 \mathrm{mM}$ imidazol) na presença de $100 \mu \mathrm{M}$ PMSF e submetidas a diversos ciclos de sonicação no aparelho Branson Digital Sonifier 450 (Branson Ultrasonics Corporation, Danbury, Connecticut, USA) em amplitude $35 \%$ por 25 segundos seguidos de 50 segundos de descanso em gelo (para não superaquecer a amostra desnaturando a proteína de interesse). O lisado celular foi tratado com sulfato de estreptomicina $1 \%$ por 30 minutos, de modo a precipitar ácidos nucléicos presentes na amostra. A amostra foi submetida à centrifugação (14000 RPM por 50 min. a $4^{\circ} \mathrm{C}$ ).

Para verificar a existência da proteína de interesse em corpos de inclusão, os precipitados foram analisados por SDS-PAGE. O precipitado foi ressuspendido em água (1 $\mathrm{ml}$ para cada $100 \mathrm{ml}$ de meio de cultura utilizado no crescimento) e em $2 \mu \mathrm{l}$ dessa suspensão adicionou-se $10 \mu \mathrm{l}$ de tampão de solubilização (60 mM tampão Tris- $\mathrm{HCl}$ pH 6.8, $\beta$-mercaptoetanol 1\%, glicerol 10\%, SDS 1\% e azul de bromofenol 0.01\%). Após 10 minutos a $95^{\circ} \mathrm{C}$, as amostras foram analisadas por SDS-PAGE. 
Após a obtenção do extrato protéico, as proteínas foram submetidas à purificação utilizando uma coluna de afinidade a níquel His-TrapTM HP (GE Healthcare) $1 \mathrm{ml}$ ou $5 \mathrm{ml}$ (para $50-200 \mathrm{ml}$ ou $1 \mathrm{~L}$ de cultura bacteriana respectivamente) e uma bomba peristáltica P1TM (GE Healthcare). As amostras foram purificadas com as seguintes soluções: Tampão de ligação (20mM Tampão Fosfato de sódio; 500 mM NaCl e 20 mM Imidazole) e de eluição (20mM Tampão Fosfato de sódio; $500 \mathrm{mM} \mathrm{NaCl}$ e $500 \mathrm{mM}$ Imidazole). As etapas anteriores à purificação consistem em lavagem da coluna em água (5 volumes de coluna); aplicação de níquel $0.1 \mathrm{M}$ ( 0.5 volume de coluna); lavagem em água (5 volumes de coluna); lavagem com tampão de ligação (10 volumes de coluna). Após estas etapas, a amostra é aplicada e em seguida lavada novamente com tampão de ligação para remover proteínas que estão interagindo fracamente com a coluna. Por último, aplica-se o tampão de eluição ( 5 volumes de coluna) e as frações são coletadas em eppendorfs. As etapas foram feitas sobre fluxo constante de $1 \mathrm{ml} / \mathrm{min}$. De modo a refinar o grau de pureza das proteínas, realizamos purificações em gradiente de Imidazole. Nesse procedimento, entre as etapas de lavagem com tampão de ligação e eluição, há lavagens da coluna com concentrações crescentes de Imidazole (50, 100, 150 e 200mM em 20 mM tampão Fosfato de sódio e 500 mM NaCl).

\subsection{Purificação de proteínas em corpos de inclusão}

Resumidamente, pellet celular resultante do processo de sonicação foi ressuspendido no reagente BugBuster ${ }^{\circledR}$ Protein Extraction (Novagen). Foi adicionado ao pellet ressuspendido lisozima $(1 \mathrm{KU} / \mathrm{ml})$ seguido de vortexação e incubação por 5 minutos à temperatura ambiente. Após o período de incubação foi adicionado reagente BugBuster (diluído 1:10) e a mistura de reação foi misturada por vortexação por 1 minuto. A suspensão foi então centrifugada a $5000 \times \mathrm{g}$ por $15 \mathrm{~min}$. a $4^{\circ} \mathrm{C}$ e o sobrenadante foi removido. Os corpos de inclusão foram ressuspendidos em metade do volume da cultura original com BugBuster (diluído 1:10) seguido de vortexação e nova centrifugação nas mesmas condições da anterior. Esta etapa foi repetida duas vezes seguida de nova ressuspensão, porém a amostra foi centrifugada a $16000 \times \mathrm{g}$ por 15 minutos a $4^{\circ} \mathrm{C}$. Pellet final foi ressuspendido em tampão de ligação (vide tópico anterior) na presença de $6 \mathrm{M}$ Uréia. Para purificação foi adicionado $6 \mathrm{M}$ de uréia em todos os tampões. 


\subsection{Mutações sítio-dirigido em Ohr de Xylella fastidiosa}

Para realizar as mutações foi utilizado o kit QuikChange ${ }^{\circledR}$ Site-Directed Mutagenesis (Stratagene). Foram sintetizados dois oligonucleotídeos (cada um complementar a sua fita oposta) contendo a mutação de interesse (Tabela 3).

Tabela 3. Oligonucleotídeos utilizados para a construção de mutantes de Ohr.

\begin{tabular}{|c|c|c|}
\hline Ohr & Sentido & Sequência $\left(5^{`} \rightarrow 3^{`}\right)$ \\
\hline \multirow[t]{2}{*}{ V36S } & Forward & GTCAAGCTATCCTCACCACAGGGA \\
\hline & Reverse & AATCCCTGTGGTGAGGATAGCTTGAC \\
\hline \multirow[t]{2}{*}{ L40T } & Forward & GTTCCACAGGGAACAGGTGGCCCG \\
\hline & Reverse & CGGGCCACCTGTTCCCTGTGGAAC \\
\hline \multirow[t]{2}{*}{ F68Y } & Forward & GGCGCCCTGAAGTATGTTGCTAATAAGG \\
\hline & Reverse & CCTTATTAGCAACATACTTCAGGGCGCC \\
\hline \multirow[t]{2}{*}{ G95S } & Forward & GAAATCCCTGGTICCTTCGGCCTAGTC \\
\hline & Reverse & GACTAGGCCGAAGGAACCAGGGATTTC \\
\hline \multirow[t]{2}{*}{ F96Y } & Forward & GAAAT CCTGGTGGTIATGGCCTAGTCGTAG \\
\hline & Reverse & CTACGACTAGGCCATAACCACCAGGGATTTC \\
\hline \multirow[t]{2}{*}{ P126H } & Forward & GCATCGTGTTTGTCATTACTCTAATGCAAAC \\
\hline & Reverse & GTTTGCATTAGAGTAATGACAAACACGATGC \\
\hline
\end{tabular}

A polimerase presente no kit (PfuTurbo $\left.{ }^{\circledR}\right)$ é capaz de estender ambas as fitas de um plasmídeo contendo o inserto de interesse com alta fidelidade e processividade. A extensão dos primers gera um plasmídeo mutante. Dessa forma, os mutantes foram gerados utilizando como molde os vetores de expressão com os respectivos genes selvagens clonados. As mutações foram realizadas utilizando o protocolo padrão do Kit QuikChange Site-directed Mutagenesis (Stratagene, Agilent Technologies, Inc., Santa Clara, Califórnia, USA) e os primers contendo a mutação de interesse. Em $50 \mu$ de reação foram adicionados: vetor molde $30 \mathrm{ng}$, cada oligonucleotídeo $12.5 \mathrm{pmol}$, dNTPs $200 \mu \mathrm{M}$ e Pfu Turbo polimerase 2.5 U. Após amplificação e digestão do DNA molde com Dpnl, uma endonuclease que somente reconhece a fita parental metilada digerindo-a, os produtos de mutagênese foram transformados em células XL1-Blue por eletroporação e plaqueadas em meio sólido seletivo LB/Amp. Colônias resultantes foram selecionadas para confirmação do inserto por reação de PCR. As colônias no qual foi confirmado o inserto foram crescidas em meio líquido LB/Amp e o vetor com o gene foi isolado (como indicado anteriormente). A região codificante do vetor isolado foi seqüenciada para verificação da geração das mutações e os vetores com as respectivas mutações confirmadas foram transformados em linhagens de $E$. coli de expressão. Na tabela 3, podemos ver os oligonucleotídeos utilizados para geração de mutações sítio-dirigido em Ohr. 
Os mutantes de Ohr C61S e C125S foram gerados através do método de PCR megaprimer e está descrita detalhadamente no paper em anexo (Cussiol et al., 2003, anexo I).

\subsection{Quantificação de proteínas}

Para a quantificação das proteínas recombinantes e comerciais disponíveis utilizamos duas técnicas de medição. A primeira, consiste na utilização do reagente Bradford (Kruger, 1994). É um método colorimétrico medido no comprimento de onda de $595 \mathrm{~nm}$ utilizando uma curva de calibração com BSA (Cf BSA x Abs).

O segundo método baseia-se na leitura de absorbância direta da proteína à 280nm baseando-se na predição do peso molecular e coeficiente de extinção $(\varepsilon)$ da proteína através da ferramenta de bioinformática Protparam Tool (ExPASy http://www.expasy.ch). Em ambos os protocolos de medição, as proteínas foram quantificadas em triplicata a $25^{\circ} \mathrm{C}$.

\subsection{Gel SDS-PAGE}

As proteínas recombinantes purificadas tiveram o seu grau de pureza analisado por SDS-Page em condições redutoras. O gel de separação foi feito com $10 \%$ ou $14 \%$ de poliacrilamida e o de empacotamento com $5 \%$. O tampão de corrida utilizado foi: MES-SDS 1X (a solução estoque 20X continha MES (1M), SDS (69.3 mM), 2-(N-morpholino) ethane sulfonic acid Tris Base (1M), EDTA (20.5 mM, pH 7.3). As condições da corrida foram: voltagem 130V, corrente 110 - 125 mA, 90 minutos. Na alíquota a ser aplicada no gel, foi adicionado tampão de amostra $1 \mathrm{x}$ na presença de DTT $(10 \mathrm{mM})$. As amostras foram incubadas em banho seco a $100^{\circ} \mathrm{C}$ por cinco minutos e aplicadas no gel.

\subsection{Quantificação de cisteínas livres pelo ensaio de DTNB}

O produto resultante da reação do tiól ou tiolato com DTNB gera o composto tionitrobenzonato (TNB), que pode ser quantificado espectrofotometricamente a $412 \mathrm{~nm}$. Neste ensaio, $170 \mu \mathrm{g}$ de proteína foi precipitado com 1 volume de TCA 20\% por 30 minutos no gelo. Em seguida, a amostra foi centrifugada em velocidade máxima por 20 minutos e lavada duas vezes com TCA $2 \%$. O pellet resultante foi ressuspendido em $400 \mu$ de tampão Tris- $\mathrm{HCl} 30 \mathrm{mM} \mathrm{pH} \mathrm{7.0,} \mathrm{EDTA} 1 \mathrm{mM}$ e uréia $8 \mathrm{M}$. Destes, $370 \mu$ foram transferidos para 
placa de ELISA e a absorbância medida a $280 \mathrm{~nm}$ num leitor de placas Zenyth 200st (Anthos Labtec Instruments GmbH, Wals, Áustria). Após determinação da concentração de proteína, DTNB foi adicionado para concentração final de $100 \mu \mathrm{M}$ e a placa foi incubada no escuro por uma hora à temperatura ambiente. A absorbância do TNB foi lida a $412 \mathrm{~nm}$ e o coeficiente de extinção molar de $13600 \mathrm{M}^{-1} . \mathrm{cm}^{-1}$ foi utilizado para determinar a concentração de TNB em condição desnaturante. A quantificação também foi realizada em soluções, sem necessidade de precipitação com TCA, pela adição direta de DTNB em condições nativa ou desnaturante. Neste caso, $170 \mu \mathrm{g}$ de proteína foi adicionada a um volume final de $370 \mu \mathrm{l}$ de tampão Tris- $\mathrm{HCl} 30 \mathrm{mM} \mathrm{pH} \mathrm{7.0,} \mathrm{EDTA} 1 \mathrm{mM}$, com ou sem uréia $8 \mathrm{M}$, e o procedimento foi realizado conforme descrito acima. Agentes oxidantes e redutores, quando utilizados, foram removidos por ultrafiltração ou cromatografia de exclusão molecular. Para amostras nativas (sem adição de uréia), o coeficiente de extinção molar do TNB é $14150 \mathrm{M}^{-1} . \mathrm{cm}^{-1}$.

\subsection{Detecção da formação de ácido sulfênico em proteínas}

Determinação da presença de ácido sulfênico em proteínas foi realizada pelo método do ânion TNB descrito por Ellis \& Poole (1997). Resumidamente, TNB foi preparado através de incubação com uma mistura praticamente equimolar de DTNB e DTT (1 DTNB: 0.9 SH). Proteínas pré-incubadas ou não com peróxidos foram tratadas com um excesso de vinte vezes de TNB. Esse composto reage com ácido sulfênico numa razão de 1:1 (Ellis \& Poole, 1997) gerando um dissulfeto misto entre TNB e um resíduo de cisteína. Excesso de TNB foi removido através de coluna de exclusão molecular PD-10 desalting. Os dissulfetos mistos foram então tratados com um excesso de dez vezes de DTT e a quantidade de TNB liberado (que é igual à quantidade de ácido sulfênico formado) foi determinado espectrofotometricamente.

\subsection{Redução de lipoamida por borohidreto de sódio}

Lipoamida foi incubada com borohidreto de sódio (10 lipoamida:1 $\mathrm{NaBH}_{4}$ ) por 1 hora à $37^{\circ} \mathrm{C}$. Em seguida, foi adicionado $\mathrm{HCl}(1-2 \mathrm{M})$ para reagir com o excesso de borohidreto na reação. Diclorometano foi adicionado (1 volume) para separar as fases orgânica e aquosa (15 minutos após mistura por vortexação). Após esse tempo, a fase orgânica foi coletada e misturada com Sulfato de sódio $\left(\mathrm{Na}_{2} \mathrm{SO}_{4}\right)$ em pó para desidratar a solução. O sobrenadante foi transferido para tubo limpo e a solução foi secada através de borbulhamento por $\mathrm{N}_{2}$. $\mathrm{O}$ 
pellet resultante foi ressuspendido em etanol absoluto e a concentração de lipoamida resultante foi estimada através de reação com DTNB.

\subsection{Solubilização de ácido lipóico pelo método do pH alcalino}

Ácido lipóico foi solubilizado em tampão fosfato de sódio pelo método do $\mathrm{pH}$ alcalino (Suzuki et al., 1994). Resumidamente, $300 \mathrm{mg}$ de ácido lipóico foi adicionado em $50 \mathrm{mM}$ tampão fosfato de sódio $\mathrm{pH}$ 7.4. Nesse $\mathrm{pH}$, ácido lipóico é insolúvel, portanto foi adicionado hidróxido de sódio $(\mathrm{NaOH}) 5 \mathrm{M}$ até a total solubilização. De modo a corrigir o pH da solução para 7.4, foi adicionado $\mathrm{HCl} 1 \mathrm{M}$. Ácido lipóico solubilizado em tampão fosfato $\mathrm{pH} 7.4$ foi utilizado para enriquecer o meio de cultura no processo de indução de modo que as enzimas recombinantes com sítio de ligação a ácido lipóico estivessem 100\% lipoiladas.

\subsection{Produção de anticorpo anti-Ohr}

A produção do anticorpo anti-Ohr foi realizada em colaboração com a Prof ${ }^{a}$. Dr ${ }^{a}$. Mariz Vainzof do Instituto de Biociências da USP, Prof. Dr. José Roberto Kfoury Júnior da Faculdade de Medicina Veterinária da USP e o Dr. Victor Genu Faria.

Duas coelhas fêmeas foram escolhidas para a imunização. Na primeira imunização, foi misturado $350 \mu \mathrm{l}$ de $\operatorname{Ohr}(1 \mathrm{mg} / \mathrm{ml})$ em $150 \mu \mathrm{l}$ de PBS 1X. A esta mistura, foi adicionado o adjuvante de Freund completo (1 Adjuvante : 1 Ohr) em PBS. A solução foi homogeneizada até que o líquido se tornasse branco de uma consistência pastosa. A injeção contendo a mistura foi aplicada no dorso do animal. Alíquotas de sangue foram coletadas após as imunizações como controle negativo. Entre cada imunização, era respeitado um intervalo de duas semanas, sendo que as imunizações posteriores foram feitas com adjuvante de Freund incompleto. Após três imunizações, os coelhos foram sedados, e através de uma seringa, o sangue dos animais foi coletado. O soro das amostras foi recolhido, aliquotado em eppendorfs e armazenado à $-80^{\circ} \mathrm{C}$.

A qualidade e a especificidade do anticorpo anti-Ohr foi atestada conforme se pode observar pela figura 9. O anticorpo anti-Ohr se mostrou bastante específico visto que reage com Ohr recombinante de $X$. fastidiosa em concentrações pequenas além de não marcar extrato protéico de E. coli e $S$. cerevisiae. Interessantemente, anticorpo anti-Ohr não reage com a proteína OsmC que está presente em E. coli. Como visto anteriormente, essa enzima possuía homologia com Ohr. Portanto, anti-Ohr parece ser altamente específico para a proteína Ohr. 


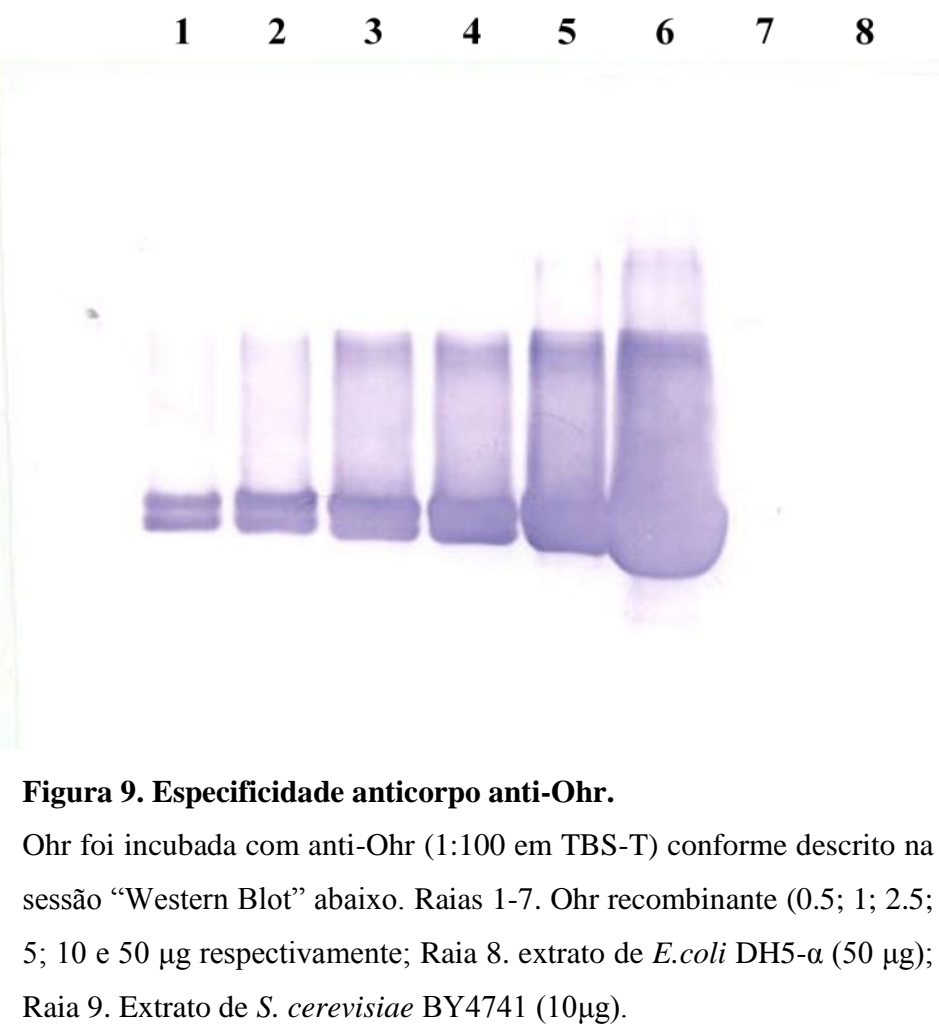

\subsection{Western Blot}

Células de Xylella fastidiosa cepa J1a12 e Escherichia coli DH5- $\alpha$ foram crescidas até atingirem densidade óptica em torno de 0.5 - 0.6 (fase logarítmica). Células foram incubadas com os respectivos tratamentos, centrifugadas e ressuspendidas em tampão de lise $2 X$ sendo então fervida por 3 minutos e congeladas. As amostras foram então aplicadas em gel SDS-Page 10\% e submetidas à eletroforese no sistema Mini Protean III (BioRad). Após o período de corrida, as amostras foram transferidas do gel para uma membrana de nitrocelulose (1 hora; $250 \mathrm{~mA}$ ) como descrito pelo fabricante (BioRad). Completada a transferência foi utilizado o reagente Ponceau para checar a qualidade da transferência. $A$ membrana foi bloqueada com TBS/Leite $5 \%$ por uma hora à temperatura ambiente, incubada com anticorpo primário overnight a $4^{\circ} \mathrm{C}$ e lavada $3 x$ com TBS-Tween $0.1 \%$ por 10 minutos. Anticorpos secundários conjugados com fosfatase alcalina (1:1000 em TBS-T) foram utilizados para revelar a membrana. 


\subsection{Imunoprecipitação de extrato protéico}

Lisados de Xylella fastidiosa e Escherichia coli $(1 \mathrm{mg}$ de proteína total dosada pelo reagente de bradford) foram incubados com Proteína A Sepharose (pré-lavada 2 vezes em Tampão Tris-HCl 20mM, pH 7.5) por 30 minutos após agitação por inversão a $4^{\circ} \mathrm{C}$. Após término da incubação sobrenadante foi coletado após spin em microcentrífuga. Sobrenadante foi incubado na presença de anti-ácido lipóico (1:50) overnight a $4^{\circ} \mathrm{C}$ sob agitação moderada. Pré-cleaning é importante para remover do extrato protéico, proteínas que se ligam inespecificamente às beads (Proteína A Sepharose). Após o período de incubação, sobrenadante na presença do anticorpo foi transferido para $100 \mu$ le beads prélavada e incubado por 4 horas sob agitação leve a $4^{\circ} \mathrm{C}$. Após esse período, o sobrenadante foi descartado após spin em microcentrífuga. Imunoprecipitado foi lavado 5 vezes em $20 \mathrm{mM}$ tampão Tris- $\mathrm{HCl}, \mathrm{pH} 7.5,300 \mathrm{mM} \mathrm{NaCl}$ e então fervido por 5 minutos em tampão de amostra $1 \mathrm{x}$ contendo $10 \mathrm{mM}$ DTT. Eletroforese, transferência e bloqueio da membrana foi executado conforme descrito nas respectivas sessões acima e depois incubada com anticorpo anti-Ohr (1:1000) overnight a $4^{\circ} \mathrm{C}$. A membrana foi subseqüentemente incubada com anticorpo de coelho contra fosfatase alcalina por uma hora e as proteínas foram detectadas após incubação com substrato BCIP/NBT da fosfatase alcalina. (Kirkegaard and Perry laboratories).

\subsection{Separação e detecção de proteínas da fração extracelular de Xylella fastidiosa}

Para isolar proteínas secretadas assim como proteínas que interagem fracamente com a membrana celular, nós usamos um protocolo modificado de Smolka et al., 2003. Resumidamente, $50 \mathrm{ml}$ de cultura de $X$. fastidiosa foi centrifugada e o pellet foi lavado duas vezes com tampão contendo $10 \mathrm{mM}$ Tris- $\mathrm{HCl}$ ( $\mathrm{pH}$ 8.8), $3 \mathrm{mM} \mathrm{KCl} ; 50 \mathrm{mM} \mathrm{NaCl}, 5 \mathrm{mM}$ EDTA e $1 \mathrm{mM}$ PMSF. O sobrenadante de cada etapa de lavagem foi precipitado com mistura gelada de etanol:acetona:ácido acético $(50: 50: 0.1 \mathrm{v} / \mathrm{v} / \mathrm{v})$ a $4^{\circ} \mathrm{C}$ por 30 minutos e solubilizado em $50 \mu \mathrm{l}$ de $10 \mathrm{mM}$ tris- $\mathrm{HCl}(\mathrm{pH}$ 8.8), 0.5\% SDS, $5 \mathrm{mM}$ EDTA e $1 \mathrm{mM}$ PMSF. Após as etapas de lavagem, as células foram então lisadas com $200 \mu \mathrm{l}$ de solução de lise $[10 \mathrm{mM}$ Tris- $\mathrm{HCl}(\mathrm{pH}$ 8.8, 0.5\% (p/v) SDS, 5 mM EDTA e 1 mM PMSF]. Após a adição de $100 \mathrm{mM}$ DTT, as proteínas (da fração celular e do sobrenadante) foram fervidas por três minutos e aplicadas em gel SDS-PAGE 14\% em condições redutoras. Após etapa de eletroforese, o 
gel foi transferido para membrana de nitrocelulose e incubado com anti-Ohr (1:1000) ou antiácido lipóico (1:5000) por uma hora à temperatura ambiente.

\subsection{Determinação da concentração de hidroperóxidos}

A concentração da solução estoque de $\mathrm{H}_{2} \mathrm{O}_{2}$ foi medida pela absorbância a $240 \mathrm{~nm}$ $\left(\varepsilon_{240 \mathrm{~nm}}=43.6 \mathrm{M}^{-1} \cdot \mathrm{cm}^{-1}\right)$. A concentração das soluções estoques de $t$-BHP e CHP foram determinadas espectrofotometricamente a $340 \mathrm{~nm}$ seguindo a oxidação de $\mathrm{NADPH}$ a $37^{\circ} \mathrm{C}$, numa reação contendo volume conhecido de hidroperóxido, glutationa $500 \mu \mathrm{M}$, glutationa redutase $6 \mu \mathrm{g} / \mu \mathrm{l}$, glutationa peroxidase $15 \mathrm{ng} / \mu \mathrm{l}$ e NADPH $200 \mu \mathrm{M}$, em 20 mM tampão Tris$\mathrm{HCl}$ pH 8.0 e 0.1 mM DTPA. A concentração dos hidroperóxidos de lipídios foi determinada por iodometria. Nesta análise, é construída uma curva padrão utilizando-se um hidroperóxido comercial (no caso foi utilizado $t$-BHP) a qual será utilizada para a quantificação do hidroperóxido de lipídio recém sintetizado. Para isto, utilizam-se tubos de ensaio âmbar com tampa e procede-se da seguinte maneira: primeiramente, é adicionado o hidroperóxido (como branco é utilizado apenas o solvente), ácido acético: $\mathrm{CHCl}_{3}$ (3:2) e lodeto de potássio ( $40 \mathrm{mM}$, dissolvido em água previamente borbulhada com $\mathrm{N}_{2}$ ). Aos tubos de ensaio é adicionado $\mathrm{N}_{2}$ por cinco segundos, sendo então incubados por cinco minutos. Após este tempo, é adicionado acetato de cádmio $5 \%(\mathrm{~m} / \mathrm{v})$. Ao final, os tubos são agitados e a absorbância da fase menos densa (superior) é lida em espectrofotômetro a $353 \mathrm{~nm}$. A partir da curva padrão criada, podemos estabelecer a quantidade de hidroperóxido sintetizado.

\subsection{Ensaio FOX (Ferrous oxidation in xylenol orange assay)}

As concentrações de hidroperóxidos no meio de reação foram determinadas através do ensaio FOX como descrito por Jiang et al., 1992. Brevemente, o ensaio se baseia na oxidação de $\mathrm{Fe}^{+2}$ à $\mathrm{Fe}^{+3}$ na presença de peróxidos. Xylenol orange é um quelante de $\mathrm{Fe}^{+3}$ que, ao se ligar a este, absorve no comprimento de onda de $560 \mathrm{~nm}$. Desse modo, quanto maior for a quantidade do hidroperóxido presente no meio de reação, maior será a oxidação à $\mathrm{Fe}^{+3}$ com conseqüente aumento de absorbância a $560 \mathrm{~nm}$. A concentração remanescente de hidroperóxido foi determinada em comparação com a absorbância a $560 \mathrm{~nm}$ de uma amostra padrão de hidroperóxido. O ensaio é realizado nas seguintes condições: $50 \mathrm{mM}$ tampão Hepes (pH 7.4), 0.1 mM DTPA e 1 mM Azida. As concentrações de Ohr, peróxido e tiól redutor variaram nos ensaios. As reações foram iniciadas após a adição do composto 
tiólico e interrompida em diferentes intervalos de tempo pela adição de $\mathrm{HCl}(200 \mathrm{mM})$. A mistura de reação é incubada com FOX (sulfato ferroso $25 \mathrm{mM}$, xilenol orange $100 \mu \mathrm{M}, \mathrm{BHT}$ $4 \mathrm{mM}$ e ácido sulfúrico $250 \mathrm{mM}, \mathrm{pH}$ 1.6) na proporção de 9 FOX : 1 Reação. Incuba-se à $37^{\circ} \mathrm{C}$ por trinta minutos e, em seguida, se faz a leitura em espectrofotômetro. O ensaio foi realizado na presença e ausência de Ohr, medindo com isso a atividade peroxidásica de Ohr na presença de tióis.

\subsection{Ensaio de atividade dissulfeto redutase}

A atividade dissulfeto redutase dos sistemas redutores lipoamida e tiorredoxina foi determinada através do composto DTNB (reagente de Elman). As reações foram monitoradas espectrofotometricamente à $412 \mathrm{~nm}$ como resultado da absorção do composto TNB $\left(\varepsilon_{412 \mathrm{~nm}}=14100 \mathrm{M}^{-1} \cdot \mathrm{cm}^{-1}\right)$. A mistura de reação contêm $50 \mathrm{mM}$ tampão fosfato de sódio (pH 7.4), $1 \mathrm{mM}$ DTPA, $0.5 \mathrm{mM}$ DTNB e $0.2 \mathrm{mM} \mathrm{NAD(P)H}$. As concentrações dos tióis redutores e das enzimas recombinantes utilizadas variaram entre os ensaios e estão indicadas nas legendas de cada figura.

\subsection{Ensaio de atividade peroxidásica da proteína Ohr pelo sistema lipoamida}

No ensaio, lipoamida ou grupo lipóico de enzimas é reduzido por Lpd à custa de elétrons provenientes do NADH (modificado de Bryk et al., 2002). A reação é iniciada com a adição do hidroperóxido e monitorada através do consumo de $\mathrm{NADH}\left(\varepsilon_{340 \mathrm{~nm}}=6290 \mathrm{M}^{-1} \mathrm{~cm}^{-}\right.$ ${ }^{1}$ ). O ensaio é realizado nas seguintes condições: $50 \mathrm{mM}$ tampão fosfato de sódio ( $\mathrm{pH} 7.4$ ), $0.1 \mathrm{mM}$ DTPA e $0.2 \mathrm{mM} \mathrm{NADH}$ à $37^{\circ} \mathrm{C}$. As concentrações das enzimas, lipoamida livre e peróxidos utilizadas no ensaio variaram conforme o experimento e estão indicadas nas legendas das figuras.

\subsection{Determinação do $\mathrm{pK}_{\mathrm{a}}$ de cisteínas reativas}

No intuito de determinar o $\mathrm{pK}_{\mathrm{a}}$ da cisteína peroxidásica de Ohr foram utilizadas três técnicas diferentes: 


\section{Absorção do tiolato à $240 \mathrm{~nm}$}

Esse ensaio se baseia na absorção do tiolato ( $\left.S^{-}\right)$na faixa do UV à $240 \mathrm{~nm}\left(\varepsilon_{240 \mathrm{~nm}}=\right.$ $4000 \mathrm{M}^{-1} \cdot \mathrm{cm}^{-1}$, Nelson \& Creighton, 1994). Uma alíquota de Ohr foi oxidada com diamida em excesso (10:1) enquanto outra alíquota foi reduzida com DTT (100mM) por duas horas à temperatura ambiente. Diamida e DTT foram removidos em coluna de exclusão molecular PD-10 em $5 \mathrm{mM}$ tampão fosfato de sódio, $25 \mathrm{mM} \mathrm{NaCl}$. A enzima (reduzida e oxidada) foi incubada em diversos tampões $(100 \mathrm{mM}$ ) com faixas de $\mathrm{pH}$ entre 4 - 11 (Tampão Acetato de Sódio para pHs 4 ; 4.5; 5; 5.5. Tampão MES-NaOH para pHs 6; 6.5. Tampão Tris-HCl para pHs $7 ; 7.5 ; 8 ; 8.5$; 9. Tampão Carbonato-Bicarbonato para pHs $9.5 ; 10 ; 10.5 ; 11$ ) contendo $\mathrm{NaCl} 200 \mathrm{mM}$ e DTPA $1 \mathrm{mM}$. Como tirosina e triptofano absorvem no comprimento de onda de 240nm, a absorbância do ânion tiolato foi detectada pela comparação com o espectro da Ohr na forma oxidada onde somente o tiolato está ausente.

\section{Modificação química por Monobromobimano (MB)}

Monobromobimano é um reagente químico estável, não fluorescente, capaz de reagir com compostos tiólicos tais como glutationa e sulfidrilas de proteínas alvo em sua forma desprotonada, formando um aduto fluorescente ( $\lambda_{\text {exc }} 396 \mathrm{~nm}, \lambda_{\mathrm{em}} 482 \mathrm{~nm}$ ) capaz de ser detectado por um fluorímetro (Kosower et al., 1979). Ohr foi reduzida com excesso de DTT (100mM) por duas horas à temperatura ambiente que foi posteriormente removido em coluna de exclusão molecular PD-10 com 5 mM tampão Hepes pH 7.4. Em seguida, Ohr (10 $\mu \mathrm{M})$ foi incubada com MB $(2 \mu \mathrm{M})$ em tampões $(50 \mathrm{mM})$ à diferentes $\mathrm{pHs}$ (3.0 à 7.0) por 20 minutos à temperatura ambiente. A força iônica da solução foi ajustada pela adição de $\mathrm{NaCl}$ (500 mM). As velocidades de alquilação por MB foram determinadas pela extrapolação da inclinação máxima das cinéticas. Os valores de $\mathrm{pK}_{\mathrm{a}}$ foram determinados utilizando a equação de Henderson-Hasselbach no programa GraphPad ${ }^{\circledR}$ Prism4. Como controle da reação, uma amostra de Ohr previamente reduzida por DTT foi alquilada com MB (2 $\mu \mathrm{M})$ por 20 minutos em 50 mM tampão Fosfato de sódio $\mathrm{pH} 7.4 ; 500 \mathrm{mM} \mathrm{NaCl}$ e seu excesso removido em coluna desalting. A amostra foi eluída em 5 mM tampão Hepes pH 7.4 e posteriormente a fluorescência da amostra foi determinada em diferentes pHs (3.0 à 7.0). Dessa maneira, foi mostrado que não há diferença na fluorescência de Ohr alquilado com $\mathrm{MB}$ para diferentes $\mathrm{pHs}$, indicando que o $\mathrm{pH}$ não interfere na fluorescência do aduto Ohr$\mathrm{MB}$.

A utilização desse composto como método de detecção do pKa de grupos tióis foi proposta pelo Dr. Gerardo Ferrer-Sueta (Universidad de la Republica, Montevidéu, Uruguai). 


\section{Modificação química por lodoacetamida (IAM)}

Ohr recombinante de $X$. fastidiosa foi reduzida com $100 \mathrm{mM}$ DTT por 1 hora à temperatura ambiente. DTT foi removido em coluna de exclusão molecular PD-10 na presença de $5 \mathrm{mM}$ de tampão Tris- $\mathrm{HCl}$ pH 7.4. Ohr $(20 \mu \mathrm{M})$ foi então incubada com $300 \mu \mathrm{M}$ de IAM na presença de tampões $(100 \mathrm{mM})$ em diferentes faixas de $\mathrm{pH}$ por 3 minutos à T.A em um volume final de reação de $10 \mu \mathrm{l}$. Após o período, mistura de reação foi colocada em banho de gelo (quenching) e diluída 100 x na reação para dosar a atividade peroxidásica de Ohr ( tópico 3.21). Foi feito um controle da incubação nos respectivos tampões na ausência de IAM.

\subsection{Preparação de RNA e Northern Bloting}

Células de Xylella fastidiosa J1a12 foram crescidas à temperatura ambiente na ausência de agitação por aproximadamente sete dias em meio PWG. Os respectivos tratamentos realizados nas células durante esse período estão detalhados na legenda das respectivas figuras. De modo geral, as células foram coletadas ainda na fase log de crescimento e centrifugadas a $4^{\circ} \mathrm{C}, 4000 \times \mathrm{g}$ e mantidas no freezer até o momento da extração do RNA. Como experimento controle, linhagem BL21(DE3) de E. coli capaz de superexpressar Ohr através do vetor de expressão pET-15b foi crescida à $37^{\circ} \mathrm{C}$ até atingir densidade óptica (OD) em torno de 0.6-1.0. Após esse período, foi adicionado 1mM de IPTG para a expressão de Ohr. Em determinados tempos, indicados nas legendas das respectivas figuras, as células foram coletadas através de centrifugação conforme descrito acima.

Células de todas as linhagens testadas foram coletadas por centrifugação a frio, com os devidos ajustes de volume para obtenção da mesma quantidade de células de todas as amostras. A extração do RNA de todas as células foi feita pelo método do Trizol (Invitrogen). As células congeladas foram lisadas imediatamente em $1 \mathrm{ml}$ de Trizol, incubadas à $65^{\circ} \mathrm{C}$ por 10 minutos e em seguida foi adicionado $0.2 \mathrm{ml}$ de clorofórmio. A mistura foi homogeneizada invertendo os tubos por 15 segundos seguido de incubação à temperatura ambiente por 5 minutos e centrifugação por 15 minutos à $12000 \times$ g. A fase aquosa foi coletada e o RNA foi precipitado por 1 hora à $-70^{\circ} \mathrm{C}$, através da adição de isopropanol. Os tubos foram então centrifugados à $12000 \times \mathrm{g}$ por 20 minutos à $4^{\circ} \mathrm{C}$, o sobrenadante foi descartado e 0 precipitado lavado em etanol 70\%. O precipitado foi seco em uma bomba de vácuo por 5 minutos à temperatura ambiente e solubilizado por 10 minutos à $60^{\circ} \mathrm{C}$ em $50 \mu$ de água milliQ autoclavada e filtrada. A qualidade e a quantidade de RNAs foram avaliadas 
espectrofotometricamente $\left(A_{260} \mathrm{~nm}\right)$ e eletroforese em gel de agarose $1.2 \%$ desnaturante (MOPS 1x, formaldeído 6.5\%).

Após a etapa de eletroforese, RNA em gel de agarose foi transferido para membrana de nitrocelulose Hybond- $\mathrm{N}^{+}$(Amershan Biosciences) por capilaridade, utilizando-se solução SSC (cloreto de sódio 3M, citrato de sódio 0,3M). RNA foi fixado na membrana através de exposição a luz ultravioleta por dois minutos. Após a secagem da membrana por duas horas em estufa a $80^{\circ} \mathrm{C}$, esta foi submetida à pré-hibridização em forno Isotemp (Fisher Scientific) a $40^{\circ} \mathrm{C}$ por 4 horas em solução de hibridização, contendo 5X SSPE (20X: NaCl 3,6M, fosfato de sódio 0,2M, EDTA 0,02M), solução Denhardt's 5X (100X: BSA 2\%, Ficoll 2\%, PVP 2\%), SDS $0.5 \%$, formamida $50 \%$ e excesso de DNA de salmão desnaturado. As hibridizações com a sonda marcada radioativamente (descrita na próxima sessão) foram realizadas com a adição das sondas previamente desnaturadas $\left(100^{\circ} \mathrm{C}\right.$ por 10 minutos seguido de banho de gelo por 10 minutos) através de incubação overnight a $42^{\circ} \mathrm{C}$. A membrana foi então lavada $2 x$ com solução de SDS + SSC por quinze minutos à temperatura ambiente. Após as lavagens, foi conferido através de contador geiger se a membrana incorporou radioatividade, e em seguida a membrana foi exposta ao filme de raios- $X$ à $-80^{\circ} \mathrm{C}$.

\subsection{Marcação radioativa de DNA por oligonucleotídeos iniciadores aleatórios (Random Primed Synthesis). Obtenção de sondas}

DNA purificado de fragmento do gene alvo foi desnaturado à $100^{\circ} \mathrm{C}$ por 10 minutos seguido de banho de gelo por 10 minutos. Após etapa de desnaturação, DNA foi incubado em mistura de reação contendo desoxirribonucleotídeos, exceto ATP, hexanucleotídeos (1 $\mu \mathrm{g} / \mu \mathrm{l}$ ) (Boehringer), a enzima klenow (Invitrogen) com o respectivo tampão e [ $\left.{ }^{\alpha 32} \mathrm{P}\right] \mathrm{dATP}$ (Perkin Elmer ${ }^{\circledR}$ Boston, MA, USA). A reação de polimerização ocorreu à temperatura ambiente por vinte minutos seguido de inativação da Klenow à $95^{\circ} \mathrm{C}$ por cinco minutos (Ausubel et al., 1994). Amostra foi aplicada em uma coluna SC300 HR (Amersham Biosciences) e centrifugada por dois minutos a 3000 RPM. Por último, novamente amostra foi incubada a $100^{\circ} \mathrm{C}$ por 10 minutos seguido de banho de gelo por 10 minutos.

Sonda para ohr e rRNA 16s foi obtida por reação de PCR utilizando primers específicos e DNA genômico de Xylella fastidiosa como molde. Os produtos de PCR foram purificados através de kit Wizard ${ }^{\circledR}$ Plus SV (Promega, Madison, WI, USA). 


\section{RESULTADOS}

\subsection{Caracterização da atividade enzimática de Ohr}

Os resultados apresentados nesse tópico (4.1) foram obtidos durante a minha iniciação científica e início do meu doutorado sendo que dessa maneira resolvi apresentálos conjuntamente em uma forma resumida, pois maiores detalhes estão presentes em dois artigos científicos na sessão de anexos da tese.

Através do processo de anotação das ORFs (Open Reading Frame) do seqüenciamento do genoma de Xylella fastidiosa (Simpson et al., 2000), observamos que uma das ORFs codificava para um gene que possuía alta similaridade com o gene ohr de Xanthomonas campestris. Foi observado que este gene está envolvido na defesa antioxidante contra peróxidos orgânicos mas não a $\mathrm{H}_{2} \mathrm{O}_{2}$ e outras fontes geradoras de ROS (Mongkolsuk et al., 1998). Análise da seqüência primária de aminoácidos mostrou que Ohr possui dois domínios altamente conservados: um mais amino(N)-terminal e outro carboxi(C)terminal sendo que em cada um desses domínios está presente um resíduo de cisteína (Cys61 e Cys125) que é conservado em todos os representantes da família Ohr/OsmC (Figura 10).

Além disso, a cisteína do domínio carboxi-terminal está presente em um motivo VCP (valina-cisteína-prolina) e é característico de algumas proteínas da família das peroxirredoxinas (Rhee et al., 1998). Dessa forma, postulamos que Ohr poderia atuar como uma peroxidase detoxificando diretamente hidroperóxidos através da reação com sua cisteína reativa. 


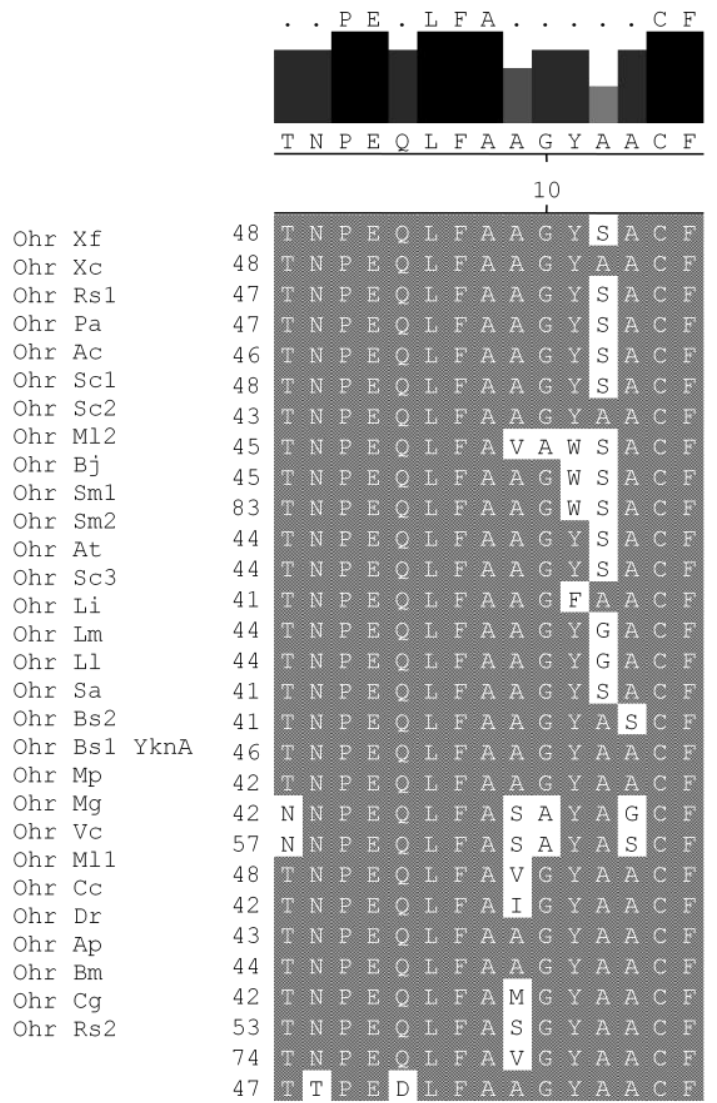

Domain 1
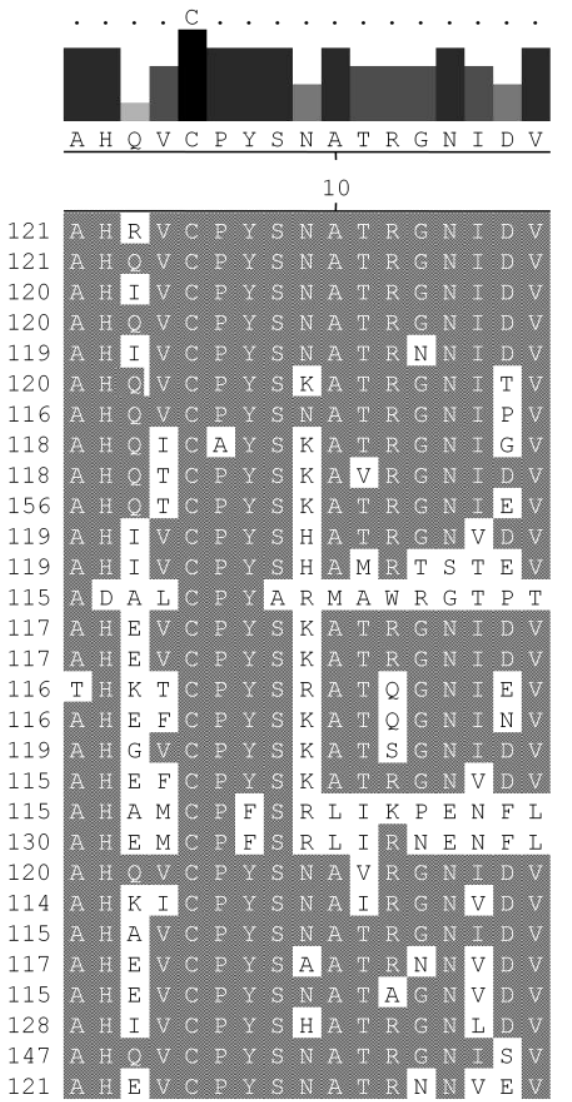

Domain 2

Figura 10. Domínios da proteína Ohr no qual estão presentes as cisteínas conservadas.

As seqüências apresentadas nesse esquema foram o consenso obtido pelo método do Clustal W do software MegAlign 5.01 (DNAstar inc.). As letras em cinza representam os resíduos que estão presentes na seqüência consenso. Modificado de Cussiol et al., 2003 anexo I.

De fato, após a obtenção de Ohr recombinante de $X$. fastidiosa, observamos que Ohr era capaz de detoxificar hidroperóxidos através de ensaio de atividade FOX. Ohr era capaz de detoxificar tanto hidroperóxidos orgânicos como $\mathrm{H}_{2} \mathrm{O}_{2}$, porém a eficiência de remoção de peróxidos orgânicos, como cumeno hidroperóxido (CHP) era muito maior do que $\mathrm{H}_{2} \mathrm{O}_{2}$ (Figura 11). Em ambos os casos, Ohr era ativa somente quando o ditiól DTT (e não monotióis como $\beta$-mercaptoetanol) estava presente na mistura de reação.

Vimos que a habilidade de Ohr em detoxificar hidroperóxidos era dependente de seus resíduos de cisteínas, pois Ohr previamente tratada com NEM, um alquilante de sulfidrilas (SH), perdia sua atividade. Além disso, Ohr mostrou atividade antioxidante de proteção a glutamina sintetase (GS) contra inativação pelo sistema oxidante $\mathrm{Fe}^{+3} / \mathrm{O}_{2} / \mathrm{DTT}$ ou $\mathrm{Fe}^{+3} / \mathrm{O}_{2} / \mathrm{DHLA}$, mas não pelo sistema $\mathrm{Fe}^{+3} / \mathrm{O}_{2} /$ ascorbato indicando que Ohr possui atividade peroxidásica dependente de tiól, ou seja, é necessário compostos tiólicos tais como DTT ou DHLA para reduzir as cisteínas de Ohr (dados mostrados em Cussiol et al., 2003, anexo I). 

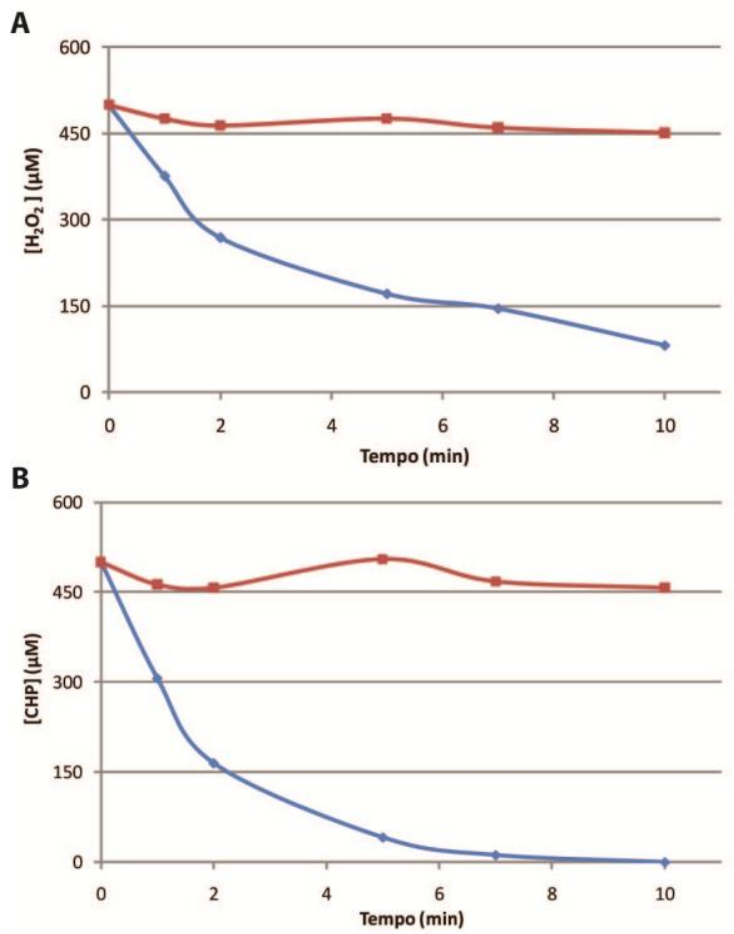

Figura 11. Atividade peroxidásica dependente de tiól de Ohr.

A concentração dos peróxidos foi determinada em diferentes períodos de tempo através do ensaio FOX como descrito em "Materiais e Métodos". As reações foram iniciadas pela adição de DTT (0.5 $\mathrm{mM})$ a $37^{\circ} \mathrm{C}$. "A" representa a cinética da decomposição de $\mathrm{H}_{2} \mathrm{O}_{2}$ na presença de $\mathrm{Ohr}(100 \mathrm{ng} / \mu \mathrm{l})$ e "B" representa a cinética de CHP na presença de Ohr $(10 \mathrm{ng} / \mu \mathrm{l})$. - (em vermelho) representa a mistura de reação sem Ohr (DTT + peróxido) e $\bullet$ (em azul) representa o sistema completo (DTT + peróxido + Ohr). Modificado de Cussiol et al., 2003 anexo I.

Interessantemente, compostos ditiólicos como DTT e DHLA foram capazes de suportar a atividade peroxidásica de Ohr no ensaio FOX. O mesmo efeito não foi observado para compostos monotiólicos, como GSH e $\beta$-mercaptoetanol, mesmo quando utilizados em concentrações de até $5 \mathrm{mM}$ (Figura 12), uma concentração dez vezes maior do que as concentrações utilizadas para DTT e DHLA. Além disso, tiorredoxina de Saccharomyces cerevisiae e de Spirulina, também não foram capazes de suportar a atividade de Ohr (dados mostrados em Cussiol et al., 2003, anexo I). 


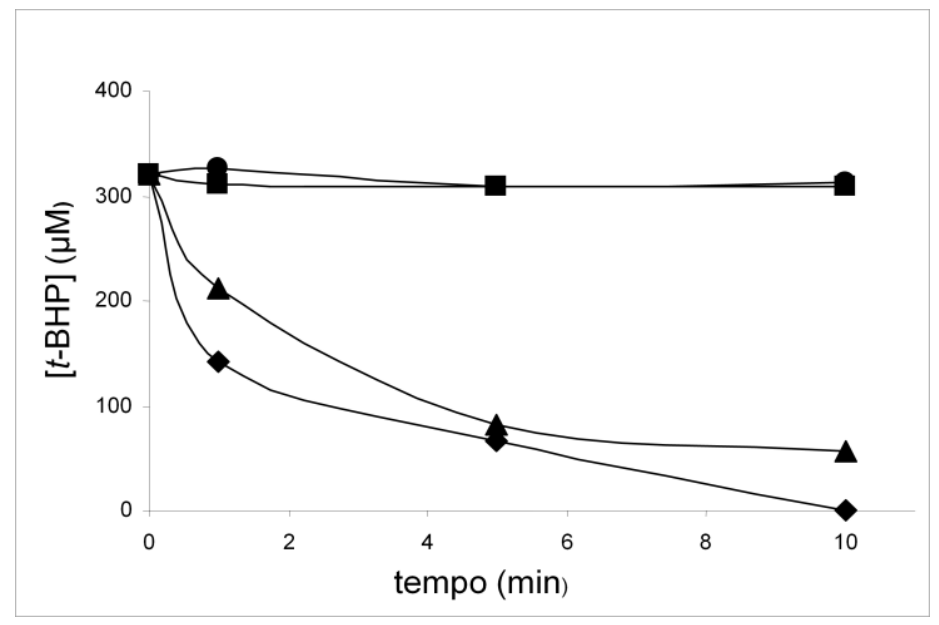

Figura 12. Especificidade de tiól da atividade peroxidásica de Ohr.

A concentração de $t$-BHP foi determinada em diferentes períodos de tempo através do ensaio FOX como descrito em "Materiais e Métodos". As reações foram iniciadas pela adição de compostos tiólicos na presença de $\mathrm{Ohr}(5 \mathrm{ng} / \mu \mathrm{l})$ à $37^{\circ} \mathrm{C}$. Os símbolos representam as reações com os seguintes compostos tiólicos. • $(\mathrm{GSH}=5 \mathrm{mM}), \boldsymbol{\square}(2$-mercaptoetanol $=5 \mathrm{mM}), \boldsymbol{\Delta}(\mathrm{DTT}=0.5$ $\mathrm{mM}) \mathrm{e} \diamond(\mathrm{DHLA}=0.5 \mathrm{mM})$. Modificado de Cussiol et al., 2003 anexo I.

Análise por mutação sítio-dirigida, na qual as cisteínas foram substituídas por resíduos de serina (C61S e C125S), mostrou que a cisteína que reage diretamente com o peróxido (peroxidásica) é a $\mathrm{N}$-terminal $\left(\mathrm{Cys}_{\mathrm{p}} 61\right)$ visto que somente no mutante $\mathrm{C} 125 \mathrm{~S}$ observamos a formação de ácido sulfênico (SOH) pelo ensaio do TNB (Figura 13).

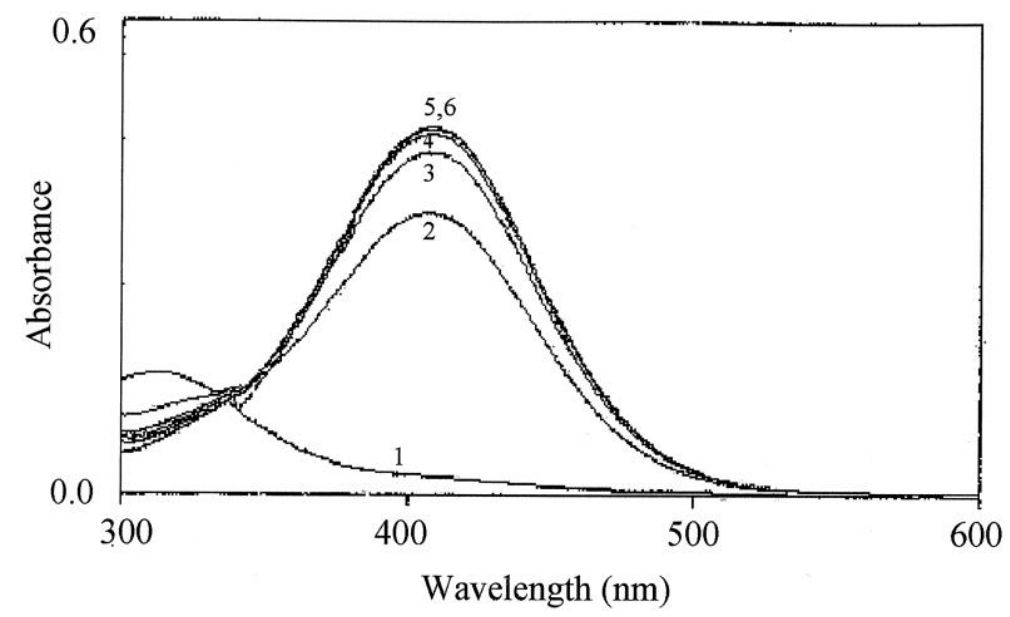

Figura 13. Formação de ácido sulfênico em Ohr C125S.

Ácido sulfênico em Ohr C125S foi medido através de sua reação com TNB. Ohr C125S $(100 \mu \mathrm{M})$ sem nenhum pré-tratamento foi incubada com TNB $(4 \mathrm{mM})$ por 15 minutos à temperatura ambiente. O dissulfeto misto foi preparado como descrito na sessão “ "Material e Métodos". Liberação do TNB do dissulfeto misto foi monitorada após 1,3,5 e 10 minutos após adição de DTT em excesso molar de dez vezes o que corresponde aos espectros de 2-6. Espectro 1 corresponde ao dissulfeto misto anterior a adição de DTT. Modificado de Cussiol et al., 2003 anexo I. 
Provavelmente, Cys 125 é responsável pela resolução do ácido sulfênico da Cys 61 a uma ponte dissulfeto, sendo portanto denominada como a cisteína de resolução (Cys 125$)$. Análises por SDS-PAGE não redutor de Ohr tratada com diferentes peróxidos não mostrou a formação de dímero mesmo após tratamentos com $\mathrm{H}_{2} \mathrm{O}_{2}$ e $t$-BHP em altas concentrações. Ao contrário, foi observada a presença de duas bandas que migravam próximas uma da outra em Ohr sendo portanto conformações diferentes do mesmo monômero (Figura 14).

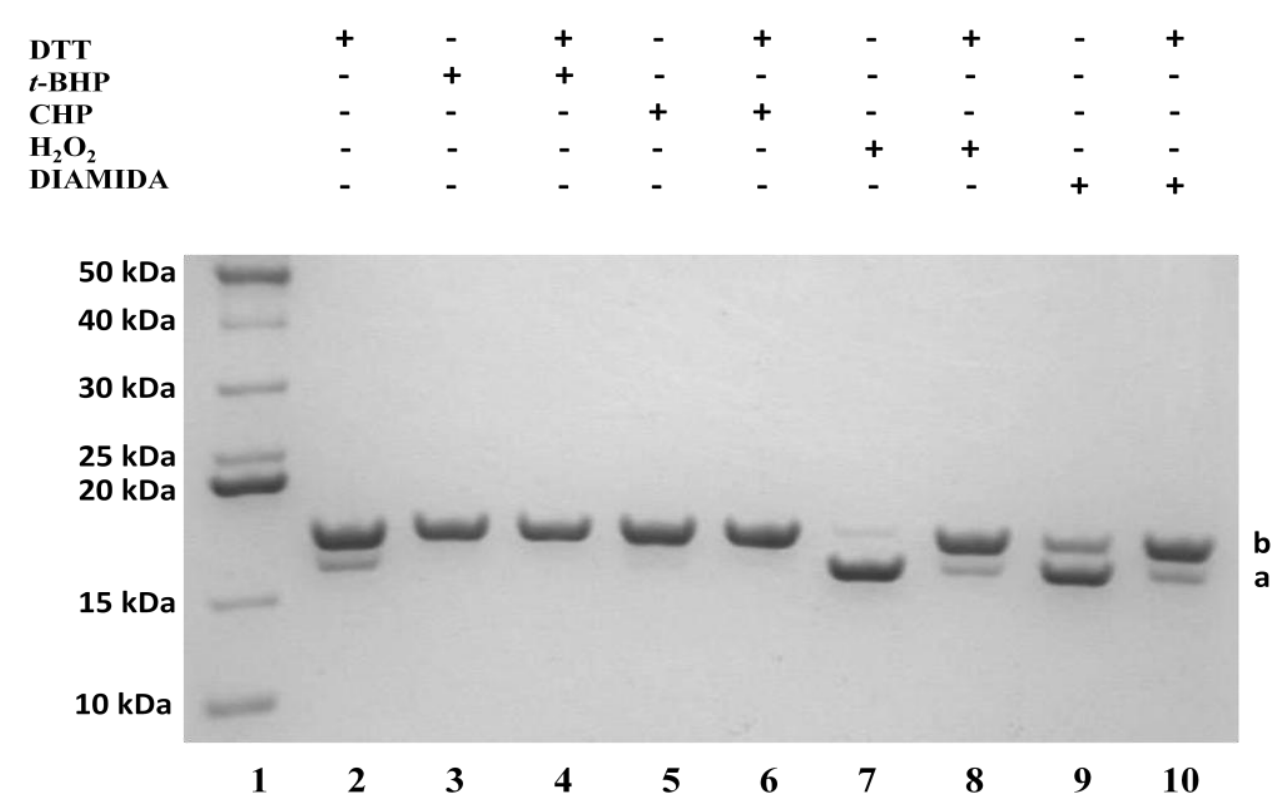

Figura 14. Análises por SDS-PAGE não redutor da migração de Ohr recombinante de Xylella fastidiosa.

Raia 1. Padrão de peso molecular, 2. Ohr tratada com 100 mM DTT por 90 minutos. Todos os oxidantes adicionados nas amostras correspondentes as bandas de 3-10 foram utilizados na proporção de 17:1 (300 $\mu \mathrm{M}$ Ohr: $5.1 \mathrm{mM}$ oxidante) e foram incubados overnight à temperatura ambiente. Em alguns casos (bandas 4,6,8 e 10), após oxidação de Ohr, o excesso de oxidante foi removido por eluição em coluna desalting PD-10 e tratadas com 100 mM DTT à temperatura ambiente. Modificado de Oliveira et al., 2006 anexo II.

Tratamento de Ohr com diamida, um indutor de pontes dissulfeto, faz com que haja aumento de intensidade da banda "a", de forma similar a tratamentos com $\mathrm{H}_{2} \mathrm{O}_{2}$ (Figura 14, bandas 7 e 9 respectivamente). Ohr pré-tratada com $\mathrm{H}_{2} \mathrm{O}_{2}$ ou diamida e depois tratada com DTT (bandas 8 e 10 respectivamente) migra preferencialmente para a posição "b" como esperado para a redução de uma ponte dissulfeto intramolecular. Interessantemente, Ohr tratada com $t$-BHP e CHP (bandas 3 e 5 respectivamente) não induz a formação da banda "a" mas sim da banda "b" indicando que nesses casos a cisteína provavelmente esteja sendo superoxidada $\left(\mathrm{SO}_{2} \mathrm{H}\right.$ ou $\left.\mathrm{SO}_{3} \mathrm{H}\right)$ apresentando a mesma migração que a forma reduzida. Através da reação de Ohr com o composto DTNB (Figura 15), foi observado que DTT conseguia regenerar a forma reduzida de Ohr somente quando esta era previamente 
oxidada por $\mathrm{H}_{2} \mathrm{O}_{2}$ ou diamida mas não por peróxidos orgânicos como $t$-BHP e $\mathrm{CHP}$, mostrando que o dissulfeto intramolecular é de fato um intermediário do ciclo catalítico. É importante ressaltar que a superoxidação da cisteína reativa de Ohr foi observada somente após longos tratamentos com peróxido em excesso molar (17 peróxido : 1 Ohr).

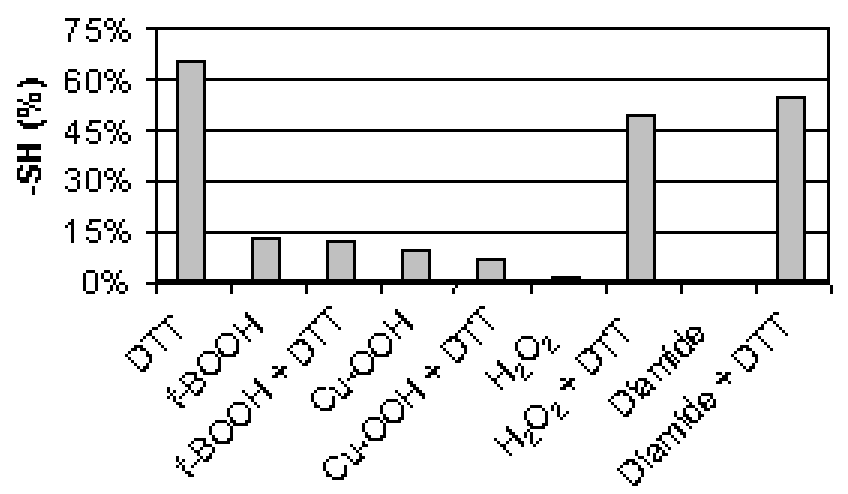

Figura 15. Análise dos intermediários do ciclo catalítico de Ohr.

As sulfidrilas de Ohr foram quantificadas por reação com o composto DTNB. Ohr foi incubada com vários oxidantes durante uma semana à $4^{\circ} \mathrm{C}$. Agentes redox foram fixados na proporção de 17:1 de Ohr. As colunas mostrando dois nomes designa que após o tratamento com o agente oxidante, este foi removido por eluição em coluna desalting PD-10 e a proteína foi tratada com $100 \mathrm{mM}$ de DTT (uma hora e meia à temperatura ambiente) na tentativa de regenerar a sulfidrila de Ohr.

Baseado nesses resultados, foi proposto um mecanismo catalítico para a enzima Ohr onde o tiól da $\mathrm{Cys}_{\mathrm{p}} 61$ é oxidado a ácido sulfênico sendo posteriormente condensado com a Cys ${ }_{r} 125$, gerando uma ponte dissulfeto intramolecular. Essa ponte dissulfeto é reduzida por agentes ditiólicos tais como DTT ou DHLA Como Ohr não aceita GSH e tiorredoxina (principais redutores biológicos de tióis peroxidases como glutationa peroxidases e peroxirredoxinas) como substrato, a descoberta de um mecanismo de redução in vivo de Ohr se mostrou um caminho interessante a se seguir.

Durante o início do meu doutorado, publiquei ainda como co-autor um artigo, onde através da resolução da estrutura de Ohr de $X$. fastidiosa pelo então pós-doutor Marcos Antonio de Oliveira, associado com dados bioquímicos muitos dos quais obtidos por mim, permitiu o aprofundamento do conhecimento do mecanismo da ação catalítica de Ohr (Oliveira et al., 2006 anexo II). Esse artigo está presente na sessão dos anexo à tese. 
Ohr é um homodímero de forma elíptica composto por duas folhas $\beta$ composta por seis fitas cercando duas alfa hélices centrais formando uma estrutura em forma de barril (Figura 16).

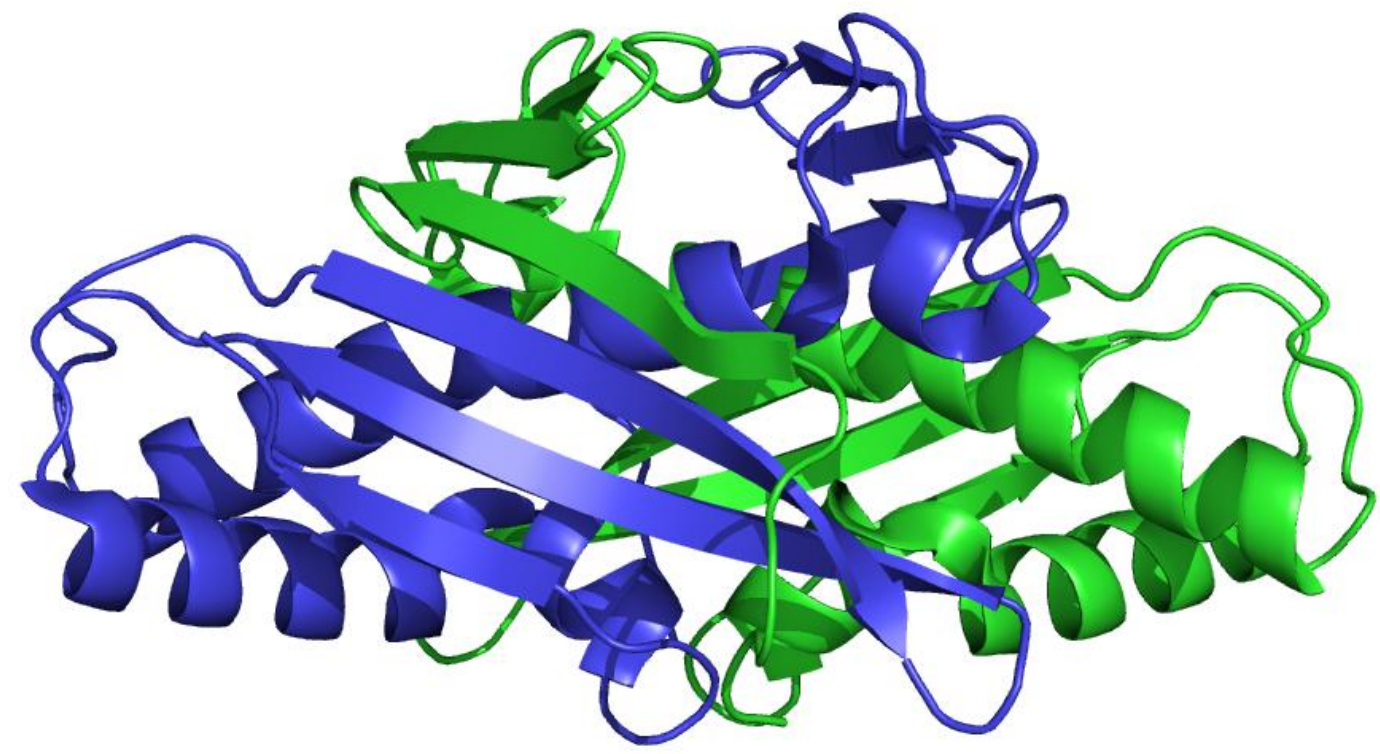

Figura 16. Estrutura tridimensional do homodímero de Ohr de Xylella fastidiosa.

Monômeros de Ohr (PDB ID: 1ZB9) estão representados pelas cores azul e verde. Figura gerada pelo programa PyMOL (www.pymol.org).

Além das cisteínas do sítio ativo, dois outros resíduos desempenham papel importante no ciclo catalítico. Um resíduo de arginina (Arg 19) faz uma ligação de hidrogênio com a cisteína peroxidásica (Cys 61) e uma ponte salina com um resíduo de glutamato (Glu 51) abaixando o $\mathrm{pK}_{\mathrm{a}}$ da Cys 61 estabilizando assim o ânion tiolato (Figura 17). Este, por ser nucleófilo, reage rapidamente com oxidantes como hidroperóxidos. De fato, mutação no resíduo de arginina na Ohr de $P$. aeruginosa diminui consideravelmente a atividade da enzima. Apesar dos resíduos de cisteína estarem distantes na seqüência primária de aminoácidos, podemos observar pela figura que na estrutura quaternária eles estão bem próximos. Dessa maneira, a formação de uma ponte dissulfeto intramolecular é viável de acontecer sem que haja um grande rearranjo do sítio ativo. Além disso, podemos supor que Ohr deve provavelmente estar presente fisiologicamente como um homodímero pois os resíduos Arg 19 e Glu 51 que interagem com a Cys 61 pertencem ao outro monômero. 


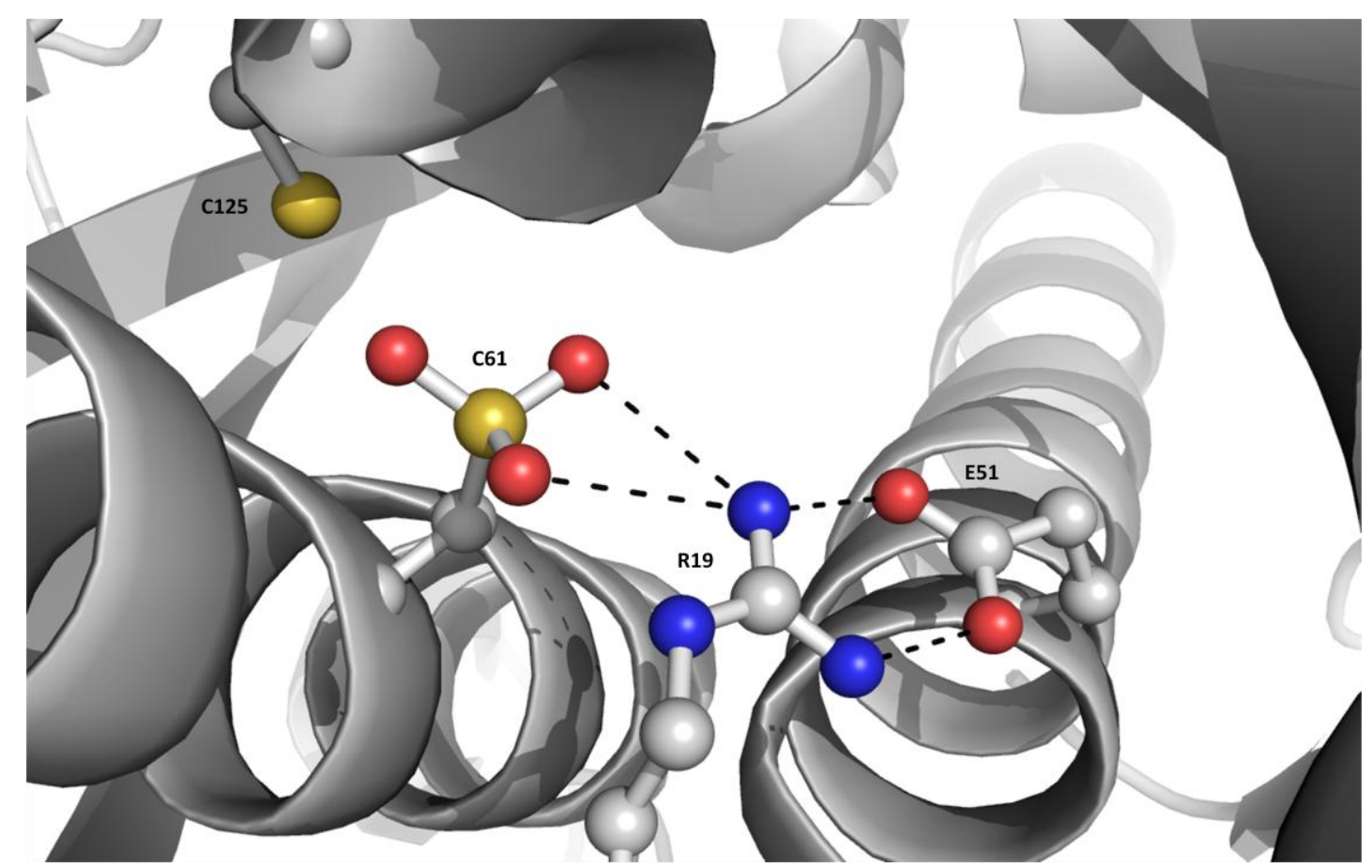

Figura 17. Interações polares entre aminoácidos do sítio ativo de Ohr de Xylella fastidiosa.

Nas representações estruturais estão destacados as cadeias laterais dos resíduos de aminoácidos componentes do sítio ativo de Ohr (PDB ID: 1ZB9). Os átomos destes aminoácidos estão representados por bastões e seguem as cores: branco (carbono), amarelo (enxofre), vermelho (oxigênio) e azul (nitrogênio). Linhas tracejadas representam as interações polares entre os aminoácidos. Figura gerada pelo programa PyMOL (www.pymol.org).

Durante o refinamento da estrutura tridimensional de Ohr, foi observado uma densidade eletrônica não esperada localizada no sítio ativo de Ohr. Essa densidade eletrônica era compatível com a presença de uma molécula de polietileno glicol (PEG) usada comumente no processo de cristalização como um agente precipitante. Análises mostraram que a cadeia carbônica de PEG realizava interações hidrofóbicas com diversos aminoácidos de Ohr ajudando a posicionar essa molécula dentro do sítio ativo. Trabalhamos com a hipótese de que a molécula de PEG não é um mero artefato de cristalização, podendo mimetizar a ligação de algum substrato endógeno, possivelmente hidroperóxidos e redutores hidrofóbicos, pois diferentemente de outras tióis peroxidases (Gpx e Prx), a cisteína reativa de Ohr está localizada em um ambiente altamente hidrofóbico e enterrada na estrutura, sendo, portanto, de difícil acesso a moléculas hidrofílicas, mas favorecendo a interação de Ohr com substratos hidrofóbicos e alongados.

De fato, alguns trabalhos mostram que moléculas de PEG podem ocupar sítios e canais normalmente pertencentes a ácidos graxos de cadeia longa (Delker et al., 2004; Barrett et al., 2004; Ambrosio et al., 2005). Outras estruturas de Ohr pertencentes a Pseudomonas aeruginosa (Lesniak et al., 2002) e Deinococcus radiodurans (Meunier-Jamin 
et al., 2004) corroboram com estes resultados. De posse desses resultados, propusemos um mecanismo catalítico para Ohr (Figura 18).
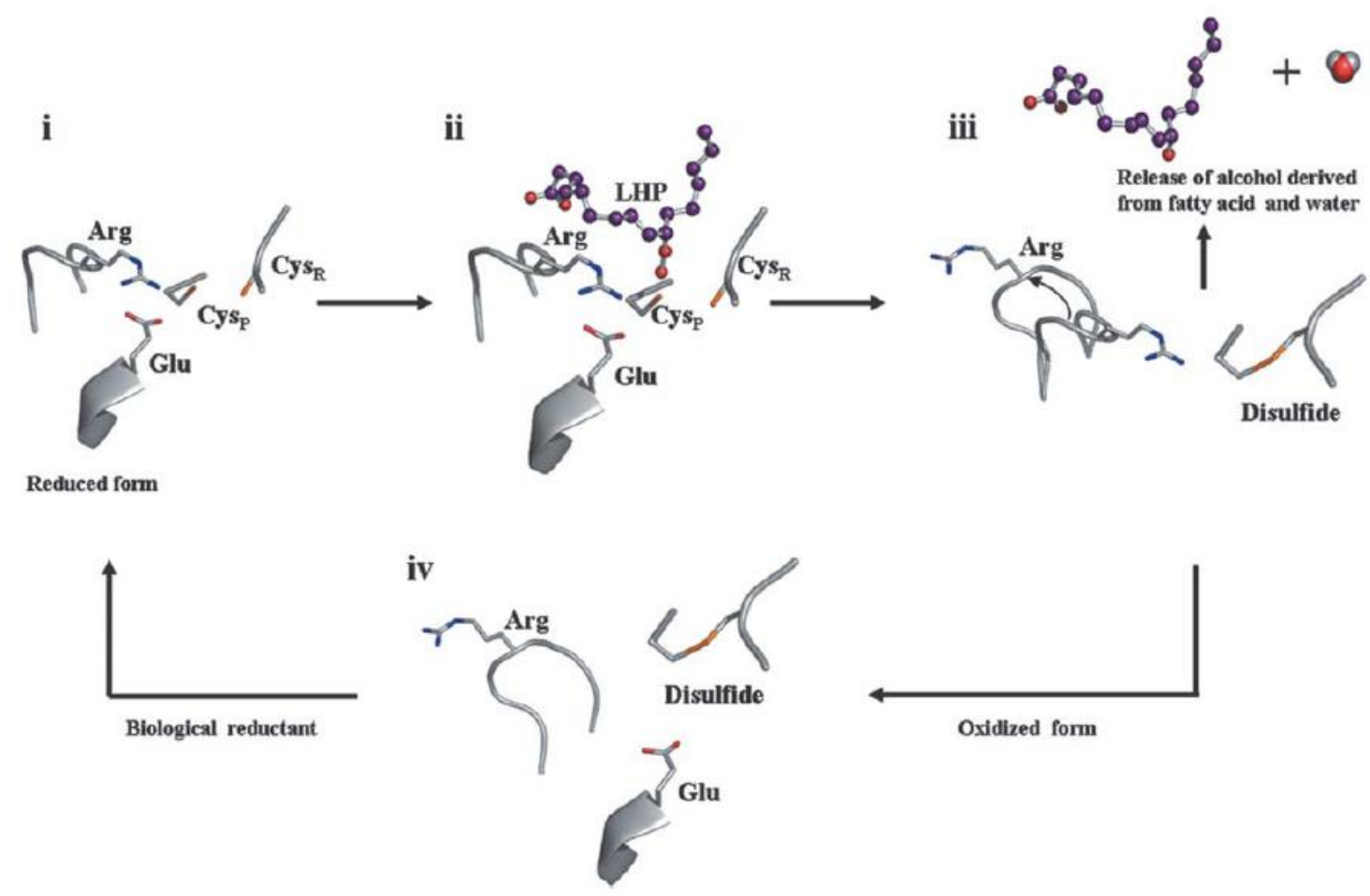

Figura 18. Mecanismo proposto do ciclo catalítico de Ohr na redução de peróxidos de lipídios.

Modificado de Oliveira et al., 2006 anexo II.

Como se pode observar na figura (em i e ii), o loop que contêm o resíduo Arg 19 está fechando o sítio ativo e seu grupo guanidina está interagindo através de uma ponte salina com o resíduo Glu 51 que é altamente conservado. Arg 19 também faz uma ligação de hidrogênio com a $\mathrm{Cys}_{\mathrm{p}} 61$. Em seguida, um substrato hidrofóbico (representado por um peróxido de lipídio) se liga ao sítio ativo, sendo estabilizado pela cadeia lateral do resíduo de arginina assim como por inúmeras interações hidrofóbicas com diferentes aminoácidos hidrofóbicos (Val 36; Leu 40; Phe 68; Gly 95; Phe 96 e Pro 126). O peróxido, reage com a sulfidrila da Cys61 sendo reduzido ao seu álcool correspondente e a uma molécula de água. Cys $_{\mathrm{p}} 61$ é oxidada a uma molécula de ácido sulfênico que reage rapidamente com a Cys 125 devido a proximidade entre esses dois resíduos (1.8 ^) formando uma ponte dissulfeto intramolecular e liberando uma molécula de água. O loop que contêm a Arg 19 se desliga, adotando uma conformação aberta e liberando o álcool formado (em iii). Em uma última etapa, Ohr é reduzida por um redutor biológico trazendo de volta o loop contendo a Arg19 para próximo do sítio ativo (em iv). 


\subsection{Caracterização do sistema redutor biológico de Ohr}

Como observado pela figura 12 através do ensaio FOX, ácido dihidrolipóico (DHLA) é capaz de reduzir a cisteína de Ohr, sustentando assim a sua atividade peroxidásica. Como DHLA é uma molécula biológica, diferentemente de DTT que é um ditiól sintético, começamos a investigar a possibilidade de essa molécula ser o redutor fisiológico de Ohr. Interessantemente, DHLA possui uma estrutura alongada e hidrofóbica, semelhante a molécula de PEG que co-cristalizou no sítio ativo de Ohr. No entanto, grande parte do ácido lipóico/dihidrolipóico da célula está ligado covalentemente via ligação amida a resíduos de lisina presentes em domínios conservados de proteínas. O grupo do Dr. Carl Nathan (em Brik et al., 2002) mostrou pela primeira vez em M. tuberculosis que uma enzima lipoilada, dihidrolipoamida aciltransferase, componente E2 do complexo da piruvato desidrogenase participa na via de redução de hidroperóxidos, atuando na redução de $\mathrm{AhpD}$, uma dissulfeto redutase que reduz AhpC, uma peroxirredoxina. A enzima E2, por sua vez, é reduzida por uma dihidrolipoamida desidrogenase, componente E3 deste complexo à custa de elétrons provenientes do NADH. Sendo assim, testamos a possibilidade de um sistema semelhante atuar na redução de Ohr de $X$. fastidiosa visto que esta pode ser reduzida por DHLA em ensaio FOX. De fato, observamos que Ohr era capaz de ser reduzida por uma molécula de lipoamida livre (o derivado amida do ácido lipóico) na presença da enzima dihidrolipoamida desidrogenase (Lpd bovina) e NADH (dados mostrados em Oliveira et al., 2006 anexo II). Nesse sistema heterólogo (adaptado de Brik et al., 2002), as cisteínas de Ohr são regeneradas a forma reduzida pelo ditiól lipoamida que por sua vez é reduzido pela enzima Lpd através de elétrons provenientes do NADH conforme ilustração abaixo:

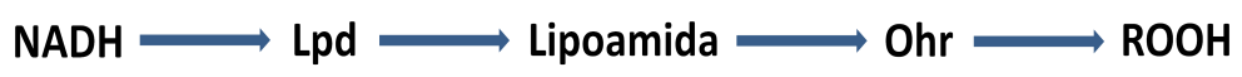

Figura 19. Fluxo de elétrons no sistema lipoamida heterólogo.

Esses dados forneceram evidências de que o sistema lipoamida pode desempenhar o papel de redutor fisiológico de Ohr. Utilizamos no ensaio, Lpd bovina e lipoamida livre, porém, é controverso na literatura se existe lipoamida livre na célula. A biossíntese de ácido lipóico e a sua inserção em enzimas alvos via ligação amida a um resíduo de lisina conservado envolve duas vias. Na primeira, ácido lipóico de fonte exógena ou ácido octanóico (o precursor direto do ácido lipóico) é substrato para a proteína LpIA (lipoato ligase) que à custa de ATP modifica ácido lipóico (ou octanóico) à lipoil-AMP. LpIA catalisa então a reação de ligação de lipoil-AMP aos domínios lipóicos através de ligação amida com liberação de AMP. Entretanto, foi observado que mutantes para IpIA não apresentam 
deficiência nas enzimas lipoiladas devido a outra via biossintética. Essa via, se mostrou dependente de lipB e envolve a enzima octanoil-[acil carrier protein]-N-lipoiltransferase. Esta enzima, transfere ácido octanóico endógeno, que está ligado via ligação tioéster com o cofator 4'-fosfopanteteína da proteína ACP (acyl carrier protein) da síntese de ácido graxos, em domínios lipóicos. Esses domínios octanoilados, são convertidos em derivados lipoilados pela ação da enzima LipA (lipoil sintetase), que catalisa a inserção de dois átomos de enxofre nas posições 6 e 8 dos ácidos graxos respectivos. Essa segunda via, não requer a presença de ácido lipóico captado do meio. Essas vias foram bem descritas em uma série de bactérias como E. coli (Jordan \& Cronan Jr., 2003) e M. tuberculosis (Ma et al., 2006). Finalmente, ácido lipóico covalentemente ligado a proteínas alvos via ligação amida pode ser clivado pela enzima lipoamidase, liberando ácido lipóico no meio (Jiang \& Cronan, 2005).

Dessa forma, provavelmente não se encontra lipoamida livre na célula, mas somente ligada aos domínios lipoilados de enzimas ou na forma de ácido lipóico livre. De fato, uma busca nos bancos de dados de Xylella fastidiosa encontrou os genes codificantes para as proteínas LipA (XF1050), LipB (XF1051) e ACP (XF0672), envolvidas na biossíntese de ácido lipóico de fonte endógena. Não foi encontrado nenhum gene que codificasse para lipoato ligase (LpIA), responsável pela lipoilação de enzimas por ácido lipóico de fonte exógena. Seqüência primária de LplA de $E$. coli foi comparada com banco de dados de $X$. fastidiosa, porém não foi encontrada similaridade com nenhuma proteína de Xylella. Não há na literatura estudos sobre as vias de biossíntese de ácido lipóico em Xylella fastidiosa, mas provavelmente esta bactéria utiliza a via endógena de lipoilação não dependendo de ácido lipóico (ou octanóico) do meio externo ou do hospedeiro. Esse fato se torna relevante, pois Xylella coloniza um ambiente pobre em nutrientes. Encontramos também no banco de dados do genoma de Xylella fastidiosa, genes que codificavam para os componentes E2 e E3 dos complexos da piruvato desidrogenase (PDH) e a-cetoglutarato desidrogenase (KDH) (Tabela 4).

Tabela 4. Anotação dos genes pertencentes aos complexos PDH e KDH de Xylella fastidiosa.

\begin{tabular}{|cccc|}
\hline ORF-ID & Gene & Enzima & Complexo \\
\hline XF0710 & IpdA & LpdA & Piruvato desidrogenase \\
\hline XF0711 & aceF/pdhB & AceF/PDHB & (PDH) \\
\cline { 1 - 3 } XF1285 & Ipd & Lpd & $\alpha$-cetoglutarato desidrogenase \\
\cline { 1 - 3 } XF1286 & sucB & SucB & (KDH) \\
\hline
\end{tabular}


A partir de DNA genômico de $X$. fastidiosa clonamos os genes em vetores de expressão de modo a produzir enzimas recombinantes.

\subsubsection{Expressão e purificação de produtos de genes do metabolismo intermediário de Xylella fastidiosa}

\section{Dihidrolipoamida desidrogenase (Lpd e LpdA)}

Após a inserção de pET15b/lpd em linhagem BL21(DE3) de E. coli, foram realizados testes de expressão (indução por $1 \mathrm{mM}$ de IPTG por 3 horas à $37^{\circ} \mathrm{C}$ ) seguido de purificação em gel SDS-PAGE redutor (Figura 20).

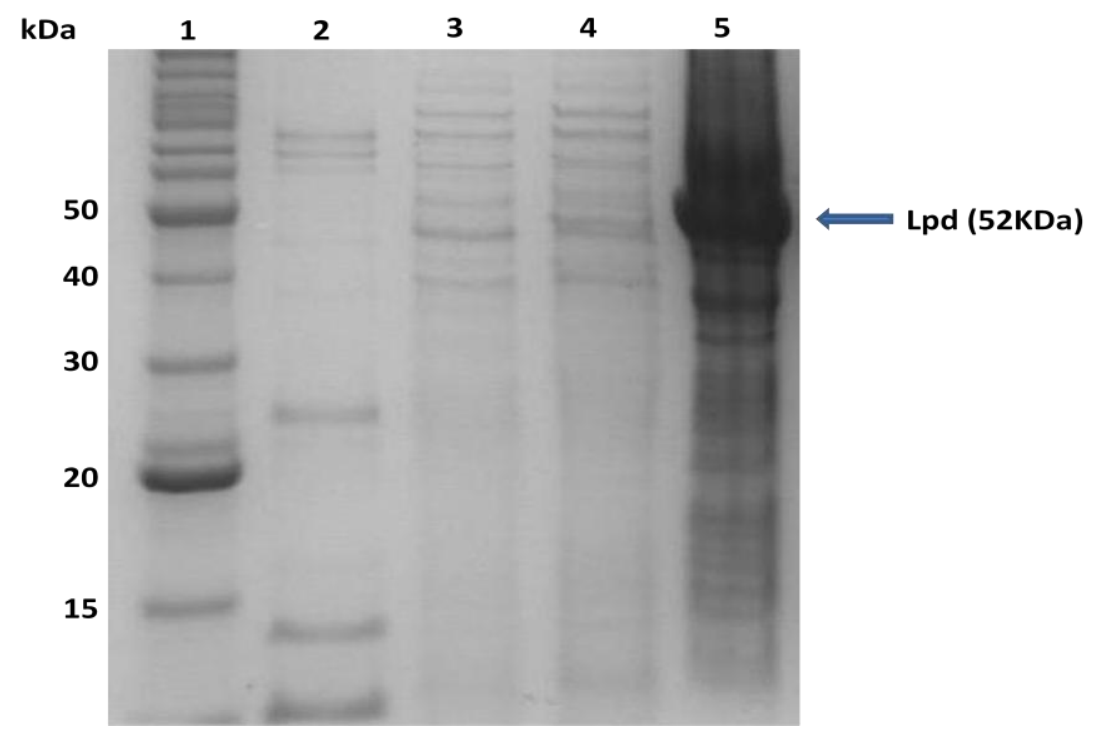

Figura 20. Presença de Lpd recombinante em corpo de inclusão.

Lisado celular de E. coli BL21(DE3) assim como etapas de purificação estão descritos na seção "Materiais e Métodos". Raia 1. Bench Mark ${ }^{\circledR}$ ladder; 2. Fração purificada; 3-4. Frações eluídas com 20 e 50 mM de Imidazole respectivamente; 5. Fração correspondente as proteínas precipitadas.

Lpd recombinante não estava presente na fração eluída (Raia 2) nem nas lavagens anteriores (Raias 3-4), mas sim no precipitado celular (Raia 5) obtido após as etapas de lise celular por sonicação, mostrando que Lpd estava presente em grandes quantidades em corpos de inclusão. Corpos de inclusão são agregados protéicos inativos presentes na forma insolúvel. Sabe-se que muitas proteínas quando superexpressas em $E$. coli vão para corpos de inclusão devido às altas concentrações (chegando à escala de milimolar) 
presentes no citossol durante a etapa de indução. Além disso, muitas proteínas para se manterem na forma solúvel necessitam de pontes dissulfeto estáveis para se enovelar corretamente em uma conformação nativa. Essas condições são dificultadas devido ao alto potencial redutor do compartimento citossólico.

Em uma primeira etapa, Lpd foi purificada dos corpos de inclusão (Figura 21), porém não conseguimos renaturá-la apropriadamente.

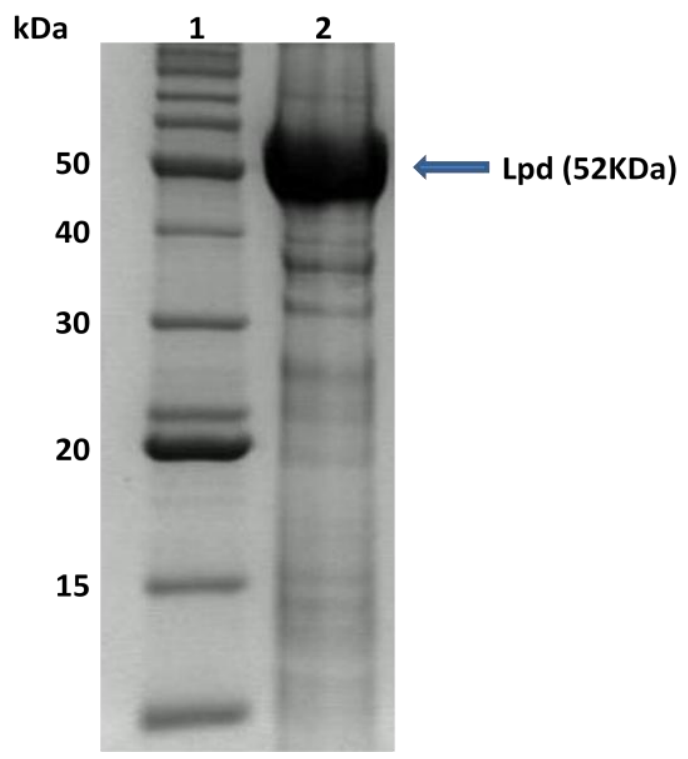

Figura 21. Purificação de Lpd recombinante de corpos de inclusão. Amostra foi corrida em gel SDS-PAGE redutor. Raia 1. Bench Mark ${ }^{\circledR}$ ladder; 2. Fração purificada.

Sabe-se que diminuir a temperatura durante a etapa de indução (Schein \& Noteborn, 1989) assim como diminuir as concentrações do agente indutor (neste caso IPTG) pode levar a uma maior quantidade de proteína solúvel. Entretanto, não conseguimos Lpd no extrato solúvel após tentativa de indução à $20^{\circ} \mathrm{C}$ overnight com metade da concentração de IPTG (0.5 mM) utilizada em condições normais. Dessa maneira, transformamos as linhagens $A D 494(D E 3)$ e Origami(DE3) com o vetor $p E T-15 b / l p d$. Essas linhagens possuem deleções em genes com atividade dissulfeto redutase(trxB em AD494; trxB e gor em Origami), diminuindo assim o potencial redox do citossol facilitando assim a formação de pontes dissulfeto. Aliando essa estratégia, em conjunto com indução overnight à $20^{\circ} \mathrm{C}$, conseguimos obter Lpd solúvel em altas quantidades, principalmente na linhagem AD494 (Figura 22). 


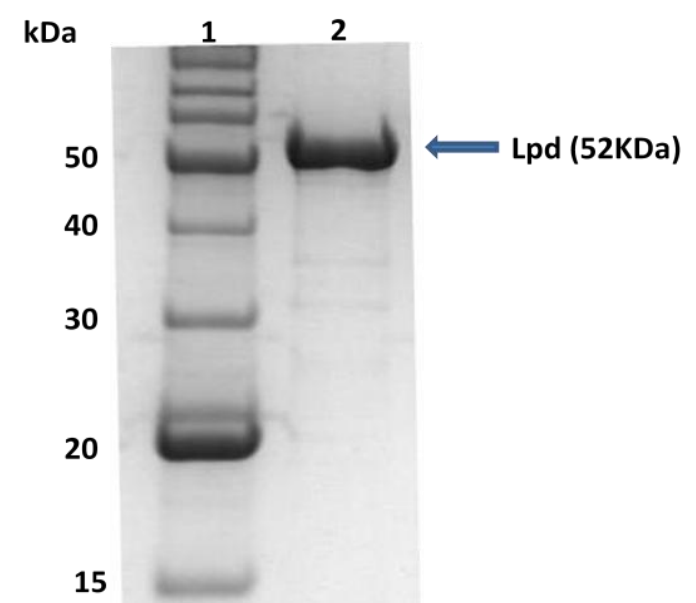

Figura 22. Purificação de Lpd solúvel em linhagem AD494(DE3).

Amostra foi corrida em gel SDS-PAGE redutor. Raia 1. Bench Mark ${ }^{\circledR}$ ladder; 2. Fração purificada.

$O$ vetor $p E T-15 b / / p d A$ foi transformado em linhagem $A D 494(D E 3)$ e os transformantes foram primeiramente induzidos à $20^{\circ} \mathrm{C}$ para garantir produção de enzima na fração solúvel celular (Figura 23).

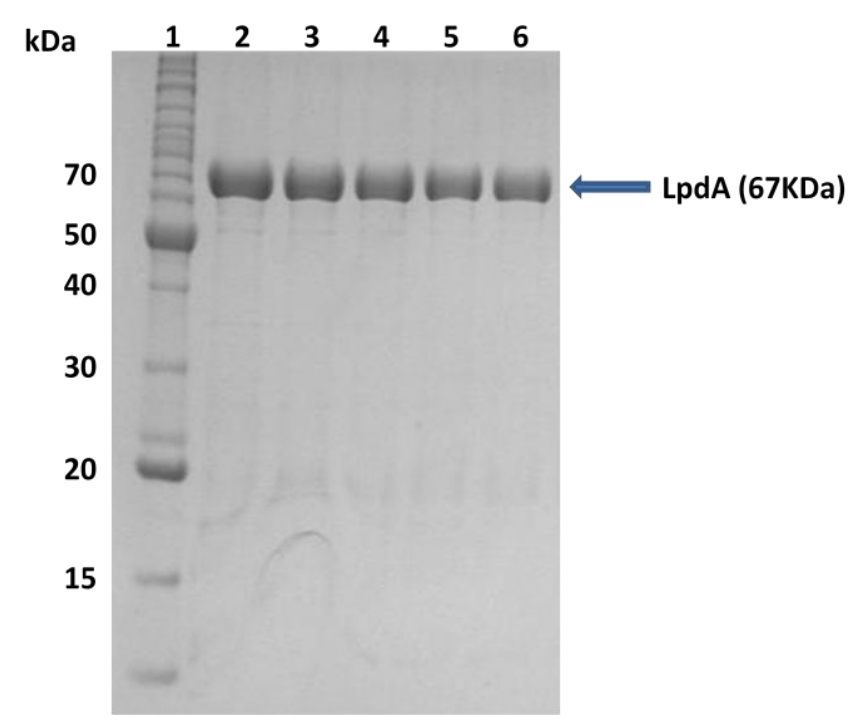

Figura 23. Purificação de LpdA solúvel em linhagem AD494(DE3).

Amostras foram corridas em gel SDS-PAGE redutor. Raia 1. Bench Mark ${ }^{\circledR}$ ladder; 2-6. Frações purificadas. 


\section{Dihidrolipoamida aciltransferase (SucB e PDHB)}

SucB e PDHB foram anotadas no banco de dados do genoma de $X$. fastidiosa (www.xylella.Incc.br) como os componentes E2 (com atividade dihidrolipoamida aciltransferase) dos complexos da a-cetoglutarato e piruvato desidrogenase respectivamente,

Não foi possível clonar sucB em pET-15b pois o gene possui sítios de restrição para as enzimas Ndel e BamHI, únicos sítios de restrição disponíveis em pET-15b para clonagem. Dessa maneira, $s u c B$ foi clonado no vetor $\mathrm{pET}$-28a que possui uma maior variedade de sítios de restrição para clonagem. Esse vetor, tem marca de seleção para o antibiótico canamicina, não sendo compatível com as linhagens AD494 ou Origami. Análise da seqüência primária de aminoácidos de SucB mostrou que essa enzima não possui cisteínas, portanto, sem necessidade da formação de pontes dissulfeto para garantir a solubilidade da proteína. Portanto, o vetor $\mathrm{pET}-28 \mathrm{a} / \mathrm{sucB}$ foi transformado em linhagem BL21(DE3) e os transformantes foram submetidos a expressão e purificados com alto grau de pureza (Figura 24).

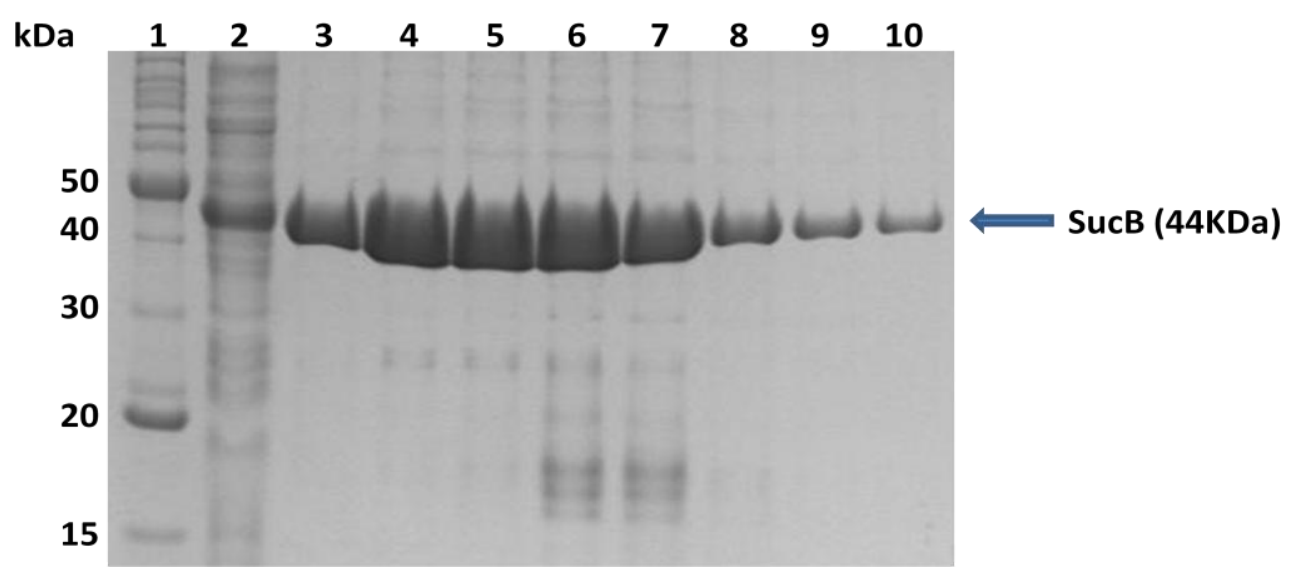

Figura 24. Purificação de SucB solúvel em linhagem BL21(DE3).

Amostras foram corridas em gel SDS-PAGE redutor. Raia 1. Bench Mark ${ }^{\circledR}$ ladder; 2. Fração eluída 100mM Imidazole; 3-10. Frações purificadas.

PDHB, ao contrário, possui cisteínas em sua estrutura primária. Sendo assim, clonamos a construção pET-15b/pdhB em AD494(DE3) conseguindo assim expressar PDHB na forma solúvel permitindo sua purificação com alto grau de pureza (Figura 25). 


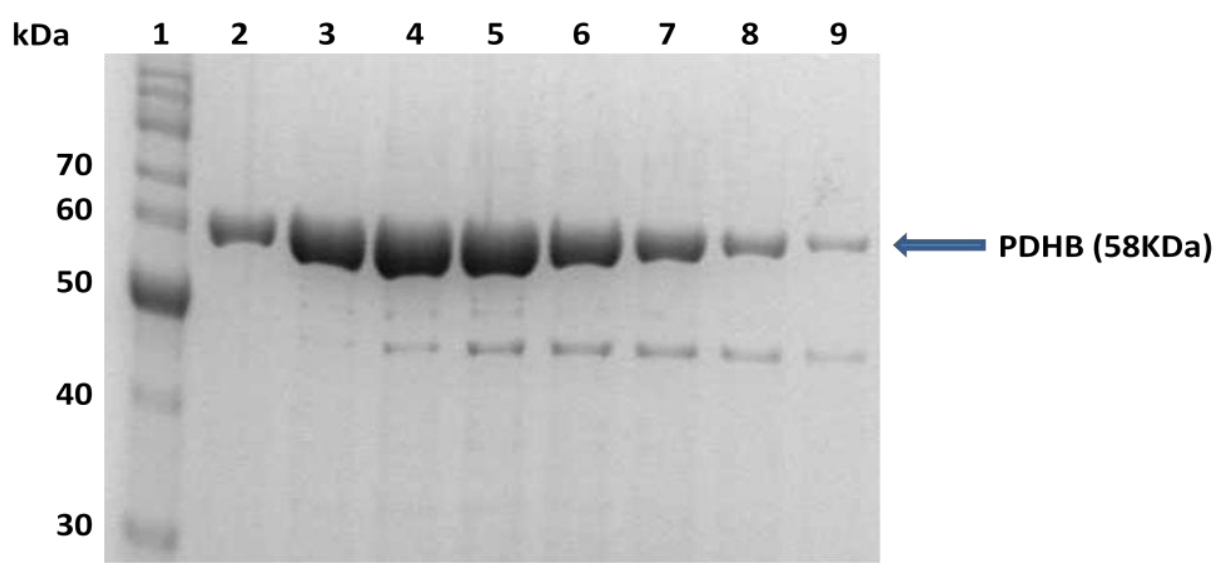

Figura 25. Purificação de PDHB solúvel em linhagem AD494(DE3).

Amostras foram corridas em gel SDS-PAGE redutor. Raia 1. Bench Mark ${ }^{\circledR}$ ladder; 2-9. Frações purificadas.

Análises in silico utilizando o PROSITE, um banco de dados da ExPASy (http://ca.expasy.org) para domínios, famílias e sítios funcionais de proteínas, mostrou que SucB e PDHB possuem domínios de ligação a ácido lipóico (um em SucB e dois em PDHB). Curiosamente, foi encontrado na porção N-terminal de LpdA de Xylella fastidiosa, um domínio de ligação a ácido lipóico além do domínio de ligação a flavina e as cisteínas do centro redox. Em Streptococcus pneumoniae, foi encontrado uma dihidrolipoamida desidrogenase (também denominada LpdA) com um domínio de ligação a ácido lipóico Nterminal, e foi mostrado nesse trabalho que esse domínio era funcional (Håkansson et al., 2007). Portanto, enzimas LpdA são dihidrolipoamida desidrogenases que também abrigam seu produto: lipoamida.

Como visto anteriormente, a reação de incorporação do ácido lipóico ou do seu precursor no resíduo de lisina de enzimas alvos é um processo enzimático de várias etapas. Visto que as enzimas necessárias nesse processo não são superexpressas, elas se tornam passo limitante da reação. Portanto, para garantir lipoilação completa, suplementamos linhagens de E. coli superexpressando LpdA, SucB e PDHB com ácido lipóico (300 $\mu \mathrm{g} / \mathrm{ml})$ durante a etapa de indução em baixa temperatura $\left(20^{\circ} \mathrm{C}\right)$ e com baixas concentrações de IPTG (0.1 mM), proporcionando uma expressão mais lenta e, garantindo assim, incorporação total de ácido lipóico nas enzimas pela enzima lipoato ligase (LpIA) de E. coli.

\subsubsection{Expressão e purificação de produtos de genes do sistema tiorredoxina de Xylella fastidiosa}


Foram clonados dois genes anotados como codificantes para Tiorredoxina Redutase: TrxR ( 36.7 kDa com cauda de poli-histidina) e YBBN, e dois genes que codificavam para duas tiorredoxinas: TsnC ( 14.7 kDa com cauda de poli-histidina) e TrxA ( 14.1 kDa com cauda de poli-histidina ).Os genes $\operatorname{trxr}(963 \mathrm{pb})$ e tsnc (339 pb) foram inseridos no vetor de expressão pET15b e expressos nas linhagens de E. coli BL21(DE3) e AD494(DE3), respectivamente. A condição ótima de indução da expressão foi a realizada a $20^{\circ} \mathrm{C}$ overnight com IPTG $0.5 \mathrm{mM}$. Todos esses genes foram primeiramente inseridos em linhagem BL21(DE3). No entanto, somente conseguimos obter TrxR solúvel e desta forma purificá-la com alto grau de pureza (Figura 26).

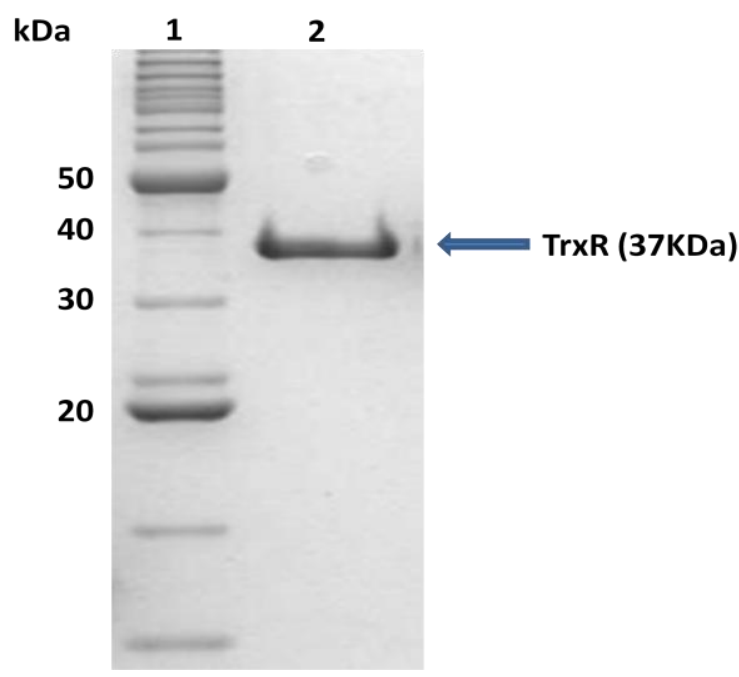

Figura 26. Purificação de TrxR solúvel em linhagem BL21(DE3).

Amostras foram corridas em gel SDS-PAGE redutor. Raia 1. Bench Mark ${ }^{\circledR}$ ladder; 2. Fração purificada.

Dessa maneira, transformamos as linhagens AD494(DE3) e Origami(DE3) com os vetores $\mathrm{pET} 15 \mathrm{~b} /$ tsnc $\mathrm{pET}-15 \mathrm{~b} /$ trxA; $\mathrm{pET}-15 \mathrm{~b} / y b b n$ porém somente conseguimos obter quantidades significativas de TsnC solúvel (Figura 27).

Infelizmente, não conseguimos obter as proteínas recombinantes TrxA e YBBN no presente estudo. Tentamos outras linhagens de expressão como Rosetta ${ }^{\mathrm{TM}}$ (que expressa tRNA possibilitando a tradução de proteínas que contenham códons raros em seu mRNA), Tuner $^{\mathrm{TM}}$ (que contém mutação em uma permease dificultando a entrada de IPTG nas células permitindo assim uma expressão mais controlada) porém sem sucesso. 


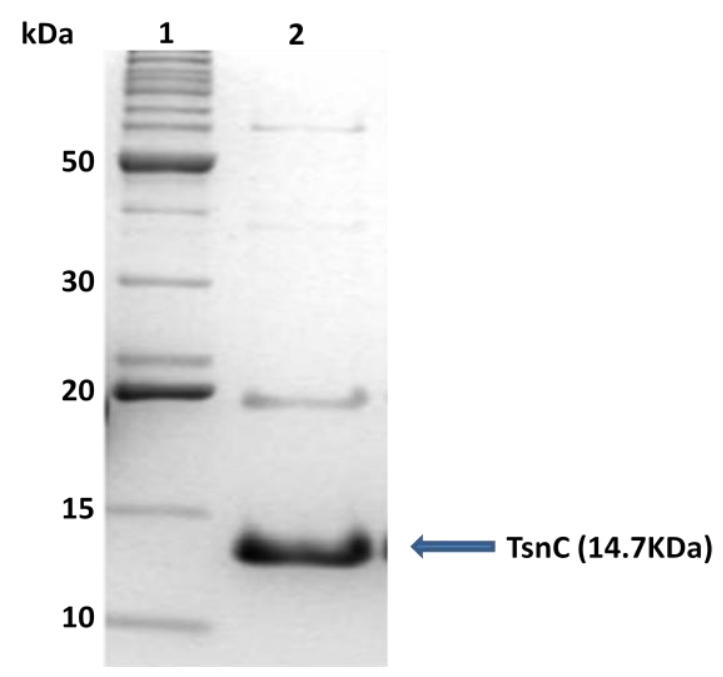

Figura 27. Purificação de TsnC solúvel em linhagem AD494(DE3).

Amostras foram corridas em gel SDS-PAGE redutor. Raia 1. Bench Mark ${ }^{\circledR}$ ladder;

2. Fração purificada.

\subsubsection{Lpd de Xylella fastidiosa sustenta a atividade peroxidásica de Ohr no sistema lipoamida}

Mostramos anteriormente que lipoamida livre era capaz de reduzir Ohr em um sistema heterólogo composto por Lpd bovina e $\mathrm{NADH}$, levando assim a redução de hidroperóxidos orgânicos (Oliveira et al., 2006 anexo II). Após clonarmos, expressarmos e purificarmos Lpd recombinante de Xylella fastidiosa testamos a capacidade dessa enzima em sustentar a atividade peroxidásica de Ohr na presença de lipoamida livre. Contrário ao esperado, nenhuma atividade peroxidásica foi detectada no ensaio, indicando que Lpd poderia estar inativa.

Entretanto, ensaio de atividade dissulfeto redutase mostrou que Lpd estava ativa, sendo capaz, portanto, de reduzir lipoamida. Interessantemente, a atividade dissulfeto redutase de Lpd era consideravelmente maior que a determinada para Lpd bovina em concentrações similares (Figura 28). Na ausência de lipoamida, não foi detectada atividade enzimática indicando que Lpd de certa maneira está ciclando mais rapidamente lipoamida e não reduzindo diretamente DTNB. 


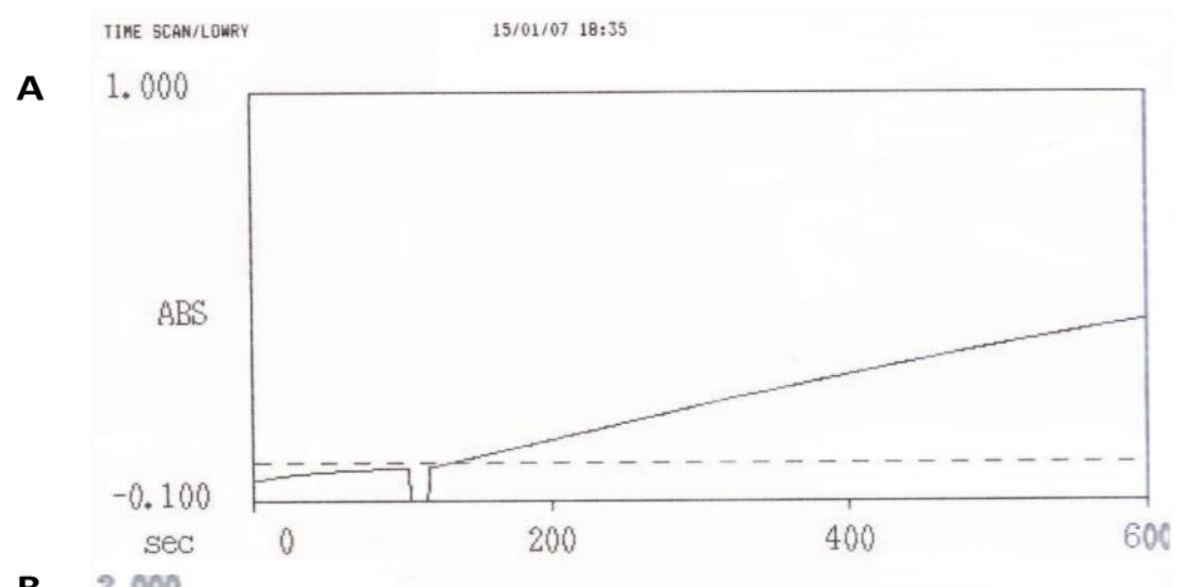

B 2000

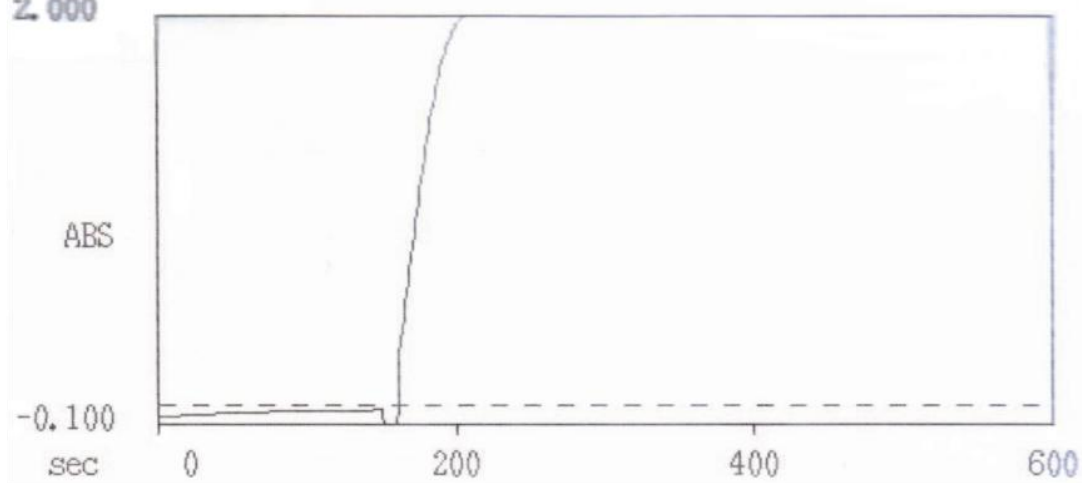

Figura 28. Comparação da atividade dissulfeto redutase de Lpd WT bovina e mutante de $X$. fastidiosa.

Mistura de reação continha Lpd bovina (A) ou Lpd de X. fastidiosa (B) $(100 \mathrm{ng} / \mu \mathrm{l})$; lipoamida $(1 \mu \mathrm{M})$ e DTNB $(0.5 \mathrm{mM})$. A reação foi iniciada com adição de NADH $(0.2 \mathrm{mM})$ à $37^{\circ} \mathrm{C}$ e monitorada à $412 \mathrm{~nm}$. Para descrição detalhada do método vide seção "Materiais e Métodos.

Seqüenciamento da construção $p E T-15 b / / p d$ mostrou que Lpd continha mutações em dois códons (posições 1154 e 1355). No primeiro caso ocorreu uma mudança de AAC (Asparagina) para AGC (Serina) e no segundo uma mudança de GGT (Glicina) para GAT (Aspartato) (Figura 29). A primeira mutação não alterou a carga do aminoácido (ambos polares sem carga), no entanto, na segunda mutação houve um incremento de uma carga negativa (Aspartato). Ambas as mutações ocorreram no domínio de dimerização de Lpd. 
T T G A T C G C G G G C C T GC C A G G C C A C G T G A G C T T T G A A A C C A T C C C A T G G G T Maj

$1160 \quad 1170 \quad 1180 \quad 1190 \quad 1200$

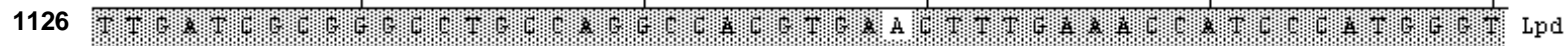

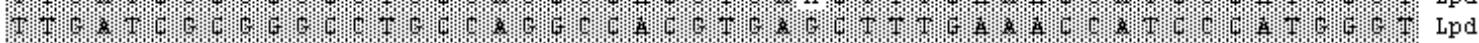
T:

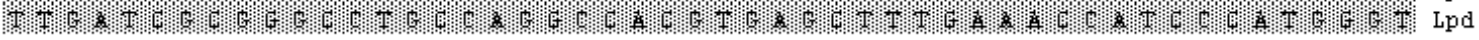

A GCGCATGCGGAAACTGACC GCGTGTTAGATT TACATCT GATCGGT GT GA Maj $\begin{array}{lllll}1360 & 1370 & 1380 & 1390 & 1400\end{array}$

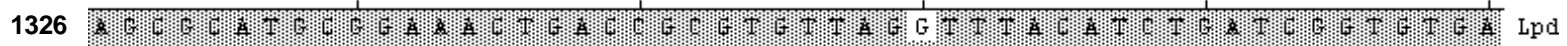
An 46 4.

Figura 29. Triagem de mutações na seqüência de Lpd recombinante de Xylella fastidiosa.

Figura de alinhamentos de proteínas foram geradas com a utilização do programa Lasergene MegAlign v.5.01 (DNASTAR, Inc., Madison, Wisconsin, USA) pelo método Clustal W.

Nota-se a presença de mutação em dois sítios com alteração no aminoácido codificado. Na posição 1154 (AAC para AGC) e na posição 1355 (GGT para GAT).

Partimos então para uma nova construção utilizando Taq Platinum Hi-fidelity ${ }^{\circledast}$ (Invitrogen) que exibe atividade de proofreading, diminuindo assim as chances da polimerase incorporar erros causando uma mutação. Dessa forma conseguimos a proteína Lpd sem mutações, como confirmado por seqüenciamento (Figura 30).

TGCCAGGCCACCGTGAACTTTGAAACCATCCC $1160 \quad 1170 \quad 1180 \quad 1190 \quad 1200$

1139 Thm $4 \cos _{1}$ A

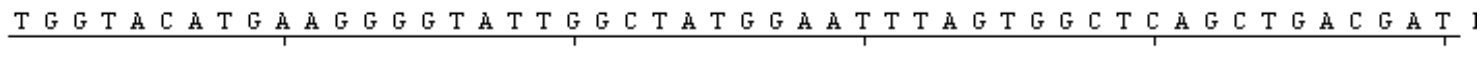

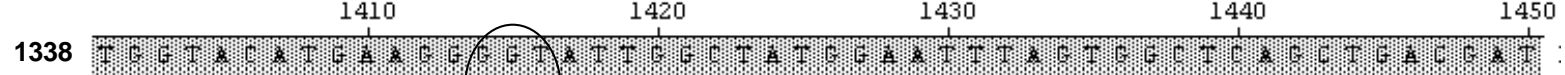

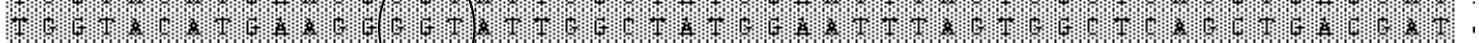

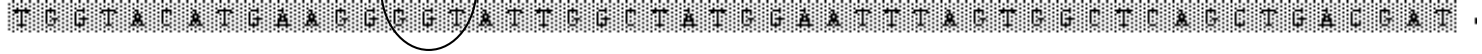

Figura 30. Ausência de mutação na seqüência da nova Lpd recombinante de Xylella fastidiosa.

Figura de alinhamentos de proteínas foram geradas com a utilização do programa Lasergene MegAlign v.5.01 (DNASTAR, Inc., Madison, Wisconsin, USA) pelo método Clustal W. Nota-se que na nova construção não há mutações nas duas posições observadas na Lpd mutante.

Lpd obtida da nova construção foi capaz de sustentar a atividade peroxidásica de Ohr na presença de lipoamida e NADH. Aparentemente, parece paradoxal que Lpd mutante possua uma atividade lipoamida redutase expressivamente aumentada (como observado no ensaio de redução do DTNB), porém não sustente a atividade de Ohr, visto que em ambos os ensaios Lpd está reduzindo lipoamida. Recentemente a estrutura tridimensional de Lpd de M. tuberculosis foi elucidada (Rajashankar et al., 2005). Lpd consiste de um homodímero 
que contêm um domínio N-terminal de ligação ao FAD, um domínio de ligação a NADH, um domínio central e dois segmentos da estrutura que mediam a formação do homodímero. Além de FAD, Lpd possui um centro redox composto por dois resíduos de cisteínas vicinais (Cys 41 e Cys 46 em M. tuberculosis). Esse centro redox é acessado através de um canal de aproximadamente $15 \AA$ de profundidade no qual se sabe ocorre a interação com a cadeia lateral de enzimas lipoiladas onde se encontra covalentemente ligada uma molécula de lipoamida. Sabe-se que resíduos do domínio de dimerização interagem com o domínio onde estão as cisteínas responsáveis pelas reações de troca tiól/dissulfeto (Brautigam et al., 2005). Portanto, podemos especular que as mutações em Lpd podem ter alterado a capacidade de dimerização de Lpd (aumentando ou diminuindo) influenciando, portanto, na atividade da enzima.

Outra hipótese é a de que Lpd além de interagir com lipoamida também interage diretamente com Ohr durante o ciclo catalítico, formando um complexo ternário. Sendo assim, as mutações podem ter afetado a interação e formação desse complexo, diminuindo a interação de Ohr com Lpd. Além disso, as mutações podem ter aumentado de alguma forma a afinidade ou o turnover com lipoamida explicando assim a maior atividade de redução de lipoamida e a abolição total da capacidade de sustentar a atividade peroxidásica de Ohr.

De modo a testar essa hipótese, comparamos a atividade de Lpd bovina com Lpd de Xylella (obtida da nova construção) no sistema dependente de lipoamida. Visto que essas enzimas são de organismos muito distintos, talvez Lpd de Xylella possua uma atividade aumentada no ensaio de redução de peróxidos devido a uma interação direta com Ohr, enquanto Lpd bovina, por pertencer a um organismo filogeneticamente distante, talvez tenha perdido aminoácidos importantes para a interação física com Ohr. De fato, foi mostrado em Lpd de $M$. tuberculosis que resíduos conservados em procariotos mas não em eucariotos eram essenciais para a modulação da atividade da enzima tanto em vias de redução quanto em vias de oxidação da lipoamida. Interessantemente, algumas mutações mapeadas afetavam somente uma das atividades não interferindo na outra (Rajashankar et al., 2005).

Primeiramente, realizamos 0 ensaio de atividade dissulfeto redutase em concentrações crescentes de Lpd de $X$. fastidiosa e bovina. Calculamos a concentração por unidades enzimáticas, ou seja, onde as enzimas exibiam a mesma atividade de redução de lipoamida e dessa forma, realizamos o ensaio de redução de peróxidos dependente de $\mathrm{NADH}$. No entanto, não observamos diferença significativa na velocidade de consumo de NADH entre as Lpd (Figura 31). 


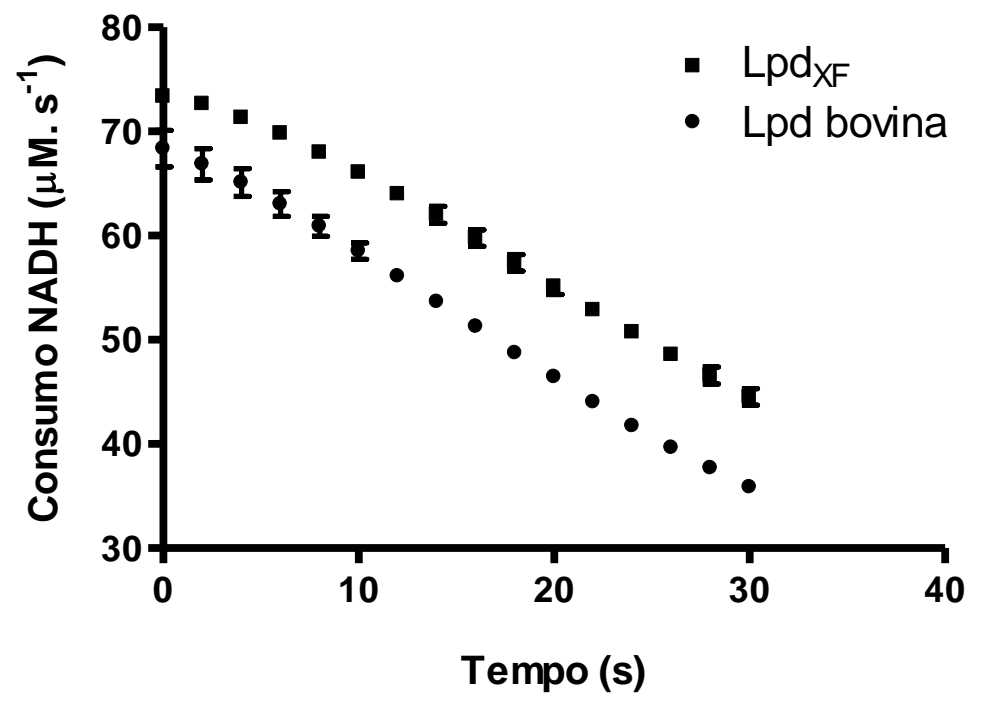

Figura 31. Comparação da atividade peroxidásica de Ohr dependente de lipoamida na presença de Lpd bovina e de $X$. fastidiosa.

Todos os pontos foram feitos em duplicatas nas seguintes condições: Ohr (0.1 $\mu \mathrm{M})$; lipoamida (0.2 mM); NADH (0.3 mM) e $t$-BHP $(0.2 \mathrm{mM})$. A reação foi iniciada com a adição de $t$-BHP e monitorada à $37^{\circ} \mathrm{C}$ a $412 \mathrm{~nm}$. As concentrações de Lpd utilizada no ensaio foi aquela na qual as duas enzimas apresentaram a mesma atividade no ensaio de atividade dissulfeto redutase.

No entanto, este resultado, não descarta completamente a nossa hipótese, pois pode ser que Lpd bovina também interaja diretamente com Ohr visto que a enzima Lpd é altamente conservada nos diferentes grupos taxonômicos. Como um dos objetivos principais do meu projeto era determinar os mecanismos de redução de Ohr, não nos aprofundamos nas prováveis causas do "comportamento" de Lpd mutante ficando aberto para uma investigação futura.

Visto que Lpd era capaz de sustentar a via de redução de peróxidos mediada por Ohr, testamos a capacidade de outras tióis peroxidases de $X$. fastidiosa em reduzir peróxidos na presença do mesmo sistema. As peroxirredoxinas AhpC e PrxQ foram cedidas pelo Dr. Bruno Brasil Horta e testadas no sistema lipoamida (Figura 32). 


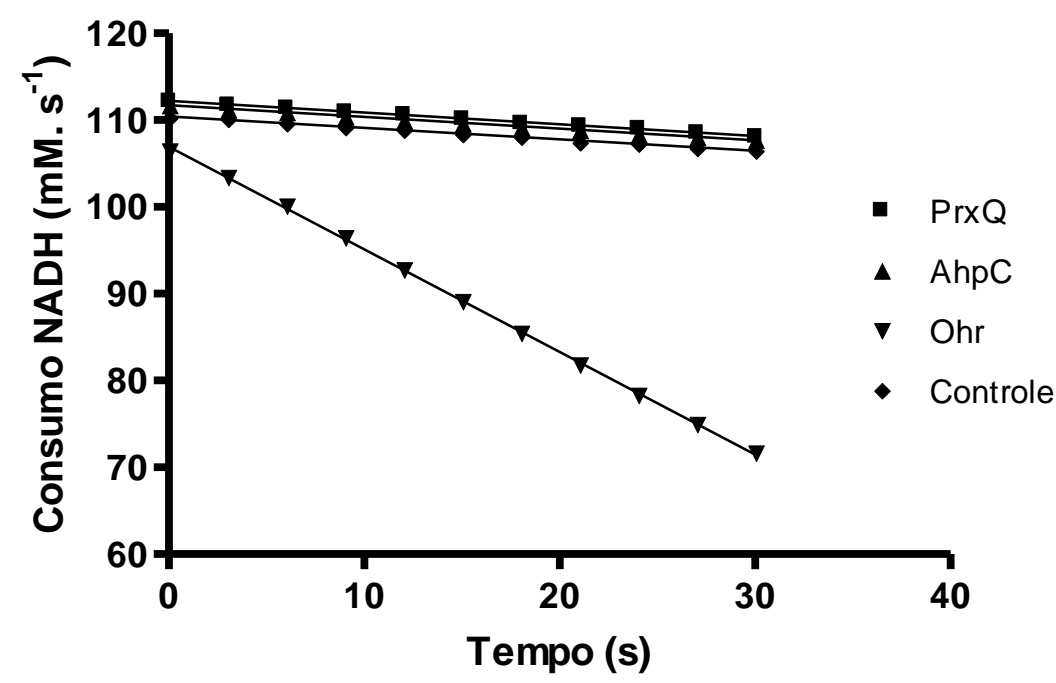

Figura 32. Comparação da atividade peroxidásica dependente de lipoamida entre Ohr e peroxirredoxinas.

Ensaio foi monitorado pela oxidação de NADH à $37^{\circ} \mathrm{C}$ a $340 \mathrm{~nm}\left(\varepsilon=6290 \mathrm{M}^{-1} \cdot \mathrm{cm}^{-1}\right)$. Mistura de reação continha: NADH $(0.2 \mathrm{mM})$, lipoamida $(0.2 \mathrm{mM})$, Lpd $(0.5 \mu \mathrm{M})$, tiól peroxidases $(0.1 \mu \mathrm{M})$ e $t$-BHP $(0.2 \mathrm{mM})$ em $50 \mathrm{mM}$ de tampão fosfato de sódio (pH 7.4), $50 \mathrm{mM} \mathrm{NaCl}, 1 \mathrm{mM}$ DTPA. $\boldsymbol{\nabla}$ (Ohr), $\boldsymbol{\Delta}$ (AhpC), $\boldsymbol{\square}$ (PrxQ), $\diamond$ (sem adição de peroxidase). A reação foi iniciada pela adição de $t$-BHP. O resultado é a média de três experimentos independentes. Dados são a média \pm s.d.

O resultado mostra que somente Ohr aceita lipoamida como substrato, indicando que, possivelmente, esse sistema pode atuar exclusivamente na redução de Ohr in vivo. Aumento em até dez vezes na concentração de AhpC e PrxQ não acarretou em aumento da atividade peroxidásica (dados não mostrados).

\subsubsection{Caracterização da atividade peroxidásica de Ohr dependente de grupos lipóicos}

Ohr possui uma preferência em detoxificar peróxidos orgânicos, tais como $t$-BHP e $\mathrm{CHP}$, quando comparado com $\mathrm{H}_{2} \mathrm{O}_{2}$. No entanto, pouco se sabe a respeito da cinética de remoção destes peróxidos. Até esse momento, tinham sido realizados ensaios de atividade com concentrações pontuais dos substratos, o que tornava a comparação da eficiência catalítica de Ohr frente a esses peróxidos muito difícil, já que a obtenção de velocidades era complicada.

Dessa forma, utilizando em um primeiro momento lipoamida livre como substrato redutor, calculamos os parâmetros cinéticos de Ohr no sistema lipoamida, utilizando equações de cinética de estado estacionário (steady state kinetic). Durante o ciclo catalítico, Ohr interage com dois substratos: o hidroperóxido que será reduzido e o tiól que irá 
regenerar suas cisteínas. Portanto, as análises cinéticas devem ser feitas por bi substrato, ou seja, onde a velocidade inicial da reação seja determinada em diferentes concentrações de ambos os substratos.

Primeiramente, através do ensaio de atividade peroxidásica mediada por lipoamida, variamos as concentrações de $t$-BHP e lipoamida no ensaio. A transferência de elétrons na reação se dá do NADH para o sistema Lipoamida/Ohr/peróxido, sendo realizada pela enzima Lpd. De modo que essa enzima não seja passo limitante na reação, ocasionando parâmetros cinéticos subestimados, Lpd foi adicionada em excesso molar (dez vezes) às outras enzimas do sistema. Os gráficos de velocidade inicial $x$ concentração do substrato mostraram um comportamento Michaeliano. Sendo assim, obtivemos os duplos recíprocos (inverso da velocidade inicial $x$ inverso da concentração do substrato, Figura 33).

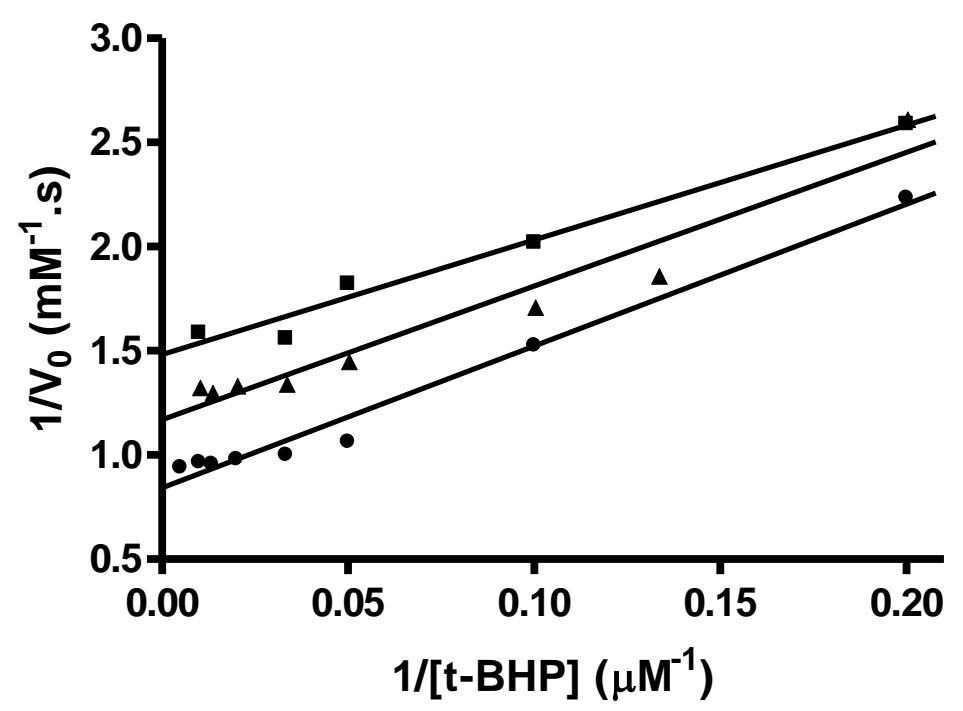

Figura 33. Plotes de Lineweaver-Burk da atividade peroxidásica de Ohr dependente de lipoamida.

Primeiramente, as velocidades iniciais foram determinadas pela taxa de oxidação de NADH $(0.2 \mathrm{mM})$ em diferentes concentrações de $t$-BHP e lipoamida conforme descrito na sessão "Materiais e Métodos". Concentrações de lipoamida:

$(7.5 \mu \mathrm{M}), \boldsymbol{\Delta}(10 \mu \mathrm{M})$ e $\bullet(15 \mu \mathrm{M})$. Após a obtenção das curvas Michaelianas foi feito o duplo recíproco obtendo assim as respectivas retas.

A presença de retas paralelas para cada concentração de lipoamida indica que o mecanismo catalítico de Ohr é do tipo Bi-Bi Ping Pong, sem a formação de um complexo ternário Ohr/peróxido/lipoamida, conforme esquematizado na Figura 34 abaixo. 


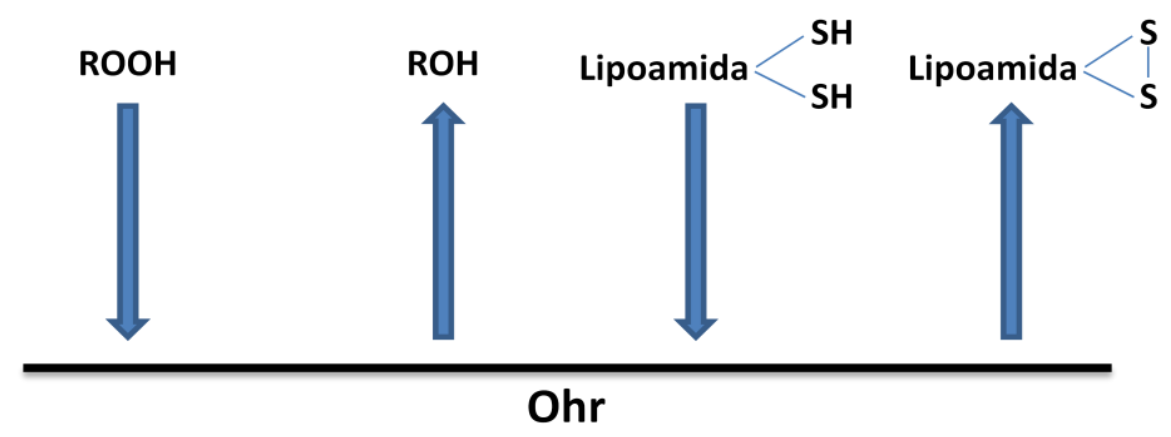

Figura 34. Representação esquemática do mecanismo catalítico de Ohr (Bi Bi Ping Pong).

Para calcular a eficiência catalítica de Ohr na remoção de $t$-BHP e $\mathrm{H}_{2} \mathrm{O}_{2}$, não utilizamos o plote de Lineweaver-Burk, mas sim regressão não-linear a partir do gráfico de $v_{0}$ x [s] (Figura 35) utilizando o software Graph Pad Prism ${ }^{\circledR}$.
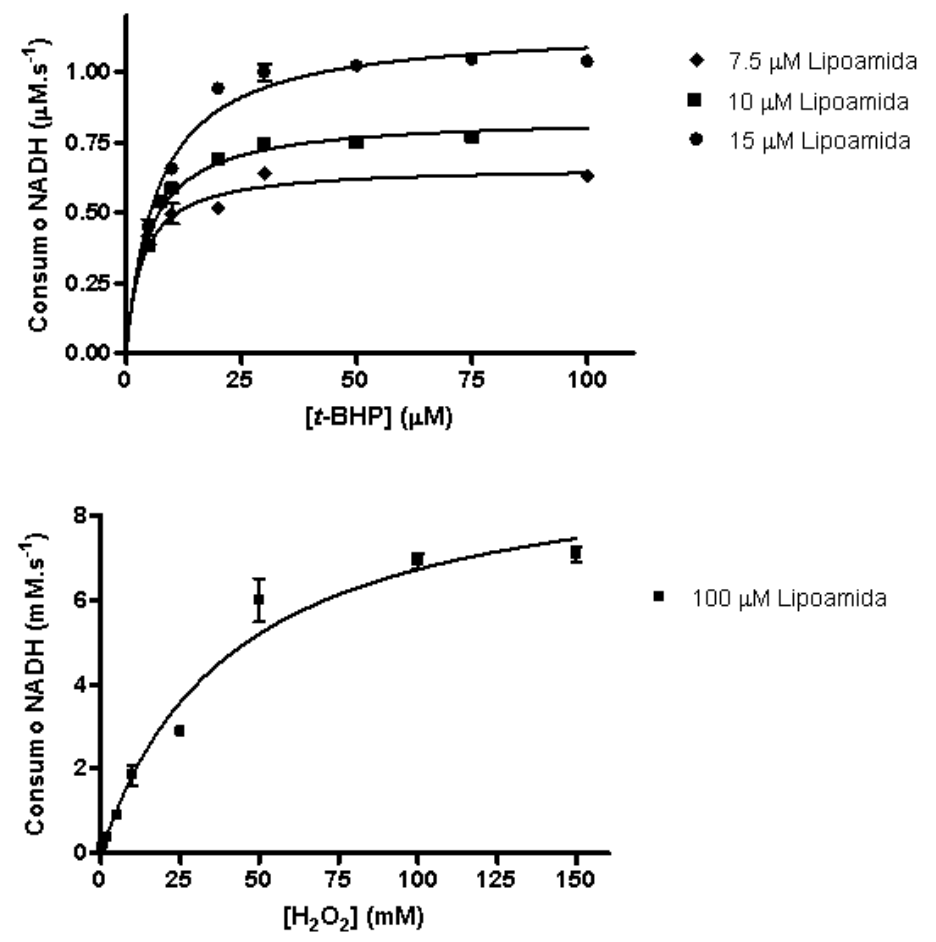

Figura 35. Atividade peroxidásica de Ohr e a especificidade por substrato.

A. Curvas de Michaelis-Menten da atividade de consumo de NADH pela concentração de $t$-BHP (A) e $\mathrm{H}_{2} \mathrm{O}_{2}$ (B) no sistema lipoamida. As concentrações de lipoamida para cada curva estão representadas no lado direito do gráfico. Os pontos no gráfico correspondem a média de três experimentos independentes representado pelas barras de erro (desvio padrão).

Em seguida, através dos plotes secundários de 1/Vmaxapp e 1/Kmapp pelo inverso da concentração de lipoamida (Segel, 1993) foram obtidos os valores de $K_{m}$ e Vmax para $t$-BHP e lipoamida (Figura 36; Tabela 5). Para obtenção dos parâmetros com $\mathrm{H}_{2} \mathrm{O}_{2}$, foi utilizada lipoamida em uma concentração saturante (Tabela 5). 

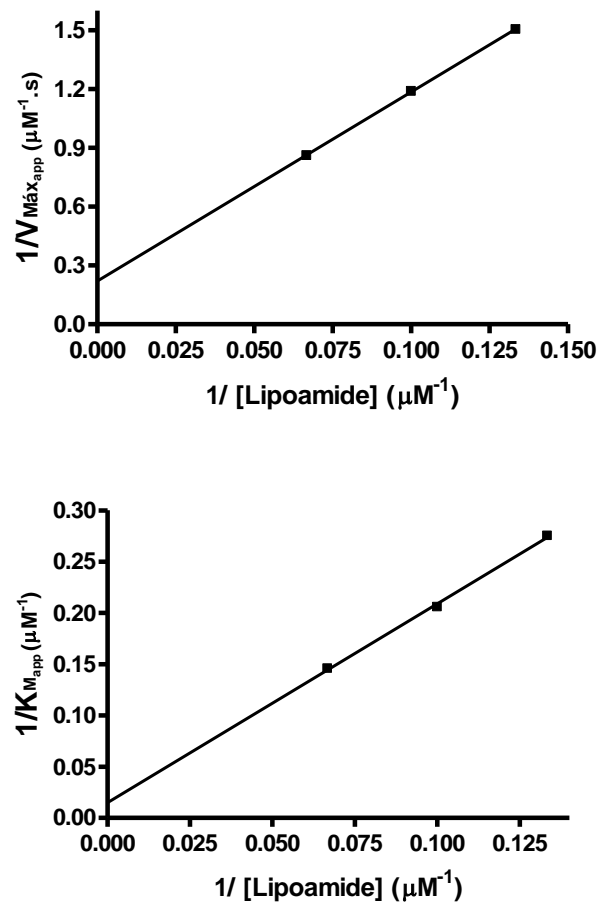

Figura 36. Obtenção dos plotes secundários para cálculo dos parâmetros enzimáticos de Ohr

Tabela 5. Parâmetros cinéticos de Ohr para diferentes substratos

\begin{tabular}{|c|c|c|c|}
\hline Substrato & $K_{m}(\mu \mathrm{M})$ & $k_{c a t}\left(s^{-1}\right)$ & $k_{c a t} / K_{m}\left(M^{-1} \cdot s^{-1}\right)$ \\
\hline$t-\mathrm{BHP}^{*}$ & $14.51 \pm 0.15$ & $17.95 \pm 7.25$ & $2.06 \times 10^{6} \pm 0.08$ \\
\hline $\mathrm{H}_{2} \mathrm{O}_{2}{ }^{*}$ & $41720.00 \pm 6530.00$ & $9.53 \pm 0.56$ & $2.30 \times 10^{2} \pm 0.20$ \\
\hline Lipoamida ${ }^{*}$ & $44.46 \pm 0.98$ & $90.9 \pm 4.70$ & $2.06 \times 10^{6} \pm 0.08$ \\
\hline
\end{tabular}

Parâmetros para $\mathrm{H}_{2} \mathrm{O}_{2}$ foram obtidos através de regressão não-linear usando concentração saturante de lipoamida $(0.1 \mathrm{mM})$. Parâmetros para $t$-BHP e lipoamida foram obtidos através de plotes secundários de 1/Vmax app e 1/Kmapp versus 1/[Lipoamida] por cinética de bi substrato (Segel, 1993). Os resultados representam três experimentos independentes e são a média \pm desvio padrão.

Ohr reduz $t$-BHP pelo menos dez mil vezes mais eficiente do que $\mathrm{H}_{2} \mathrm{O}_{2}$ como pode ser observado pela eficiência catalítica $\left(k_{c a t} / K_{m}\right)$ mostrada na tabela 5 . Essa diferença pode ser atribuída a baixa afinidade de Ohr (alto $K_{m}$ ) por $\mathrm{H}_{2} \mathrm{O}_{2}$, pois são necessárias concentrações na escala milimolar para saturar a enzima, enquanto concentrações na escala micromolar são necessárias para $t$-BHP e lipoamida. Não conseguimos analisar os parâmetros de $\mathrm{Ohr}$ com $\mathrm{H}_{2} \mathrm{O}_{2}$ pelo modelo de bi substrato, pois devido à baixa eficiência 
catalítica de Ohr na redução desse substrato, essa etapa da reação se torna passo limitante não se alterando em concentrações crescentes de lipoamida.

Visto que grande parte do ácido lipóico da célula está covalentemente ligado a enzimas lipoiladas e que não há lipoamida livre, caracterizamos também a cinética com as enzimas recombinantes lipoiladas, SucB, PDHB e LpdA em sustentar a atividade peroxidásica de Ohr. Primeiramente, a atividade dessas enzimas foi confirmada através do ensaio de atividade dissulfeto redutase (Figura 37).

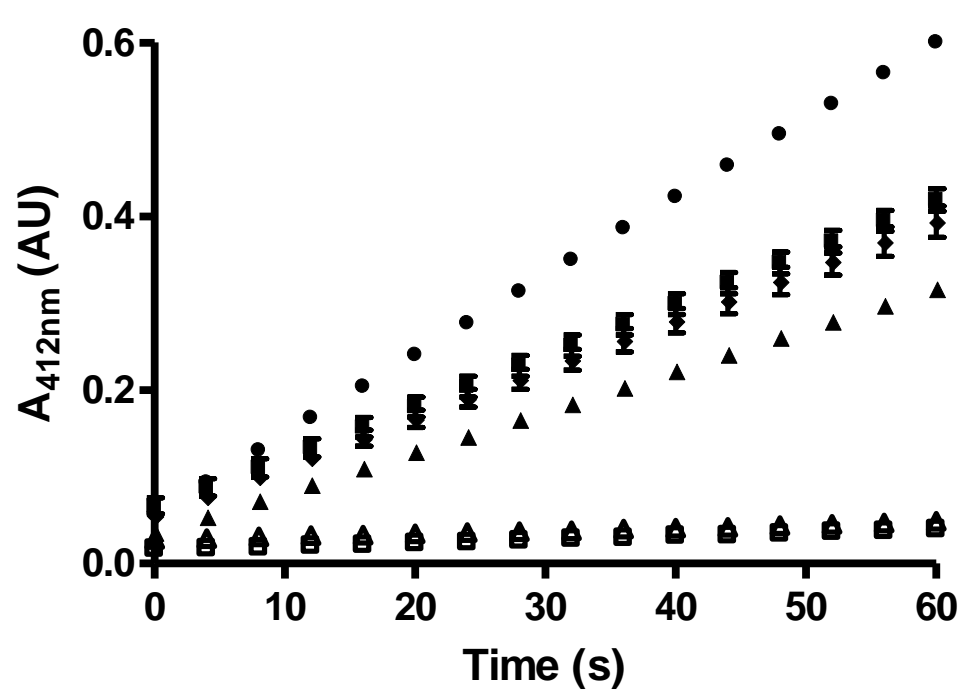

Figura 37. Atividade dissulfeto redutase das enzimas lipoiladas.

Reações foram monitoradas à $412 \mathrm{~nm}$ através da redução do DTNB $(0.5 \mathrm{mM})$. $\bullet$ (1 $\mu \mathrm{M}$ LpdA + 0.5 $\mu \mathrm{M}$ PDHB $), \diamond(1 \mu \mathrm{M} \mathrm{Lpd}+1 \mu \mathrm{M}$ SucB $), \boldsymbol{\square}(1 \mu \mathrm{M}$ lipoamida $+1 \mu \mathrm{M}$ Lpd $), \boldsymbol{\Delta}(1 \mu \mathrm{M}$ LpdA $), \square(1$ $\left.\mu \mathrm{M} \mathrm{LpdA}{ }^{-\mathrm{LA}}\right), \Delta\left(1 \mu \mathrm{M} \mathrm{Lpd}+1 \mu \mathrm{M} \mathrm{SucB}^{-\mathrm{LA}}\right)$. $-\mathrm{LA}$ corresponde às proteínas na qual a etapa de expressão não foi suplementada com ácido lipóico (LA). Para descrição detalhada do método vide sessão "Materiais e Métodos".

SucB na presença de Lpd $(\bullet)$, e PDHB na presença de LpdA $(\bullet)$ mostraram atividade no ensaio indicando que houve incorporação de ácido lipóico. Como experimento controle, SucB $(\triangle)$ e LpdA $(\square)$, expressas na ausência de ácido lipóico na etapa de indução, não mostraram atividade dissulfeto redutase indicando que a presença de ácido lipóico é fundamental para a redução do dissulfeto do DTNB. LpdA (A) sozinha, também demonstrou atividade dissulfeto redutase, mostrando que seu domínio de ligação à ácido lipóico é funcional.

Em seguida, foi testada se essas enzimas lipoiladas eram capazes de reduzir Ohr. Como visto pela figura 38, SucB e PDHB promoveram redução de peróxido dependente de 
Ohr na presença de Lpd. LpdA sozinha ou em combinação com SucB ou PDHB também suportou a atividade peroxidásica de Ohr.

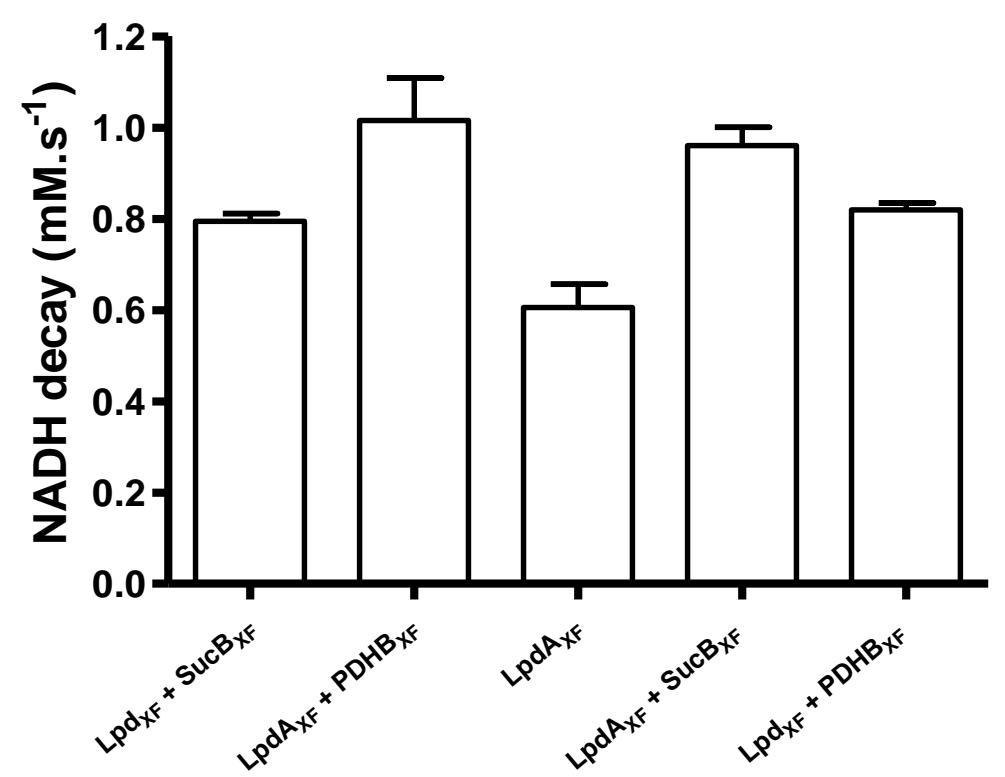

Figura 38. Enzimas recombinantes lipoiladas de $X$. fastidiosa suportam a atividade de $O \mathrm{hr}$.

Mistura de reação continha: NADH (0.2 mM), Lpd ( $2 \mu \mathrm{M})$, Ohr $(0.1 \mu \mathrm{M})$, LpdA (2 $\mu \mathrm{M})$, SucB $(2 \mu \mathrm{M})$, PDHB $(1 \mu \mathrm{M})$. Reações foram iniciadas pela adição de $t$-BHP $(0.2 \mathrm{mM})$ e acompanhadas pela oxidação do NADH. Os resultados representam três experimentos independentes e as barras de erro são a média \pm desvio padrão.

Através desses resultados reconstituímos três possíveis vias envolvidas na decomposição de peróxidos orgânicos.

Utilizando lipoamida livre foi demonstrado que a eficiência catalítica de Ohr na decomposição de $t$-BHP é alta estando na ordem de $10^{6} \mathrm{M}^{-1} \cdot \mathrm{s}^{-1}$ (Tabela 5). Dessa forma, é importante determinar se a transferência de elétrons dos grupos lipóicos de enzimas é cineticamente favorável quando comparado aos dados obtidos na presença de lipoamida livre. Portanto, calculamos os parâmetros cinéticos por análise de bi substrato de PDHB e SucB na presença de $t$-BHP através dos plotes secundários (Figura 39) também de acordo com o modelo descrito por Segel, 1993. 

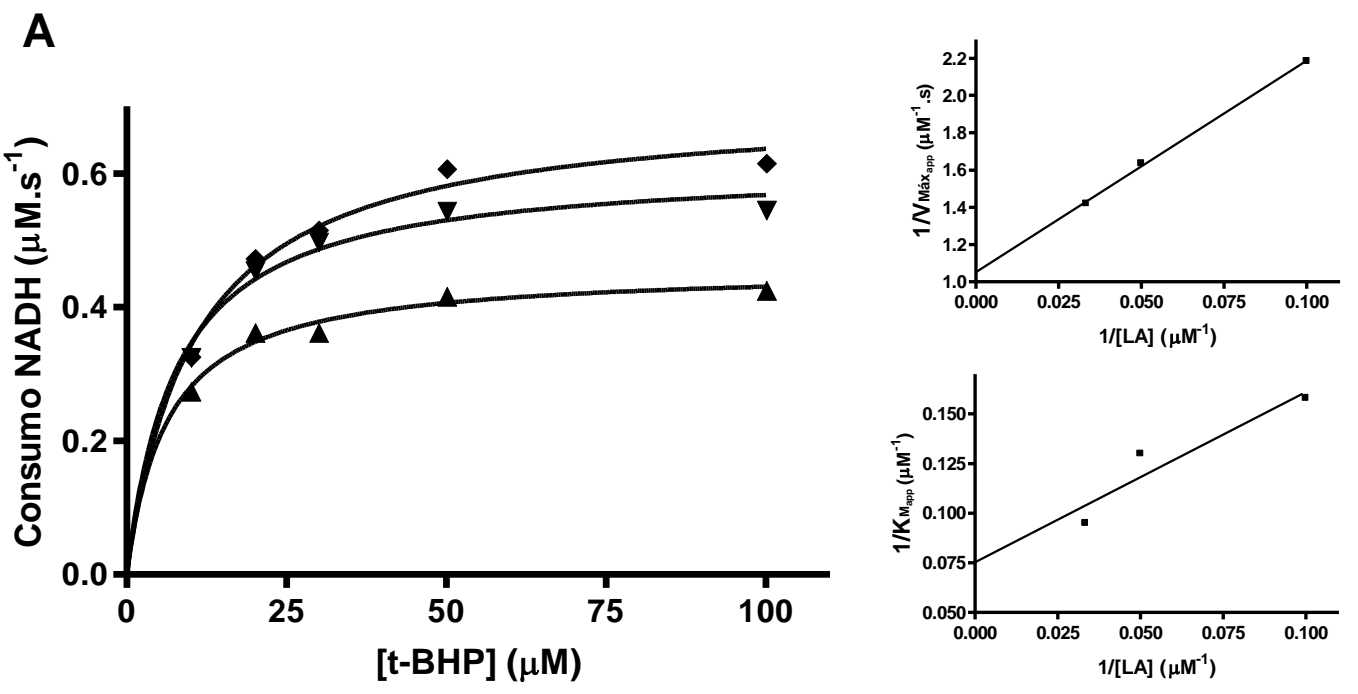

B
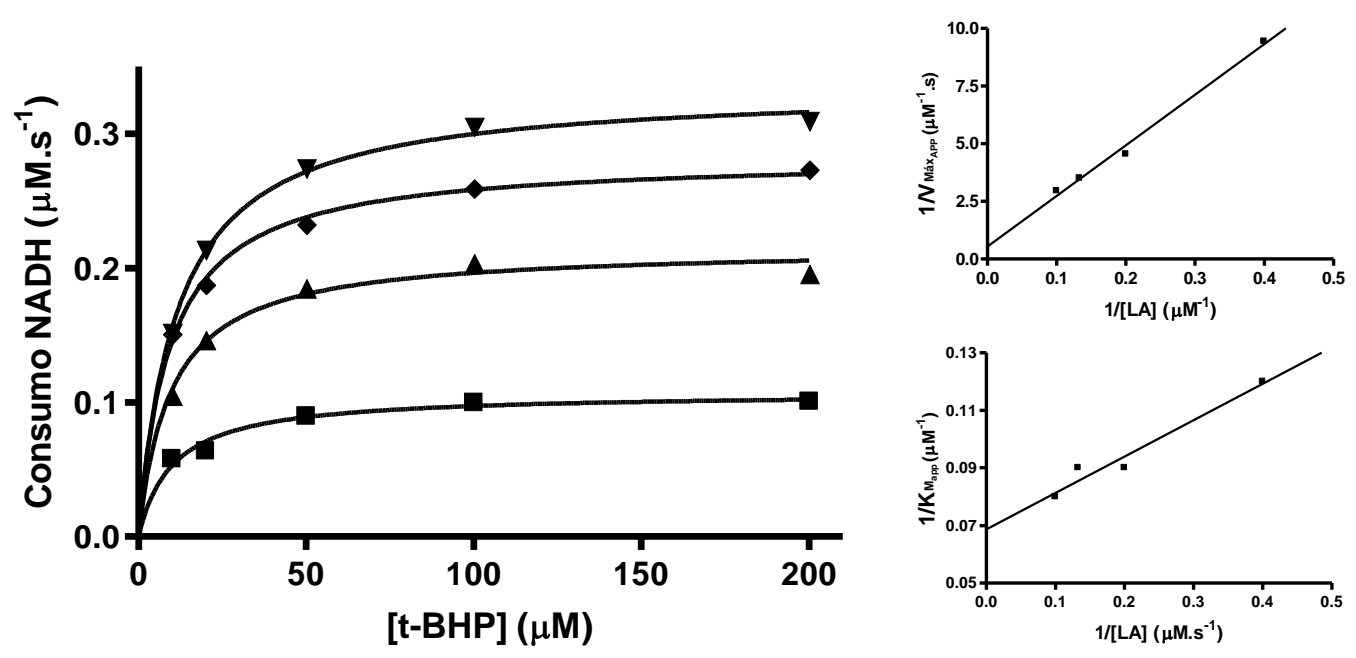

Figura 39. Cinética enzimática para Ohr na presença de enzimas lipoiladas.

Taxas de oxidação de NADH (0.2 mM) em várias concentrações de $t$-BHP e enzimas lipoiladas (PDHB em A e SucB em B) foram determinadas com as seguintes concentrações de enzimas: Ohr $(0.1 \mu \mathrm{M})$, Lpd $(1 \mu \mathrm{M})$. Os gráficos maiores mostram a taxa da reação dos grupos lipóicos das enzimas lipoiladas em várias concentrações plotado contra concentrações de $t$-BHP.

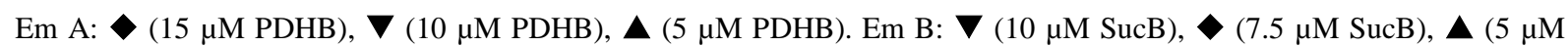
SucB), $\mathbf{\square}\left(2.5 \mu \mathrm{M}\right.$ SucB). $V \max _{a p p}$ e $K m_{a p p}$ foram determinados através de regressão não linear pela equação de MichaelisMenten. Os gráficos menores mostram os plotes secundários de 1/Vmax app e 1/Kmapp versus 1/[LA] onde LA representa as enzimas lipoiladas. Os plotes secundários foram criados para calcular o $K_{m}$ e $V_{\max }$ para ambos os substratos.

Os parâmetros cinéticos de Ohr determinados relativos a SucB e PDHB foram similares em comparação aos obtidos com lipoamida livre (Tabela 6). 
Tabela 6. Parâmetros cinéticos de Ohr para diferentes substratos

\begin{tabular}{|c|c|c|c|}
\hline Substrato & $K_{m}(\mu \mathrm{M})$ & $k_{c a t}\left(s^{-1}\right)$ & $k_{c a t} / K_{m}\left(\mathrm{M}^{-1} \cdot \mathrm{s}^{-1}\right)$ \\
\hline$t-\mathrm{BHP}^{*}$ & $14.51 \pm 0.15$ & $17.95 \pm 7.25$ & $2.06 \times 10^{6} \pm 0.08$ \\
\hline $\mathrm{H}_{2} \mathrm{O}_{2}{ }^{*}$ & $41720.00 \pm 6530.00$ & $9.53 \pm 0.56$ & $2.30 \times 10^{2} \pm 0.20$ \\
\hline Lipoamida & $44.46 \pm 0.98$ & $90.9 \pm 4.70$ & $2.06 \times 10^{6} \pm 0.08$ \\
\hline PDHB & $10.93 \pm 0.15$ & $9.5 \pm 0.20$ & $0.87 \times 10^{6} \pm 0.01$ \\
\hline SucB & $38.51 \pm 14.12$ & $17.95 \pm 7.25$ & $0.46 \times 10^{6} \pm 0.02$ \\
\hline
\end{tabular}

Utilizando concentrações saturantes de $t$-BHP foi possível analisar a dependência da reação de redução de peróxidos na presença de diferentes concentrações de LpdA (Figura 40).

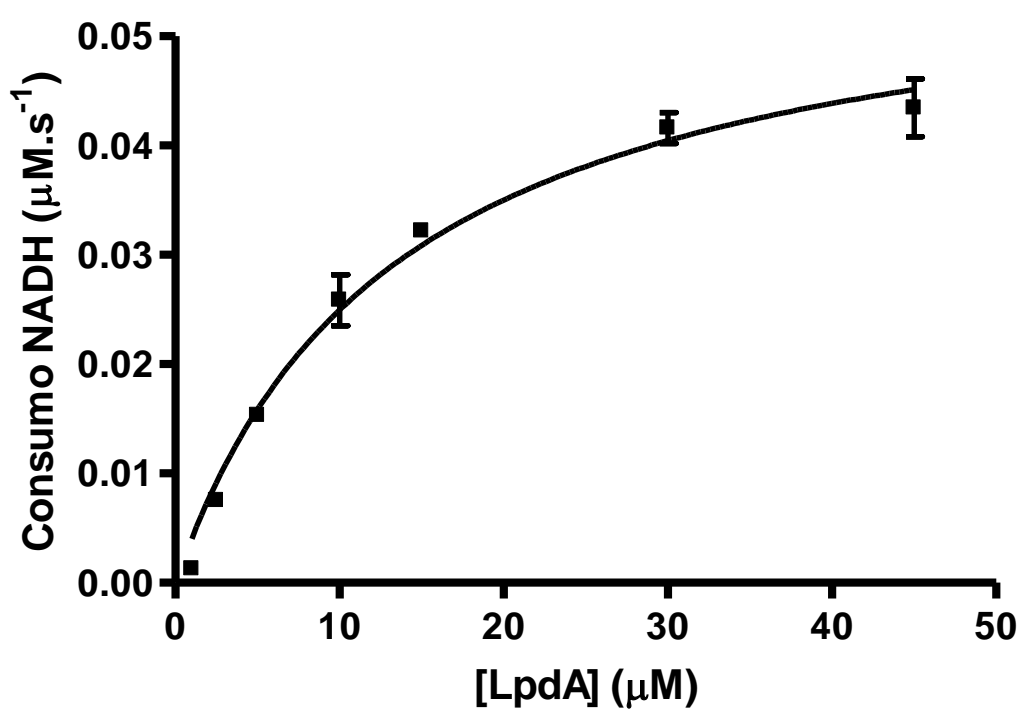

Figura 40. Dependência da atividade de Ohr em concentrações de LpdA.

Mistura de reação continha $\mathrm{Ohr}(0.1 \mu \mathrm{M})$ em $50 \mathrm{mM}$ de tampão fosfato de sódio (pH 7.4), $50 \mathrm{mM} \mathrm{NaCl}$, 1 mM DTPA. Reações foram iniciadas pela adição de $t$-BHP $(0.2 \mathrm{mM})$ e acompanhadas pela oxidação do $\mathrm{NADH}(0.2 \mathrm{mM})$ à $37^{\circ} \mathrm{C}$. Os resultados representam três experimentos independentes e são a média \pm desvio padrão.

Os valores de $K_{m}$ determinados para $\operatorname{LpdA}(13.5 \pm 1.9 \mu \mathrm{M})$ também foram muito similares aqueles obtidos para SucB e PDHB (Tabela 6). No entanto, comparar os valores de $K_{m}$ é complicado visto que os parâmetros relativos à SucB e PDHB foram obtidos em uma concentração fixa de flavoenzima (Lpd $=1 \mu \mathrm{M})$, enquanto que para $\operatorname{Lpd} \mathrm{A}$ a concentração de flavoenzima presente na mistura de reação varia de acordo com o valor indicado no eixo das abscissas, pois esta enzima possui tanto o domínio de ligação a flavina quanto o domínio de ligação a ácido lipóico. Para testar se o aumento na atividade peroxidásica pode também ser influenciada pelo aumento na concentração de flavina, 
realizamos o ensaio de atividade peroxidásica com SucB em diferentes concentrações de Lpd (Figura 41).

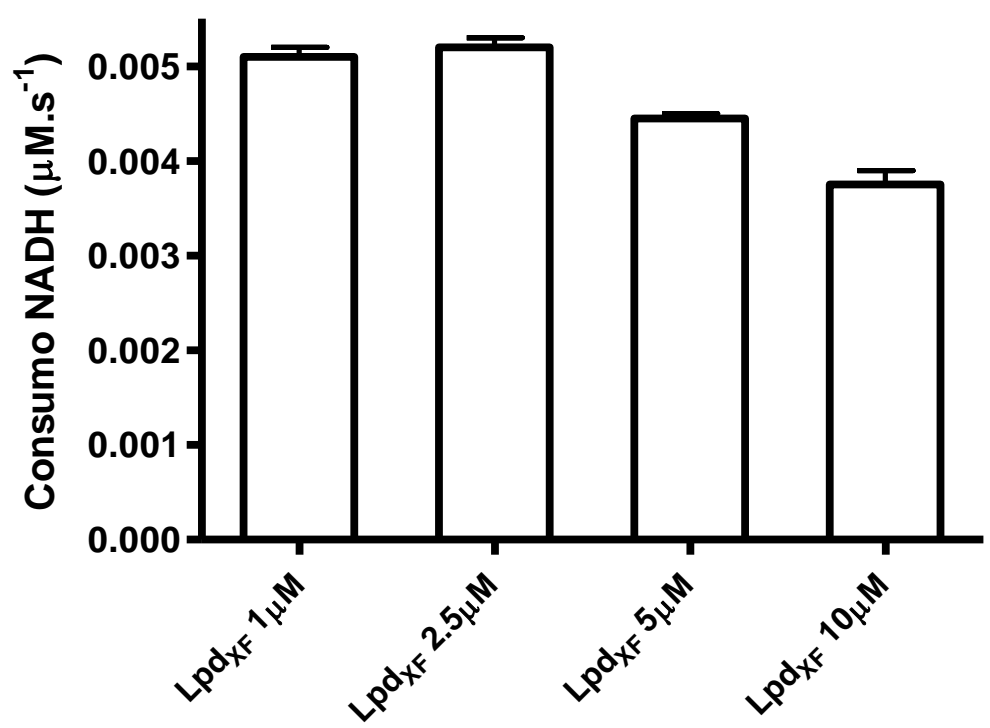

Figura 41. Atividade peroxidásica de Ohr em concentrações crescente de Lpd.

Atividade peroxidásica foi monitorada pela oxidação de NADH a $340 \mathrm{~nm} \quad\left(\varepsilon=6290 \mathrm{M}^{-1} \cdot \mathrm{cm}^{-1}\right)$ em incubações contendo Ohr $(0.1 \mu \mathrm{M})$, SucB $(2.5 \mu \mathrm{M}), t$-BHP $(0.2 \mathrm{mM})$ e NADH $(0.2 \mathrm{mM})$. O ensaio foi realizado como descrito na sessão "Materiais e Métodos". Os resultados representam três experimentos independentes e são a média \pm desvio padrão.

Como podemos ver pelo gráfico, concentrações crescentes de Lpd não influenciam na atividade do sistema, mostrando que essas concentrações não são passo-limitante da reação.

Nós também investigamos se outros sistemas clássicos redutores, descritos na literatura como redutores de outras tióis peroxidases (peroxirredoxinas e glutationa peroxidase) poderiam atuar como doadores de elétrons alternativos para Ohr. A atividade dissulfeto redutase de tiorredoxina e tiorredoxina redutase recombinante de Xylella fastidiosa (TsnC e TrxR respectivamente) foi dosada mostrando que essas enzimas estavam ativas (Figura 42). 


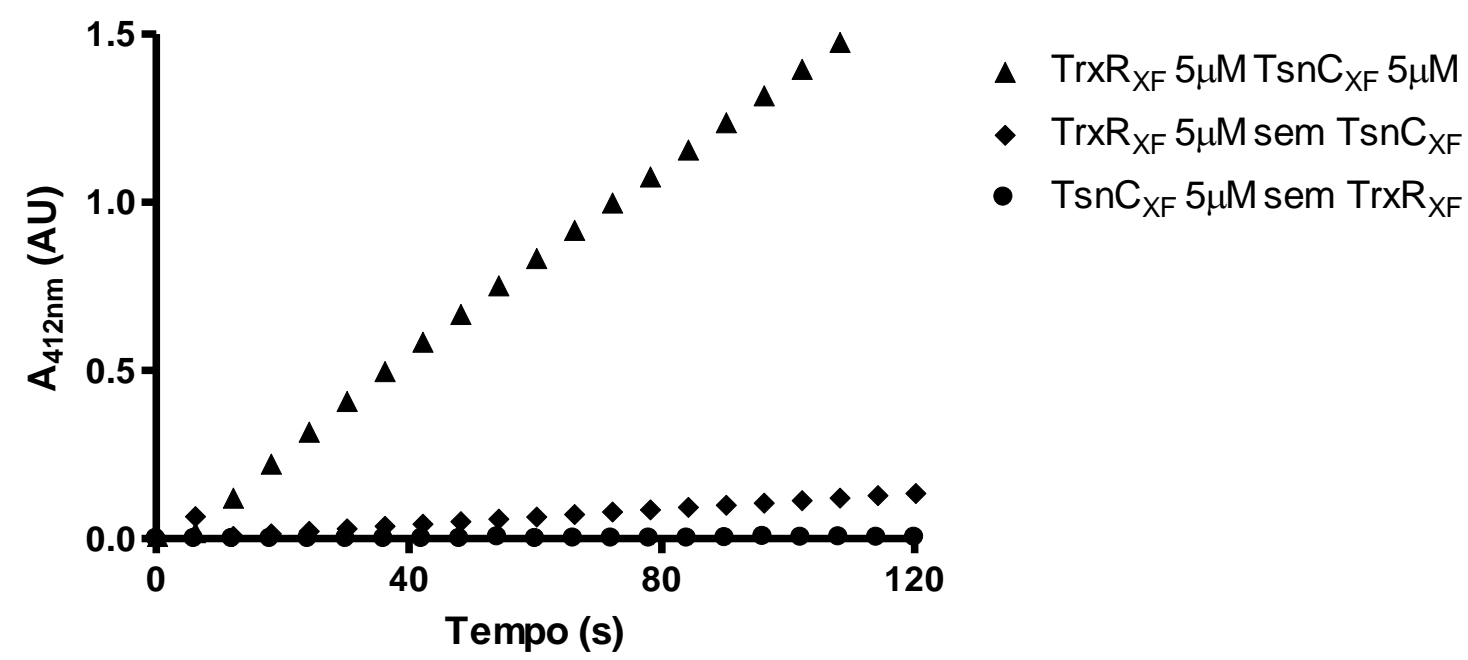

Figura 42. Atividade dissulfeto redutase do sistema tiorredoxina de $X$. fastidiosa.

Reações foram monitoradas à $412 \mathrm{~nm}\left(\varepsilon=14100 \mathrm{M}^{-1}\right.$. $\left.\mathrm{cm}^{-1}\right)$ através da redução do DTNB em $50 \mathrm{mM}$ tampão fosfato de sódio (pH 7.4); 1 mM DTPA e $0.2 \mathrm{mM}$ NADH à $37^{\circ} \mathrm{C}$. Símbolos representam: • $(5 \mu \mathrm{M}$ TsnC), $\bullet(5 \mu \mathrm{M}$ TrxR $), \boldsymbol{\Delta}(5 \mu \mathrm{M} \operatorname{TrxR}+5$ $\mu \mathrm{M}$ TSNC).

No entanto, o sistema tiorredoxina de $X$. fastidiosa falhou em suportar a atividade peroxidásica de Ohr mesmo utilizando altas concentrações de TsnC e TrxR. Nas mesmas condições, PrxQ de Xylella fastidiosa foi capaz de remover $t$-BHP (Figura 43).

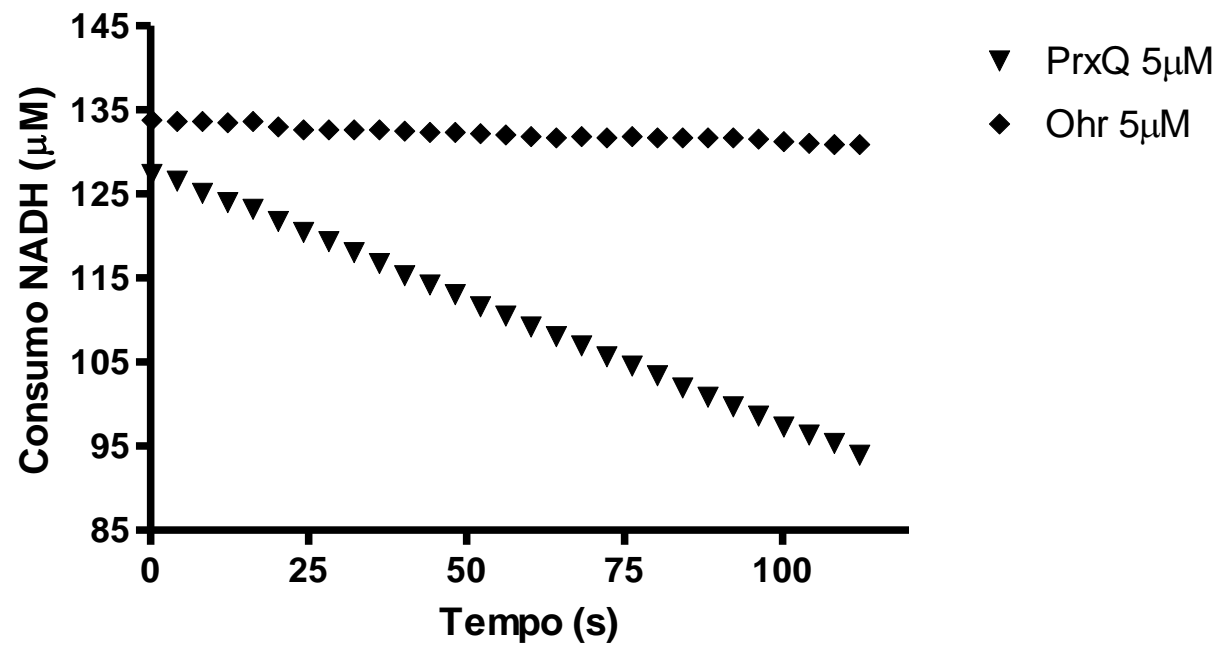

Figura 43. Atividade peroxidásica de Ohr e PrxQ no sistema tiorredoxina de $X$. fastidiosa.

Mistura de reação continha NADPH $(0.2 \mathrm{mM})$ e $t$-BHP $(0.2 \mathrm{mM}) . \nabla(5 \mu \mathrm{M} \operatorname{TrxR}+5 \mu \mathrm{M}$ TsnC $+5 \mu \mathrm{M} \operatorname{PrxQ}), \diamond(5 \mu \mathrm{M}$ TrxR $+5 \mu \mathrm{M}$ TsnC $+10 \mu \mathrm{M}$ Ohr). Reações foram monitoradas pela oxidação do NADPH à $340 \mathrm{~nm}\left(\varepsilon=6220 \mathrm{M}^{-1} \cdot \mathrm{cm}^{-1}\right) \mathrm{a}$ $37^{\circ} \mathrm{C}$. 
Outras tióis peroxidases apresentam atividade peroxidásica na presença de glutationa ou glutarredoxina (Rouhier et al., 2002; Bréhelin et al., 2003). Previamente, já havíamos demonstrado que GSH não suporta atividade peroxidásica de Ohr mesmo em concentrações muito altas em ensaio FOX (Figura 12 e Cussiol et al., 2003, anexo I). Nós agora mostramos que glutarredoxina 1 e 2 de $S$. cerevisiae (cedidas pela $\operatorname{Dr}^{\mathrm{a}}$ Karen Fulan Discola) e glutarredoxina 1 de E. coli na presença de GSH e glutationa redutase (GR) de $S$. cerevisiae não suportam a atividade peroxidásica de Ohr. Não foi observado consumo algum de NADPH mesmo na presença de GSH na concentração de $1 \mathrm{mM}$. Dado o fato de que $2 \mu \mathrm{M}$ de lipoamida covalentemente ligada à enzimas lipoiladas é suficiente para suportar a atividade peroxidásica de Ohr (Figura 38), provavelmente o sistema glutationa não é o redutor fisiológico de Ohr.

\subsubsection{Ohr interage com proteínas lipoiladas in vivo}

De modo obter evidências de que o sistema lipoamida suporta a atividade peroxidásica de Ohr in vivo, fizemos uso de anticorpos policlonais anti-Ohr e anti ácidolipóico. Primeiramente, imunoprecipitamos lisado celular de Xylella fastidiosa com anticorpo anti-ácido lipóico. Consistente com a nossa hipótese, observamos que Ohr coimunoprecipitava com enzimas lipoiladas (Figura 44).

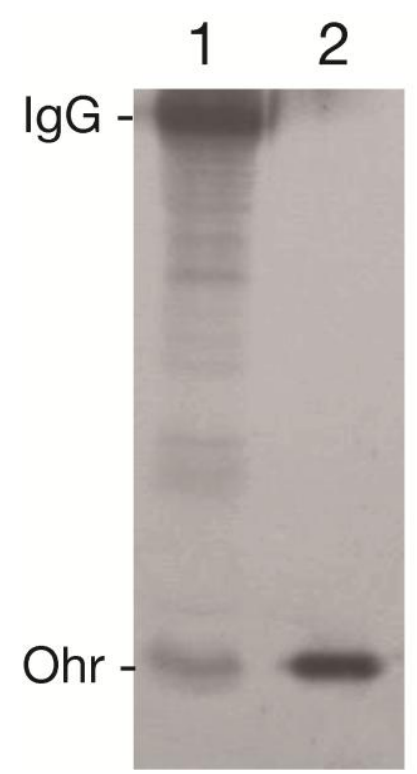

Figura 44. Ohr co-imunoprecipita com enzimas lipoiladas em Xylella fastidiosa.

Proteínas de lisado de Xylella fastidiosa foram imunoprecipitadas com anti-ácido lipóico e analisadas por western blot com anti-Ohr. Raia 1, imunoprecipitado protéico nas beads (30 $\mu \mathrm{l})$ e Raia 2, Ohr recombinante sem His-Tag $(0.1 \mu \mathrm{g})$. 
No mesmo imunoprecipitado, também foi realizado western blot com anticorpo anti ácido-lipóico (1:5000), onde não foi observada banda migrando na posição correspondente a Ohr. Esse experimento controle reforça a suposição de que a banda observada na figura 44 corresponde a Ohr. É importante ressaltar que este experimento foi repetido e os mesmos resultados foram obtidos, indicando que Ohr interage fisicamente com enzimas lipoiladas em Xylella fastidiosa.

Evidências imunoquímicas mostraram que todas as enzimas lipoiladas pertencentes aos complexos da 2-oxoácidos desidrogenase (preditas na anotação do genoma de Xylella fastidiosa) estavam presentes no lisado celular (Figura 45, raias 5-7).

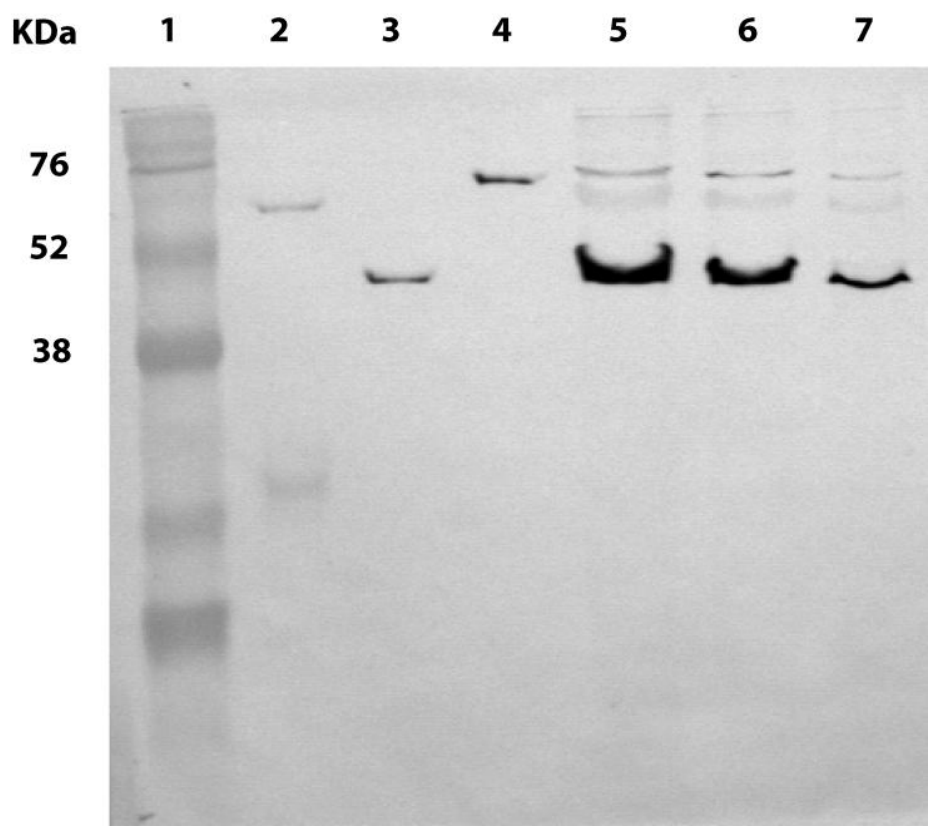

Figura 45. Imunodetecção de enzimas lipoiladas em Xylella fastidiosa.

Raia 1, Padrão de massa molecular Rainbow ${ }^{\mathrm{TM}}$; raia 2, PDHB $(0.1 \mu \mathrm{g})$; raia 3, SucB $(0.1 \mu \mathrm{g})$; raia 4, LpdA (0.1 $\left.\mu \mathrm{g}\right)$; raias 5 7, lisados de Xylella fastidiosa $(15,10$ e $5 \mu \mathrm{g}$, respectivamente). Após etapa de transferência, membrana foi incubada com anti-ácido lipóico (1:5000) overnight à $4^{\circ} \mathrm{C}$ e revelada através de reação com fosfatase alcalina conforme descrito na sessão "Materiais e Métodos".

Como visto anteriormente pelos dados cinéticos, todas as enzimas detectadas por anti-ácido lipóico são capazes de suportar a atividade peroxidásica de Ohr. O gene gcvH (XF 0181) de Xylella fastidiosa codifica para uma enzima lipoilada denominada Proteína $\mathrm{H}$, pertencente ao sistema de clivagem da glicina. Sua massa molecular foi predita em 15.8 $\mathrm{kDa}$, porém não conseguimos detectá-la em nenhum de nossos experimentos utilizando anticorpo anti-ácido lipóico. Além disso, sua massa molecular é muito menor do que a de todas as outras enzimas lipoiladas, evitando assim uma interpretação equivocada da Figura 
45. Através de análises semi quantitativas por imagem, pudemos estimar a concentração intracelular dessas enzimas. SucB é a proteína lipoilada mais abundante, presente no extrato em concentrações de micromolar (0.9 $\mu \mathrm{M}$ aproximadamente). LpdA e PDHB estão presentes em menores concentrações (0.07 e $0.13 \mu \mathrm{M}$ respectivamente).

Encontramos Ohr tanto na fração intracelular (Figura 46 raia 2) quanto na fração extracelular (Figura 46 raias 3,4). Além disso, foi encontrado na fração extracelular juntamente com Ohr, uma proteína reativa com anti-ácido lipóico que co-migrava com SucB (o componente E2 do complexo da a-cetoglutarato desidrogenase) (Figura 46, raias 9,10). LpdA foi detectada somente na fração intracelular (Raia 8) de Xylella.

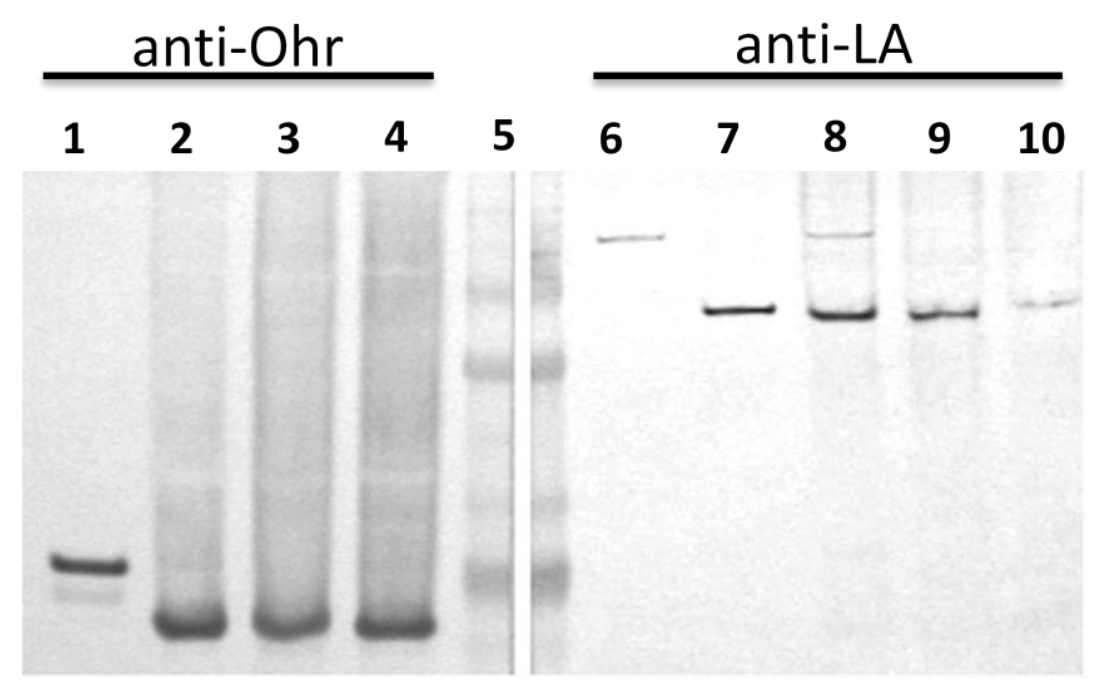

Figura 46. Detecção de Ohr e enzimas lipoilada nas frações intra e extracelular

Frações contendo proteínas extracelulares foram obtidas lavando as células duas vezes com tampão Tris. Raias 1-4 correspondem a anti-Ohr (1:1000), e Raias 6-10 correspondem a anti-ácido lipóico (1:5000). Raia 1, Ohr (0.1 $\mu$ g); Raia 2, lisado de $X$. fastidiosa, raia 3, primeira lavagem do sobrenadante; raia 4, segunda lavagem do sobrenadante; raia 5, Padrão de peso molecular Rainbow ${ }^{\mathrm{TM}}$; raia 6, LpdA $(0.1 \mu \mathrm{g})$; raia 7 , SucB $(0.1 \mu \mathrm{g})$; raia 8 , lisado de $X$. fastidiosa; raia 9 , primeira lavagem do sobrenadante; raia 10, segunda lavagem do sobrenadante.

Como mostrado pelos ensaios de co-imunoprecipitação, Ohr é capaz de interagir fisicamente com proteínas lipoiladas em extrato celular de $X$. fastidiosa. Além disso, LpdA, PDHB e SucB sustentam a atividade peroxidásica de Ohr com alta eficiência como atestado pelos experimentos cinéticos. Sendo assim, a habilidade do extrato de $X$. fastidiosa de sustentar a atividade de Ohr deve diminuir drasticamente se proteínas lipoiladas forem imunodepletadas. De fato, imunodepleção de proteínas lipoiladas em extratos de $X$. fastidiosa e E. coli, utilizando anti-ácido lipóico reduziu drasticamente a taxa de oxidação de NADH quando comparada a mesma preparação que não sofreu imunodepleção (Figura 47) 


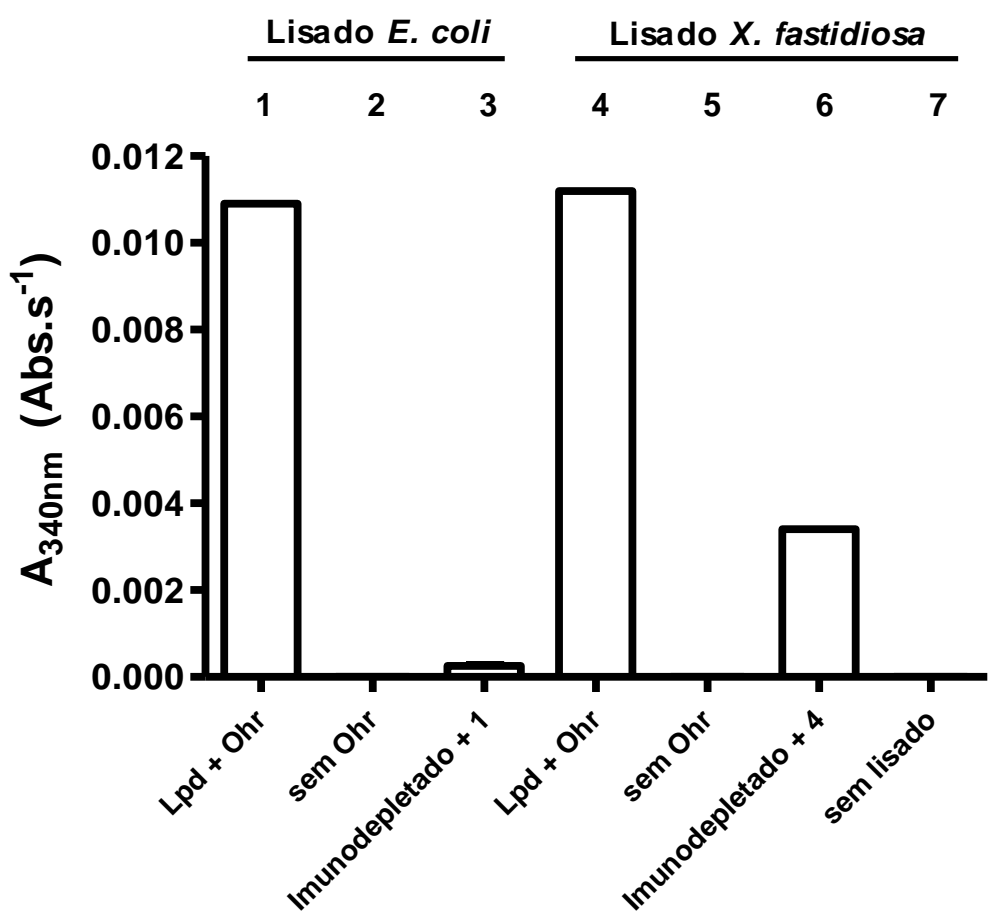

Figura 47. Habilidade dos imunodepletados de $E$. coli (Ec) e $X$. fastidiosa (Xf) de suportar a atividade de Ohr.

Lisados bacterianos $(0.5 \mathrm{mg} / \mathrm{ml})$ foram incubados com NADH $(0.2 \mathrm{mM})$, Ohr $(1 \mu \mathrm{M})$, Lpd $(2.5 \mu \mathrm{M})$ e $t$-BHP $(0.2 \mathrm{mM})$ e monitorados através do consumo de NADH à $340 \mathrm{~nm}$ conforme descrito em "Materiais e Métodos".

A atividade residual detectada nos extratos imunodepletados (Figura 47, Raia 3 e 6) se correlaciona com a presença de proteínas lipoiladas que não foram completamente removidas na etapa de imunoprecipitação como podemos comprovar pela figura 48.

\section{kDa}

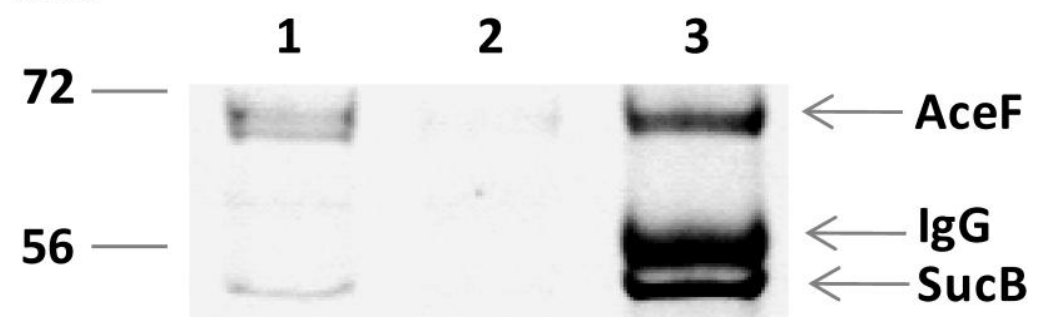

Figura 48. Imunodepleção do lisado de $E$. coli.

Amostras foram analisadas por western blot com anti-ácido lipóico (1:5000). Raia 1, lisado de E. coli; Raia 2, lisado imunodepletado (10 $\mu \mathrm{g})$; Raia 3, imunocomplexos nas beads $(10 \mu \mathrm{l})$. Setas indicam as proteínas lipoiladas SucB (44 kDa; número de acesso do gene ECK0114, subunidade E2 do complexo da $\alpha$-cetoglutarato desidrogenase) e AceF (66 kDa; número de acesso do gene ECK0715, subunidade E2 do complexo da piruvato desidrogenase) da linhagem K12 de E. coli. 
Em conjunto, os resultados apresentados aqui corroboram a hipótese de que proteínas lipoiladas (SucB, PDHB e/ou LpdA) são os redutores biológicos de Ohr.

Estes resultados geraram um artigo científico que atualmente está em processo de submissão e está na sessão de anexos da tese (anexo V).

\subsubsection{OsmC de Escherichia coli é reduzida por enzimas lipoiladas de $X$. fastidiosa}

Como visto anteriormente, OsmC é uma proteína da família Ohr/OsmC relacionada ao estresse induzido por choque osmótico. OsmC é uma tiól peroxidase com preferência por hidroperóxidos orgânicos e possui uma estrutura quaternária muito similar a das proteínas da subfamília Ohr (Lesniak et al., 2003). Seu mecanismo catalítico é idêntico ao presente na subfamília Ohr. Como em Ohr, seu mecanismo de redução é até o momento desconhecido. No trabalho de mestrado da Ms. Telma Regina Sugimoto, foi demonstrado que o sistema heterólogo composto por lipoamida/Lpd bovina/NADH suportava a atividade peroxidásica de OsmC de E. coli (Sugimoto, 2006). De posse desses dados, e possuindo enzimas recombinantes do metabolismo intermediário, observamos que Lpd de $X$. fastidiosa assim como visto para Ohr suportava a atividade de OsmC na presença de lipoamida livre. Em colaboração com o aluno de mestrado Tiago Geronimo Pires Alegria, foram calculados os parâmetros cinéticos de OsmC recombinante de E. coli (clonada pela Ms. Telma Regina Sugimoto) na presença de peróxidos orgânicos (Figura 49 e Tabela 7).
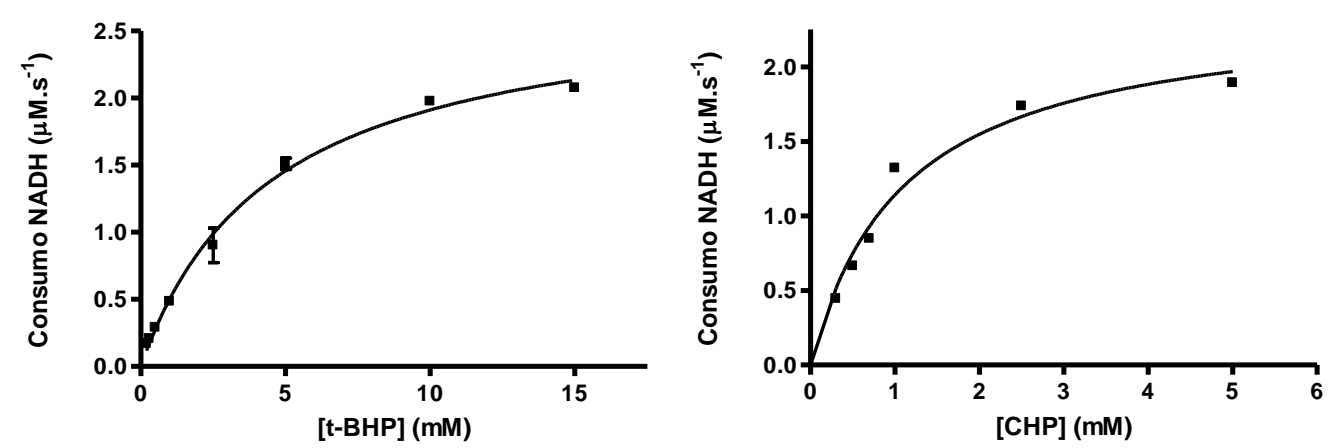

Figura 49. Cinética enzimática para OsmC recombinante de $E$. coli.

Parâmetros foram calculados através de uma curva de regressão não linear utilizando o software Graph Pad Prism ${ }^{\circledR}$. Atividade peroxidásica foi monitorada através de consumo de NADH à $340 \mathrm{~nm}\left(\varepsilon=6290 \mathrm{M}^{-1}\right.$. $\left.\mathrm{cm}^{-1}\right)$ em incubações contendo OsmC $(0.2 \mu \mathrm{M})$; Lpd $(2 \mu \mathrm{M})$; lipoamida $(30 \mu \mathrm{M})$ e peróxidos nas concentrações especificadas na figura. Os resultados representam três experimentos independentes e são a média \pm desvio padrão. 
Tabela 7. Parâmetros cinéticos de OsmC para diferentes substratos.

\begin{tabular}{lccc|}
\hline Peróxido & $\boldsymbol{K}_{\boldsymbol{m}}(\mathbf{m M})$ & $\boldsymbol{k}_{\text {cat }}\left(\mathbf{s}^{-1}\right)$ & $\boldsymbol{k}_{\text {cat }} / \boldsymbol{K}_{\boldsymbol{m}}\left(\mathbf{M}^{-1} \cdot \mathbf{s}^{-1}\right)$ \\
\hline$t$-BHP & $4.53 \pm 0.46$ & $13.89 \pm 0.55$ & $3.07 \times 10^{3} \pm 0.19$ \\
CHP & $1.11 \pm 0.15$ & $12.02 \pm 0.66$ & $1.08 \times 10^{4} \pm 0.09$
\end{tabular}

Parâmetros para $t$-BHP e CHP foram obtidos através de regressão não-linear usando lipoamida (30 $\mu \mathrm{M})$. Os resultados representam três experimentos independentes e são a média \pm desvio padrão.

Não foi possível calcular os parâmetros na presença de $\mathrm{H}_{2} \mathrm{O}_{2}$, pois não foi encontrado uma concentração saturante de peróxido mesmo em concentrações acima de $100 \mathrm{mM}$. Dados na tabela 7 indicam que OsmC reduz cumeno hidroperóxido (CHP) aproximadamente uma ordem de grandeza mais eficiente que $t$-BHP. Embora o turnover $\left(k_{\text {cat }}\right)$ de Ohr para os dois substratos seja praticamente o mesmo, CHP possui uma maior afinidade $\left(K_{m}\right)$ do que $t$-BHP.

Comparativamente, OsmC possui uma menor eficiência catalítica do que Ohr (de aproximadamente duas ordens de grandeza). Essa menor eficiência é devido ao alto $K_{m}$ para ambos os peróxidos (na faixa de milimolar) enquanto para Ohr observamos valores na faixa de micromolar (14.5 $\mu \mathrm{M}$ para $t$-BHP). No entanto, é provável que na presença de prováveis hidroperóxidos biológicos (CHP é um hidroperóxido sintético) a eficiência catalítica de OsmC aumente consideravelmente. Não conseguimos calcular os parâmetros de OsmC por uma análise de bi substrato provavelmente devido ao mesmo fenômeno observado para Ohr na presença de $\mathrm{H}_{2} \mathrm{O}_{2}$. A baixa eficiência catalítica de Ohr na redução desses substratos (alto $K_{m}$ ) faz com que essa etapa da reação se torne passo limitante não se alterando em concentrações crescentes de lipoamida.

Visto que lipoamida é capaz de doar elétrons para OsmC, investigamos a possibilidade das enzimas lipoiladas recombinantes de $X$. fastidiosa sustentarem a atividade de OsmC. SucB, PDHB e/ou LpdA foram capazes de regenerar OsmC a forma reduzida. Ohr em concentrações equimolares à OsmC possui uma atividade peroxidásica consideravelmente maior (Figura 50). 


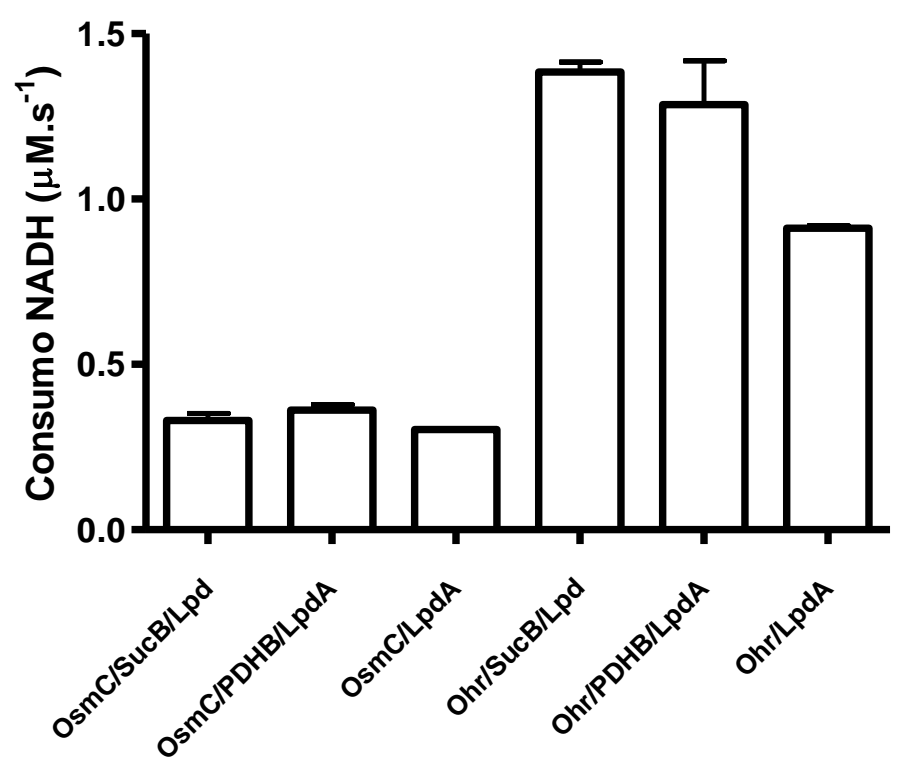

Figura 50. Atividade comparada de Ohr e OsmC na presença de enzima lipoiladas de $X$. fastidiosa.

Os ensaios foram realizados em tampão fosfato de sódio 50mM pH 7,4; NaCl 50mM; DTPA 1mM; NADH 0,2mM; t-BHP $0,2 \mathrm{mM}$ à $37^{\circ} \mathrm{C}$. As concentrações das enzimas para cada condição foram: 1. (Lpd $2 \mu \mathrm{M}$; SucB $2 \mu \mathrm{M}$ e OsmC $\left.0.5 \mu \mathrm{M}\right) ; 2$.

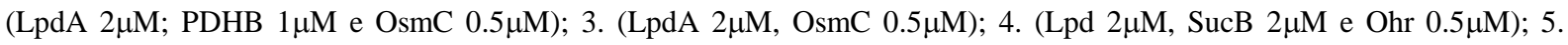
(LpdA $2 \mu \mathrm{M}$, PDHB $1 \mu \mathrm{M}$ e Ohr $0.5 \mu \mathrm{M})$; 6. (LpdA $2 \mu \mathrm{M}$ e $\mathrm{Ohr} 0.5 \mu \mathrm{M})$. Os resultados representam três experimentos independentes e são a média \pm desvio padrão.

No entanto, esse dado não é muito conclusivo, pois foi utilizado $t$-BHP no ensaio numa concentração de $200 \mu \mathrm{M}$ que embora para Ohr já esteja saturante $\left(K_{m} \approx 14.5 \mu \mathrm{M}\right)$, para OsmC ainda não atingiu o ponto de saturação devido ao $K_{m}$ elevado de OsmC $\left(K_{m} \approx\right.$ $4.5 \mathrm{mM}$ ) para este hidroperóxido. Além disso, OsmC está sendo usada em um sistema heterólogo de $X$. fastidiosa. Sabe-se que Ohr e OsmC apesar de compartilharem semelhanças estruturais possuem diferenças na cavidade do sítio ativo (Jenkins et al., 2008). Portanto, a apresentação do grupo lipóico pelas enzimas lipoiladas de Xylella pode ser menos eficiente para OsmC.

\subsection{Ohr é capaz de reduzir peróxidos derivados de lipídios}

Estudos anteriores por modelagem molecular mostraram que hidroperóxido de ácido oléico se encaixava perfeitamente no sítio ativo de Ohr com sua função peróxido voltada para a cisteína peroxidásica de Ohr (Oliveira et al., 2006 anexo II). Dessa forma, foi proposto que hidroperóxidos derivado de ácidos graxos insaturados deveriam ser os substratos biológicos de Ohr. 
Através do ensaio de redução de peróxidos monitorado pelo consumo de NADH, observamos inicialmente que Ohr possuía atividade na presença de hidroperóxido de ácido linoléico. Esse peróxido foi sintetizado e cedido gentilmente pelo laboratório do Prof. Dr. Paolo Di Mascio e da Prof ${ }^{a}$ Dr $^{a}$ Sayuri Miyamoto (Instituto de Química - USP). Através de gráfico cinético de consumo de NADH pela concentração de peróxido, observamos uma inibição da atividade em concentrações relativamente baixas de peróxido de ácido linoléico $(\approx 200 \mu \mathrm{M}$, Figura 51). Fisher et al., 1999, demonstrou que peróxidos derivados de lipídios formam agregados micelares a partir de uma concentração crítica, escondendo seu grupo polar e deste modo ficando inacessível a enzima. Foi observado que a atividade de redução de peróxidos orgânicos de uma "non-selenium" glutationa peroxidase (NSGPx) era 40\% menor na ausência de Triton X-100 (0.1\%).

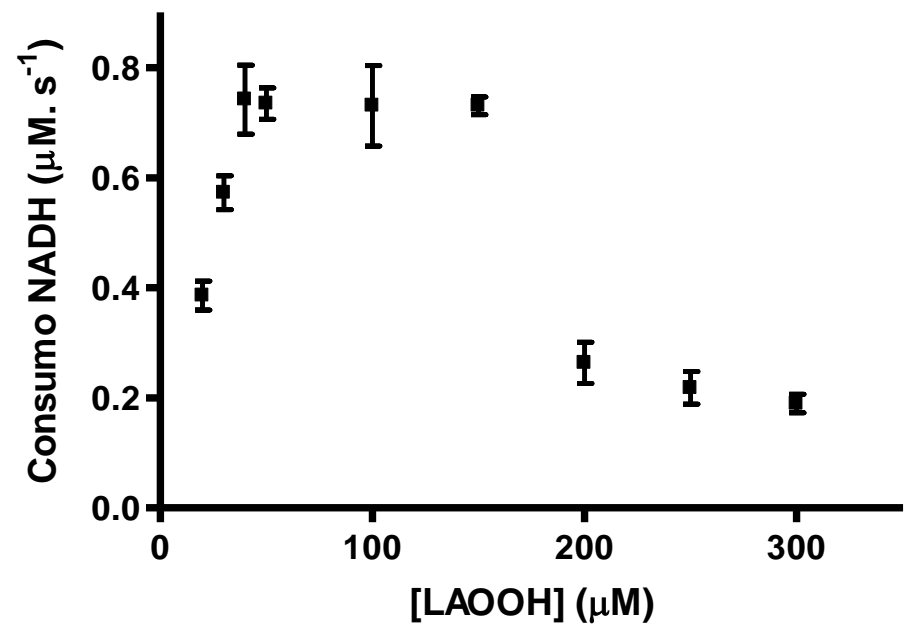

Figura 51. Redução de peróxido linoléico por Ohr.

A solução de peróxido solubilizada em etanol foi adicionada no meio de reação de modo que a concentração final de etanol ficasse para todos os pontos em 1\%. Os ensaios foram realizados em duplicatas nas seguintes condições: Ohr $(0.1 \mu \mathrm{M})$; Lpd $(0.5 \mu \mathrm{M})$; lipoamida $(200 \mu \mathrm{M})$. A reação foi iniciada com a adição do peróxido e monitorada a $340 \mathrm{~nm}$ à $37^{\circ} \mathrm{C}$.

Dessa forma, repetimos os ensaios anteriores adicionando Triton X-100 (0.1\%) ao meio de reação Observamos que para uma determinada condição a ausência de Triton X100 diminui a atividade da enzima em até 90\% (Figura 52). Esses estudos estão sendo finalizados pelo mestrando Thiago Geronimo Pires Alegria de nosso grupo. 


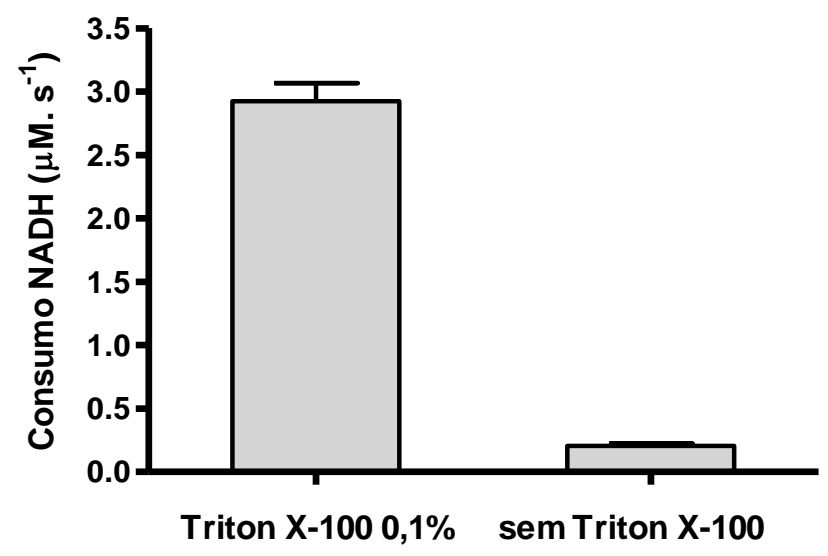

Figura 52. Atividade de redução de hidroperóxido de ácido oléico no sistema lipoamida.

Os ensaios foram realizados em duplicatas nas seguintes condições: Ohr (0.1 $\mu \mathrm{M})$; Lpd $(0.5 \mu \mathrm{M})$; lipoamida $(200 \mu \mathrm{M})$; OLOOH $(300 \mu \mathrm{M})$. A reação foi iniciada com a adição do peróxido e o consumo de NADH foi monitorado a $340 \mathrm{~nm}$ à $37^{\circ} \mathrm{C}$.

\subsection{Caracterização de resíduos de aminoácidos envolvidos na catálise de Ohr}

Como mencionado anteriormente, através de análise da estrutura de Ohr, observamos que uma série de aminoácidos presentes no sítio ativo realizavam interações hidrofóbicas com uma molécula de PEG co-cristalizada no sítio ativo, provavelmente mimetizando um substrato biológico de Ohr. Postulamos que esses resíduos eram importantes para a atividade de Ohr posicionando e/ou estabilizando o peróxido ou o grupo lipóico de enzimas lipoiladas no sítio ativo (Oliveira et al., 2006 anexo II).

Dessa forma, conseguimos clonar, expressar e purificar seis mutantes de Ohr: V36S; L40T; F68Y; G95S; F96Y e P126H. Todos os mutantes foram clonados em linhagem BL21(DE3) e as mutações foram triadas por seqüenciamento de nucleotídeos conforme descrito na sessão "Materiais e Métodos". As amostras foram purificadas por cromatografia de afinidade a metal e o seu grau de pureza atestado por gel SDS-PAGE redutor (Figura 53). 


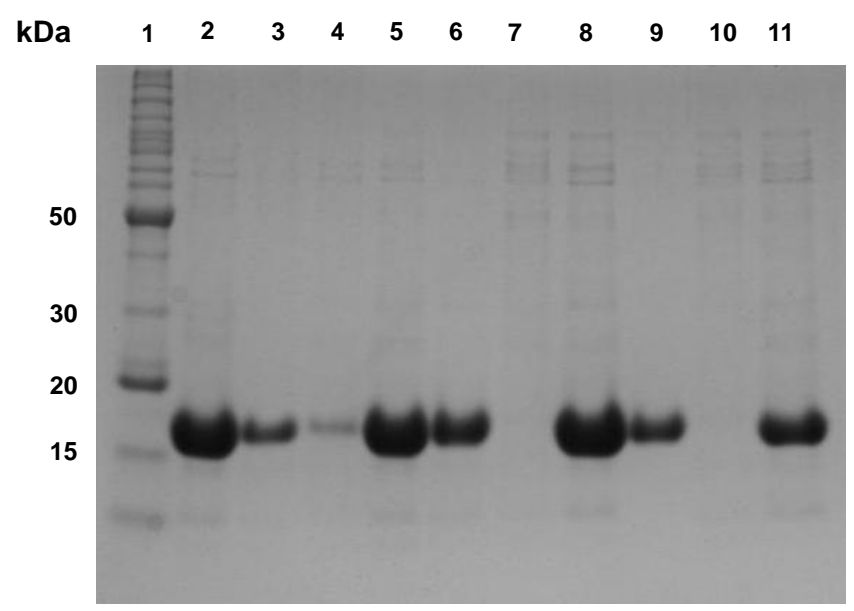

Figura 53. Purificação de mutantes de Ohr recombinante em gel SDS-Page redutor.

Raia 1. Bench Mark ${ }^{\circledR}$ Ladder; Raias 2-3. Frações eluídas de Ohr V36S; Raias 4-5. Frações eluídas de Ohr L40T; Raias 6-7. Ohr F68Y; Raia 8. Ohr G95S; Raia 9-10. Ohr F96Y; Raia 11: Ohr P126H.

Após a obtenção dos mutantes, comparamos a atividade peroxidásica destes com Ohr selvagem (WT) (Figura 54).

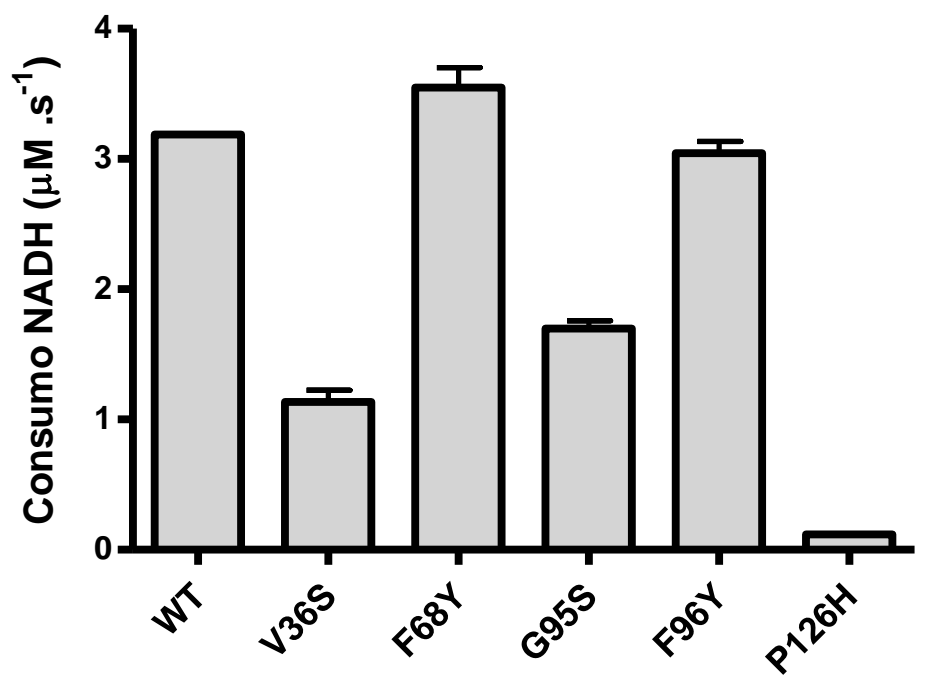

Figura 54. Atividade peroxidásica de Ohr WT e mutantes no sistema lipoamida.

A atividade peroxidásica de Ohr WT e mutantes foi monitorada através de consumo de NADH à $340 \mathrm{~nm}\left(\varepsilon=6290 \mathrm{M}^{-1} . \mathrm{cm}^{-1}\right)$ em incubações contendo $\mathrm{Ohr}(0.2 \mu \mathrm{M})$; Lpd $(2 \mu \mathrm{M})$; SucB $(2 \mu \mathrm{M})$ e $t$-BHP $(200 \mu \mathrm{M})$. Mistura de reação continha $50 \mathrm{mM}$ tampão fosfato Sódio (pH 7.4); $50 \mathrm{mM} \mathrm{NaCl}$ e 1 mM DTPA. Os resultados representam três experimentos independentes e são a média \pm desvio padrão.

Houve perda significativa de atividade nos mutantes V36S; G95S e P126H. Os dados de atividade corroboram os dados estruturais obtidos anteriormente, indicando que dos mutantes estudados, os resíduos Val-36; Gly-95 e Pro-126 são importantes para a atividade 
catalítica de Ohr. No entanto, analisando a substituição do aminoácido feita na posição 126 vemos que houve uma substituição de um aminoácido alifático e, portanto, hidrofóbico por um aminoácido de carga positiva. Esse incremento de carga pode gerar interações eletrostáticas com resíduos vizinhos alterando assim as características do sítio ativo.

Diferentemente dos resíduos Arg-19 e Glu-51 que interagem diretamente com a cisteína peroxidásica $\left(\mathrm{Cys}_{\mathrm{p}} 61\right)$ estabilizando sua sulfidrila na forma de ânion tiolato, os resíduos de aminoácidos analisados por mutação sítio-dirigida parecem interagir diretamente com o substrato de Ohr e não com as cisteínas do sítio ativo conforme dados de estrutura (Oliveira et al., 2006 anexo II). De modo a determinar se esses resíduos também estão envolvidos na estabilização do tiolato de Ohr, calculamos o $\mathrm{pK}_{\mathrm{a}}$ para cada mutante e comparamos com o $\mathrm{pK}_{\mathrm{a}}$ da proteína selvagem.

Em uma primeira tentativa, tentamos determinar o $\mathrm{pK}_{\mathrm{a}}$ através de modificação química com lodoacetamida (IAM). Esse composto alquila mais rapidamente a sulfidrila em sua forma aniônica (tiolato). Conseqüentemente, a determinação da velocidade da reação em função do $\mathrm{pH}$ pode ser usado para medir o valor de $\mathrm{pK}_{\mathrm{a}}$ do grupo tiól de uma cisteína (Snyder et al., 1987). O ensaio foi feito conforme descrito em "Materiais e Métodos". No entanto, não obtivemos nenhum resultado, pois iodoacetamida não reagiu com a cisteína de Ohr em nenhuma das faixas de $\mathrm{pH}$ testadas. Aparentemente, como iodoacetamida é um composto hidrossolúvel, este não teria acesso a cisteína peroxidásica que está enterrada na própria estrutura protéica em um ambiente altamente hidrofóbico.

Por essa razão, partimos para a determinação do $\mathrm{pK}_{\mathrm{a}}$ por um método que não necessitasse de modificação química. De fato, conseguimos determinar o $\mathrm{pK}_{\mathrm{a}}$ através da absorção do tiolato à 240nm (Nelson \& Creighton, 1994). No entanto, esse método não se mostrou reprodutível, pois só foi possível calcular o $\mathrm{pK}_{\mathrm{a}}$ da proteína selvagem (Figura 55). $\mathrm{O}$ $\mathrm{pK}_{\mathrm{a}}$ calculado para a cisteína de Ohr foi de aproximadamente 5.8, o que está próximo ao $\mathrm{pK}_{\mathrm{a}}$ calculado para outras tióis peroxidases como as peroxirredoxinas. 


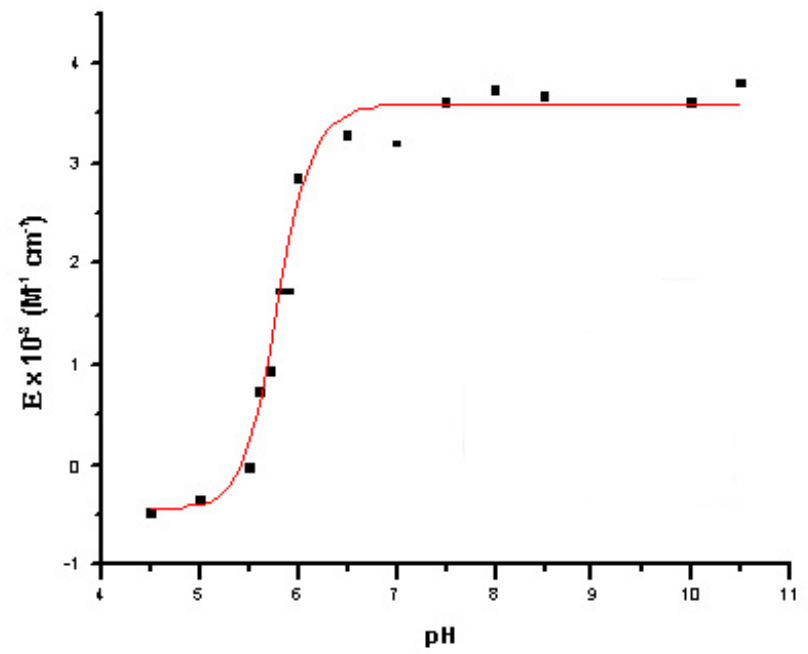

Figura 55. Ionização do grupo tiól da Cys 61 de Ohr.

Através de absorbância à $240 \mathrm{~nm}$ em função do $\mathrm{pH}$ à temperatura ambiente foi determinado o valor de $\mathrm{pK}_{\mathrm{a}}$ do grupo tiól da Cys 61 de Ohr. No ensaio foi utilizado $\mathrm{Ohr}(15 \mu \mathrm{M})$ na presença dos respectivos tampões $(100 \mathrm{mM})$ para cada faixa de $\mathrm{pH}$; $\mathrm{NaCl}(200 \mathrm{mM})$ e DTPA (1mM).

Através de ensaio FOX, determinamos a atividade peroxidásica de Ohr em diferentes pHs (Figura 56). Como podemos observar, o pico de atividade é observado em pH próximo do fisiológico (7.4). De acordo com os dados de $\mathrm{pK}_{\mathrm{a}}, \mathrm{Cys}_{\mathrm{p}} 61$ de Ohr está em maior proporção em sua forma desprotonada. Em pH próximo de 4.0, quase não há atividade peroxidásica visto que a maior parte da cisteína está na forma protonada menos reativa. $\mathrm{A}$ queda de atividade observada em pHs mais alcalinos pode ser causado pela perda de estrutura terciária devido a instabilidade nessa faixa de $\mathrm{pH}$ ou então devido a desprotonação de outros grupos de resíduos de aminoácidos que contribuem para a atividade catalítica de Ohr. Esse perfil de atividade de Ohr em função do $\mathrm{pH}$ está de acordo com o $\mathrm{pK}_{\mathrm{a}}$ equivalente a 5.8 determinado na figura 55 . 


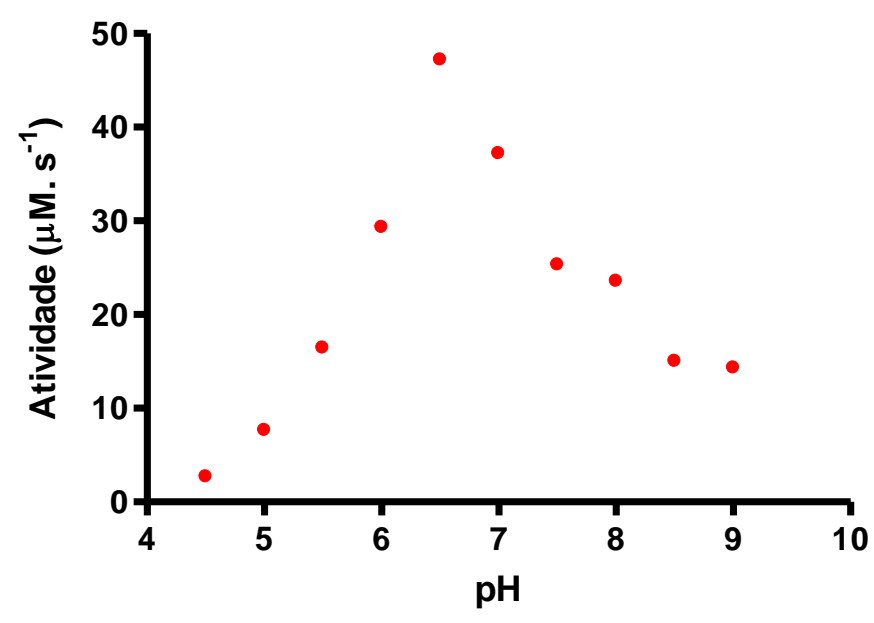

Figura 56. Efeito do $\mathrm{pH}$ na atividade de Ohr.

Ohr $(0.1 \mu \mathrm{M})$ foi incubada a $37^{\circ} \mathrm{C}$ na presença de DTPA $(0.1 \mathrm{mM})$, Azida $(1 \mathrm{mM}), t$-BHP $(0.2 \mathrm{mM})$, DTT $(0.5 \mathrm{mM})$ na presença de tampão $(50 \mathrm{mM})$ em diferentes faixas de $\mathrm{pH}$. A reação foi interrompida com a adição de $\mathrm{HCl}(0.2 \mathrm{M})$ e o consumo de peróxido foi determinado através de reação com o composto Xylenol Orange na presença de $\mathrm{Fe}^{+2}$. Para maiores detalhes experimentais vide sessão "Materiais e Métodos".

Finalmente, através do método de alquilação pelo composto monobromobimano (Discola et al., 2009 anexo IV), conseguimos calcular o $\mathrm{pK}_{\mathrm{a}}$ de Ohr WT e mutantes. Através da equação de Henderson-Hasselbalch obtivemos valores de $\mathrm{pK}_{\mathrm{a}}$ (Tabela 8), calculados no programa GraphPad ${ }^{\circledR}$ Prism4 (Figura 57).

Tabela 8. Valores de $\mathrm{pK}_{\mathrm{a}}$ da cisteína peroxidásica de Ohr WT e mutantes.

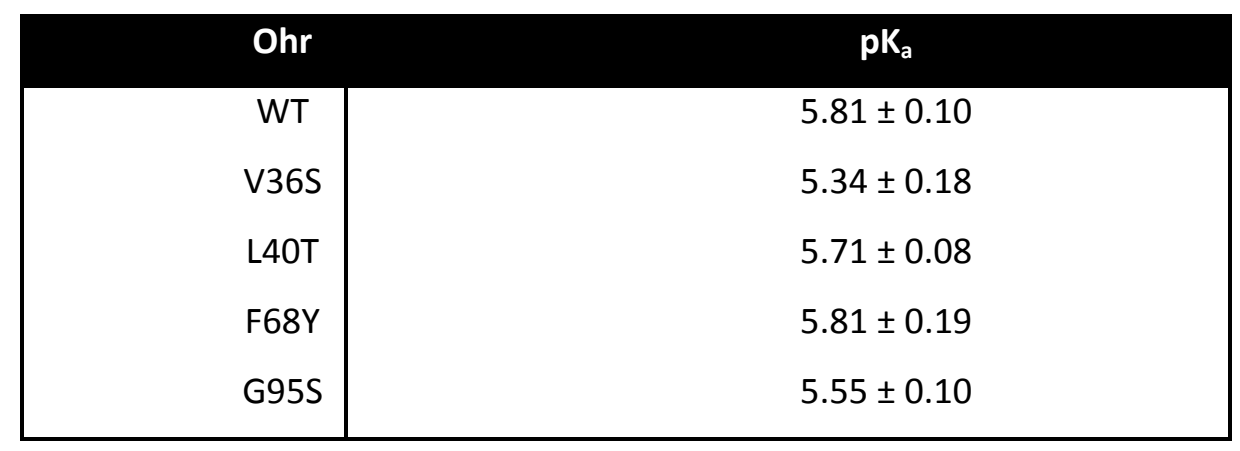



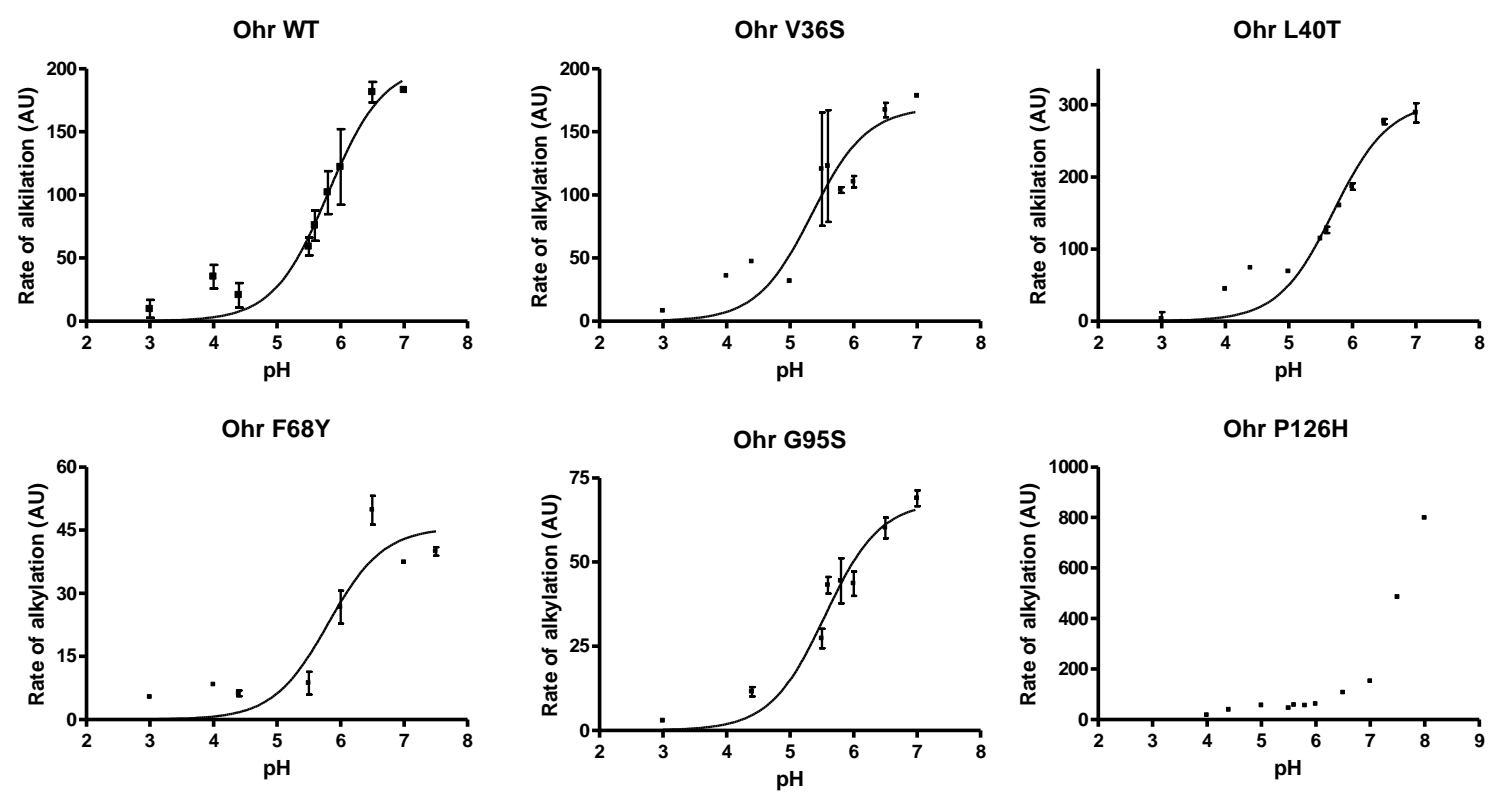

Figura 57. Ionização do grupo tiól da Cys 61 de Ohr.

Através da alquilação da Cys 61 por monobromobimano em função do $\mathrm{pH}$ foi determinado o valor de $\mathrm{pK}_{\mathrm{a}}$ do grupo tiól da Cys 61 de Ohr. No ensaio foi utilizado Ohr $(10 \mu \mathrm{M})$ previamente reduzida na presença de monobromobimano $(2.8 \mu \mathrm{M})$ e dos respectivos tampões $(50 \mathrm{mM}) ; \mathrm{NaCl}(500 \mathrm{mM})$. Foi realizada uma cinética por 20 minutos à $37^{\circ} \mathrm{C}$ e os resultados foram analisados utilizando a equação de Henderson-Hasselbach conforme descrito em "Materiais e Métodos".

Primeiramente, observamos que o $\mathrm{pK}_{\mathrm{a}}$ calculado para Ohr WT está de acordo com o obtido pelo método de absorção do tiolato (Figura 55) que foi de aproximadamente 5.8. Podemos observar também que não há uma diferença significativa nos $\mathrm{pK}_{\mathrm{a}}$ calculados para os outros mutantes principalmente V36S e G95S que apresentaram menor atividade peroxidásica que WT. Sendo assim, podemos afirmar que esses resíduos não estão envolvidos na estabilização do ânion tiolato da cisteína peroxidásica de Ohr, mas sim interagem diretamente com os substratos, corroborando assim os dados estruturais obtidos anteriormente. Não foi possível calcular o $\mathrm{pK}_{\mathrm{a}}$ do mutante $\mathrm{P} 126 \mathrm{H}$, pois não obtivemos uma curva sigmoidal que se ajustasse a equação de Henderson-Hasselbach. Provavelmente o incremento de carga com a presença de um resíduo de histidina na posição 126 gerou um aumento do $\mathrm{pK}_{\mathrm{a}}$ da cisteína peroxidásica tornando-a assim menos reativa explicando porque esse mutante $(\mathrm{P} 126 \mathrm{H})$ perdeu completamente a atividade (Figura 54).

\subsection{Regulação gênica de ohr em Xylella fastidiosa}


Sabe-se que a expressão de Ohr em muitas bactérias está sobre o controle do repressor da transcrição OhrR (Sukchawalit et al., 2001 e Fuangthong et al., 2001). Esse repressor possui uma cisteína $\mathrm{N}$-terminal reativa que é oxidada na presença de hidroperóxidos orgânicos, o que gera uma mudança na interação com o promotor de ohr liberando-o para transcrição. No entanto, não foi encontrado na anotação do genoma de Xylella fastidiosa um gene que conserve similaridade com OhrR de outros organismos. Por isso, a regulação da transcrição de ohr pode estar sobre o controle de outro fator de transcrição em $X$. fastidiosa.

Primeiramente, de posse de anticorpo anti-Ohr, realizamos testes de expressão da enzima Ohr em culturas de $X$. fastidiosa cepa J1a12. Meios de cultura contendo $X$. fastidiosa foram tratados com uma série de peróxidos em diferentes tempos e o extrato celular foi submetido a western blot utilizando anticorpo anti-Ohr (Figura 58). No entanto, não observamos diferenças no nível de expressão em nenhuma das condições testadas.

A

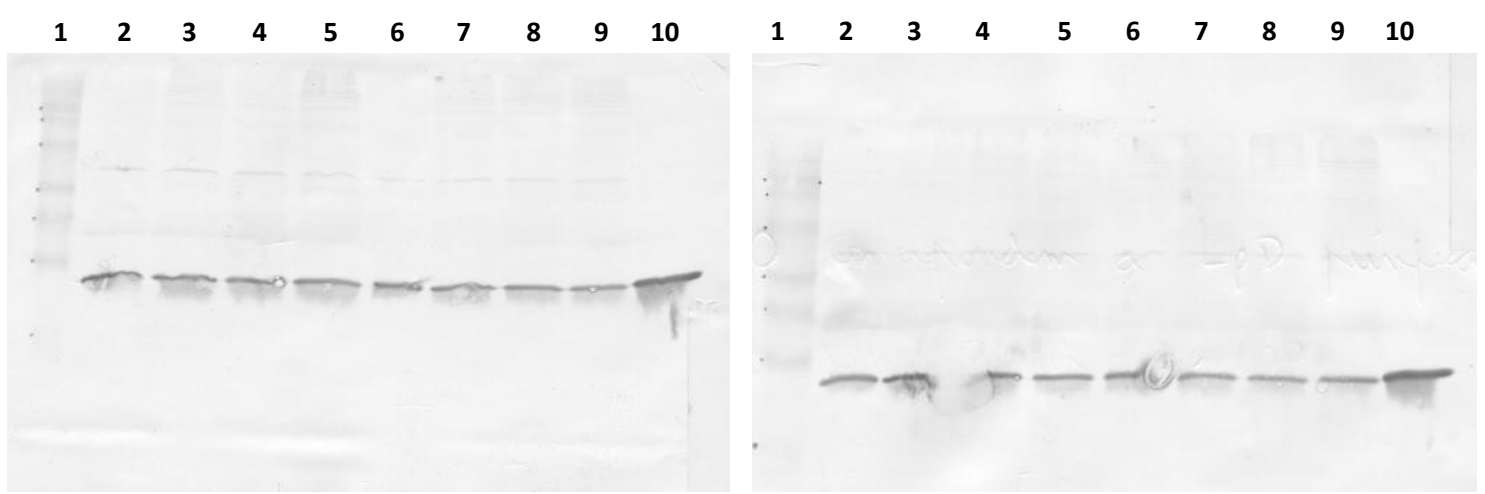

Figura 58. Western Blot utilizando anticorpo anti-Ohr.

$X$. fastidiosa J1a12 foi submetida a diversos tratamentos e o extrato obtido foi submetido a eletroforese em gel SDS-Page e transferido para membrana de nitrocelulose e incubado com anti-Ohr conforme descrito na sessão "Material e Métodos". A:

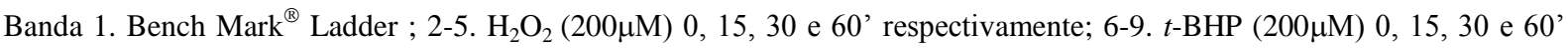

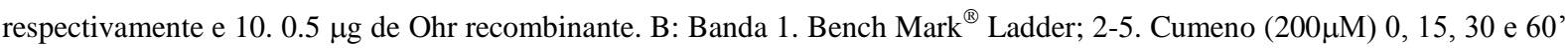
respectivamente; 6-9. LAOOH $(200 \mu \mathrm{M})$ 0, 15, 30 e 60' respectivamente e 10. 0.5 $\mu \mathrm{g}$ de Ohr recombinante.

Pela figura, há uma expressão de Ohr mesmo sem tratamento com peróxido indicando que Ohr provavelmente também está sendo expressa em uma condição basal. Como não podemos observar uma resposta visível, tentamos aumentar o tempo de incubação com peróxidos em até 5 horas. De maneira semelhante, não foi possível visualizar diferenças no padrão de expressão entre os tratamentos. Recentemente, Jenkins et al., 2008, mostraram por northern blot que Ohr de Mycoplasma gallisepticum era expressa constitutivamente diferentemente de outras bactérias onde o gene ohr está sobre o controle do repressor OhrR. Também foi observado que a transcrição de ohr não aumentava após 
tratamentos com peróxidos orgânicos, mas que o gene era induzido após tratamento com etanol e reprimido na presença de $\mathrm{NaCl}$. Esses dados lançaram a possibilidade de que o gene ohr de $X$. fastidiosa também poderia ser induzido por outros tipos de estresse. Sabe-se para M. gallisepticum que o consumo de oxigênio é aumentado na presença de etanol (AbuAmero et al., 2000) assim como a produção de $\mathrm{H}_{2} \mathrm{O}_{2}$ (Abu-Amero et al., 2005). Sendo assim, novamente por western blot e utilizando anticorpo anti-Ohr, tratamos as células com peróxidos, etanol e $\mathrm{NaCl}$ (Figura 59).

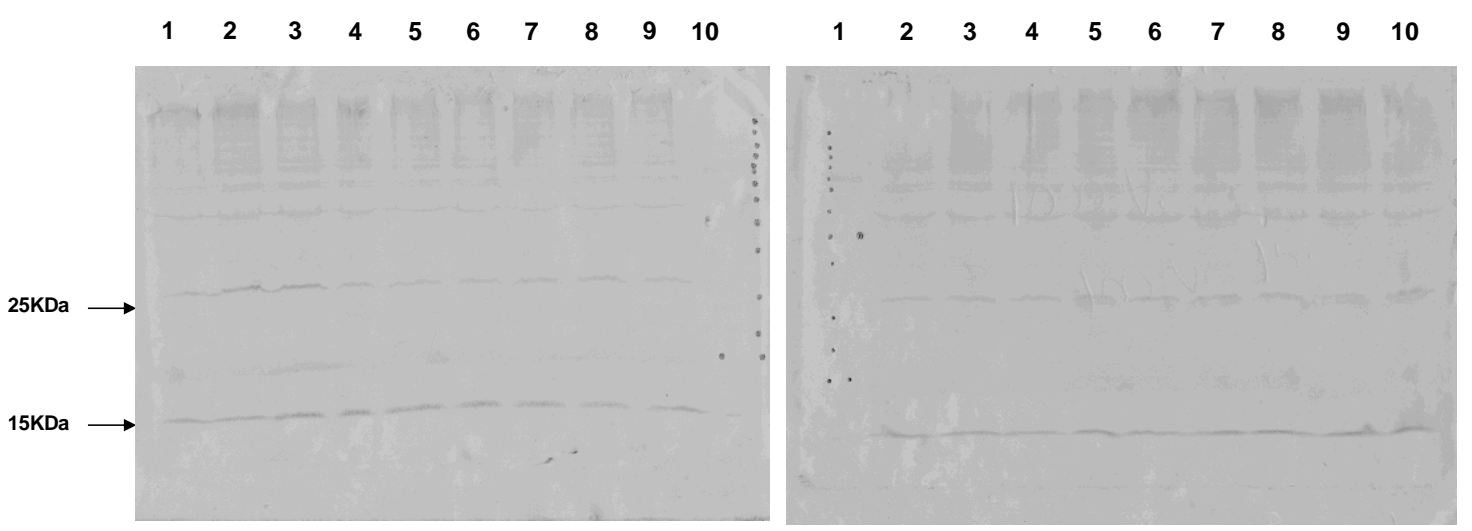

Figura 59. Western Blot utilizando anticorpo anti-Ohr.

$X$. fastidiosa J1a12 foi submetida a diversos tratamentos e o extrato obtido foi submetido a eletroforese em gel SDS-Page e transferido para membrana de nitrocelulose e incubado com anticorpo anti-Ohr conforme descrito na sessão "Material e Métodos”. A: Banda 1. Tempo 0’; 2-3. EtOH (2\%) 1h e 2h30'; 4-5. EtOH (4\%) 1h e 2h30'; 6-7. $\mathrm{NaCl}(1 \%)$ 1h e 2h30'; 8-9. $\mathrm{NaCl}(2 \%)$ 1h e 2h30' e 10. Bench Mark ${ }^{\circledR}$ Ladder. B: Banda 1. Bench Mark $^{\circledR}$ Ladder; 2. Tempo 0'; 3-4. $\mathrm{H}_{2} \mathrm{O}_{2}(0.5 \mathrm{mM})$ 1h e 2h30'; 5-6. CHP (0.5 mM) 1h e 2h30'; 7-8. $t$-BHP (0.5 $\mathrm{mM}) 1 \mathrm{~h}$ e $2 \mathrm{~h} 30^{\prime}$ e 9-10. $t$-BHP (1mM) 1h e 2h30'.

Como podemos observar pela figura 59, não houve aumento visível nos níveis de Ohr em nenhuma das condições testadas. As marcações acima de 15kDa possivelmente estão relacionadas com formas diméricas e oligoméricas de Ohr.

Foi proposto que a transcrição de ohr em $M$. gallisepticum estaria sobre o controle de um fator sigma alternativo de função extra citoplasmática denominado sigma $E\left(\sigma^{\mathrm{E}}\right)$. Esse fator sigma, está relacionado, na maioria das vezes, com a resposta ao estresse global. Sabe-se que em Pseudomonas syringae, $\sigma^{\mathrm{E}}$ desempenha papel crucial na resistência mediada por ROS (Keith et al, 1999). Análises feitas pelo pós-doutor José Freire da Silva Neto (ICB-USP), mostraram que $\sigma^{\mathrm{E}}$ está relacionado com a resposta a choque térmico em $X$. fastidiosa (da Silva Neto et al., 2007). Análise de genes regulados por $\sigma^{\mathrm{E}}$ em Xylella fastidiosa mostrou que a seqüência consenso para o sítio de ligação desse fator sigma é: $\left.{ }_{G} A A C n n-[N]_{16-17-G} T_{C} n n A\right)$. Essa seqüência consenso é similar aos respectivos ortólogos de 
E. coli e Pseudomonas aeruginosa. Análise da região promotora de ohr encontrou pouca similaridade com o consenso para $\sigma^{\mathrm{E}}$, no entanto, especula-se que a seqüência de bases AAC na região -35 e as bases $T$ e A flanqueando a região -10 devem constituir um requerimento mínimo para a ligação desse fator sigma. Além disso, foi proposto que bactérias com poucos genes codificantes de fatores sigma de função extracitoplasmática (o caso de Xylella fastidiosa) permitem uma maior variação na seqüência de bases da região promotora de seus genes regulados. Sendo assim, não foi possível descartar a priori que ohr poderia estar sendo regulada por $\sigma^{\mathrm{E}}$ em Xylella fastidiosa somente por análise da região promotora.

Para testar essa hipótese, obtivemos com o Dr. José Freire da Silva Neto, linhagem mutante de Xylella fastidiosa para o gene $r p o E$ que codifica o fator $\sigma^{\mathrm{E}}$. Anteriormente, observou-se que essa mutação (gene nocauteado) conferia à célula maior suscetibilidade a choque térmico e osmótico (da Silva Neto et. al., 2007). Como controle utilizamos um mutante $\Delta r p o N$ de Xylella fastidiosa. Esse gene codifica para o fator sigma $54\left(\sigma^{54}\right)$ que está envolvido na regulação de genes envolvidos em diversos processos tais como transporte e metabolismo de diferentes fontes de carbono e nitrogênio, fixação do nitrogênio, síntese do flagelo e pili, patogenicidade e produção de alginatos (revisado por Potvin et. al, 2007). Em Xylella fastidiosa, recentemente foi demonstrado que este fator sigma está envolvido na regulação de genes envolvidos na biogênese das proteínas da fímbria tipo I e IV (da Silva Neto et. al, 2008). Caso ohr estivesse sob o controle de $\sigma^{\mathrm{E}}$, esperaríamos não encontrar expressão de ohr nessa linhagem mutante, visto que o fator sigma exerce uma regulação positiva sendo necessário para que a RNA polimerase reconheça a região promotora e inicie a transcrição gênica. Entretanto, observamos uma banda correspondente a Ohr de mesma intensidade que a da linhagem selvagem e do mutante $\Delta r p o N($ Figura 60 )

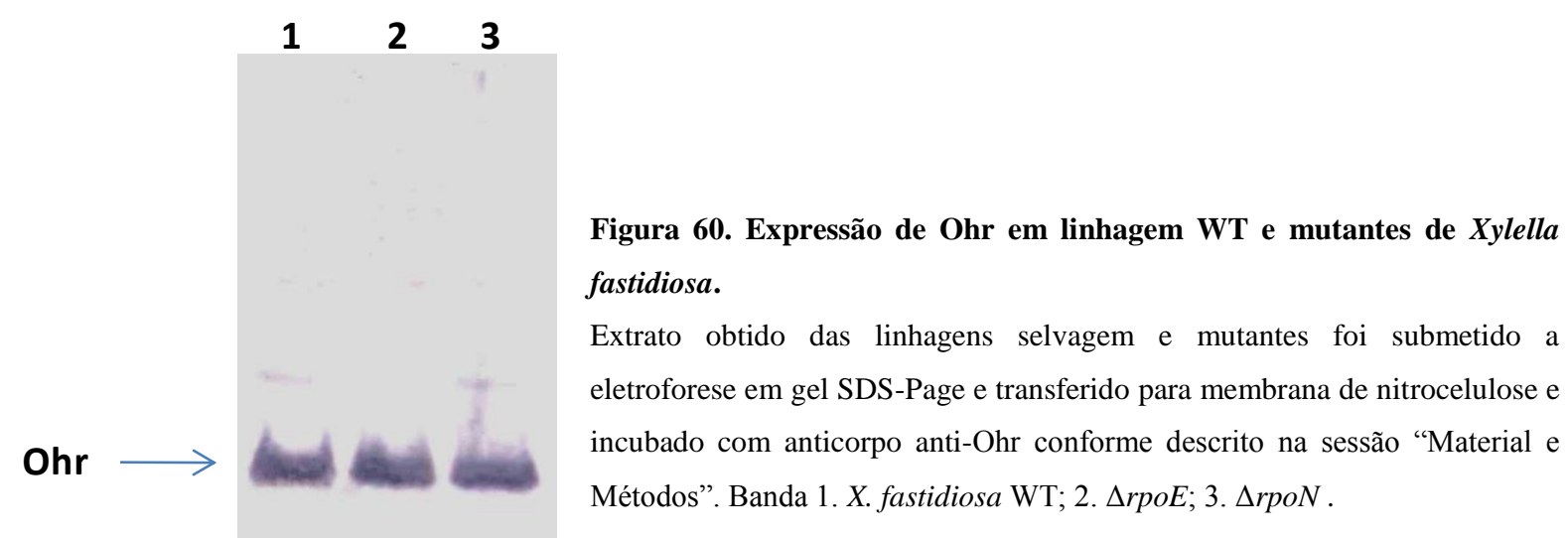


Por não conseguirmos observar diferenças nos níveis protéicos de Ohr, partimos para experimentos de northern blot, pois em muitos casos, os níveis de RNA podem se alterar muito mais drasticamente do que os de proteína, devido a diferenças de turnover de RNA e proteínas. Especialmente para algumas proteínas abundantes (como peroxirredoxinas, ver Demasi et al., 2006), os níveis de proteínas pré-existentes (anteriores à indução) podem ser muito elevados, dificultando a detecção de sua indução em situações de estresse.

Conseguimos extrair RNA de $X$. fastidiosa tratada em condições de estresse oxidativo, osmótico e salino como podemos atestar pela Figura 61, entretanto, não foi possível detectar mRNA de ohr.

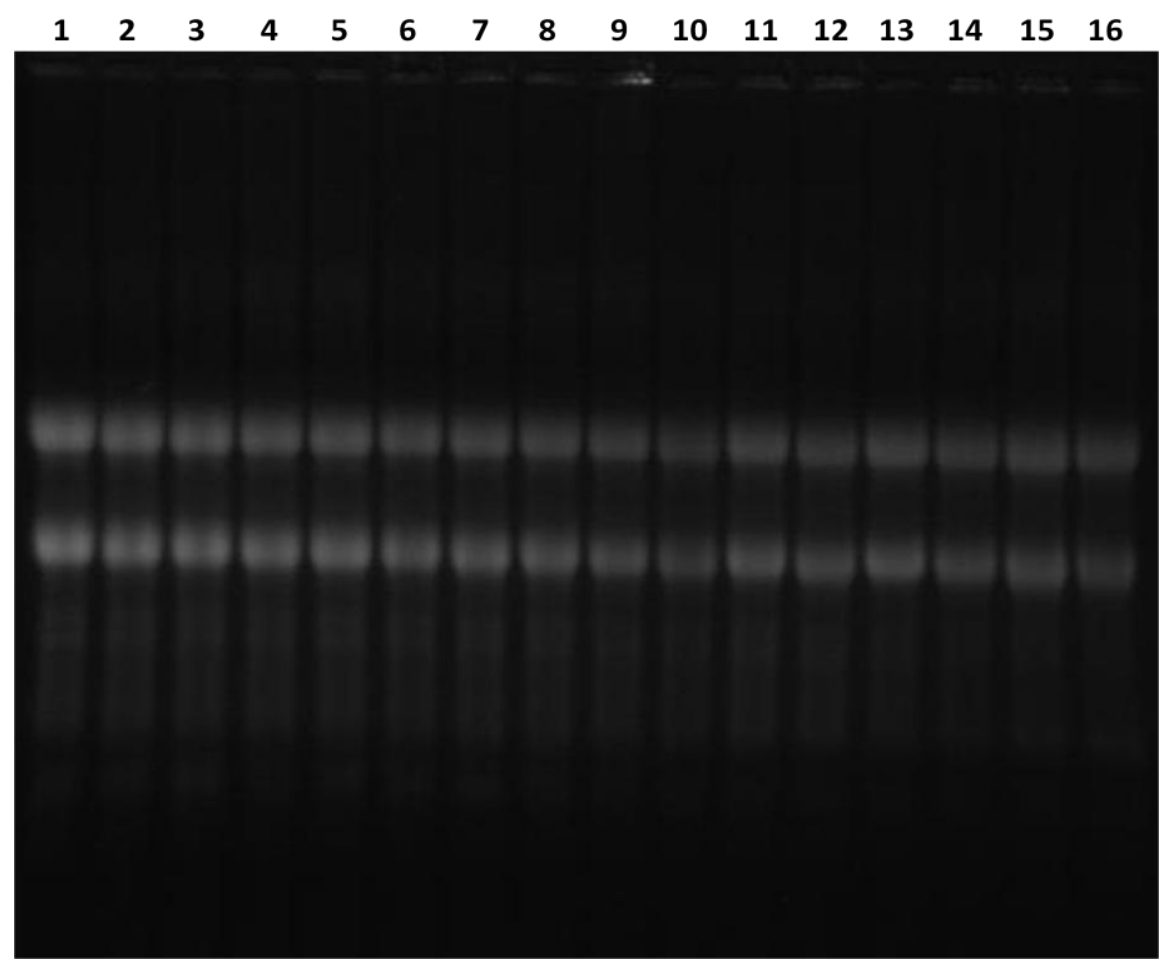

Figura 61. Análise por eletroforese de RNA total de Xylella fastidiosa.

Banda 1-4. $500 \mu \mathrm{M} \mathrm{H}_{2} \mathrm{O}_{2}$ por $0,15,30$ e 60 minutos respectivamente. 5-8. $500 \mu \mathrm{M} t$-BHP por 0, 15, 30 e 60 minutos respectivamente. 9-12. EtOH 4\% por 0, 15, 30 e 60 minutos respectivamente. 13-16. $\mathrm{NaCl} 1.5 \%$ por 0, 15, 30 e 60 minutos respectivamente.

Anteriormente, mostramos que Ohr é capaz de reduzir peróxidos derivados de lipídios como peróxido de ácido oléico $(\mathrm{OLOOH})$ e ácido linoléico (LAOOH) (Figuras 47 e 48) sendo provavelmente seus substratos biológicos. Também, foi mostrado em Xanthomonas campestris e Bacillus subtillis que a expressão de ohr é altamente induzível por LAOOH. Dessa forma, tratamos linhagem de $X$. fastidiosa com peróxidos de lipídios, $t-B H P, \mathrm{H}_{2} \mathrm{O}_{2}$ e etanol de modo a determinar se ohr somente é induzível por hidroperóxidos de lipídios. 
Novamente, não conseguimos detectar mRNA de ohr em nenhum dos tratamentos. De modo a testar se havia algum problema na técnica, construímos uma sonda para rRNA 16S e hibridizamos com a membrana previamente utilizada para detectar mRNA de ohr. rRNA $16 S$ é um bom controle experimental visto que é constitutivamente expresso em altíssimas quantidades. rRNA $16 \mathrm{~S}$ foi detectado em todas as amostras na qual ohr não pode ser detectada (Figura 62).

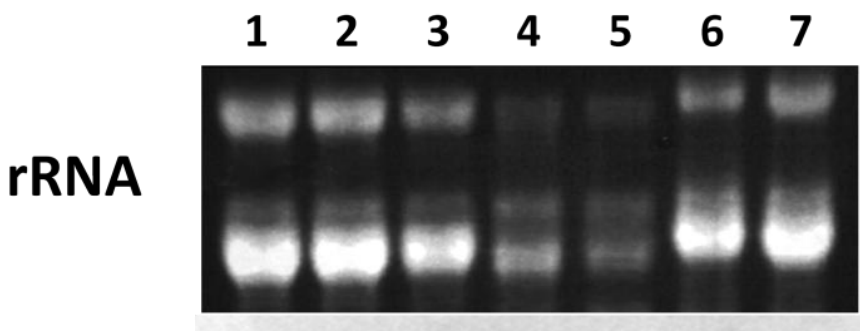

\section{rRNA 16s}

Figura 62. Experimento controle da expressão de rRNA 16S em Xylella fastidiosa.

Células foram tratadas por 30 minutos com os seguintes tratamentos. Banda 1. Sem tratamento; 2. $\mathrm{H}_{2} \mathrm{O}_{2}(0.5 \mathrm{mM})$; $3 . t$-BHP (0.5 mM); 4. LAOOH (0.5 mM); 5. OLOOH (0.5 mM); 6. EtOH (4\%); 7. Metanol (0.1\%).

Aparentemente, houve degradação de RNA nos tratamentos com peróxidos de lipídios (Bandas 4 e 5) o que indica que a concentração utilizada $(0.5 \mathrm{mM})$ provavelmente está sendo deletéria para a célula. Foi feito um tratamento controle com metanol (Banda 7) pois os peróxidos de lipídios estão diluídos em metanol. Portanto, a mesma concentração de metanol presente nos tratamentos com peróxidos de lipídios foi utilizada no experimento controle. Não foi observada degradação de RNA nesse tratamento provando que hidroperóxidos de lipídios estão exercendo efeito citotóxico nas concentrações utilizadas.

De modo a determinar se o problema era que a sonda de ohr não estava hibridizando com o RNA, induzimos linhagem de E. coli que superexpressava ohr (clonada no plasmídeo pET-15b) com IPTG e após extração de RNA total realizamos experimento de northern blot (Figura 63). mRNA de ohr foi detectado em níveis altos excluindo a possibilidade da sonda de ohr não hibridizar com o RNA. 


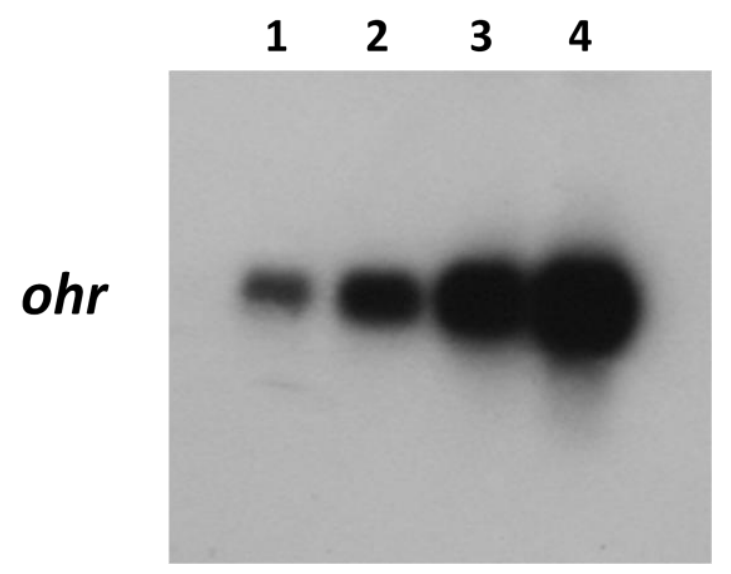

Figura 63. Experimento controle da expressão de ohr em linhagem BL21(DE3) de E. coli contendo pET 15b/ohr.

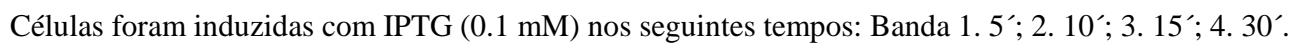

Finalmente, Xylella fastidiosa foi tratada diariamente com concentrações baixíssimas de peróxidos e outros agentes indutores de estresse por uma semana. Após esse período, RNA total foi extraído e hibridizado com sonda para ohr (Figura 64). Conseguimos detectar mRNA de ohr em todos os tratamentos, porém também detectamos ohr em células não tratadas (banda 1), indicando que não foi o tratamento que proporcionou expressão de ohr mas sim, uma maior hibridização da sonda e/ou uma maior exposição do filme a solução reveladora.

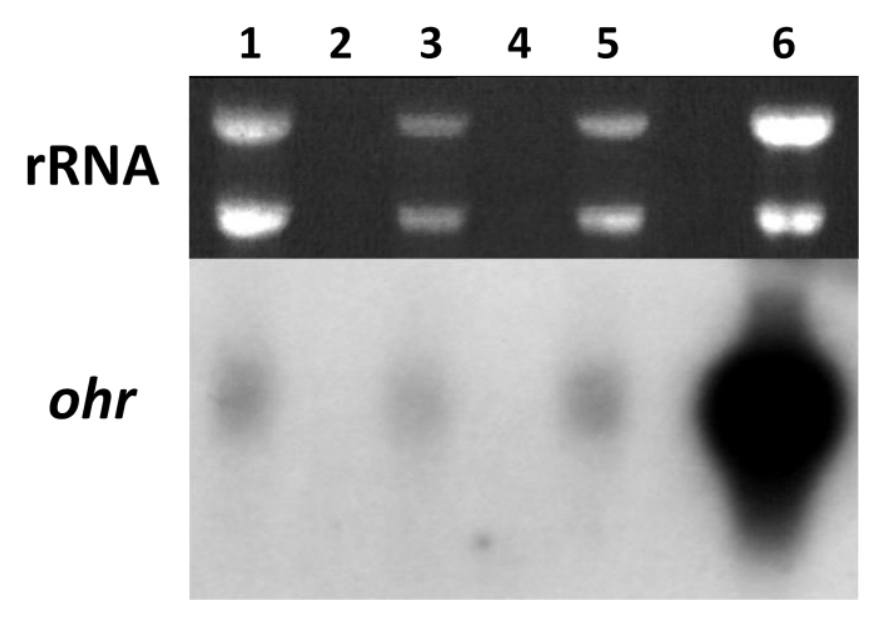

Figura 64. Expressão de ohr em Xylella fastidiosa.

Células foram tratadas por uma semana com os seguintes tratamentos: Banda 1. Sem tratamento; 2. $\mathrm{H}_{2} \mathrm{O}_{2}(10 \mu \mathrm{M}) ; 3$. LAOOH $(10 \mu \mathrm{M}) ; 4$. OLOOH $(10 \mu \mathrm{M})$; 5. EtOH $(0.5 \%)$; 6. E. coli induzida com IPTG $(0.1 \mathrm{mM})$ por 10 minutos.

Células de $X$. fastidiosa foram crescidas até OD de 0.3 antes de iniciar os tratamentos. OD medida ao final dos tratamentos estava em torno de 0.5 - 0.6 para todos os tratamentos menos para $\mathrm{H}_{2} \mathrm{O}_{2}$ e $\mathrm{OLOOH}$ que OD continuou em 0.3. Podemos ver pela 
Figura 64 que rRNA foi degradado nesses tratamentos indicando que houve morte celular. Parte da cultura celular ao fim dos tratamentos foi coletada para análise dos níveis de Ohr por western blot (Figura 65). Embora tratamentos com $\mathrm{H}_{2} \mathrm{O}_{2}$ e OLOOH tenham ocasionado morte celular, conseguimos detectar níveis de Ohr parecidos com o presente nos outros tratamentos corroborando a hipótese de que Ohr é uma proteína muito estável.

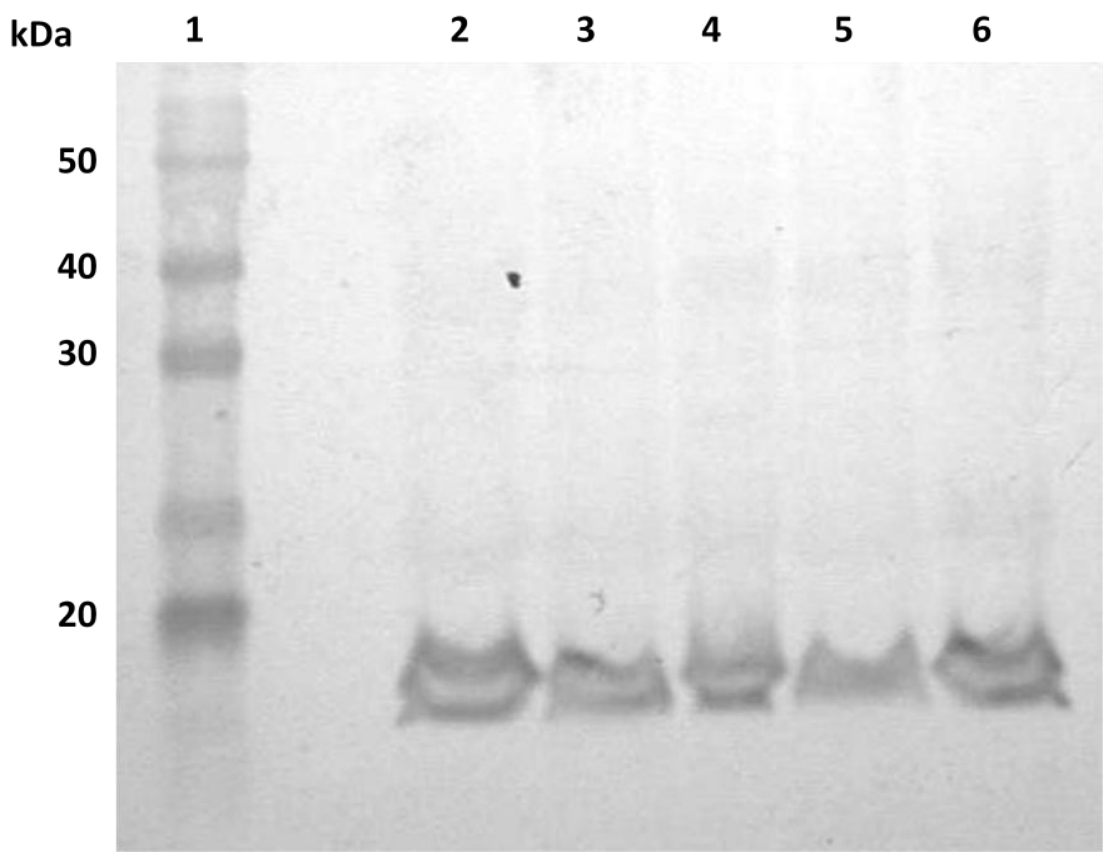

Figura 65. Níveis de Ohr em Xylella fastidiosa após tratamentos por uma semana.

$X$. fastidiosa $\mathrm{J} 1 \mathrm{a} 12$ foi submetida a diferentes tratamentos e o extrato obtido foi submetido à eletroforese em gel SDS-Page, transferido para membrana de nitrocelulose e incubado com anticorpo anti-Ohr conforme descrito na sessão "Material e Métodos". 1. Padrão de massa molecular Rainbow ${ }^{\mathrm{TM}}$, 2. Sem tratamento, 3. $\mathrm{H}_{2} \mathrm{O}_{2}(10 \mu \mathrm{M})$, 4. LAOOH (10 $\mu$ M), 5. OLOOH $(10 \mu \mathrm{M}), 6 . \mathrm{EtOH}(0.5 \%)$.

\section{DISCUSSÃO}

\section{Vias de redução e oxidação de Ohr de Xylella fastidiosa}

Através de evidências estruturais, cinéticas e fisiológicas mostramos que Ohr interage física e funcionalmente com grupos lipóicos de enzimas lipoiladas dos complexos do metabolismo intermediário celular de Xylella fastidiosa. A possibilidade de ácido dihidrolipóico (DHLA) e seu derivado lipoamida serem o redutor fisiológico de Ohr foi proposta primeiramente pelo nosso grupo (Figura 12, Cussiol et al., 2003, anexo I) assim 
como lipoamida acoplada a lipoamida desidrogenase e NADH suportava a atividade peroxidásica de Ohr (Oliveira et al., 2006 anexo II). Outros grupos também levantaram a possibilidade de DHLA ser o redutor fisiológico de Ohr. Meunier-Jamin e colaboradores, 2004 observaram que uma molécula de DHLA se encaixava perfeitamente no sítio ativo de Ohr de Deinococcus radiodurans.

Tradicionalmente, proteínas lipoiladas são vistas como aceptores de elétrons em vias oxidantes, embora também possam atuar em vias de redução (Bunik et al., 2003). Proteínas lipoiladas de $M$. tuberculosis reduzem uma dissulfeto redutase (AhpD), sustentando assim indiretamente a atividade peroxidásica de AhpC (Brik et al., 2002). Curiosamente, $X$. fastidiosa não possui um gene que codifica para $A h p D$, sendo AhpC diretamente reduzida pelo sistema da AhpF (Horta, 2009). Ao contrário, M. tuberculosis não possui um gene que codifica para AhpF. Além disso, também foi proposto que a forma reduzida de proteínas lipoiladas poderiam doar elétrons para a ribonucleotídeo redutase via Grx1 (Beckwit, 2009). Interessantemente, o estado redox do complexo ligado a ácido lipóico é um indicador da disponibilidade dos substratos da reação (2-oxoácidos, CoA e $N^{+} D^{+}$) e do status dos dissulfetos tiólicos do meio (Bunik et al., 2003).

Os resultados observados nas tabelas 5 e 6 mostram que a eficiência catalítica de Ohr na detoxificação de peróxidos orgânicos como $t$-BHP e CHP $\left(10^{6} \mathrm{M}^{-1} \cdot \mathrm{s}^{-1}\right)$ na presença de enzimas lipoiladas é similar ou até mesmo mais alta que outras peroxidases dependentes de tiól (Poole, 2005; Fourquet et al., 2008; Winterbourn \& Hampton, 2008). Além disso, Ohr é altamente especializada na detoxificação de hidroperóxidos orgânicos, pois a sua eficiência catalítica na presença de $\mathrm{H}_{2} \mathrm{O}_{2}$ diminui em até dez mil vezes. Essa baixa eficiência catalítica é devido a baixa afinidade (alto $K_{m}$ ) de Ohr por este peróxido e corrobora com nossos dados estruturais que mostram que a cisteína peroxidásica de Ohr está presente em um domínio altamente hidrofóbico. Esta alta diferença de afinidade entre hidroperóxidos nunca havia sido descrita antes para uma tiól peroxidase. Ahp1 de Saccharomyces cerevisiae é a principal enzima relacionada com a detoxificação de hidroperóxidos orgânicos em leveduras. No entanto, essa enzima também catalisa a redução de $\mathrm{H}_{2} \mathrm{O}_{2}$ na mesma ordem de grandeza (Park et al., 2000). A defesa antioxidante contra $\mathrm{H}_{2} \mathrm{O}_{2}$ deve ser realizada em conjunto por catalases, peroxirredoxinas, como AhpC e PrxQ e glutationa peroxidase em Xylella fastidiosa.

É relevante salientar que os níveis dos componentes pertencentes ao sistema lipoamida são capazes de sustentar a atividade peroxidásica de Ohr in vivo porque a concentração das enzimas lipoiladas em Xylella fastidiosa estão na faixa dos valores de $K_{m}$ obtidos pelas análises cinéticas de estado estacionário. Corroborando com esses dados, em Escherichia coli, onde as células foram crescidas em meio mínimo, E1, E2 e E3 foram 
identificadas como três das dezenove proteínas mais induzidas por crescimento aeróbico após anaerobiose. Para E3 houve uma indução de 4.5 vezes, com os níveis de proteína alcançando $6.7 \mu \mathrm{g} / \mathrm{mg}$ de proteína total (Pedersen et al., 1978 e Smith et al., 1983). Níveis de ácido lipóico no citossol também são abundantes (Noll et al., 1988 e Reed et al., 1993) tornando a sua capacidade de sustentar a atividade peroxidásica de Ohr passível de se ocorrer in vivo.

Esse sistema de redução é exclusivo de Ohr, visto que outras tióis peroxidases de $X$. fastidiosa como $\operatorname{PrxQ}$ e AhpC não apresentaram atividade peroxidásica dependente de lipoamida (Figura 32). Recentemente o Dr. Bruno Brasil Horta mostrou em sua tese de doutorado que a peroxirredoxina $\operatorname{PrxQ}$ é reduzida pelo sistema tiorredoxina de $X$. fastidiosa (TsnC/TrxR) possuindo eficiência catalítica na redução de peróxidos orgânicos como $t$-BHP e CHP na mesma ordem de grandeza que $\mathrm{H}_{2} \mathrm{O}_{2}$ enquanto AhpC é reduzida pelo sistema da AhpF (Horta, 2009). Em contraste, o sistema tiorredoxina/tiorredoxina redutase de $X$. fastidiosa não suporta a atividade peroxidásica de Ohr (Figura 43). Comparando com dados de literatura, é evidente que as concentrações de tiorredoxina e tiorredoxina redutase utilizadas nesse experimento foram altas o suficiente para suportar a atividade peroxidásica de outras tiól peroxidases. Como exemplo, quantidades consideravelmente menores de enzimas do sistema tiorredoxina de Saccharomyces cerevisiae $(0.225 \mu \mathrm{M}$ de tiorredoxina $2 \mathrm{e}$ $0.075 \mu \mathrm{M}$ de tiorredoxina redutase 1) sustentaram a atividade peroxidásica de Tsa1 e Tsa2 do mesmo organismo (Munhoz \& Netto, 2004).

Obtivemos evidências de que Ohr, além de estar presente na fração intracelular, também é encontrado na fração extracelular podendo interagir com a membrana celular juntamente com a enzima SucB, capaz de regenerar a forma reduzida de Ohr (Figura 46). Evidências encontradas em literatura suportam esses dados. Análises proteômicas em Xylella fastidiosa mostraram que Ohr é uma das principais proteínas encontradas na fração extracelular de $X$. fastidiosa (Smolka et al., 2003). Neste estudo, também foi encontrada na fração secretada a enzima LpdA, uma dihidrolipoamida desidrogenase com um domínio de ligação à ácido lipóico (substrato dessa enzima). LpdA também é capaz de sustentar a atividade peroxidásica de Ohr (Figura 38 e 40). Em outro artigo, estudos de fracionamento celular combinado com análises estruturais, demonstraram que Ohr está presente tanto na fração intracelular quanto na fração de membrana (Jenkins et al., 2008). No modelo proposto, Ohr estaria orientada na membrana celular com as porções $\mathrm{N}$ e $\mathrm{C}$ terminal expostas a superfície intra e extracelular, enquanto as duas longas a-hélices centrais estariam embebidas na membrana. Dessa forma, Ohr estaria atuando tanto na detoxificação de peróxidos exógenos e endógenos. 
É controverso se Ohr pode ser uma proteína de membrana visto que Ohr é extremamente solúvel. No entanto, pode ser que Ohr esteja interagindo fracamente com a membrana plasmática e não como uma proteína integrante de membrana. Interessantemente, Smolka et al., 2003 também detectaram outras proteínas antioxidantes na fração extracelular como SOD (Mn) e AhpC. Dessa forma, temos uma proteína responsável pela detoxificação de radical ânion superóxido $\left(\mathrm{O}_{2}^{-\bullet}\right)$, outra especializada na detoxificação de $\mathrm{H}_{2} \mathrm{O}_{2}$ enquanto Ohr seria o principal responsável pela detoxificação de hidroperóxidos orgânicos.

Esta é a primeira descrição de uma proteína com atividade peroxidásica dependente de grupos lipóicos apresentados por enzimas do metabolismo intermediário. A habilidade de utilizar equivalentes redutores de grupos lipóicos, somado a sua estrutura única e devido ao fato de estar presente em muitas bactérias patógenas deve representar um nicho não explorado para o desenvolvimento de moléculas inibidoras. Notavelmente, grupos lipóicos são essenciais para a viabilidade dos patógenos no hospedeiro. Em Listeria monocytogenes, uma linhagem mutante para LpIA (lipoato ligase) tem a sua habilidade de crescer no citossol do hospedeiro comprometida e é menos virulenta em animais devido a sua deficiência em captar ácido lipóico do hospedeiro. LipB parece ser essencial para a viabilidade de $M$. tuberculosis visto que mutantes para lipB se tornam inviáveis (Sassetti et al., 2003). Outro trabalho, mostrou que DlaT (dihidrolipoamida aciltransferase), componente E2 do complexo PDH de M. tuberculosis, também é essencial para a patogenicidade da bactéria visto que linhagem $\Delta d l a T$ se torna mais suscetível a estresse nitrosativo e a morte por macrófagos (Shi et al., 2006).

Mostramos que Ohr é capaz de detoxificar hidroperóxido de ácido oléico e linoléico (Figura 51 e 52). Aparentemente, a inibição da atividade peroxidásica vista na Figura 50 não é somente um efeito de formação de micelas pois resultados feitos pelo aluno de mestrado Thiago Geronimo Pires Alegria (dados não publicados) em nosso laboratório mostram que também há inibição da atividade peroxidásica de Ohr na presença de Triton X-100 e outros detergentes como Tween 20. De fato, concentrações equimolares de LAOOH e OLOOH são capazes de superoxidar a cisteína reativa de Ohr (dados não publicados) enquanto o mesmo efeito não é observado para os hidroperóxidos sintéticos como $t$-BHP e CHP indicando que $\mathrm{LAOOH}$ e OLOOH devem possuir uma maior afinidade pelo sítio ativo de Ohr. Interessantemente, Ohr não foi capaz de detoxificar hidroperóxido derivado de colesterol (dados não mostrados). Esse hidroperóxido possui uma cadeia carbônica longa formada por muitos anéis o que aumenta a sua densidade eletrônica tornando menos propícia a sua acomodação no sítio ativo de Ohr. 
Esses dados são corroborados por análises da cavidade do sítio ativo de Ohr onde uma molécula de PEG co-cristalizada apresentava interações hidrofóbicas com aminoácidos e, portanto, mimetizava a ligação de um possível substrato biológico alongado e hidrofóbico de Ohr. Foi possível modelar uma molécula de hidroperóxido de ácido oléico no sítio ativo de Ohr sendo que sua função peróxido estava orientada em direção a cisteína peroxidásica (Oliveira et al., 2006 anexo II).

DHLA e seu derivado lipoamida, possíveis redutores biológicos de Ohr, conservam semelhanças estruturais com os ácidos graxos. De fato, é a partir destes que ocorre a biossíntese de ácido lipóico (Jordan \& Cronan Jr, 1997). Estudos por espectroscopia de ressonância magnética nuclear mostraram que Xylella fastidiosa possui grandes quantidades de hidroperóxido de ácido oléico (18:1) e outros ácidos graxos monoinsaturados como palmitoléico (16:1) e vacênico (18:1) em sua membrana (Osiro et al., 2004). Como Ohr se encontra tanto na fração intracelular quanto na fração extracelular,juntamente com seu sistema redutor, podemos especular que esta enzima atua tanto na defesa exógena quanto endógena contra hidroperóxidos derivados de ácidos graxos insaturados como ácido oléico e linoléico (principalmente o primeiro). O fitopatógeno Xylella fastidiosa está comumente sofrendo ação dos mecanismos de defesas de seus vetores e hospedeiros. Dentre esses mecanismos de defesa, o estresse oxidativo promovido pela planta pode gerar direta ou indiretamente, ROS capazes de iniciar a peroxidação lipídica. Além desse processo não enzimático, a peroxidação lipídica pode ser catalisada por enzimas como lipoxigenases e dioxigenases durante a resposta planta patógeno (Gobel et al., 2003). Além de alterar a fluidez da membrana alterando suas propriedades assim como a de proteínas que interagem com ela, peróxidos de lipídios podem sofrer o fenômeno de translocação, passando para a fase aquosa intracelular podendo danificar DNA e outros processos enzimáticos. Hidroperóxidos de lipídios também podem também se translocar para a fase aquosa (Girotti, 2008). Dessa forma, a detoxificação de hidroperóxidos de lipídios é crucial para a sobrevivência do organismo.

Visto que Ohr provavelmente reduz hidroperóxidos derivado de ácidos graxos insaturados à custa de elétrons provenientes de enzimas lipoiladas do metabolismo intermediário celular, propusemos um mecanismo catalítico de Ohr (Figura 66) que vem a complementar aquele proposto na figura 18. 

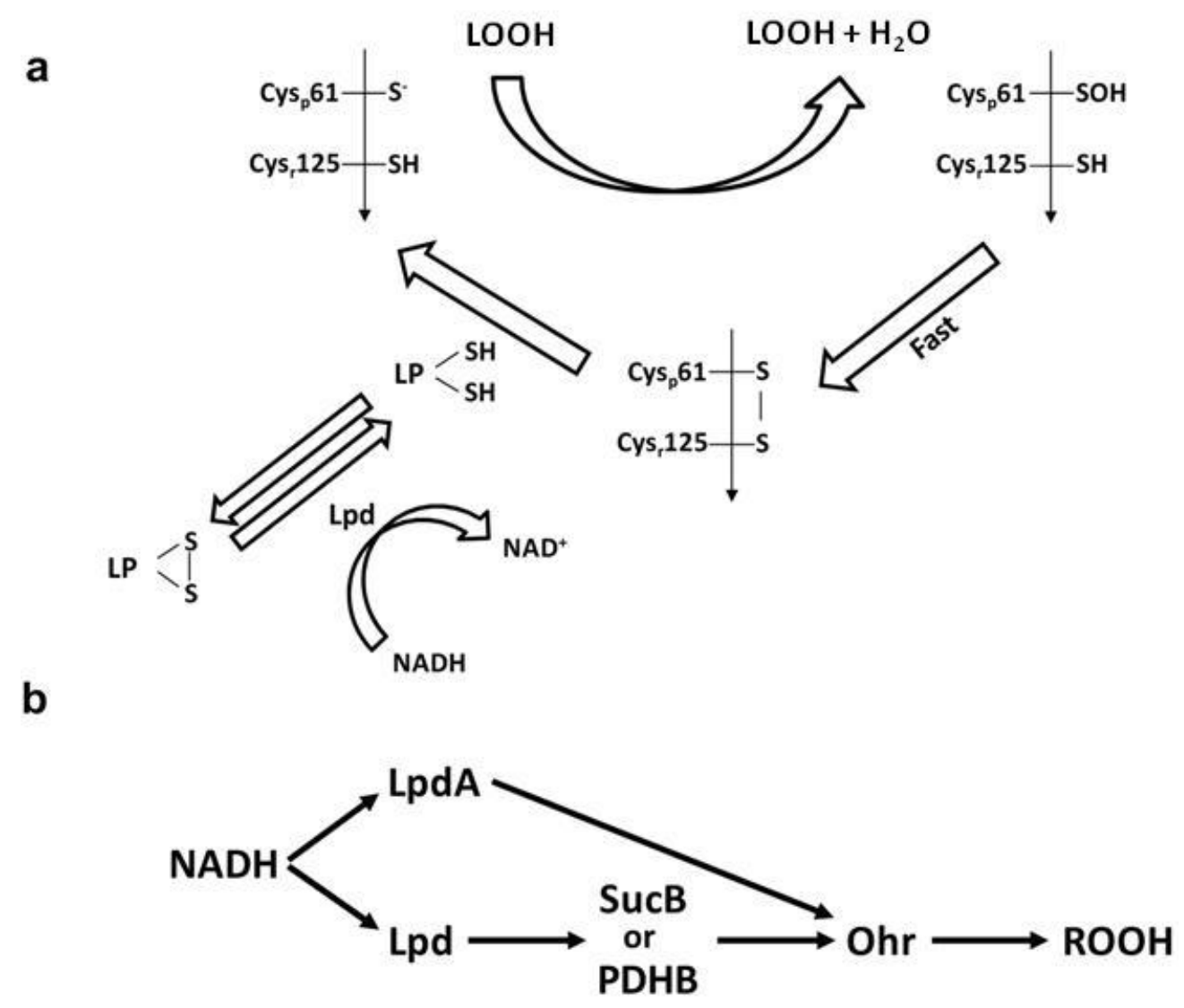

Figura 66. Esquema proposto para a via de redução de Ohr.

(a). O dissulfeto de Ohr é reduzido por uma proteína lipoilada (LP). (b). Redução de Ohr por proteínas lipoiladas. As setas representam o fluxo de elétrons vindo do NADH.

Ohr reduz um hidroperóxido de lipídio ( $\mathrm{LOOH}$ ) através da reação com, o tiolato (S-) da cisteína reativa $\left(\mathrm{Cys}_{\mathrm{p}} 61\right)$. Esta se oxida a ácido sulfênico ( $\mathrm{SOH}$ ) que devido a proximidade com a cisteína de resolução $\mathrm{Cys}_{\mathrm{r}} 125$ reage rapidamente formando uma ligação dissulfeto intramolecular. O ditiól do grupo lipóico de enzimas lipoiladas reduz a ligação dissulfeto formada restaurando a forma reduzida da enzima Ohr para mais um ciclo de redução de peróxidos. O grupo lipóico oxidado das enzimas lipoiladas,é reduzido pela enzima dihidrolipoamida desidrogenase (Lpd) através de elétrons provenientes de uma molécula de NADH (Figura 66A).

Ohr pode ser reduzida diretamente por LpdA, ou pode ser reduzida por SucB e PDHB na presença de Lpd em Xylella fastidiosa (Figura 66B). SucB e/ou LpdA podem ser os redutores de Ohr tanto intracelularmente quanto extracelularmente. O papel fisiológico de LpdA ainda não é claro. Como seu gene está localizado próximo a genes codificantes de proteínas do complexo da piruvato desidrogenase, ele foi anotado como seu componente E3. No entanto, em Streptococcus pneumoniae, LpdA não está associado com nenhum dos 
complexos da 2-oxoácido desidrogenase. Desta forma, de modo semelhante, LpdA pode estar atuando em Xylella fastidiosa exclusivamente como participante da via de redução de peróxidos orgânicos por Ohr.

A utilização de proteínas lipoiladas para a redução de Ohr representa uma área de investigação emergente visto que proteínas específicas são capazes de desempenhar funções catalíticas múltiplas promovendo meios de regular processos divergentes através de um simples gatilho molecular.

Vindo a complementar o esquema proposto acima, obtivemos evidências de que os aminoácidos valina 36 e glicina 95 contribuem para a atividade peroxidásica de Ohr interagindo diretamente com os substratos da reação. Análises do sítio ativo de Ohr mostram que esses dois resíduos realizam interações hidrofóbicas com uma molécula de PEG (Figura 67). A estrutura dessa molécula se assemelha muito aos substratos biológicos de Ohr, portanto podemos inferir que as mesmas interações ocorrem na presença dessas moléculas.

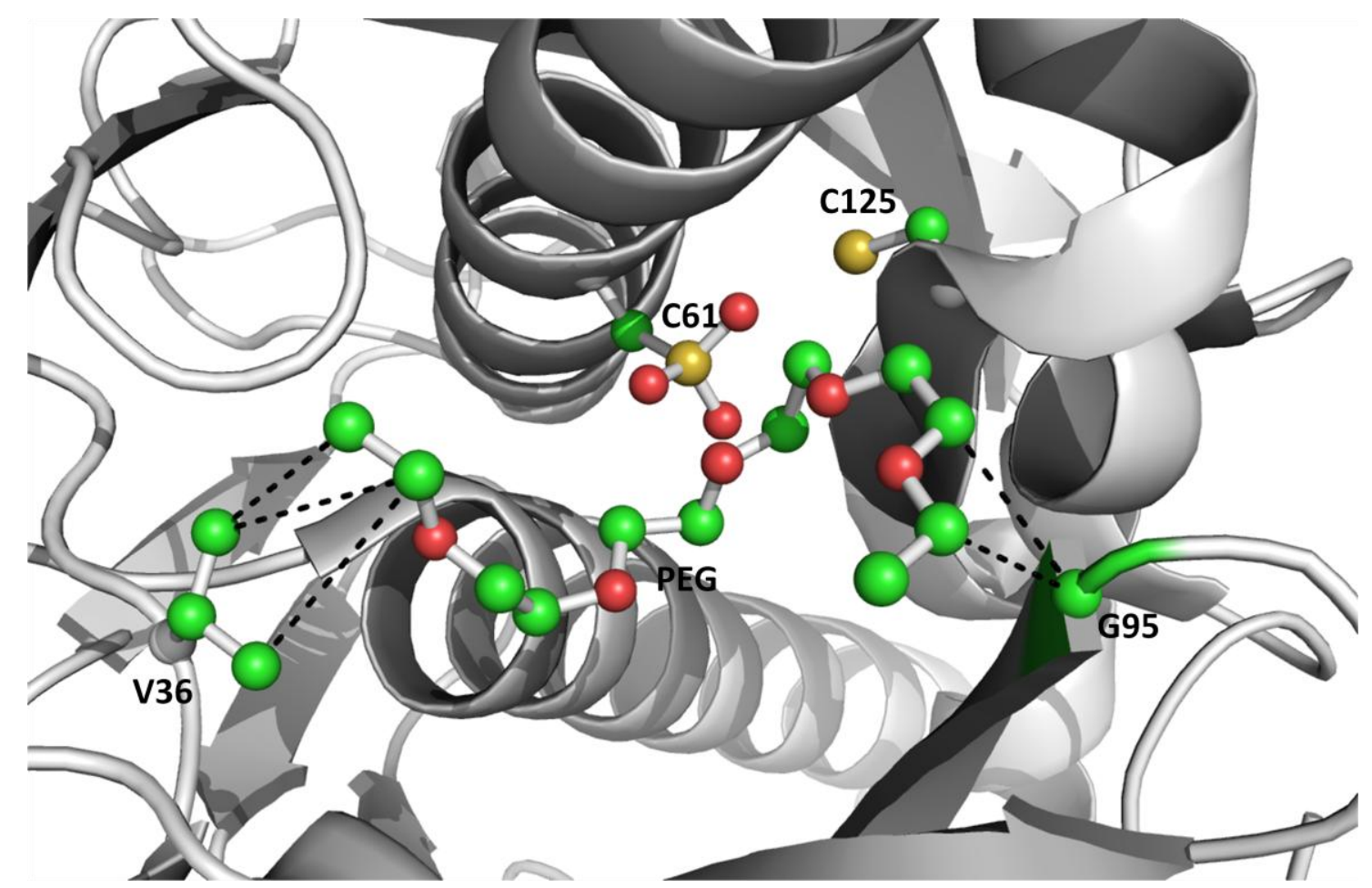

Figura 67. Interações hidrofóbicas de resíduos do sítio ativo com uma molécula de PEG.

Na estrutura está mostrado as cadeias laterais de resíduos de aminoácidos do sítio ativo e uma molécula de PEG. Os átomos destes aminoácidos e da cadeia do PEG estão representados por bastões e bolas e seguem as cores: verde (carbono), amarelo (enxofre) e vermelho (oxigênio). As linhas tracejadas representam as interações hidrofóbicas entre átomos de carbono da cadeia lateral de V36 e G95 com carbonos da molécula de PEG. 
Através de alinhamento de seqüência primária de Ohr de várias bactérias (Figura 68) podemos observar que o resíduo de valina (posição 36 em Xylella) não é totalmente conservado, estando presente também em Ohr de Agrobacterium tumefaciens e Deinococcus radiodurans. Em outras bactérias o resíduo de valina é substituído por resíduos polares mais hidrofílicos como treonina (em Xanthomonas campestris, Pseudomonas aeruginosa e Methylobacterium extorquens) ou polar hidrofóbico como metionina (em Bacillus subtillis). O resíduo de glicina (posição 95 em $X$. fastidiosa), no entanto, é bem conservado entre as bactérias sendo substituído em poucos casos por alanina (Actinobacillus pleuropneumoniae, Deinococcus radiodurans e Mycoplasma gallisepticum), outro aminoácido hidrofóbico muito semelhante a glicina.

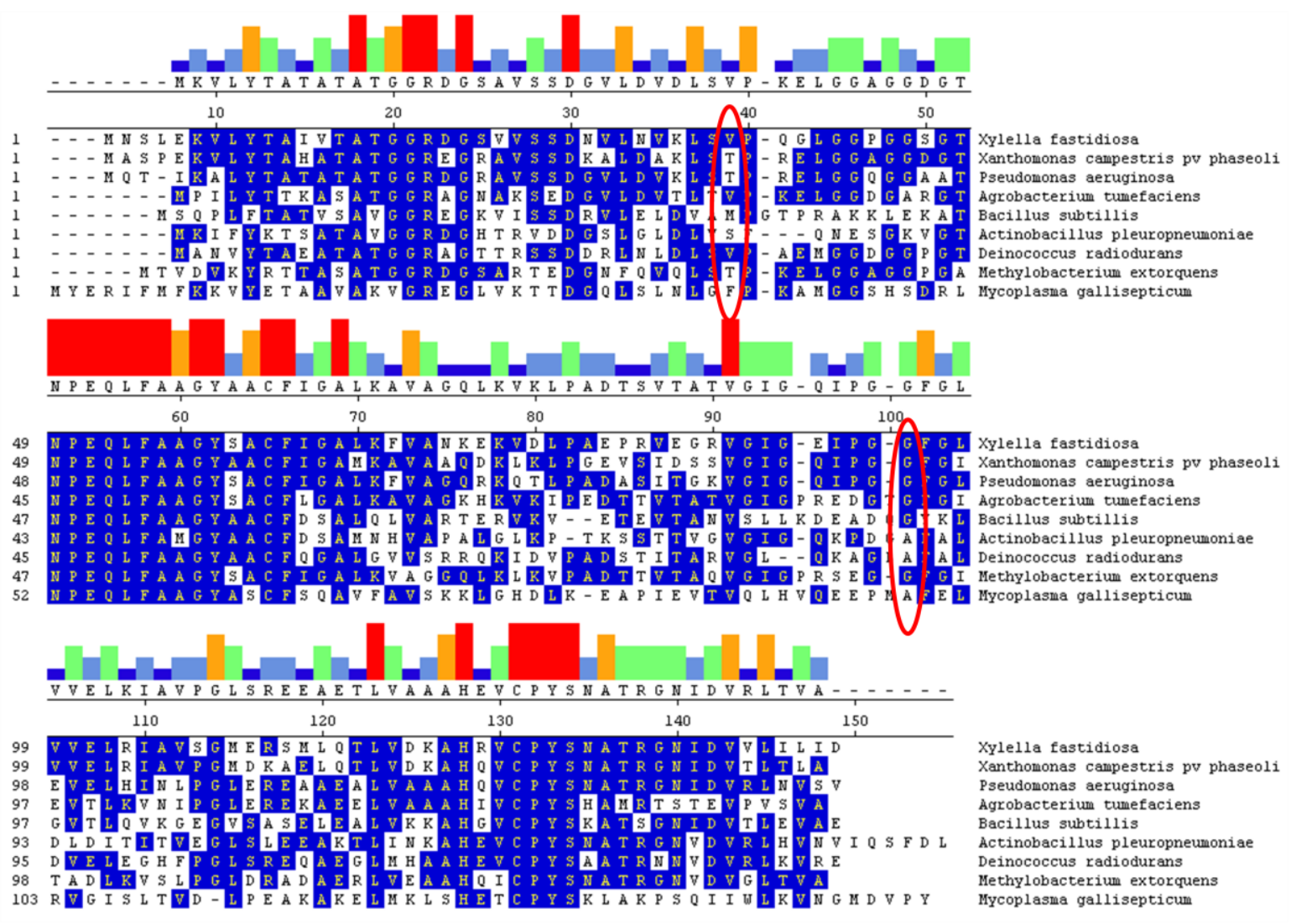

Figura 68. Alinhamento de aminoácidos da proteína Ohr de diferentes bactérias.

Resíduos de aminoácidos e motivos conservados estão destacados em azul. Círculo em vermelho está destacando os aminoácidos valina 36 e glicina 95 de X. fastidiosa. Figura de alinhamentos de proteínas foi gerado com a utilização do programa Lasergene MegAlign v.5.01 (DNASTAR, Inc., Madison, Wisconsin, USA) e incluí Ohr de: Actinobacillus pleuropneumoniae (GI:157837295); Deinococcus radiodurans(GI:15806857); Bacillus subtilis (GI:16078381); Agrobacterium tumefaciens (GI:15888188); Xanthomonas campestris pv. phaseoli (GI:7531169); Pseudomonas aeruginosa (GI:15598046); Xylella fastidiosa (GI:15838425); Methylobacterium extorquens (GI:254561629) e Mycoplasma gallisepticum (GI:31544491). 
Como esses aminoácidos não são totalmente conservados na subfamília Ohr, diferentemente daqueles responsáveis pela estabilização do tiolato (Arg-19, Glu-51, Cys-61 e possivelmente Pro-126 em $X$. fastidiosa), podemos inferir que as substituições de aminoácidos podem levar a alterações no sítio ativo gerando diferenças na especificidade pelos substratos que cada Ohr pode detoxificar. Substituição de um aminoácido hidrofóbico por um polar mais hidrofílico irá implicar em alterações nas interações hidrofóbicas. Bactérias possuem diferentes componentes em sua membrana celular e, portanto, peroxidação lipídica deve gerar um "pool" de diferentes hidroperóxidos de lipídios de acordo com a sua composição lipídica. Durante a evolução, devem ter sido selecionadas bactérias na qual a composição dos aminoácidos do sítio ativo de Ohr interagia melhor com os peróxidos de lipídios formados, garantindo assim uma maior eficiência na remoção destes. Através de análise por alinhamento e sobreposição da estrutura de Ohr de Xylella fastidiosa e Pseudomonas aeruginosa tentamos compreender melhor o papel dos resíduos Valina 36 e Glicina 95 na atividade de Ohr (Figura 69). O resíduo Valina 36 presente em Xylella está substituído por um resíduo de treonina em Pseudomonas. Podemos ver pela estrutura que esses resíduos quase se sobrepõe. A presença de um resíduo de treonina nessa posição confere uma maior hidrofilicidade devido ao grupo hidroxila capaz de realizar ligação de hidrogênio com a molécula de PEG (3.4 Å). No mutante V36S, o resíduo de valina também foi substituído por serina, um aminoácido polar com um grupo hidroxila na cadeia lateral muito semelhante a treonina. Como PEG mimetizaria um provável peróxido de ácido graxo de cadeia insaturada, postulado em Xylella como sendo de ácido oléico, é provável que Ohr de Pseudomonas não seja tão eficiente na remoção deste peróxido, pois a presença desse aminoácido acarretaria uma maior hidrofilicidade. 


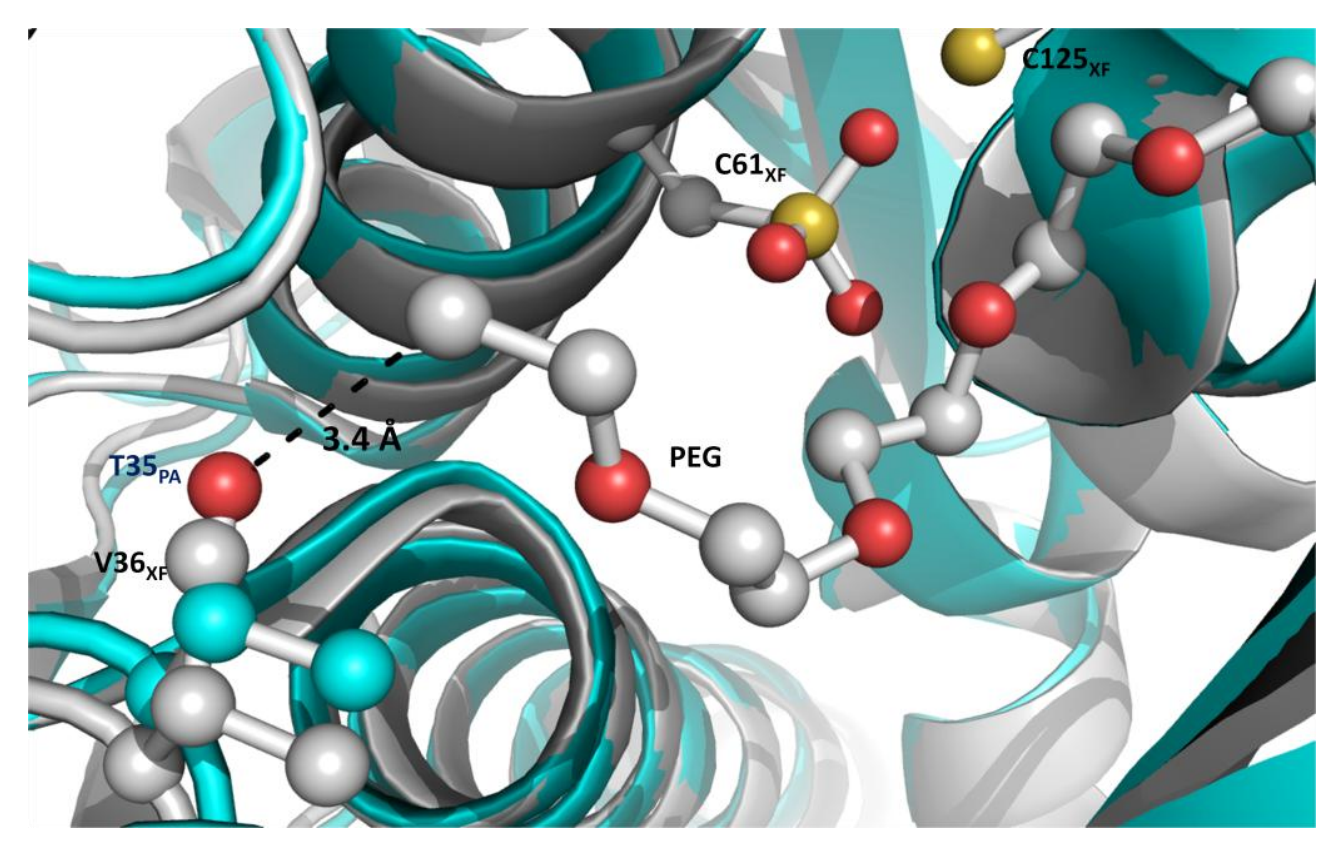

Figura 69. Interação e posição de aminoácidos de $X$. fastidiosa e $P$. Aeruginosa com uma molécula de PEG.

Foi feito alinhamento da estrutura terciária de Ohr de X. fastidiosa (em branco, PDB ID: 1ZB9) com Ohr de P. Aeruginosa ( em ciano, PDB ID: 1N2F) obtendo r.m.s.d. de 1.11 A. As cadeias laterais dos resíduos de aminoácidos estão representadas por bolas e bastões. Carbonos da estrutura de X. fastidiosa e P. aeruginosa estão representados em branco e em ciano respectivamente. Enxofre (amarelo) e oxigênio (vermelho). Reta tracejada representa ligação de hidrogênio.

Análise da cavidade do sítio ativo de Ohr na presença de PEG mostra que os resíduos de Valina 36 e Glicina 95 estão localizados bem na entrada da cavidade que dá acesso à cisteína peroxidásica (Figura 70).

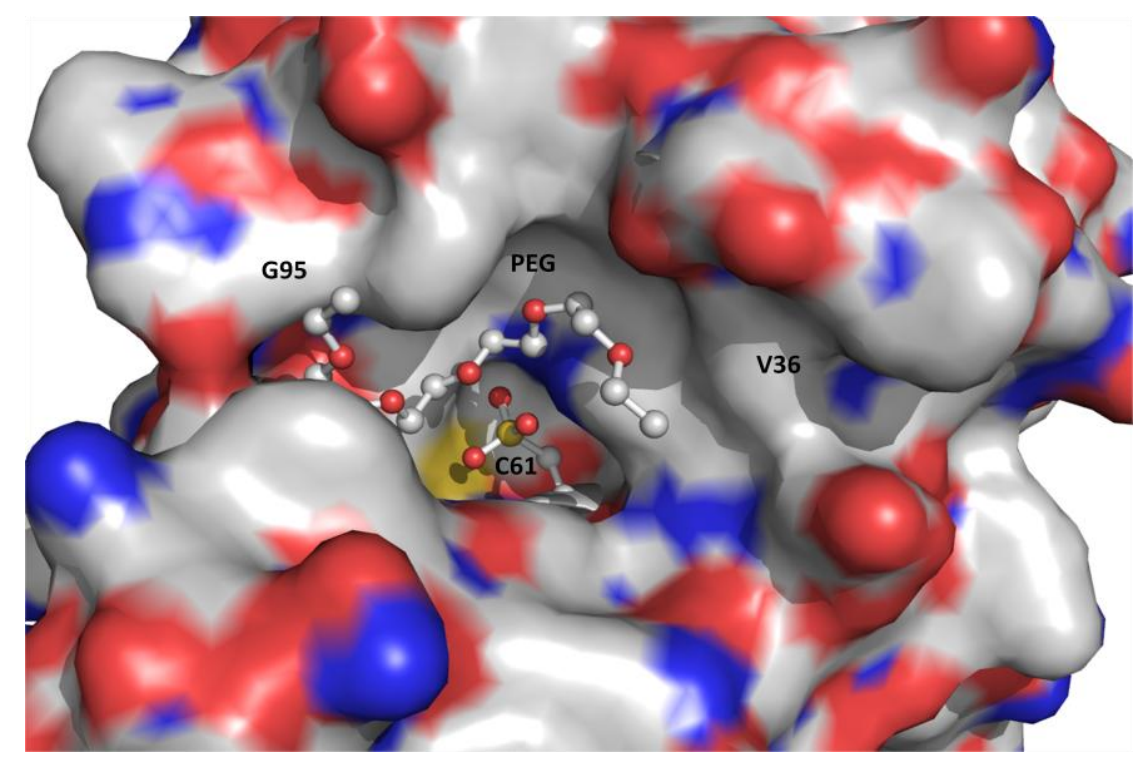

Figura 70. Análise da superfície de Ohr de $X$. fastidiosa.

A cadeias laterais da cisteína 61 e da molécula de PEG estão representadas por bolas e bastões. Carbono (branco), enxofre (amarelo), oxigênio (vermelho) e nitrogênio (azul). 
É vasta a literatura mostrando que a estabilização do tiolato é vista como a principal responsável pela atividade peroxidásica de muitas proteínas. Entretanto, tiorredoxinas, glutarredoxinas e dissulfeto isomerases não possuem capacidade de reduzir ligações peróxido mas sim reduzir ou formar pontes dissulfeto e apresentam cisteínas reativas com valores de $\mathrm{pK}_{\mathrm{a}}$ iguais ou até mesmo menores do que Ohr e outras tióis peroxidases (revisado por Netto et al., 2006 anexo III). Desta forma, nossos resultados mostram que outros resíduos, além daqueles relacionados com a estabilização do tiolato são também importantes para a atividade peroxidásica de Ohr, devendo existir mecanismos semelhantes para outras tióis-peroxidases.

Nessa tese, também fornecemos evidências que apontam que OsmC de Escherichia coli também reduz hidroperóxidos na presença de enzimas lipoiladas (Figura 50). Estudos anteriores, mostraram que OsmC de E. coli possui atividade peroxidásica sobre peróxidos orgânicos em um mecanismo catalítico idêntico à Ohr. As duas subfamílias protéicas compartilham o mesmo enovelamento protéico, mesmo possuindo baixa identidade de seqüência primária (Lesniak et al., 2003). Embora OsmC seja induzida em condições de estresse osmótico, existem evidências de que choque osmótico pode levar a geração de ROS (Price \& Hendry, 1991). Algumas bactérias como Bacillus subtillis e Deinococcus radiodurans expressam tanto Ohr quanto OsmC, o que pode parecer numa primeira análise um contra senso, visto que são funcional e estruturalmente similares. No entanto, embora Ohr e OsmC tenham preferências por hidroperóxidos orgânicos, dados estruturais mostram que há uma distribuição diferente de aminoácidos hidrofóbicos entre Ohr e OsmC (Lesniak et al., 2003). O formato tridimensional da cavidade do sítio ativo difere nas duas estruturas.

Interessantemente, um resíduo de fenilalanina da $\mathrm{His}_{6}$-Tag de OsmC recombinante de $E$. coli co-cristalizou ligado à entrada do sítio ativo dessa enzima, indicando que OsmC provavelmente tem uma preferência por hidroperóxidos aromáticos (Shin et al., 2004). Como exemplos de hidroperóxidos aromáticos fisiológicos, temos aqueles derivados de bases nitrogenadas do DNA (Prado et al., 2009). De fato, nossos dados cinéticos por estado estacionário mostram que OsmC, diferentemente de Ohr, possuem uma eficiência catalítica dez vezes maior na presença de hidroperóxidos aromáticos como cumeno hidroperóxido $(\mathrm{CHP})$ do que por $t$-BHP. Essa diferença é devida à maior afinidade (menor $K_{m}$ ) de OsmC por CHP. Interessantemente, em bactérias que expressam tanto Ohr quanto OsmC, a última só é induzida em condições de estresse osmótico enquanto que bactérias que possuem somente OsmC, esta também é induzida em condições de estresse oxidativo (Atichartpongkul et al., 2001). 
A família Ohr/OsmC compreende na verdade três subfamílias sendo OsmC a subfamília do tipo I, Ohr a subfamília do tipo II e a subfamília do tipo III compreendem proteínas de função ainda desconhecida. Sabe-se por análise comparativa de estrutura entre as três subfamílias que Ohr e OsmC são mais semelhantes enquanto o grupo III possui características mais peculiares como uma maior abertura da cavidade catalítica, assim como a ausência de um resíduo de arginina conservado no sítio ativo o que poderia impossibilitar sua função como uma tiól peroxidase (Shin et al., 2004).

\section{Regulação gênica de ohr em Xylella fastidiosa}

Também investigamos os mecanismos de regulação gênica de Ohr. Infelizmente, não conseguimos determinar precisamente o mecanismo de regulação gênica de ohr. No entanto, julgamos que fornecemos importantes evidências de que, diferentemente da maioria dos organismos estudados até agora, ohr aparentemente é expressa constitutivamente, não sendo regulada positiva ou negativamente por $\sigma^{\mathrm{E}}$ ou OhrR respectivamente. Esses dados não permitem afirmar que ohr não está sob o controle de fatores de transcrição, pois estudos adicionais precisam ser realizados.

Devido aos baixos níveis de mRNA de ohr detectados por northern blot, podemos fazer algumas suposições. Na primeira, mRNA de ohr é muito instável, sendo rapidamente degradado. Outra hipótese, não mutuamente exclusiva em relação a primeira é a de que a proteína Ohr é muito estável, possuindo uma meia vida altíssima.. A segunda hipótese está de acordo com experimentos de dicroísmo celular, onde Ohr começa a perder sua estrutura secundária somente a temperaturas acima de $65^{\circ} \mathrm{C}$ (dados não mostrados). De fato, Ohr recombinante conserva sua atividade peroxidásica em tampão fosfato meses após a purificação. Dessa maneira, talvez seja possível detectar diferenças nos níveis de RNA entre os diferentes tratamentos pela técnica de RT-PCR quantitativo que é muito sensível.

O fato de Ohr ser expressa mesmo na ausência de tratamentos indutores de estresse, pode indicar que essa bactéria esteja sujeita a condições de estresse tanto no vetor quanto na planta hospedeira.

\section{Ohr não é uma peroxirredoxina}

É importante ressaltar que apesar das semelhanças nos mecanismos de catálise de Ohr com as peroxirredoxinas julgamos ser errôneo classificar Ohr como uma peroxirredoxina. Alguns grupos de pesquisa vêm classificando Ohr nessa superfamília protéica (Lee et al., 2007). 
Das semelhanças, podemos destacar que ambas as enzimas necessitam de compostos tiólicos para regenerar as cisteínas do sítio ativo através da mesma reação global onde a taxa de consumo de tiól pelo consumo de peróxido está em torno de dois (Figura 5, Cussiol et al., 2003 anexo I). Assim como nas peroxirredoxinas, Ohr remove hidroperóxidos através de um resíduo de cisteína que está presente em um ambiente favorável para a estabilização de sua sulfidrila na forma desprotonada (ânion tiolato) em pH fisiológico. Tanto em Ohr quanto nas peroxirredoxinas, a presença de um grupo guanidina de um resíduo de arginina é um fator chave para a estabilização do tiolato (Figura 71).

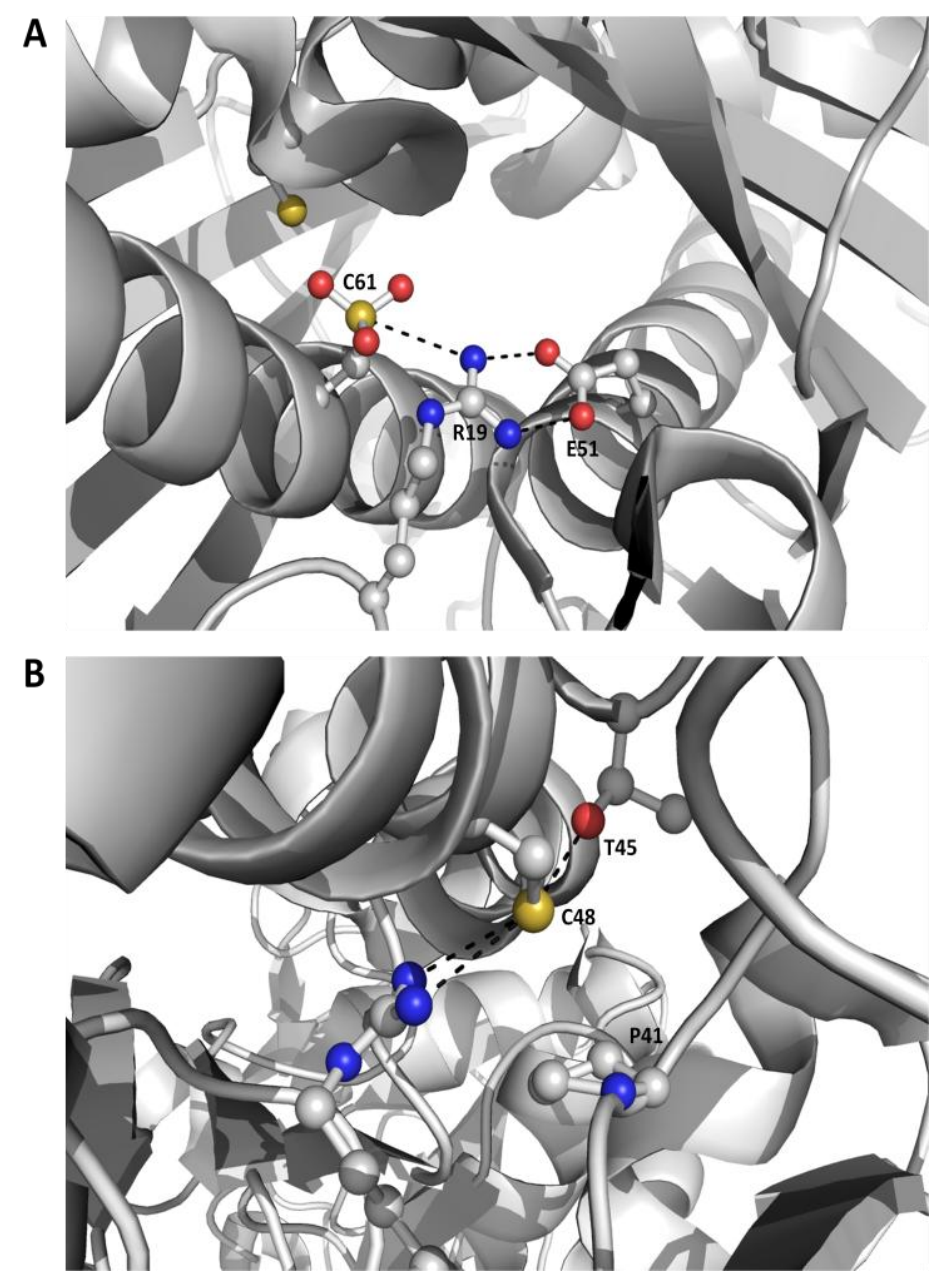

Figura 71. Comparação do mecanismo de estabilização do tiolato entre Ohr e PrxV

Em A. PrxV de Homo sapiens (PDB ID: 2VL3); B. Ohr de Xylella fastidiosa (PDB ID: 1ZB9). Nas representações estruturais estão destacados as cadeias laterais dos resíduos de aminoácidos componentes do sítio ativo. Os átomos destes aminoácidos estão representados por bastões e seguem as cores: branco (carbono), amarelo (enxofre), vermelho (oxigênio) e azul (nitrogênio). Linhas tracejadas representam as interações polares entre os aminoácidos.

Em Ohr, um resíduo de arginina (R19) forma uma ligação de hidrogênio com a cisteína peroxidásica (C61) e uma ponte salina com um resíduo de glutamina (E51) abaixando o $\mathrm{pK}_{\mathrm{a}}$ da $\mathrm{C61}$ (Figura 71A). Nas peroxirredoxinas, como AhpC, um resíduo de 
arginina e um resíduo de treonina conservados fazem ligações de hidrogênio com a cisteína peroxidásica estabilizando o tiolato (Figura 71B). Um resíduo de prolina está relacionado com a proteção do sítio ativo das peroxirredoxinas contra a superoxidação (revisado por Netto et al., 2006 anexo III).

Entretanto, uma série de evidências contrárias a esta classificação podem ser apontadas. Primeiramente, apesar do mecanismo de estabilização do tiolato ser semelhante entre as duas classes de peroxidases, os resíduos envolvidos não são conservados entre os duas famílias protéicas. Ohr não apresenta identidade de seqüência primária com nenhuma peroxirredoxina conhecida mesmo com as presentes em bactérias (Cussiol et al., 2003 anexo I). Além disso, Ohr não compartilha o mesmo enovelamento com as peroxirredoxinas (Figura 72).

A

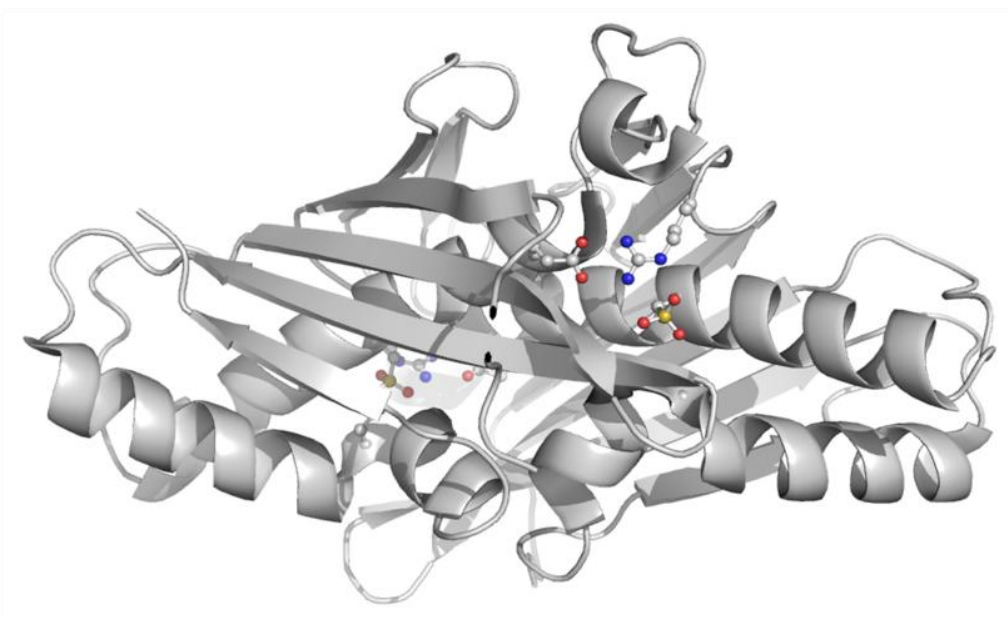

B

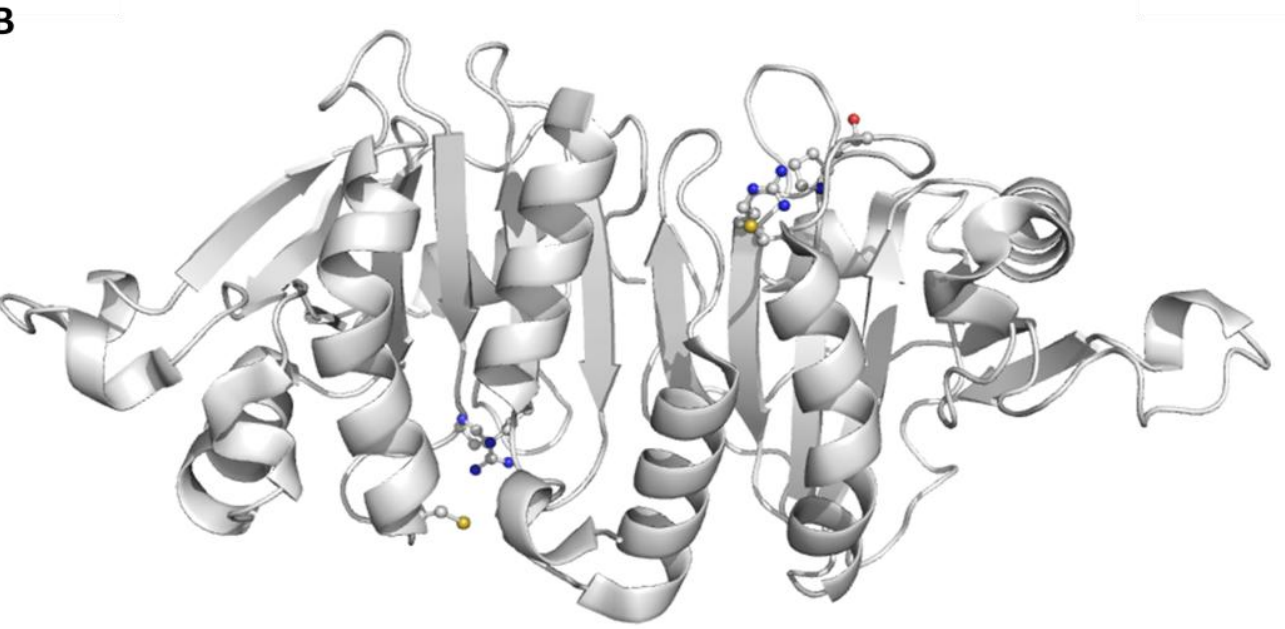

Figura 72. Comparação das estruturas quaternárias de tióis peroxidases.

Em A, Ohr de Xylella fastidiosa (PDB ID: 1ZB9) e B. AhpC de Mycobacterium tuberculosis (PDB ID: 2BMX).

Resíduos representados por bolas e bastões são aqueles componentes do sítio ativo responsáveis pela estabilização do tiolato da cisteína reativa. 
Enquanto a estrutura de Ohr é composta por duas folhas $\beta$ de seis fitas englobando duas alfa hélices centrais formando uma estrutura em forma de barril (Figura 72A), as peroxirredoxinas compartilham um enovelamento protéico presente em uma série de outras proteínas com diferentes atividades enzimáticas, denominado como enovelamento tiorredoxina (Copley et al., 2004). O enovelamento tiorredoxina consiste em uma folha $\beta$ formada por quatro ou cinco fitas $\beta$ que estão flanqueadas por quatro $\alpha$ hélices (Figura 72B). Ao contrário das peroxirredoxinas, onde a cisteína peroxidásica está presente superficialmente na estrutura em um ambiente de fácil acesso ao solvente ( Figura 73A), a cisteína peroxidásica de Ohr está enterrada na estrutura, estando presente em uma cavidade cercada por resíduos de aminoácidos hidrofóbicos (Figura 73B).

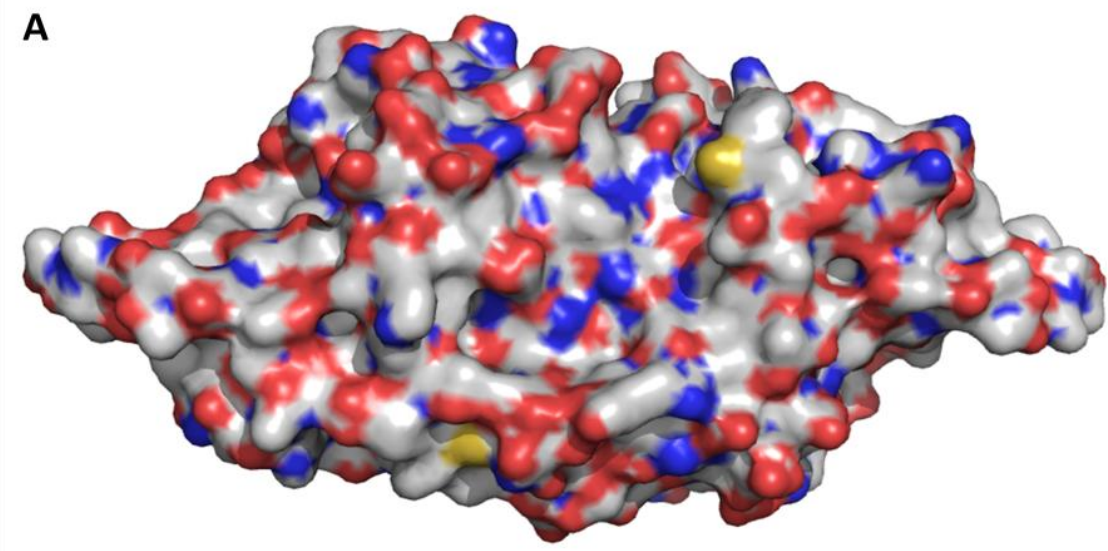

B

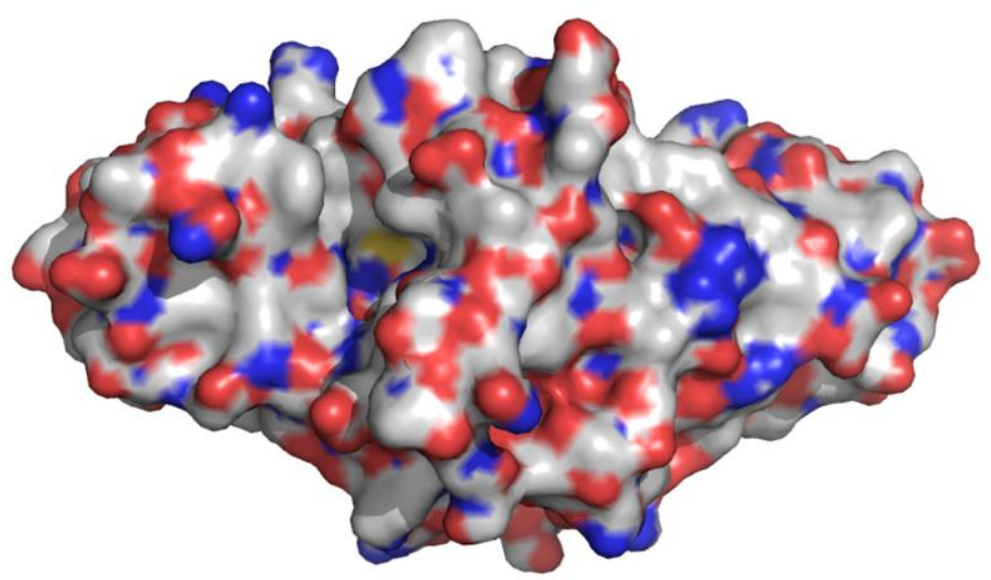

Figura 73. Análise comparativa da superfície protéica de tióis peroxidases.

Em A. AhpC de Mycobacterium tuberculosis (PDB ID: 2BMX) e B. Ohr de Xylella fastidiosa (PDB ID: 1ZB9). As cores representam os átomos de carbono (branco), enxofre (amarelo), oxigênio (vermelho) e nitrogênio (azul). As cisteínas de AhpC e Ohr estão localizadas nas posições onde está presente o átomo de enxofre em amarelo. 
Nossos resultados apontam que Ohr não aceita como redutores os sistema tiorredoxina e glutationa, responsáveis pela redução da maioria das peroxirredoxinas caracterizadas até então. Interessantemente, foi caracterizado em Mycoplasma gallisepticum uma proteína de superfície celular designada MGA1142 com homologia a família Ohr/OsmC. Esta bactéria é um patógeno aviário que causa doença respiratória crônica em galinhas. A atividade dessa proteína (MGA1142) foi descrita primeiramente não devido a sua capacidade de detoxificar peróxidos, mas sim devido a sua capacidade de ligação à heparina (Jenkins et al., 2007). A ligação da heparina está relacionada com o estabelecimento da doença visto que está presente na matriz extracelular do hospedeiro. Dessa forma, a bactéria é capaz de se ligar ao trato respiratório do hospedeiro. Essa proteína foi caracterizada mais tarde como pertencente a subfamília Ohr apresentando atividade peroxidase sobre hidroperóxidos orgânicos (Jenkins et al., 2008).

Visto que Ohr está presente exclusivamente em bactérias, sendo a maioria delas patógenas e não conserva nenhuma homologia com outras peroxidases, podemos especular que estas proteínas podem ter se originado de uma proteína ancestral com atividade parecida com a de Ohr de Mycoplasma gallisepticum. Mutações em resíduos do sítio ativo desta enzima propiciaram um ambiente propício para a reatividade da cisteína sobre peróxidos. Análise da cavidade do sítio ativo dessa proteína mostrou que embora pertencente ao grupo I (Ohr), esta conserva maiores semelhanças com as proteínas do grupo III. As proteínas do grupo III não possuem o resíduo de arginina responsável por estabilizar o tiolato da cisteína. Como a atividade desse grupo ainda é desconhecida, podemos especular que as proteínas dessa classe assim como Ohr de M. gallisepticum tenham atividade de ligação a glicosaminoglicanos como heparina. Estudos recentes indicam que Xylella fastidiosa tem como característica importante o fato de interagir com polissacarídeos da superfície celular do vetor e da planta hospedeira (Chatterjee et al., 2008). Dessa forma, o estudo da participação de Ohr nesse processo em Xylella e outras bactérias pode se mostrar um caminho promissor a se seguir de modo a entender os mecanismos de patogenicidade e a evolução de novas atividades enzimáticas em uma família protéica.

Esses dados em conjunto, apontam que provavelmente ocorreu uma convergência de função entre as peroxirredoxinas e Ohr/OsmC. 


\section{CONCLUSÕES}

Este trabalho representou uma caracterização bastante completa de Ohr de Xylella fastidiosa, membro de uma nova classe de enzimas antioxidantes.

Inicialmente, associamos pela primeira vez uma atividade bioquímica a genes da família Ohr/OsmC: peroxidase dependente de ditiól, baseada em uma cisteína reativa. Posteriormente, realizamos correlações entre estrutura e função, mostrando que o enovelamento estrutural de Ohr é distinto das demais enzimas antioxidantes (catalase,SOD, GPx e Prx).

Identificamos também a via biológica de redução de Ohr de Xylella fastidiosa: enzimas lipoiladas. Essa é a primeira descrição de uma proteína antioxidante que utiliza diretamente equivalentes redutores de sulfidrilas de grupos lipóicos complexados a proteínas.

Em relação a oxidação de Ohr, mostramos que Ohr reduz peróxidos orgânicos aproximadamente quatro ordens de grandeza mais eficientemente do que $\mathrm{H}_{2} \mathrm{O}_{2}$. Esta diferença na especificidade por peróxidos como substratos nunca havia sido observada na literatura para uma tiól peroxidase. Além disso, mostramos que Ohr é capaz de reduzir peróxidos derivados de ácidos graxos de cadeia insaturada como hidroperóxido de ácido oléico e linoléico. Sendo assim, fornecemos evidências adicionais que corroboram a hipótese de que esses peróxidos sejam os substratos biológicos de Ohr.

$\mathrm{O} \mathrm{pK}_{\mathrm{a}}$ da $\mathrm{Cys}_{\mathrm{p}} 61$ de Ohr está em torno de 5.8, demonstrando que em pH fisiológico o grupo tiól desse aminoácido está em sua maior parte na forma desprotonada, e portanto, capaz de reagir com peróxidos. No entanto, obtivemos evidências de que aminoácidos (Valina 36 e Glicina 95) que não contribuem para a estabilização do tiolato, são importantes para a reatividade de Ohr. Esses resíduos parecem interagir diretamente com o substrato de Ohr posicionando e/ou estabilizando a molécula no sítio ativo.

Finalmente, através de estudos de regulação gênica, mostramos que o gene ohr aparentemente não está sob controle de um ativador ou repressor da transcrição conhecido. Possivelmente, ohr de Xylella fastidiosa é expressa constitutivamente diferentemente de ortólogos de outros organismos filogeneticamente próximos como Xanthomonas campestris que é regulada negativamente por OhrR.

\section{PERSPECTIVAS}

Como perspectivas imediatas geradas pelos resultados dessa tese pretendemos: 
- Determinar os parâmetros cinéticos de Ohr de $X$. fastidiosa na presença de diferentes hidroperóxidos de lipídeos. Este trabalho já está sendo realizado em colaboração com o aluno de mestrado Thiago Geronimo Pires Alegria.

- Determinar os parâmetros cinéticos por análise de bi substrato dos mutantes de Ohr V36S e G95S, na presença de hidroperóxidos de lipídeos e enzimas lipoiladas, tentando compreender em qual das etapas do ciclo catalítico (redução e/ou oxidação) esses aminoácidos são importantes.

- Analisar a expressão gênica de ohr por RT-PCR quantitativo sob diferentes condições de estresse com o intuito de detectar alterações nos níveis de ohr.

- Detectar se Ohr de $X$. fastidiosa possui atividade de ligação a heparina ou a outro glicosaminoglicano.

\section{REFERÊNCIAS BIBLIOGRÁFICAS}

1. Abramovitch, R.B. \& Martin, G.B. (2004) "Strategies used by bacterial pathogens to suppress plant defenses”. Curr. Opin. Plant Biol., 7: 356-64.

2. Abu-amero, K.K.; Abu-Groun, E.A.; Halablab, M.A. \& Miles, R.J. (2000) "Kinetics and distribution of alcohol oxidising activity in Acholeplasma and Mycoplasma species". FEMS Microbiol. Lett., 183: 147-151.

3. Abu-Amero, K.K.; Miles, R.J. \& Halablab, M.A. (2005) "Cholesterol protects Acholeplasma laidlawii against oxidative damage caused by hydrogen peroxide". Veterinary Research Communications, 29: 373-380.

4. Akpinar, D.; Yargiçoglu, P.; Derin, N.; Alicigüzel, Y.\& Agar, A. (2008) "The effect of lipoic acid on antioxidant status and lipid peroxidation in rats exposed to chronic restraint stress" Physiol. Res., 57: 893-901.

5. Almeida, R.P.P. \& Purcell, A.H. (2006) "Patterns of Xylella fastidiosa colonization on the precibarium of sharpshooter vectors relative to transmission to plants". Ann. Entomol. Soc. Am., 99: 884-890.

6. Amaro, A.A.; Maia, M.L. \& Ghilardi, A.A. "Custos de produção na atual conjuntura da citricultura. In: Donadio, L.C. \& Rodrigues, O. (Coord.) Bebedouro: Seminário 
Internacional de Citros - Tratos Culturais, 4, Campinas: Fundação Cargill, 1998, p 481-499.

7. Ambrosio, A.L.; Nonato, M.C.; de Araujo, H.S.; Arni, R.; Ward, R.J.; Ownby, C.L.; de Souza, D.H.F. \& Garrat, R.C. (2005) "A molecular mechanism for Lys49phospholipase A2 activity based on ligand-induced conformational change". J. Biol. Chem. 280: 7326-7335.

8. Atichartpongkul, S.; Loprasert, S.; Vattanaviboon, P.; Whangsuk, W.; Helmann, J.D. \& Mongkolsuk, S. (2001) "Bacterial Ohr and OsmC paralogues define two protein families with distinc functions and patterns of expression". Microbiology, 147: 1775-1782.

9. Ausubel, F.M.; Brent, R.; Kingstone, R.E.; Moore, D.D.; Seidman, J.A.; Smith, J.A. \& Struhl, K. (1994) em Current Protocols in Molecular Biology, John Wiley \& Sons, Inc., Caps. 2, 3 e 13.

10. Avery, A.M. \& Avery, S.V. (2001) "Saccharomyces cerevisiae expresses three phospholipid hydroperoxide glutathione peroxidases". J. Biol. Chem., 276: 3373033735 .

11. Balentine, J.D. (1982) Pathology of $\mathrm{O}_{2}$ Toxicity. Academic Press, New York.

12. Barrett, M.L.; Harris, R.L.; Antonyuk, S.; Hough, M.A.; Ellis, M.J.; Sawers, G.; Eady, R.R. \& Hasnain, S.S. (2004). "Insights into redox partner interactions and substrate binding in nitrite reductase from Alcaligenes xylosoxidans: crystal structures of the Trp138His and His313GIn mutants". Biochemistry, 51: 16311-16319.

13. Beckwith, J. (2009) "Genetic suppressors and recovery of repressed biochemical memory". J. Biol. Chem., 284: 12585-12592.

14. Benesch, R.E.\& Benesch, R. (1955). "The acid strength of the-SH group in cysteine and related compounds". J. Am. Chem. Soc., 77: 5877-5881.

15. Borukhov, S. \& Nudler, E. (2003) "RNA polymerase holoenzyme: structure, function and biological implications". Curr. Opin. Microbiol., 6: 93-100.

16. Brautigam, C.A.; Chuang, J.L.; Tomchick, D.R.; Machius, M. \& Chuang, D.T. (2005) "Crystal structure of human dihydrolipoamide dehydrogenase: NAD $/ \mathrm{NADH}$ binding and the structural basis of disease-causing mutations" J. Mol. Biol., 350: 543552.

17. Bréhelin, C.; Meyer, E.H.; de Souris, J.; Bonnard, G. \& Meyer, Y. (2003) "Resemblance and dissemblance of Arabidopsis type II peroxiredoxins: similar sequences for divergent gene expression, protein localization, and activity". Plant Physiol., 132: 2045-2057.

18. Bryk, R.; Griffin, P. \& Nathan, C. (2000) "Peroxynitrite reductase activity of bacterial peroxiredoxins". Nature, 407: 211-215.

19. Bryk, R.; Lima, C.D.; Erdjument-Bromage, H.; Tempst, P. \& Nathan, C. (2002) "Metabolic enzymes of mycobacteria linked to antioxidant defense by a thioredoxinlike protein". Science, 295: 1073-1077.

20. Bunik, V.I. (2003) "2-Oxo acid dehydrogenase complexes in redox regulation". Eur. J. Biochem., 270: 1036-1042.

21. Chae, H.Z.; Kim, I.H.; Kim, K. \& Rhee, S.G. (1993) "Cloning, sequencing, and mutation of thiol-specific antioxidant gene of Saccharomyces cerevisiae" J. Biol. Chem., 268: 16815-16821. 
22. Chae, H.Z.; Chung, S.J. \& Rhee, S.G. (1994a) "Thioredoxin-dependent peroxide reductase from yeast". J. Biol. Chem., 269: 27670-27678.

23. Chae, H.Z.; Robison, K.; Poole, L.B.; Church, G.; Storz, G. \& Rhee, S.G. (1994b) "Cloning and sequencing of thiol-specific antioxidant from mammalian brain: alkylhydroperoxide reductase and thiol-specific antioxidant define a large family of antioxidant enzymes". Proc. Natl. Acad. Sci. USA, 91: 7017-7021.

24. Chae, H.Z.; Uhm, T.B. \& Rhee, S.G. (1994c) "Dimerization of thiol-specific antioxidant and the essential role of cysteine-47". Proc. Natl. Acad. Sci. USA, 91: 7022-7026.

25. Chatterjee, S.; Almeida, R.P.P. \& Lindow, S. (2008) "Living in two worlds: The plant and insect lifestyles of Xylella fastidiosa". Annu. Rev. Phytopathol., 46: 243271.

26. Choi, H.; Kim, S.; Mukhopadhyay, P.; Cho, S.;Woo, J.; Storz, G. \& Ryu, S. (2001) "Structural basis of the redox switch in the OxyR transcription factor". Cell, 105: 103-113.

27. Chuchue, T.; Tanboon, W.; Prapagdee, B.; Dubbs, J.M.; Vattanaviboon, P. \& Mongkolsuk, S. (2006) "ohrR and ohr are the primary sensor/regulator and protective genes against organic hydroperoxide stress in Agrobacterium tumefaciens". J. Bacteriol., 188: 842-851.

28. Coddington, J.W.; Hurst, J.K. \& Lymar, S.V. (1999) "Hydroxyl radical formation during peroxynitrous acid decomposition". J. Am. Chem. Soc., 121: 2438-2443.

29. Copley, S.D.; Novak, W.R.; \& Babbitt, P.C. (2004) "Divergence of function in the thioredoxin fold suprafamily: evidence for evolution of peroxiredoxins from a thioredoxin-like ancestor". Biochemistry, 43:13981-95.

30. Cussiol, J.R.R.; Alves, S.V.; Oliveira, M.A. \& Netto, L.E.S. (2003) "Organic Hydroperoxide resistance gene encodes a thiol-dependent peroxidase". J. Biol. Chem., 278: 11570-11578.

31. Dang, J.L.; Dietrich, R.A. \& Richberg, M.H. (1996) "Death don't have no mercy: cell death programs in plant-microbe interactions". Plant Cell, 8: 1793-1807.

32. da Silva Neto, J.F.; Koide T.; Gomes, S.L. \& Marques, M.V. (2007) "The single extracytoplasmic-function sigma factor of Xylella fastidiosa is involved in the heat shock response and presents an unusual regulatory mechanism". J. Bacteriol., 189: 551-560.

33. da Silva Neto, J.F.; Koide, T.; Abe, C.M.; Gomes, S.L. \& Marques, M.V. (2008) "Role of $\sigma^{54}$ in the regulation of genes involved in type I and type IV pili biogenesis in Xylella fastidiosa". Arch. Microbiol., 189: 249-261.

34. Davis, M.J.; French, W.J. \& Schaad, N.W. (1981) "Axenic culture of the bacteria associated with phony peach disease of peach and plum leaf scald". Current Microbiol., 6: 309-314.

35. Delker, S.L.; West, A.P.; Jr. McDermott, L.; Kennedy, M.W. \& Bjorkman, P.J. (2004). "Crystallographic studies of ligand binding by Zn-alpha2-glycoprotein". J. Struct. Biol., 205: 213.

36. Discola, K.F.; Oliveira, M.A.; Cussiol, J.R.R.; Monteiro, G.; Bárcena, J.A.; Porras, P.; Padilla, C.A.; Guimarães, B.G. \& Netto, L.E.S. (2009) "Structural aspects of the distinct biochemical properties of glutaredoxin 1 and glutaredoxin 2 from Saccharomyces cerevisiae". J. Mol. Biol., 385: 889-901. 
37. Doke, N. (1983) "Involvement of superoxide anion generation in the hypersensitive response of potato-tuber tissues to infection with an incompatible race of Phytophthora infestans and to the hyphal wall components". Physiol. Plant. Pathol., 23: 345-357.

38. Mur, L.A.J.; Kenton, P.; Lloyd, A.J.; Ougham, H. \& Prats, E. (2008) "The hypersensitive response; the centenary is upon us but how much do we know?". J. Experimental Botany, 59: 501-520.

39. Ellis, H.R. \& Poole, L.B. (1997) "Roles for the two cysteine residues of AhpC in catalysis of peroxide reduction by alkyl hydroperoxide reductase from Salmonella typhimurium". Biochemistry, 36: 13349-56.

40. Blee, E. (1998) "Phytooxylipins and plant defense reactions". Prog. Lipid Res., 37: 33-72.

41. Fisher, A.B.; Dodia, C.; Manevich, Y.; Chen, J-W. \& Feinstein, S.I. (1999) "Phospholipid Hydroperoxides Are Substrates for Non-selenium Glutathione Peroxidase". J. Biol. Chem., 274: 21326-21334.

42. Fourquet, S.; Huang, M.E.; D'Autreaux, B.; \& Toledano, M.B. (2008) "The dual functions of thiol-based peroxidases in $\mathrm{H}_{2} \mathrm{O}_{2}$ scavenging and signaling". Antioxid. Redox. Signal., 10: 1565-1576.

43. Fuangthong, M.; Atichartpongkul, S.; Mongkolsuk, S. \& Helmann, J.D. (2001) "OhrR is a repressor of ohrA, a key organic hydroperoxide resistance determinant in Bacillus subtilis". J. Bacteriol., 183: 4134-4141.

44. Fuangthong, M. \& Helmann, J.D. (2002) "The OhrR repressor senses organic hydroperoxides by reversible formation of a cysteine-sulfenic acid derivative" Proc Natl Acad Sci USA, 99: 6690-6695.

45. Girotti, A.W. (2008) "Translocation as a means of disseminating lipid hydroperoxide-induced oxidative damage and effector action" Free Rad. Biol. Med., 44: 956-968.

46. Gobel, C.; Feussner, I.; Schmidt, A.; Scheel, D.; Sanchez-Serrano, J.; Hamberg, M. \& Rosahl, S. (2001) "Oxylipin profiling reveals the preferential stimulation of the 9-lipoxygenase pathway in elicitortreated potato cells". J. Biol. Chem., 276: 6267-6273.

47. Gobel, C.; Feussner, I. \& Rosal, S. (2003) "Lipid peroxidation during the hypersensitive response in potato in the absence of 9-lipoxygenases". J. Biol. Chem., 278: 52834-52840.

48. Gourion, B.; Rossignol, M. \& Vorholt, J.A. (2006) "A proteomic study of Methylobacterium extorquens reveals a response regulator essential for epiphytic growth". Proc. Natl. Acad. Sci. USA, 103:13186-13191.

49. Gourion, B.; Francez-Charlot, A. \& Vorholt, J.A. (2008) "PhyR is involved in the general stress response of Methylobacterium extorquens AM1". J. Bacteriol., 190: 1027-1035.

50. Grant, J.J. \& Loake, G.J. (2000) "Role of reactive oxygen intermediates and cognate redox signaling in disease resistance". Plant Physiology, 124: 21-29.

51. Gutierrez, C. \& Devedjian, J.C. (1991) "Osmotic induction of gene osmC expression in Escherichia coli K12". J Mol Biol., 220: 959-973. 
52. Håkansson, A.P. \& Smith, A.W. "Enzymatic characterization of dihydrolipoamide dehydrogenase from Streptococcus pneumoniae harboring its own substrate". J Biol Chem., 282: 29521-30.

53. Halliwell, B. \& Gutteridge, J.M.C. (2007) "Cellular responses to oxidative stress: adaptation, damage, reapir, senescence and death", In: Halliwell; B.; e Gutteridge; J.M.C. (Ed.), "Free Radicals in Biology and Medicine", Fourth edition, Oxford: Oxford University Press, p. 187-267.

54. Halliwell, B. \& Gutteridge, J.M.C. (2007) "Antioxidant defences: endogenous and diet derived", In: Halliwell; B.; e Gutteridge; J.M.C. (Ed.), "Free Radicals in Biology and Medicine", Fourth edition, Oxford: Oxford University Press, p. 79-186.

55. Herbig, A. \& Helmann, J.D. (2002) "Metal ion uptake and oxidative stress". In: Sonenshein, A.L.; Hoch, J.A. \& Losick, R. (Eds), "Bacillus subtillis and its closest relatives" Washington, DC: American Society for Microbiology Press, p. 405-414.

56. Hofmann, B.; Hecht, H.J. \& Flohe, L. (2002). "Peroxiredoxins". Biol. Chem., 383: 347-364.

57. Holmgren, A. (1985) "Thioredoxin” Ann. Rev. Biochem., 54: 237-271.

58. Hong, M.; Fuangthong, M.; Helmann, J.D. \& Brennan, R.G. (2005) "Structure of an OhrR-ohrA operator complex reveals the DNA binding mechanism of the MarR family". Mol. Cell, 20: 131-141.

59. Hopkins, D.L. (1989) "Xylella fastidiosa: a xylem-limited bacterial pathogen of plants”. Annu. Rev. Phytopathol., 27: 271-290.

60. Horta, B.B. (2009) "Caracterização funcional e estrutural de peroxidases dependentes de tiól da bactéria fitopatogênica Xylella fastidiosa" Tese de doutorado apresentada ao Departamento de Genética e Biologia Evolutivo do Instituto de Biociências da Universidade de São Paulo.

61. Jacobson, F.S.; Morgan, R.W.; Christman, M.F. \& Ames, B.N. (1989) "An alkyl hydroperoxide reductase from Salmonella typhimurium involved in the defense of DNA against oxidative damage. Purification and properties". J. Biol. Chem., 264: 1488-1496.

62. Jalloul, A.; Montillet, J.L.; Assigbetse, K.; Agnel, J.P.; Delannoy, E.; Triantaphylides, C.; Daniel, J.F.; Marmey, P.; Geiger, J.P. \& Nicole, M. (2002). "Lipid peroxidation in cotton: Xanthomonas interactions and the role of lipoxygenases during the hypersensitive reaction". The Plant Journal, 32: 1-12.

63. Jenkins, C.; Samudrala, R.; Geary, S.J. \& Djordjevic, S.P. (2008) "Structural and functional characterization of an organic hydroperoxide resistance protein from Mycoplasma gallisepticum". J. Bacteriol., 190: 2206-2216.

64. Jeong, J.S.; Kwon, S.J.; Kang, S.W.; Rhee, S.G. \& Kim, K. (1999) "Purification and characterization of a second type thioredoxin peroxidase (type II TPx) from Saccharomyces cerevisiae". Biochemistry, 38: 776-783.

65. Jiang, Y. \& Cronan, J.E. (2005) "Expression cloning and demonstration of Enterococcus faecalis lipoamidase (pyruvate dehydrogenase inactivase) as a SerSer-Lys triad amidohydrolase". J. Biol. Chem., 280: 2244-2256.

66. Jiang, Z.Y.; Hunt, J.V. \& Wolff, S.P. (1992) "Ferrous ion oxidation in the presence of xylenol orange for detection of lipid hydroperoxide in low density lipoprotein". Anal Biochem., 202: 384-389. 
67. Jordan S.W. \& Cronan Jr., J.E. (1997) "A new metabolic link. The acyl carrier protein of lipid synthesis donates lipoic acid to the pyruvate dehydrogenase complex in Escherichia coli and mitochondria". J. Biol. Chem. 272: 17903-17906.

68. Jordan, S.W. \& Cronan Jr., J.E. (2003) "The Escherichia coli lipB gene encodes lipoyl (octanoyl)-acyl carrier protein: protein Transferase". J. Bacteriol., 185: 1582-1589.

69. Kang, J.G.; Paget, M.S.; Seok, Y.J.; Hahn, M.Y.; Bae, J.B. \& Hahn, J.S. (1999) "RsrA, an anti-sigma factor regulated by redox change". EMBO J., 18: $4292-$ 4298.

70. Kawano, T. (2003) "Roles of the reactive oxygen species-generating peroxidase reactions in plant defense and growth induction", Plant Cell Rep., 21: 829837.

71. Keith, L.M.W. \& Bender, C.L. (1999) "AlgT $\left(\sigma^{22}\right)$ controls alginate production and tolerance to environmental stress in Pseudomonas syringae". J. Bacteriol., 181: 7176-7184.

72. Kenton, P.; Mur, L.A.J.; Atzorn, R.; Wasternack, C. \& Draper, J. (1999). "Jasmonic acid accumulation in tobacco hypersensitive response lesions". Molecular Plant-Microbe Interactions, 12: 74-78.

73. Kirkman, H.N. \& Gaetani, G.F.G. (1984) "Catalase: A tetrameric enzyme with four tightly bound molecules of NADPH" Proc. Natl. Acad. Sci. USA, 81: 4343-4347.

74. Kim, K.; Kim, I.H.; Lee, Ki-Y.; Rhee, S.G. \& Stadtman, E.R. (1988) "The isolation and purification of a specific "protector" protein which inhibits enzyme inactivation by a thiol $/ \mathrm{Fe}(\mathrm{III}) / \mathrm{O}_{2}$ mixed-function oxidation system" J. Biol. Chem., 263: 4704-4711.

75. Klomsiri, C.; Panmanee, W.; Dharmsthiti, S.; Vattanaviboon, P. \& Mongkolsuk, S. (2005) "Novel roles of ohrR-ohr in Xanthomonas sensing, metabolism and physiological adaptative response to lipid hydroperoxide" J. Bacteriol., 187: 32773281.

76. Kosower, N.S.; Kosower, E.M.; Newton, G.L. \& Ranney, H.M. (1979) "Bimane fluorescent labels: Labeling of normal human red cells under physiological conditions". Proc. Natl. Acad. Sci. USA, 76: 3382-3386.

77. Kruger, N.J. (1994) "The Bradford method for protein quantitation". Methods Mol. Biol., 32: 9-15.

78. Lee, J.W. \& Helmann, J.D. (2006) "The PerR transcription factor senses $\mathrm{H}_{2} \mathrm{O}_{2}$ by metal-catalysed histidine oxidation". Nature, 440: 363-367.

79. Lee, J.W.; Soonsanga, S. \& Helmann, J.D. (2007) "A complex thiolate switch regulates the Bacillus subtilis organic peroxide sensor OhrR". Proc Natl Acad Sci USA, 104: 8743-8748.

80. Lesniak, J.; Barton, W.A. \& Nikolov, D.B. (2002) "Structural and functional characterization of the Pseudomonas hydroperoxide resistance protein Ohr". EMBO J., 21: 6649-6659.

81. Lesniak, J.; Barton, W.A. \& Nikolov, D.B. (2003) "Structural and functional features of the Escherichia coli hydroperoxide resistance protein OsmC" Protein Science, 12: 2838-2843. 
82. Levine, A.; Tenhaken, R.; Dixon, R. \& Lamb, C. (1994). " $\mathrm{H}_{2} \mathrm{O}_{2}$ from the oxidative burst orchestrates the plant hypersensitive disease resistance response". Cell, 79: 583-593.

83. Link, A.J.; Robison, K. \& Church, G.M. (1997) "Comparing the predicted and observed properties of proteins encoded in the genome of Escherichia coli K-12". Electrophoresis, 18: 1259-1313.

84. Loprasert, S.; Fuangthong, M.; Whangsuk, W.; Atichartpongkul, S. \& Mongkolsuk, S. (2000). "Molecular and physiological analysis of an OxyR-regulated ahpC promoter in Xanthomonas campestris pv. Phaseoli". Mol. Microbiol. 37: 15041514.

85. Ma, Q.; Zhao, X.; Eddine, A.N. Geerlof, A.; Li, X.; Cronan, J.E.; Kaufmann, S.H.E. \& Wilmanns, M. (2006). "The Mycobacterium tuberculosis LipB enzyme functions as a cysteinelysine dyad acyltransferase". Proc. Natl. Acad. Sci. USA, 103: 8662-8667.

86. May, M.J.; Hammond-Kosack, K.E. \& Jones, J.D.G. (1996). "Involvement of reactive oxygen species, glutathione metabolism, and lipid peroxidation in the Cfgene-dependent defense response of tomato cotyledons induced by race-specific elicitors of Cladosporium fulvum". Plant Physiology, 110: 1367-1379.

87. McCord, J.M. \& Fridovich, I. (1969) "Superoxide dismutase: an enzymic function for erythrocuprein (hemocuprein)". J. Biol. Chem., 244: 6049-6055.

88. Medinas, D.B.; Cerchiaro, G.; Trindade, D.F. \& Augusto, O. (2007) "The carbonate radical and related oxidants derived from bicarbonate buffer". IUBMB Life, 59(4-5): 255-262.

89. Meunier-Jamin, C.; Kapp, U.; Leonard, G.A. \& McSweeney, S. (2004) "The structure of organic hydroperoxide resistance protein from Deinococcus radiodurans: do conformational changes facilitate recycling of the redox disulphide?". J. Biol. Chem., 279: 25830-25837.

90. Moini, H.; Packer, L. \& Saris, N.E. (2002) "Antioxidant and prooxidant activities of alpha-lipoic acid and dihydrolipoic acid". Toxicol. Appl. Pharmacol., 182: 84-90.

91. Mongkolsuk, S.; Loprasert, S.; Whangsuk, W.; Fuangthong, M. \& Atichartpongkul, S.(1997). "Characterization of transcription organization and analysis of unique expression patterns of an alkyl hydroperoxide reductase $C$ gene $(a h p C)$ and the peroxide regulator operon ahpF-oxyR-orfX from Xanthomonas campestris pv. Phaseoli". J. Bacteriol., 179: 3950-3955.

92. Mongkolsuk, S.; Praituan, W.; Loprasert, S.; Fuangthong, M. \& Chamnongpol, S. (1998) "Identification and characterization of a new organic hydroperoxide resistance (ohr) gene with a novel pattern of oxidative stress regulation from Xanthomonas campestris pv. phaseoli". J. Bacteriol., 180: 2636-2643.

93. Mongkolsuk, S. \& Helmann, J.D. (2002) "Regulation of inducible peroxide stress responses". Mol. Microbiol., 45: 9-15.

94. Monteiro, G.; Horta, B.B.; Pimenta, D.C.; Augusto, O.; \& Netto L.E.S. (2007) "Reduction of 1-Cys peroxiredoxins by ascorbate changes the thiol-specific antioxidant paradigm, revealing another function of vitamin C". Proc. Natl. Acad. Sci. USA, 104: 4886-91. 
95. Monteiro, P.B.; Teixeira, D.C.; Palma, R.R.; Garnier, M.; Bové, J.M. \& Renaudin, J. (2001) "Stable transformation of the Xylella fastidiosa citrus variegated clorosis strain with oriC plasmids". Appl. Environ. Microbiol., 67: 2263-2269.

96. Mooney, R.A.; Darst, S.A. \& Landick, R. (2005) "Sigma and RNA polymerase: an on-again, off again relationship?". Mol. Cell, 20: 335-345.

97. Munhoz, D.C. \& Netto, L.E.S. (2004) "Cytosolic Thioredoxin peroxidase I and II are important defenses of yeast against organic hydroperoxide insult". J. Biol. Chem., 279: 35219-35227.

98. Nelson, J.W. \& Creighton, T.E. (1994) "Reactivity and ionization of the active site cysteine residues of DsbA, a protein required for disulfide bond formation in vivo". Biochemistry, 33: 5974-5983.

99. Netto, L.E.S.; Chae, H.Z.; Kang, S.W.; Rhee, S.G. \& Stadtman, E.R. (1996) "Removal of hydrogen peroxide is involved with the antioxidant properties of Thiol Specific Antioxidant (TSA). TSA possesses thiol peroxidase activity". J. Biol. Chem., 271: $15315-15321$.

100. Netto, L.E.S. (2001) "Oxidative stress response in sugarcane", Rev. Bras. Genet., 24: 93-102.

101. Netto, L.E.; de Oliveira, M.A.; Monteiro, G.; Demasi, A.P.; Cussiol, J.R.; Discola, K.F.; Demasi, M.; Silva, G.M.; Alves, S.V.; Faria, V.G. \& Horta, B.B. "Reactive cysteine in proteins: Protein folding, antioxidant defense, redox signaling and more". Comp Biochem Physiol C Toxicol Pharmacol., 146:180-93; 2006.

102. Noll, K.M. \& Barber, T.S. (1988) "Vitamin contents of archaebacteria". J. Bacteriol., 170: 4315-4321.

103. Ochsner, U. A.; Hasset, D. J. \& Vasil. M. L. (2001) "Genetic and physiological characterization of ohr, encoding a protein involved in organic hydroperoxide resistance in Pseudomonas aeruginosa". J. Bacteriol., 183: 773-778.

104. Oh, S-Y.; Shin, J-H. \& Roe, J-H. (2007) "Dual role of OhrR as a repressor and an activator in response to organic hydroperoxides in Streptomyces coelicolor". J. Bacteriol., 189: 6284-6292.

105. Oliveira, M.A.; Guimarães, B.G.; Cussiol, J.R.R.; Medrano, F.J.; Gozzo, F.C. \& Netto, L.E.S. (2006) "Structural insights into enzyme-substrate interaction and characterization of enzymatic intermediates of Organic hydroperoxide resistance protein from Xylella fastidiosa". J. Mol. Biol., 359: 433-445.

106. Osiro, D.; Muniz, J.R.; Coleta Filho, H.D.; de Sousa, A.A.; Machado, M.A.; Garratt, R.C. \& Colnago, L.A. (2004). "Fatty acid synthesis in Xylella fastidiosa: correlations between genome studies, ${ }^{13} \mathrm{C}$ NMR data, and molecular models". Biochem. Biophys. Res. Commun., 323: 987-995.

107. Ouedraogo, G.D. \& Redmond, R.W. (2003) "Secondary reactive oxygen species extend the range of photosensitization effects in cells: DNA damage produced via initial membrane photosensitization". Photochem. Photobiol., 77: 192203.

108. Paget, M.S.B. \& Buttnner, M.J. (2003) "Thiol-based regulatory switches". Annu. Rev. Genet., 37: 91-121.

109. Paget, M.S. \& Helmann, J.D. (2003) "The $\sigma^{70}$ family of sigma factors". Genome Biol., 4: 203. 
110. Panmanee, W.; Vattanaviboon, P.; Eiamphungporn, W.; Whangsuk, W.; Sallabhan, R. \& Mongkolsuk, S. (2002) "OhrR, a transcription repressor that senses and responds to changes in organic peroxide levels in Xanthomonas campestris pv. Phaseoli". Mol. Microbiol., 45: 1647-1654.

111. Park, S.G.; Cha, M.K.; Jeong, W. \& Kim, I.H. (2000) "Distinct physiological functions of thiol peroxidase isoenzymes in Saccharomyces cerevisiae". J. Biol. Chem., 275: 5723-5732.

112. Pedersen, S.; Bloch, P.L.; Reeh, S. \& Neidhardt, F.C. (1978) "Patterns of protein synthesis in E. coli: a catalog of the amount of 140 individual proteins at different growth rates". Cell, 14: 179-190.

113. Pedrajas, J.R.; Miranda-Vizuete, A.; Javanmardy, N.; Gustafsson, J.A. \& Spyrou, G. (2000) "Mitochondria of Saccharomyces cerevisiae contain oneconserved cysteine type peroxiredoxin with thioredoxin peroxidase activity". J. Biol. Chem., 275: 16296-16301.

114. Perham, R.N.; Jones, D.D.; Chauhan, H.J. \& Howard, M.J. (2002) "Substrate channeling in 2-oxo acid dehydrogenase multienzyme complexes". Biochem. Soc. Trans., 30: 47-51.

115. Pfeiffer, S.; Gorren, A.C.F.; Schmidt, K.; Werner, E.R.; Hansert, B.; Bohle, D.S. \& Mayer, B. (1997) "Metabolic fate of peroxynitrite in aqueous solution. Reaction with nitric oxide and $\mathrm{pH}$-dependent decomposition to nitrite and oxygen in a 2:1 stoichiometry" J. Biol. Chem., 272: 3465-3470.

116. Pitzschke, A.; Forzani, C. \& Hirt, H. (2006) "Reactive Oxygen Species Signaling in Plants", Antioxidants \& Redox Signaling, 8: 1757-1764.

117. Poole, L.B. (2005) "Bacterial defenses against oxidants: mechanistic features of cysteine-based peroxidases and their flavoprotein reductases". Arch. Biochem. Biophys., 433: 240-254.

118. Porta, H. \& Rocha-Sosa, M. (2002) "Plant lipoxygenases. Physiological and molecular features". Plant Physiology, 130: 15-21.

119. Potvin, E.; Sanschagrin, F. \& Levesque, R. C. (2008) "Sigma factors in Pseudomonas aeruginosa". FEMS Microbiol. Rev., 32: 38-55.

120. Powis, G. \& Montfort, W.R. (2001) "Properties and biological activities of thioredoxins". Annu. Rev. Biophys. Biomol. Struct, 30: 421-455.

121. Prado, F.M.; Oliveira, M.C.; Miyamoto, S.; Martinez, G.R.; Medeiros, M.H.; Ronsein, G.E. \& Di Mascio, P. (2009) "Thymine hydroperoxide as a potential source of singlet molecular oxygen in DNA" Free. Radic. Biol. Med., 47: 401-409.

122. Price, A.H. \& Hendry, G.A.F. (1991) "Iron-catalyzed oxygen radical formation and its possible contribution to drought damage in nine native grasses and three cereals" Plant, Cell and Environment, 14: 477-484.

123. Rajashankar, K.R.; Bryk, R.; Kniewel, R.; Buglino, J.A.; Nathan, C.F. \& Lima, C.D. (2005) "Crystal structure and functional analysis of lipoamide dehydrogenase from Mycobacterium tuberculosis" J. Biol. Chem., 280: 33977-33983.

124. Redak, R.A.; Purcell, A.H.; Lopes, J.R.; Blua, M.J.; Mizell, R.F.3 ${ }^{\text {rd }}$ \& Andersen, P.C. (2004) "The biology of xylem fluid-feeding insect vectors of Xylella fastidiosa and their relation to disease epidemiology". Annu. Rev. Entomol., 49: 243-70. 
125. Reed, K.E. \& Cronan, J.E. Jr. (1993) "Lipoic acid metabolism in Escherichia coli: sequencing and functional characterization of the $\operatorname{lip} A$ and $\operatorname{lip} B$ genes". J. Bacteriol., 175: 1325-1336.

126. Reed, L.J. (2001) "A trail of research from lipoic acid to a-keto acid dehydrogenase complexes". J. Biol. Chem., 276: 38329-38336.

127. Rhee, S.G.; Kang, S.W.; Netto, L.E.; Seo, M.S. \& Stadtman, E.R. (1998) "A family of novel peroxidases, peroxiredoxins". Biofactors, 10: 207-209.

128. Rhodius, V. A.; Suh, W.C.; Nonaka, G.; West, J. \& Gross, C.A. (2006). "Conserved and variable functions of the $\sigma^{\mathrm{E}}$ stress response in related genomes". PLoS Biol., 4: e2.

129. Rince, A.; Giard, J.C.; Pichereau, V.; Flahaut, S. \& Auffray, Y. (2001) "Identification and characterization of gsp65, an organic hydroperoxide resistance (ohr) gene encoding a general stress protein in Enterococcus faecalis". J. Bacteriol., 183: 1482-1488.

130. Rouhier, N.; Gelhaye, E. \& Jacquot, J.P. (2002) "Glutaredoxin dependent peroxiredoxin from poplar: protein-protein interaction and catalytic mechanism". J. Biol. Chem., 277: 13609-13614.

131. Sassetti, C. M.; Boyd, D.H. \& Rubin, E.J. (2003) "Genes required for mycobacterial growth defined by high density mutagenesis". Mol. Microbiol., 48: 7784.

132. Schein, C.H. \& Noteborn, M.H.M. (1989) Bio/Technology, 7: 1141-1148.

133. Schupke, H.; Hempel, R.; Peter, G.; Hermann, R.; Wessel, K.; Engel, J. \& Kronbach, T. (2001) "New metabolic pathways of a-lipoic acid". Drug Metab. Dispos., 29: 855-862.

134. Segel, H.I. "Enzyme Kinetics - Behavior and Analysis of Rapid Equilibrium and Steady-State Enzyme Systems". Wiley, New York, 1993, p. 606-612.

135. Seo, M.S.; Kang, S.W.; Kim, K.; Baines, I.C.; Lee, T.H. \& Rhee, S.G. (2000) "Identification of a new type of mammalian peroxiredoxin that forms an intramolecular disulfide as a reaction intermediate". J. Biol. Chem., 275: 20346-20354.

136. Shea, R.J. \& Mulks, M.H. (2002) "ohr, encoding an organic hydroperoxide reductase, is an in vivo-induced gene in Actinobacillus pleuropneumoniae". Infect. Immun., 70: 794-802.

137. Shi, S. \& Ehrt, S. (2006) "Dihydrolipoamide acyltransferase (DlaT) is critical for Mycobacterium tuberculosis pathogenesis". Infect Immun., 74: 56-63.

138. Shin, D.H.; Choi, I.G.; Busso, D.; Jancarik, J.; Yokota, H.; Kim, R. \& Kim, S.H. (2004) "Structure of OsmC from Escherichia coli: a salt-shock-induced protein". Acta Crystallographica Section D Biological Crystallography, 60: 903-911.

139. Simpson, A.J.; Reinach, F.C.; Arruda, P.; Abreu, F.A.; Acencio, M.; Alvarenga, R.; Alves, L.M.; Araya, J.E.; Baia, G.S.; Baptista, C.S.; Barros, M.H.; Bonaccorsi, E.D.; Bordin, S.; Bove, J.M.; Briones, M.R.; Bueno, M.R.; Camargo, A.A.; Camargo, L.E.; Carraro, D.M.; Carrer, H.; Colauto, N.B.; Colombo, C.; Costa, F.F.; Costa, M.C.; Costa-Neto, C.M.; Coutinho, L.L.; Cristofani, M.; Dias-Neto, E.; Docena, C.; El-Dorry, H.; Facincani, A.P.; Ferreira, A.J.; Ferreira, V.C.; Ferro, J.A.; Fraga, J.S.; Franca, S.C.; Franco, M.C.; Frohme, M.; Furlan, L.R.; Garnier, M.; Goldman, G.H.; Goldman, M.H.; Gomes, S.L.; Gruber, A.; Ho, P.L.; Hoheisel, J.D; Junqueira, M.L.; Kemper, E.L.; Kitajima, J.P.; Krieger, J.E.; Kuramae, E.E.; Laigret, F.; Lambais, M.R.; Leite, 
L.C.; Lemos, E.G.; Lemos, M.V.; Lopes, S.A.; Lopes, C.R.; Machado, J.A.; Machado, M.A.; Madeira, A.M.; Madeira, H.M.; Marino, C.L.; Marques, M.V.; Martins, E.A.; Martins, E.M.; Matsukuma, A.Y.; Menck, C.F.; Miracca, E.C.; Miyaki, C.Y.; MonteriroVitorello, C.B.; Moon, D.H.; Nagai, M.A.; Nascimento, A.L.; Netto, L.E.; Nhani, A.Jr; Nóbrega, F.G.; Nunes, L.R.; Oliveira, M.A.; de Oliveira, M.C.; de Oliveira, R.C.; Palmieri, D.A.; Paris, A.; Peixoto, B.R.; Pereira, G.A.; Pereira, H.A.Jr; Pesquero, J.B.; Quaggio, R.B.; Roberto, P.G.; Rodrigues, V.; de M Rosa, A.J.; de Rosa, V.E.Jr; de As, R.G.; Santelli, R.V.; Sawasaki, H.E.; da Silva, A.C.; da Silva, A.M.; da Silva, F.R.; da Silva, W.A.Jr; da Silveira, J.F.; Silvestri, M.L.; Siqueira, W.J.; de Souza, A.A.; de Souza, A.P.; Terenzi, M.F.; Truffi, D.; Tsai, S.M.; Tsuhako, M.H.; Vallada, H.; Van Sluys, M.A.; Verjovski-Almeida, S.; Vettore, A.L.; Zago, M.A.; Zatz, M.; Meidanis, J. \& Setúbal, J.C. (2000) "The genome sequence of the plant pathogen Xylella fastidiosa. The Xylella fastidiosa Consortium of the Organization for Nucleotide Sequencing and Analysis", Nature, 406: 151-7.

140. Smith, M.W. \& Neidhardt, F.C. (1983) "Proteins induced by aerobiosis in Escherichia coli'. J. Bacteriol., 154: 344-350.

141. Smolka, M.B.; Martins-de-Souza, D.; Winck, F.V.; Santoro, C.E.; Castellari, R.R.; Ferrari, F.; Brum, I.J.; Galembeck, E.; Della Coletta Filho, H.; Machado, M.A.; Marangoni, S. \& Novello, J.C. (2003) "Proteome analysis of the plant pathogen Xylella fastidiosa reveals major cellular and extracellular proteins and a peculiar codon bias distribution". Proteomics, 3: 224-237.

142. Snyder, G.H. (1987) "Intramolecular disulfide loop formation in a peptide containing two cysteines". Biochemistry, 26: 688-694.

143. Soonsanga, S.; Lee, J-W. \& Helmann, J.D. (2008) "Oxidant-dependent switching between reversible and sacrificial oxidation pathways for Bacillus subtilis OhrR". Mol. Microbiol., 68: 978-986.

144. Stadtman, E.R. (1990) "Metal ion-catalyzed oxidation of proteins: biochemical mechanism and biological consequences" Free Radic. Biol. Med., 9: 315-325.

145. Storz, E.; Jacobson, F.S.; Tartaglia, L.A.; Morgan, R.W.; Silveira, L.A. \& Ames, B.N. (1989) "An alkyl hydroperoxide reductase induced by oxidative stress in Salmonella typhimurium and Escherichia coli: genetic characterization and cloning of ahp". J. Bacteriol., 171: 2049-2055.

146. Storz, G. \& Zheng, M. (2000) "Oxidative stress". In Storz, G. \& Hengge-Aronis, R. (Eds), "Bacterial Stress Responses". Washington, DC: American Society for Microbiology Press, p. 47-59.

147. Sugimoto, T.R. (2006) "Caracterização de sistemas antioxidantes de bactérias" Tese de mestrado apresentada ao Departamento de Genética e Biologia Evolutivo do Instituto de Biociências da Universidade de São Paulo.

148. Sukchawalit, R.; Loprasert, S.; Atichartpongkul, S. \& Mongkolsuk, S. (2001) "Complex regulation of the organic hydroperoxide resistance gene (ohr) from Xanthomonas involves OhrR, a novel organic peroxide inducible negative regulator, and posttranscriptional modifications". J. Bacteriol., 183: 4405-4412.

149. Suzuki, J.; Tsuchiya, M. \& Packer, L. (1994) "Determination of structureantioxidant activity relationships of dihydrolipoic acid". Methods in Enzymol., 234: 454-461. 
150. Tartagalia, L.; Storz, G.; Brodsky, M.H.; Lai, A. \& Ames, B.N. (1990) "Alkyl hydroperoxide reductase from Salmonella typhimurium". J. Biol. Chem., 265: 1053510540.

151. Tenhaken, R.; Levine, A.; Brisson, L.F.; Dixon, R.A. \& Lamb, C. (1995) "Function of the oxidative burst in hypersensitive disease resistance" Proc. Natl. Acad. Sci. USA, 92: 4158-4163.

152. Tian, J.; Bryk, R.; Shi, S.; Erdjument-Bromage, H.; Tempst, P. \& Nathan, C. (2005) "Mycobacterium tuberculosis appears to lack a-ketoglutarate dehydrogenase and encodes pyruvate dehydrogenase in widely separated genes". Molec. Micro., 57: 859-868.

153. Torres, M.A.; Dangl, J.L. \& Jones, J.D. (2002). "Arabidopsis gp91phox homologues AtrbohD and AtrbohF are required for accumulation of reactive oxygen intermediates in the plant defense response". Proc. Natl. Acad. Sci. USA, 99: 517522.

154. Trivelli, X.; Krimm, I.; Ebel, C.; Verdoucq, L.; Prouzet-Mauleon, V.; Chartier, Y.; Tsan, P.; Lauquin, G.; Meyer, Y. \& Lancelin, J.M. (2003) "Characterization of the yeast peroxiredoxin Ahp1 in its reduced active and overoxidized inactive forms using NMR". Biochemistry, 42: 14139-14149.

155. Trujillo, M.; Folkes, L.; Bartesaghi, S.; Kalyanaraman, B.; Wardman, P. \& Radi, R. (2005) "Peroxynitrite-derived carbonate and nitrogen dioxide radicals readily react with lipoic and dihydrolipoic acid" Free Radic. Biol. Med., 39: 279-288.

156. Ursini, F.; Maiorino, M.; Brigelius-Flohé, R.; Aumann, K. D.; Roveri, A.; Schomburg, D. \& Flohé, L. (1995) "Diversity of glutathione peroxidases". Methods Enzymol., 252: 38-53.

157. Verdoucq, L.; Vignols, F.; Jacquot, J.P.; Chartier, Y. \& Meyer, Y. (1999) "In vivo characterization of a thioredoxin $\mathrm{H}$ target protein defines a new peroxiredoxin family". J. Biol. Chem., 274: 19714-19722.

158. Vila, A.; Korytowski, W. \& Girotti, A.W. (2000) "Dissemination of peroxidative stress via intermembrane transfer of lipid peroxides: model studies with cholesterol hydroperoxides". Arch. Biochem. Biophys., 380: 208-218.

159. Williams Jr., H. (1985) "Mechanism and structure of thioredoxin reductase from Escherichia coll' Flavoprotein Structure and mechanism, 9: 1267-1276.

160. Winterbourn, C.C. (2008) "Reconciling the chemistry and biology of reactive oxygen species" Nature Chemical Biology., 4: 278-286.

161. Winterbourn, C.C. \& Hampton, M.B. (2008) "Thiol chemistry and specificity in redox signaling". Free Radic. Biol. Med., 45: 549-561.

162. Wojtaszek, P. (1997) "Oxidative burst: an early plant response to pathogen infection". Biochem. J., 322: 681-692.

163. Yoshioka, H.; Numata, N.; Nakajima, K.; Katou, S.; Kawakita, K.; Rowland, O.; Jones, J.D. \& Doke, N. (2003). "Nicotiana benthamiana gp91phox homologs NbrbohA and $\mathrm{NbrbohB}$ participate in $\mathrm{H}_{2} \mathrm{O}_{2}$ accumulation and resistance to Phytophthora infestans". The Plant Cell, 15: 706-718. 
9. ANEXOS 


\section{ANEXO I}

Cussiol, J.R.R.; Alves, S.V.; Oliveira, M.A. \& Netto, L.E.S. (2003) "Organic Hydroperoxide resistance gene encodes a thiol-dependent peroxidase". J. Biol. Chem., 278: 11570-11578. 


\title{
Organic Hydroperoxide Resistance Gene Encodes a Thiol-dependent Peroxidase*
}

Received for publication, January 9, 2003

Published, JBC Papers in Press, January 22, 2003, DOI 10.1074/jbc.M300252200

\author{
José Renato Rosa Cussiol, Simone Vidigal Alves, Marco Antonio de Oliveira, \\ and Luis Eduardo Soares Netto \\ From the Departamento de Biologia, Instituto de Biociências, Universidade de São Paulo, Rua do Matão 277, \\ São Paulo SP Brazil 05508-900
}

\begin{abstract}
ohr (organic hydroperoxide resistance gene) is present in several species of bacteria, and its deletion renders cells specifically sensitive to organic peroxides. The goal of this work was to determine the biochemical function of Ohr from Xylella fastidiosa. All of the Ohr homologues possess two cysteine residues, one of them located in a VCP motif, which is also present in all of the proteins from the peroxiredoxin family. Therefore, we have investigated whether Ohr possesses thiol-dependent peroxidase activity. The ohr gene from $X$. fastidiosa was expressed in Escherichia coli, and the recombinant Ohr decomposed hydroperoxides in a dithiothreitol-dependent manner. Ohr was about twenty times more efficient to remove organic hydroperoxides than to remove $\mathrm{H}_{2} \mathrm{O}_{2}$. This result is consistent with the organic hydroperoxide sensitivity of $\Delta o h r$ strains. The dependence of Ohr on thiol compounds was ascertained by glutamine synthetase protection assays. Approximately two thiol equivalents were consumed per peroxide removed indicating that $\mathrm{Ohr}$ catalyzes the following reaction: $2 \mathrm{RSH}+\mathrm{ROOH} \rightarrow \mathrm{RSSR}+\mathrm{ROH}+\mathrm{H}_{2} \mathrm{O}$. Pretreatment of $\mathrm{Ohr}$ with $\mathrm{N}$-ethyl maleimide and substitution of cysteine residues by serines inhibited this peroxidase activity indicating that both of the Ohr cysteines are important to the decomposition of peroxides. C125S still had a residual enzymatic activity indicating that Cys-61 is directly involved in peroxide removal. Monothiol compounds do not support the peroxidase activity of $\mathrm{Ohr}$ as well as thioredoxin from Saccharomyces cerevisiae and from Spirulina. Interestingly, dithiothreitol and dyhydrolipoic acid, which possess two sulfhydryl groups, do support the peroxidase activity of Ohr. Taken together our results unequivocally demonstrated that $\mathrm{Ohr}$ is a thiol-dependent peroxidase.
\end{abstract}

The infection of both plants and animals induces a defense response that results in an oxidative burst with the increased generation of $\operatorname{ROS}^{1}$ (1). Lipid hydroperoxides can be generated from the attack of ROS to the bacterial membrane. Organic

\footnotetext{
* The costs of publication of this article were defrayed in part by the payment of page charges. This article must therefore be hereby marked "advertisement" in accordance with 18 U.S.C. Section 1734 solely to indicate this fact.

† To whom correspondence should be addressed. Tel.: 55-1130917589; Fax: 55-11-30917553; E-mail: nettoles@ib.usp.br.

${ }^{1}$ The abbreviations used are: ROS, reactive oxygen Species; AhpC, alkyl hydroperoxide reductase, subunit $\mathrm{C} ; \mathrm{AhpF}$, alkyl hydroperoxide reductase, subunit $\mathrm{F}$; AhpR, alkyl hydroperoxide reductase holo-protein; DHLA, dyhydrolipoic acid; DTNB, 5,5'-dithiobis(2-nitrobenzoic acid); DTT, dithiothreitol; FOX, ferrous oxidation xylenol; NEM, $N$ ethyl maleimide; $t$-bOOH, tertbutylhydroperoxide; $\mathrm{Cu}-\mathrm{OOH}$, cumene hydroperoxide; TNB, 2-nitro-5-thiobenzoic acid.
}

hydroperoxides can also be formed during metabolism of certain drugs or during oxidation of $n$-alkanes (2). These peroxides can then react with metals or with metalloproteins leading to the production of secondary free radicals $(3,4)$, which may be related to the fact that organic peroxides possess bactericidal activity (5).

The alkyl hydroperoxide reductase $(\mathrm{AhpR})$ is frequently considered the main enzyme responsible for the conversion of organic peroxides to the corresponding alcohols in bacteria (6, 7). This enzyme comprises two subunits, AhpF and AhpC. $\mathrm{AhpC}$ is a thiol-dependent peroxidase that belongs to the peroxiredoxin family (8). A cysteine residue of $\mathrm{AhpC}$ is oxidized to sulfenic acid (R-SOH) by peroxides. NADH reduces the sulfenic acid back to its sulfhydryl (R-SH) form in a reaction catalyzed by $\mathrm{AhpF}$. AhpF is a flavo-enzyme that shares homology with thioredoxin reductase (9).

Recently a gene was isolated in Xanthomonas campestris pv. phaseoli because its deletion rendered cells highly sensitive to killing by organic peroxides but not to $\mathrm{H}_{2} \mathrm{O}_{2}$ or superoxide generators (10). Therefore, it was named organic hydroperoxide resistance (ohr) gene. ohr gene expression was highly induced by $t$-bOOH, weakly induced by $\mathrm{H}_{2} \mathrm{O}_{2}$, and not induced at all by superoxide (10). Recently, homologues of this gene were also characterized in other bacteria such as Bacillus subtilis and Pseudomonas aeruginosa $(11,12)$ among others. Interestingly, $\mathrm{Ohr}$, but not AhpR, appears to play a significant role in $\mathrm{Cu}$ $\mathrm{OOH}$ resistance in $B$. subtilis (12). In Enterococcus faecalis, ohr deletion rendered the cells more sensitive to $t$-bOOH and also to ethanol (13). Sequence analysis has shown that ohr homologues are widely spread among different bacteria genera, many of them pathogenic (14). Ohr also shares similarities with OsmC, which is involved in bacterial defense against osmotic stress (14).

All the Ohr and OsmC homologues have two cysteine residues located in motifs that are also very conserved. One of the cysteine residues is part of a VCP motif that is also found in peroxiredoxins. Therefore, it was postulated that $\mathrm{Ohr}$ could decompose peroxides directly, similarly to $\mathrm{AhpC}$, a peroxiredoxin found in bacteria (14). In fact, AhpC complement ohr deletion in Escherichia coli and in $X$. campestris (10). In $P$. aeruginosa, the deletion of $o h r$ rendered the cells more sensitive to organic peroxide than $a h p C$ deletion, and the double mutant $o h r, a h p C$ is more sensitive than the single mutants (11). Finally, media from mutants for Ohr contain higher levels of organic peroxides than the correspondent wild-type cells (11, $15)$.

Despite the suggestions that $\mathrm{Ohr}$ might directly detoxify organic hydroperoxides, it was not possible to rule out the possibility that $\mathrm{Ohr}$ is involved in other processes such as the transport of organic molecules (10) or in yet undefined signal- 
ing pathways that lead to activation of secondary molecules that would then inactivate organic peroxides. Here, for the first time, the biochemical activity of $\mathrm{Ohr}$ was elucidated: $\mathrm{Ohr}$ from Xylella fastidiosa possesses a thiol-dependent peroxidase activity, which is probably responsible for the hypersensitivity of $\Delta o h r$ mutants to treatment with organic hydroperoxides.

\section{MATERIALS AND METHODS}

Materials-All the reagents were purchased with the highest degree of purity. DHLA was purchased in the reduced form from Sigma (T8620). DHLA is a yellow oil, and its stock solution was prepared by dilution to $50 \mathrm{~mm}$ concentration in $20 \mathrm{~mm}$ phosphate buffer, $\mathrm{pH}=7.5$ and heated at $45{ }^{\circ} \mathrm{C}$ for $30 \mathrm{~min}$. DHLA concentration was ascertained by the use of the Ellman's reagent as described bellow.

Nucleic Acid Extraction, Cloning, and Nucleotide Sequencing-The ohr gene was PCR-amplified from the cosmid XF-07F02 that was used in the $X$. fastidiosa sequencing genome project (16). The following forward 5'-CGCGGATCCCATATGAATTCACTGGAG (Xfo1) and reverse 5'-CGCAAGCTTGGATCCTTAGTCAATCAG (Xfo2) primers were used. The underlined bases represent the NdeI and BamHI sites, respectively. The PCR product was cloned into the pGEM-T easy vector (Promega) resulting in the pGEM/ohr plasmid. An E. coli DH5- $\alpha$ strain was transformed with $\mathrm{pGEM} / \mathrm{oh} r$, and white colonies were selected from LB-ampicillin-5-bromo-4-chloro-3-indolyl- $\beta$-D-galactopyranoside (X-gal) medium. Plasmid extraction was performed using the Rapid Plasmid Miniprep System Concert kit (Invitrogen). The plasmid PGEM/ohr was used to generate the two individually ohr mutant proteins, C61S and C125S, in which cysteines Cys-61 and Cys- 125 were replaced by serines through PCR megaprimer methods $(17,18)$. In the case of the C61S construct, PCR was performed first with the mutagenic primer $\mathrm{XfoC} 1$ forward 5'-TTATTCTGCCTCTTTCATTGG-3' and Xfo2 reverse, where the bold letters denote the mutation performed. A single band of $277 \mathrm{bp}$ was eluted out from the agarose gel and used as a primer (megaprimer) along with the primer Xfo1 to the second PCR step to amplify the rest of $\mathrm{Ohr}$ gene. In the case of the C125S construct, replacement was performed in one-step PCR using the primers Xfo1 and a large terminal mutagenic primer XfoC2 $5{ }^{\prime}$-CGCAAGCTTGGATCCTTAGTCAATCAGAATCAAAACGACGTCGATATTTCCACGGGTTGCATTAGAGTACGGAGAAACACGATGC-3', where the boldface typing represents the codon mutation and the underlined bases represents the BamHI restriction site. The final mutated PCR products were ligated in pGEMT easy vector to produce PGEM/C61S and PGEM/C125S, independently.

pET15b, pGEM/ohr, PGEM/ohrC61S, and PGEM/C125S were first digested with $N d e \mathrm{I}$ and after by BamHI. The fragments generated by NdeI/Bam HI digestion of plasmids derived from pGEMs were extracted from agarose gel by the Rapid Gel Extraction Concert kit (Invitrogen) and were individually ligated to the digested $\mathrm{pET}-15 \mathrm{~b}$ expression vector. The resulting pET15b/ohr, PET15b/C61S, and PET15b/C125S plasmids were sequenced in an Applied Biosystems ABI Prism 37796 to confirm that the constructions were correct. An $E$. coli DH5- $\alpha$ strain was transformed with the expression vectors and cultured to increase plasmid production. Another plasmid extraction was performed, and $E$. coli $\mathrm{Bl} 21(\mathrm{DE} 3)$ cells were transformed with the same constructs. The resulting strains were used for expression and purification of $\mathrm{Ohr}$, C61S, and C125S.

Protein Expression and Purification-E. coli Bl21(DE3) strains transformed with $\mathrm{pET} 15 \mathrm{~b} / \mathrm{ohr}, \mathrm{pET} 15 \mathrm{~b} / \mathrm{C} 61 \mathrm{~S}$, and $\mathrm{pET} 15 \mathrm{~b} / \mathrm{C} 125 \mathrm{~S}$ were cultured $(50 \mathrm{ml})$ overnight in $\mathrm{LB}+$ ampicillin medium, transferred to 1 liter of fresh LB + ampicillin $(100 \mu \mathrm{g} / \mathrm{ml})$ medium, and cultured further until the $A_{600}$ reached $0.6-0.8$. Isopropyl-1-thio- $\beta$-D-galactopyranoside was then added to a final concentration equivalent to $1 \mathrm{mM}$. After $3 \mathrm{~h}$ of incubation, cells were harvested by centrifugation. The pellet was washed and suspended in the start buffer (phosphate buffer, $20 \mathrm{mM}, \mathrm{pH}$ 7.4). Seven cycles of $30 \mathrm{~s}$ of sonication ( $35 \%$ amplitude) following $30 \mathrm{~s}$ in ice were applied to cell suspension. The cell extracts were kept in ice during streptomycin sulfate $1 \%$ treatment for $15 \mathrm{~min}$. The suspension was centrifuged at $31,500 \times g$ for 30 min to remove nucleic acid precipitates. Finally cell extract was applied to a nickel affinity column (Hi-trap from Amersham Biosciences). The conditions of protein purification were optimized using the gradient procedure for imidazole concentration described by the manufacturer.

Determination of Peroxide Concentration-Peroxide concentration was determined by the ferrous oxidation xylenol (FOX) assay as previously described (3). Reactions were initiated by the addition of thiol compounds and stopped at different intervals by addition of $20 \mu \mathrm{l}$ of $\mathrm{HCl}$ (1M) into $100-\mu \mathrm{l}$ reaction mixtures. No peroxide consumption was detected in the absence of thiols. $\mathrm{H}_{2} \mathrm{O}_{2}$ concentration in stock solutions was checked by its absorbance $\left(\epsilon_{240 \mathrm{~nm}}=43.6 \mathrm{M}^{-1} \cdot \mathrm{cm}^{-1}\right)$.

Determination of Sulfhydryl Groups Concentration-The amount of thiol groups remaining in solution was determined by the Ellman's reagent (DTNB), using the $\epsilon_{412 \mathrm{~nm}}=13,600 \mathrm{~m}^{-1} \cdot \mathrm{cm}^{-1}$ for 2-nitro-5thiobenzoic acid (TNB) (19). As described above, reactions were stopped at different intervals by addition of $20 \mu \mathrm{l}$ of $\mathrm{HCl}(1 \mathrm{M})$ into $100-\mu \mathrm{l}$ reaction mixtures. Samples were neutralized by dilution (1:10) in a solution containing Hepes (1 M, pH 7.4) and DTNB (5 mM). Absorbance at $412 \mathrm{~nm}$ was immediately recorded.

Glutamine Synthetase Protection Assay-Antioxidant activities of Ohr, OhrC61S, OhrC125S, and cTPxI were measured by their ability to protect glutamine synthetase from oxidative inactivation. Several $\mathrm{H}_{2} \mathrm{O}_{2}$-removing enzymes such as GSH peroxidase, catalase, and cTPxI can protect glutamine synthetase (20). The procedure used to determine glutamine synthetase activity was the same described by Kim et al. (20).

Ohr Inactivation by NEM Treatment-Recombinant $\mathrm{Ohr}(2 \mathrm{mg} / \mathrm{ml})$ was treated with NEM (1 mM) for $1 \mathrm{~h}$ at room temperature and then was dialyzed against phosphate buffer $(20 \mathrm{mM}), \mathrm{pH}$ 7.4. The concentration of histidine-tagged $\mathrm{Ohr}$ was determined using the extinction coefficient $\epsilon_{280 \mathrm{~nm}}=3960 \mathrm{M}^{-1} \cdot \mathrm{cm}^{-1}$, which was determined using the software of ExPASy proteomics from Swiss Institute of bioinformatics (ca.expasy.org/tools/protparam.html).

Thrombin Proteolysis of Ohr-Histidine tag of recombinant Ohr was digested with thrombin $(0.01 \mathrm{units} / \mu \mathrm{l})$ using the thrombin cleavage capture kit from Novagen. The digestion was carried out for $16 \mathrm{~h}$ at $25^{\circ} \mathrm{C}$. The concentration of the recombinant protein without histidine tag was determined spectrophotometrically, using the same extinction coefficient $\epsilon_{280 \mathrm{~nm}}=3960 \mathrm{M}^{-1} \cdot \mathrm{cm}^{-1}$ determined above because the histidine tag does not contain optically active residues.

Sulfenic Acid Formation-Determination of sulfenic acid (R-SOH) in wild-type as well as in mutant proteins was performed by the TNB anion method described by Ellis and Poole (21). In summary, TNB was prepared by incubation of an almost equimolar mixture of DTNB and DTT (1 DTNB:0.9 SH). Proteins preincubated or not with peroxides were treated with a 20 -fold excess of TNB. As described before (21), TNB reacts with sulfenic acids in a 1:1 stoichiometry, generating a mixed disulfide between TNB and a cysteine residue. Excess of TNB was removed by PD-10 desalting column (Amersham Biosciences). Mixed disulfides were then treated with 10-fold excess of DTT, and the amount TNB released (which was equal to the amount sulfenic acid formed) was determined spectrophotometrically.

\section{RESULTS}

Genetic and Biochemical Analysis of Ohr-Ohr from X. fastidiosa possesses a very high degree of similarity with proteins from various bacteria such as $X$. campestris pv. phaseoli and $P$. aeruginosa (14). In general, the ohr gene is present in a single copy, but in some cases such as B. subtilis, Mesorhizobium loti, and Ralstonia solanacearum two copies of ohr are present (12, $22,23)$. In Streptomyces coelicolor, three copies of ohr appear to be present (24). A blastp analysis on the $X$. fastidiosa genome using the tools available at the site aeg.lbi.ic.unicamp.br/xf/ detected only one copy of $\mathrm{hr}$ in this bacteria located between coordinates 1,742,868 and 1,743,299 with 432 nucleotides. The predicted amino acid sequence possesses 143 residues and a molecular mass equivalent to $14.9 \mathrm{kDa}$. Among other characteristics $\mathrm{Ohr}$ proteins have two conserved cysteine residues that are at positions 61 and 125 in the homologue from $X$. fastidiosa. Based on sequence homology two domains of $\mathrm{Ohr}$ can be defined: domain 1 , which contains cysteine 61 and a high number of hydrophobic residues, and domain 2, which has cysteine 125 in a VCP motif (Fig. 1A). The VCP motif is also present in the peroxiredoxin family, whose proteins are thioldependent peroxidases (25). The two proposed domains are highly conserved among Ohr homologues, especially domain 1 (14) (Fig. 1A). Because ohr deletion renders cells very sensitive to organic peroxide treatment, a hydrophobicity analysis of $\mathrm{Ohr}$ protein was carried out (26). Our data indicated that cysteine 61 is in a highly hydrophobic environment, whereas cysteine 125 is in a hydrophilic environment (Fig. $1 B$ ).

To investigate whether $\mathrm{Ohr}$ possesses thiol-dependent peroxidase activity, ohr gene from $X$. fastidiosa was expressed in 
A

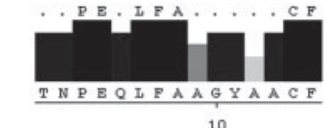

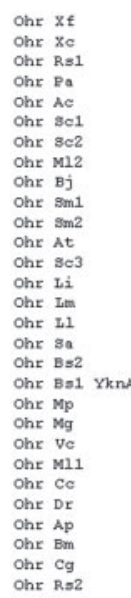

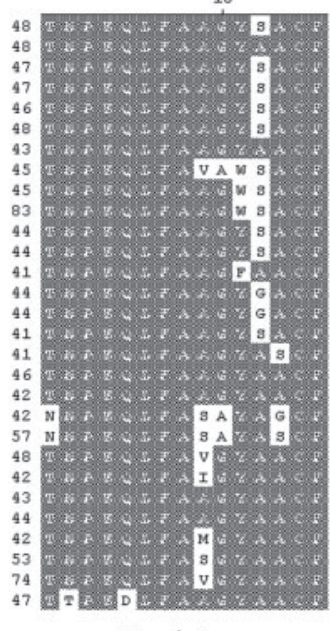

Domain 1
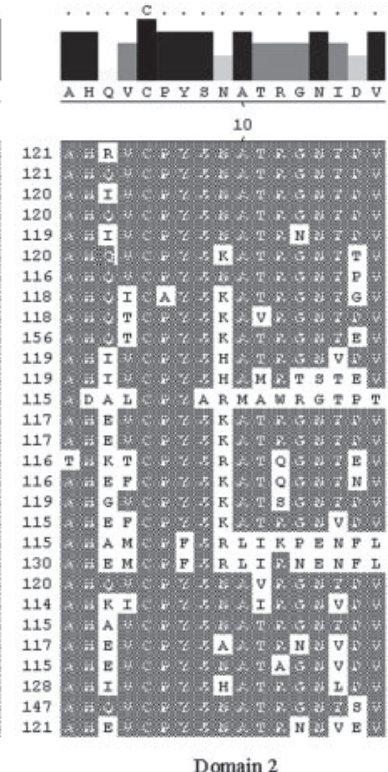

B

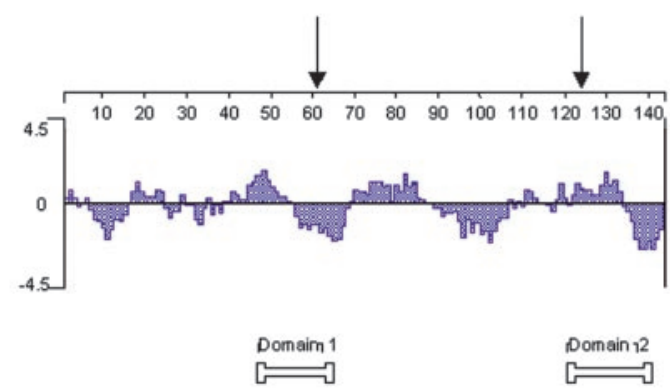

FIG. 1. Domains of $\mathrm{Ohr}$ proteins that contain cysteine residues. $A$, the sequences represented in this scheme were the consensus obtained by the Clustal W method from the MegAlign 5.01 software (DNAstar Inc.) including the Ohr proteins from: Deinococcus radiodurans (Ohr Dr = GI:15806857); Caulobacter crescentus (Ohr Cc GI: 13422184); Mesorhizobium loti (Ohr Ml1 = GI:14024371; Ohr Ml2 = GI:13475574); Vibrio cholerae (Ohr Vc = GI:15601759); Mycoplasma genitalium (Ohr Mg GI:1723166); Mycoplasma pneumoniae $(\mathrm{Ohr} \mathrm{Mp}=$ GI:13508407); B. subtilis (Ohr Bc1or YknA = GI:16078381, Ohr Bc2 = GI:16078379); Staphylococcus aureus ssp. aureus Mu50 (Ohr $\mathrm{Sa}=$ GI:15923818); Lactococcus lactis ssp. lactis (Ohr Ll = GI:15672574); Listeria monocytogenes EGD-e (Ohr Ll = GI:16804238); Listeria innocua $(\mathrm{Ohr} \mathrm{Li}=\mathrm{GI}: 16801366) ;$ S. coelicolor $(\mathrm{Ohr} \mathrm{Sc1}=\mathrm{GI}: 6562797$, Ohr Sc2 = GI:7546676, Ohr Sc3 = GI:9885209); Agrobacterium tumefaciens (Ohr At GI:15888188); Sinorhizobium meliloti (Ohr Sm1 = GI:16263744, Ohr Sm2 = GI:15964715); Bradyrhizobium japonicum $(\mathrm{Ohr} \mathrm{Bj}=\mathrm{GI}: 8708902)$; Acinetobacter calcoaceticus $(\mathrm{Ohr}$ Ac $=$ GI: 7531260); Pseudomonas aeruginosa (Ohr Pa = GI:15598046); Ralstonia solanacearum (Ohr Rs1 = GI:17549328, Ohr Rs2 = GI:17548547); Xanthomonas campestris pv. phaseoli $(\mathrm{Ohr}$ Xc $=$ GI:7531169); Xylella fastidiosa (Ohr Xf = GI:15838425). The letters in shade represent residues that match the consensus. The histogram shows the strength of the residues belonging to the two domains. $B$, hydrophilicity plot according to Ref. 26. In this scheme, the amino acid sequence of Ohr from $X$. fastidiosa is displayed in the $x$-axis,whereas hydrophilicity values are displayed in the $y$-axis. According to this method, hydrophilic residues have positive values, whereas hydrophobic residues have negative values. The arrows show the positions of cysteines in $\mathrm{Ohr}$ sequence.

E. coli and purified by nickel affinity chromatography (see "Materials and Methods"). A histidine tag recombinant Ohr was obtained with high degree of purity as ascertained by SDS-PAGE (Fig. 2). Two bands corresponding to Ohr were observed, both of which migrate closely to $17 \mathrm{kDa}$, as expected for a monomer (Fig. 2A). Removal of histidine tag by thrombin proteolysis also resulted in two bands both of which migrated at $\sim 15 \mathrm{kDa}$ (data not shown). The abundance of each band was dependent on the oxidative condition to which $\mathrm{Ohr}$ was exposed
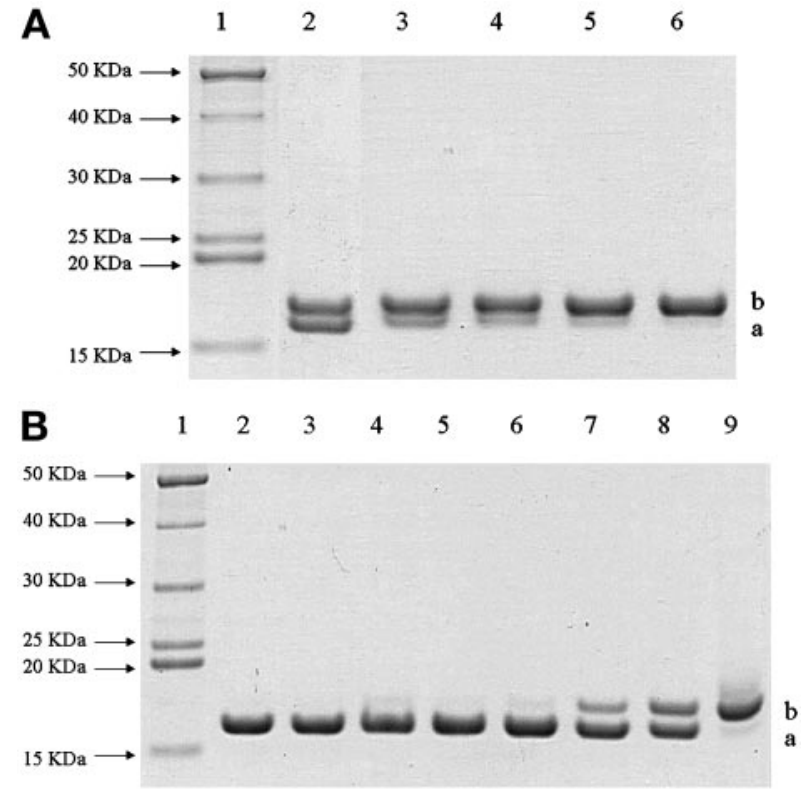

FIG. 2. SDS-PAGE analysis of purified recombinant Ohr from $\boldsymbol{X}$. fastidiosa. Recombinant $\mathrm{Ohr}$ was expressed in $E$. coli and purified as described under "Material and Methods." Treatments were carried out for $1 \mathrm{~h}$ at room temperature. A, lane 1, molecular mass standard (BenchMark ${ }^{\mathrm{TM}}$ Protein Ladder, Invitrogen); lane 2, untreated Ohr; lanes 3-6 represent $\mathrm{Ohr}$ treated with the following concentrations of DTT: $60 \mu \mathrm{M}, 1 \mathrm{mM}, 10 \mathrm{mM}$, and $100 \mathrm{mM}$, respectively. $B$, lane 1 , molecular mass standard (BenchMark ${ }^{\mathrm{TM}}$ Protein Ladder, Invitrogen); lanes $2-5$ represent $\mathrm{Ohr}$ treated with the following concentrations of $\mathrm{H}_{2} \mathrm{O}_{2}: 60$ $\mu \mathrm{M}, 0.5 \mathrm{mM}, 1 \mathrm{mM}$, and $10 \mathrm{mM}$, respectively; lanes $6-9$ represent $\mathrm{Ohr}$ treated with the following concentrations of $t$-bOOH: $60 \mu \mathrm{M}, 0.5 \mathrm{mM}, 1$ $\mathrm{mm}$, and $10 \mathrm{mM}$, respectively. Letters $a$ and $b$ denote the lower and upper band, respectively.

(Fig. 2) and was independent of the presence of the histidine tag (data not shown). Bands corresponding to dimers did not appear even after treatments of $\mathrm{Ohr}$ with $\mathrm{H}_{2} \mathrm{O}_{2}$ or organic hydroperoxide at various concentrations (Fig. $2 B$ ) indicating that no disulfide bond was formed between two Ohr molecules. Since the two bands observed in Fig. 2 have approximately the monomer size, they should represent different configurations of Ohr monomers. The lower band (band $a$ ) should correspond to an oxidized state of $\mathrm{Ohr}$, which is generated after $\mathrm{H}_{2} \mathrm{O}_{2}$ treatment or at mild concentrations of $t-\mathrm{bOOH}$ (Fig. $2 B$ ). On the other side, the upper band (band $b$ ) may represent a mixture of reduced and oxidized states of Ohr. This is because Ohr treatment with increasing concentrations of DTT provoked augment of band $b$ intensity (Fig. $2 A$ ) as well as Ohr treatment with high organic peroxide concentrations (Fig. $2 B$ ). The meanings of these two bands are further discussed below, after the description of results with Ohr site-specific mutants. In any case, it is important to emphasize that different monomeric configurations were also observed before for cTPxI, a thiol-dependent peroxidase from Saccharomyces cerevisiae (27).

Thiol-dependent Peroxidase Activity of Ohr-Recombinant Ohr decomposed peroxides only if DTT was also present in the reaction mixture (Fig. 3). Because the substrates were present in a $350-4100$-excess over the protein, it is reasonable to think that $\mathrm{Ohr}$ was acting catalytically. In the conditions described in Fig. 3, the specific activity of Ohr was 20.0, 17.0, and 1.3 $\mu \mathrm{M} / \mathrm{min} / \mathrm{ng}$ when, respectively, $t$-bOOH, Cu-OOH, and $\mathrm{H}_{2} \mathrm{O}_{2}$ were considered the substrates. This indicates that $\mathrm{Ohr}$ was 10-20 times more efficient in the removal of organic peroxides than in the removal of $\mathrm{H}_{2} \mathrm{O}_{2}$. These results are consistent with the high susceptibility of $\Delta o h r$ mutants to organic peroxides but not to $\mathrm{H}_{2} \mathrm{O}_{2}$ (Ref. 14 and references cited herein). In any case, $\mathrm{Ohr}$ did decompose $\mathrm{H}_{2} \mathrm{O}_{2}$ when DTT was present in the 

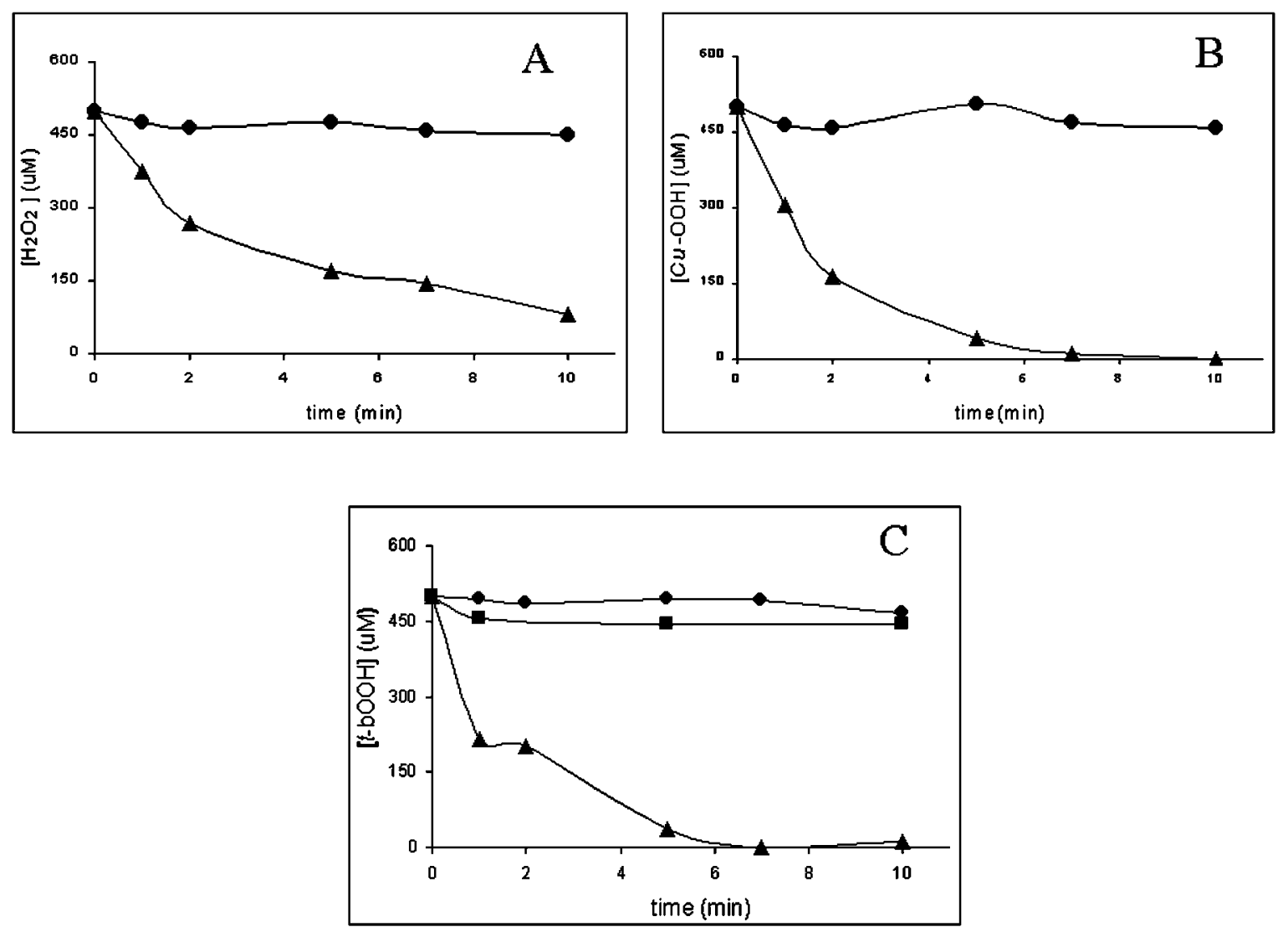

FIG. 3. Thiol-dependent peroxidase activity of $\mathbf{O h r}$. Peroxide concentration was determined at different periods by FOX assay as described under "Material and Methods." The reactions were carried out in Hepes buffer $50 \mathrm{~mm}, \mathrm{pH} 7.4$, in the presence of azide (1 mM) and DTPA (0.1 mM). The concentration of peroxides at time zero was $500 \mu \mathrm{M}$. Reactions were initiated by the addition of DTT $(0.5 \mathrm{~mm}) . A$ represents the kinetics of $\mathrm{H}_{2} \mathrm{O}_{2}$ decomposition in the presence of $\mathrm{Ohr}(100 \mathrm{ng} / \mu \mathrm{l}) . B$ and $C$ represent the kinetics of $\mathrm{Cu}-\mathrm{OOH}$ and $t$-bOOH decomposition, respectively, in the presence of $\mathrm{Ohr}(10 \mathrm{ng} / \mu \mathrm{l})$. $\bullet$ represents the reaction mixture without $\mathrm{Ohr}(\mathrm{DTT}+$ peroxide); $\mathbf{\Delta}$ represents the full system $(\mathrm{DTT}+$ peroxide $+\mathrm{Ohr})$ Reaction mixtures without DTT did not show any decomposition of peroxides even in the presence of Ohr. The symbol in $C$ represents Ohr whose cysteine residues were previously alkylated with NEM.

reaction mixture. This ability of $\mathrm{Ohr}$ to decompose peroxides was dependent on the integrity of its cysteine residues because pretreatment of Ohr with NEM inhibited its peroxidase activity (Fig. 3C). Therefore, it is reasonable to think that Cys-61, Cys-125, or both are directly involved in the decomposition of peroxides by Ohr.

Ohr also possesses antioxidant property as demonstrated by its capacity to protect glutamine synthetase from inactivation by thiol-containing oxidative system composed of DTT/Fe ${ }^{3+} / \mathrm{O}_{2}$ or composed of DHLA $/ \mathrm{Fe}^{3+} / \mathrm{O}_{2}$ (Fig. $4 A$ ). Probably, this protection was due to the thiol-dependent peroxidase activity of $\mathrm{Ohr}$ because other thiol-dependent peroxidase such as GSH peroxidase and cTPxI also protect glutamine synthetase from inactivation (20). In fact, the glutamine synthetase protection assay has been used to investigate whether proteins possess peroxide-removing activity $(28,29)$. Ohr did not protect glutamine synthetase against the ascorbate $/ \mathrm{Fe}^{3+} / \mathrm{O}_{2}$ system, indicating that this protein is a thiol-specific antioxidant protein (Fig. 4A). The protective activity of $\mathrm{Ohr}$ was dependent on the concentration of protein and is comparable to the cTPxI activity (Fig. 4B). Removal of histidine tag by thrombin treatment did not alter the enzymatic characteristics of $\mathrm{Ohr}$ nor its ability to protect glutamine synthetase (data not shown).

When $\mathrm{H}_{2} \mathrm{O}_{2}$ was used as substrate, the specific activity of Ohr (Fig. 3) was similar to cTPxI (data not shown). These results are consistent with the glutamine synthetase assays (Fig. $4 B$ ) where these two proteins were also equally protective. The oxidative inactivation of glutamine synthetase is dependent on $\mathrm{H}_{2} \mathrm{O}_{2}$ formation by metal catalyzed oxidation systems
A.

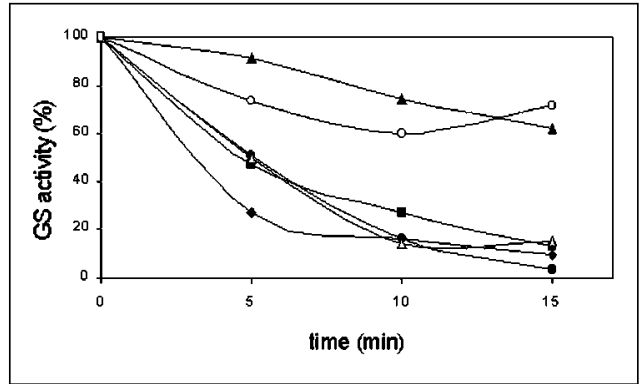

B.

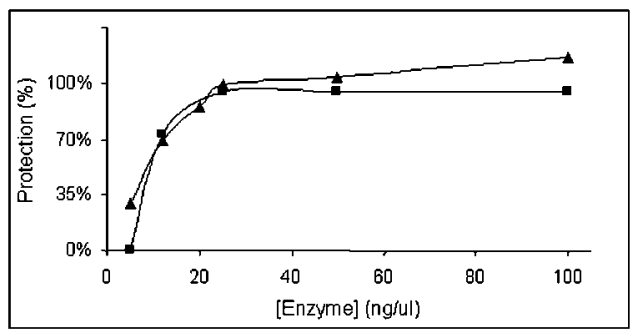

FIG. 4. Ohr protected glutamine synthetase from oxidative inactivation. Glutamine synthetase $(G S)$ protection assay was performed as described under "Material and Methods." All reaction mixtures contain: $\mathrm{Fe}^{3+}=1 \mu \mathrm{M}$; glutamine synthetase $1 \mathrm{mg} / \mathrm{ml}$; azide $=1$ mM in Hepes buffer $50 \mathrm{~mm}, \mathrm{pH}$ 7.4. A, the symbols represent: (DTT 10 $\mathrm{mm}$ addition); $\mathbf{\Delta}$ (DTT $10 \mathrm{~mm}+\mathrm{Ohr} 100 \mathrm{ng} / \mu \mathrm{l}$ addition); (ascorbate $10 \mathrm{~mm}$ addition); (ascorbate $10 \mathrm{~mm}+\mathrm{Ohr} 100 \mathrm{ng} / \mu \mathrm{l}$ addition); $\triangle$ (DHLA $10 \mathrm{~mm}$ addition); $\bigcirc$ (DHLA $10 \mathrm{~mm}+\mathrm{Ohr} 100 \mathrm{ng} / \mu$ l addition). $B$, reactions were carried out for $15 \mathrm{~min}$. The symbols represent: $\boldsymbol{\Delta}=\mathrm{Ohr}$ and $\mathbf{\square}=\mathrm{cTPxI}$ at the concentrations described in the $x$-axis. 
A.

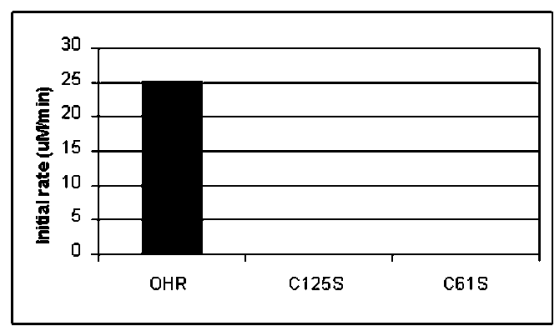

B.

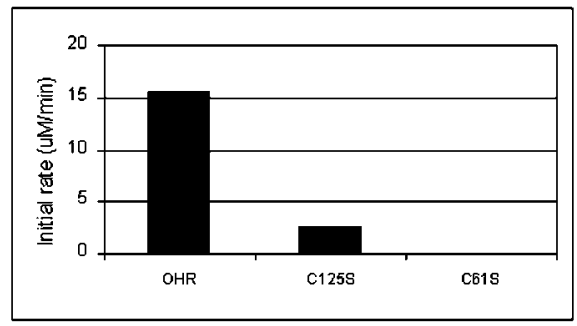

FIG. 5. Effect of $\mathrm{Ohr}$ cysteine removal on peroxide decomposition and on glutamine synthetase protection. $A$, initial rate of $t$-bOOH decomposition by $\mathrm{Ohr}, \mathrm{C} 125 \mathrm{~S}$, and C61S measured by the FOX assay. Protein concentrations were $2 \mathrm{ng} / \mu \mathrm{l}$, and initial peroxide concentration was $200 \mu \mathrm{M}$. Reactions were initiated by DTT $(0.5 \mathrm{~mm})$ addition. $B$, initial rate of $\mathrm{H}_{2} \mathrm{O}_{2}$ decomposition by $\mathrm{Ohr}$, C125S, and C61S measured by the FOX assay. Protein concentrations were $50 \mathrm{ng} /$ $\mu \mathrm{l}$, and initial peroxide concentration was $200 \mu \mathrm{M}$. Reactions were initiated by DTT $(0.5 \mathrm{~mm})$ addition. $C$, glutamine synthetase protection assay. All reaction mixtures contain: $\mathrm{Fe}^{3+}=1 \mu \mathrm{M}$; glutamine synthetase $1 \mathrm{mg} / \mathrm{ml}$; azide $=1 \mathrm{~mm}$ in Hepes buffer $50 \mathrm{~mm}, \mathrm{pH}$ 7.4. Reactions were carried out for $30 \mathrm{~min}$. The symbols represent: $\square \mathrm{Ohr}, \bullet \mathrm{C} 125 \mathrm{~S}, \boldsymbol{\Delta}$ C61S.

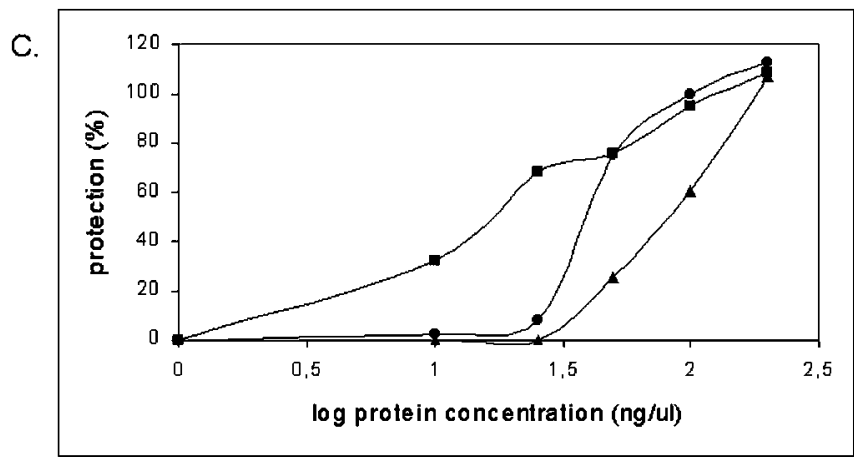

and by its posterior conversion to hydroxyl radical through the Fenton reaction (30). Therefore protection of glutamine synthetase from inactivation probably occurs through the removal of $\mathrm{H}_{2} \mathrm{O}_{2}$ by antioxidant enzymes (31).

Analysis of Cysteine Replacements on Ohr Activity-The role of Ohr cysteines in peroxide reduction was strongly suggested since treatment of $\mathrm{Ohr}$ with NEM lead to protein inactivation (Fig. 3). To specifically investigate the roles of Cys-61 and Cys-125 on Ohr catalysis these two residues were individually replaced by serine generating, respectively, C61S and C125S. Initially, the capacity of the mutant proteins to decompose hydroperoxides was investigated. C61S and C125S had no detectable peroxidase activity when $t$-bOOH was used as a substrate (Fig. $5 A$ ). When $\mathrm{H}_{2} \mathrm{O}_{2}$ was the substrate, $\mathrm{C} 125 \mathrm{~S}$ had a residual activity, whereas $\mathrm{C} 61 \mathrm{~S}$ did not decompose any peroxide (Fig. 5B). These results indicated that both cysteine residues are important for catalysis. Replacement of either Cys-61 or Cys-125 also provoked great decreases in the ability of Ohr to protect glutamine synthetase from oxidative inactivation (Fig. 5C). C61S only showed some protective effect at very high doses, which might be attributable to nonspecific activity. Interestingly, replacement of two of the cysteines of human peroxiredoxin V (prx V), which forms a stable intramolecular disulfide intermediate during its catalytic cycle, produced similar effects (32). Therefore, the results described in Fig. 5 represented an initial suggestion that an intramolecular disulfide is also a reaction intermediate of wild-type Ohr. Further evidences are presented below.

The migration of Ohr mutants was also analyzed by SDSPAGE (Fig. 6) under both reducing and non-reducing conditions to understand the meaning of the two monomeric bands observed in Fig. 2. As standards for mutant proteins, wild-type Ohr was treated with peroxides $(60 \mu \mathrm{M})$ and with DTT (100 $\mathrm{mM}$ ), which provoked the appearance of the monomeric lower (band $a$ ) and upper band (band $b$ ) respectively. Interestingly, neither C61S nor C125S, in any condition tested, migrated at the same position that the wild-type protein treated with peroxides $(60 \mu \mathrm{M})$ (band a) (Fig. 6). Therefore, band a observed for the wild-type protein (Fig. 2) should represent an intramolecular intermediate since any of the mutants can form an intramolecular disulfide bond. This was expected since an intramolecular disulfide bond should lead to a more compact

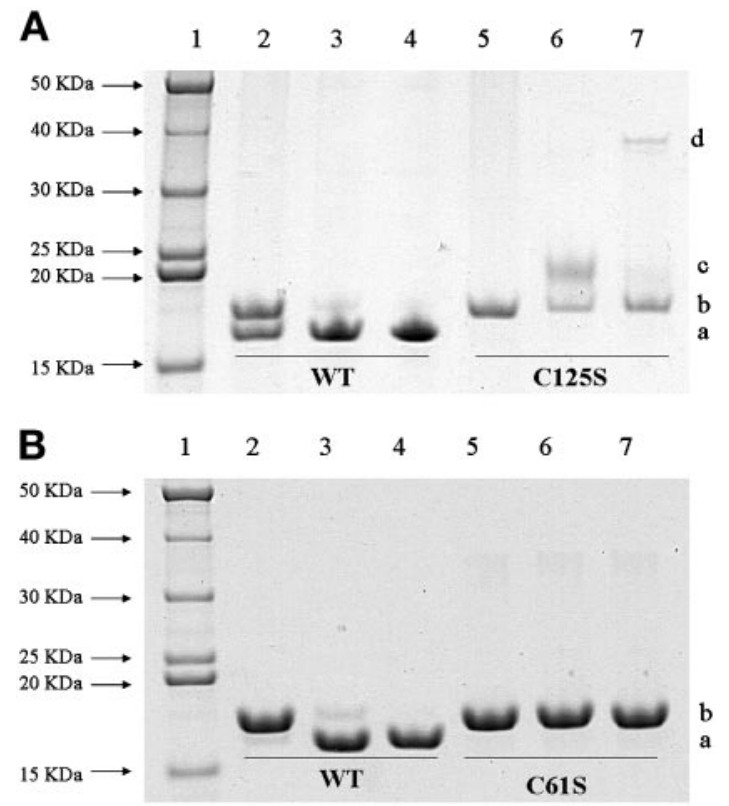

FIG. 6. Migration of mutant proteins in SDS-PAGE. Treatments were carried out for $1 \mathrm{~h}$. A, lane 1, molecular mass standard (BenchMark $^{\mathrm{TM}}$ Protein Ladder, Invitrogen); lanes 2-4 represent wild-type Ohr treated with DTT $(100 \mathrm{mM}), t-\mathrm{bOOH}(60 \mu \mathrm{M})$ and $\mathrm{H}_{2} \mathrm{O}_{2}(60 \mu \mathrm{M})$, respectively; lanes 5-7 represent C125S treated with DTT (100 mM), $t$-bOOH $(60 \mu \mathrm{M})$, and $\mathrm{H}_{2} \mathrm{O}_{2}(60 \mu \mathrm{M})$, respectively; $B$, lane 1 , molecular mass standard (BenchMark ${ }^{\mathrm{TM}}$ Protein Ladder, Invitrogen); lanes 2-4 represent wild-type $\mathrm{Ohr}$ treated with DTT (100 mM), $t$-bOOH $(60 \mu \mathrm{M})$, and $\mathrm{H}_{2} \mathrm{O}_{2}(60 \mu \mathrm{M})$, respectively; lanes $5-7$ represent C61S treated with DTT $(100 \mathrm{mM}), t$-bOOH $(60 \mu \mathrm{M})$, and $\mathrm{H}_{2} \mathrm{O}_{2}(60 \mu \mathrm{M})$, respectively. Letters $a, b$, $c$, and $d$ refer to the bands described under "Results."

protein configuration that would migrate faster than the other REDOX states.

Interestingly, two other bands, named $c$ and $d$, could also be observed in C125S exposed to oxidative conditions (Fig. 6A). Band $d$ was detected in non-treated C125S (data not shown) as well as in C125S submitted to mild oxidative conditions (Fig. $6 A$, lane 7). Under stronger oxidative conditions, band $c$ became predominant and band $d$ disappeared (Fig. 6A, lane 6 and data not shown). Sometimes a band of $\sim 30 \mathrm{kDa}$ was observed in 


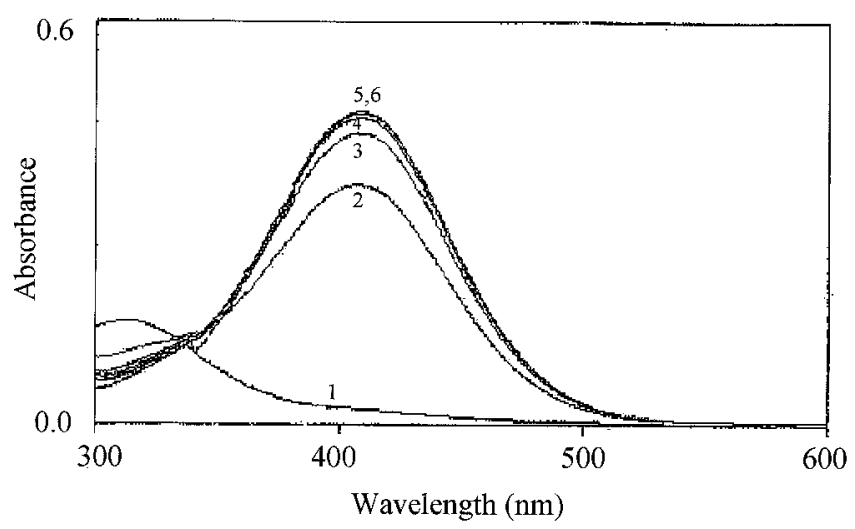

FIG. 7. Sulfenic acid formation in C125S. Sulfenic acid in $\mathrm{C} 125 \mathrm{~S}$ was measured by its reaction with TNB. C125S (100 $\mu \mathrm{M})$ with no pretreatment was incubated with TNB (4 mM) for $15 \mathrm{~min}$ at room temperature. A mixed disulfide C125S-TNB was prepared as described under "Material and Methods." Release of TNB from the mixed disulfide was recorded after 1, 3, 5, 10, and 30 min after addition of 10 -fold excess of DTT, which corresponds to the spectra $2-6$. Spectrum 1 corresponds to the mixed disulfide before DTT addition.

substitution of band $c$ after C125S treatment with organic peroxides (data not shown). The meaning of band $c$ is unknown and could be attributed to proteolysis or to generation of crosslinks in the dimer.

Since band $d$ should correspond to a dimer of two C125S proteins bound through their Cys-61, it appears that this sulfhydryl group is relatively reactive toward peroxides. As expected for a dimer exposed to reducing condition, when $\mathrm{C} 125 \mathrm{~S}$ was treated with DTT in denaturing conditions, only a monomeric band (band $b$ ) was detected (Fig. 6A, lane 5).

On the contrary, C61S migrated preferentially as a monomer (Fig. 6B). Only after treatment of cells with very high peroxide concentrations could a dimer be observed (data not shown), indicating that Cys-125 is not very oxidizable by peroxides.

The possible formation of stable sulfenic acid intermediates (R-SOH) in Ohr, C125S, and C61S was also analyzed. Using the compound TNB, we could only clearly detect sulfenic acid intermediates in C125S protein (Fig. 7). This result further indicated that Cys-61 but not Cys-125 is very reactive.

Thiol Substrate Specificity-The possibility that other thiol compounds besides DTT support the peroxidase activity of Ohr was also analyzed. No decomposition of $t$-bOOH by Ohr was detected when DTT was replaced by monothiols such as GSH, 2-mercaptoethanol (Fig. 8A), and cysteine (data not shown). It is important to note that even when GSH was added at a concentration 10-fold higher than DTT no peroxidase activity could be observed (Fig. $8 A$ ). Therefore, $\mathrm{Ohr}$ does not possess GSH peroxidase activity.

To check if thioredoxin could be the biological substrate for $\mathrm{Ohr}$, thioredoxin was added to the reaction mixture containing DTT, $t$-bOOH, and Ohr. In the case of cTPxI, addition of thioredoxin to the reaction mixture increased the specific activity of this protein (28). The addition of thioredoxin from Spirulina or from $S$. cerevisiae did not increase significantly the ability of $\mathrm{Ohr}$ to decompose $t$-bOOH, taking into account the decomposition of peroxides by thioredoxin itself (Fig. $8 B$ ). The peroxidase activity of $\mathrm{Ohr}$ may be specific for thioredoxin from $X$. fastidiosa. Alternatively, other thiol compound than thioredoxin can be the reducing agent of $\mathrm{Ohr}$.

Interestingly, Ohr was also capable of decomposing peroxides (Fig. $8 A$ ) and protecting glutamine synthetase from inactivation (Fig. 4A) if DHLA was present in the reaction mixture. Like DTT, DHLA is also a dithiol compound. Enzymes required for DHLA biosynthesis are present in X. fastidiosa (XF1269, $\mathrm{XF1270)}$ in an operon configuration indicating that this thiol

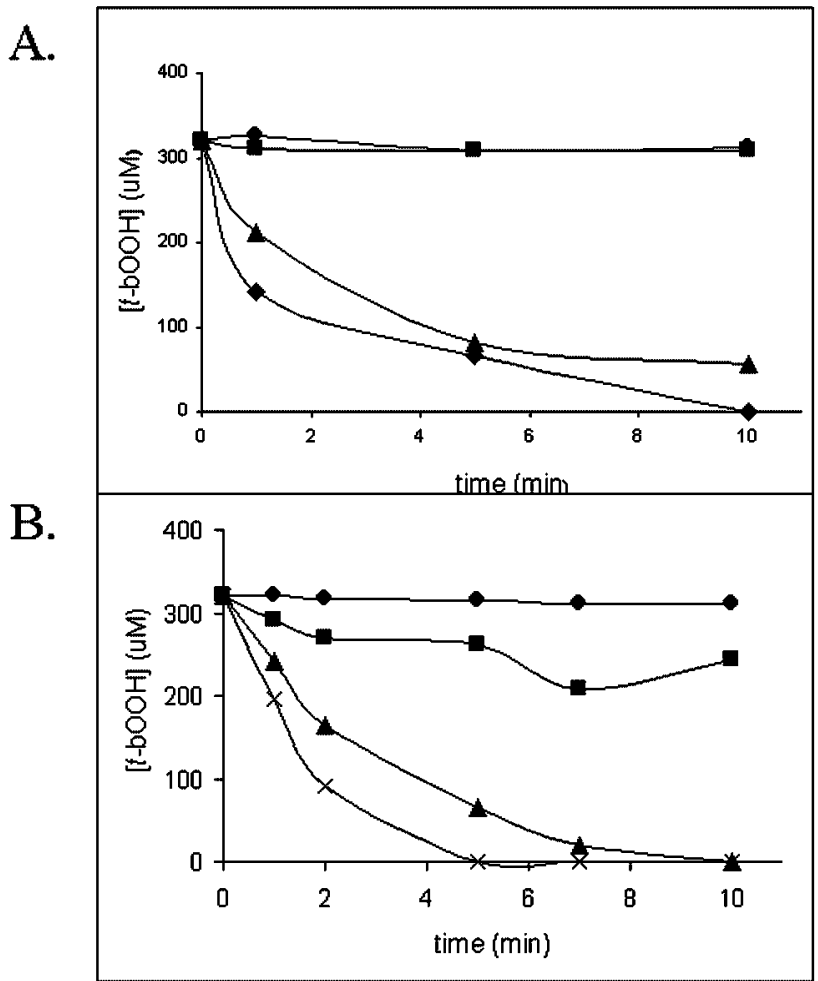

FIG. 8. Thiol specificity of the $\mathrm{Ohr}$ peroxidase activity. $t$-bOOH concentration was determined by the FOX assay as described under "Material and Methods." Reactions were initiated by addition of thiol compounds and terminated by addition of $20 \mu \mathrm{l}$ of $\mathrm{HCl}(1 \mathrm{M})$ into $100-\mu \mathrm{l}$ reaction mixtures. Reactions were carried out in Hepes buffer $50 \mathrm{~mm}$, $\mathrm{pH} 7.4$ in the presence of azide $(1 \mathrm{mM})$ and DTPA $(0.1 \mathrm{mM})$. A, symbols represent the reactions with the following thiol compounds: $(\mathrm{GSH}=$ $5 \mathrm{~mm})$, (2-mercaptoethanol $=10 \mathrm{~mm}), \boldsymbol{\Delta}(\mathrm{DTT}=0.5 \mathrm{~mm})$, and $($ DHLA $=0.5 \mathrm{~mm}) . B$, the symbols represent: (no further addition); (thioredoxin $80 \mathrm{ng} / \mu \mathrm{l}) ; \boldsymbol{\Delta}(\mathrm{Ohr} 5 \mathrm{ng} / \mu \mathrm{l})$; and $\mathrm{X}$ (thioredoxin $+\mathrm{Ohr}$ ).

compound should be present in this bacteria. The possibility that DHLA is the in vivo reducing power of $\mathrm{Ohr}$ is discussed below.

Because the ability of Ohr to decompose peroxides is dependent on the presence of DTT, the stoichiometry of the reaction catalyzed by this protein was investigated as described before for cTPxI (31). The data described in Table I indicated that the ratio of thiol consumption per peroxide consumption is around 2 , which is consistent with the same reaction catalyzed by proteins belonging to the peroxiredoxin family: $2 \mathrm{RSH}+\mathrm{ROOH}$ $\rightarrow \mathrm{RSSR}+\mathrm{ROH}+\mathrm{H}_{2} \mathrm{O}$. Therefore, Ohr is a thiol-dependent peroxidase.

\section{DISCUSSION}

The present report attribute for the first time a biochemical function for a protein belonging to the $\mathrm{Ohr} / \mathrm{OsmC}$ family. Taken together, our results demonstrate unequivocally that $\mathrm{Ohr}$ from $X$. fastidiosa possesses thiol-dependent peroxidase activity. This biochemical activity is consistent with the increased sensitivity to organic peroxides observed for several bacterial species in which this gene is deleted $(10-13,15)$.

Ohr possesses a very high specific activity for organic peroxides in comparison with peroxiredoxins. In our hands, the specific activity of Ohr is approximately 10-20 times higher than the specific activity of cTPxI when organic peroxides were used as substrates (data not shown). AhpC is the other thioldependent peroxidase present in $X$. fastidiosa and in several other bacteria. AhpC belongs to the peroxiredoxin family like cTPxI, and therefore they are expected to behave similarly. Results showing that mutation of ohr renders cells more sen- 
TABLE I

Stoichiometry of the reaction catalyzed by Ohr

Kinetics were started by addition of peroxide and were stopped by $\mathrm{HCl}$ as described under "Materials and Methods." Assays for determination of peroxide and sulfhydryl concentrations are also described under "Materials and Methods."

\begin{tabular}{lcccc}
\hline Reaction mixture & Time & $\begin{array}{c}\text { Peroxide } \\
\text { removed }\end{array}$ & -SH consumed & $\begin{array}{c}\text {-SH/peroxide } \\
\text { ratio }\end{array}$ \\
\hline & $(M I N)$ & $(\mu M)$ & $(\mu M)$ & \\
$\mathrm{H}_{2} \mathrm{O}_{2}(500 \mu \mathrm{M})$ & 5 & 283.6 & 547.2 & 1.93 \\
$\mathrm{DTT}(500 \mu \mathrm{M})$ & & & & \\
$\mathrm{OHR}(24 \mathrm{ng} / \mu \mathrm{l})$ & & & & 1.98 \\
$\mathrm{H}_{2} \mathrm{O}_{2}(500 \mu \mathrm{M})$ & 10 & 382.4 & 756 & \\
$\mathrm{DTT}(500 \mu \mathrm{M})$ & & & & \\
$\begin{array}{l}\text { OHR }(24 \mathrm{ng} / \mu \mathrm{l}) \\
\mathrm{t}-\mathrm{BHP}(500 \mu \mathrm{M})\end{array}$ & 5 & 435.4 & 799.2 & 1.83 \\
$\begin{array}{l}\mathrm{DTT}(500 \mu \mathrm{M}) \\
\text { OHR }(2 \mathrm{ng} / \mu \mathrm{l})\end{array}$ & & & & \\
$\mathrm{t}-\mathrm{BHP}(500 \mu \mathrm{M})$ & 10 & 465.9 & 892.8 & 1.91 \\
$\mathrm{DTT}(500 \mu \mathrm{M})$ & & & & \\
OHR $(2 \mathrm{ng} / \mu \mathrm{l})$ & & & & \\
\hline
\end{tabular}

sitive to organic peroxide killing than $a h p C$ deletion $(11,12)$ lead us to speculate that this probably occurs because Ohr has higher specific activity toward organic peroxides than peroxiredoxins, but this suggestion awaits experimental confirmation.

The relationship between $\mathrm{Ohr}$ and $\mathrm{AhpCF}$ proteins has been studied in other bacteria. AhpC acts in concert with $\mathrm{AhpF}$ (a thioredoxin reductase homologue) to reduce peroxides to the corresponding alcohols at the expense of NADH (9). It is well known that the expression of $a h p C$ and $a h p F$ are regulated by OxyR, a transcriptional regulator that is activated by $\mathrm{H}_{2} \mathrm{O}_{2}$ (33). This should also occur in $X$. fastidiosa because $a h p C$, $a h p F$, and $o x y R$ genes are contiguous and therefore probably belong to the same operon (aeg.lbi.ic.unicamp.br/xf/). On the other hand, the expression of ohr genes in B. subtilis and $X$. campestris are not regulated by $\mathrm{OxyR}$ but by $\mathrm{OhrR}(12,34)$. OhrR is a member of the MarR family of transcriptional repressors. No OhrR homologue was found in a search through the site of $X$. fastidiosa genome suggesting that $o h r$ is regulated by a different mechanism in this microorganism.

$X$. fastidiosa contains several peroxide-removing enzymes as analyzed by the bioinformatic tools available at aeg.lbi.ic. unicamp.br/xf/and using the sequencing data generated by the genome project supported by FAPESP (16). Besides $a h p C$ (XF1530), two other genes codify for proteins that contain AhpC/ TSA domains as defined by the pFAM analysis. Additionally, one catalase and one GSH peroxidase homologue are also present. Each one of these peroxide-removing enzymes may utilize different substrates or may act during specific stress conditions.

$\mathrm{Ohr}$ is also capable of decomposing $\mathrm{H}_{2} \mathrm{O}_{2}$ although with a lower efficiency compared with the removal of organic peroxides (Fig. 3). Probably Ohr does not play an important role in the defense of $X$. fastidiosa against this oxidant. In other related bacteria, $\Delta$ ohr mutants are not hypersensitive to $\mathrm{H}_{2} \mathrm{O}_{2}$ $(10,11,15)$. Moreover, in $X$. campestris pv. phaseoli and in $B$. subtilis ohr expression is not regulated by OxyR, which is activated by $\mathrm{H}_{2} \mathrm{O}_{2}(12,34)$. Catalases appear to be the primary defense of Xanthomonas against exogenous $\mathrm{H}_{2} \mathrm{O}_{2}(35,36) . X$. fastidiosa possesses at least one catalase (XF2232), similar to HPI, (katG) from E. coli, which is OxyR-regulated (33) and should be a key component of the antioxidant defense against exogenous $\mathrm{H}_{2} \mathrm{O}_{2}$. On the other side, several studies indicate that AhpR should be an important component in the removal of $\mathrm{H}_{2} \mathrm{O}_{2}$ endogenously generated in bacteria (37-39).

The reduction of peroxides by $\mathrm{Ohr}$ requires at least one of its cysteine residues because NEM pretreatment abolishes its per-
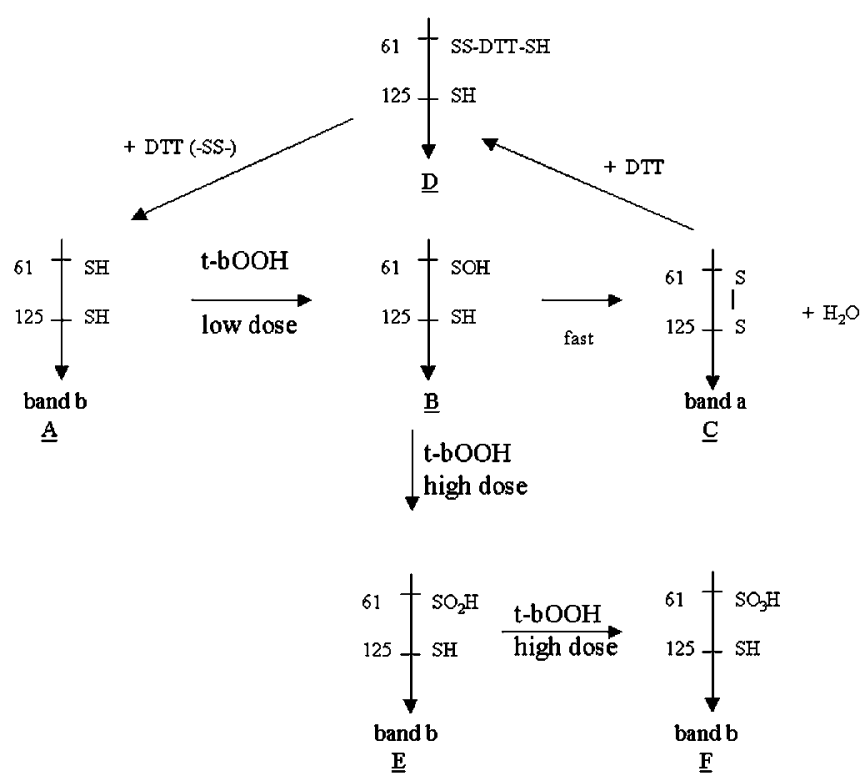

FIG. 9. Proposed scheme for the enzymatic mechanism of Ohr. The reduced form of $\mathrm{Ohr}(A)$ can react with peroxides leading to the formation of Cys-61-SOH intermediate $(B)$, which can then be rapidly converted to an intramolecular disulfide intermediate after reaction with Cys-125 $(C)$. The intramolecular disulfide can be reduced back to (A) by DTT or DHLA. In the presence of high amounts of organic peroxides, Cys-61-SOH can be further oxidized to Cys-61- $\mathrm{SO}_{2} \mathrm{H}(E)$ or Cys-61- $\mathrm{SO}_{3} \mathrm{H}(F)$, which co-migrates with the reduced form of Ohr in the position corresponding to the band $b$ in the gels of Figs. 2 and 6 .

oxidase activity (Fig. $3 C$ ). Ohr has two cysteine residues that are present in all of its homologues (Fig. 1A) and therefore potentially could be involved in peroxide reduction. Substitution of Cys-61 or Cys-125 by serine dramatically reduces the ability of Ohr to decompose peroxides (Fig. 5), indicating that both cysteine residues are important for the catalytic activity. However, it is important to note that C125S, but not C61S, still has a residual peroxidase activity, suggesting an essential role for Cys-61. In fact, Cys-61, but not Cys 125, was easily oxidized by any of the peroxides (Fig. 6), and it appears that Cys-61 is directly involved on peroxide reduction, whereas Cys-125 is the resolving cysteine. Our data fit very well in the scheme described in Fig. 9. At low concentrations of organic peroxides, Cys-61 could be oxidized to sulfenic acid, which should be rapidly converted to the intramolecular disulfide intermediate (electrophoretic band $a$ ). In support with this model, we could only detect sulfenic acid intermediate in C125S protein (Fig. 7). Cys-61-SOH should be more stable in C125S than in wild-type Ohr because the mutant protein lacks Cys-125 to react with Cys-61-SOH. At high levels of organic peroxides, sulfenic acid of Cys-61 should react first with another peroxide molecule and not with Cys-125 sulfhydryl group, leading to the formation of a cysteine sulfinic acid ( $\left.\mathrm{R}-\mathrm{SO}_{2} \mathrm{H}\right)$. Further reaction of Cys-61$\mathrm{SO}_{2} \mathrm{H}$ with another organic peroxide molecule can provoke the formation of Cys-61 sulfonic acid ( $\left.\mathrm{R}-\mathrm{SO}_{3} \mathrm{H}\right)$. Both Cys-61- $\mathrm{SO}_{2} \mathrm{H}$ and Cys-61- $\mathrm{SO}_{3} \mathrm{H}$ should correspond to the electrophoretic band $b$ observed in Fig. 2 when Ohr was exposed to high concentrations of organic peroxides.

Disulfide intermediates are stable compounds among other factors because they can not be overoxidized as sulfenic acids can be (40). Therefore is tempting to speculate that Cys-125 prevents Ohr inactivation by avoiding Cys-61 overoxidation to sulfinic or sulfonic acids. It is well described that overoxidation of peroxiredoxin provoked their inactivation (41). In the case of the mutant protein $\mathrm{C} 125 \mathrm{~S}$, in addition to overoxidation of Cys61 , dimer formation (Fig. 6A) could represent another pathway of protein oxidation. 
Band $b$ was never observed when $\mathrm{Ohr}$ was treated with $\mathrm{H}_{2} \mathrm{O}_{2}$ (Fig. 2), indicating that this peroxide has lower capacity than organic peroxides to overoxidize Cys-61 to sulfinic or sulfonic acids. In fact, $\mathrm{H}_{2} \mathrm{O}_{2}$ had lower ability than organic peroxides to induce dimer formation in the mutant protein C125S (data not shown). Cys-61 is located in a very hydrophobic environment (Fig. $1 B$ ), which is probably ideal to accommodate an organic peroxide but not $\mathrm{H}_{2} \mathrm{O}_{2}$. This hypothesis would explain the higher specific activity of $\mathrm{Ohr}$ toward organic peroxides in comparison with $\mathrm{H}_{2} \mathrm{O}_{2}$ (Fig. 3).

The biological-reducing substrate of Ohr is still unknown. GSH should be present in $X$. fastidiosa because this bacteria contains homologues for the two genes ( $g s h 1$ and gsh2) involved in its biosynthesis (aeg.lbi.ic.unicamp.br/xf/). However, this thiol was not capable of reducing peroxides in the presence of Ohr, even when it was present in a concentration ten times higher than DTT concentration (Fig. 8A). Thioredoxin from neither Spirulina (data not shown) nor from $S$. cerevisiae (Fig. $8 B$ ) increased the rate of peroxide removal by $\mathrm{Ohr}$. We can not exclude, however, the possibility that thioredoxin or glutaredoxin systems of $X$. fastidiosa specifically reduces Ohr.

In addition to DTT, DHLA supported the peroxidase activity of $\mathrm{Ohr}$ (Figs. $4 A$ and $8 A$ ). Therefore, Ohr utilized only dithiols, but not monothiols, as substrate. Dithiols such as DTT and DHLA have very negative redox potentials, which indicate that these compounds have very high reducing power. The redox potentials for dithiols are in the range from -0.31 to -0.33 , whereas for monothiols such as GSH and cysteine the redox potentials are in the range of -0.24 to -0.25 (42). Probably the intramolecular disulfide bond of $\mathrm{Ohr}$ is very stable, and only very strong reducing agents are able to convert them to the reduced form. Another possibility is related to possible structural constrains of the $\mathrm{Ohr}$ active site. According to our results, the active site of this protein is very hydrophobic and may not be capable of accommodating two monothiols but can interact with only one dithiol molecule. This is because in the case of dithiols only one molecule would be enough to reduce Ohr back to the dithiol configuration according to Reaction 1.

$$
\begin{gathered}
\mathrm{Ohr}(-\mathrm{SS}-)+\mathrm{R}-(\mathrm{SH})_{2} \rightarrow \mathrm{Ohr}-\left[\text { Cys-61]-SSR-SH } \rightarrow \mathrm{Ohr}-(\mathrm{SH})_{2}+\mathrm{RSSR}\right. \\
\text { REACTION } 1
\end{gathered}
$$

In the case of monothiols, two molecules would be required to fully reduce Ohr. First, a mixed disulfide between Ohr and the monothiol would be generated (Reaction 2), which would then be reduced to the Ohr dithiol configuration by other monothiol molecule and the release of a disulfide compound (Reaction 3).

$$
\begin{gathered}
\mathrm{Ohr}(-\mathrm{SS}-)+\mathrm{R}-\mathrm{SH} \rightarrow \mathrm{Ohr}-\mathrm{SSR} \\
\text { REACTION } 2
\end{gathered}
$$

$\mathrm{Ohr}-\mathrm{SSR}+\mathrm{R}-\mathrm{SH} \rightarrow \mathrm{Ohr}-\mathrm{SH}+\mathrm{RSSR}$

\section{REACTION 3}

The possibility that DHLA is the biological substrate of $\mathrm{Ohr}$ is supported by the fact that its biosynthetic pathway is present in X. fastidiosa (XF 1269,XF1270). Interestingly, Bryk et al. (43) characterized a peroxidase system dependent on lipoic acid in Mycobacterium tuberculosis. Bryk et al. (43) demonstrated that lipoic acid utilized came from a thiol linked through an amide linkage dihydrolipoamide succinyltransferase, a component of $\alpha$-ketoacid oxidases, and was reduced by NADH in a reaction catalyzed by dihydrolipoamide dehydrogenase. Both dihydrolipoamide succinyltransferase (XF1549) and dihydrolipoamide dehydrogenase (XF1548) enzymes are also present in $X$. fastidiosa (aeg.lbi.ic.unicamp.br/xf/). Several reducing systems from $X$. fastidiosa are in the process to be expressed to find the reducing substrate of Ohr. In any case, our data suggest that $\mathrm{Ohr}$ may be a dihydrolipoic acid peroxidase.
Contrary to peroxiredoxins, GSH peroxidase, and catalases, Ohr belongs to a family of proteins that are present only in bacteria, most of them pathogenic to plants or mammals. Thus Ohr may be promising as a target for drug development in agriculture and medicine, considering the fact that plant and mammal defenses against pathogens involves generation of oxidative burst (1).

Acknowledgments-We thank Gisele Monteiro for revising the manuscript and Fundação de Amparo à Pesquisa do Estado de São Paulo (FAPESP) and Pró-Reitoria de Pesquisa da Universidade de São Paulo for financial support.

\section{REFERENCES}

1. Tenhaken, R., Levine, A., Brisson, L. F., Dixon, R. A., and Lamb, C. (1995) Proc. Natl. Acad. Sci. U. S. A. 92, 4158-4163

2. Maeng, J. H., Sakai, Y., Tani, Y., and Kato, N. (1996) J. Bacteriol. 178, 3695-3700

3. Jiang, Z-Y., Hunt, J. V., and Wolff, S. P. (1992) Anal. Biochem., 202, 384-389

4. Barr, D. P., and Mason, R. P. (1995) J. Biol. Chem. 270, 12709-12716

5. Akaike, T., Sato, K., Ijiri, S., Miyamoto, Y., Kohno, M., Ando, M., Maeda, H. (1992) Arch. Biochem. Biophys. 294, 55-63

6. Bsat, N., Chen, L., and Helmann, J. D. (1996) J. Bacteriol. 178, 6579-6586

7. Jacobson, F. S., Morgan, R. W., Christman, M. F., and Ames, B. N. (1989) J. Biol. Chem. 264, 1488-1496

8. Chae, H. Z., Robison, K. Poole, L. B. Church, G., Storz, G., and Rhee, S. G. (1994) Proc. Natl. Acad. Sci. 91, 7017-7021

9. Poole, L. B., and Ellis, H. R. (1996) Biochemistry 35, 56-64

10. Mongkolsuk, S., Praituan, W., Loprasert, S., Fuangthong, M., Chamnongpol, S. (1998) J. Bacteriol. 180, 2636-2643

11. Ochsner, U. A., Hassett, D. J., and Vasil, M. L. (2001) J. Bacteriol. 183, $773-778$

12. Fuangthong, M., Atichartpongkul, S., Mongkolsuk, S., and Helmann, J. D. (2001) J. Bacteriol. 183, 4134-4141

13. Rince, A., Giard, J. C., Pichereau, V., Flahaut, S., and Auffray, Y. (2001) J. Bacteriol. 183, 1482-1488

14. Atichartpongkul, S., Loprasert, S., Vattanaviboon, P., Whangsuk, W., Helmann, J. D., and Mongkolsuk, S. (2001) Microbiology 147, 1775-1782 15. Shea, R. J., and Mulks, M. H. (2002) Infect. Immun. 70, 794-802

16. Simpson, A. J. G., Reinach, F. C., Arruda, P., Abreu, F. A., Acencio, M., Alvarenga, R., Alves, L. M., Araya, J. E., Baia, G. S., Baptista, C. S., Barros, M. H., Bonaccorsi, E. D., Bordin, S., Bove, J. M., Briones, M. R., Bueno, M. R., Camargo, A. A., Camargo, L. E., Carraro, D. M., Carrer, H., Colauto, N. B., Colombo. C., Costa, F. F., Costa, M. C., Costa-Neto, C. M., Coutinho, L. L., Cristofani, M., Dias-Neto, E., Docena, C., El-Dorry, H., Facincani, A. P., Ferreira, A. J., Ferreira, V. C., Ferro, J. A., Fraga, J. S., Franca, S. C., Franco, M. C., Frohme, M., Furlan, L. R., Garnier, M, Goldman, G. H., Goldman, M. H., Gomes, S. L., Gruber, A., Ho, P. L., Hoheisel, J. D., Junqueira, M. L., Kemper, E. L., Kitajima, J. P., Krieger, J. E., Kuramae, E. E., Laigret, F., Lambais, M. R., Leite, L. C. C., Lemos, E. G., Lemos, M. V., Lopes, S. A., Lopes, C. R., Machado, J. A., Machado, M. A., Madeira, A. M., Madeira, H. M., Marino, C. L., Marques, M. V., Martins, E. A., Martins, E. M., Matsukuma, A. Y., Menck, C. F., Miracca, E. C., Miyaki, C. Y., Monteiro-Vitorello, C. B., Moon, D. H., Nagai, M. A., Nascimento, A. L., Netto, L. E. S., Nhani, A., Jr., Nobrega. F. G., Nunes, L. R., Oliveira, M. A., de Oliveira, M. C. de Oliveira, R. C., Palmieri, D. A., Paris, A. Peixoto, B. R., Pereira, G. A. G., Pereira, H. A., Jr., Pesquero, J. B., Quaggio, R. B., Roberto, P. G., Rodrigues, V., de M. Rosa, A. J., de Rosa, V. E., Jr., de Sa, R. G., Santelli, R. V., Sawasaki, H. E., da Silva, A. C., da Silva, A. M., da Silva, F. R., da Silva, W. A., Jr., da Silveira, J. F., Silvestri, M. L., Siqueira, W. J., de Souza, A. A., de Souza, A. P., Terenzi, M. F., Truffi, D. Tsai, S. M., Tsuhako, M. H., Vallada, H., Van Sluys, M. A., VerjovskiAlmeida, S., Vettore, A. L., Zago, M. A., Zatz, M., Meidanis, J., Setubal, J. C. (2000) Nature 406, 151-159

17. Sarkar, G., Sommer, S. S. (1990) BioTechniques 4, 404-407

18. Datta, A. K. (1995) Nucleic Acids Res. 21, 4530-4531

19. Riddles, P. W., Robert, L. B., and Zerner, B. (1983) Methods Enzymol. 91, 49-60

20. Kim, K., Kim, I. H., Lee, Ki-Y., Rhee, S. G., and Stadtman, E. R. (1988) J. Biol. Chem. 263, 4704-4711

21. Ellis, H. R., and Poole, L. B. (1997) Biochemistry 36, 13349-13356

22. Kaneko, T., Nakamura, Y., Sato, S., Asamizu, E., Kato, T., Sasamoto, S., Watanabe, A., Idesawa, K., Ishikawa, A., Kawashima, K., Kimura, T., Kishida, Y., Kiyokawa, C., Kohara, M., Matsumoto, M., Matsuno, A. Mochizuki, Y., Nakayama, S., Nakazaki, N., Shimpo, S., Sugimoto, M., Takeuchi, C., Yamada, M., and Tabata, S. (2000) DNA Res. 7, 331-338

23. Salanoubat, M., Genin, S., Artiguenave, F., Gouzy, J., Mangenot, S., Arlat, M., Billault, A., Brottier, P., Camus, J. C., Cattolico, L., Chandler, M., Choisne, N., Claudel-Renard, C., Cunnac, S., Demange, N., Gaspin, C., Lavie, M., Moisan, A., Robert, C., Saurin, W., Schiex, T., Siguier, P., Thebault, P., Whalen, M., Wincker, P., Levy, M., Weissenbach, J., and Boucher, C. A. (2002) Nature 415, 497-502

24. Redenbach, M., Kieser, H. M., Denapaite, D., Eichner, A., Cullum, J., Kinashi, H., and Hopwood, D. A. (1996) Mol. Microbiol. 21, 77-96

25. Rhee, S. G., Kang, S. W., Netto, L. E. S., Seo, M. S., and Stadtman, E. R. (1999) Biofactors 10, 207-209

26. Kyte, J., and Doolittle, R. F. (1982) J. Mol. Biol. 157, 105-132

27. Chae, H. Z., Uhm, T. B., and Rhee, S. G. (1994) Proc. Natl. Acad. Sci. (U. S. A.) 91, 7022-7026 
28. Lee, S. P., Hwang, Y. S., Kim, Y. J., Kwon, K. S., Kim, H. J., Kim, K., and Chae, H. Z. (2001) J. Biol. Chem. 276, 29826-29832

29. Yamashita, H., Avraham, S., Jiang, S., London, R., Van Veldhoven, P. P Subramani, S., Rogers, R. A., Avraham, H. (1999) J. Biol. Chem. 274, 29897-29904

30. Stadtman, E. R. (1990) Free Rad. Biol. Med., 9, 315-325

31. Netto, L. E. S., Chae, H. Z., Kang, S. W., Rhee, S. G., and Stadtman, E. R. (1996) J. Biol. Chem. 271, 15315-15321

32. Seo, M. S., Kang, S. W., Kim, K., Baines, I. C., Lee, T. H., and Rhee, S. G. (2000) J. Biol. Chem. 275, 20346-20354

33. Storz, G., and Imlay, J. A. (1999) Curr. Opin. Microbiol. 2, 188-194

34. Sukchawalit, R., Loprasert, S., Atichartpongkul, S., and Mongkolsuk, S. (2001) J. Bacteriol. 183, 4405-4412

35. Sriprang, R., Vattanaviboon, P., and Mongkolsuk, S. (2000) Appl. Environ.
Microbiol. 66, 4017-4021

36. Vattanaviboon, P., and Mongkolsulk, S. (2000) Gene 241, 259-265

37. Mongkolsuk, S., Whangsuk, W., Vattanaviboon, V., Loprasert, S., and Fuangthong, M. (2000) J. Bacteriol. 182, 2636-2643

38. Ochsner, U. A., Vasil, M. L., Alsabbagh, E., Parvatiyar, K., and Hassett, D. J. (2000) J. Bacteriol. 182, 4533-4544

39. Seaver, L. C., and Imlay, J. A. (2001) J. Bacteriol. 183, 7173-7181

40. Radi, R., Beckman, J. S., Bush, K. M., and Freeman, B. A. (1991) J. Biol. Chem. 266, 4244-4250

41. Yang, K. S., Kang, S. W., Woo, H. A., Hwang, S. C., Chae, H. Z., Kim, K., and Rhee, S. G. (2002) J. Biol. Chem. 277, 38029-38036

42. Lees, W. J., and Whitesides, G. M. (1993) J. Org. Chem. 251, 642-647

43. Bryk, R., Lima, C. D., Erdjument-Bromage, H., Tempst, P., and Nathan, C. (2002) Science 295, 1073-1077 


\section{ANEXO II}

Oliveira, M.A.; Guimarães, B.G.; Cussiol, J.R.R.; Medrano, F.J.; Gozzo, F.C. \& Netto, L.E.S. (2006) "Structural insights into enzyme-substrate interaction and characterization of enzymatic intermediates of Organic hydroperoxide resistance protein from Xylella fastidiosa". J. Mol. Biol., 359: 433-445. 


\title{
Structural Insights into Enzyme-Substrate Interaction and Characterization of Enzymatic Intermediates of Organic Hydroperoxide Resistance Protein from Xylella fastidiosa
}

\author{
Marcos A. Oliveira ${ }^{1}$, Beatriz G. Guimarães ${ }^{2}$, José R. R. Cussiol ${ }^{1}$ \\ Francisco J. Medrano ${ }^{2}$, Fábio C. Gozzo ${ }^{2}$ and Luis E. S. Netto ${ }^{1 *}$
}

${ }^{1}$ Departamento de Genética e Biologia Evolutiva, Instituto de Biociências, Universidade de São Paulo 05508-900, Brazil

${ }^{2}$ Center for Structural Molecular Biology, Brazilian Synchrotron Light Laboratory LNLS POBox 6192, CEP 13084-971, Campinas SP Brazil

\begin{abstract}
Organic hydroperoxide resistance proteins (Ohr) belong to a family of proteins that possess thiol-dependent peroxidase activity endowed by reactive cysteine residues able to reduce peroxides. The crystal structure of Ohr from Xylella fastidiosa in complex with polyethylene glycol, providing insights into enzyme-substrate interactions is described herein. In addition, crystallographic studies, molecular modeling and biochemical assays also indicated that peroxides derived from long chain fatty acids could be the biological substrates of Ohr. Because different oxidation states of the reactive cysteine were present in the Ohr structures from X. fastidiosa, Pseudomonas aeruginosa and Deinococcus radiodurans it was possible to envisage a set of snapshots along the coordinate of the enzyme-catalyzed reaction. The redox intermediates of X. fastidiosa Ohr observed in the crystals were further characterized in solution by electrospray ionization mass spectrometry and by biochemical approaches. In this study, the formation of an intramolecular disulfide bond and oxidative inactivation through the formation of a sulfonic acid derivative was unequivocally demonstrated for the first time. Because Ohr proteins are exclusively present in bacteria, they may represent promising targets for therapeutical drugs. In this regard, the structural and functional analyses of Ohr presented here might be very useful.
\end{abstract}

(C) 2006 Elsevier Ltd. All rights reserved.

Keywords: Ohr crystal structure; fatty acid peroxide; organic peroxide; thiols; sulfonic acid

\section{Introduction}

Oxidative burst is an important component of the host response against bacterial infection in plants

Abbreviations used: AhpC, alkyl hydroperoxide reductase subunit $C$; AhpF, alkyl hydroperoxide reductase subunit F; AhpR, alkyl hydroperoxide reductase; $\mathrm{OHP}$, organic hydroperoxides; DrOhr, organic hydroperoxide-resistance protein from Deinococcus radiodurans; DTNB, 5,5'-dithiobis(2-nitrobenzoic acid); $\mathrm{Ohr}$, organic hydroperoxide-resistance protein; $\mathrm{Ohr}_{\mathrm{mo}}$, mildly oxidized $\mathrm{Ohr} ; \mathrm{Ohr}_{\mathrm{fo}}$, fully oxidized $\mathrm{Ohr}$; $\mathrm{PaOhr}$, organic hydroperoxide-resistance protein from Pseudomonas aeruginosa; PEG, polyethylene glycol; ESI, electrospray ionization; $t$ - $\mathrm{BOOH}$, tert-butyl hydroperoxide.

E-mail address of the corresponding author: nettoles@ib.usp.br and animals. Oxidants can cause damage to macromolecules such as DNA, lipids and proteins. ${ }^{1,2}$ In response to this oxidative burst, several complex mechanisms have evolved in bacteria to detoxify $\mathrm{H}_{2} \mathrm{O}_{2}$, superoxide anion radicals and organic hydroperoxides (OHP). ${ }^{3-5}$ Lipids are major targets during oxidative burst as free radicals can directly attack unsaturated and polyunsaturated fatty acids in membranes and initiate lipid peroxidation. In addition to the non-enzymatic process, lipid peroxidation may also be catalyzed by enzymes such as lipoxygenases and dioxygenases in response to pathogen infection. ${ }^{6} \mathrm{~A}$ primary effect of lipid peroxidation is a decrease in membrane fluidity, which alters membrane properties and can significantly alter the properties of membrane-bound proteins. 7,8 Therefore, lipid peroxidation is an extremely deleterious process 
and the detoxification of its products is crucial to bacterial survival and proliferation in the host. ${ }^{4,6}$ $\mathrm{OHP}$ is one of the most toxic products of lipid peroxidation that possesses bactericidal properties. ${ }^{1}$

Alkyl hydroperoxide reductase (AhpR) is commonly considered the most important defense protein in OHP detoxification. ${ }^{5}$ AhpR is capable of converting $\mathrm{OHP}$ into their respective alcohols at the expense of NADH or NADPH. This enzyme system consists of two subunits: alkyl hydroperoxide reductase $\mathrm{F}(\mathrm{AhpF})$ and alkyl hydroperoxide reductase $\mathrm{C}$ (AhpC). ${ }^{3,5} \mathrm{AhpC}$ is a thiol-dependent peroxidase that belongs to a large family of enzymes named peroxiredoxins. ${ }^{9}$

In addition to AhpR, organic hydroperoxide resistance protein (Ohr) has also been implicated in the defense of bacteria against OHP-induced stress. The first description of $\mathrm{Ohr}$ came from studies of the phytopathogen Xanthomonas campestris pv. phaseoli. ${ }^{4}$ The deletion of the Ohr gene from $X$. campestris rendered the mutants highly sensitive to OHP but not to other oxidants. Additionally, ohr expression was highly induced by $\mathrm{OHP}$, but not by a superoxide generator and was only weakly induced by $\mathrm{H}_{2} \mathrm{O}_{2}$. Furthermore, Ohr but not AhpR seems to play a significant role in $\mathrm{OHP}$ resistance in Bacillus subtilis ${ }^{10}$ and ohr overexpression in Escherichia coli double mutant $\Delta a h p C / \triangle a h p F$ reverted the phenotype of hypersensitive to OHP. ${ }^{4}$ Recently, Klomsiri et al. ${ }^{11}$ showed that the Ohr and not AhpC is required for the adaptive response of X. campestris pv. phaseoli to alkyl hydroperoxide derived from linoleic acid. Collectively, these results indicate that $\mathrm{Ohr}$ plays a primary role in $\mathrm{OHP}$ detoxification.

Ohr proteins are only present in bacteria, most of which are pathogenic to plants and animals. ${ }^{12} \mathrm{Ohr}$ from Xylella fastidiosa (XfOhr), the causative agent of crops and citrus diseases, is a thiol-dependent peroxidase that catalyzes the following reaction: $2 \mathrm{RSH}+\mathrm{ROOH} \rightarrow \mathrm{RSSR}+\mathrm{ROH}+\mathrm{H}_{2} \mathrm{O}$. The enzyme is able to decompose OHP at least one order of magnitude more efficiently than $\mathrm{H}_{2} \mathrm{O}_{2}$. Additionally, in vitro XfOhr only decomposes peroxides in the presence of dithiols such as DTT. No decomposition of peroxides is detected when DTT is replaced by monothiols such as GSH, 2-mercaptoethanol or cysteine. $^{13}$

Analysis of Ohr-protein sequences from several bacteria showed that all homologues possess two conserved cysteine residues. ${ }^{12}$ The replacement of cysteine for serine residues abolishes the peroxidase activity of Ohr showing that both cysteine residues are essential for the peroxidase activity of Ohr. ${ }^{13,14}$ The Ohr family of proteins also comprises OsmC, which are proteins that share moderate levels of identity with Ohr. OsmC and Ohr proteins cluster in two subfamilies based on their sequences, function and pattern of expression. ${ }^{12}$ Long ago, OsmC proteins were implied in the response of bacteria against osmotic stress, ${ }^{15}$ and more recently OsmC was also involved in defense against $\mathrm{OHP}$ due to its thiol dependent peroxidase activity. ${ }^{16,17}$
Two crystal structures of Ohr from X. fastidiosa are reported here. In the first structure $(1.8 \AA$ resolution), the reactive cysteine is oxidized to a sulfonic acid $\left(\mathrm{Cys}-\mathrm{SO}_{3} \mathrm{H}\right)$, which has never been described before. The second structure $(2.4 \AA$ resolution) corresponds to a mixture of different oxidation states, as confirmed by mass spectrometry experiments. Structural analyses together with biochemical approaches provide a detailed characterization of the redox intermediates and the catalytic cycle of Ohr proteins. We also describe that sulfonic acids in XfOhr are only formed after long periods of incubation with $\mathrm{OHP}$ in large excess and that this reaction leads to oxidative inactivation. Finally, these multiple approaches provided insights into enzyme-substrate interactions.

\section{Results}

\section{The crystal structures of $X$. fastidiosa Ohr}

Structures of X. fastidiosa Ohr were determined in different oxidative states from two crystals, whose proteins were fully oxidized $\left(\mathrm{XfOhr}_{\mathrm{fo}}\right)$ in one case, and mildly oxidized $\left(\mathrm{XfOhr}_{\mathrm{mo}}\right)$ in the other. In both cases, the final atomic models include two crystallographically independent monomers (referred to as $\mathrm{A}$ and $\mathrm{B}$ ) forming a homodimer. The $\mathrm{XfOhr}_{\mathrm{fo}}$ model was refined at $1.8 \AA$ resolution $\left(R_{\text {factor }}=0.196\right)$ and the quality of the electron density allowed modeling of amino acid residues 2 to 143 (out of 143) in monomer $\mathrm{A}$ and 3 to 143 in monomer $\mathrm{B}$. The $\mathrm{XfOhr}_{\text {mo }}$ model was refined at $2.4 \AA$ resolution to a crystallographic $R$ factor of 0.192 . Amino acid residues 3 to 143 were modeled in both monomers. As expected, both models present very similar tertiary and quaternary structures. The overall rms deviation for $276 \mathrm{C}^{\alpha}$ positions between $\mathrm{XfOhr}_{\mathrm{fo}}$ and $\mathrm{XfOhr}_{\mathrm{mo}}$ dimers is $0.22 \AA$. Analysis of the packing shows that residues involved in crystal contacts are different in monomers A and B. Superposition of $\mathrm{XfOhr}_{\mathrm{fo}}$ and $\mathrm{XfOhr}_{\mathrm{mo}}$ structures shows that the contacts involving monomer $\mathrm{A}$ are almost identical in both structures. In the case of monomer B, crystallographic neighbors are slightly closer in the $\mathrm{XfOhr}_{\mathrm{fo}}$ structure (a rigid body displacement) but no significant conformational change is observed in the contact regions (data not shown). Global structural analysis and comparisons with homologous structures were performed using the high resolution $\mathrm{XfOhr}_{\mathrm{fo}}$ structure. A superposition of the structures of $X$. fastidiosa $\mathrm{Ohr}$ and its counterparts from Pseudomonas aeruginosa (PaOhr, 66\% identity) ${ }^{14}$ and Deinococcus radiodurans (DrOhr, 50\% identity) ${ }^{18}$ results in overall rms deviations of $1.00 \AA$ (268 $\mathrm{C}^{\alpha}$ aligned) and $1.31 \AA$ (262 $\mathrm{C}^{\alpha}$ aligned), respectively (Figure 1). As expected, no significant differences were found in the global structure. As previously described, ${ }^{14,18} \mathrm{Ohr}$ is an elliptically shaped homodimer with the two monomers tightly intertwined. Two six-stranded $\beta$-sheets surround a two-helix central core forming a barrel-like 

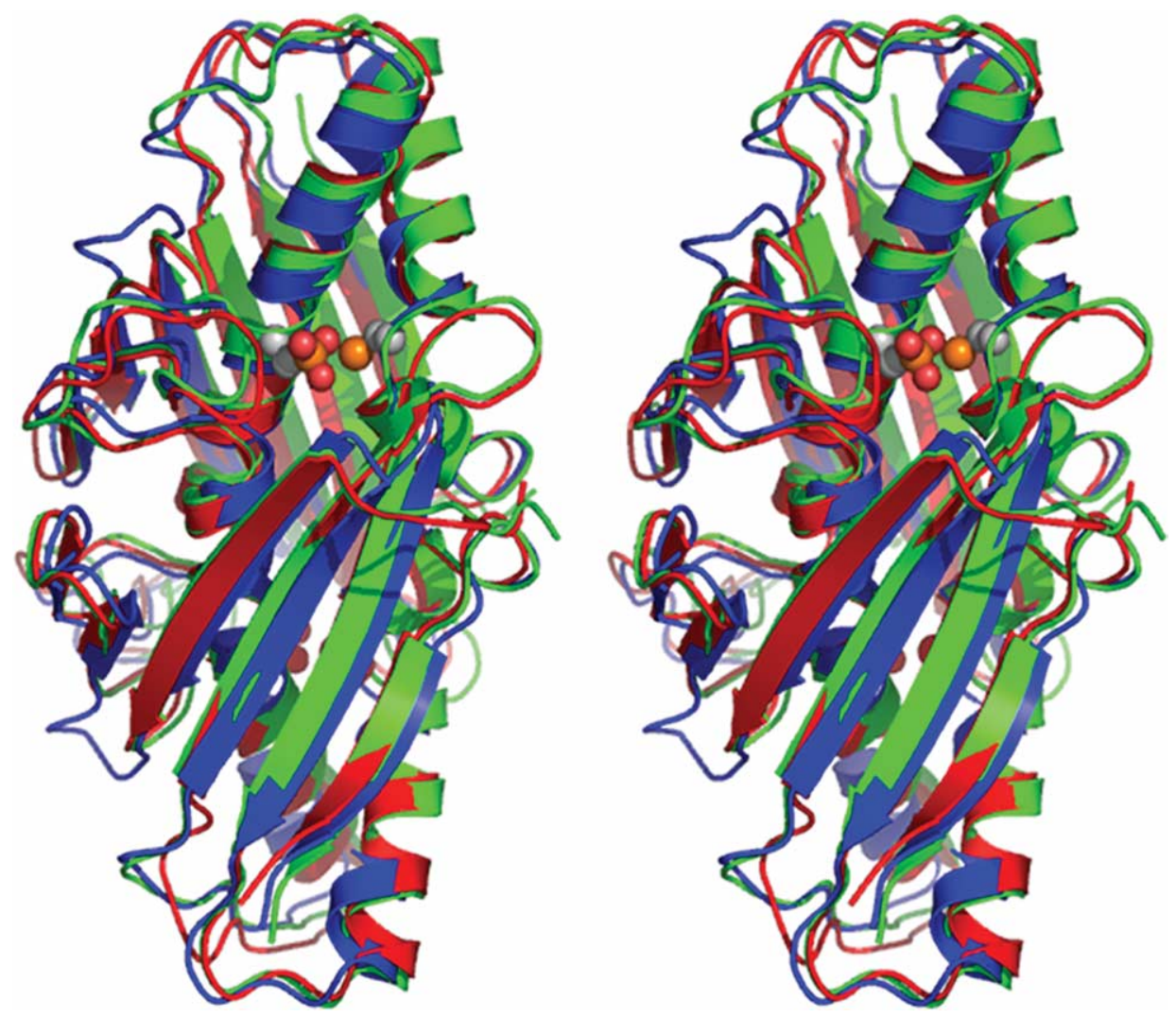

Figure 1. Overall structural comparison between Ohr from different species. Stereo ribbon diagram illustrating the superposition of Ohr from X. fastidiosa (red), P. aeruginosa (green) and D. radiodurans (blue). X. fastidiosa Ohr catalytic cysteine residues are represented in CPK.

structure. Each $\beta$-sheet is composed of three strands from one monomer and three from the other. Four short helices complete the dimer organization. The two conserved cysteine residues that compose the active site come from the same monomer, the two active site pockets being located on opposite sides of the dimer.

\section{Active site comparisons and basis for the substrate binding}

Despite the overall similarity of their structures, $\mathrm{PaOhr}$, DrOhr and the two forms of $\mathrm{X}$. fastidiosa Ohr show interesting differences in their active sites. In the structure of $\mathrm{PaOhr}$, the catalytic cysteine residues are in the reduced state $(\mathrm{Cys}-\mathrm{SH})$ and a bound DTT molecule was found in the two active site pockets. The conserved $\operatorname{Arg} 18\left(\mathrm{~N}^{\eta 1}\right)$ from one subunit forms a hydrogen bond with the reactive Cys60 $\left(\mathrm{S}^{\gamma}\right)$ from the other subunit and also forms a salt bridge with the invariant Glu50. Arg18 appears to play an important role in the catalytic mechanism by lowering the $\mathrm{p} K_{\mathrm{a}}$ value of the Cys60 thiol, since the R18Q mutation severely compromises the enzyme activity. ${ }^{14}$ In the structure of DrOhr the distance between the Cys $\left(S^{r}\right)$ atoms of the two catalytic cysteine residues (Cys57 and Cys121) is $2.8 \AA$, which is consistent with a mixture of a disulfide bond $(2.2 \AA)$ and dithiol configuration (3.7 $\AA$ ). In this structure, the loop containing the
Arg15 (equivalent to Arg18 in PaOhr) adopts a conformation that moves the arginine away from the active site pocket. ${ }^{18}$

In the $\mathrm{XfOhr}_{\mathrm{fo}}$ structure the electron density maps clearly showed the Cys61 (equivalent to Cys60 in PaOhr and Cys57 in DrOhr) fully oxidized to a sulfonic acid group (Cys-SO $\mathrm{S}_{3} \mathrm{H}$ ) (Figure 2(a)). On the other hand, in the $\mathrm{XfOhr}_{\mathrm{mo}}$ structure the electron density maps suggested that the reactive cysteine was present in more than one oxidative state, similarly to DrOhr. The $F_{\mathrm{o}}-F_{\mathrm{c}}$ electron density map clearly showed the presence of additional atoms when a Cys-SH was modeled (Figure 2(b)), nevertheless a sulfonic acid group also did not fit well to the electron density after refinement. Setting the occupancies of the oxygen atoms to 0.4 we were able to model the $\mathrm{SO}_{3}$ group. An additional peak in the $F_{\mathrm{o}}-F_{\mathrm{c}}$ electron density map suggesting a disulfide form was also observed (Figure 2(c)). These results indicated that a mixture of different oxidation states was present in the crystal. In fact, mass spectrometry experiments performed under conditions where $\mathrm{XfOhr}_{\text {mo }}$ crystals grew showed that Cys61 is in a mixture of sulfhydryl, disulfide and overoxidized forms (see Supplementary Data). Since different enzyme redox intermediates were present in the $\mathrm{XfOhr}_{\text {mo }}$ crystal, the resolution of this structure provided important information on the catalytic intermediates, as will be further discussed below. 
(a)

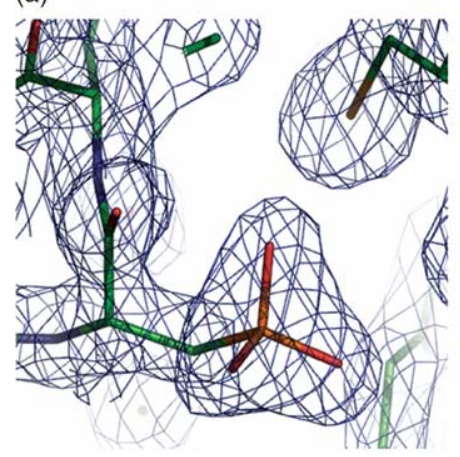

(b)

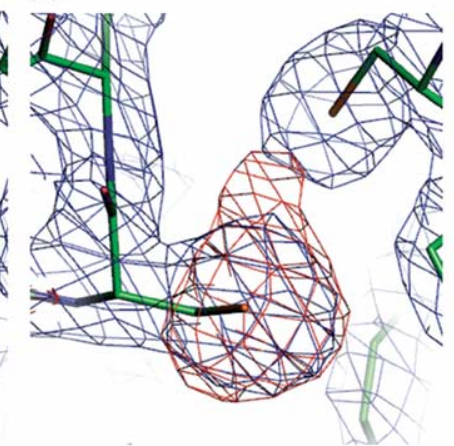

(c)

Figure 2. Oxidation states of the reactive cysteine in the $\mathrm{XfOhr}_{\mathrm{fo}}$ and $\mathrm{XfOhr}_{\mathrm{mo}}$ structures. $2 F_{\mathrm{o}}-F_{\mathrm{c}}$ maps are shown in blue and contored at $1.5 \sigma$ while $F_{\mathrm{o}}-F_{\mathrm{c}}$ maps are shown in red and contoured at $2.8 \sigma$. (a) XfOhr $\mathrm{fo}_{\mathrm{fo}}$ shows Cys61 fully oxidized to sulfonic acid. (b) $\mathrm{XfOhr}_{\text {mo }}$ refinement with the cysteine in the reduced form clearly shows the presence of additional density. (c) A sulfonic acid group could be modeled when the occupancies of the oxygen atoms were set to 0.4 . Final refinement of $\mathrm{XfOhr}_{\mathrm{mo}}$ also shows an additional peak in the $F_{\mathrm{o}}-F_{\mathrm{c}}$ electron density map suggesting a disulfide form.

Interestingly, in $\mathrm{XfOhr}_{\mathrm{fo}}$ and $\mathrm{XfOhr}_{\mathrm{mo}}$ structures the loop containing Arg19 (equivalent to Arg18 in PaOhr and Arg15 in DrOhr) follows the conformation found in reduced PaOhr structure, bringing the arginine side-chain close to the active site (Figure 3). In $\mathrm{XfOhr}_{\mathrm{fo}}$ Arg19 conformation is further stabilized by a number of interactions with the $\mathrm{SO}_{3} \mathrm{H}$ group of the overoxidized Cys61, in addition to the salt bridge with the conserved Glu51 (see Supplementary Data, Figure S1A). The catalytic cysteine residues are engulfed and surrounded by several hydrophobic amino acids (see Figure S1B of Supplementary Data).

During the last refinement cycles, the Fourier difference maps clearly showed an elongated electron density in the entrance of both active site pockets. The electron density was interpreted as corresponding to a polyethylene glycol (PEG) molecule derived from the crystallization solution (see Materials and Methods). An ethylene glycol polymer with 17 non-hydrogen atoms could be modeled, which corresponds to a PEG molecule of approximately $400 \mathrm{Da}$ (Figure 4(a)). It is well known that commercially available PEG reagents contain a mixture of molecules of different molecular masses, which could explain the electron density for a lower molecular mass PEG than that used for crystallization. Another possibility is that only a portion of the molecule is ordered in the crystal and thus visible in the electron density maps.

The XfOhr active site pocket perfectly accommodates a PEG molecule that lies above the Arg19 sidechain and is involved in several hydrophobic contacts (Figure 4(b)). Notably, side-chains of residues Phe68, Phe96*, Val36* and Pro126 undergo significant displacement when compared to equivalent residues in $\mathrm{PaOhr}$ and DrOhr structures (Figure 4(c)). Furthermore, the entire loop Gly90Phe96 undergoes a displacement upon PEG binding (not shown).

Very similar electron density was found in both active sites of both structures $\left(\mathrm{XfOhr}_{\mathrm{fo}}\right.$ and $\mathrm{XfOhr}_{\mathrm{mo}}$ ), the position and conformation of the modeled PEG molecules being essentially the same (not shown). Monomers A and B are involved in different crystal contacts and the entrance of both active sites is highly exposed to the solvent, their structures not being stabilized by the crystal packing. These results suggest that the PEG binding is not a mere artifact induced by crystallization, but it may mimic the binding of the endogenous substrates. In fact, recent works have shown that PEG molecules can occupy sites and channels that naturally belong to long chain fatty acids. ${ }^{19-21}$ Interestingly, a peroxide molecule derived from oleic acid can be easily modeled into the PEG electron density with the peroxide function falling very close to Cys61 (Figure 5 and Figure S1C of Supplementary Data). Therefore, we propose here that physiological substrates of Ohr proteins may

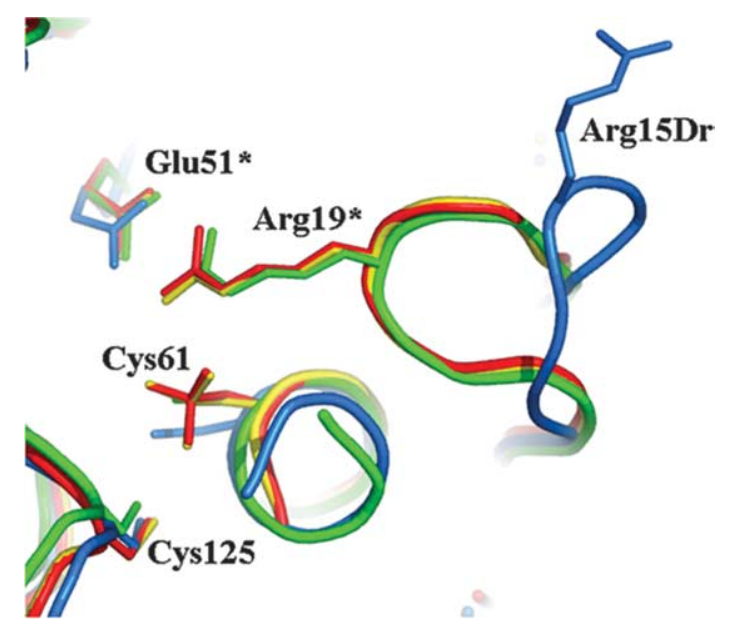

Figure 3. Active site of X. fastidiosa Ohr. In X. fastidiosa Ohr the loop containing the Arg19 (equivalent to Arg18 in $\mathrm{PaOhr}$ and Arg15 in DrOhr) adopts a conformation as in the reduced PaOhr structure $\left(\mathrm{Ohr}_{\mathrm{fo}}\right.$ is shown in red, $\mathrm{Ohr}_{\mathrm{mo}}$ in yellow, PaOhr in green and DrOhr in blue). The DrOhr atomic coordinates (PDB code 1USP) does not include the side-chain atoms of Arg15. We modeled a rotamer to illustrate the loop movement. 
(a)

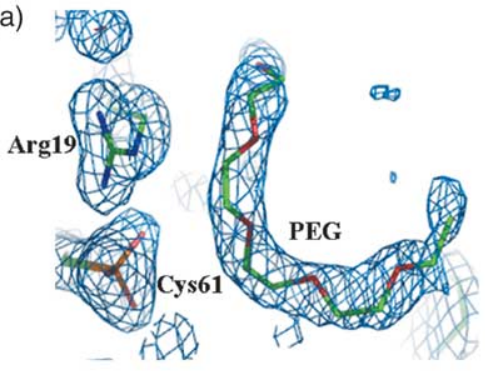

(b)

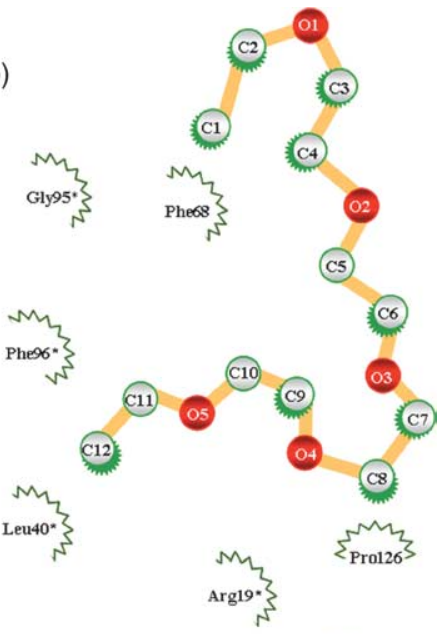

(c)
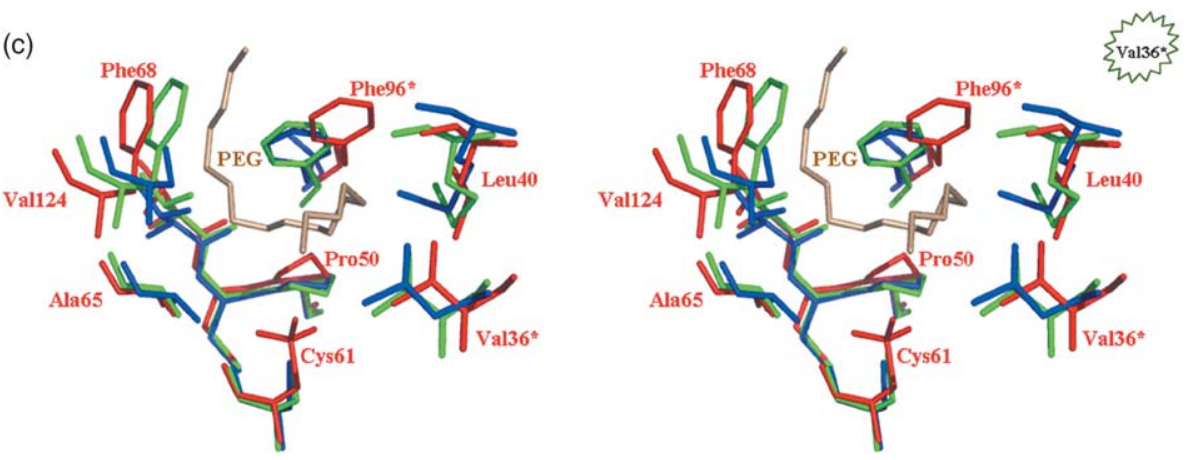

Figure 4. PEG binding in the X. fastidiosa $\mathrm{Ohr}_{\mathrm{fo}}$ active site pocket. (a) Final $2 F_{\mathrm{o}}-F_{\mathrm{c}}$ map contoured at $1.5 \sigma$ showing the PEG electron density. (b) Protein-PEG hydrophobic interactions according to LIGPLOT analysis. ${ }^{45}$ Hydrophobic interactions are shown in green. (c) Stereo image of active site residues superposition of $\mathrm{XfOhr}_{\mathrm{fo}}$ (red), $\mathrm{PaOhr}$ (green) and DrOhr (blue). The asterisk $\left(^{*}\right)$ refers to residues from the other monomer.

possess an elongated shape, such as peroxides derived from long chain fatty acids and lipoamide. Accordingly, XfOhr was able to reduce hydroperoxides derived from long chain fatty acids such as oleic acid, as observed by preliminary experiments (data not shown). Unfortunately, we could not establish enzymatic parameters for the decomposition of peroxide derived from oleic acid among other reasons because the solvents used to solubilize this oxidant, inhibited XfOhr activity.
We are working on the establishment of a suitable protocol to determine the catalytic constants.

\section{Characterization of Ohr catalytic intermediates}

As described in the previous section, Cys61 of $\mathrm{XfOhr}_{\mathrm{fo}}$ is in the sulfonic acid form, which is not reducible by standard reducing agents such as DTT and thioredoxin. It is well known that when thioldependent peroxidases have their reactive cysteine
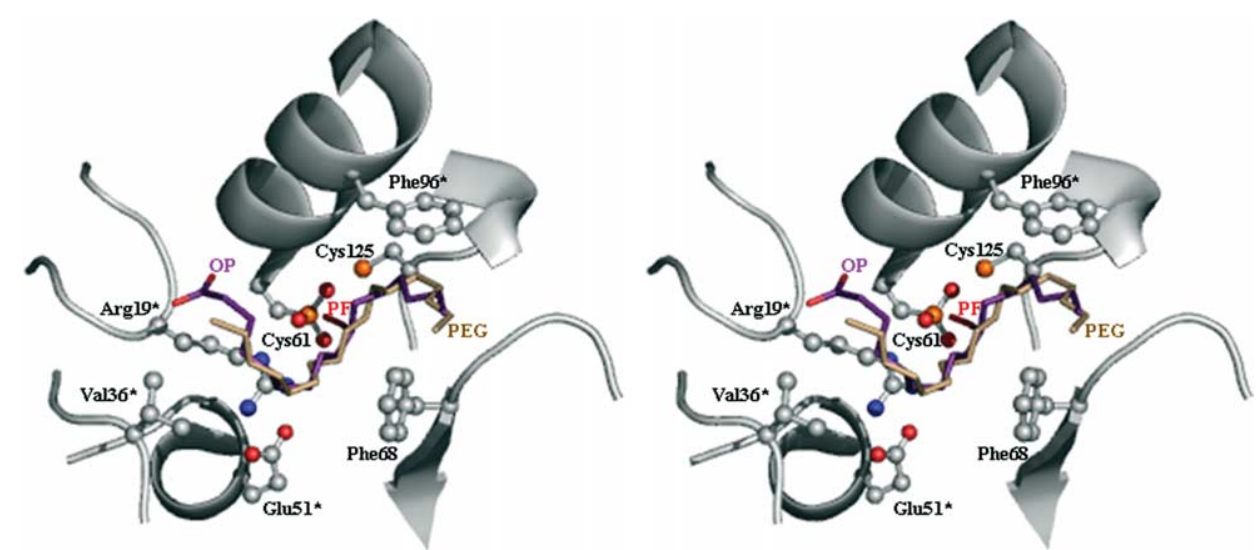

Figure 5. Model of binding of a fatty acid hydroperoxide to X. fastidiosa Ohr. A hydroperoxide derived from oleic acid ( $\mathrm{OP}=$ cis-hydroperoxide octadec 10 enoic acid) was manually modeled based on the PEG electron density. Note that the oxygen atoms of the peroxide function (PF) fall nearby the reactive cysteine side-chain (Cys61). 
residues over oxidized they are rendered inactive ${ }^{22}$ unless sulfiredoxin is present in the reaction mixture. ${ }^{23}$ Thus, we decided to verify whether $\mathrm{XfOhr}$ is susceptible to oxidative inactivation by treatment with a large excess of peroxides. Since XfOhr can accept electrons from lipoic acid, ${ }^{13} \mathrm{XfOhr}$ activity can be followed by decay in $A_{340} \mathrm{~nm}$ due to NADH absorption according to the pathway described below. A similar approach was described for a thiol-dependent peroxidase from Mycobacterium tuberculosis. ${ }^{24}$

$$
\begin{aligned}
& \mathrm{NADH} \rightarrow \text { lipoamide dehydrogenase (bovine) } \\
& \quad \rightarrow \text { lipoamide } \rightarrow \mathrm{Ohr} \rightarrow \text { peroxide }
\end{aligned}
$$

Initially, XfOhr activity was determined in the presence of various concentrations of peroxides and no inactivation was observed even when large excess of peroxides were employed (Figure 6(a)). Next, we decided to analyze the kinetics of inactivation after pre-incubation of XfOhr with amounts of peroxides equivalent to those employed in the crystallization trials (17t-BOOH:1XfOhr and $1 t$-BOOH:1XfOhr). After various intervals of incubation (indicated in the $X$-axis of Figure $6(\mathrm{~b})$ )), the excess of peroxide was removed by ultra-filtration and XfOhr activity was determined. Considerable inactivation was achieved only after $3 \mathrm{~h}$ of preincubation and only when XfOhr was incubated with large excess of $t$-BOOH (Figure 6(b)). Reversely, XfOhr was highly resistant to inactivation by $\mathrm{H}_{2} \mathrm{O}_{2}$, even under a condition where this peroxidase was extensively inactivated by $t-\mathrm{BOOH}$ (Figure 6(c)).

These findings are consistent with our previous observation that only $\mathrm{OHP}$, but not $\mathrm{H}_{2} \mathrm{O}_{2}$, can over oxidize XfOhr. ${ }^{13}$ This observation was based on the fact that in non-reducing SDS-PAGE the disulfide intermediate of XfOhr migrates faster than the other states. In fact, it is well known that proteins with an intra-molecular disulfide bond migrate faster in non-reducing SDS-PAGE than the other oxidation states. ${ }^{25}$ Therefore, we decided to mix XfOhr and peroxides in the same proportion (17 peroxides: 1 XfOhr) used to obtain the $\mathrm{XfOhr}_{\mathrm{fo}}$ crystals (Figure 7(a)). Two bands were detected for the non-treated XfOhr, which probably corresponds to the dithiol (band $b$ ) and the intra-molecular disulfide bond (band a), (Figure 7(a)). XfOhr treated with DTT migrated preferentially to position $b$ (lane 2), whereas $\mathrm{H}_{2} \mathrm{O}_{2}$ induced formation of band a (lane 7), as described. ${ }^{13} \mathrm{XfOhr}$ treated with diamide also provoked the formation of band a (lane 9). XfOhr pretreated with $\mathrm{H}_{2} \mathrm{O}_{2}$ or diamide and then treated with DTT migrated preferentially at position $\mathrm{b}$ (lanes 8 and 10, respectively), as would be expected for an intra-molecular disulfide reduction. These results represent further experimental evidence that an intramolecular disulfide is a redox intermediate of XfOhr because diamide induces only a disulfide bridge as an oxidation product. ${ }^{26}$
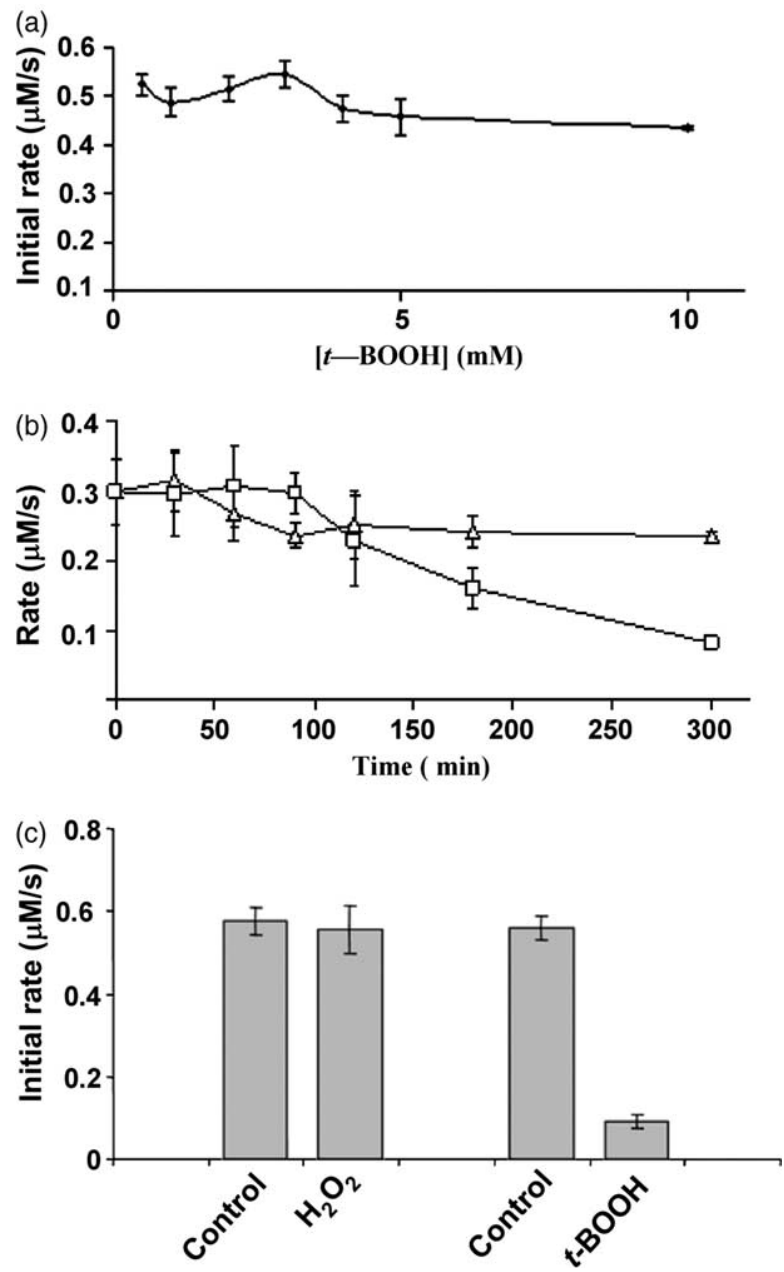

Figure 6. Determination of XfOhr activity. (a) NADH consumption assay. Reaction mixtures contained NADH, lipoamide, bovine dihydrolipoamide dehydrogenase, $\mathrm{XfOhr}$ and $t-\mathrm{BOOH}$ as described in Materials and Methods. (b) XfOhr inactivation kinetics after preincubation with $t$ - $\mathrm{BOOH}$. The amounts of peroxides were equivalent to those employed in the crystallization trials (17 $t$-BOOH:1XfOhr and $1 t$-BOOH:1XfOhr). After various intervals of incubation (indicated in the $X$-axis of (b)), the excess of peroxide was removed by ultrafiltration and XfOhr activity was determined by $\mathrm{NADH}$ consumption. (c) Oxidative inactivation of XfOhr by peroxides. XfOhr $(300 \mu M)$ was pre-incubated with $\mathrm{H}_{2} \mathrm{O}_{2}$ (5.1 mM) or with $5.1 \mathrm{mM} t$-BOOH for one week at $4{ }^{\circ} \mathrm{C}$. Excess of peroxides was removed and afterwards, NADH consumption was followed in the conditions described for (a), except that for $\mathrm{H}_{2} \mathrm{O}_{2}$, XfOhr was added at $5.9 \mu \mathrm{M}$ (ten times higher). Reactions were initiated by $300 \mu \mathrm{M}$ peroxide addition. Initial rates were obtained from the linear portion of the curve.

Interestingly, treatment of XfOhr with a large excess of OHPs did not induce the formation of band a (lanes 3 and 5), suggesting again that in this case $\mathrm{XfOhr}$ is over oxidized. In fact, no alteration in XfOhr migration was detected for the samples previously oxidized with OHPs and then treated 

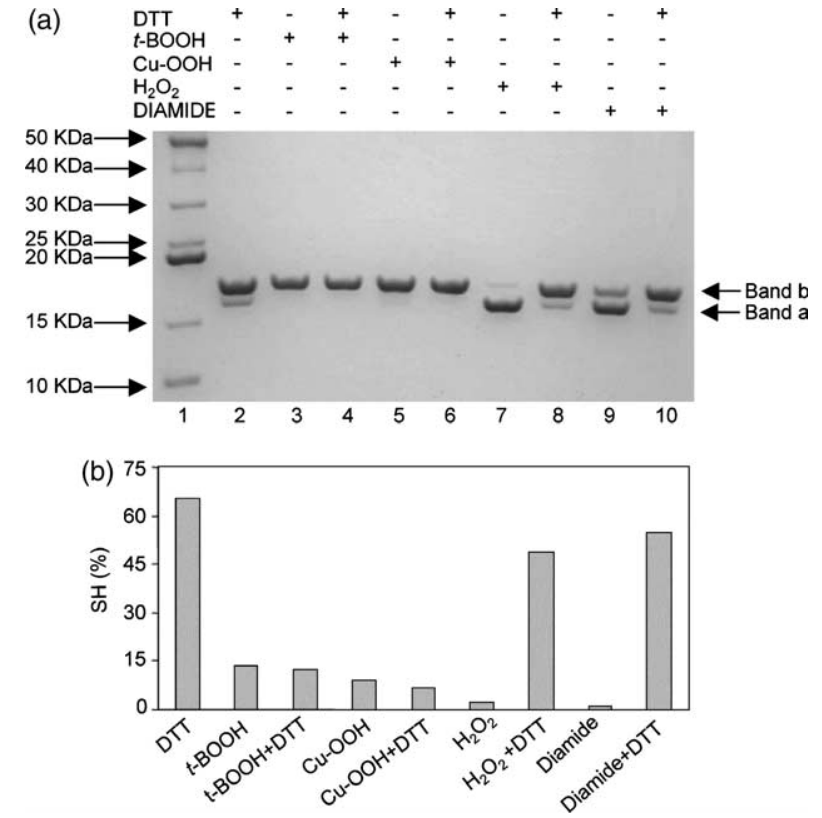

Figure 7. Analysis of intermediates in the Ohr catalytic cycle. (a) Non-reducing SDS-PAGE. Lane 1 corresponds to molecular mass standard and lane 2 corresponds to XfOhr treated with $100 \mathrm{mM}$ DTT for $90 \mathrm{~min}$. All oxidants added in the samples corresponding to lanes 3-10 were used in the 17:1 proportion (XfOhr $=300 \mu \mathrm{M}$, oxidant $=$ $5.1 \mathrm{mM}$ ) and were incubated overnight at room temperature. In some cases (lanes 4, 6, 8 and 10), after oxidation of $\mathrm{XfOhr}$, the excess of the oxidant was removed by elution in PD-10 columns and finally treated with $100 \mathrm{mM}$ DTT for $90 \mathrm{~min}$ at room temperature. (b) Ellman's assay. Sulfhydryl groups quantification by reaction with DTNB. Ohr was incubated with various oxidants during a week at $4{ }^{\circ} \mathrm{C}$. Redox agents were fixed at the proportion 17:1 of XfOhr. The columns presenting two names of substances designate that after treatment with oxidizing agent, their excess was eliminated by molecular exclusion chromatography and the protein was then treated with $100 \mathrm{mM}$ DTT in an attempt to regenerate their sulfhydryl groups.

with DTT (lanes 4 and 6), which is consistent with the fact that the sulfonic acids are not reducible by DTT. It is important to emphasize here that OHPs induce formation of band a, but only when added at stoichiometric amounts. ${ }^{13}$

Since reduced and over oxidized forms of Ohr are expected to migrate to the same position (band $b$ ) in SDS-PAGE, $^{13}$ we decided to investigate the formation of sulfhydryl groups in this anti-oxidant protein after treatment of Ohr with various redox compounds. Formation of sulfhydryl groups in XfOhr was monitored by reaction with DTNB, the Ellman's reagent. About $60 \%$ of XfOhr sulfhydryl groups reacted with DTNB after reduction with DTT (Figure 7(b)). These results probably reflect the fact that XfOhr cysteine residues are embedded in the polypeptide structure (see Figure S1B of Supplementary Data) and therefore their accessibility to DTNB would be difficult. In fact, all the
XfOhr sulfhydryl groups reacted with DTNB when reduction by DTT was carried out with protein denatured by $1 \%(\mathrm{w} / \mathrm{v})$ SDS (data not shown). Again, the crystallization conditions used to obtain $\mathrm{XfOhr}_{\mathrm{fo}}$ were simulated and oxidants were added in large excess over XfOhr. As expected, all of the oxidants decreased the amount of XfOhr sulfhydryl groups (Figure 7(b)). After elimination of the excess of these oxidants, XfOhr was treated with DTT in an attempt to regenerate their sulfhydryl groups. Regeneration of sulfhydryl groups only occurred when XfOhr was treated with oxidants under conditions expected to generate the intramolecular disulfide intermediate: that is $\mathrm{H}_{2} \mathrm{O}_{2}$ and diamide. Regeneration of sulfhydryl groups did not occur for XfOhr treated with OHP, which is consistent with the observation that only these compounds can over oxidize and inactivate XfOhr when added in large excess. The fact that $\mathrm{H}_{2} \mathrm{O}_{2}$ and diamide-treated XfOhr were reducible by DTT is further experimental evidence that an intra-molecular disulfide bond is in fact an intermediate of the catalytic cycle (Figure 7(b)). Accordingly, isoeletrofocusing gels indicated that more acidic forms of XfOhr were formed only when this protein was exposed to OHP for long intervals (data not shown).

In the structure of DrOhr, reactive cysteine is present as a mixture of oxidative states, among them an intramolecular disulfide form, ${ }^{18}$ which is consistent with our proposal that this intermediate is only generated under mild oxidative conditions. So far, we have presented results that further indicate that this intermediate is in fact formed in solution. To unequivocally demonstrate the identity of redox intermediates of XfOhr in solution, mass spectrometry experiments with native and trypsindigested enzyme were carried out (see Supplementary Data, Figures S2 and S3 and explanatory text for experimental details). In agreement with our biochemical assays, we observed intramolecular disulfide bond formation by mass spectrometry experiments when XfOhr was treated with $\mathrm{H}_{2} \mathrm{O}_{2}$ and diamide (Table 1). $t$-BOOH also induced intramolecular disulfide bond formation but only when added at much lower doses $(1 t$-BOOH: 1 $\mathrm{XfOhr}$ ). Contrary to the differential reactivity towards cysteine residues, both $\mathrm{H}_{2} \mathrm{O}_{2}$ and $t$ - $\mathrm{BOOH}$ oxidized methionine residues (Table 1 ).

\section{Discussion}

A detailed characterization of the molecular mechanism of a protein belonging to the Ohr family was performed using multiple approaches. $\mathrm{XfOhr}_{\text {mo }}$ structure and biochemical assays have unequivocally shown that an intramolecular disulfide is a redox intermediate of XfOhr in solution (Table 1). Furthermore, the elucidation of XfOhr structure in complex with PEG and comparisons with Ohr from other species, which are in different oxidative states, provides a set of snapshots along the coordinate of the enzyme-catalyzed reaction 
Table 1. Characteristics of Ohr protein under various redox conditions

\begin{tabular}{|c|c|c|c|c|c|}
\hline Ligand & $\begin{array}{l}\text { Inactivation } \\
(\%)^{\mathrm{a}}\end{array}$ & $\begin{array}{l}-\mathrm{SH} \text { recovery } \\
(\%)^{\mathrm{b}}\end{array}$ & Gel migration $^{c}$ & $\begin{array}{l}\text { Products detected by mass } \\
\text { spectra }^{\mathrm{d}}\end{array}$ & Crystallographic structure \\
\hline $\mathrm{H}_{2} \mathrm{O}_{2}$ & $\mathrm{O}$ & 70 & -RSSR- (intra) & $\begin{array}{l}\text {-RSSR- (intra) C(SO)C } \\
\text { (Met. sulfoxide) }\end{array}$ & ND \\
\hline Diamide & ND & 70 & -RSSR-(intra) & -RSSR-(intra) & ND \\
\hline$t-\mathrm{BOOH}$ & 84 & 0 & $-\mathrm{CysSO}{ }_{3} \mathrm{H}$ & $\begin{array}{l}\text {-CysSSCys-(intra) }{ }^{\mathrm{e}} \\
-{\text { - } y s \mathrm{SO}_{3} \mathrm{H}} \\
\text { Met-C(SO)C (Met. sulfoxide) }\end{array}$ & $\begin{array}{l}\text { CysSSCys-(intra) } \\
- \text { CysSO }_{3} \mathrm{H} \\
\text { Met-C(SO)C (Met. sulfoxide) }\end{array}$ \\
\hline $\mathrm{Cu}-\mathrm{OOH}$ & ND & 0 & $-\mathrm{CysSO}_{3} \mathrm{H}$ & ND & ND \\
\hline DTT & 0 & 100 & 2Cys-SH & $2 \mathrm{Cys}-\mathrm{SH}$ & $2 \mathrm{Cys} \mathrm{SH}^{\mathrm{f}}$ \\
\hline
\end{tabular}

ND, not determined.

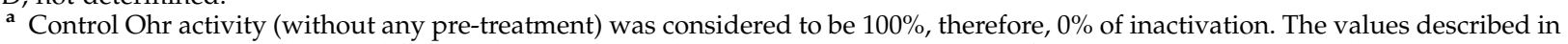
this column were obtained by the difference between control activities minus the activity after Ohr treatment by high doses (17 oxidant:1 XfOhr) of oxidants (see the legend to Figure 6(c)).

b Recovery of sulfhydryl groups after exposure of XfOhr to high doses of oxidants (17 oxidants: 1 XfOhr). Experimental details are described in the legend to Figure 7(b). Recovery was calculated considering the amount of sulfhydryl group in the protein reduced by DTT as $100 \%$.

c Redox states described in this column were proposed based on the fast migration on intra-molecular disulfide bond relative to the other oxidative states. ${ }^{13}$ Again, $\mathrm{XfOhr}$ was treated with high doses of oxidants (17:1).

d Oxidative states determined by native and trypsin digested XfOhr under various conditions. See Supplementary Data for experimental details.

e Disulfide was only observed when XfOhr was mildly oxidized (1 XfOhr:1 $t$-BOOH).

f Structure described by Lesniak et al. ${ }^{14}$

(Figure 8). In the reduced form (Figure 8(i)), the Arg19 containing loop is closed and the respective guanidine group is stabilized by a salt bridge with conserved Glu51 and an H-bond with Cys61 $\left(\mathrm{S}^{\gamma}\right)$, as seen in PaOhr structure. ${ }^{14}$ Arg19 is likely to make a major contribution to the stabilization of the Cys61 thiolate anion. In the next step (Figure 8(ii)), the substrate binds to the active site. In vitro, different types of peroxides can be reduced by $\mathrm{Ohr},{ }^{13,14}$ but according to the structure of XfOhr-PEG complex, the active site can better accommodate elongated molecules which interact with the hydrophobic
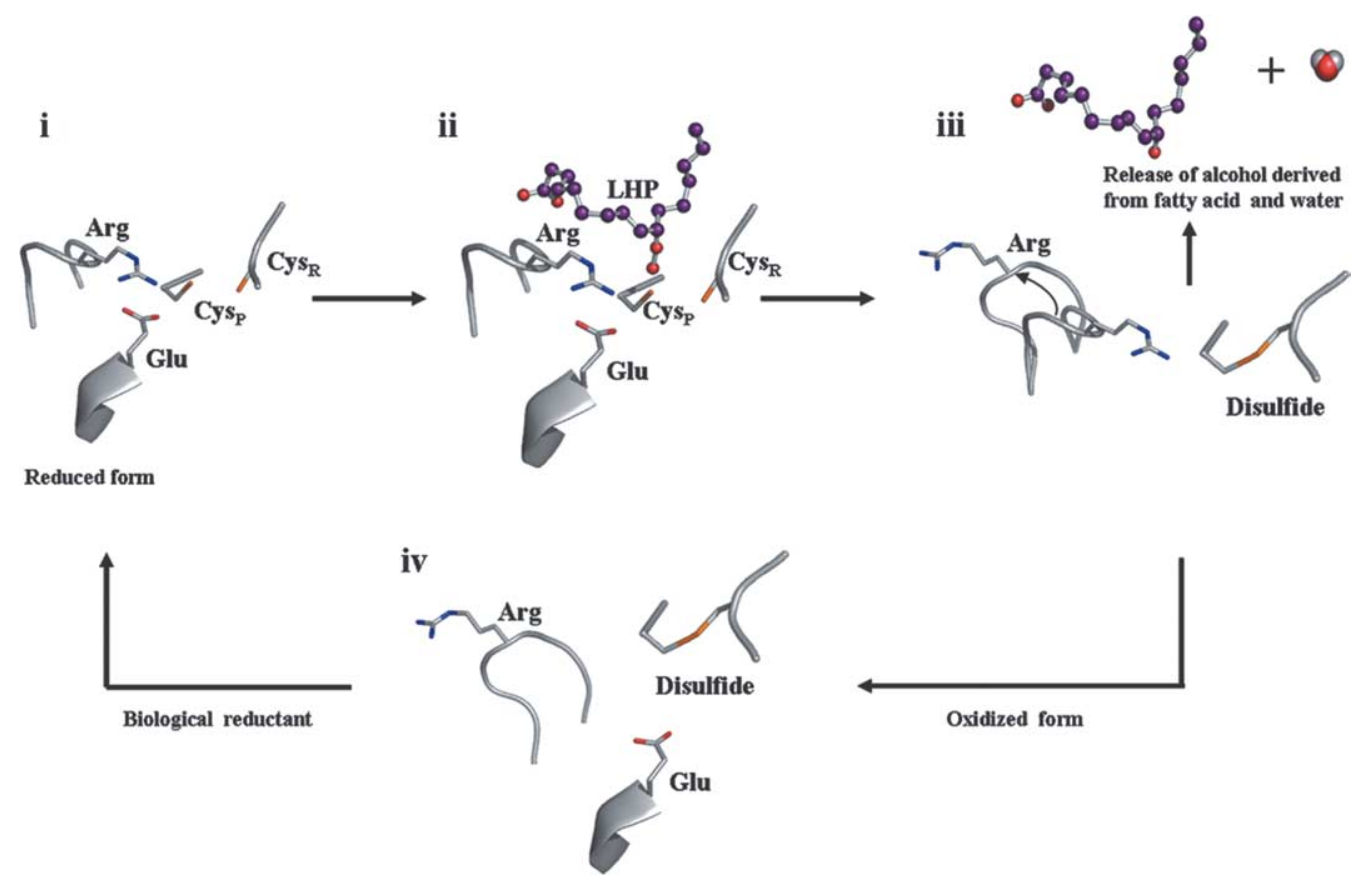

Figure 8. Proposed molecular mechanism of lipid hydroperoxides reduction by Ohr. (i) Reduced form of the enzyme (Cys61-S ${ }^{-}$). The guanidine group of Arg19* is stabilized by a salt bridge with conserved Glu and an H-bond with $\mathrm{S}^{\gamma}$ of Cys61. (ii) The lipid hydroperoxide (LHP) binds to the active site, standing over the hydrophobic moiety of the Arg19* side-chain and is stabilized by a number of hydrophophic interactions (see Figures 4(c) and 5(a)). (iii) After peroxide reduction, Cys61 is oxidized to sulfenic acid $(\mathrm{SOH})$, which is quickly attacked by the sulfhydryl group of Cys125, forming an intra-molecular disulfide. The loop containing Arg19* detaches, releasing the lipid with an alcohol function. (iv) The last step involves the reduction of the disulfide by a biological reductant (dithiol) and a rearrangement of the loop bringing the Arg back to the active site. 
moiety of the Arg19 side-chain, stabilized by a number of additional hydrophophic interactions (Figure 4). Remarkably, the oxygen atoms of the peroxide function of modeled fatty acid peroxide appear nearby Cys61 (Figure 5). After peroxide decomposition (Figure 8(iii)), Cys61 is oxidized to sulfenic acid (Cys-SOH), which is quickly attacked by the sulfhydryl group of the resolving cysteine (Cys125) forming an intra-molecular disulfide. The loop containing Arg19 detaches, releasing the product (an alcohol derivative) and consequently, Ohr adopts the open conformation, as seen in DrOhr structure. ${ }^{18}$ Finally, the last step (Figure 8(iv)) involves the reduction of the disulfide by a redox partner and a rearrangement of the loop, bringing the Arg19 side-chain back to the active site. The detailed molecular mechanism involved in this step remains to be elucidated, since the biological partner of Ohr protein is not known, although lipoamide has been considered as a candidate. ${ }^{13,88}$

According to this model, Ohr can be overoxidized to sulfonic acid (Cys- $\left.\mathrm{SO}_{3} \mathrm{H}\right)$ if the sulfenic acid (Cys-SOH) intermediate reacts with two peroxide molecules, probably in two steps. Since the sulfenic acid of Cys61 is probably very reactive towards Cys125, its over oxidation to sulfonic acid should occur only when very high concentrations of peroxide are employed, which is consistent with our data obtained through several biochemical assays (Table 1).

At this point, it is elucidative to compare Ohr and OsmC structures. Four structures from three different proteins belonging to different species (E. coli, Mycoplasma pneumoniae and Thermus thermophilus) were reported. ${ }^{16,17,27,28}$ The overall quartenary structures are very similar, but variations can be observed specially in the N-terminal region corresponding to the loop where arginine 19 is located in XfOhr. The N-terminal loops in OsmC proteins are longer and contain a more extended $\beta$-strand. Whereas Glu51 is conserved in all OsmC structures, the function of Arg19 of XfOhr is replaced by a nonconserved arginine residue that is located farther away (Arg39 in E. coli). ${ }^{16,17,27}$ Furthermore, other residues in the active site of $\mathrm{Ohr}$ are replaced in OsmC. As an example, OsmC presents a higher content of aliphatic amino acids (e.g. Phe) and other substitutions, such as tyrosine 58 and 127 of XfOhr are replaced in OsmC for His and Val residues, respectively. These differences, among others, are reflected in the different shapes of OsmC and Ohr active sites. $^{16,17,27}$

Interestingly, in the case of OsmC protein from T. thermophilus, the reactive cysteine is also over oxidized but in a sulfinate $\left(\mathrm{Cys}-\mathrm{SO}_{2} \mathrm{H}\right)$ instead of a sulfonate state $\left(\mathrm{Cys}-\mathrm{SO}_{3} \mathrm{H}\right) .{ }^{17}$ In this case, one of the oxygen atoms of the sulfinate is stabilized by two hydrogen bonds with $\mathrm{N}^{\eta}$ of arginine 37 . In the case of XfOhr, no evidence of sulfinic acid formation was obtained by crystal structure and by mass spectrometry experiments (see Supplementary Data, Figures S1A, S2 and S3 and explanatory text). Instead, our results indicate that the formation and stabilization of a sulfonate is strongly favored. Two oxygen atoms (OD1 and OD2) of the sulfonylated cysteine in $\mathrm{XfOhr}_{\mathrm{fo}}$ structure form H-bonds with the $\mathrm{N}^{\varepsilon}$ and $\mathrm{N}^{\eta 1}$ of arginine 19 , respectively. The third oxygen atom (OD3) interacts with the sulfur of Cys125 (Figure S1A of Supplementary Data). Further experimental support for the strong stabilization of sulfonylated cysteine came from mass spectrometry experiments. In fact, peaks corresponding to the XfOhr dimer during mass spectrometry experiments were detected only when this enzyme was pre-treated under conditions in which the sulfonylated cysteine is expected to form (data not shown).

The hydrophobicity of the active site (see Figure S1B of Supplementary Data) might prevent cysteine residues from being exposed to high concentrations of hydrophilic peroxides, such as $\mathrm{H}_{2} \mathrm{O}_{2}$, and consequently avoid over oxidation of this residue to sulfonate state. In fact, all of the reduced cysteine residues in XfOhr were only detected when this protein was previously denatured by SDS (data not shown). The hydrophobicity of the XfOhr active site may be related to the fact that this peroxidase is only reduced by dithiols like DTT and DHLA but not by monothiols, ${ }^{13}$ because these reductants are hydrated. Since the reduction of a disulfide bond by a monothiol requires two molecules of reductants whereas reduction by a dithiol requires only one molecule, less water might need to be removed, when compounds with two sulfhydryl groups are utilized as substrates by XfOhr. In any case, apparently there is no steric restraint for the accommodation of two monothiol molecules into the XfOhr active site as shown by molecular modeling (data not shown). It is also possible that this specificity relies on the higher redox potentials of dithiols in comparison with monothiols.

In addition to hydrophobicity, our studies also suggested that the biological Ohr substrate/ partner can be molecules of elongated shape. In this regard, the heterologous system containing $\mathrm{NADH}$, bovine lipoamide dehydrogenase and lipoamide, was shown to efficiently support XfOhr peroxidase activity. In a similar approach described for a thiol-dependent peroxidase from Mycobacterium turbeculosis, Bryk et al. ${ }^{24}$ utilized a system containing lipoamide bound through an amide linkage to dihydrolipoamide succinyltransferase, which was more efficient than the heterologous one. This kind of structural organization situates the lipoamide molecule in a manner to construct an elongated shaped arm-like structure. The genome analysis shows that the lipoamide containing enzymes are present in X. fastidiosa and thus it may be a possible XfOhr reductant system. ${ }^{13}$

The results presented here also support the hypothesis that peroxides derived from long chain fatty acids can be substrates of Ohr (Figures 4 
and 5). These insights into enzyme-substrate interaction came in part from the analysis of XfOhr structures in complex with PEG (Figure 5). Interestingly, electron density from a PEG molecule was only observed in XfOhr amongst all OsmC and Ohr structures described. DrOhr crystallization condition contains PEG $4000,{ }^{18}$ the same PEG used to obtain XfOhr crystals. We believe that because in the DrOhr structure the N-terminal Arg loop adopts an open conformation that corresponds to the situation of substrate release (Figure 8(iv)), this should avoid PEG/substrate binding. In the case of PaOhr, the catalytic cysteine residues are in the reduced state (closed conformation), suitable for PEG/substrate binding (Figure 8(ii)). However, the presence of a DTT molecule in the active site might have avoided the accommodation of a PEG molecule, even when this precipitant was present in the mother liquor. Finally, the absence of PEG molecules in the OsmC structures might be related with the differences in the shapes of their active sites. It is noteworthy the fact that in E. coli OsmC, a phenylalanine residue is bound to the entrance of the active site, suggesting that the substrate of these enzymes might be aromatic hydroperoxides, ${ }^{27}$ instead of elongated and hydrophobic molecules. Finally, the exclusive presence of PEG in the active site of XfOhr among all OsmC/Ohr described structures perhaps is somehow related with the fact that only this enzyme possesses their reactive cysteine residues in the sulfonate state which provoked a stronger stabilization of the closed conformation of the Arg loop (Figure S1A of Supplementary Data).

In cells, OHPs should be generated by oxidation of double bonds in both mono and polyunsaturated fatty acids. Despite that the majority of the bacterial fatty acids are saturated, a considerable fraction of these biomolecules are monounsaturated in certain pathogenic bacteria. ${ }^{29-31}$. Recently, nuclear magnetic resonance spectroscopy studies revealed that $X$. fastidiosa also possesses a large amount of oleic (18:1), palmitoleic (16:1) and vaccenic (18:1) fatty acids in its membrane. ${ }^{32}$ We are currently investigating the reduction of peroxides derived from unsaturated fatty acids by Ohr. Nevertheless, preliminary results indicate that peroxide derived from linoleic acid is reduced by XfOhr with efficiency comparable with $t-\mathrm{BOOH}$, therefore, at least one order of magnitude higher than $\mathrm{H}_{2} \mathrm{O}_{2}$. Furthermore, the finding that $\mathrm{Ohr}$ play a central role in the adaptive response of Xanthomonas to linoleic hydroperoxide supports the idea that elongated fatty acid peroxides might be the substrate of this peroxidase. $^{11}$

Because Ohr proteins are exclusively present in bacteria, most of them causative agents of disease in animals and plants, thus they may represent promising targets for therapeutical drugs. In this regard, the detailed characterization of Ohr catalytic intermediates presented here would probably be very useful.

\section{Materials and Methods}

\section{Crystallization and data collection}

$X$. fastidiosa Ohr was expressed, purified and crystallized as described. ${ }^{33}$ In an attempt to obtain the crystal structure of XfOhr in different oxidative states, after purification, XfOhr was incubated with several redox agents such as $\mathrm{H}_{2} \mathrm{O}_{2}$, tert-butyl hydroperoxide ( $t$ $\mathrm{BOOH})$, diamide and DTT at different concentrations. Afterwards, crystallization trials were performed using the hanging-drop vapor diffusion method and crystals were obtained from protein samples incubated with $10 \mathrm{mM}$ or $0.58 \mathrm{mM}$ of $t-\mathrm{BOOH}$ at $310 \mathrm{~K}$ for $1 \mathrm{~h}$. These treatments correspond to molecular proportions of 17 $t$-BOOH to $1 \mathrm{XfOhr}$ and $1 \mathrm{t}$-BOOH to $1 \mathrm{XfOhr}$, respectively. The optimal crystallization condition was obtained with the reservoir solution consisting of $25 \%$ (w/v) PEG 4000 and $0.1 \mathrm{M}$ Tris- $\mathrm{HCl}$ buffer ( $\mathrm{pH} 8.7$ ). The crystals obtained from samples treated with $10 \mathrm{mM}$ t-BOOH $\quad\left(\right.$ ffOhr $\left._{\mathrm{fo}}\right)$ reached $0.25 \mathrm{~mm} \times 0.25 \mathrm{~mm} \times$ $0.05 \mathrm{~mm}$ after two weeks. The crystals obtained from samples treated with $0.58 \mathrm{mM} t-\mathrm{BOOH}\left(\mathrm{XfOhr}_{\mathrm{mo}}\right)$ reached $0.20 \mathrm{~mm} \times 0.20 \mathrm{~mm} \times 0.05 \mathrm{~mm}$ after eight weeks.

The crystals, cryo-protected by $25 \%$ glycerol, were cooled to $110 \mathrm{~K}$ and X-ray diffraction data were collected using synchrotron radiation at the protein crystallography beamline D03B at the Brazilian Synchroton Light Laboratory. Data sets were indexed using the program MOSFLM ${ }^{34}$ and the resulting intensities were scaled and merged using the program SCALA ${ }^{35,36}$ from the CCP4 package. ${ }^{37}$ Unit cell parameters and data collection statistics are shown in Table 2. The data for $\mathrm{XfOhr}_{\mathrm{fo}}$ have been reported by Oliveira et $a l^{33}$ and are repeated here for comparison.

Table 2. Crystal parameters and data collection statistics

\begin{tabular}{|c|c|c|}
\hline Ohr crystals & $\mathrm{Ohr}_{\mathrm{fo}}{ }^{\mathrm{a}}$ & $\mathrm{Ohr}_{\mathrm{mo}}$ \\
\hline Space group & $P_{6} 22$ & $P_{6} 22$ \\
\hline Unit-cell parameters $(\AA)$ & $a=b=87.6$ and $c=160.2$ & $a=b=91.5$ and $c=157.6$ \\
\hline Resolution limits $(\AA)$ & $34.30-1.80(1.90-1.80)$ & $79.31-2.40(2.53-2.40)$ \\
\hline Total no. reflections & 370,764 & 117,837 \\
\hline No. unique reflections & 34,330 & 15,924 \\
\hline Completeness (\%) & $99.9(99.9)$ & $99.9(99.9)$ \\
\hline Multiplicity & $10.8(11.1)$ & $7.4(7.1)$ \\
\hline$R_{\mathrm{sym}}(\%)$ & $7.4(32.8)$ & $6.1(26.7)$ \\
\hline$\langle I / \sigma(I)\rangle$ & $6.2(2.2)$ & $10.3(2.8)$ \\
\hline
\end{tabular}


Table 3. Refinement statistics of X. fastidiosa Ohr crystals

\begin{tabular}{|c|c|c|}
\hline Ohr crystals & $\mathrm{Ohr}_{\text {fo }}$ & $\mathrm{Ohr}_{\mathrm{mo}}$ \\
\hline \multicolumn{3}{|l|}{ Reflections } \\
\hline Working & 32,616 & 15,130 \\
\hline Test & 1714 & 794 \\
\hline $\begin{array}{l}\text { Non-hydrogen atoms (except } \\
\text { waters) }\end{array}$ & 2342 & 2294 \\
\hline No. of water molecules & 256 & 182 \\
\hline $\begin{array}{l}R_{\text {factor }} / R_{\text {free }}(\%) \\
\text { r.m.s.d. values }\end{array}$ & $19.6 / 21.4$ & $19.2 / 24.3$ \\
\hline Bonds & 0.005 & 0.012 \\
\hline Angles & 1.8 & 1.7 \\
\hline \multicolumn{3}{|l|}{ Average $B$ factor } \\
\hline Main-chain & 19.7 & 27.2 \\
\hline Side-chains and water molecules & 24.6 & 28.6 \\
\hline \multicolumn{3}{|l|}{ Ramachandran analysis (\%) } \\
\hline Favored regions & 94.1 & 95.6 \\
\hline Additionally, allowed regions & 5.9 & 4.4 \\
\hline PDB code & 1ZB9 & 1ZB8 \\
\hline
\end{tabular}

\section{Structure determination and refinement}

The structures were solved by molecular replacement using the program AMoRe. ${ }^{38}$ The $\mathrm{XfOhr}_{\text {fo }}$ structure was solved using the atomic coordinates of P. aeruginosa $\mathrm{Ohr}$ (PDB code 1N2F) as the search model. Crystallographic refinement was carried out using the CNS package. ${ }^{39}$ Initial model for $\mathrm{XfOhr}_{\mathrm{mo}}$ was obtained from the $\mathrm{XfOhr}_{\mathrm{fo}}$ coordinates. Structure refinement was performed using the program REFMAC 5.0. ${ }^{40}$ In both cases, refinement cycles were alternated with visual inspection of the electron density maps and model rebuilding with the program O. ${ }^{41}$ During the final cycles water molecules were introduced using the program Water Pick from the CNS package for the $\mathrm{XfOhr}_{\mathrm{fo}}$ structure and $\mathrm{ARP} / \mathrm{wARP}^{42}$ in the case of $\mathrm{XfOhr}_{\mathrm{mo}}$. At this stage of the $\mathrm{XfOhr}_{\mathrm{mo}}$ refinement, the $F_{\mathrm{o}}-F_{\mathrm{c}}$ electron density map clearly showed the presence of additional atoms when the reactive cysteine was modeled in the reduced form $(\mathrm{Cys}-\mathrm{SH})$, nevertheless a sulfonic acid $\left(\mathrm{Cys}-\mathrm{SO}_{3} \mathrm{H}\right)$ also did not fit well to the electron density after refinement. The Cys- $\mathrm{SO}_{3} \mathrm{H}$ oxygen atoms were then refined with occupancies varying from 0.0 to 1.0. Based on careful analysis of the Fourier difference maps, their final occupancies were fixed at 0.4 , as the best model for the mixture of the different oxidation states present in the crystal (see Results). After fixing occupancies to $0.4, B$ values of OD1, OD2 and OD3 were refined to 15.0, 16.0 and $17.6 \AA^{2}$, respectively, while protein atoms around present B-factors varied from $18.0 \AA^{2}$ to $22.0 \AA^{2}$. The final models present an $R_{\text {factor }}$ of $0.196\left(R_{\text {free }}=0.214\right)$ and $R_{\text {factor }}$ of $0.192\left(R_{\text {free }}=0.243\right)$ for $X_{f O h r_{f o}}$ and $X_{f O h r}$, respectively, with good overall stereochemistry. As defined by the program PROCHECK ${ }^{43}$ all non-glycine and non-proline residues fall in the most favored or additionally allowed regions of the Ramachandran plot. Further details of refinement are presented in Table 3. Molecular graphic Figures were generated using the program Pymol†.

\section{Determination of XfOhr activity by lipoamide system}

An assay to measure XfOhr activity was developed based on the ability of this enzyme to utilize lipoic acid as

$\dagger$ http:/ / www.pymol.org substrate. ${ }^{24}$ Using recombinant bovine lipoamide dehydrogenase (L-6777) and lipoamide (T-5875) from Sigma Co. (St. Louis, MO), decay in $A_{340 \mathrm{~nm}}$ due to NADH absorbance was followed in reaction mixtures that contained $50 \mathrm{mM}$ Kpi (pH 7.0), $100 \mu \mathrm{M}$ EDTA (pH 8.0), $0.2 \mathrm{mM}$ NADH, $50 \mu \mathrm{M}$ lipoamide, 0.4 unit dihydrolipoamide dehydrogenase and $0.59 \mu \mathrm{M}$ XfOhr. Reactions were carried out at $25^{\circ} \mathrm{C}$ and were initiated by addition of peroxide at various concentrations.

The experiments that simulate the conditions to obtain $\mathrm{XfOhr}_{\mathrm{fo}}$ crystals were carried out by pre-treatment of $300 \mu \mathrm{M}$ XfOhr with $5.1 \mathrm{mM} t$-BOOH (equivalent to 17 molecules of peroxide to 1 molecule of protein) for one week at $4{ }^{\circ} \mathrm{C}$. Excess of peroxide was removed by elution in PD-10 desalting columns (Amersham Biosciences). XfOhr was also submitted to similar pre-treatment with $\mathrm{H}_{2} \mathrm{O}_{2}$. XfOhr activity was then measured by $\mathrm{NADH}$ consumption under the conditions described above using the lipoamide assay system.

\section{Determination of sulfhydryl groups content in XfOhr}

XfOhr aliquots $(300 \mu \mathrm{M})$ were pretreated for one week at $4{ }^{\circ} \mathrm{C}$ with the following oxidants: diamide, $\mathrm{H}_{2} \mathrm{O}_{2}$ or $t$ - $\mathrm{BOOH}$ at $17: 1$ stoichiometry (oxidant/protein). The excess of oxidants was removed by PD-10 desalting columns (Amersham Biosciences) and the amount of thiol groups remaining in XfOhr was determined by Ellman's reagent (DTNB) assay, in the presence of $1 \%$ SDS. ${ }^{44}$ In addition to these measurements, sulfhydryl groups in XfOhr were also determined after removal of the oxidants and subsequent treatment with DTT $(100 \mathrm{mM})$ for $90 \mathrm{~min}$ at room temperature, to verify possible regeneration of sulfhydryl groups in XfOhr. As a control, XfOhr was also reduced by $100 \mathrm{mM}$ DTT for $90 \mathrm{~min}$ at room temperature and the excess of DTT was removed by elution in PD-10 desalting columns (Amersham Biosciences) prior to DTNB measurements.

\section{Electrospray ionization mass spectrometry}

Protein sample solutions in $5 \mathrm{mM}$ Tris- $\mathrm{HCl}$ buffer $(\mathrm{pH}$ 7.5) were treated with redox agents as described above at the same concentrations for $90 \mathrm{~min}$ or one week. After treatment the samples were diluted to $0.58 \mathrm{nM}$ and mass spectrometric experiments were performed in a ESI quadrupole time of flight mass spectrometer (Q-Tof Ultima API, Micromass) coupled with a capillary HPLC system (CapLC; Micromass, UK). For protein mass measurement experiments, the samples $(6 \mu \mathrm{l}$, corresponding to $3.5 \mathrm{nmol})$ were desalted on-line using a C18 trap column (Optipak C18; Waters). The protein was eluted from the trap column using a $1: 1$ water/acetonitrile $+0.1 \% \quad(\mathrm{v} / \mathrm{v})$ formic acid solution. The protein spectra were deconvoluted using the MaxEnt 1 program as supplied by the manufacturer.

For the LC-MS/MS analysis, the samples were digested with trypsin for $4 \mathrm{~h}$ at $37^{\circ} \mathrm{C}$ in $50 \mathrm{mM}$ $\mathrm{NH}_{4} \mathrm{HCO}_{3}$. The peptides $(6 \mu \mathrm{l})$ were desalted on-line and eluted using a gradient of $0-60 \%(\mathrm{v} / \mathrm{v})$ acetonitrile for $1 \mathrm{~h}$. The spectra were acquired using the Data Directed Analysis, selecting the doubly and triply charged peptides for MS/MS experiments. All the MS/MS spectra were processed using the Proteinlynx Global Server software and the MASCOT search engine (Matrix Science, Boston). 


\section{Protein Data Bank accession codes}

The atomic coordinates have been deposited with the RCSB Protein Data Bank and are available under accession codes 1ZB9 $\left(\mathrm{Ohr}_{\mathrm{fo}}\right)$ and 1ZB8 $\left(\mathrm{Ohr}_{\mathrm{mo}}\right)$.

\section{Acknowledgements}

This work is supported by grants from Fundação de Amparo à Pesquisa do Estado de São Paulo (FAPESP); Conselho Nacional de Pesquisa e Tecnologia $(\mathrm{CNPq})$, as part of the Instituto do Milênio Redoxoma and by the Brazilian Synchrotron Light Laboratory (LNLS) under proposals D03B - 1689 and MAS - 3149. We thank Jim Hesson for the revision of English grammar.

\section{Supplementary Data}

Supplementary data associated with this article can be found, in the online version, at doi:10.1016/ j.jmb.2006.03.054

\section{References}

1. Akaike, T., Sato, K., Ijiri, S., Miyamoto, Y., Kohno, M., Ando, M. \& Maeda, H. (1992). Bactericidal activity of alkyl peroxyl radicals generated by heme-iron-catalyzed decomposition of organic peroxides. Arch. Biochem. Biophys. 294, 55-63.

2. Tenhaken, R., Levine, A., Brisson, L. F., Dixon, R. A. \& Lamb, C. (1995). Function of the oxidative burst in hypersensitive disease resistance. Proc. Natl Acad. Sci. USA, 92, 4158-4163.

3. Storz, G., Tartaglia, L. A., Farr, S. B. \& Ames, B. N. (1990). Bacterial defenses against oxidative stress. Trends Genet. 6, 363-368.

4. Mongkolsuk, S., Praituan, W., Loprasert, S. Fuangthong, M. \& Chamnongpol, S. (1998). Identification and characterization of a new organic hydroperoxide resistance gene $(\mathrm{ohr})$ with a novel pattern of oxidative stress regulation from Xanthomonas campestris pv. phaseoli. J. Bacteriol. 180, 2636-2643.

5. Poole, L. B. (2005). Bacterial defenses against oxidants: mechanistic features of cysteine-based peroxidases and their flavoprotein reductases. Arch. Biochem. Biophys. 433, 240-254.

6. Gobel, C., Feussner, I. \& Rosal, S. (2003). Lipid peroxidation during the hypersensitive response in potato in the absence of 9-lipoxygenases. J. Biol. Chem. 278, 52834-52840.

7. Richter, C. (1987). Biophysical consequences of lipid peroxidation in membranes. Chem. Phys. Lipids, 44, 175-189.

8. Girotti, A. W. (1998). Lipid hydroperoxide generation, turnover, and effector action in biological systems. J. Lipid Res. 39, 1529-1542.

9. Copley, S. D., Novak, W. R. \& Babbitt, P. C. (2004). Divergence of function in the thioredoxin fold suprafamily: evidence for evolution of peroxiredoxins from a thioredoxin-like ancestor. Biochemistry, 43, 13981-13995.
10. Fuangthong, M., Atichartpongkul, S., Mongkolsuk, S. \& Helmann, J. D. (2001). OhrR is a repressor of ohrA, a key organic hydroperoxide resistance determinant in Bacillus subtilis. J. Bacteriol. 183, 4134-4141.

11. Klomsiri, C., Panmanee, W., Dharmsthiti, S., Vattanaviboon, P. \& Mongkolsuk, S. (2005). Novel roles of ohrR-ohr in Xanthomonas sensing, metabolism, and physiological adaptive response to lipid hydroperoxide. J. Bacteriol. 187, 3277-3281.

12. Atichartpongkul, S., Loprasert, S., Vattanaviboon, P., Whangsuk, W., Helmann, J. D. \& Mongkolsuk, S. (2001). Bacterial Ohr and OsmC paralogues define two protein families with distinct functions and patterns of expression. Microbiology, 147, 1775-1782.

13. Cussiol, J. R., Alves, S. V., Oliveira, M. A. \& Netto, L. E. S. (2003). Organic hydroperoxide resistance gene encodes a thiol-dependent peroxidase. J. Biol. Chem. 180, 2636-2643.

14. Lesniak, J., Barton, W. A. \& Nikolov, D. B. (2002). Structural and functional characterization of the Pseudomonas hydroperoxide resistance protein Ohr. EMBO J. 21, 6649-6659.

15. Gutierrez, C. \& Devedjian, J. C. (1991). Osmotic induction of gene OsmC expression in Escherichia coli K12. J. Mol. Biol. 20, 959-973.

16. Lesniak, J., Barton, W. A. \& Nikolov, D. B. (2003). Structural and functional features of the Escherichia coli hydroperoxide resistance protein OsmC. Protein Sci. 12, 2838-2843.

17. Rehse, P. H., Ohshima, N., Nodake, Y. \& Tahirov, T. H. (2004). Crystallographic structure and biochemical analysis of the Thermus thermophilus osmotically inducible protein C. J. Mol. Biol. 338, 959-968.

18. Meunier-Jamin, C., Kapp, U., Leonard, G. A. \& McSweeney, S. (2004). The structure of organic hydroperoxide resistance protein from Deinococcus radiodurans: do conformational changes facilitate recycling of the redox disulphide? J. Biol. Chem. 279, 25830-25837.

19. Delker, S. L., West, A. P., Jr, McDermott, L., Kennedy, M. W. \& Bjorkman, P. J. (2004). Crystallographic studies of ligand binding by Zn-alpha2-glycoprotein. J. Struct. Biol. 205, 213.

20. Barrett, M. L., Harris, R. L., Antonyuk, S., Hough, M. A., Ellis, M. J., Sawers, G. et al. (2004). Insights into redox partner interactions and substrate binding in nitrite reductase from Alcaligenes xylosoxidans: crystal structures of the Trp138His and His313Gln mutants. Biochemistry, 51, 16311-16319.

21. Ambrosio, A. L., Nonato, M. C., de Araujo, H. S., Arni, R., Ward, R. J., Ownby, C. L. et al. (2005). A molecular mechanism for Lys49-phospholipase A2 activity based on ligand-induced conformational change. J. Biol. Chem. 280, 7326-7335.

22. Wood, Z. A., Poole, L. B. \& Karplus, P. A. (2003). Peroxiredoxin evolution and the regulation of hydrogen peroxide signaling. Science, 300, 650-653.

23. Biteau, B., Labarre, J. \& Toledano, M. B. (2003). ATPdependent reduction of cysteine-sulphinic acid by S. cerevisiae sulphiredoxin. Nature, 425, 980-984.

24. Bryk, R., Lima, C. D., Erdjument-Bromage, H., Temst, P. \& Nathan, C. (2002). Metabolic enzymes of Mycobacteria linked to antioxidant defense by a thioredoxin-like protein. Science, 295, 1073-1077.

25. Tanaka, T., Izawa, S. \& Inoue, Y. (2005). GPX2, encoding a phospholipid hydroperoxide glutathione peroxidase homologue, codes for an atypical 2-Cys peroxiredoxin in Saccharomyces cerevisiae. J. Biol. Chem. 280, 42078-42087. 
26. Kosower, N. S., Kosower, E. M., Wertheim, B. \& Correa, W. S. (1969). Diamide, a new reagent for the intracellular oxidation of glutathione to the disulfide. Biochem. Biophys. Res. Commun. 37, 593-596.

27. Shin, D. H., Choi, I. G., Busso, D., Jancarik, J., Yokota, H., Kim, R. \& Kim, S. H. (2004). Structure of OsmC from Escherichia coli: a salt-shock-induced protein. Acta Crystallog. sect. D, 60, 903-911.

28. Choi, I. G., Shin, D. H., Brandsen, J., Jancarik, J., Busso, D., Yokota, H. et al. (2003). Crystal structure of a stress inducible protein from Mycoplasma pneumoniae at $2.85 \AA$ resolution. J. Struct. Funct. Genomics, 4, 31-34.

29. Nichols, P. D., Mayberry, W. R., Antworth, C. P. \& White, D. C. (1985). Determination of monounsaturated double-bond position and geometry in the cellular fatty acids of the pathogenic bacterium Francisella tularensis. J. Clin. Microbiol. 5, 738-740.

30. Basile, F., Beverly, M. B., Voorhees, K. J. \& Hadfield, T. L. (1998). Pathogenic bacteria: their detection and differentiation by rapid lipid profiling with pyrolysis mass spectrometry. Trends Anal. Chem. 17, 95-109.

31. Schultz, C. P., Wolf, V., Lange, R., Mertens, E., Wecke, J., Naumann, D. \& Zahringer, U. (1998). Evidence for a new type of outer membrane lipid in oral spirochete Treponema denticola. Functioning permeation barrier without lipopolysaccharides. J. Biol. Chem. 273, 15661-15666.

32. Osiro, D., Muniz, J. R., Coleta Filho, H. D., de Sousa, A. A., Machado, M. A., Garratt, R. C. \& Colnago, L. A. (2004). Fatty acid synthesis in Xylella fastidiosa: correlations between genome studies, ${ }^{13} \mathrm{C}$ NMR data, and molecular models. Biochem. Biophys. Res. Commun. 323, 987-995.

33. Oliveira, M. A., Netto, L. E. S., Medrano, F. J., Barbosa, J. A., Alves, S. V., Cussiol, J. R. R. \& Guimarães, B. G. (2004). Crystallization and preliminary X-ray diffraction analysis of an oxidized state of Ohr from Xylella fastidiosa. Acta Crystallog. sect. D, 60, 337-339.

34. Leslie, A. G. W. (1992). Joint CCP4/ESF-EAMBCB. Newsletter Protein Crystallography 26, Daresbury Laboratory, Warrington, UK.
35. Kabsch, W. (1988). Evaluation of single-crystal X-ray diffraction data from a position-sensitive detector. J. Appl. Crystallog. 21, 916-924.

36. Blessing, R. H. (1995). An empirical correction for absorption anisotropy. Acta Crystallog. sect A, 51, 33-38.

37. Collaborative Computational Project, Number 4. (1994). Acta Crystallog. sect. D, 50, 760-763.

38. Navaza, J. (1994). AmoRe: an automated package for molecular replacement. Acta Crystallog. sect. D, 57, 1367-1372.

39. Brunger, A. T., Adams, P. D., Clore, G. M., DeLano, W. L., Gros, P., Grosse-Kunstleve, R. W. et al. (1998). Crystallography \& NMR system: a new software suite for macromolecular structure determination. Acta Crystallog. sect. D, 54, 905-921.

40. Murshudov, G. N., Vagin, A. A. \& Dodson, E. J. (1997). Refinement of macromolecular structures by the maximum-likelihood method. Acta Crystallog. sect. $D$, 53, 240-255.

41. Jones, T., Zou, J., Cowan, S. \& Kjeldgaard, M. (1991). Improved methods for binding protein models in electron density maps and the location of errors in these models. Acta Crystallog. sect. A, 47, 110-119.

42. Perrakis, A., Sixma, T. K., Wilson, K. S. \& Lamzin, V. S. (1997). wARP: improvement and extension of crystallographic phases by weighted averaging of multiple refined dummy atomic models. Acta Crystallog. sect. D, 53, 448-455.

43. Laskowski, R. A., MacArthur, M. W., Moss, D. S. \& Thornton, J. M. (1993). PROCHECK: a program to check the stereochemical quality of protein structures. J. Appl. Crystallog. 26, 283-291.

44. Riddles, P. W., Blakeley, R. L. \& Zerner, B. (1979). Ellman's reagent: 5,5'-dithiobis(2-nitrobenzoic acid) - a reexamination. Anal. Biochem. 94, 75-81.

45. Wallace, A. C., Laskowski, R. A. \& Thornton, J. M. (1995). LIGPLOT: a program to generate schematic diagrams of protein-ligand interactions. Protein Eng. 8, 127-134.

Edited by M. Guss

(Received 30 December 2005; received in revised form 23 March 2006; accepted 24 March 2006) Available online 7 April 2006 


\section{ANEXO III}

Netto, L.E.; de Oliveira, M.A.; Monteiro, G.; Demasi, A.P.; Cussiol, J.R.; Discola, K.F.; Demasi, M.; Silva, G.M.; Alves, S.V.; Faria, V.G. \& Horta, B.B. "Reactive cysteine in proteins: Protein folding, antioxidant defense, redox signaling and more". Comp Biochem Physiol C Toxicol Pharmacol., 146:180-93; 2006. 


\author{
Review
}

\title{
Reactive cysteine in proteins: Protein folding, antioxidant defense, redox signaling and more
}

\author{
Luis Eduardo Soares Netto ${ }^{\mathrm{a}, *}$, Marcos Antonio de Oliveira ${ }^{\mathrm{a}}$, Gisele Monteiro ${ }^{\mathrm{a}}$, \\ Ana Paula Dias Demasi a , José Renato Rosa Cussiol a , Karen Fulan Discola a , Marilene Demasi ${ }^{\text {b }}$, \\ Gustavo Monteiro Silva ${ }^{a}$, Simone Vidigal Alves ${ }^{a}$, Victor Genu Faria ${ }^{a}$, Bruno Brasil Horta ${ }^{\text {a }}$ \\ a Departamento de Genética e Biologia Evolutiva, Instituto de Biociências, Universidade de São Paulo, São Paulo-SP, Brazil \\ b Laboratório de Bioquímica e Biofisica, Instituto Butantan, São Paulo-SP, Brazil
}

Received 1 May 2006; received in revised form 13 July 2006; accepted 31 July 2006

Available online 6 September 2006

\begin{abstract}
Cysteine plays structural roles in proteins and can also participate in electron transfer reactions, when some structural folds provide appropriated environments for stabilization of its sulfhydryl group in the anionic form, called thiolate $\left(\mathrm{RS}^{-}\right)$. In contrast, sulfhydryl group of free cysteine has a relatively high $\mathrm{pK}_{\mathrm{a}}(8,5)$ and as a consequence is relatively inert for redox reaction in physiological conditions. Thiolate is considerable more powerful as nucleophilic agent than its protonated form, therefore, reactive cysteine are present mainly in its anionic form in proteins. In this review, we describe several processes in which reactive cysteine in proteins take part, showing a high degree of redox chemistry versatility.

(C) 2006 Elsevier Inc. All rights reserved.
\end{abstract}

Keywords: Antioxidant; Cysteine; Disulfide; Peroxide; Electron transfer; Signaling; Thiols; Thiolate

\section{Contents}

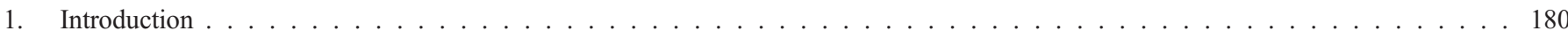

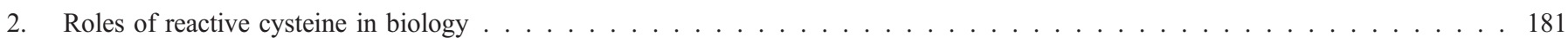

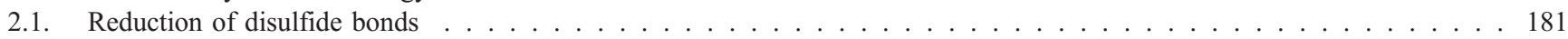

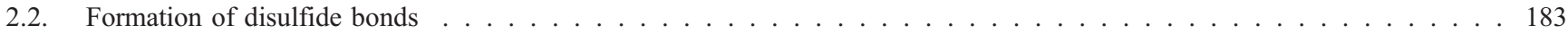

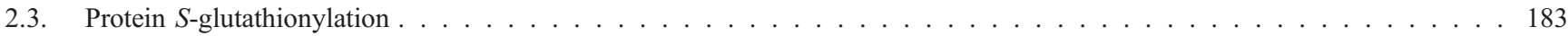

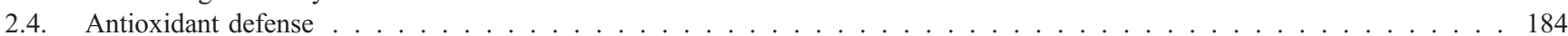

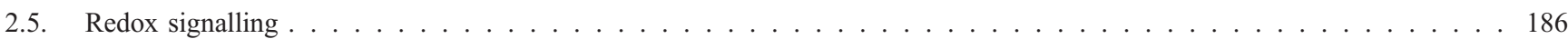

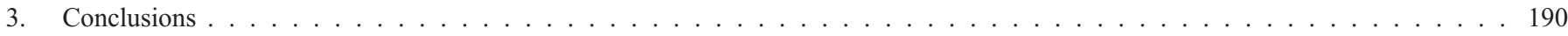

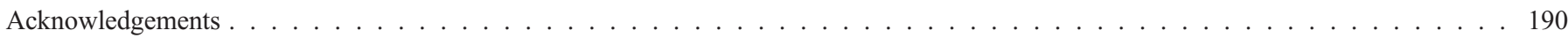

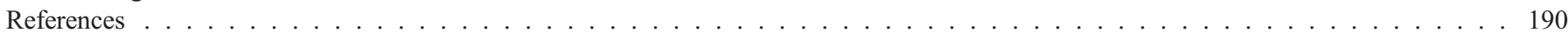

\footnotetext{
This paper is part of the 4th special issue of CBP dedicated to The Face of Latin American Comparative Biochemistry and Physiology organized by Marcelo Hermes-Lima (Brazil) and co-edited by Carlos Navas (Brazil), Rene Beleboni (Brazil), Rodrigo Stabeli (Brazil), Tania Zenteno-Savín (Mexico) and the editors of CBP. This issue is dedicated to the memory of two exceptional men, Peter L. Lutz, one of the pioneers of comparative and integrative physiology, and Cicero Lima, journalist, science lover and Hermes-Lima's dad.

* Corresponding author. Tel.: +55 11 30917589; fax: +55 1130917553.

E-mail address: nettoles@ib.usp.br (L.E.S. Netto).
}

\section{Introduction}

Proteins are the final products of gene expression and are responsible to execute the biological information contained in the nucleotide sequences of their respective genes. A classical dogma in biology is that the genetic information presented in the nucleotide sequence of DNA is expressed in a two-stage 
process: transcription and translation. Proteins need to adopt proper tertiary and quaternary structures to perform their biological functions. Because most proteins spontaneously fold into their native conformation under physiological conditions, the central dogma also implies that protein's primary structure dictates its tertiary structure.

Our interest is on proteins that have the ability to participate in electron transfer reactions. Most proteins rely on organic and on inorganic redox cofactors $\left(\mathrm{NAD}^{+}, \mathrm{FAD}\right.$, heme, $\mathrm{Cu}, \mathrm{Fe}$ and other transition metals) for redox activity. In contrast, for other proteins, amino acids, mainly cysteines, are responsible for this property. Free cysteine possesses low reactivity to undergo redox transitions (Wood et al., 2003b). However, protein folding can generate environments in which cysteine residues are reactive. The reactivity of a sulfhydryl group is related to its $\mathrm{pK}_{\mathrm{a}}$, since its deprotonated form (thiolate $=\mathrm{RS}^{-}$) is more nucleophilic and reacts faster with oxidants than the protonated form (R-SH). The sulfhydryl groups of most cysteines (linked to a polypeptide backbone or free cysteine) possess low reactivity, which is related to the fact that their $\mathrm{pK}_{\mathrm{a}}$ is around 8,5 (Benesch and Benesch, 1955). In contrast, some redox proteins possess a reactive cysteine that is stabilized in the thiolate form by a basic residue, in most cases a lysine or an arginine residue (Copley et al., 2004). In conclusion, reactive cysteines in proteins are kept in a reactive form (thiolate $=\mathrm{RS}^{-}$) by structural interactions with other amino acids. These reactive cysteines residues are compounds with very versatile redox chemistry because its sulfur atom can undergo redox transitions into any oxidation state between +6 and -2 (Jacob et al., 2003). Several proteins took advantage of this versatility to perform various biological functions as will be discussed below.

\section{Roles of reactive cysteine in biology}

\subsection{Reduction of disulfide bonds}

Many proteins with reactive cysteines are involved in controlling thiol/disulfide exchange reactions (Fig. 1A), a central theme in biology. Thiol/disulfide-exchange reactions are nucleophilic substitutions. A thiol or thiolate (RSH or $\mathrm{RS}^{-}$) acts as a nucleophilic agent on a disulfide bond (RS-SR). These reactions are, for example, used to form and reversibly destroy structural disulfides in proteins and peptides, to regulate enzyme activity and to maintain cellular redox balance. The rate of this reaction is dependent on the $\mathrm{pK}_{\mathrm{a}}$ of the sulfhydryl compound that is the nucleophilic agent. The lower the $\mathrm{pK}_{\mathrm{a}}$, higher is the amount of deprotonated form of sulfhydryl group (thiolate) and faster are the reactions at physiological $\mathrm{pH}$. The tri-peptide glutathione ( $\gamma$-Glu-Cys-Gly, GSH) is the most abundant thiol in cells and is vital for the maintanance of the intracellular redox balance, among other functions (reviewed by Jacob et al., 2003). Glutathione is almost completely protonated at physiological $\mathrm{pH}$ because its $\mathrm{pK}_{\mathrm{a}}$ is 9,2 (Jung et al., 1972) which disfavor its reaction with disulfides. However, it should be also considered that glutathione levels in cells are very high, which should favor disulfide reduction, since rate of a reaction depend also on the concentration of substrates.
Besides glutathione, thiol proteins such as thioredoxin, glutaredoxin (also known as thioltransferase) and protein disulfide isomerase are also involved in the regulation of the intracellular redox balance and, therefore, they are also known as thiol/disulfide oxido-reductases. Thioredoxin appears to be a very ancient protein since it is widespread among all the living organisms. These small proteins $(12-13 \mathrm{kDa})$ possess disulfide reductase activity endowed by two vicinal cysteines present in a CXXC motif (typically CGPC), which are used to reduce target proteins that are recognized by other domains of thioredoxin polypeptide. The reduction of target proteins results in a disulfide bridge between the two cysteines from the thioredoxin CXXC motif, which is then reduced by thioredoxin reductase that utilizes reducing equivalents from NADPH. Some of the target proteins of thioredoxin include ribonucleotide reductase (important for DNA synthesis), methionine sulfoxide reductase, peroxiredoxins and transcription factors such as p53 and NF-kB (reviewed by Powis and Montfort, 2001).

Since thioredoxin plays multiple roles, it was surprising to observe that deletion of their genes in Escherichia coli resulted in a viable bacteria, capable to synthesize desoxyribonucleotides, among other processes. Holmgren (1976) showed that glutaredoxin was the backup for thioredoxin in the reduction of ribonucleotides. Like thioredoxin, glutaredoxin possess a CXXC motif in their active site (typically CPYC) and most of them are low molecular weight proteins $(12-13 \mathrm{kDa})$. Glutaredoxin can also catalyze the reduction of disulfide bond in target proteins like thioredoxin through thiol/disulfide exchange reactions (Fig. 1A).

Furthermore, glutaredoxin also catalyzes the reduction of mixed disulfides with glutathione in a process that only the Nterminal cysteine thiolate participates (reviewed by Fernandes and Holmgren, 2004). Interestingly, some glutaredoxin isoforms possess only the N-terminal cysteine and are only capable to reduce mixed disulfides with glutathione. Thioredoxins reduce a wider range of disulfides in proteins than glutaredoxins, but cannot reduce mixed disulfides with glutathione. The disulfide form of glutaredoxin is reduced by glutathione, which is then reduced by NADPH in a reaction catalyzed by glutathione reductase.

The thioredoxin system $(\mathrm{NAPDH}+$ thioredoxin reductase + thioredoxin) and the glutathione system (NADPH+ glutathione reductase+glutathione) are the major thiol dependent redox pathways present in the cells. Glutathione systems may or may not contain glutaredoxin, depending on the process considered. Several enzymes and other effectors can be reduced by both systems but many processes are reduced by either thioredoxin or by glutathione system. Interestingly, in platyhelminths, the thioredoxin and glutathione systems are linked in only one pathway. This worm possesses a seleno-cysteine containing enzyme named thioredoxin-glutathione reductase, which possess thioredoxin reductase, glutathione reductase and glutaredoxin activities (Sun et al., 2001).

The two electron redox potential of the cysteine/cystine couple in thiol/disulfide oxido-reductases is influenced by several factors. Thioredoxin and glutaredoxin are strong reducing agents and therefore possess a very negative redox 
A.

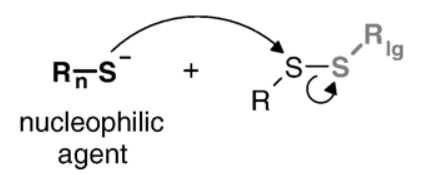

B.

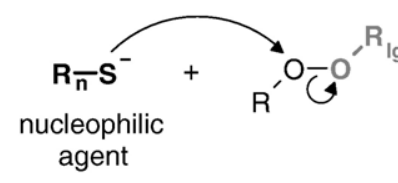

C.

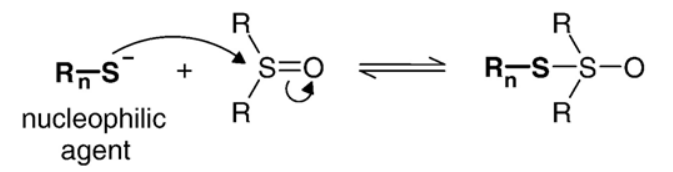

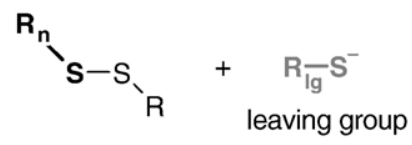

$\mathrm{R}_{\mathrm{n}}-\mathrm{OH}+\mathrm{R}_{\overline{\mathrm{lg}}} \mathrm{OH}$

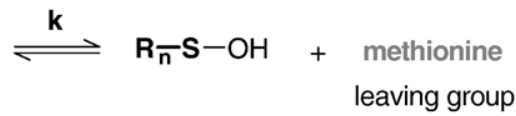

Fig. 1. Nucleophilic substitutions and reactive cysteines. (A) Thiol-disulfide exchange reaction. This reaction is faster when the sulfhydryl group is deprotonated (thiolate). Therefore, rate of this reaction is given by $V=k\left[R_{\mathrm{n}}-S^{-}\right]\left[\mathrm{RSSR}_{\mathrm{gg}}\right]$. The same rationale applies for the other reactions depicted here. (B) Peroxide reduction, resulting in a sulfenic acid derivative (Cys-SOH) and an alcohol corresponding to the peroxide. The sulfenic acid derivative can have different outcomes depending on the kind of peroxiredoxin considered (see Fig. 4) and on the environment where it is located. (C) Sulfoxide reduction, resulting in methionine regeneration and sulfenic acid formation in methionine sulfoxide reductase, which is reduced back to its sulfhydryl from by thioredoxin (reviewed by Weissbach et al., 2002). Abbreviations: $1 \mathrm{~g}=$ leaving group; $\mathrm{n}=$ nucleophilic agent.

potential. In contrast, protein disulfide isomerases (PDI) and DbsAs (bacterial PDI counterparts) possess much lower negative potentials (Table 1). Therefore reduction potential of the best oxidant (DsbA) is $146 \mathrm{mV}$ higher than the best reductant (thioredoxin), corresponding to a ratio of 105 in thermodynamic stability of the dithiol/disulfide equilibrium (Xiao et al., 2005). This diversity in potentials reflects the biological roles of these thiol proteins. Thioredoxins and glutaredoxins preferentially reduce disulfide bridges, whereas protein disulfide isomerase and DbsAs preferentially generate disulfide bonds in proteins (Jacob et al., 2003).

It is interestingly to observe that in spite of these great differences in redox properties all these oxido-reductases share several similarities: (1) $\mathrm{S} \gamma$ atom is mostly deprotonated in $\mathrm{N}$-terminal cysteine residue of the CXXC motif at physiological conditions. Therefore, the most $\mathrm{N}$-terminal cysteine is more

Table 1

Properties of Thiol/disulfide oxido-reductases

\begin{tabular}{llll}
\hline Oxido-reductase & $\begin{array}{l}\text { Motif in } \\
\text { active site }\end{array}$ & $\begin{array}{l}\text { Redox Potential } \\
\left(\mathrm{E}^{\mathrm{o}}, \mathrm{mV}\right)\end{array}$ & $\mathrm{pK}_{\mathrm{a}}$ \\
\hline Thioredoxin & Cys-Gly-Pro-Cys & $-270^{\mathrm{a}}$ & $6.3-7.5^{\mathrm{f}}$ \\
Glutaredoxin & Cys-Pro-Tyr-Cys & -198 to $-233^{\mathrm{b}}$ & $3.5-3.8^{\mathrm{g}}$ \\
Tryparedoxin & Cys-Pro-Pro-Cys & $-249^{\mathrm{c}}$ & $7.2^{\mathrm{h}}$ \\
$\begin{array}{l}\text { Protein Disulfide } \\
\text { Isomerase (PDI) }\end{array}$ & Cys-Gly-His-Cys & $-127^{\mathrm{d}}$ & $3.5-6.7^{\mathrm{I}}$ \\
DbsA & Cys-Pro-His-Cys & $-125^{\mathrm{e}}$ & $3.5^{\mathrm{j}}$ \\
\hline
\end{tabular}

a - Miranda-Vizuete et al. (1997), Nishinaka et al. (2001). ${ }^{\text {b }}$ - Aslund et al. (1997). ${ }^{\mathrm{c}}$ - Reckenfelderbaumer et al. (2002). ${ }^{\mathrm{d}}$ - Lundstrom and Holmgren (1993). ${ }^{\mathrm{e}}$ - Collet and Bardwell (2002). ${ }^{\mathrm{f}}$ — Holmgren (1972), Kallis and Holmgren (1980), Reutimann et al. (1981), Dyson et al. (1997), Li et al. (1993), Chivers et al. (1997), Dillet et al. (1998), Vohnik et al. (1998). ${ }^{\mathrm{g}}$ — Gan et al. (1990), Yang and Wells (1991), Mieyal et al. (1991), Jao et al. (2006). h - Reckenfelderbaumer and Krauth-Siegel (2002); ${ }^{\mathrm{i}}$ — Darby and Creighton (1995), Hawkins and Freedman (1991); ${ }^{j}$ — Nelson and Creighton (1994), Grauschopf et al. (1995). nucleophilic and more exposed than the second cysteine. The most $\mathrm{C}$-terminal cysteine is usually protonated and more buried in the polypeptide chain; (2) global fold of five stranded $\beta$-sheet flanked by four helices, the so-called thioredoxin fold (Fig. 2A); (3) the active site that contains the CXXC motif is located on a surface loop at the end of strand $\beta 2$ and followed by a long $\alpha$-helix (Fig. 2A).

Several reasons have been raised to explain this variation of the reducing capabilities, such as the composition of the amino acids in the CXXC motif (Table 1), network of charged amino acids and structural factors, such as the dipole property of the $\alpha$-helix where the buried cysteine is located (reviewed by Carvalho et al., 2006). These different redox properties among thiol/disulfide oxido-reductases appear not to be related with the stability of the disulfide bonds, since their lengths are very similar among these proteins (reviewed by Carvalho et al., 2006). In any case, for all of these enzymes, the $\mathrm{pK}_{\mathrm{a}}$ of the reactive cysteine is considerably lower than the $\mathrm{pK}_{\mathrm{a}}$ of free cysteine (Table 1), but the mechanism by which the thiolate is stabilized varies.

The stabilization of the thiolate anion in thioredoxin is relatively well characterized and was taken as an example for thiol/disulfide oxido-reductases. It depends on: (i) a network of charged residues, especially on specific aspartate and lysine residues (Fig. 2B); (ii) dipole character of the $\alpha$-helix where the C-terminal cysteine is located and (iii) hydrogen bonding between the reactive and the $\mathrm{C}$-terminal cysteine residues (reviewed by Carvalho et al., 2006).

Interestingly, mutations of Asp26 and Lys57 of thioredoxin affect only the $\mathrm{pK}_{\mathrm{a}}$ of the active site thiol, but not the structure of the protein (Dyson et al., 1997). For the other oxido-reductases the network of charged residues is different and involves Glu 30 for PDI (PDB ID=1MEK), Glu 24 for DsbA $(\mathrm{PDB} I D=1 \mathrm{~A} 23)$ and Glu30, Asg26 and Lys27 for glutaredoxin $(\mathrm{PDB}$ ID $=1 \mathrm{KTE})$. 
A.

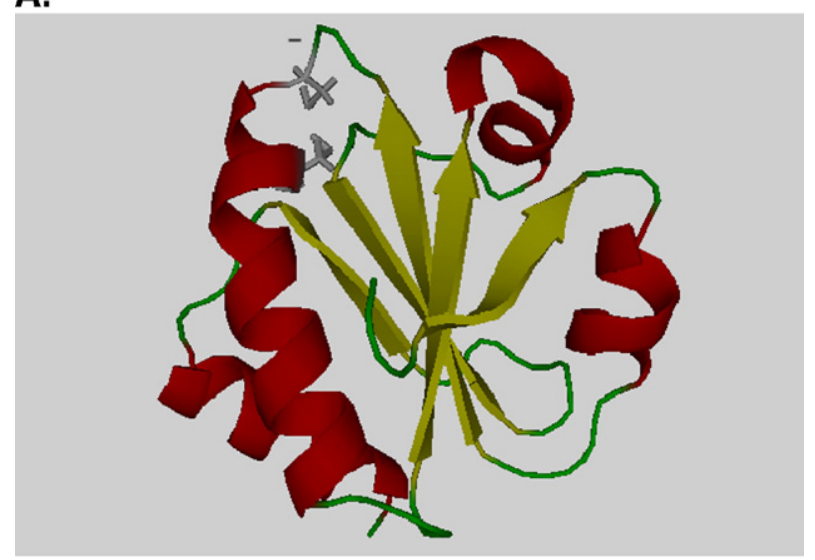

B.

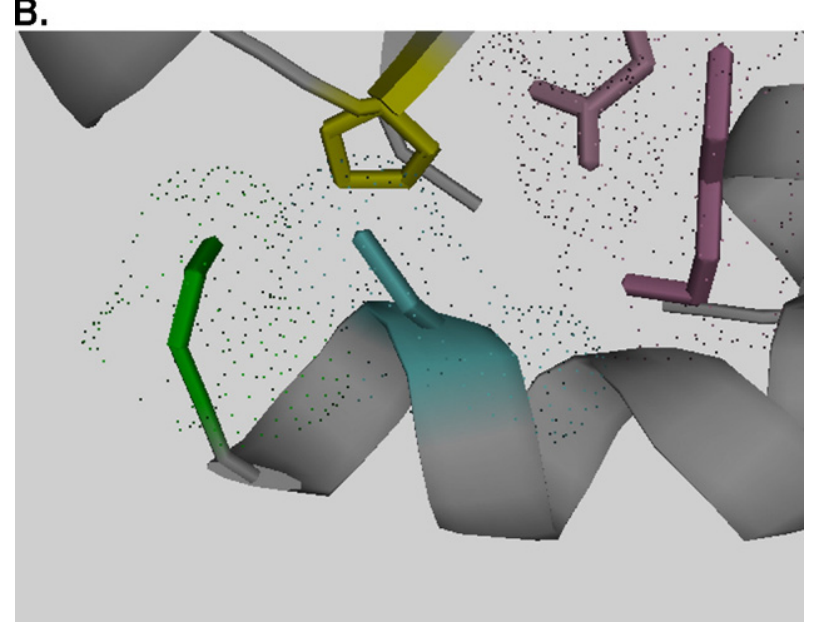

Fig. 2. Structural characteristics of thiol/disulfide oxido-reductases. Thioredoxin from Escherichia coli (PDB ID = 1XOB) was chosen as a model to describe several features common to thiol/disulfide oxido-reductases. (A) General view of thioredoxin fold: $\beta$-sheet composed of five strands (yellow) flanked by four $\alpha$-helixes (red). Both main and side chains of the two cysteine residues belonging to the CXXC motif are showed (gray). The reactive cysteine (Cys 32) is the most exposed one. (B) View of the active site, showing the network of amino acids involved in the stabilization of reactive cysteine in the thiolate form. Residues involved in the network of charged amino acids are represented with colors and with dots representing their electronic densities (Asp 26 - magenta, Cys 32 - green, Cys 35 - cyan, Lys 57 - magenta). Pro76 (yellow) is not involved in the network of charged residues that stabilize the thiolate form of reactive cysteine, but its main and side chains are shown here because this residue plays a central role in the recognition of thioredoxin substrates. Figures were generated by the Pymol software (www.pymol.org). (For interpretation of the reference to colour in this figure legend, the reader is referred to the web version of this article.)

We are interested in the functional and structural characterization of proteins belonging to thioredoxin and glutathione systems form the yeast Saccharomyces cerevisiae. In this regard, we solved the structure of thioredoxin reductase I (Oliveira et al., 2005) and preliminary data indicated that the two thioredoxin systems are not completely redundant.

\subsection{Formation of disulfide bonds}

The formation of disulfide bonds stabilizes the most active conformation of proteins that will be secreted. One would expect that PDI and DsbA would be more suitable to catalyze the formation of disulfide bond given their reduction potential (Table 1). In fact, the search for the enzymatic catalyst of oxidative folding led to isolation of PDI (Goldberger et al., 1963). PDI can catalyze the formation, reduction or isomerization of disulfide bonds depending on the redox conditions of the assay and on the nature of the substrate protein. However, the environment in which PDI is found (endoplasmic reticulum), favors only the formation and isomerization of disulfide bonds. Both, the formation of disulfide bond and isomerase activities occur by thiol/disulfide exchange reactions (Fig. 1A). Like thioredoxins and glutaredoxins, the ability of PDI to catalyze thiol/disulfide exchange reactions is given by a CXXC motif (typically CGHC) among other factors (Aslund et al., 1997). When the cysteines in the active site are present in the disulfide form, PDI can directly oxidize thiol groups of target proteins into disulfide bridges (dithiol oxidase activity). In contrast, the isomerase activity of PDI relies on the dithiol (reduced) configuration state of the active site cysteines, suitable for disulfide reshuffling (reviewed by Frand et al., 2000).

In spite of the different redox properties among all these oxido-reductases, they can catalyze both reduction and formation of disulfide bonds in vitro, depending on the experimental conditions. In fact, Grx 1 from E. coli is even more efficient than PDI to catalyze disulfide bond formation (Xiao et al., 2005), indicating that kinetic parameters should also to be taken into account. Therefore, it is important to consider the environment in which the thiol oxido-reductase is located to analyze its function. In eukaryotic cells, protein disulfide bond formation takes place within the lumen of the endoplasmic reticulum. Proteins that will be secreted to the extracellular space are processed inside this organelle. The redox state of the endoplasmic reticulum is more oxidizing than that of cytosol, a difference that favors the formation of disulfide bonds, which is important to maintain the structure of the exported protein in the harsh extracellular environment. The major redox buffer in the cytosol as well as in the lumen of ER is the couple GSH/GSSG. However, GSH/GSSG ratios are quite different: $1: 1$ to $3: 1$ for the lumen of endoplasmic reticulum and 30:1 to 100:1 for the cytosol and mitochondrial matrix. Therefore, the ability of thioredoxin and glutaredoxin to catalyze reduction of disulfide bond in protein and of PDI to catalyze the reverse process is consequence of several factors such as redox potentials of vicinal sulfhydryl groups in these proteins and redox balance of the environment.

\subsection{Protein S-glutathionylation}

Another thiol/disulfide exchange process that deserves special consideration here is $S$-glutathionylanion of cysteine residues in proteins. In resting state, levels of $S$-glutathionylated proteins in cells are around $1 \%$, but upon oxidative stress a significant increase is observed. Therefore, initially, the meaning of the $S$-glutathionylation was thought to be the protection of cysteine residues against overoxidation to sulfinic $\left(\mathrm{RSO}_{2} \mathrm{H}\right)$ or sulfonic $\left(\mathrm{RSO}_{3} \mathrm{H}\right)$ acids, which can lead to protein inactivation 
(Thomas et al., 1995). Later, it was shown that for some enzymes, protein $S$-glutathionylation affects enzyme activities, suggesting a regulatory role for this process (Chrestensen et al., 2000; Davis et al., 1997; Demasi et al., 2003). If $S$-glutathionylation is in fact a regulatory event, it is expected the occurrence of proteins capable to catalyze the addition and removal of glutathione from target proteins. Glutaredoxins, especially those containing only one cysteine in their active site, have been most frequently implied as dethiolases (Molina et al., 2004). The yeast $S$. cerevisiae has five glutaredoxins, three monothiolic and two dithiolic, distributed in different compartments and performing similar, but not completely redundant roles (Wheeler and Grant, 2004). We have recently solved the crystal structure of glutaredoxin 2 (Discola et al., 2005) and unpublished results have demonstrated its role on the removal of GSH from $S$-glutathionylated $20 \mathrm{~S}$ proteasome extracted from yeast cells. We hope that with the elucidation of glutaredoxin 2 structure it will be possible to obtain insights into the mechanisms by which this thiol/disulfide oxido-reductase act as a dethiolase in the yeast $S$. cerevisiae.

\subsection{Antioxidant defense}

Proteins with reactive cysteine considered so far, catalyze thiol/disulfide exchange reactions. In contrast, thiol-dependent peroxidases have evolved the ability to cleave a peroxide bond that is a more difficult process than the reduction of a disulfide bond (Fig. 1B). Copley et al. (2004) elegantly hypothesized that peroxiredoxins, a class of thiol-dependent peroxidases, present

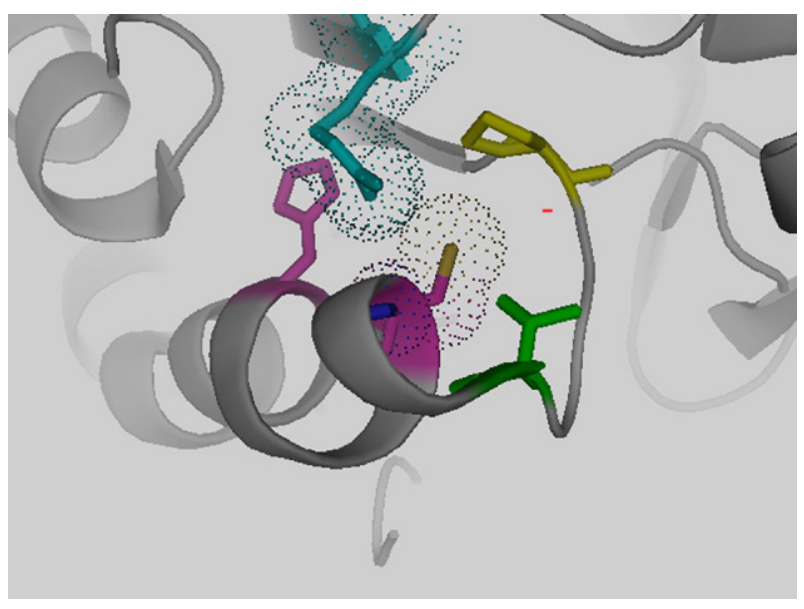

Fig. 3. Structure of peroxiredoxin active site. Reactive cysteine in peroxiredoxins corresponds to the $\mathrm{C}$-terminal cysteine of CXXC motifs in thioredoxins (Copley et al., 2004). Therefore, they are located in an $\alpha$-helix as the C-terminal cysteine of thioredoxin is. Structure of human peroxiredoxin $5(\mathrm{PDB} I D=1 \mathrm{HD} 2)$ is shown as an example. Electronic density of arginine residue (Arg127) involved in the stabilization of the thiolate is represented with dots, as well as reactive cysteine (Cys47). Thiolate function ( $\mathrm{RS}^{-}$) of Cys 47 is brown. Main and side chains of a threonine residue (Thr44 that corresponds to the N-terminal cysteine in thioredoxin) that plays a role in stabilization of thiolate is shown in green, as well as the chains of Pro 40 (yellow) that is involved in protection of peroxiredoxin from overoxidation. Finally, main and side chains of histidine 51 (purple), forming a salt bridge with Arg 127 (cyan) is also shown here. Figure was generated by the Pymol software (www.pymol.org). (For interpretation of the reference to colour in this figure legend, the reader is referred to the web version of this article.) several amino acids substitutions from the more ancient thiol/ disulfide oxido-reductases, which make them capable to reduce OO bonds through a reactive cysteine.

Both hydrogen and organic hydroperoxides can be decomposed by peroxiredoxins and in most of cases they utilize reductive equivalents from thioredoxins (Netto et al., 1996). Therefore, the majority of peroxiredoxins are also called thioredoxin peroxidases. Recently, it was shown that some peroxiredoxins can also decompose peroxynitrite (Bryk et al., 2000; Dubuisson et al., 2004; Trujillo et al., 2004; Wong et al., 2002). These reactions catalyzed by peroxiredoxins have been implied in both peroxide detoxification and cellular signaling as will be discussed below. Like other thiol/disulfide oxidoreductases, peroxiredoxins are widespread in nature and are found in several cell compartments such as cytosol, mitochondria, nucleus and chloroplast (Rhee et al., 2005a).

As described for the thiol/disulfide oxido-reductases, the high reactivity of the active site cysteine in peroxiredoxins is related to the fact that the thiol group of this residue possesses very low $\mathrm{pK}_{\mathrm{a}}$. In the case of peroxiredoxins, the presence of a guanidine group from a fully conserved arginine residue (Wood et al., 2003 b) is a key factor for the stabilization of the thiolate. Interestingly, the reactive cysteine from peroxiredoxins is homologous to the C-terminal cysteine of the CXXC motif in oxido-reductases, which is not the most nucleophilic. The reactive cysteine (the most $\mathrm{N}$-terminal and most solvent exposed seen in Fig. 2) in oxido-reductases was replaced by a threonine residue in peroxiredoxins and the other cysteine acquired high nucleophilicity due to several structural features and amino acids interactions, such as the hydrogen bonding with an arginine residue mentioned above (Fig. 3).

Other peroxide-removing enzymes evolved other strategies to decompose peroxides. Catalase and mammalian glutathione peroxidase utilize heme or seleno-cysteine to decompose peroxides, whereas peroxiredoxins have a very reactive cysteine in their active site. Initially, these differences in the active sites was thought to reflect the fact that peroxiredoxins would have moderate catalytic efficiency $\left(\sim 10^{5} \mathrm{M}^{-1} \mathrm{~s}^{-1}\right)$, (Hofmann et al., 2002) when compared with catalases $\left(\sim 10^{6} \mathrm{M}^{-1} \mathrm{~s}^{-1}\right)$ (Hillar et al., 2000) and glutathione peroxidases $\left(\sim 10^{8} \mathrm{M}^{-1} \mathrm{~s}^{-1}\right)$ (Hofmann et al., 2002). Recently, however, some reports have described higher rate constants $\left(10^{6}-10^{7} \mathrm{M}^{-1} \mathrm{~s}^{-1}\right)$ for the reaction of reduced peroxiredoxins with different kinds of peroxides (Akerman and Muller, 2005; Baker and Poole, 2003; Dubuisson et al., 2004; Parsonage et al., 2005). In any case, it is important to emphasize that peroxiredoxins are abundant in aerobic cells. For example: (i) peroxiredoxins are among the ten most abundant proteins in E. coli (Link et al., 1997); (ii) peroxiredoxins are the second or third most abundant protein in erythrocytes (Moore et al., 1991) and (iii) compose $0.1-0.8 \%$ of the soluble proteins in other mammalian cells (Chae et al., 1999). Furthermore, it was demonstrated that peroxiredoxin, but not catalase, was responsible for protection of bacteria against endogenously generated hydrogen peroxide (Costa Seaver and Imlay, 2001).

There are several kinds of peroxiredoxins and several classifications were proposed based on different criteria. 
Generally, every aerobic cell possesses several different kinds of peroxiredoxins. The most frequently used criteria for classification is the presence or absence of additional conserved cysteines (Wood et al., 2003b). Peroxiredoxins that contain two conserved cysteines are called 2-Cys Prx, whereas those that possess only one conserved cysteine are referred as 1-Cys Prx. In both cases, the reactive cysteine attacks the hydroperoxide and is oxidized to sulfenic acid (Cys-SOH), while the corresponding alcohol is released (Fig. 4). Because the reactive cysteine is the one that directly interact with peroxides it is called peroxidatic cysteine and is located at the $\mathrm{N}$-terminal part of the protein. Three peroxiredoxin classes can be recognized based on the next step of the catalytic cycle (1-Cys Prx; typical 2-Cys Prx and atypical 2-Cys Prx). The 1-Cys Prx presents the simplest mechanism: they are oxidized to a stable sulfenic acid and then reduced back by a reductant. The biological electron donors of most 1-Cys Prx are still unknown. One exception is the 1-Cys Prx from yeast, whose electron donor is mitochondrial thioredoxin (Pedrajas et al., 2000). Furthermore, mammalian 1-Cys Prx can form heterodimer complexes with
Glutathione $S$-transferase $\pi$, being capable to accept electrons from glutathione (Ralat et al., 2006).

The enzymatic mechanism of 2-Cys Prx differs from the 1Cys Prx's mechanism because these proteins have a second conserved cysteine, also called resolving cysteine, which is also involved in the catalytic cycle. The sulfenic acid formed in the peroxidatic cysteine reacts with the resolving cysteine of other protein, generating an intermolecular disulfide bridge. In the case of atypical 2-Cys Prx, the resolving cysteine belongs to the same polypeptide backbone of the peroxidatic cysteine, therefore an intramolecular disulfide bond is generated. For the majority of the typical and atypical 2-Cys Prx proteins, disulfide bonds are reduced by thioredoxins (Fig. 4).

Alternatively, peroxiredoxins can be classified according to their amino acid sequence, which is very variable among five different groups (Trivelli et al., 2003). In spite of the fact that peroxiredoxins groups share very low amino acid sequence similarity, they have residues that are very conserved among all members (Wood et al., 2003b): (1) A proline that limits solvent and peroxide access in the active site and therefore probably
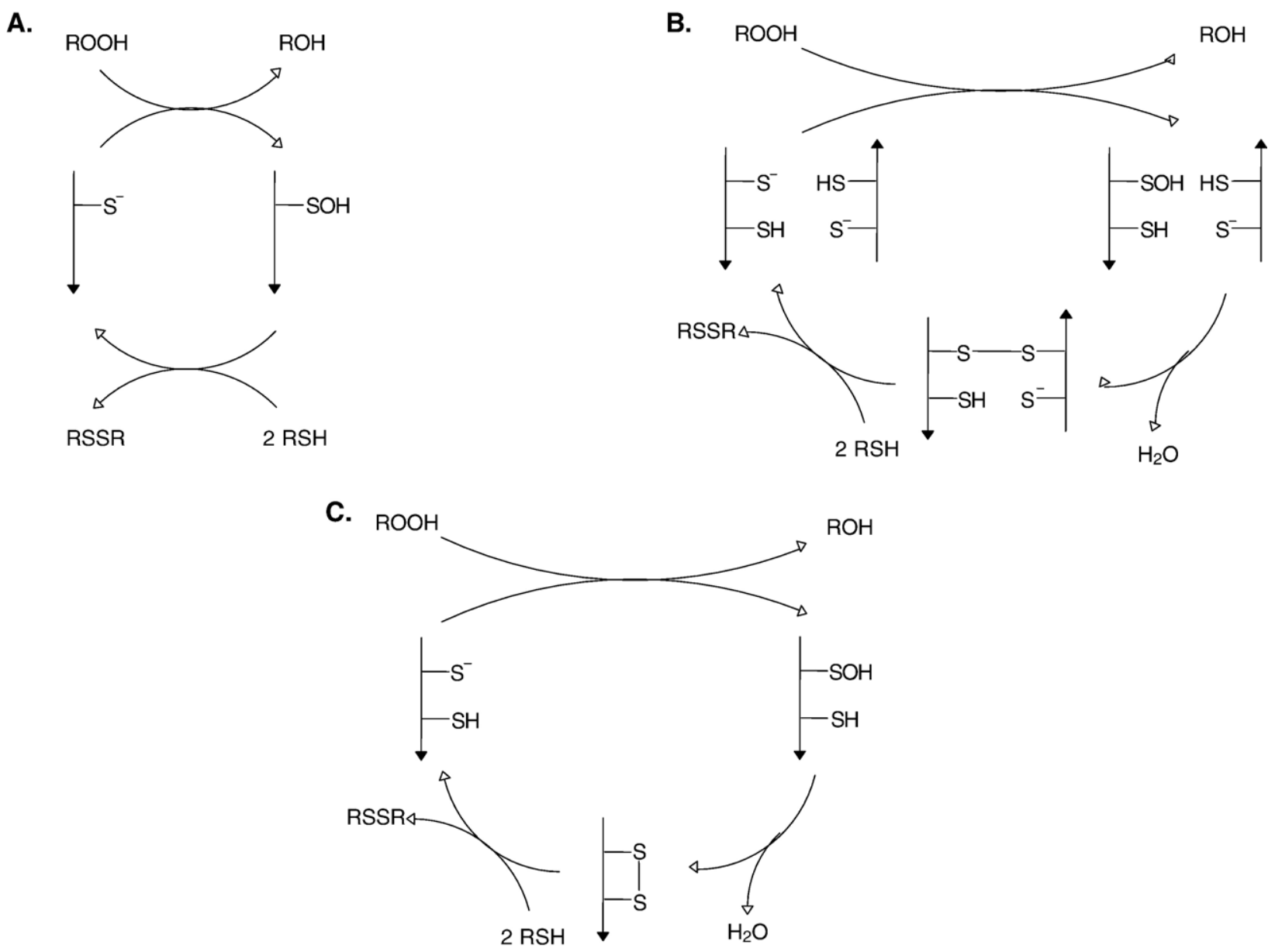

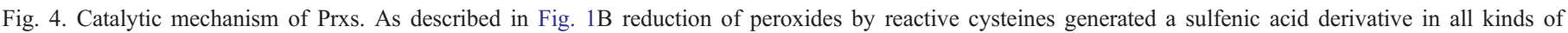

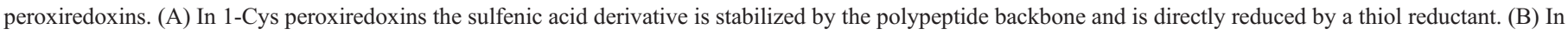

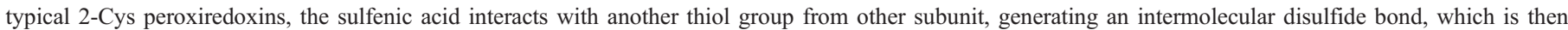

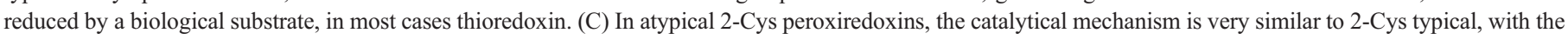
exception that an intramolecular disulfide bond is formed. 
shields the cysteine sulfenic acid from overoxidation; (2) an arginine residue that is involved in the stabilization of peroxidatic cysteine in the thiolate form and (3) an threonine residue that also interacts with the sulfur atom of peroxidatic cysteine (Fig. 3). Besides these similarities, all peroxiredoxins possess a common structural feature: the thioredoxin fold, which was described before. Interestingly, all other thiol/disulfide oxido-reductases presented here (thioredoxin, glutaredoxin and protein disulfide isomerase) also possess the thioredoxin fold (Fig. 2A). Differently than the thiol/disulfide oxido-reductases, peroxiredoxins contain central insertions, $\mathrm{N}$-terminal and $\mathrm{C}$-terminal expansions to the thioredoxin fold that are different for different groups of these thiol dependent peroxidases. Due to these structural similarities and through a motif analysis, it was proposed that all these thiol proteins might have a common ancestor (Copley et al., 2004).

The yeast $S$. cerevisiae, which has been used as model for higher eukaryotes, possesses five peroxiredoxins belonging to four different sub-groups (Park et al., 2000). Our studies have demonstrated that although all five yeast peroxiredoxins have the same biochemical activity (thioredoxin dependent peroxidase); their cellular functions are not completely redundant. For example, cytosolic thioredoxin peroxidase I (Tsa1/YML028W) is specifically important for the defense of yeast with dysfunctional mitochondria (Demasi et al., 2001; Demasi et al., 2006), whereas mitochondrial thioredoxin peroxidase I (PrxI/ YBL064C) is more important in conditions where yeast obtain ATP preferentially by respiration (Monteiro et al., 2002; Monteiro and Netto, 2004). Finally, cytosolic thioredoxin peroxidase II (cTPxII/Tsa2/YDR453C) appears to be an important backup for cTPxI for the defense against organic peroxides, independently of the functional state of mitochondria (Munhoz and Netto, 2004). Interestingly, mitochondria are protected not only by the mitochondrial isoform ( $\operatorname{PrxI} /$ YBL064C) but also by cytosolic isoforms and in cooperation with mitochondrial pool of glutathione against $\mathrm{Ca}^{2+}$ induced stress (Monteiro et al., 2004). This partial redundancy observed among yeast peroxiredoxins probably parallels the roles that these peroxidases play in mammalian cells.

Recently, a new kind of peroxidase that also operates through a reactive cysteine was described (Lesniak et al., 2002; Cussiol et al., 2003). Initially, it was demonstrated that the deletion of genes encoding these peroxidases rendered Xanthomonas campestris specifically sensitive to organic peroxides, but not to hydrogen peroxide (Mongkolsuk et al., 1998). Therefore, this gene was named organic hydroperoxide resistance (Ohr) and was later shown to be exclusively present in bacteria, most of them pathogenic. Interestingly, only dithiols support the peroxidase activity of $\mathrm{Ohr}$ and it is considerably more efficient in the removal of organic peroxides than in the decomposition of hydrogen peroxide (Cussiol et al., 2003). It was noteworthy to observe that differently than other thiol-dependent peroxidases (glutathione peroxidases and peroxiredoxins), Ohr does not possess the thioredoxin fold. Instead, Ohr is a dimer composed of two six-strand $\beta$-sheet and two central $\alpha$-helixes (Lesniak et al., 2002; Meunier-Jamin et al., 2004; Oliveira et al., 2006). Contrary to the other thiol/disulfide oxido-reductases

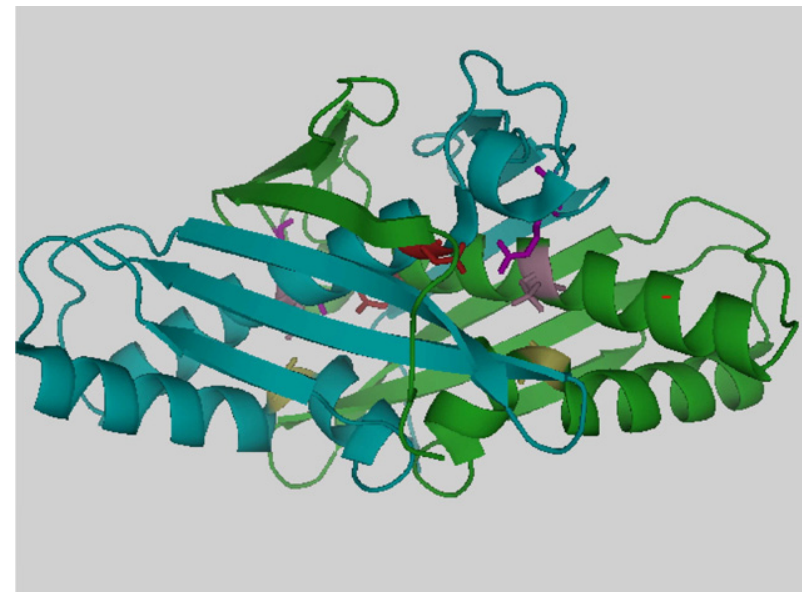

Fig. 5. Ohr structure with hidden cysteines residues. Overall view of Xylella fastidiosa quartenary structure $(\mathrm{PDB}=1 \mathrm{ZB} 9)$. Contrary to peroxiredoxins and thiol/disulfide oxido-reductases, reactive cysteine (Cys61 in pink) is buried in the polypeptide backbone (two $\beta$-sheet composed of six strands). The side chain of Arg 19 (magenta) that is involved in the stabilization of thiolate form of Cys 61 and Glu51 (red) that forms a salt bridge with Arg19 are also shown in dark color. Cys 125 (in yellow), involved in the formation of an intramolecular disulfide bond, is also represented with black color. Figure was generated by the Pymol software (www.pymol.org). (For interpretation of the reference to colour in this figure legend, the reader is referred to the web version of this article.)

and peroxidases described so far, the reactive cysteine is located in a very hydrophobic environment (Fig. 5). Due to these differences and because $\mathrm{Ohr}$ are exclusively present in bacteria, these peroxidases might represent interesting targets for drug design.

Finally, antioxidant proteins also make use of reactive cysteine to repair oxidative damage. Methionine sulfoxide reductase has a reactive cysteine capable to cleave an $\mathrm{S}=\mathrm{O}$ bond, also by a nucleophilic substitution mechanism (Weissbach et al., 2002), (Fig. 1C).

\subsection{Redox signalling}

Since reactive cysteines can decompose peroxides yielding products that can be reduced back to the sulfhydryl form, several proteins containing this kind of residues are in principle adapted to participate in redox signaling mediated by hydrogen peroxide. Although hydrogen peroxide has been classically associated with oxidative stress, there is a growing amount of evidences about the role of this mild oxidant as a cell messenger (Rhee et al., 2005b). Hydrogen peroxide can cross membranes and is relatively stable, two features suitable for a cell messenger in analogy to nitric oxide (Stone, 2004). This idea was strengthened by the discovery that non-phagocytic cells also possess NADPH oxidase, a source for hydrogen peroxide (Bokoch and Knaus, 2003). In fact, there are numerous reports about the effect of hydrogen peroxide in terms of both cellular responses and signaling pathways activated (reviewed by Stone, 2004).

The best characterized mediator of peroxide induced stress is OxyR, a transcription activator found only in bacteria. Genes regulated by OxyR includes enzymes involved in peroxide 
decomposition (catalase, peroxiredoxin, thioredoxin, glutathione reductase and glutaredoxin) and cell signaling (small RNA molecule). The mechanism by which OxyR senses $\mathrm{H}_{2} \mathrm{O}_{2}$ involves a reactive cysteine that once again is stabilized in the thiolate form by a conserved arginine among other amino acids (Choi et al., 2001). The oxidation of this cysteine generates a disulfide bond that causes a conformational change in the protein. Both the oxidized and reduced forms of OxyR can bind DNA, but only the oxidized form is capable to recognize specific elements in the promoters of target genes and activate their transcription (Fig. 6A). The reactive cysteine of OxyR possesses a relatively high rate constant $\left(2 \times 10^{5} \mathrm{M}^{-1} \mathrm{~s}^{-1}\right.$, see Aslund et al., 1999) and can activate transcription when intracellular concentrations of hydrogen peroxide are as little as $100 \mathrm{nM}$ (Costa Seaver and Imlay, 2001). The activation of OxyR is reversed by reduction of reactive cysteine by GSH and glutaredoxin 1 (Fig. 6).

Response of bacteria to oxidative stress is mediated by other transcriptional regulators besides OxyR. OhrR is a transcriptional repressor that is also capable to sense peroxides through a reactive cysteine (Mongkolsuk and Helmann, 2002). The only one known target of OhrR so far described is Ohr that is specifically induced by organic peroxides, the preferable substrate of this dithiol-dependent peroxidase. Therefore, $\mathrm{Ohr} /$ OhrR is a pathway specifically involved in the oxidative stress response to organic, but not to hydrogen peroxide (Klomsiri et al., 2005). In vitro, reduced OhrR binds tightly to its target DNA and therefore blocks the transcription of ohr (Fuangthong et al., 2001). Oxidation of a conserved and reactive cysteine in OhrR by peroxides leads to derepression of ohr transcription, which is reversed by a reducing agent such as DTT. Differently than OxyR, OhrR is oxidized to a sulfenic acid (CysSOH) instead of a disulfide (Fuangthong and Helmann, 2002).

Another transcriptional repressor of bacteria that was implied in peroxide sensing in bacteria through reactive cysteines is PerR (Mongkolsuk and Helmann, 2002). PerR belongs to a family of transcriptional regulators that are dimeric proteins and that contain two metal sites per monomer. One binds zinc and appears to play mainly structural roles, whereas the second site can bind both iron and manganese and has a regulatory role. PerR complexed with either $\mathrm{Mn}^{+2}$ or $\mathrm{Fe}^{+2}$ can bind DNA and repress transcription of its target genes such as catalase and peroxiredoxin. However, only when PerR is complexed with $\mathrm{Fe}^{+2}$ there is derepression of gene expression and lack of DNA binding ability (Herbig and Helmann, 2001). Because DNA binding of PerR is restored by thiol reductants and because PerR has a CXXC motif, it was proposed that peroxide sensing might involve a reactive cysteine being oxidized to a disulfide bond. Very recently, however, the same group has shown that PerR senses hydrogen peroxide by a Fenton-like reaction mediated by $\mathrm{Fe}^{+2}$ complexed with histidines. This process provokes oxidation of histidine residues (His37 and His91) to 2-oxohistidines. This is the first description of a metal catalyzed protein oxidation process involved with redox signaling (Lee and Helmann, 2006).

Besides transcriptional regulators, bacteria also possess a chaperone (Hsp33), whose activity is redox regulated through reduction/oxidation cycles that involve a reactive cysteine (Janda et al., 2004). In this case, cysteines residues in the reduced state can bind zinc but after oxidation to disulfide bonds, Hsp33 loses this ability but acquires high affinity for unfolded proteins (chaperone holdase activity). Thioredoxin (or glutaredoxin) can then reduce the reactive cysteine of Hsp33, restoring its ability to bind zinc. This ensures that proteins with transient exposed hydrophobic surfaces do not form insoluble aggregates. Upon return to non stress conditions other chaperone systems are available to interact with the partially unfolded proteins released by Hsp33 (reviewed by Winter and Jakob, 2004). Interestingly, Hsp33 appears to be active in severe oxidative stress, condition in which other chaperones are inactive (Winter et al., 2005).

Another level of regulation was possible in eukaryotes with the appearance of cellular compartments. In fact, the control of a transcriptional regulator's activity by regulated nuclear

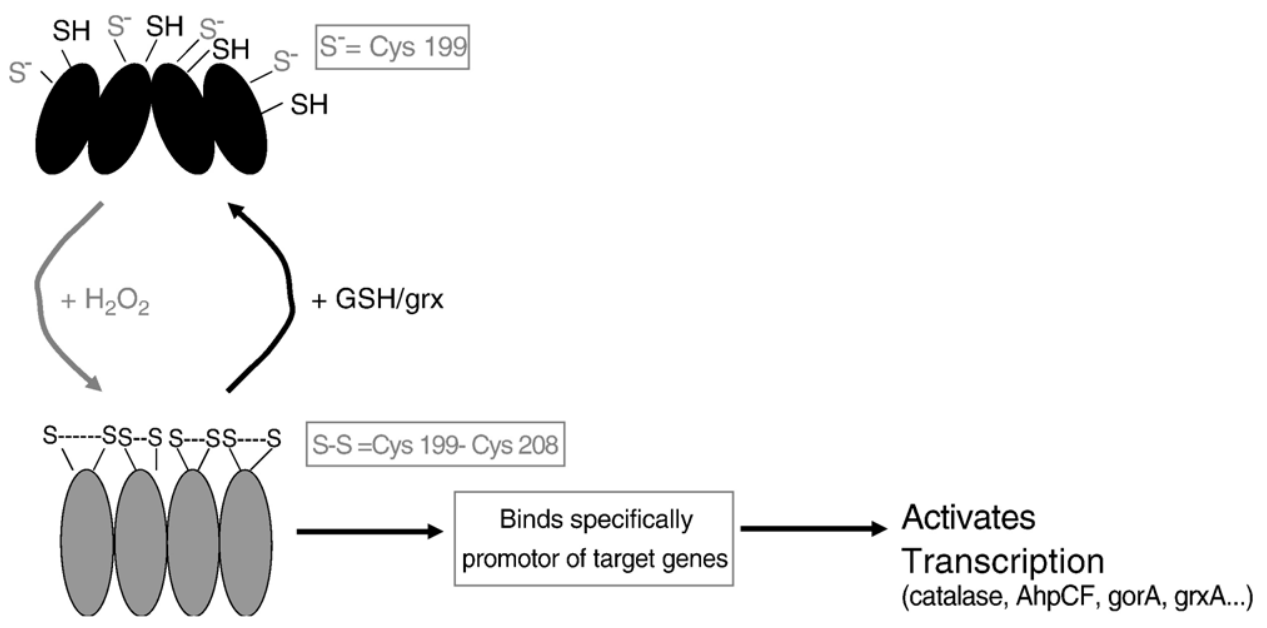

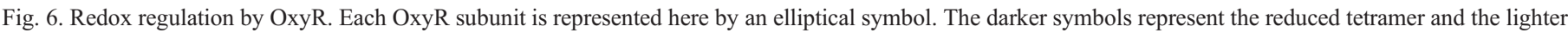

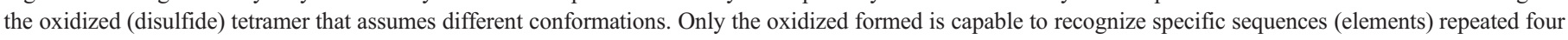
times in the promoters of targets genes and as a consequence stimulate their transcription. 
accumulation is a common theme in biology. Therefore, the higher the amount of a transcriptional regulator in the nucleus, the higher is its activity (repression or induction of gene expression). The best characterized mechanism of a redox signaling process in an eukaryotic cell through a reactive cysteine is that mediated by Yap1 (reviewed by Paget and Buttner, 2003).Yap1 belongs to the AP-1 family of proteins that includes the proto-oncogenes Jun and Fos, all of them possessing a Leu zipper involved in the dimerization of these proteins (Fig. 7A). Yap1 also possesses a nuclear export signal (NES) that in basal conditions is recognized by $\mathrm{Cmr} 1$ that then transport this transcriptional activator from the nucleus to the cytosol (Fig. 7B i). Therefore, in basal conditions Yap1 is preferentially located in the cytosol, does not interact with target promoters and consequently does not induce gene expression. Upon oxidation, Yap1 cysteine residues are oxidized and NES adopt a different conformation, not recognizable by Crm1. Therefore, Yap1 accumulates in the nucleus, being capable to physically interact with target promoters.

Yap1 can be oxidized into two products: (1) a disulfide between cysteines residues of the $\mathrm{C}$-terminal cysteine rich domain (Fig. 7B ii) or (2) a disulfide between one cysteine of the $\mathrm{N}$-terminal and the other of the $\mathrm{C}$-terminal rich domain (Fig. 7B v). Mode (1) of Yap1 oxidation is the simplest and is mediated by thiol oxidizing agents such as diamide (Fig. 7B ii). The mode (2) is a pathway that involves other proteins besides Yap1. In this case, the oxidant is a peroxide molecule that is sensed by a protein, homologous to the seleniumdependent glutathione peroxidase (Gpx3/Orp1) from mammalian cells (Delaunay et al., 2002). Gpx3/Orp1 is oxidized to a sulfenic acid derivative (Fig. 7B iii), which condenses with a reactive cysteine of Yap1, generating a mixed disulfide bond (Fig. 7B iv). Finally a thiolate group from the N-terminal cysteine rich domain attacks the mixed disulfide, generating an intra-molecular disulfide bond in Yap1, which is not recognized by $\mathrm{Crm} 1$ and accumulates in the nucleus (Fig. $7 \mathrm{~B} \mathrm{v}$ ). Besides Yap1, other transcriptional regulators are involved in the response of yeast to oxidative stress which is a very complex phenomenon. As an example, the regulation of mitochondrial thioredoxin peroxidase I involves Hap1 (YLR256W), Msn2/4 (YMR037C/YKL062W) and Yap1 among other regulators (Monteiro et al., 2002; Monteiro and Netto, 2004).

The mechanisms by which hydrogen peroxide is sensed in mammalian cells are much more controversial. Much attention

A.
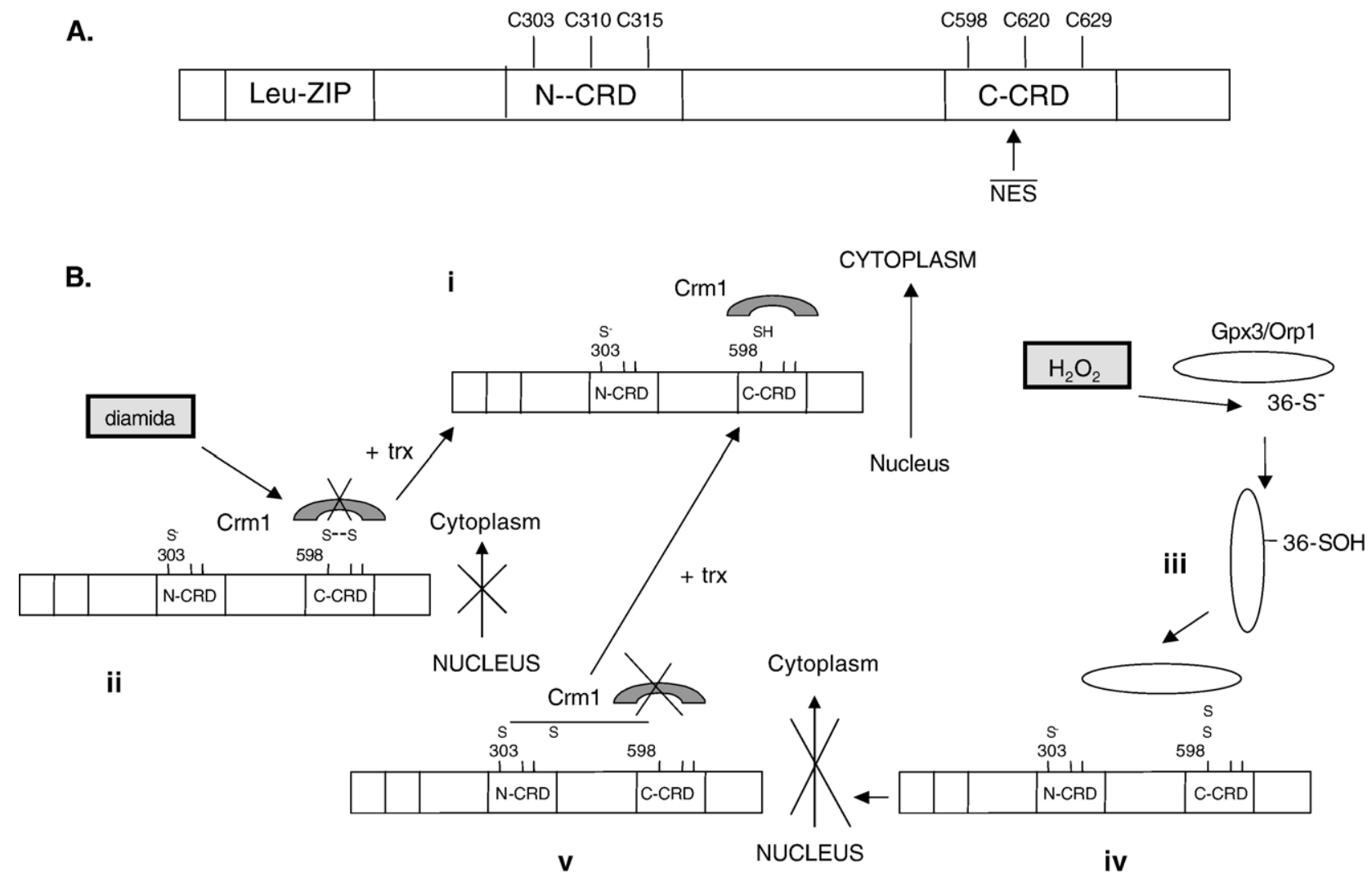

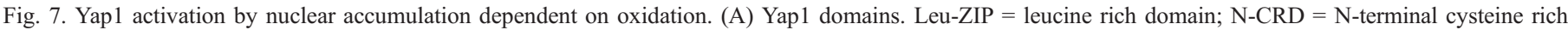

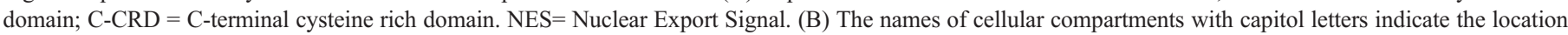

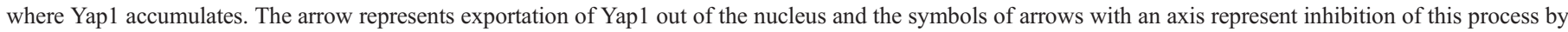

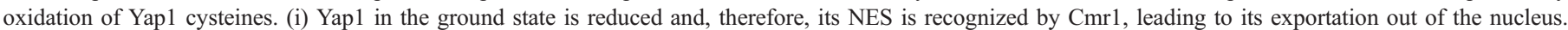

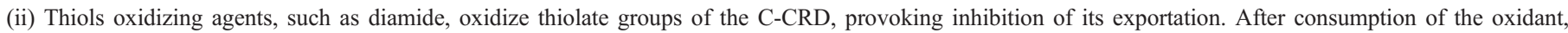

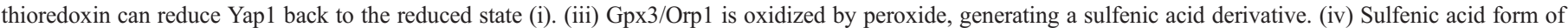

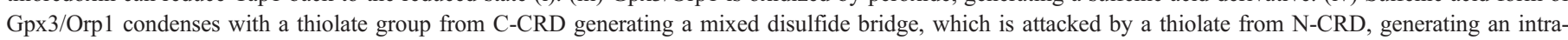

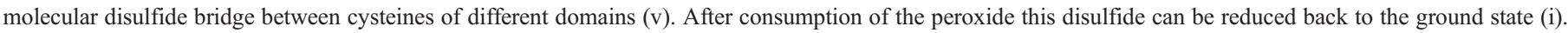




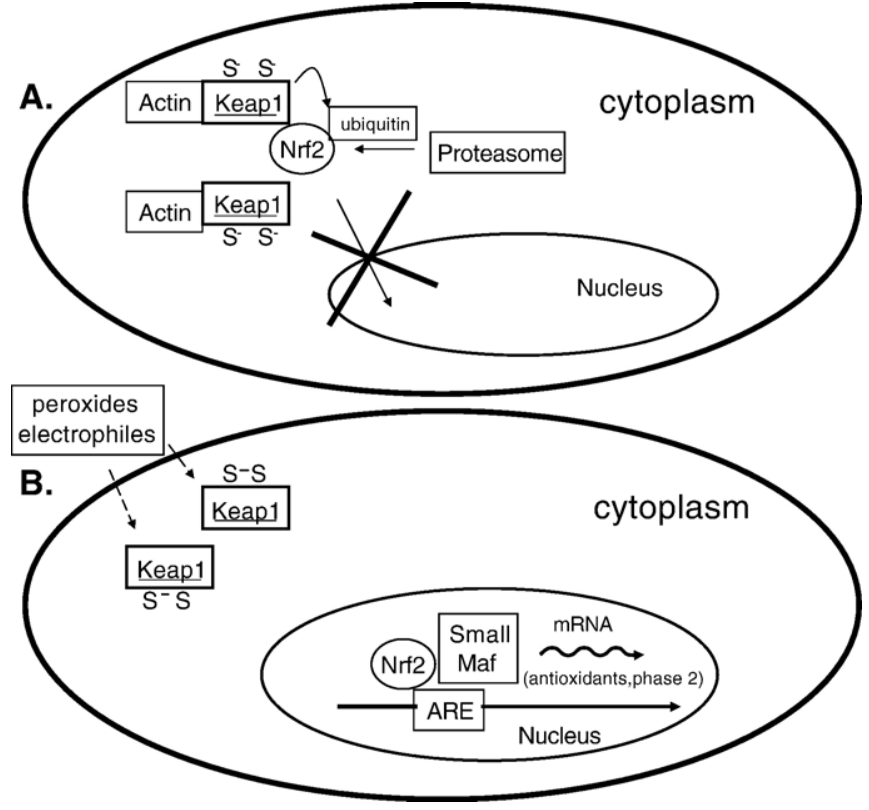

Fig. 8. Nrf2 activation by nuclear accumulation dependent on oxidation of Keap1. (A) Under basal conditions, Keap1 is in the reduced state and sequester $\mathrm{Nrf} 2$ in the cytoplasm. Keap1 is also connected to the cell cytoskeleton. In this condition, Keap1 also induces ubiquitination of Nfr2 that is then degraded by proteasome. (B) Under oxidative stress, thiolate groups of keap1 are oxidized, leading to Nrf2 release that can then accumulate in the nucleus and activate transcription in the target genes.

is given to protein tyrosine phosphatases (PTP) as biological sensors of hydrogen peroxide. Hydrogen peroxide can react with cysteines from the active site of PTP, generating sulfenic acids, which was proposed to be a redox regulatory event (Lee et al., 1998). Later, two groups have shown independently that sulfenic acids in PTP are converted to sulfenyl-amide by reaction of sulfenic acids with backbone amide of a serine residue (Salmeen et al., 2003; Van Montfort et al., 2003). The sulfenyl-amide form of PTP is inactive; therefore this process should provoke an increase in the levels of tyrosine phosphorylation. As a consequence, PTP targets such as MAP kinases should be phosphorylated in higher levels. Besides sulfenylamides, reactive cysteines were also found in the sulfinate $\left(\mathrm{RSO}_{2}^{-}\right)$and sulfonate $\left(\mathrm{RSO}_{3}^{-}\right)$forms in the crystal structure of PTP, when these proteins were treated with large excess of hydrogen peroxide (Van Montfort et al., 2003). Contrary to the sulfinate and sulfonate forms, sulfenyl-amides can be reduced back by classical reductants such as DTT and thioredoxin (Salmeen et al., 2003; Van Montfort et al., 2003). Therefore, because their formation is reversible, sulfenyl-amides were proposed as an important step in the redox signaling by PTPs.

However, redox regulation by PTP is controversial, mainly because the reaction of these phosphatases with hydrogen peroxide is slow (reaction constant is around $10 \mathrm{M}^{-1} \mathrm{~s}^{-1}$ ), (Stone, 2004). Considering that intracellular concentration of hydrogen peroxide is in between 1 to $700 \mathrm{nM}$ and that the levels of glutathione are around $1-10 \mathrm{mM}$, a target for redox regulation should react faster with this mild oxidant than PTP does. In fact, as mentioned before, one biological sensor of hydrogen peroxide in bacteria, the transcriptional factor OxyR possesses a reaction constant of $2 \times 10^{5} \mathrm{M}^{-1} \mathrm{~s}^{-1}$ (Aslund et al., 1999). OxyR, like other thiol proteins mentioned here, possesses a very reactive cysteine, which is deprotonated at physiological $\mathrm{pH}$. Therefore, the hydrogen peroxide sensor in mammalian cells should be in principle a protein that possesses a reaction constant with hydrogen peroxide in this range.

Peroxiredoxins are good candidates as biological redox sensors in mammalian cell, since their reaction constants with hydrogen peroxide are around $10^{5} \mathrm{M}^{-1} \mathrm{~s}^{-1}$ or even higher (Akerman and Muller, 2005; Baker and Poole, 2003; Parsonage et al., 2005). In fact, there are many suggestions that peroxiredoxins could be the biological sensors of hydrogen peroxide (Wood et al., 2003a,b). In this regard, it was shown that bacterial 2-Cys Prx are one hundred times more resistant to hydrogen peroxide inactivation than some of their counterparts in eukaryotic cells (Wood et al., 2003a). In both cases, the inactivation by hydrogen peroxide occurs due to oxidation of sulfenic acid (Cys-SOH) in the reactive cysteine to sulfinic acid (Cys- $\left.\mathrm{SO}_{2} \mathrm{H}\right)$. Interestingly, the all 2-Cys Prx that are sensitive to inactivation possess two common motifs: GGLG and YF (Wood et al., 2003a). Therefore, it seems very probable that the high sensitivity of these peroxiredoxins to peroxide inactivation it is not a limitation in the mechanism of catalysis, but instead a property that was selected during evolution of eukaryotes (Wood et al., 2003a).

In support to this hypothesis, it was shown that sulfinic acids in 2-Cys Prx are reduced in vivo in sensitive 2-Cys Prx (Woo et al., 2003). This was a quite surprising result, since it is well established that sulfinic acids in peroxiredoxins and in any other protein are not reducible in vitro by classical reducing agents, such as DTT and thioredoxin. The enzymatic system responsible to regenerate sulfhydryl groups from sulfinic acids in 2-Cys Prx was first identified in the yeast $S$. cerevisiae and was named sulfiredoxin (Biteau et al., 2003). Sulfiredoxin is a low molecular weight protein $(13 \mathrm{kDa})$ that possesses homologues in higher eukaryotes including human, but its physiological role was unknown. The proposed mechanism of catalysis involves phosphotransferase and thiol transferase activities through a reactive cysteine and it is dependent on ATP. The basis of this mechanism was confirmed by biochemical and crystallographic studies (Jonsson et al., 2005). Biteau et al. (2003) suggested that sulfinic acid formation in 2-Cys Prx could represent an additional level of redox regulation for peroxiredoxins. The sulfiredoxin homologue in mammalian cells was also identified and in this case it was shown that sulfinic acid regeneration is exclusive for 2-Cys Prx (Chang et al., 2004; Woo et al., 2005). Recently, Budanov et al. (2004) have shown that another class of proteins can also reduce sulfinic acids specifically of mammalian peroxiredoxins. Like sulfiredoxins, sestrin possesses a conserved cysteine that is responsible for the catalytic mechanism. Moreover, the reduction is also dependent on ATP. However, sestrins do not share homology with sulfiredoxins. Sestrin expression is regulated by p53 indicating that this process possesses high physiological relevance.

The importance of sulfinic acids generated in the peroxidatic cysteines of 2-Cys Prx was further strengthened by the observation that peroxiredoxins from yeast also possess 
chaperone activity. Interestingly, the chaperone activity is independent of peroxidatic and resolving cysteines. Both peroxides and high temperatures induce chaperone activity, which is dependent on the oligomerization of peroxiredoxin polypeptides. Remarkably, under oxidative and thermal stresses these protein form very high molecular weight complexes that can be visualized by electron microscopy. Therefore, peroxidatic cysteines of these yeast peroxiredoxins are important not only for the decomposition of peroxides but also to induce protein oligomerization and consequently chaperone activity. In fact, sulfinic acid formation was suggested as a trigger event for the formation of a superchaperone that possesses a molecular weight of more than $1000 \mathrm{kDa}$ (Jang et al., 2004). This dual chaperone/ peroxidase activities of yeast 2-Cys Prx was implied with the observation that it specifically protects cells with dysfunctional mitochondria from peroxide insult (Demasi et al., 2006). Recently, the chaperone activity was also described for peroxiredoxins from mammals and bacteria (Moon et al., 2005; Chuang et al., 2006).

The versatility of peroxiredoxin function can be further demonstrated by the observation that addition of single amino acid (Phe) close to the reactive cysteine converts a bacterial peroxiredoxin into a disulfide reductase (Ritz et al., 2001). This appears to be a relevant phenomenon, since bacteria lacking both thioredoxin reductase and glutathione reductase are viable only if cells possess peroxiredoxin with disulfide reductase activity (Ritz et al., 2001).

Recently, a novel redox mechanism for regulation of gene expression was demonstrated in mammals (Venugopal and Jaiswal, 1996; Itoh et al., 1997). As the redox regulation of Yap1 activity, the regulation of $\mathrm{Nfr} 2$, also a leucine zipper transcriptional activator, involves control of its nuclear localization. However, differently than Yap1, Nfr2 is not directly redox regulated, but instead reactive cysteines of a cytoplasmatic anchor (Keap1) are susceptible to oxidation by peroxides and electrophiles. Under basal conditions, Nfr2 is sequestered from the nuclei by Keap1 through non-covalent interactions (Itoh et al., 1999). Because Keap1 is bound to actin, Nrf2 is also connected to the cell cytoskeleton (reviewed by Motohashi and Yamamoto, 2004). These protein-protein interactions also induced ubiquitination of $\mathrm{Nfr} 2$ and consequently proteolytic digestion by proteasome (Fig. 8A). When mammalian cells are exposed to peroxides and electrophiles, reactive cysteines of Keap1 are oxidized to disulfide bonds, it suffers a conformational change and consequently $\mathrm{Nfr} 2$ is released and accumulates in the nucleus, being capable to recognize its target promoters (Fig. 8B).

\section{Conclusions}

The majority of the cysteine residues in proteins play no role in electron transfer reaction, because their $\mathrm{pK}_{\mathrm{a}}$ make them appear mainly in the protonated form in physiological conditions. In contrast, some protein foldings create environments in which the deprotonated form of cysteine $\left(\mathrm{RS}^{-}=\right.$ thiolate) is stabilized, being susceptible to oxidation. Thiol/ disulfide reactions are the most frequently considered, but thiol/ sulfenic acid reactions have also been implicated in some biological processes a long time ago. Recently, thiol/sulfinic redox chemistry has received attention in terms of redox signaling. Therefore, the versatile redox chemistry of thiolate in proteins has served to various biological roles as described in this review and should be a promising research field.

\section{Acknowledgements}

This work is supported by grants from Fundação de Amparo à Pesquisa do Estado de São Paulo (FAPESP); Conselho Nacional de Pesquisa e Tecnologia (CNPq), as part of the Instituto do Milênio Redoxoma and by the Brazilian Synchrotron Light Laboratory (LNLS) under proposals D03B-1689 and MAS-3149.

\section{References}

Akerman, S.E., Muller, S., 2005. Peroxiredoxin-linked detoxification of hydroperoxides in Toxoplasma gondii. J. Biol. Chem. 280, 564-570.

Aslund, F., Berndt, K.D., Holmgren, A., 1997. Redox potentials of glutaredoxins and other thiol-disulfide oxidoreductases of the thioredoxin superfamily determined by direct protein-protein redox equilibria. J. Biol. Chem. 272, 30780-30786

Aslund, F., Zheng, M., Beckwith, J., Storz, G., 1999. Regulation of the OxyR transcription factor by hydrogen peroxide and the cellular thiol-disulfide status. Proc. Natl. Acad. Sci. U. S. A. 96, 6161-6165.

Baker, L.M., Poole, L.B., 2003. Catalytic mechanism of thiol peroxidase from Escherichia coli. Sulfenic acid formation and overoxidation of essential Cys61. J. Biol. Chem. 278, 9203-9211.

Benesch, R.E., Benesch, R., 1955. The acid strength of the-SH group in cysteine and related compounds. J. Am. Chem. Soc. 77, 5877-5881.

Biteau, B., Labarre, J., Toledano, M.B., 2003. ATP-dependent reduction of cysteine-sulphinic acid by Saccharomyces cerevisiae sulphiredoxin. Nature 425, 980-984.

Bokoch, G.M., Knaus, U.G., 2003. NADPH oxidases: not just for leukocytes anymore! Trends Biochem. Sci. 28, 502-508.

Bryk, R., Griffin, P., Nathan, C., 2000. Peroxinytrite reductase activity of bacterial peroxiredoxins. Nature 407, 211-215.

Budanov, A.V., Sablina, A.A., Feinstein, E., Koonin, E.V., Chumakov, P.M., 2004. Regeneration of peroxiredoxins by p53 - regulated sestrins, homologs of bacterial AhpD. Science 304, 596-600.

Carvalho, A.P., Fernandes, P.A., Ramos, M.J., 2006. Similarities and differences in the thioredoxin superfamily. Prog. Biophys. Mol. Biol. 91, 229-248.

Chae, H.Z., Kim, H.J., Kang, S.W., Rhee, S.G., 1999. Characterization of three isoforms of mammalian peroxiredoxin that reduce peroxides in the presence of thioredoxin. Diabetes Res. Clin. Pract. 45, 101-112.

Chang, T.-S., Jeong, W., Woo, H.A., Lee, S.M., Park, S., Rhee, S.G., 2004 Characterization of mammalian sulfiredoxin and its reactivation of hyperoxiidized peroxiredoxin through reduction of cysteine sulfinic acid in the active site cysteine. J. Biol. Chem. 279, 50994-51001.

Chivers, P.T., Prehoda, K.E., Volkman, B.F., Kim, B.M., Markley, J.L., Raines, R.T., 1997. Microscopic $\mathrm{pK}_{\mathrm{a}}$ values of Escherichia coli thioredoxin. Biochemistry 36, 14985-14991.

Chrestensen, C.A., Starke, D.W., Mieyal, J.J., 2000. Acute Cadmium exposure inactivate thioltransferase (glutaredoxin), inhibits intracellular reduction of protein-glutathionyl-mixed disulfides, and initiates apoptosis. J. Biol. Chem. 295, 26556-26565.

Choi, H., Kim, S., Mukhopadhyay, P., Cho, S., Woo, J., Storz, G., Ryu, S., 2001. Structural basis of the redox switch in the OxyR transcription factor. Cell 105, 103-113.

Chuang, M.H., Wu, M.S., Lo, W.L., Lin, J.T., Wong, C.H., Chiou, S.H., 2006. The antioxidant protein alkylhydroperoxide reductase of Helicobacter pylori switches from a peroxide reductase to a molecular chaperone function. Proc. Natl. Acad. Sci. U. S. A. 103, 2552-2557. 
Collet, J.F., Bardwell, J.C., 2002. Oxidative protein folding in bacteria. Mol. Microbiol. 44, 1-8.

Copley, S.D., Novak, W.R.P., Babbitt, P.C., 2004. Divergence of function in the thioredoxin fold suprafamily: evidence for evolution of peroxiredoxins from a thioredoxin-like ancestor. Biochemistry 43, 13981-13995.

Costa Seaver, L., Imlay, J.A., 2001. Alkyl hydroperoxide reductase is the primary scavenger of endogenous hydrogen peroxide in Escherichia coli. J. Bacteriol. 183, 7173-7181.

Cussiol, J.R., Alves, S.V., Oliveira, M.A., Netto, L.E.S., 2003. Organic hydroperoxide resistance gene encodes a thiol-dependent peroxidase. J. Biol. Chem. 180, 2636-2643.

Darby, N.J., Creighton, T.E., 1995. Characterization of the active site cysteine residues of the thioredoxin-like domains of protein disulfide isomerase. Biochemistry $34,16770-16780$.

Davis, D.A., Newcomb, F.M., Strke, D.W., Ott, D.E., Mieyal, J.J., Yarchoan, R., 1997. Thioltransferase (glutaredoxin) is detected within HIV-1 and can regulate the activity of glutathionylated HIV-1 protease in vitro. J. Biol. Chem. 272, 25935-25940.

Delaunay, A., Pflieger, D., Barrault, M.B., Vinh, J., Toledano, M.B., 2002. A thiol peroxidase is an $\mathrm{H} 2 \mathrm{O} 2$ receptor and redox-transducer in gene activation. Cell 111, 471-481.

Demasi, A.P.D., Pereira, G.A.G., Netto, L.E.S., 2001. Cytosolic thioredoxin peroxidase $I$ is essential for the antioxidant defense of yeast with dysfunctional mitochondria. FEBS Lett. 509, 430-434.

Demasi, M., Silva, G.M., Netto, L.E.S., 2003. 20S proteasome from Saccharomyces cerevisiae is responsive to redox modifications and is $S$-glutathionylated. J. Biol. Chem. 278, 679-685.

Demasi, A.P.D., Pereira, G.A.G., Netto, L.E.S., 2006. Yeast oxidative stress response: influences of cytosolic thioredoxin peroxidase I and of the mitochondrial functional state. FEBS J. 273, 805-816.

Dillet, V., Dyson, H.J., Bashford, D., 1998. Calculations of electrostatic interactions and pKas in the active site of Escherichia coli thioredoxin. Biochemistry 37, 10298-10306.

Discola, K.F., Oliveira, M.A., Silva, G.M., Barcena, J.A., Porras, P., Padilla, A., Netto, L.E.S., Guimarães, B.G., 2005. Crystallization and preliminary X-ray diffraction analysis of glutaredoxin 2 from Saccharomyces cerevisiae in different oxidation states. Acta Crystallogr., F F61, 445-447.

Dubuisson, M., Vander-Stricht, D., Clippe, A., Etienne, F., Nauser, T., Kissner, R., Koppenol, W.H., Rees, J.F., Knoops, B., 2004. Human peroxiredoxin 5 is a peroxynitrite reductase. FEBS Lett. 571, 161-165.

Dyson, H.J., Jeng, M.F., Tennant, L.L., Slaby, I., Lindell, M., Cui, D.S., Kuprin, S., Holmgren, A., 1997. Effects of buried charged groups on cysteine thiol ionization and reactivity in Escherichia coli thioredoxin: structural and functional characterization of mutants of Asp 26 and Lys 57. Biochemistry $36,2622-2636$

Fernandes, A.P., Holmgren, A., 2004. Glutaredoxins: glutathione-dependent redox enzymes with functions far beyond a simple thioredoxin backup system. Antioxid. Redox Signal. 6, 63-74.

Frand, A.R., Cuozzo, J.W., Kaiser, C.A., 2000. Pathways for protein disulphide bond formation. Trends Cell Biol. 10, 203-210.

Fuangthong, M., Helmann, J.D., 2002. The OhrR repressor senses organic hydroperoxides by reversible formation of a cysteine-sulfenic acid derivative. Proc. Natl. Acad. Sci. U. S. A. 99, 6690-6695.

Fuangthong, M., Atichartpongkul, S., Mongkolsuk, S., Helmann, J.D., 2001. OhrR is a repressor of ohrA, a key organic hydroperoxide resistance determinant in Bacillus subtilis. J. Bacteriol. 183, 4134-4141.

Gan, Z.R., Sardana, M.K., Jacobs, J.W., Polokoff, M.A., 1990. Yeast thioltransferase - the active site cysteines display differential reactivity. Arch. Biochem. Biophys. 282, 110-115.

Goldberger, R.F., Epstein, C.J., Anfinsen, C.B., 1963. Acceleration of reactivation of reduced bovine pancreatic ribonuclease by a microsomal system from rat liver. J. Biol. Chem. 238, 628-635.

Grauschopf, U., Winther, J.R., Korber, P., Zander, T., Dallinger, P., Bardwell, J.C.A., 1995. Why is DsbA such an oxidizing disulfide catalyst? Cell 83, 947-955.

Hawkins, H.C., Freedman, R.B., 1991. The reactivities and ionization properties of the active-site dithiol groups of mammalian protein disulphide-isomerase. Biochem. J. 275 (Pt 2), 335-339.
Herbig, A.F., Helmann, J.D., 2001. Roles of metal ions and hydrogen peroxide in modulating the interaction of the Bacillus subtilis PerR peroxide regulon repressor with operator DNA. Mol. Microbiol. 41, 849-859.

Hillar, A., Peters, B., Pauls, R., Loboda, A., Zhang, H., Mauk, A.G., Loewen, P.C., 2000. Modulation of the activities of catalase-peroxidase HPI of Escherichia coli by site-directed mutagenesis. Biochemistry 39, 5868-5875.

Hofmann, B., Hecht, H.J., Flohe, L., 2002. Peroxiredoxins. Biol. Chem. 383, $347-364$.

Holmgren, A., 1972. Tryptophan fluorescence study of conformational transitions of the oxidized and reduced form of thioredoxin. J. Biol. Chem. 247, 1992-1998.

Holmgren, A., 1976. Hydrogen donor system for Escherichia coli ribonucleoside-diphosphate reductase dependent upon glutathione. Proc. Natl. Acad. Sci. U. S. A. 73, 2275-2279.

Itoh, K., Chiba, T., Takahashi, S., Ishii, T., Igarashi, K., Katoh, Y., Oyake, T., Hayashi, N., Satoh, K., Hatayama, I., Yamamoto, M., Nabeshima, Y., 1997. An Nrf2/small Maf heterodimer mediates the induction of phase II detoxifying enzyme genes through antioxidant response elements. Biochem. Biophys. Res. Commun. 236, 313-322.

Itoh, K., Wakabayashi, N., Katoh, Y., Ishii, T., Igarashi, K., Engel, J.D., Yamamoto, M., 1999. Keap1 represses nuclear activation of antioxidant responsive elements by Nrf2 through binding to the amino-terminal Neh2 domain. Genes Dev. 13, 76-86.

Jacob, C., Giles, G.I., Giles, N.M., Sies, H., 2003. Sulfur and selenium: the role of oxidation state in protein structure and function. Angew. Chem., Int. Ed. $42,4742-4758$.

Janda, I., Devedjiev, Y., Derewenda, U., Dauter, Z., Bielnicki, J., Cooper, D.R., Graf, P.C., Joachimiak, A., Jakob, U., Derewenda, Z.S., 2004. The crystal structure of the reduced, Zn2+-bound form of the B. subtilis Hsp33 chaperone and its implications for the activation mechanism. Structure 12, 1901-1907.

Jang, H.H., Lee, K.O., Chi, Y.H., Jung, B.G., Park, S.W., Park, J.H., Lee, J.R., Lee, S.S., Moon, J.C., Yun, J.W., Choi, Y.K., Kim, W.Y., Kang, J.S., Cheong, G.-W., Yun, D.-J., Rhee, S.G., Cho, M.J., Lee, S.Y., 2004. Two enzymes in one: two yeast peroxiedoxins display oxidative stress-dependent switching from a peroxidase to a molecular chaperone. Cell 117, 625-635.

Jao, S.C., English Ospina, S.M., Berdis, A.J., Starke, D.W., Post, C.B., Mieyal, J.J., 2006. Computational and mutational analysis of human glutaredoxin (thioltransferase): probing the molecular basis of the low $\mathrm{pK}_{\mathrm{a}}$ of cysteine 22 and its role in catalysis. Biochemistry 45, 4785-4796.

Jonsson, T.J., Murray, M.S., Johnson, L.C., Poole, L.B., Lowther, W.T., 2005. Structural basis for the retroreduction of inactivated peroxiredoxins by human sulfiredoxin. Biochemistry 44, 8634-8642.

Jung, G., Breitmaier, E., Voelter, W., 1972. Dissociation equilibrium of glutathione. A Fourier transform-13C-NMR spectroscopic study of $\mathrm{pH}-$ dependence and of charge densities. Eur. J. Biochem. 24, 438-445.

Kallis, G.B., Holmgren, A., 1980. Differential reactivity of the functional sulfhydryl groups of cysteine-32 and cysteine- 35 present in the reduced form of thioredoxin from Escherichia coli. J. Biol. Chem. 255, 10261-10265.

Klomsiri, C., Panmanee, W., Dharmsthiti, S., Vattanaviboon, P., Mongkolsuk, S., 2005. Novel roles of ohrR-ohr in Xanthomonas sensing, metabolism, and physiological adaptive response to lipid hydroperoxide. J. Bacteriol. 187, 3277-3281.

Lee, J.W., Helmann, J.D., 2006. The PerR transcription factor senses $\mathrm{H} 2 \mathrm{O} 2$ by metal-catalysed histidine oxidation. Nature 440, 363-367.

Lee, S.R., Kwon, K.S., Kim, S.R., Rhee, S.G., 1998. Reversible inactivation of protein tyrosine phosphatase 1B in A431 cells stimulated with epidermal growth factor. J. Biol. Chem. 273, 15366-15372.

Lesniak, J., Barton, W.A., Nikolov, D.B., 2002. Structural and functional characterization of the Pseudomonas hydroperoxide resistance protein $\mathrm{Ohr}$. EMBO J. 21, 6649-6659.

Li, H., Hanson, C., Fuchs, J.A., Woodward, C., Thomas Jr., G.J., 1993. Determination of the $\mathrm{pK}_{\mathrm{a}}$ values of active-center cysteines, cysteines-32 and -35, in Escherichia coli thioredoxin by Raman spectroscopy. Biochemistry $32,5800-5808$

Link, A.J., Robison, K., Church, G.M., 1997. Comparing the predicted and observed properties of proteins encoded in the genome of Escherichia coli K-12. Electrophoresis 18, 1259-1313. 
Lundstrom, J., Holmgren, A., 1993. Determination of the reduction-oxidation potential of the thioredoxin-like domains of protein disulfide-isomerase from the equilibrium with glutathione and thioredoxin. Biochemistry 32, 6649-6655

Meunier-Jamin, C., Kapp, U., Leonard, G.A., McSweeney, S., 2004. The structure of organic hydroperoxide resistance protein from Deinococcus radiodurans: do conformational changes facilitate recycling of the redox disulphide? J. Biol. Chem. 279, 25830-25837.

Mieyal, J.J., Starke, D.W., Gravina, S.A., Hocevar, B.A., 1991. Thioltransferase in human red blood cells: kinetics and equilibrium. Biochemistry 30, 8883-8891.

Miranda-Vizuete, A., Damdimopoulos, A.E., Gustafsson, J., Spyrou, G., 1997. Cloning, expression, and characterization of a novel Escherichia coli thioredoxin. J. Biol. Chem. 272, 30841-30847.

Molina, M.M., Belli, G., Torre, M.A., Rodriguez-Manzaneque, M.T., Herrero, E., 2004. Nuclear monothiol glutaredoxins of Saccharomyces cerevisiae can function as mitochondrial glutaredoxins. J. Biol. Chem. 279, 51923-51930.

Mongkolsuk, S., Helmann, J.D., 2002. Regulation of inducible peroxide stress responses. Mol. Microbiol. 45, 9-15.

Mongkolsuk, S., Praituan, W., Loprasert, S., Fuangthong, M., Chamnongpol, S., 1998. Identification and characterization of a new organic hydroperoxide resistance (ohr) gene with a novel pattern of oxidative stress regulation from Xanthomonas campestris pv. phaseoli. J Bacteriol. 180, 2636-2643.

Monteiro, G., Netto, L.E.S., 2004. Glucose repression of PRX1 expression is mediated by Tor $1 \mathrm{p}$ and Ras $2 \mathrm{p}$ through inhibition of Msn $2 / 4 \mathrm{p}$ in Saccharomyces cerevisiae. FEMS Microbiol. Lett. 241, 221-228.

Monteiro, G., Pereira, G.A.G., Netto, L.E.S., 2002. Regulation of mitochondrial thioredoxin peroxidase I expression by two different pathways: one dependent on cAMP and the other on heme. Free Radic. Biol. Med. 32, 278-288.

Monteiro, G., Kowaltowski, A.J., Barros, M.H., Netto, L.E.S., 2004 Glutathione and thioredoxin peroxidases mediate susceptibility of yeast mitochondria to $\mathrm{Ca}(2+)$-induced damage. Arch. Biochem. Biophys. 425, 14-24.

Moon, J.C., Hah, Y.S., Kim, W.Y., Jung, B.G., Jang, H.H., Lee, J.R., Kim, S.Y., Lee, Y.M., Jeon, M.G., Kim, C.W., Cho, M.J., Lee, S.Y., 2005. Oxidative stress-dependent structural and functional switching of a human 2-Cys peroxiredoxin isotype II that enhances HeLa cell resistance to $\mathrm{H} 2 \mathrm{O} 2$ induced cell death. J. Biol. Chem. 280, 28775-28784.

Moore, R.B., Mankad, M.V., Shriver, S.K., Mankad, V.N., Plishker, G.A., 1991. Reconstitution of $\mathrm{Ca}(2+)$-dependent $\mathrm{K}+$ transport in erythrocyte membrane vesicles requires a cytoplasmatic protein. J. Biol. Chem. 266, 18964-18968.

Motohashi, H., Yamamoto, M., 2004. Nrf2-Keap1 defines a physiologically important stress response mechanism. Trends Mol. Med. 10, 549-557.

Munhoz, D.C., Netto, L.E.S., 2004. Cytosolic thioredoxin peroxidase I and II are important defenses of yeast against organic hydroperoxide insult: catalases and peroxiredoxins cooperate in the decomposition of $\mathrm{H}_{2} \mathrm{O}_{2}$ by yeast. J. Biol. Chem. 279, 35219-35227.

Nelson, J.W., Creighton, T.E., 1994. Reactivity and ionization of the active site cysteine residues of DsbA, a protein required for disulfide bond formation in vivo. Biochemistry 33, 5974-5983.

Netto, L.E.S., Chae, H.Z., Kang, S.W., Rhee, S.G., Stadtman, E.R., 1996. Removal of hydrogen peroxide by thiol-specific antioxidant enzyme (TSA) is involved with its antioxidant properties. TSA possesses thiol peroxidase activity. J. Biol. Chem. 271, 15315-15321.

Nishinaka, Y., Masutani, H., Nakamura, H., Yodoi, J., 2001. Regulatory roles of thioredoxin in oxidative stress-induced cellular responses. Redox Rep. 6, 289-295.

Oliveira, M.A., Discola, K.F., Alves, S.V., Barbosa, J.A.R.G., Medrano, F.J., Netto, L.E.S., Guimarães, B.G., 2005. Crystallization and preliminary X-ray diffraction analysis of NADPH-dependent thioredoxin reductase from $\mathrm{Sac}$ charomyces cerevisiae. Acta Crystallogr., Sect. F Struct. Biol. Cryst. Commun. 61, 387-390.

Oliveira, M.A., Guimarães, B.G., Cussiol, J.R.R., Medrano, F.J., Gozzo, F.C., Netto, L.E.S., 2006. Strutural insights into enzyme-substrate interaction and characterization of enzymatic intermediates of organic hydroperoxide resistence protein from Xylella fastidiosa. J. Mol. Biol. 359, 433-445.

Paget, M.S., Buttner, M.J., 2003. Thiol-based regulatory switches. Annu. Rev. Genet. 37, 91-121.
Park, S.G., Cha, M.K., Jeong, W., Kim, I.H., 2000. Distinct physiological functions of thiol peroxidase isoenzymes in Saccharomyces cerevisiae. J. Biol. Chem. 275, 5723-5732.

Parsonage, D., Youngblood, D.S., Sarma, G.N., Wood, Z.A., Karplus, P.A., Poole, L.B., 2005. Analysis of the link between enzymatic activity and oligomeric state in $\mathrm{AhpC}$, a bacterial peroxiredoxin. Biochemistry 44, 10583-10592.

Pedrajas, J.R., Miranda-Vizuete, A., Javanmardy, N., Gustfsson, J.A., Spyrou, G., 2000. Mitochondrial of Saccharomyces cerevisiae contain oneconserved cysteine type peroxiredoxin with thioredoxin peroxidase activity. J. Biol. Chem. 26, 16296-16301.

Powis, G., Montfort, W.R., 2001. Properties and biological activities of thioredoxins. Annu. Rev. Biophys. Biomol. Struct. 30, 421-455.

Ralat, L.A., Manevich, Y., Fisher, A.B., Colman, R.F., 2006. Direct evidence for the formation of a complex between 1-cysteine peroxiredoxin and glutathione S-transferase pi with activity changes in both enzymes. Biochemistry 45, 360-372.

Reckenfelderbaumer, N., Krauth-Siegel, R.L., 2002. Catalytic properties, thiol $\mathrm{pK}$ value, and redox potential of Trypanosoma brucei tryparedoxin. J. Biol. Chem. 277, 17548-17555.

Reutimann, H., Straub, B., Luisi, P.L., Holmgren, A., 1981. A conformational study of thioredoxin and its tryptic fragments. J. Biol. Chem. 256, 6796-6803.

Rhee, S.G., Chae, H.Z., Kim, K., 2005a. Peroxiredoxins: a historical overview and speculative preview of novel mechanisms and emerging concepts in cell signaling. Free Radic. Biol. Med. 38, 1543-1552.

Rhee, S.G., Kang, S.W., Jeong, W., Chang, T.S., Yang, K.S., Woo, H.A., 2005b. Intracellular messenger function of hydrogen peroxide and its regulation by peroxiredoxins. Curr. Opin. Cell Biol. 17, 183-189.

Ritz, D., Lim, J., Reynolds, C.M., Poole, L.B., Beckwith, J., 2001. Conversion of a peroxiredoxin into a disulfide reductase by a triplet repeat expansion. Science 294, 158-160.

Salmeen, A., Andersen, J.N., Myers, M.P., Meng, T.C., Hinks, J.A., Tonks, N.K., Barford, D., 2003. Redox regulation of protein tyrosine phosphatase $1 \mathrm{~B}$ involves a sulphenyl-amide intermediate. Nature 423, 769-773.

Stone, J.R., 2004. An assessment of proposed mechanisms for sensing hydrogen peroxide in mammalian systems. Arch. Biochem. Biophys. 422, 119-124.

Sun, Q.A., Kirnarsky, L., Sherman, S., Gladyshev, V.N., 2001. Selenoprotein oxidoreductase with specificity for thioredoxin and glutathione systems. Proc. Natl. Acad. Sci. U. S. A. 98, 3673-3678.

Thomas, J.A., Poland, B., Honzatko, R., 1995. Protein sulfhydryls and their role in the antioxidant function of protein $S$-thiolation. Arch. Biochem. Biophys. 319, 1-9.

Trivelli, X., Krimm, I., Ebel, C., Verdoucq, L., Prouzet-Mauleon, V., Chartier, Y., Tsan, P., Lauquin, G., Meyer, Y., Lancelin, J.M., 2003. Characterization of yeast peroxiredoxin ahp1 in its reduced and overoxidized inactive forms using NMR. Biochemistry 42, 14139-14149.

Trujillo, M., Budde, H., Pineyro, M.D., Stehr, M., Robello, C., Flohe, L., Radi, R., 2004. Trypanosoma brucei and Trypanosoma cruzi tryparedoxin peroxidases catalytically detoxify peroxynitrite via oxidation of fast reacting thiols. J. Biol. Chem. 279, 34175-34182.

Van Montfort, R.L., Congreve, M., Tisi, D., Carr, R., Jhoti, H., 2003. Oxidation state of the active-site cysteine in protein tyrosine phosphatase $1 \mathrm{~B}$. Nature 423, 773-777.

Venugopal, R., Jaiswal, A.K., 1996. Nrf1 and Nrf2 positively and c-Fos and Fra1 negatively regulate the human antioxidant response element-mediated expression of $\mathrm{NAD}(\mathrm{P}) \mathrm{H}$ :quinone oxidoreductase1 gene. Proc. Natl. Acad. Sci. U. S. A. 93, 14960-14965.

Vohnik, S., Hanson, C., Tuma, R., Fuchs, J.A., Woodward, C., Thomas Jr., G.J., 1998. Conformation, stability, and active-site cysteine titrations of Escherichia coli D26A thioredoxin probed by Raman spectroscopy. Protein Sci. 7, 193-200.

Weissbach, H., Etienne, F., Hoshi, T., Heinemann, S.H., Lowther, W.T., Matthews, B., St John, G., Nathan, C., Brot, N., 2002. Peptide methionine sulfoxide reductase: structure, mechanism of action, and biological function. Arch. Biochem. Biophys. 397, 172-178.

Wheeler, G.L., Grant, C.M., 2004. Regulation of redox homeostasis in the yeast Saccharomyces cerevisiae. Physiol. Plant. 120, 12-20. 
Winter, J., Jakob, U., 2004. Beyond transcription-new mechanisms for the regulation of molecular chaperones. Crit. Rev. Biochem Mol Biol. 39, 297-317.

Winter, J., Linke, K., Jatzek, A., Jakob, U., 2005. Severe oxidative stress causes inactivation of DnaK and activation of the redox-regulated chaperone Hsp33. Mol. Cell 17, 381-392.

Wong, C.M., Zhou, Y., Ng, R.W., Kung, H.F., Jin, D.Y., 2002. Cooperation of yeast peroxiredoxins Tsa1p and Tsa2p in the cellular defense against oxidative and nitrosative stress. J. Biol. Chem. 277, 5385-5394.

Woo, H.A., Chae, H.Z., Hwang, S.C., Yang, K.S., Kang, S.W., Kim, K., Rhee, S.G., 2003. Reversing the inactivation of peroxiredoxins caused by cysteine sulfinic acid formation. Science 300, 653-656.

Woo, H.A., Jeong, W., Chang, T.-S., Park, K.J., Park, S.J., Yang, J.S., Rhee, S.G., 2005. Reduction of cysteine sulfinicacid by sulfiredoxin is specific to 2-Cys peroxiredoxins. J. Biol. Chem. 280, 325-328.
Wood, Z.A., Poole, L.B., Karplus, P.A., 2003a. Peroxiredoxin evolution and the regulation of hydrogen peroxide signaling. Science 300, 650-653.

Wood, Z.A., Schroder, E., Harris, J.R., Poole, L.B., 2003b. Structure, mechanism and regulation of peroxiredoxins. Trends Biochem. Sci. 28, 32-40.

Xiao, R., Lundstrom-Ljung, J., Holmgren, A., Gilbert, H.F., 2005. Catalysis of thiol/disulfide exchange. Glutaredoxin 1 and protein-disulfide isomerase use different mechanisms to enhance oxidase and reductase activities. J. Biol. Chem. 280, 21099-21106.

Yang, Y.F., Wells, W.W., 1991. Identification and characterization of the functional amino acids at the active center of pig liver thioltransferase by site-directed mutagenesis. J. Biol. Chem. 266, 12759-12765. 


\section{ANEXO IV}

Discola, K.F.; Oliveira, M.A.; Cussiol, J.R.R.; Monteiro, G.; Bárcena, J.A.; Porras, P.; Padilla, C.A.; Guimarães, B.G. \& Netto, L.E.S. (2009) "Structural aspects of the distinct biochemical properties of glutaredoxin 1 and glutaredoxin 2 from Saccharomyces cerevisiae". J. Mol. Biol., 385: 889-901. 


\title{
Structural Aspects of the Distinct Biochemical Properties of Glutaredoxin 1 and Glutaredoxin 2 from Saccharomyces cerevisiae
}

\author{
Karen Fulan Discola ${ }^{1,2}$, Marcos Antonio de Oliveira ${ }^{2,3}$, \\ José Renato Rosa Cussiol ${ }^{2}$, Gisele Monteiro ${ }^{2}$, José Antonio Bárcena ${ }^{4}$, \\ Pablo Porras ${ }^{4}$, C. Alicia Padilla ${ }^{4}$, Beatriz Gomes Guimarães ${ }^{5}$ \\ and Luis Eduardo Soares Netto ${ }^{2 *}$
}

\author{
${ }^{1}$ Departamento de Bioquímica, \\ Instituto de Biologia, \\ Universidade Estadual de \\ Campinas, 13083-970 \\ Campinas, Brazil \\ ${ }^{2}$ Departamento de Genética e \\ Biologia Evolutiva, Instituto de \\ Biociências, Universidade de \\ São Paulo, 05508-900 \\ São Paulo, Brazil
}

${ }^{3}$ Departamento de Biologia, Universidade Estadual Paulista, 11330-900 São Vicente, Brazil

${ }^{4}$ Departamento de Bioquímica y Biología Molecular, Universidad de Córdoba, 14071 Córdoba, Spain

${ }^{5}$ Laboratório Nacional de Luz Síncrotron, Campinas, Brazil

Received 27 May 2008; received in revised form 6 October 2008; accepted 15 October 2008

Available online

28 October 2008

\begin{abstract}
Glutaredoxins (Grxs) are small (9-12 kDa) heat-stable proteins that are ubiquitously distributed. In Saccharomyces cerevisiae, seven Grx enzymes have been identified. Two of them (yGrx1 and yGrx2) are dithiolic, possessing a conserved Cys-Pro-Tyr-Cys motif. Here, we show that yGrx2 has a specific activity 15 times higher than that of yGrx1, although these two oxidoreductases share $64 \%$ identity and $85 \%$ similarity with respect to their amino acid sequences. Further characterization of the enzymatic activities through two-substrate kinetics analysis revealed that yGrx2 possesses a lower $K_{\mathrm{M}}$ for glutathione and a higher turnover than yGrx1. To better comprehend these biochemical differences, the $\mathrm{p} K_{\mathrm{a}}$ of the $\mathrm{N}$-terminal active-site cysteines (Cys27) of these two proteins and of the yGrx2-C30S mutant were determined. Since the $\mathrm{pK}_{\mathrm{a}}$ values of the yGrx1 and yGrx2 Cys27 residues are very similar, these parameters cannot account for the difference observed between their specific activities. Therefore, crystal structures of yGrx2 in the oxidized form and with a glutathionyl mixed disulfide were determined at resolutions of 2.05 and $1.91 \AA$, respectively. Comparisons of yGrx2 structures with the recently determined structures of yGrx1 provided insights into their remarkable functional divergence. We hypothesize that the substitutions of Ser23 and Gln52 in yGrx1 by Ala23 and Glu52 in yGrx2 modify the capability of the active-site Cterminal cysteine to attack the mixed disulfide between the $\mathrm{N}$-terminal active-site cysteine and the glutathione molecule. Mutagenesis studies supported this hypothesis. The observed structural and functional differences between yGrx1 and yGrx2 may reflect variations in substrate specificity.

(C) 2008 Elsevier Ltd. All rights reserved.
\end{abstract}

Edited by R. Huber

Keywords: glutaredoxin; Saccharomyces cerevisiae; glutathione; disulfide; $X$-ray structure

\footnotetext{
*Corresponding author. E-mail address: nettoles@ib.usp.br.
}

Present address: Synchrotron SOLEIL, Saint-Aubin, France.

Abbreviations used: Grx, glutaredoxin; GR, glutathione reductase; GSH, reduced glutathione; GSSG, oxidized glutathione, glutathione disulfide; HED, $\beta$-hydroxyethyl disulfide; $\beta$-ME-SG, glutathionylated $\beta$-mercaptoethanol; $t$ - $\mathrm{BOOH}$, tert-butyl-hydroperoxide; yGrx1, glutaredoxin 1 from yeast; $\mathrm{yGrx} 1_{\mathrm{GS}}$, yeast Grx1-C30S mutant glutathionylated; yGrx1 $1_{\text {red, }}$ yeast Grx1 reduced; yGrx2, glutaredoxin 2 from yeast; yGrx2 ${ }_{G S}$, yeast Grx2-C30S mutant glutathionylated; yGrx2 $2_{\text {ox }}$ yeast Grx2 oxidized; BSA, bovine serum albumin; EDTA, ethylenediaminetetraacetic acid. 


\section{Introduction}

Glutaredoxins (Grxs) are small, heat-stable oxidoreductases with conserved cysteine residues present in CXXC motifs. ${ }^{1}$ These oxidoreductases are reduced by glutathione (GSH), producing glutathione disulfide (GSSG) that is then reduced by $\mathrm{NADPH}$ in a reaction catalyzed by glutathione reductase (GR). ${ }^{1}$ Grxs were first discovered in Escherichia coli as dithiol, GSH-dependent hydrogen donors for ribonucleotide reductase in a mutant lacking thioredoxin. ${ }^{2}$ Later, it was described that Grxs can also reduce mixed disulfides between proteins or low molecular weight thiols and GSH in reactions that require only their $\mathrm{N}$-terminal activesite cysteine. ${ }^{3-5}$ It is important to note that the reduction of glutathionylated substrates through the monothiol mechanism seems to be the major activity of Grxs; all dithiol Grxs described so far catalyze these reactions, but not all dithiol Grxs catalyze the reduction of protein disulfides by the dithiol mechanism. ${ }^{6}$ Therefore, Grxs are receiving increasing attention in redox regulation processes due to their ability to catalyze the reduction of disulfides. ${ }^{7}$

In the monothiol mechanism, Grxs specifically interact with the GSH moiety of the protein-SG mixed disulfide target, using only the N-terminal cysteine of the CXXC motif (Fig. 1, reaction a). ${ }^{5,9} \mathrm{~A}$ covalent Grx-SG mixed intermediate is formed and the target protein is released in its reduced form. Then, a second molecule of GSH reduces the GrxSG mixed intermediate, generating reduced Grx and GSSG (Fig. 1, reaction b). ${ }^{10}$ GSSG is then reduced by GR at the expense of NADPH.

The reduction of the Grx-SG mixed disulfide by the second GSH molecule (Fig. 1, reaction b) is the rate-determining step of the overall process. ${ }^{8}$ If the

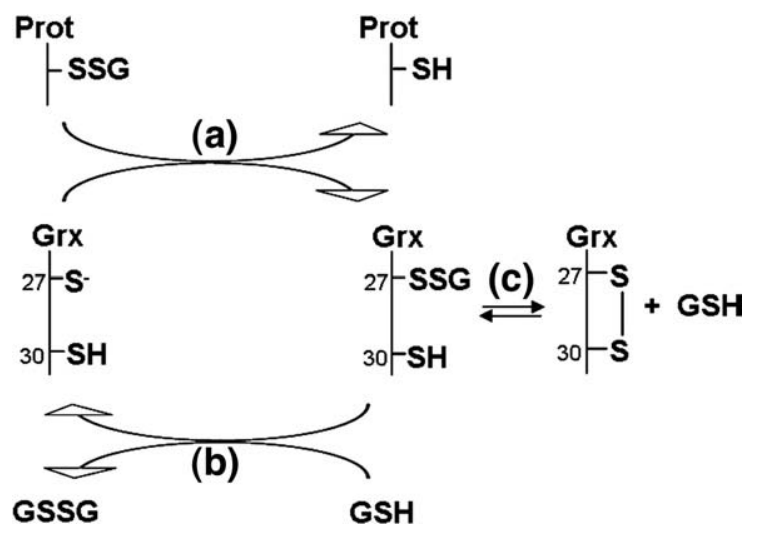

Fig. 1. Scheme of Grx monothiol mechanism. (a) The $\mathrm{N}$-terminal cysteine of the Grx active site interacts with the GSH moiety of the protein-SG mixed disulfide target, then a covalent Grx-SG mixed intermediate is formed and the target protein is released in its reduced form. (b) A second molecule of GSH reduces the Grx-SG mixed intermediate, generating reduced Grx and glutathione disulfide (GSSG). (c) The oxidized form of Grx with an intramolecular disulfide bond can be formed by the nucleophilic attack of Cys30 and is reduced back by two GSH molecules. Adapted from Srinivasan et al. ${ }^{8}$ reduction of the Grx-SG by an external nucleophile such as GSH is favored, the reaction tends to proceed by the monothiol mechanism. However, if the nucleophilic attack of the C-terminal cysteine on the Grx-SG is favored, a side reaction can occur and produce oxidized Grx with an intramolecular disulfide bond (Fig. 1, reaction c). In this case, the reaction proceeds through the dithiol mechanism, and the disulfide bond of Grx is reduced by two GSH molecules. ${ }^{11,12}$

Another common feature of Grxs is that the $\mathrm{pK}$ of their N-terminal active-site cysteine thiol is generally very low (around 3.0 to 4.0). Therefore, most of these cysteine residues are deprotonated at physiological $\mathrm{pH}$, whereas the C-terminal activesite cysteine is usually protonated. ${ }^{12-14}$ The thiolate form of the N-terminal cysteine of Grx appears to contribute to its catalytic activity because it is a good leaving group (Fig. 1, reaction $b$ ) rather than a good nucleophile (Fig. 1, reaction a), which is in line with the observation that reaction $b$ is the ratelimiting step. 8,12

In Saccharomyces cerevisiae, seven Grx genes have been identified (GRX1-7). Glutaredoxin 1 and 2 from yeast (yGrx1 and yGrx2) are dithiolic Grxs, which contain the conserved CPYC motif in their active sites. ${ }^{15}$ yGrx2 is present in two molecular weight isoforms $(11,900$ and 15,900), each synthesized by one of two in-frame translation initiation start sites. ${ }^{16}$ The cytosolic isoform is synthesized from the second AUG and lacks an N-terminal extension, while the long isoform that carries a mitochondrial targeting presequence is translated from the first AUG. ${ }^{17}$ The latter is translocated to the mitochondria where it is either processed by the mitochondrial processing peptidase to a short soluble isoform that localizes to the matrix or left unprocessed and retained in the outer mitochondrial membrane. ${ }^{17}$ yGrx3, yGrx4 and yGrx5 are monothiol isoforms that contain the motif CGFS in their active sites. ${ }^{18}$ yGrx3 and yGrx4 are required for Aft1 iron regulation in the nucleus, whereas yGrx5 is thought to be involved in iron-sulfur cluster metabolism and assembly. ${ }^{19,20}$ Recently, two other monothiolic enzymes, yGrx6 and yGrx7, were described in S. cerevisiae. ${ }^{21}$

The current work is focused on the two dithiolic enzymes, yGrx1 and the short isoform of yGrx2. These proteins are highly similar (64\% identity and $85 \%$ similarity), although single deletions of their genes have rendered yeast mutants with distinct phenotypes. ${ }^{15} \Delta G R X 1$ is sensitive to oxidative stress caused by superoxide anion, whereas $\triangle G R X 2$ is sensitive to stress induced by hydrogen peroxide. ${ }^{15}$ Furthermore, studies with yeast knockouts have indicated that yGrx2 accounts for most of the GSHdependent oxidoreductase activity in the cell. ${ }^{15}$ Since yGrx1 and yGrx2 expression levels are similar, ${ }^{15}$ the exhibited phenotypes in knockout strains could reflect that yGrx2 is a more efficient enzyme than yGrx1.

We compared recombinant dithiolic Grxs from yeast and observed that the specific activity of yGrx2 
was 15 times higher than that of yGrx1 in the standard $\beta$-hydroxyethyl disulfide (HED) assay, despite their high amino acid sequence similarity. Bisubstrate kinetics analysis indicated that both $K_{\mathrm{M}}$ toward GSH and turnover rate account for this enzymatic difference. In an attempt to better understand the functional differences between yGrx1 and yGrx2, we elucidated the crystallographic structure of yGrx2 in the oxidized state and of the yGrx2C30S mutant in complex with GSH through a mixed disulfide. Comparisons between these structures and those of $\mathrm{GGrx}^{22}$ revealed that residues near the active-site region could be directly implicated in the functional differences of yGrx1 and yGrx2. Mutagenesis studies supported this hypothesis.

\section{Results and Discussion}

\section{yGrx2 is more active as an oxidoreductase than yGrx1}

Yeast cell-free extracts from $\Delta G R X 2$ but not from $\triangle G R X 1$ lose most of their GSH-dependent oxidoreductase activity, ${ }^{15}$ indicating that $\mathrm{yGrx} 2$ accounts for the majority of this enzymatic activity. Based on this observation, we measured the specific activities of pure recombinant yeast dithiolic Grxs, using the standard assay of reduction of the mixed disulfide formed between HED and GSH (glutathionylated $\beta$-mercaptoethanol, $\beta$-ME-SG). ${ }^{23}$ yGrx2 was approximately 15 times more active than yGrx1 (Table 1, Supplementary Data), although they share a high level of sequence similarity (Fig. 2a).

To eliminate any artifacts due to metal contamination, which could result from leaching of nickel during affinity chromatography, we compared the activity results of yGrx1 and yGrx2 purified with cobalt-affinity chromatography. Although cobalt binds more strongly to a Talon affinity column (Clontech) than nickel to a Hi-Trap affinity column (GE Healthcare), the specific activities were essen- tially the same. Furthermore, we also removed the N-terminal his-tag from the yGrx1 and yGrx2 recombinant proteins, but their oxidoreductase activities remained the same. Therefore, yGrx2 is intrinsically more active than yGrx1, which explains results of previous studies on yeast knockout strains. $^{15}$

\section{Two-substrate kinetics for yGrx1 and yGrx2}

In order to better characterize the activity of yeast dithiol Grxs, we varied the concentration of HED at different concentrations of GSH and determined the apparent $K_{\mathrm{M}}$ and $k_{\mathrm{cat}}$ of $\mathrm{yGrx1}$ and yGrx2 for $\beta$-ME-SG (Table 2). ${ }^{21,26} \beta$-ME-SG was formed during a 3-min preincubation and the reactions were started with the addition of Grx. We confirmed in separate experiments that the GR concentration used was not rate limiting (data not shown). The apparent $K_{\mathrm{M}}$ and $V_{\max }$ values were determined by non-linear regression of MichaelisMenten plots (see Supplementary Data). yGrx1 presented higher affinity (lower apparent $K_{\mathrm{M}}$ values) for $\beta$-ME-SG than yGrx2, but a lower turnover number (lower $k_{\text {cat }}$ values) than yGrx2 (Table 2). These parameters are related to the formation of the Grx-SG mixed disulfide (Fig. 1, reaction a). As a consequence, the catalytic efficiency $\left(k_{\text {cat }} / K_{\mathrm{M}}\right.$ in $\left.\mathrm{M}^{-1} \mathrm{~s}^{-1}\right)$ of $\mathrm{yGrx1}$ is approximately five times lower compared with yGrx2.

Kinetic data linearization by Lineweaver-Burk resulted in intersecting lines on double-reciprocal plots (data not shown), which indicates a sequential mechanism for both yGrx1 and yGrx2. Similar patterns were obtained for yGrx7 and human Grx from red blood cells in the HED assay, which confirm that the $\beta$-ME-SG formation in the preincubation reaction is nonenzymatic. ${ }^{21,26}$

We built secondary plots with the reciprocal values of $V_{\max }^{\mathrm{app}}$ versus the reciprocal of GSH concentrations to obtain the "true" kinetics parameters (Fig. $3 \mathrm{a}$ and $\mathrm{b}){ }^{27}$ yGrx2 has a lower $K_{\mathrm{M}}$ for GSH than yGrx1 and a higher turnover number, resulting in a

Table 1. Values of specific activity* and $\mathrm{p} K_{\mathrm{a}}$ of Cys27 for yGrx1, yGrx2, and the mutants yGrx1-C30S, yGrx1-S23A, yGrx1-S23A-Q52E, yGrx2-C30S, yGrx2-A23S and yGrx2-A23S-E52Q

\begin{tabular}{|c|c|c|c|}
\hline \multirow[b]{2}{*}{ Protein } & \multirow[b]{2}{*}{$\begin{array}{c}\text { Specific activity } \\
\left(\mu \mathrm{mol} \mathrm{min}{ }^{-1} \mathrm{mg}^{-1}\right)\end{array}$} & \multicolumn{2}{|c|}{$\mathrm{p} K_{\mathrm{a}}$ Cys27 } \\
\hline & & $\begin{array}{c}\text { Monobromobimane } \\
\text { alkylation }\end{array}$ & $\begin{array}{c}\text { Iodoacetamide } \\
\text { inactivation }\end{array}$ \\
\hline Grx1 & $8.2 \pm 0.3$ & $3.2 \pm 0.2$ & $4.0 \pm 0.2$ \\
\hline Grx1-C30S & $38.7 \pm 0.5$ & N.D. & N.D. \\
\hline Grx1-S23A & $27.8 \pm 0.5$ & N.D. & N.D. \\
\hline Grx1-S23A-Q52E & $24.5 \pm 0.4$ & N.D. & N.D. \\
\hline Grx2 & $125 \pm 7$ & $3.1 \pm 0.2$ & $3.5 \pm 0.2$ \\
\hline Grx2-C30S & $38 \pm 1$ & N.D. & $3.2 \pm 0.2$ \\
\hline Grx2-A23S & $74 \pm 5$ & N.D. & N.D. \\
\hline Grx2-A23S-E52Q & $54 \pm 2$ & N.D. & N.D. \\
\hline
\end{tabular}


(a) yeast_Grx2
yeast_Grx1
human_Grx1
Ecoli_Grx3
human_Grx2
Ecoli_Grx1

yeast_Grx yeast_Gxy human_Gx1 Ecoli_Grx3 human_Gx2 Ecoli_Gx 1

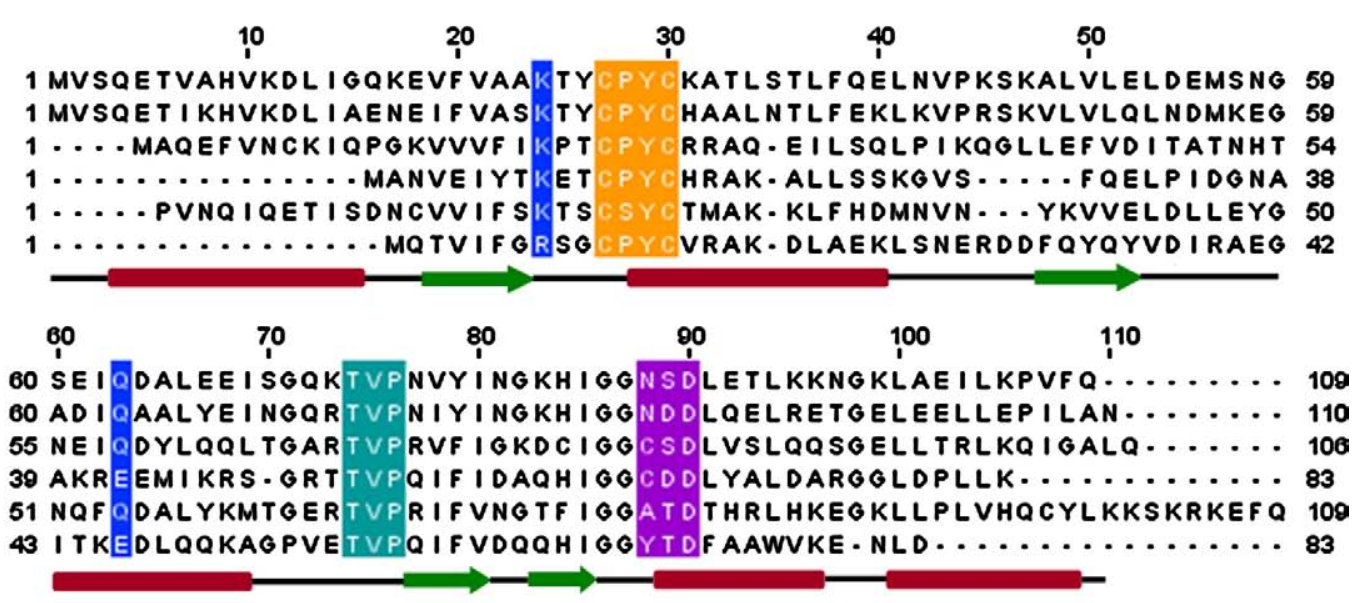

(b)

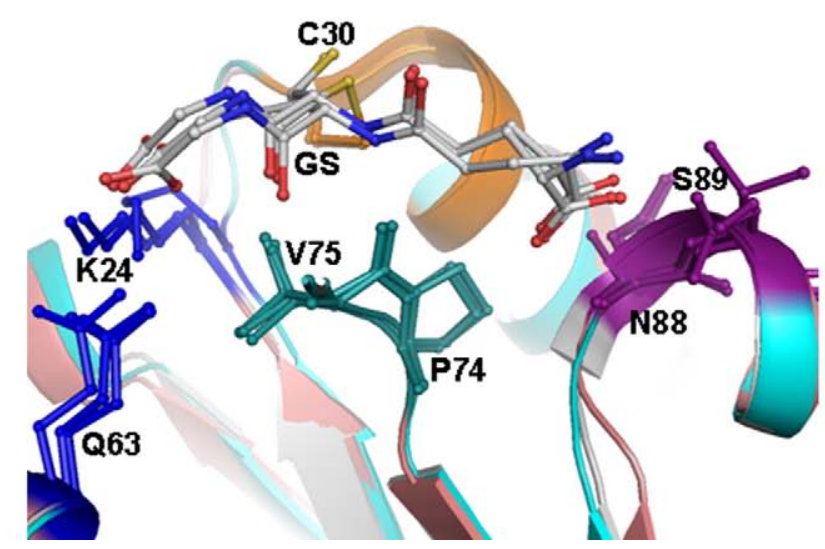

Fig. 2. Alignment of Grxs with glutathionylated structures. (a) Sequences were aligned using $\mathrm{ClustalW}^{24}$ and the alignment representation was produced with Jalview. ${ }^{25}$ The active-site residues of Grxs are highlighted with an orange rectangle and residues within the blue rectangles are involved in interactions with the Gly residue from GSH. The green rectangle indicates residues that form the TVP motif involved in interactions with the Cys residue from GSH, and within the violet rectangle are the residues participating in interactions with the GSH $\gamma$-Glu residue. The secondary-structure elements of yGrx2 are indicated at the bottom of the figure (arrows representing $\beta$-sheets and cylinders for $\alpha$-helices). (b) Structural superposition of yGrx2 (cyan), yGrx1 (gray) and human Grx2 (pink) glutathionylated structures. The residues involved in interactions with the GSH moiety are identified with the sequence number of yGrx2, and residues highlighted in (a) are shown in the same colours.

catalytic efficiency 2 orders of magnitude higher than that of yGrx1 (Table 3). Since these parameters are related to the rate-limiting step (Fig. 1, reaction $b$ ) of the overall monothiol mechanism, both the lower $K_{\mathrm{M}}$ for GSH and higher turnover number are responsible for the high specific activity of yGrx2 (Table 3).

\section{Properties of the yGrx1-C30S and yGrx2-C30S mutants}

As previously described, the substitution of the C-terminal active-site cysteine by a serine residue in dithiolic Grxs does not abolish the GSH-dependent oxidoreductase activity in the HED assay because it

Table 2. Apparent kinetic constants for the reduction of the mixed disulfide formed between GSH and HED by yGrx1 and yGrx2, determined from Michaelis-Menten plots

\begin{tabular}{|c|c|c|c|c|c|}
\hline \multicolumn{3}{|c|}{ yGrx1 } & \multicolumn{3}{|c|}{ yGrx2 } \\
\hline [GSH] (mM) & $K_{\mathrm{M}}^{\mathrm{app}}(\mathrm{mM})$ & $k_{\text {cat }}^{\text {app }}\left(\mathrm{s}^{-1}\right)$ & [GSH] (mM) & $K_{\mathrm{M}}^{\mathrm{app}}(\mathrm{mM})$ & $k_{\text {cat }}\left(\mathrm{s}^{-1}\right)$ \\
\hline 0.5 & 0.12 & 1.3 & 0.5 & 0.9 & 47 \\
\hline 1.0 & 0.12 & 2.2 & 1.0 & 0.7 & 66 \\
\hline 1.5 & 0.14 & 3.5 & 1.5 & 0.6 & 85 \\
\hline 2.0 & 0.13 & 4.2 & & & \\
\hline
\end{tabular}

The reaction mixture contained $100 \mathrm{mM}$ Tris- $\mathrm{HCl}, \mathrm{pH} 7.4,6 \mu \mathrm{g} / \mathrm{ml} \mathrm{GR}, 0.1 \mathrm{mg} / \mathrm{ml} \mathrm{BSA}, 0.2 \mathrm{mM}$ NADPH and $2 \mathrm{mM}$ EDTA. The concentration of HED was varied from 0.03 to $2.2 \mathrm{mM}$ at fixed concentrations of GSH, and the reactions were started by the addition of 500 or $50 \mathrm{nM}$ of yGrx1 or yGrx2, respectively. 
proceeds via the monothiol mechanism..$^{5,13,28}$ The yGrx1-C30S mutant presented higher specific activity than wild-type yGrx1, similarly to the mutants for the C-terminal active-site cysteine of human Grx1 and Grx2 and pig Grx (Table 1). ${ }^{13,28,29}$ Nevertheless, the specific activity of yGrx2-C30S decreased to $38 \pm 2 \mu \mathrm{mol} \mathrm{min}{ }^{-1} \mathrm{mg}^{-1}$, which corresponds to $30 \%$ of the wild-type yGrx2 activity (Table 1). This observation is very consistent with data previously reported for C14S mutants of Grx1 and Grx3 from E. coli. ${ }^{5,11}$

As mentioned before, it was described for human Grx1 that the overall reaction rate in the HED assay is determined by the rate of Grx-SG intermediate reduction. ${ }^{8}$ The occurrence of the side reaction (Fig. 1, reaction $\mathrm{c}$ ), which results in the formation of the intramolecular disulfide bond, is implicated in a decrease in the reaction rate, probably because part of the enzyme and GSH are involved in a nonproductive exchange reaction. ${ }^{28}$ The substitution of the C-terminal active-site cysteine by a serine residue in dithiolic Grxs eliminates the possibility of this side reaction and in principle should increase the reaction rate. This was the case for yGrx1-C30S, pig Grx and the human Grx1 and Grx2 mutants. ${ }^{13,28,29}$

However, for yGrx2-C30S and E. coli Grx1 and Grx3, the same mutation causes a decrease in specific activity. ${ }^{5,11}$ The reasons for this effect are not
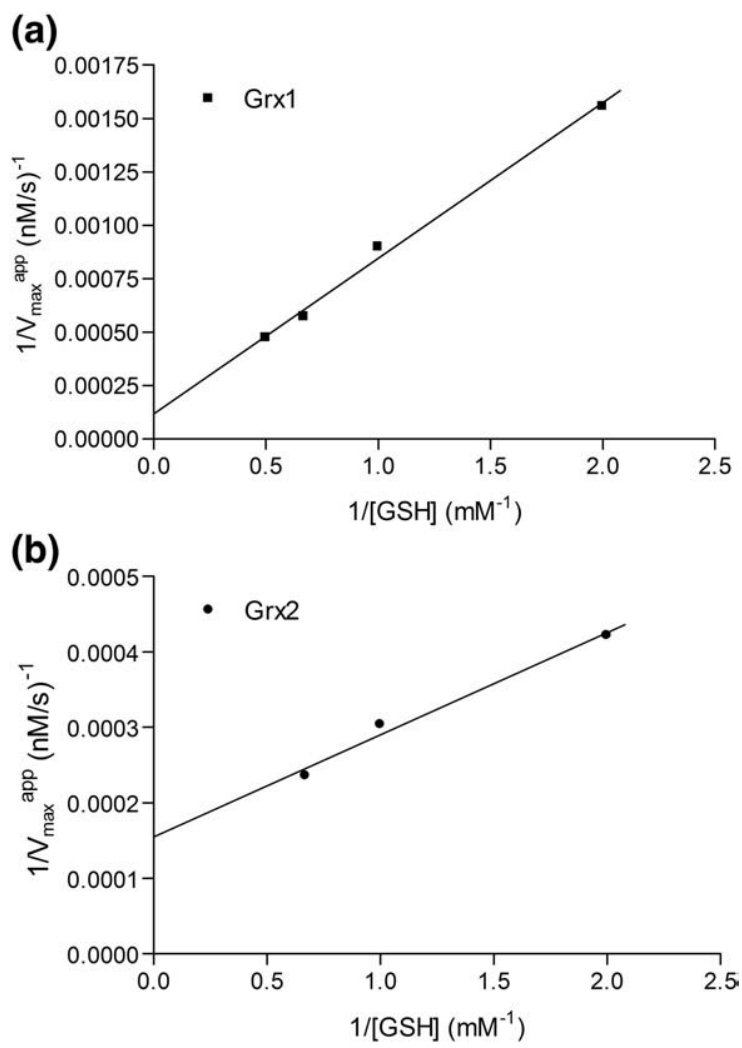

Fig. 3. Secondary plots (reciprocal values of $V_{\max }^{\mathrm{app}}$ versus the reciprocal of GSH concentration) used for the determination of the kinetic constants of yGrx1 (a) and yGrx2 (b) for GSH.
Table 3. Kinetic constants for the reduction of the mixed disulfide formed between GSH and HED by yGrx1 and yGrx2, obtained with the secondary plots of $1 / V_{\max }^{\mathrm{app}}$ versus $1 /[\mathrm{GSH}]$

\begin{tabular}{lccc}
\hline & \multicolumn{3}{c}{$\mathrm{GSH}$} \\
\cline { 2 - 4 } Protein & $K_{\mathrm{M}}(\mathrm{mM})$ & $k_{\text {cat }}\left(\mathrm{s}^{-1}\right)$ & $k_{\text {cat }} / K_{\mathrm{M}}(\mathrm{M} . \mathrm{s})^{-1}$ \\
\hline Grx1 & 6.2 & 17.1 & $2.75 \times 10^{3}$ \\
Grx2 & 0.9 & 129 & $1.43 \times 10^{5}$ \\
\hline
\end{tabular}

clear but might be related to differential structural features among different Grx isoforms. Future studies are necessary in order to better understand the particularities of these enzymes.

\section{The $\mathrm{p} K_{\mathrm{a}}$ of reactive cysteines cannot explain the difference between the oxidoreductase activities of the dithiolic yGrxs}

In the previous sections, it was demonstrated that yGrx2 possesses higher activity than yGrx1, which is related to both a lower $K_{\mathrm{M}}$ for GSH and higher turnover $\left(k_{\text {cat }}\right)$. It is well known that the N-terminal active-site cysteine residue of Grxs possesses a very low $\mathrm{p} K_{\mathrm{a}}$ value and that this feature is important for catalysis. ${ }^{8,12-14}$ Therefore, a significant difference in the $\mathrm{pK}_{\mathrm{a}}$ values of $\mathrm{yGrx1}$ and $\mathrm{yGrx} 2$ might explain the variation in the reactivities between these two enzymes.

The $\mathrm{p} K_{\mathrm{a}}$ relative to the thiol group of the $\mathrm{N}$-terminal active-site cysteine (Cys27) of both yGrx2 and yGrx1 were determined by two independent methods (Table 1, Fig. 4). The values obtained by iodoacetamide inactivation are very similar to those previously determined for yGrx2 and human Grx1 using the same approach. ${ }^{12,14}$ The substitution of the C-terminal cysteine to a serine in the yGrx2-C30S mutant resulted in a slight decrease (not significant) in the $\mathrm{p} K_{\mathrm{a}}$ value of Cys27 (Table 1, Fig. 4a). Furthermore, analysis by specific thiolate monobromobimane alkylation (which generates a fluorescent adduct $)^{30}$ indicated that the $\mathrm{pK}_{\mathrm{a}}$ values of Cys27 from yGrx1 and yGrx2 are even more similar if not identical (Table 1, Fig. 4b). In the case of yGrx1, although the $\mathrm{pK}_{\mathrm{a}}$ values for $\mathrm{yGrx1}$ Cys27 determined by the independent approaches presented some divergence (Table 1), both of them indicated that the corresponding sulfhydryl moiety should be present mostly as thiolate under physiological conditions.

Thiol-disulfide exchange reactions are expected to proceed as $\mathrm{S}_{\mathrm{N}}$ 2-type, in which the rate is dependent on the basicity $\left(\mathrm{p} K_{\mathrm{a}} \mathrm{s}\right)$ of the nucleophile and the leaving groups ${ }^{31,32}$ and the reactive specie is the ionized thiolate. ${ }^{33}$ For a thiol-disulfide exchange reaction where the thiolate anion $\left(\mathrm{SR}_{\text {nuc }}\right)$ attacks one of the two sulfur atoms of the disulfide bond, the central sulfur $\left(\mathrm{SR}_{\mathrm{c}}\right)$ will have the higher $\mathrm{p} K_{\mathrm{a}}$ value. , $^{8,12}$ As described by the following reaction,

$$
\mathrm{SR}_{\mathrm{nuc}}+\mathrm{SR}_{\mathrm{lg}} \mathrm{SR}_{c} \rightarrow \mathrm{SR}_{\mathrm{nuc}} \mathrm{SR}_{c}+\mathrm{SR}_{\mathrm{lg}}
$$


(a)

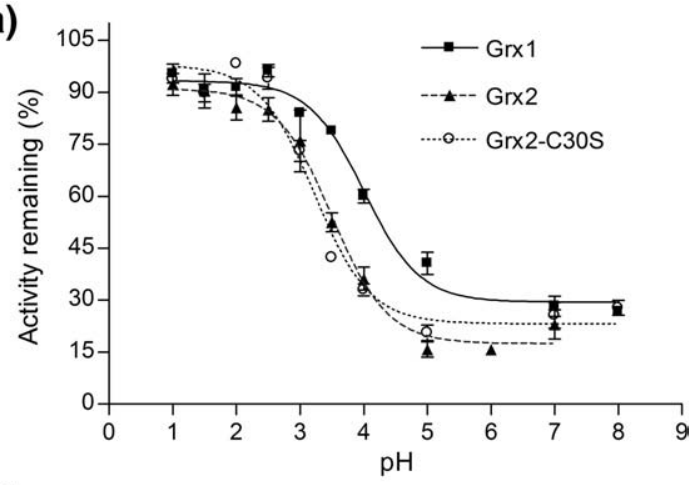

(b)

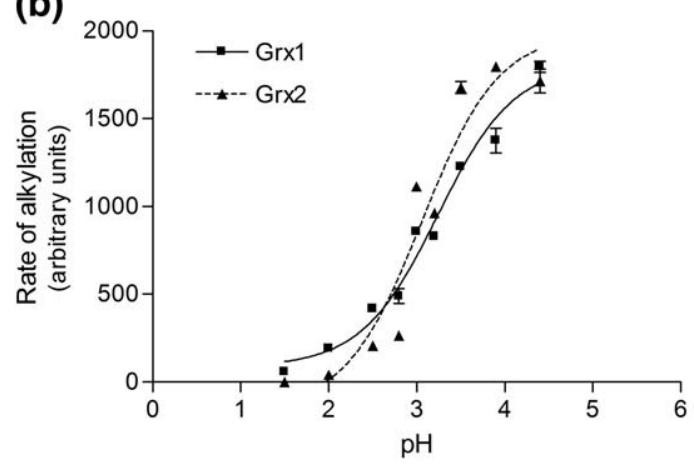

Fig. 4. Determination of $\mathrm{p} K_{\mathrm{a}}$ values for reactive cysteines. (a) Iodoacetamide inactivation. yGrx1 (filled squares), yGrx2 (filled triangles) and yGrx2-C30S (open circles). The enzymes (250 nM yGrx1, $20 \mathrm{nM}$ yGrx2, or $100 \mathrm{nM}$ yGrx2-C30S) were incubated with $300 \mu \mathrm{M}$ iodoacetamide at different $\mathrm{pH}$ values for $3 \mathrm{~min}$ at room temperature and then assayed using the standard assay for Grxs after a 100-fold dilution. The percentage of remaining activity at each $\mathrm{pH}$ was determined by comparing the activity of the enzyme incubated with and without iodoacetamide. All buffers were used at a concentration of $10 \mathrm{mM}$ and ionic strength was adjusted with the addition of $0.5 \mathrm{M} \mathrm{NaCl}$. (b) Monobromobimane alkylation. yGrx1 (filled squares) and yGrx2 (filled triangles). The prereduced yGrx1 and yGrx2 enzymes $(10 \mu \mathrm{M})$ were alkylated with $2 \mu \mathrm{M}$ of monobromobimane at different $\mathrm{pH}$ values, as described in Materials and Methods.

the lower the $\mathrm{p} K_{\mathrm{a}}$ of the leaving sulfur $\left(\mathrm{SR}_{\mathrm{lg}}\right)$, the faster the rate will be, according to the Brønsted equation: $\log k=c+\beta_{\text {nuc }} \mathrm{p} K_{\mathrm{a}(\text { nuc })}+\beta_{\mathrm{c}} \mathrm{p} K_{\mathrm{a}(\mathrm{c})}+\beta_{\lg } \mathrm{p} K_{\mathrm{a}(\mathrm{lg}) \text {, }}$ where $\beta_{\text {nuc, }} \beta_{c}$ and $\beta_{l g}$ are the Brønsted base coefficients for the nucleophile, central group and leaving group, respectively. ${ }^{8,12}$ Accordingly, for a given homologous set of thiol-disulfide exchange reactions, the second-order rate constant increases by a factor of four for each unit decrease in the $\mathrm{p} K_{\mathrm{a}}$ of the leaving group $\left(\Delta k=4 \Delta^{\mathrm{pKa}}\right)$. $^{31,32}$ Assuming that GSHmediated reduction of the Grx-SG intermediate is the rate-limiting step in the HED assay, ${ }^{8}$ the difference in the $\mathrm{p} K_{\mathrm{a}}$ values of $y \mathrm{Grx} 1$ and $y \mathrm{Grx} 2$ Cys27 residues would result in an increase of the rate constant of yGrx2 by 2.0-fold relative to that of yGrx1 when the results from iodoacetamide inactivation are considered, and an increase of 1.15-fold when the results from monobromobimane alkylation are considered
(Table 1). However, the difference observed in the enzymatic activities is much higher than expected due to the difference in the $\mathrm{p} K_{\mathrm{a}}$ values, suggesting the involvement of other factors, possibly structural features. Although the Brønsted equation applies quite well to low molecular weight thiols, ${ }^{32}$ some deviation occurs in proteins, ${ }^{12}$ further indicating that structural features besides $p K_{a}$ values are important in controlling thiol-disulfide exchange rates.

It is important to mention that in this work we have assumed that the rate-limiting reaction in the HED assay for yGrxs is the reduction of the Grx-SG mixed disulfide intermediate, as described for human Grx1. ${ }^{8}$ This is because yGrx2 activity presented a $\mathrm{pH}$ dependence similar to that of human Grx1, with a $\mathrm{pH}$ optimum value near 9.0. ${ }^{14}$ Also, Cys27 from yGrx1 and yGrx2 presented $\mathrm{p} K_{\mathrm{a}}$ values similar to that of human Grx1, suggesting that the thiolate $\mathrm{p} K_{\mathrm{a}}$ of the second substrate $(\mathrm{GSH})$ is involved in the rate-determining step. 8,26 Therefore, when all the information are taken together, $\mathrm{p} K_{\mathrm{a}}$ values for $\mathrm{yGrx1}$ and yGrx2 Cys27 should not be an important factor in the control of the overall reaction rate.

\section{Crystal structures of yGrx2}

Since the $\mathrm{p} K_{\mathrm{a}}$ values of the reactive cysteines did not correlate with their intrinsic activities, we decided to compare the structural features of yGrx1 and yGrx2. The crystal structures of yGrx1 in the reduced and glutathionylated forms (named here as $y G r x 1_{\text {red }}$ and $y G r x 1_{G S}$, respectively) were recently reported, ${ }^{22}$ and to perform comparisons, we crystallized yGrx2 and solved its structure in two different forms.

Before crystallization, yGrx2 was subjected to treatments with oxidizing [tert-butyl-hydroperoxide $(t-\mathrm{BOOH})$, diamide and hydrogen peroxide] and reducing (DTT and GSH) agents in an attempt to obtain its structure in different oxidation states. The first structure was solved and refined at $2.05 \AA$ resolution, corresponding to yGrx2 pretreated with $t-\mathrm{BOOH}$ (named herein as $\mathrm{yGrx} 2_{\mathrm{ox}}$ ). The $\mathrm{yGr} 2_{\mathrm{ox}}$ structure was used as a search model to solve the other structures of yGrx2 under different treatments. After structure solving and refinement of all data sets, we observed that in all cases (even in proteins treated with reductants), the two cysteines in the active site were oxidized, forming an intramolecular disulfide bond. The alignment of these structures showed that they were identical, and electron density map analyses indicate that no oxidation of any other residue, except the activesite cysteines, was observed, not even in the structure of yGrx2 pretreated with $t$-BOOH. We then performed analysis on the oxidized structure obtained from the data set that presented the best resolution and statistics (Table 4). Other attempts were made to obtain yGrx2 structure in the reduced form, but all of them failed.

In another attempt to obtain the reduced structure of yGrx2, we constructed the yGrx2-C30S mutant, which was also used to obtain the yGrx2 structure 
Table 4. Diffraction and refinement statistics of oxidized and glutathionylated yeast Grx2

\begin{tabular}{|c|c|c|}
\hline & Oxidized (yGrx2 $2_{o x}$ & Glutathionylated (yGrx2 ${ }_{\mathrm{GS}}$ ) \\
\hline \multicolumn{3}{|l|}{ Diffraction data statistics } \\
\hline Space group & $P 4_{1} 2_{2} 2$ & $P 2{ }_{1} 2{ }_{1}{ }_{1}$ \\
\hline Unit cell dimensions $(\AA)$ & $a=b=47.63, c=94.59$ & $a=37.0076, b=45.2051, c=105.0348$ \\
\hline Resolution range $(\AA)$ & $42.56-2.05(2.16-2.05)$ & $37.01-1.91(2.01-1.91)$ \\
\hline Measured reflections & 90,136 & 247,826 \\
\hline Unique reflections & 7295 & 14,326 \\
\hline Completeness (\%) & $99.8(99.3)$ & $99.7(98.3)$ \\
\hline Multiplicity (\%) & $12.3(11.2)$ & $8.6(8.2)$ \\
\hline$R_{\text {sym }}$ & $0.08(0.294)$ & $0.070(0.389)$ \\
\hline$\langle I / \sigma(I)\rangle$ & $28.9(7.8)$ & $23.6(4.5)$ \\
\hline \multicolumn{3}{|l|}{ Refinement statistics } \\
\hline$R_{\text {factor }}$ & 0.198 & 0.196 \\
\hline$R_{\text {free }}$ & 0.230 & 0.262 \\
\hline No. of nonhydrogen atoms & 899 & 1829 \\
\hline No. of water molecules & 65 & 137 \\
\hline rmsd & & \\
\hline Bond lengths $(\AA)$ & 0.012 & 0.012 \\
\hline Bond angles $(\AA)$ & 1.450 & 1.392 \\
\hline \multicolumn{3}{|l|}{ Average $B$-factor $\left(\AA^{2}\right)$} \\
\hline Main chain & 18.7 & 13.0 \\
\hline Side chain & 22.2 & 16.9 \\
\hline \multicolumn{3}{|l|}{ Ramachandran analysis (\%) } \\
\hline Favored regions & 97.9 & 95.8 \\
\hline Additionally allowed regions & 2.1 & 4.2 \\
\hline
\end{tabular}

in a complex with GSH. Crystals of yGrx2-C30S with a glutathionyl mixed disulfide (yGrx $2_{\mathrm{GS}}$ ) were obtained, and the structure was refined at $1.91 \AA$ resolution (Table 4). However, again, we could not obtain crystals of reduced yGrx2-C30S after several trials.

yGrx $2_{\text {ox }}$ crystallizes in space group $P 4_{1} 2{ }_{1} 2$, with one molecule in the asymmetric unit, whereas glutathionylated yGrx2-C30S crystallizes in space group $P 2{ }_{1} 2_{1} 2_{1}$, with two molecules in the asymmetric unit (referred to as chains A and B). Structures were refined to final $R$ values of $R$-factor $=0.198$ and $R_{\text {free }}=0.230$ (yGrx $2_{\text {ox }}$ ) and $R$-factor $=0.196$ and $R_{\text {free }}=0.262$ (yGrx $2_{\mathrm{GS}}$ ). The high quality of the electron density maps allowed an accurate assignment of the entire polypeptide chain of $y G r x 2_{o x}$ (109 residues). Chain $\mathrm{A}$ of $\mathrm{yGrx} 2_{\mathrm{GS}}$ and residues 2 through 108 of yGrx2 $2_{G S}$ chain B were also assigned. Molecules of GSH were modeled as bound to each of the chains $\mathrm{A}$ and $\mathrm{B}$ in the $\mathrm{yGrx} 2_{\mathrm{GS}}$ structure. Ramachandran analyses showed that $97.9 \%$ of the residues in the $\mathrm{yGrx}_{\mathrm{ox}}$ and $95.8 \%$ of the residues in the $y \mathrm{Grx} 2_{\mathrm{GS}}$ structures were in the most favored regions and that no residues were in disallowed regions.

The overall yGrx2 structure is similar to previously determined Grx structures with a central mixed fourstranded $\beta$-sheet flanked by five $\alpha$-helices (Fig. 5). The active site is localized to the second $\alpha$-helix and the loop that precedes it. The N-terminal active site cysteine, Cys27, is solvent exposed and the Cterminal Cys30 is buried one turn later along the helix $\alpha 2$ in the interior of the molecule. The distance between the $\gamma$-sulfur atoms of Cys27 and Cys30 in the intramolecular disulfide bond is $2.07 \AA$ (Fig. 6a) and the distance between the $\gamma$-sulfur atoms of
Cys27 and the glutathione cysteine $\left(\mathrm{Cys}_{\mathrm{GS}}\right)$ in the mixed disulfide bond is $2.08 \mathrm{~A}$ (Fig. 6b).

The $\mathrm{yGrx}_{\mathrm{ox}}$ and $\mathrm{yGrx} 2_{\mathrm{GS}}$ models have very similar tertiary structures (Fig. 5). The alignment of the $y \mathrm{Grx} 2_{\mathrm{ox}}$ and $\mathrm{yGrx} 2_{\mathrm{GS}}$ structures results in an overall rmsd of $0.59 \AA$ for all $109 \mathrm{C}^{\alpha}$ atoms. Despite

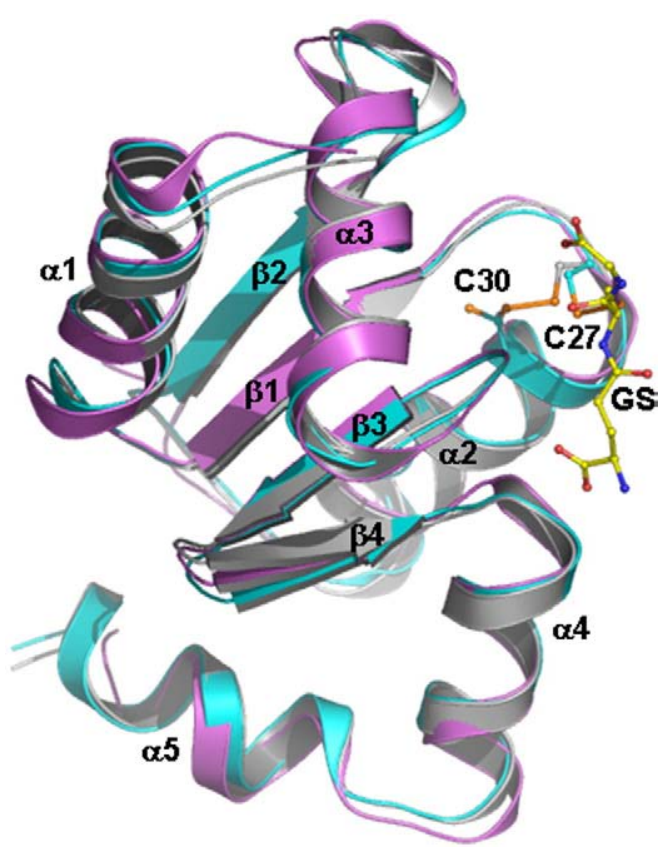

Fig. 5. Cartoon representation of the overall fold of yGrx1 and yGrx2 showing the structural alignment of yGrx $_{\mathrm{GS}}\left(\alpha\right.$-carbon atoms in violet; PDB code 2JAC), ${ }^{22}$ $\mathrm{yGrx} 2_{\mathrm{ox}}\left(\alpha\right.$-carbon atoms in gray) and $\mathrm{yGrx} 2_{\mathrm{GS}}(\alpha$-carbon atoms in cyan). The GSH molecule bonded to the yGrx2C30S mutant is shown in yellow. 
the global similarity between yGrx $2_{\text {ox }}$ and yGrx $2_{\mathrm{GS}}$, local conformational changes between structures of yGrx2 in the oxidized and glutathionylated forms occur in the active-site loop that is situated between the strand $\beta 1$ and the helix $\alpha 2$. Several residues changed their conformation in the $\mathrm{yGrx}_{\mathrm{GS}}$ structure, in comparison to the $\mathrm{yGrx} 2_{\text {ox }}$ structure, and interact with the GSH moiety (Fig. 7).

Both yGrx2 structures are very similar to those determined for yGrx1 in the reduced [Protein Data Bank (PDB) code 2JAD] and glutathionylated (PDB code 2JAC) forms (Fig. 5).22 The alignment of yGrx $2_{\mathrm{GS}}$ with $y \mathrm{Grx} 1_{\mathrm{GS}}$ results in an rmsd of $0.7 \AA$ for $108 \mathrm{C}^{\alpha}$ atoms of $\mathrm{yGrx2}$, and the interactions between these proteins and the GSH moiety are very similar (see Supplementary Data). Other Grx structures have been determined with a glutathionyl mixed disulfide: human Grx1 (PDB code 1B4Q), ${ }^{28}$ human Grx2 (PDB code 2FLS), ${ }^{35}$ E. coli Grx1 (PDB code 1 GRX) ${ }^{9}$ and E. coli Grx3 (PDB code 3GRX). ${ }^{11}$ Comparison of these structures shows that the Grx residues that interact with the GSH moiety are highly

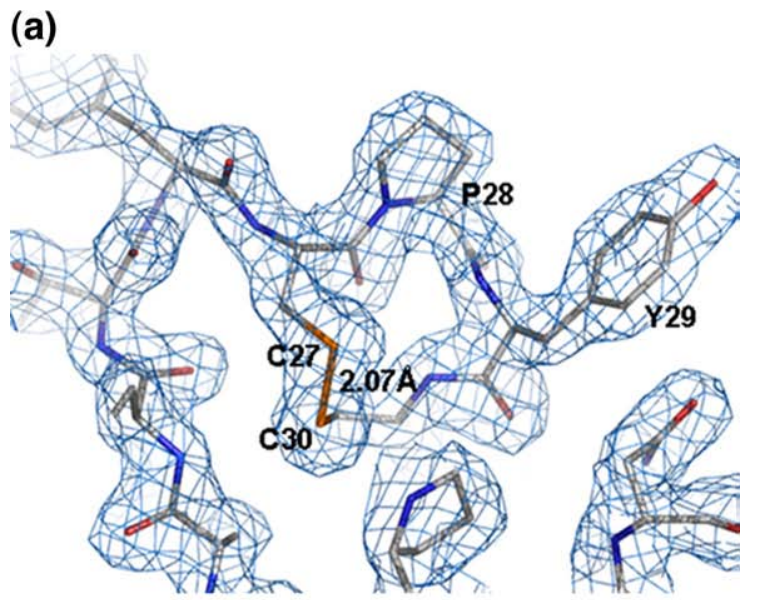

(b)

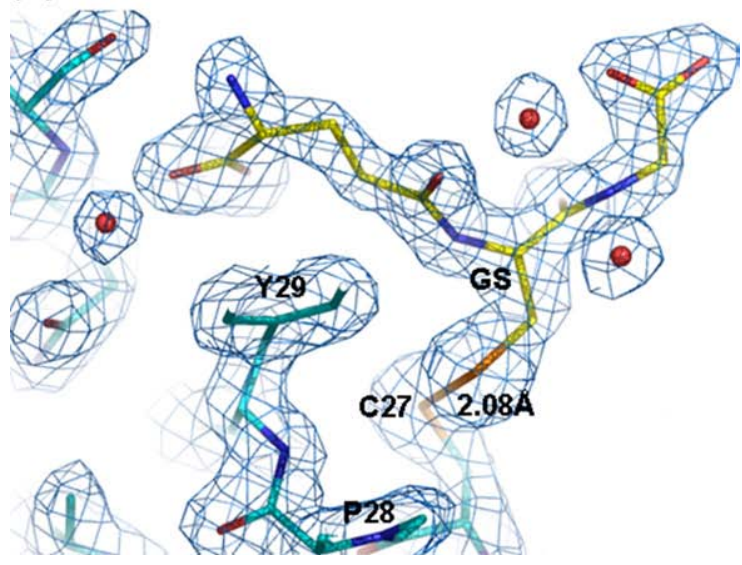

Fig. 6. Electron density maps $\left(2 F_{\mathrm{o}}-F_{\mathrm{c}}\right.$, contoured at $1.0 \sigma$ ) for the active site of (a) yGrx $2_{o x}$ and (b) yGrx $2_{G s}$. The continuous electron density between the sulfur atoms of Cys27 and Cys30 and Cys27 and the GSH cysteine residue show the disulfide bonds. The bond lengths of the intramolecular disulfide and the mixed disulfide with GSH are 2.07 and $2.08 \AA$, respectively.

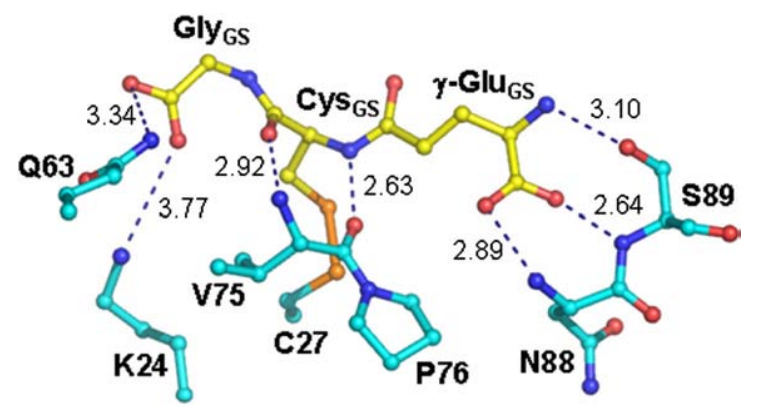

Fig. 7. yGrx2 interactions with GSH in the $y G r \times 2_{G S}$ structure. yGrx2 residues involved in interactions with the GSH moiety are represented in cyan and the GSH is shown in yellow. The hydrogen bonds and salt bridges are indicated by blue dashed lines, with the atomic distances in angstroms.

conserved (Fig. 2a and b). Nevertheless, there are differences among Grx enzymes and also between yGrx1 and yGrx2 (see below).

The alignment of the $y \mathrm{Grx} 2_{\mathrm{GS}}$ structure with the glutathionylated structures of human Grx1, human Grx2, E. coli Grx1 and E. coli Grx3 resulted in an overall rmsd of $1.67 \AA$ (for $99 \mathrm{C}^{\alpha}$ atoms of yGrx2), $1.20 \AA$ (for $97 \mathrm{C}^{\alpha}$ atoms of yGrx2), $2.08 \AA$ (for $64 \mathrm{C}^{\alpha}$ atoms of yGrx2) and $1.68 \AA$ (for $79 \mathrm{C}^{\alpha}$ atoms of yGrx2), respectively. Therefore, the overall structure of yGrx2 is more similar to the yGrx1 and human Grx1 and Grx2 structures than to the bacterial counterparts. These eukaryotic Grx structures have the same secondary structural elements, whereas E. coli Grx structures do not possess the first helix found in the eukaryotic Grxs, and E. coli Grx1 does not possess the last helix found in the other Grxs.

\section{Comparison between yGrx2 and yGrx1 structures}

Although the overall structures of yGrx1 and yGrx2 are very similar, an evident difference between the $y \mathrm{Grx} 2_{\mathrm{GS}}$ and $\mathrm{yGrx} 1_{\mathrm{GS}}$ structures is the conformation adopted by Ser30. In yGrx $1_{\mathrm{GS}}$, the Ser30 side chain is directed toward Cys27, whereas in $\mathrm{yGrx}_{\mathrm{GS}}$ the Ser30 side chain is turned to the opposite side (Fig. 8). In fact, the distance between the Ser30 hydroxyl oxygen and the sulfur atom of Cys27 is $3.47 \AA$ in $y G r x 1_{\mathrm{Gs}}$ and $5.14 \AA$ in $y \mathrm{grx} 2_{\mathrm{GS}}$. Assuming that a cysteine at position 30 could have a side-chain conformation similar to that of serine in the C30S mutants of both $y \mathrm{Grx} 1_{\mathrm{GS}}$ and $y \mathrm{Grx} 2_{\mathrm{GS}}$, Cys 30 of yGrx $1_{\mathrm{GS}}$ would be able to attack the Cys27 and form an intramolecular disulfide bond, whereas the Cys30 of yGrx $2_{\mathrm{GS}}$ would be in an unfavorable configuration for an attack on the corresponding mixed disulfide between Cys27 and GSH. If the formation of the intramolecular disulfide bond is disfavored in yGrx2, reduction of the glutathionyl mixed disulfide by an external nucleophile, such as 


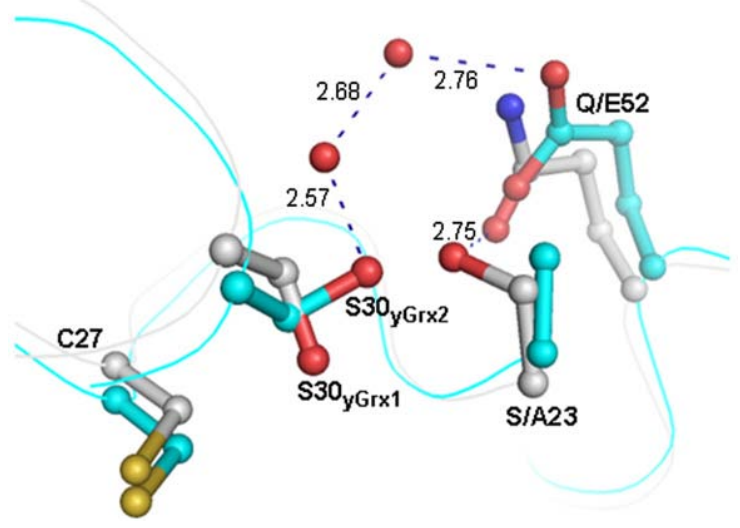

Fig. 8. Side-chain conformation of Ser30 in the structures of the C30S mutants of $y G r x 1^{22}$ (gray) and yGrx2 (cyan) in their glutathionylated forms. It is clear that the distances from the Cys27 sulfur atoms (yellow) to the Ser30 oxygen atom (red) are very different between yGrx1 and yGrx2, indicating that the conformation of a Ser30 residue in yGrx2 is less favorable to attack the mixed disulfide.

GSH, is then favored (Fig. 1). Consequently, the monothiol mechanism (involved in the HED assay) is also favored.

Corroborating the above interpretation, in E. coli Grx3 glutathionylated structure, ${ }^{11}$ Ser14 (which replaces the C-terminal active-site cysteine in this structure) presents a more buried conformation similar to that of $\mathrm{GGrx}_{\mathrm{GS}}$ Ser30. In all other Grx structures reported in the glutathionylated form (all obtained with mutations of the C-terminal activesite cysteine to serine), including the E. coli Grx1, ${ }^{9}$ the conformation of this Ser is similar to that found in $\mathrm{yGrx}_{\mathrm{GS}}$. The more buried conformation of Ser30 in the $y \mathrm{Grx} 2_{\mathrm{GS}}$ structure appears to be related to the interaction with the Glu52 carboxylate via two water molecules (Fig. 8). The distance between the oxygen of the carboxylate of Glu52 and the hydroxyl of

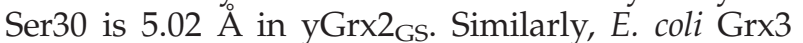
possesses the Glu30 residue, and an oxygen atom of its carboxylate group is located at $5.74 \AA$ from the hydroxyl of Ser14 in its glutathionylated structure. Glu30 of E. coli Grx3 does not occupy the same position as yGrx2 Glu52, although the distances between the carboxylate groups of these Glu residues and the hydroxyl of the Ser are similar in both structures. Also, in both structures, the Ser adopts a more buried conformation than that adopted in other Grx glutathionylated structures. Remarkably, like yGrx2, E. coli Grx3 possesses higher monothiolic activity than E. coli Grx1, although to a much lower extent (twofold).

Other Grxs, such as pig Grx and human Grx1, possess an Asp residue at the equivalent position of yGrx2 Glu52. In these Grxs, however, there is an Ile residue that prevents the contact (direct or indirect) between the Asp and the C-terminal active-site residue. In the equivalent position of the mammalian Grx isoleucine residue, yGrx2 possesses an alanine residue (Ala23), which, due to the short side chain, does not prevent interaction between Ser30 and Glu52 (Fig. 8). E coli Grx3 also does not possess bulky residues that could prevent interactions between Ser14 and Glu30. Yeast Grx1 possesses a Gln52 replacing Glu52; however, this residue makes a hydrogen bond with the hydroxyl of Ser23 (yGrx2 Ala23) and does not interact with Ser30 (Fig. 8).

Our analyses suggest that the unfavorable conformation of yGrx2 Cys30 to form intramolecular disulfide could be related to interactions established with Glu52, which are possible due to the noninterfering side chain of Ala23. In contrast, the favorable conformation of yGrx1 Cys30 to attack the Grx-SG is probably related to the fact that those interactions present in yGrx2 are not possible in yGrx1 due to the substitution of Ala23 by Ser23, which forms a hydrogen bond with Gln52, avoiding the interaction between Cys30 and Gln52.

In order to test this hypothesis, we constructed mutants of both yGrx1 and yGrx2 (yGrx1-S23A, yGrx1-S23A-Q52E, yGrx2-A23S and yGrx2-A23SE52Q). yGrx1-S23A and yGrx1-S23A-Q52E presented specific activities 3.4- and 3.0-fold higher than that of the wild-type yGrx1, respectively, whereas yGrx2-A23S and yGrx2-A23S-E52Q mutants exhibited specific activities 1.7- and 2.3-fold lower than that of the wild-type yGrx2, respectively (Table 1).

The higher activity of yGrx1-S23A and the lower activity of yGrx2-A23S compared with the activities of their respective wild-type isoforms indicated that these residues are in fact involved in the variation in the activities between dithiolic yGrxs. To further corroborate our hypothesis, the yGrx1 and yGrx2 double mutants should have higher and lower specific activities, respectively, than the single mutants yGrx1-S23A and yGrx2-A23S, indicating that the residues Ser/Ala23 and Gln/Glu52 have an additive effect in the activity of dithiolic yGrxs. However, this additive effect of Ser/Ala23 and Gln/Glu52 can be observed only in the yGrx2-A23S-Q52E double mutant, but not in yGrx1-S23A-E52Q (Table 1). Consequently, it is not clear if Gln/Glu52 is really related with the variation in the specific activity of dithiolic yGrxs.

Another possibility is that only Ser/Ala23 but not Gln/Glu52 exerts influence on yGrx1 and yGrx2 activities. In this case, Ser23 in yGrx1 could act as a base, taking away the proton from Cys30, favoring thiolate formation and, consequently, the attack of Cys30 on the Grx-SG intermediate (Fig. 1, reaction c). As a result, the formation of the intramolecular disulfide bond would switch the mechanism from the monothiol to the dithiol, which would result in a lower reaction rate in the HED assay, as discussed before. In the case of yGrx2, the more inert character of Ala23 should not influence the reactivity of Cys30 in the Grx-SG intermediate, allowing the reduction of the mixed disulfide by an external GSH molecule, therefore favoring the monothiol mechanism. This feature is consistent with the observation that yGrx1 presented higher $K_{\mathrm{M}}$ for GSH and lower $k_{\text {cat }}$ values compared to yGrx2. This hypothesis is also in agreement with the mutagenesis experiments, since the 
substitution of Ala23 by Ser in yGrx2-A23S mutant provokes a decrease in its specific activity compared with the yGrx2 wild-type enzyme, whereas the substitution of Ser23 by Ala in yGrx1-S23A causes an increase in its specific activity compared with the yGrx1 (Table 1).

It is important to mention here that in the structure of $\mathrm{yGrx}_{\mathrm{GS}}$ the $\mathrm{N}$-terminal active-site Cys27 residue is not bonded to the cysteine of GSH, ${ }^{22}$ whereas in the $\mathrm{yGrx}_{\mathrm{GS}}$ structure the glutathionyl mixed disulfide is observed (Fig. 6b). This difference might be a complicating factor for the comparison of these two structures, because it could have relevant consequences with respect to local structural conformations. However, as mentioned by the authors, the disulfide bond of yGrx1-SG was probably broken upon exposure to synchrotron radiation, and the orientation of GSH and yGrx1 residues probably was not affected, since the interactions with the GSH moiety were similar to those found in other glutathionylated Grx structures. ${ }^{22,28,35}$ Furthermore, there are structures available in the PDB where the glutathionyl mixed disulfide is present and the serine residues equivalent to yGrx1 Ser30 presented the same conformation as in the yGrx1 $1_{\mathrm{GS}}$ structure. ${ }^{9,28}$ Additionally, the hypotheses raised here from structural comparisons were strengthened by biochemical assays with mutant proteins (Table 1).

Another aspect that is probably related to the different biochemical activities of yGrx1 and yGrx2 is their redox potential. In fact, Grx1 and Grx3 from E. coli also share high amino acid sequence and overall structure similarity, although they possess very distinct redox potentials $\left(\Delta E^{\circ \prime}=35 \mathrm{mV}\right) .{ }^{36} \mathrm{In}$ contrast, Grx1 and Grx2 from humans possess more similar redox potentials $\left(\Delta E^{\circ \prime}=11 \mathrm{mV}\right),{ }^{37}$ although they do not share the same degree of similarity. In this case, it is important to mention that human Grx2 presents several unusual features such as an additional disulfide bond with a very negative redox potential $(-317 \mathrm{mV}) .{ }^{36}$ Several aspects of the relationships between redox potential and protein structure remain to be established.

In conclusion, the great enzymatic difference observed between yGrx1 and yGrx2 appears not to be related to the $\mathrm{p} K_{\mathrm{a}}$ of their reactive cysteines, but to specific structural features of these enzymes. Considering the conformation of Ser30/Cys30 in dithiolic yGrxs glutathionylated structures and the influence of Ser23 and Ala23 in the yGrx1 and yGrx2 activities, respectively, we hypothesize that yGrx2 could be more specially adapted than yGrx1 to the monothiol mechanism. These structural and functional differences between yGrx1 and yGrx2 might reflect variations in substrate specificity.

\section{Materials and Methods}

\section{Cloning, expression and purification}

Wild-type yeast GRX2 gene was cloned into the pET15b expression vector, expressed in E. coli and purified by cobalt-affinity chromatography as previously described. ${ }^{34}$

Site-directed mutagenesis was employed to mutate the cysteine 30 residue of Grx2 to a serine residue. The GRX1 and GRX2 genes were PCR amplified from S. cerevisiae genomic DNA of the strain W303 with the primers $5^{\prime}$ CGCGATCCATATGATGGTATCTCAAGAAAC-3' (forward GRX1), 5'-CGCAAGCTTGGATCCTTAATTTGCAAGAATAGG-3' (reverse GRX1), 5'-CGCGATCCATATGATGGTATCCCAGGAAACAGTTGCTCACGTAAAGGATCTGATTGGCCAAAAGGAAGTGTTTGTTGCAGCAAAGACATACTGCCCTTACAGCAAAGCTACTTTG-3' (forward GRX2-C30S, mutated sequence underlined), 5'-CGCAAGCTTGGATCCCTATTGAAATACCGGCTTC-3' (reverse GRX2-C30S). The forward primers contain NdeI restriction sites and the reverse primers contain BamHI restriction sites. The PCR products and the expression vector $\mathrm{pET} 15 \mathrm{~b}$ were first digested with $\mathrm{NdeI}$ and BamHI, and then the products were ligated into the pET15b. The GRX1-S23A, GRX1-C30S and GRX2-A23S mutants were prepared with the QuickChange Site-Directed Mutagenesis Kit from Stratagene according to the manufacturer's recommendations. The pET15b/GRX1 and pET15b/GRX2 plasmids were used as templates with two complementary primers containing the desired mutation (underlined): $5^{\prime}-$ GAGATCTTCGTCGCAGCAAAAACGTACTGTCC-3' (forward GRX1-S23A); 5'-CGTACTGTCCATACTCTCATGCAGCCCTAAAC-3' (forward GRX1-C30S); 5'GAAGTGTTTGTTGCATCCAAGACATACTGCCC-3' (forward GRX2-A23S). The mutants GRX1-S23A-Q52E and GRX2-A23S-E52Q were also prepared using the same strategy, with the pET15b/GRX1-S23A and the pET15b/ GRX2-A23S plasmids as templates and the following primers: 5'-GTT CTG GTT TTG GAG TTG AAT GAC ATG AAG-3' (forward GRX1-Q52E); 5'-G GCC CTT GTG TTG CAG TTA GAT GAA ATG AGC-3' (forward GRX2$E 52 Q)$. The gene sequences were confirmed by automated DNA sequencing and the resulting plasmids were used to transform E. coli BL21(DE3). Protein expression was induced by the addition of $1 \mathrm{mM}$ IPTG to cultures grown in $\mathrm{LB}$ medium at $310 \mathrm{~K}$ to $\mathrm{OD}_{600}=0.8$. The cells were harvested after $3 \mathrm{~h}$ of incubation at $310 \mathrm{~K}$.

Cell pellets were resuspended in $20 \mathrm{mM}$ sodium phosphate buffer, pH 7.4, $500 \mathrm{mM} \mathrm{NaCl}, 20 \mathrm{mM}$ imidazole and $1 \mathrm{mM}$ PMSF and lysed by sonication. Subsequently, the cell extract was kept on ice for 20 min during a 1\% streptomycin sulfate treatment. The extract was centrifuged at $16,000 \mathrm{~g}$ for $45 \mathrm{~min}$ to remove cell debris, and the supernatant was further clarified by filtration. The proteins were purified by metal-affinity chromatography (Nickel-Hi-trap from GE Healthcare or Cobalt-Talon metal-affinity resin from Clontech) with imidazole gradients. Protein purity was confirmed by SDS-PAGE.

Yeast Grx1 and Grx2 his-tag fusion proteins were digested with the Thrombin Clean Cleave Kit by Sigma, following the manufacturer's protocol.

\section{Assay for Grx activity}

Specific activities of yGrx1, yGrx2 and of the mutants yGrx1-S23A, yGrx1-C30S, yGrx1-S23A-Q52E, yGrx2A23S, yGrx2-C30S and yGrx2-A23S-E52Q were measured with the standard assay for Grxs, at $30^{\circ} \mathrm{C}$, using a mixed disulfide between HED and GSH as the substrate. ${ }^{23}$ Concentrations of yGrx1, yGrx2 and yGrx2-C30S were varied from 50 to 400,5 to 35 and 10 to $200 \mathrm{nM}$, respectively, and the concentrations of the mutants yGrx1-S23A, yGrx1S23A-Q52E, yGrx1-C30S, yGrx2-A23S and yGrx2-A23S- 
E52Q were varied from 10 to $100 \mathrm{nM}$. The reaction mixture, containing $100 \mathrm{mM}$ Tris- $\mathrm{HCl}, \mathrm{pH} 7.4,6 \mu \mathrm{g} / \mathrm{ml}$ GR, $1 \mathrm{mM}$ GSH, $0.7 \mathrm{mM}$ HED, $0.1 \mathrm{mg} / \mathrm{ml}$ bovine serum albumin (BSA), $0.2 \mathrm{mM}$ NADPH and $2 \mathrm{mM}$ ethylenediaminetetraacetic acid (EDTA) in a volume of $1 \mathrm{ml}$, was incubated at $30^{\circ} \mathrm{C}$ for $3 \mathrm{~min}$ for the formation of the mixed disulfide between GSH and HED. The reaction was started by the addition of Grx and followed by the decrease in the absorbance at $340 \mathrm{~nm}$ due to the oxidation of NADPH. Measured activities in all assays were corrected by subtracting the velocities of the control reactions without the enzyme, and three independent experiments were performed at each substrate concentration.

\section{Two-substrate kinetics}

Two-substrate kinetics were performed at $30^{\circ} \mathrm{C}$, varying the concentration of HED from 0.03 to $2.2 \mathrm{mM}$ at fixed concentrations of GSH $(0.5,1.0,1.5$ and 2.0 for yGrx1; $0.5,1.0$ and 1.5 for yGrx2). ${ }^{21}$ The reaction mixture contained the same components at the same concentrations as described for the measurement of Grx-specific activities. In this case, we also waited for $3 \mathrm{~min}$ for the formation of the mixed disulfide between GSH and HED before starting the reaction with the addition of Grx. The concentrations of yGrx1 and yGrx2 used in these assays were 500 and $50 \mathrm{nM}$, respectively. Measured activities in all assays were corrected by subtracting the velocities of the control reactions without the enzyme. Three independent experiments were performed at each substrate concentration, and the apparent $K_{\mathrm{M}}$ and $V_{\max }$ values were determined by non-linear regression of Michaelis-Menten plots. The reciprocal values of $V_{\max }^{\mathrm{app}}$ were plotted versus the reciprocal of the GSH concentration to provide the kinetic parameters for $\mathrm{GSH} .{ }^{27}$

\section{$\mathrm{p} K_{\mathrm{a}}$ determination of $\mathrm{N}$-terminal cysteine}

To determine the $p K_{a}$ of the $\mathrm{N}$-terminal active-site cysteine of yGrx1, yGrx2 and the yGrx2-C30S mutant, the prereduced enzymes were incubated at different $\mathrm{pH}$ values with or without $300 \mu \mathrm{M}$ iodoacetamide for $3 \mathrm{~min}$ at room temperature. ${ }^{12,14,26}$ After incubation, a 100-fold dilution in an ice-cold bath quenched the reaction mixture, and the protein was assayed for activity with the standard assay for Grx, described in Materials and Methods. The percentage of remaining activity at each $\mathrm{pH}$ was determined by comparing the activity of the enzyme incubated with and without iodoacetamide at the same $\mathrm{pH}$. The concentration of enzyme used in the assays was 250, 20 and $100 \mathrm{nM}$ for yGrx1, yGrx2 and yGrx2-C30S, respectively. Buffers for incubation of enzymes were used at $10 \mathrm{mM}$ concentration $(\mathrm{KCl}-\mathrm{HCl}, \mathrm{pH} 1.0$ and 1.5; citratephosphate, $\mathrm{pH}$ 2.0, 2.5, 3.0, 3.5, 4.0, 5.0 and 6.0; Tris- $\mathrm{HCl}$, $\mathrm{pH} 7.0$ and 8.0), and for the assay, $100 \mathrm{mM}$ Tris-HCl buffer, $\mathrm{pH}$ 7.4, was used. The ionic strength was adjusted to $0.5 \mathrm{M}$ by the addition of $\mathrm{NaCl}$.

In a second, independent approach, the $\mathrm{p} K_{\mathrm{a}}$ of the $\mathrm{N}$-terminal active-site cysteine residues was determined by monobromobimane alkylation that generates a fluorescent product $\left(\lambda_{\text {exc }} 396 \mathrm{~nm}, \lambda_{\mathrm{em}} 482 \mathrm{~nm}\right) .{ }^{30} \mathrm{yGrx} 1$ and yGrx2 were previously reduced by excess DTT $(100 \mathrm{mM})$ for $2 \mathrm{~h}$ in the presence of $0.1 \mathrm{mM}$ diethylenetriamine pentaacetic acid at room temperature. Excess DTT was removed by size-exclusion chromatography (PD-10 columns, GE Healthcare), with $5 \mathrm{mM}$ Tris- $\mathrm{HCl}, \mathrm{pH} 7.5$ (Grx2) or $\mathrm{pH}$ 8.5 (Grx1), as elution buffer. Protein concentration was determined by absorbance at $280 \mathrm{~nm}$ and specific extinction coefficient $\left(\varepsilon_{\mathrm{yGrx} 1}=6085, \varepsilon_{\mathrm{yGrx} 2}=4470\right)$. yGrx1 and
yGrx2 $(10 \mu \mathrm{M})$ were incubated with monobromobimane $(2 \mu \mathrm{M})$ at various $\mathrm{pH}$ values in 96-well plates in triplicate. All buffers used in the alkylation reactions were at $50 \mathrm{mM}$ concentration $(\mathrm{KCl}-\mathrm{HCl}$, pH 1.0 and 1.5; citrate-phosphate, $\mathrm{pH} 2.0$ to 5.0 ) and reactions proceeded at $37^{\circ} \mathrm{C}$ with shaking. The ionic strength was adjusted to $0.5 \mathrm{M}$ by the addition of $\mathrm{NaCl}$. The rates of monobromobimane alkylation were determined by extrapolation of the maximum inclination in the kinetics. As a control, it was verified that the fluorescence of the same protein-monobromobimane adduct does not change as a function of $\mathrm{pH}$.

The plots displayed in Fig. $4 a$ and $b$ were fitted by nonlinear regression to sigmoidal dose-response curves with GraphPad Prism4 software. The Hill slope utilized was equal to 1.00. The $\mathrm{p} K_{\mathrm{a}}$ values were obtained from the inflection point, in this case, $\log \mathrm{EC}_{50}$.

\section{Crystallization and X-ray data collection}

In an attempt to obtain the crystal structure of yGrx2 in different oxidative states, prior to crystallization, yGrx2 samples $(10 \mathrm{mg} / \mathrm{ml}$ in $5 \mathrm{mM}$ Tris- $\mathrm{HCl}, \mathrm{pH} 7.4)$ were submitted to treatment for $1 \mathrm{~h}$ at $310 \mathrm{~K}$ with $1 \mathrm{mM}$ hydrogen peroxide, $10 \mathrm{mM} t-\mathrm{BOOH}, 3 \mathrm{mM}$ diamide, $10 \mathrm{mM}$ DTT or $10 \mathrm{mM}$ GSH. We also subjected freshly grown yGrx2 crystals to soaking experiments with $10 \mathrm{mM}$ DTT and $10 \mathrm{mM}$ GSH in an effort to obtain the structure of reduced yGrx2. Furthermore, to obtain yGrx2-C30S with a glutathionyl mixed disulfide for crystallization, the purified protein was first incubated with $50 \mathrm{mM}$ DTT for $1 \mathrm{~h}$ at room temperature. Excess DTT was removed by gelfiltration chromatography using a PD10 column (GE Healthcare). Then, the reduced protein was treated with $25 \mathrm{mM}$ GSSG for $1 \mathrm{~h}$ at room temperature followed by gelfiltration chromatography. The glutathionylated sample of yGrx2-C30S was concentrated to $13 \mathrm{mg} / \mathrm{ml}$ in $5 \mathrm{mM}$ Hepes, pH 7.4.

Crystallization trials for yGrx2 were performed with the hanging-drop vapor-diffusion method, as previously described. ${ }^{34}$ Crystals of yGrx2 suitable for X-ray diffraction measurements were obtained under all the treatments in condition 10 of the Crystal Screen kit [ $30 \%$ polyethylene glycol (PEG) 4000, $0.1 \mathrm{M}$ sodium acetate, $\mathrm{pH} 4.6$, and 0.2 M ammonium acetate]. Crystals of yGrx2-C30S with a glutathionyl mixed disulfide were obtained in condition 22 of the Crystal Screen kit; after optimization, we obtained crystals suitable for X-ray diffraction experiments under the following conditions: 30\% PEG 4000/0.1 M sodium acetate, $\mathrm{pH}$ 5.4/0.2 M sodium acetate.

Crystals were produced from samples subjected to all treatments described and different data sets were collected. The crystals, cryoprotected by $20 \%$ glycerol, were cooled to $110 \mathrm{~K}$ and X-ray diffraction data were collected using synchrotron radiation at the protein crystallography beamline D03B MX1 at the Brazilian Synchroton Light Laboratory.

\section{Data processing, structure solution and refinement}

All data sets were indexed and integrated with MOSFLM $^{38}$ and scaled and merged using SCALA ${ }^{39,40}$ from the CCP4 suite. ${ }^{41}$ The first structure of yGrx2 (oxidized with $t$-BOOH) was solved by molecular replacement with the program AMORE, ${ }^{42}$ using as a search model a polyalanine theoretical model constructed with the program MODELLER ${ }^{43}$ and the coordinates of a thioltransferase from Sus scrofa (PDB code 1KTE), ${ }^{44}$ as previously described. $^{34}$ The other structures of yGrx2 and 
glutathionylated yGrx2-C30S were solved by molecular replacement with the refined structure of oxidized yGrx2 (yGrx $2_{\text {ox }}$ ) using the programs AMORE and PHASER. ${ }^{42,45}$

Refinements of all yGrx2 structures were performed with REFMAC 5.0,46 and a TLS atomic displacement model $^{47}$ was used in the later stages of the structure refinement of yGrx2-C30S with a glutathionyl mixed disulfide. The programs $\mathrm{O}^{48}$ and $\mathrm{COOT}^{49}$ were used for visual inspection and manual model building between the refinement cycles. The stereochemical quality of the final models was assessed by PROCHECK. ${ }^{50}$ Structural alignments were performed with the programs $\mathrm{O}^{48}$ or COOT. ${ }^{49}$ Molecular graphics figures were generated with the program PyMOL. ${ }^{51}$

\section{Protein Data Bank accession numbers}

Atomic coordinates of the S. cerevisiae Grx2 oxidized and glutathionylated structures have been deposited in the RCSB PDB with the accession codes 3D4M and 3D5J, respectively.

\section{Acknowledgements}

This work was supported by grants from the Fundação de Amparo à Pesquisa do Estado de São Paulo, by the Conselho Nacional de Desenvolvimento Científico e Tecnológico (Projeto Milenio Redoxoma), the Brazilian Synchrotron Light Laboratory under proposal D03B-1795 and by Spanish MCyT, grant BFU2006-02990 (BMC). We thank Dr. Gerardo Ferrer-Sueta (Universidad de la Republica, Montevideo, Uruguay) and Dr. Marilene Demasi (Instituto Butantan, São Paulo, Brazil) for helpful discussions and experimental support.

\section{Supplementary Data}

Supplementary data associated with this article can be found, in the online version, at doi:10.1016/ j.jmb.2008.10.055

\section{References}

1. Holmgren, A. (1989). Thioredoxin and glutaredoxin systems. J. Biol. Chem. 264, 13963-13966.

2. Holmgren, A. (1976). Hydrogen donor system for Escherichia coli ribonucleoside-diphosphate reductase dependent upon glutathione. Proc. Natl Acad. Sci. USA, 73, 2275-2279.

3. Holmgren, A. (1978). Glutathione-dependent enzyme reactions of the phage $\mathrm{T} 4$ ribonucleotide reductase system. J. Biol. Chem. 253, 7424-7430.

4. Holmgren, A. (1979). Glutathione-dependent synthesis of deoxyribonucleotides. Characterization of the enzymatic mechanism of Escherichia coli glutaredoxin. J. Biol. Chem. 254, 3672-3678.

5. Bushweller, J. H., Åslund, F., Wüthrich, K. \& Holmgren, A. (1992). Structural and functional characterization of the mutant Escherichia coli glutaredoxin
$(\mathrm{C} 14 \rightarrow \mathrm{S})$ and its mixed disulfide with glutathione. Biochemistry, 31, 9288-9293.

6. Lillig, C. H., Berndt, C. \& Holmgren, A. (2008). Glutaredoxin systems. Biochim. Biophys. Acta, 1780, 1304-1317.

7. Gallogly, M. M. \& Mieyal, J. J. (2007). Mechanisms of reversible protein glutathionylation in redox signaling and oxidative stress. Curr. Opin. Pharmacol. 7, 381-391.

8. Srinivasan, U., Mieyal, P. A. \& Mieyal, J. J. (1997). pH profiles indicative of rate-limiting nucleophilic displacement in thioltransferase catalysis. Biochemistry, 36, 3199-3206.

9. Bushweller, J. H., Billeter, M., Holmgren, A. \& Wüthrich, K. (1994). The nuclear magnetic resonance solution structure of the mixed disulfide between Escherichia coli glutaredoxin $(\mathrm{C} 14 \rightarrow \mathrm{S})$ and glutathione. J. Mol. Biol. 235, 1585-1597.

10. Fernandes, A. P. \& Holmgren, A. (2004). Glutaredoxins: glutathione-dependent redox enzymes with functions far beyond a simple thioredoxin backup system. Antioxid. Redox Signal. 6, 63-74.

11. Nordstrand, K., Åslund, F., Holmgren, A., Otting, G. \& Berndt, K. D. (1999). NMR structure of Escherichia coli glutaredoxin 3-glutathione mixed disulfide complex: implications for the enzymatic mechanism. J. Mol. Biol. 286, 541-552.

12. Jao, S., Ospina, S. M. E., Berdis, A. J., Starke, D. W., Post, C. B. \& Mieyal, J. J. (2006). Computational and mutational analysis of human glutaredoxin (thioltransferase): probing the molecular basis of the low $\mathrm{p} K_{\mathrm{a}}$ of cysteine 22 and its role in catalysis. Biochemistry, 45, 4785-4796.

13. Yang, Y. \& Wells, W. W. (1991). Identification and characterization of the functional amino acids at the active center of pig liver thioltransferase by sitedirected mutagenesis. J. Biol. Chem. 266, 12759-12765.

14. Gan, Z., Sardana, M. K., Jacobs, J. W. \& Polokoff, M. A. (1990). Yeast thioltransferase-active site cysteines display differential reactivity. Arch. Biochem. Biophys. 282, 110-115.

15. Luikenhuis, S., Perrone, G., Dawes, I. W. \& Grant, C. M. (1998). The yeast Saccharomyces cerevisiae contains two glutaredoxin genes that are required for protection against reactive oxygen species. Mol. Biol. Cell, 9, 1081-1091.

16. Pedrajas, J. R., Porras, P., Martínez-Galisteo, E., Padilla, C. A., Miranda-Vizuete, A. \& Bárcena, J. A. (2002). Two isoforms of Saccharomyces cerevisiae glutaredoxin 2 are expressed in vivo and localize to different subcellular compartments. Biochem. J. 364, 617-623.

17. Porras, P., Padilla, C. A., Krayl, M., Voos, W. \& Barcena, J. A. (2006). One single in-frame AUG codon is responsible for a diversity of subcellular localizations of glutaredoxin 2 in Saccharomyces cerevisiae. J. Biol. Chem. 281, 16551-16562.

18. Rodríguez-Manzaneque, M. T., Ros, J., Cabiscol, E., Sorribas, A. \& Herrero, E. (1999). Grx5 glutaredoxin plays a central role in protection against protein oxidative damage in Saccharomyces cerevisiae. Mol. Cell. Biol. 19, 8180-8190.

19. Ojeda, L., Keller, G., Muhlenhoff, U., Rutherford, J. C., Lill, L. \& Winge, D. R. (2006). Role of glutaredoxin 3 and glutaredoxin 4 in the iron regulation of Aft1 transcriptional activator in Saccharomyces cerevisiae. J. Biol. Chem. 281, 17661-17669.

20. Rodríguez-Manzaneque, M. T., Tamarati, J., Belli, G., Ros, J. \& Herrero, E. (2002). Grx5 is a mitochondrial glutaredoxin required for the activity of iron/sulfur enzymes. Mol. Biol. Cell, 13, 1109-1121. 
21. Mesecke, N., Mittler, S., Eckers, E., Herrmann, J. M. \& Deponte, M. (2008). Two novel monothiol glutaredoxins from Saccharomyces cerevisiae provide further insight into iron-sulfur cluster binding, oligomerization, and enzymatic activity of glutaredoxins. Biochemistry, 47, 1452-1463.

22. Håkansson, K. O. \& Winther, J. R. (2007). Structure of glutaredoxin Grx1p C30S mutant from yeast. Acta Crystallog., Sect. D: Biol. Crystallogr. 63, 288-294.

23. Holmgren, A. \& Åslund, F. (1995). Glutaredoxin. Methods Enzymol. 252, 283-292.

24. Chenna, R., Sugawara, H., Koile, T., Lopez, R. Gibson, T. J., Higgins, D. G. \& Thompson, J. D. (2003). Multiple sequence alignment with the Clustal series of programs. Nucleic Acids Res. 31, 3497-3500.

25. Clamp, M., Cuff, J., Searle, S. M. \& Barton, G. J. (2004) The Jalview Java alignment editor. Bioinformatics, 20 426-427.

26. Mieyal, J. J., Starke, D. W., Gravina, S. A. \& Hocevar, B. (1991). Thioltransferase in human red blood cells: kinetics and equilibrium. Biochemistry, 30, 8883-8891.

27. Segel, H. I. (1975). Enzyme Kinetics: Behavior and Analysis of Rapid Equilibrium and Steady-State Enzyme Systems. Wiley, New York.

28. Yang, Y., Jao, S., Nanduri, S., Starke, D. W., Mieyal, J. J. \& Qin, J. (1998). Reactivity of the human thioltransferase (glutaredoxin) C7S, C25S, C78S, C82S mutant and NMR solution structure of its glutathionyl mixed disulfide intermediate reflect catalytic specificity. Biochemistry, 37, 17145-17156.

29. Johansson, C., Lillig, C. H. \& Holmgren, A. (2004). Human mitochondrial glutaredoxin reduces $S$-glutathionylated proteins with high affinity accepting electrons from either glutathione or thioredoxin reductase. J. Biol. Chem. 279, 7537-7543.

30. Kosower, N. S., Kosower, E. M., Newton, G. L. \& Ranney, H. M. (1979). Bimane fluorescent labels: labeling of normal human red cells under physiological conditions. Proc. Natl Acad. Sci. USA, 76, 3382-3386.

31. Gilbert, H. F. (1990). Molecular and cellular aspects of thiol-disulfide exchange. Adv. Enzymol. Relat. Areas Mol. Biol. 63, 69-172.

32. Szajewski, R. P. \& Whitesides, G. M. (1980). Rate constants and equilibrium constants for thiol-disulfide interchange reactions involving oxidized glutathione. J. Am. Chem. Soc. 102, 2011-2026.

33. Creighton, T. E. \& Darby, N. J. (1993). Dissecting the disulfide couple folding pathway of bovine pancreatic inhibitor: forming the first disulfide bonds in analogues of the reduced protein. J. Mol. Biol. 232, 873-896.

34. Johansson, C., Kavanagh, K. L., Gileadi, O. \& Oppermann, U. (2007). Reversible sequestration of active site cysteines in a $2 \mathrm{Fe} 2 \mathrm{~S}$-bridge dimmer provides a mechanism for glutaredoxin 2 regulation in human mitochondria. J. Biol. Chem. 282, 3077-3082.

35. Åslund, F., Berndt, K. D. \& Homlgren, A. (1997). Redox potentials of glutaredoxins and other thioldisulfide oxidoreductases of the thioredoxin super- family determined by direct protein-protein equilibria. J. Biol. Chem. 272, 30780-30786.

36. Sagemark, J., Elgán, T. H., Bürglin, T. R., Johansson, C., Holmgren, A. \& Berndt, K. D. (2007). Redox properties and evolution of human glutaredoxins. Prot. Struct. Funct. Bioinf. 68, 879-892.

37. Discola, K. F., Oliveira, M. A., Monteiro, G. S., Bárcena, J. A., Porras, P., Padilla, A. et al. (2005). Crystallization and preliminary X-ray crystallographic studies of glutaredoxin 2 from Saccharomyces cerevisiae in different oxidation states. Acta Crystallogr., Sect. F, 61, 445-447.

38. Leslie, A. G. W. (1992). Joint CCP4/ESF-EAMBCB. Newsletter Protein Crystallography 26. Daresbury Laboratory, Warrington, UK.

39. Kabush, W. (1988). Evaluation of single-crystal X-ray diffraction data from a position-sensitive detector. J. Appl. Crystallogr. 21, 916-924.

40. Blessing, R. H. (1995). An empirical correction for absorption anisotropy. Acta Crystallogr., Sect. A: Found. Crystallogr. 51, 33-38.

41. Collaborative Computational Project, Number 4. (1994). Acta Crystallogr., Sect. D: Biol. Crystallogr. 50, 760-763.

42. Navaza, J. (1994). AmoRe: an automated package for molecular replacement. Acta Crystallogr., Sect. D: Biol. Crystallogr. 57, 1367-1372.

43. Claude, J. B., Suhre, K., Notredame, C., Claverie, J. M. \& Abergel, C. (2004). CaspR: a Web server for automated molecular replacement using homology modelling. Nucleic Acids Res. 32, W606-W609.

44. Katti, S. K., Robbins, A. H., Yang, Y. \& Wells, W. W. (1995). Crystal structure of thioltransferase at $2.2 \AA$ resolution. Protein Sci. 4, 1998-2005.

45. Read, R. J. (2001). Pushing the boundaries of molecular replacement with maximum likelihood. Acta Crystallogr., Sect. D: Biol. Crystallogr. 57, 1373-1382.

46. Murshudov, G. N., Vagin, A. A. \& Dodson, E. J. (1997). Refinement of macromolecular structures by the maximum-likelihood method. Acta Crystallogr., Sect. D: Biol. Crystallogr. 53, 240-255.

47. Winn, M. D., Isupov, M. N. \& Murshudov, G. N. (2001). Use of TLS parameters to model anisotropic displacements in macromolecular refinement. Acta Crystallogr., Sect. D: Biol. Crystallogr. 57, 122-133.

48. Jones, T., Zou, J., Cowan, S. \& Kjeldgaard, M. (1991). Improved methods for binding protein models in electron density maps and the location of errors in these models. Acta Crystallogr., Sect. A: Found Crystal$\log$ r. 47, 110-119.

49. Emsley, P. \& Cowtan, K. (2004). Coot: model-building tools for molecular graphics. Acta Crystallogr., Sect. D: Biol. Crystallogr. 60, 2126-2132.

50. Laskowski, R. A., MacArthur, M. W., Moss, D. S. \& Thornton, J. M. (1993). PHOCHECK: a program to check the stereochemical quality of protein structures. J. Appl. Crystallogr. 26, 283-291.

51. DeLano, W. L. (2002). The PyMOL Molecular Graphics System. DeLano Scientific, San Carlos, CA. 


\section{ANEXO V}

Cussiol, J.R.R.; Alegria, T.G.P.; Szweda, L.I. \& Netto, L.E.S. (2010) "Ohr (organic hydroperoxide resistance protein) possesses a previously undescribed activity: Lipoyldependent peroxidase". 
(27746 characters with spaces)

Ohr (organic hydroperoxide resistance protein) possesses a previously undescribed activity: Lipoyldependent peroxidase.

José R. R. Cussiol ${ }^{1}$, Thiago G. P. Alegria ${ }^{1}$ Luke I. Szweda $^{2}$ \& Luis E. S. Netto ${ }^{1 *}$

${ }^{1}$ Departamento de Genética e Biologia Evolutiva- IB - USP, Rua do Matão 277, São Paulo SP Brazil 05508-900

${ }^{2}$ Free Radical Biology and Aging Research Program, Oklahoma Medical Research Foundation, 825 N.E. 13th Street, Oklahoma City, OK 73104

*Corresponding author. Tel: 5511 30917590; Fax: 5511 30917553; E-mail: nettoles@ib.usp.br Running title: Ohr is a Lipoyl-dependent peroxidase

\section{ABSTRACT}

The Organic Hydroperoxide Resistance (Ohr) family of 15-kDa Cys-based, thiol-dependent peroxidases is central to the bacterial response to stress induced by organic hydroperoxides, but not by hydrogen peroxide. Ohr is unique in its structure and the requirement of dithiol, but not monothiols, to support its activity. However, the physiological reducing system of Ohr has not yet been identified. Here we show that lipoylated enzymes interact physically and functionally with this Cys-based peroxidase, whereas thioredoxin and glutathione systems failed to support Ohr peroxidase activity. These results represent the first description of a peroxidase that is directly reduced by lipoylated enzymes.

Keywords: cys based thiol-dependent peroxidases, antioxidant defense, organic hydroperoxide, lipoic acid, phytopathogenic bacterium

\section{INTRODUCTION}


Release of oxidants is one of the main responses of a host against pathogens. During host-pathogen interactions, in an attempt to kill the pathogen, plant or animal hosts generate various oxidants by enzymatic systems (Tenhaken et al; Janssen et al, 2003; Huang et al, 2009). For instance, organic hydroperoxides are other oxidants that can be formed by the reaction of molecular oxygen with unsaturated fatty acids catalyzed by lipoxygenases in response to pathogen infection (Jalloul et al 2002; Gobel et al, 2003; Montillet et al, 2002; Maeng et al, 1996). To counteract this oxidative stress, pathogens have developed various antioxidant pathways (Wang et al, 2006; Poole, 2005). Organic Hydroperoxide Resistance Protein (Ohr) is a Cys-based, thiol-dependent peroxidase that plays a central role in the response of bacteria against organic peroxide-induced insult (Atichartpongkul et al, 2001). Ohr is exclusively present in bacteria (most of them pathogenic) and possesses a unique alpha/beta fold that is not observed in the structures of peroxiredoxin and glutathione peroxidase (Oliveira et al, 2006; Lesniak et al, 2002). Ohr peroxidase activity requires reduction of the enzyme's disulfide group formed upon catalytic reduction of the organic hydroperoxide (Cussiol et al, 2003). However, the enzyme's physiological reducing agent has not yet been identified.

Because only dithiols, but not monothiols, can be utilized by Ohr, we and others hypothesized that lipoate may act as a natural reducing agent of Ohr (Oliveira et al, 2006; Cussiol et al, 2003; Meunier-Jamin et al, 2004). Lipoate is a dithiol/disulfide redox compound well known to play important roles in metabolic pathways due to its capacity to serve as a cofactor in the multienzyme complexes that catalyze the oxidative decarboxylation of alpha-keto acids (Reed, 2001). Besides lipoylated E2 subunits, 2-oxo acid dehydrogenase multienzyme complexes also contain E3 subunits with dihydrolipoamide dehydrogenase (Lpd) activity that can catalyze the redox processes between lipoylated E2 enzymes and NADH/NAD ${ }^{+}$in both reductive and oxidative directions (Bunik, 2003). Free dihydrolipoate, the reduced form of lipoate, has also been reported to scavenge free radicals and other oxidants (Moini et al, 2002). However, the cellular availability of lipoate is significantly lower than that of other endogenous low molecular weight antioxidants such as GSH and ascorbic acid (Schupke et al, 2001). Here, we show that peroxidase activity of Ohr from Xylella fastidiosa is supported by lipoylated proteins, but not by thioredoxin and glutathione systems. 


\section{RESULTS AND DISCUSSION}

Ohr interacts with lipoylated enzymes in vivo

Lipoylated proteins from $X$. fastidiosa, a bacterial phytopathogen, were immunoprecipitated utilizing a polyclonal antibody specific for lipoic acid (anti-LA). Consistent with our hypothesis, we observed that Ohr co-precipitated with lipoylated enzymes (Fig. 1a). Moreover, we observed that Ohr is present in the extracellular fraction (or weakly attached to the cell surface) along with a protein reactive to anti-LA that co-migrated with SucB, the E2 subunit of the $\alpha$-ketoglutarate dehydrogenase complex (Fig. 1b, lanes 3, 4, 9, 10). Furthermore, another study detected $\mathrm{Ohr}$ and LpdA in the extracellular environment through proteomic analyses of $X$. fastidiosa (Smolka et al, 2003). LpdA is an enzyme harboring its own substrate, a lipoyl group (Håkansson \& Smith, 2007).

Ohr was also found in the intracellular fraction of $X$. fastidiosa (Fig. 1b, lane 2). Therefore, we investigated whether any other lipoylated proteins were present in this compartment. Immunochemical evidence indicated that all three lipoylated enzymes (LpdA, PDHB and SucB) predicted by the annotation of the X. fastidiosa genome (www.xylella.lncc.br) are present in the cell lysates (Fig. 1c). Thus, in principle, all of these proteins could support Ohr peroxidase activity in the intracellular compartment. If this is the case, then the ability of X. fastidiosa lysates to support Ohr activity should be decreased if lipoylated proteins were immunodepleted. In fact, the removal of lipoylated proteins from $X$. fastidiosa and Escherichia coli lysates reduced the rate of NADH oxidation compared to the same preparation that was not immunodepleted with anti-LA (Fig. 1d). The residual activity detected in the immunodepleted lysates correlated with the presence of lipoylated proteins that were not completely removed during the immunoprecipitation step (Supplementary Fig.1).

Lipoyl-dependent peroxidase activity of Ohr

Next, we investigated the ability of Lpd from X. fastidiosa to alternatively function as a physiological reductant of Ohr instead of their classical function as oxidants during alpha-keto acid oxidative 
decarboxylation. Initially, the disulfide reductase activity of recombinant Lpd from $X$. fastidiosa in the presence of free lipoamide was demonstrated (Fig. 2a). We then showed that this lipoamide-dependent system supported the peroxidase activity of Ohr (Fig. 2b). Interestingly, only Ohr, but not the other two Cys-based peroxidases from X. fastidiosa (PrxQ and AhpC) presented lipoyl-dependent peroxidase activity (Fig. 2b). Parallel lines were obtained in Lineweaver-Burk plots, indicating a ping-pong reaction mechanism (Fig. 2c), as expected for other Cys-based peroxidases (Trujillo et al, 2007; Tosatto et al, 2008). Using a bi-substrate kinetic approach (Segel, 1993), $K_{m}$ values in the micromolar range for lipoamide and $t$-BHP were obtained (Table 1, first lane; Supplementary Fig. 2). In contrast, millimolar amounts of $\mathrm{H}_{2} \mathrm{O}_{2}$ are required to saturate $\mathrm{Ohr}$ (Fig. 2d) under non-limiting amounts of lipoamide. Therefore, Ohr reduced $t$-BHP at least ten thousand times more efficiently than $\mathrm{H}_{2} \mathrm{O}_{2}$ (Table 1). The Ohr active site pocket is surrounded by several hydrophobic residues (Oliveira et al, 2006; Lesniak et al, 2002), which may explain the very high $K_{m}$ value for $\mathrm{H}_{2} \mathrm{O}_{2}$. This large difference in affinities for hydroperoxides has never been described before for other Cys-based peroxidases. Furthermore, the catalytic efficiency of Ohr to detoxify $t$-BHP $\left(10^{6} \mathrm{M}^{-1} \cdot \mathrm{s}^{-1}\right)$ is similar or even higher than other Cys-based thiol peroxidases (Poole, 2005; Fourquet et al, 2008; Winterbourn \& Hampton, 2008). This is the first detailed enzymatic characterization of a Cys-based peroxidase belonging to the Ohr family of proteins.

Reconstitution of the Ohr physiological reducing system

Initially, we cloned and expressed enzymes from $X$. fastidiosa predicted to have lipoyl binding domains (Supplementary Fig. 3), which include: SucB (the E2 component of 2-oxoglutarate dehydrogenase complex), PDHB (the E2 component of pyruvate dehydrogenase complex) and LpdA. The physiological role of LpdA is still unclear. Since its gene is located closed to genes encoding proteins of pyruvate dehydrogenase complex, it was annotated as its E3 component. However, LpdA in Streptococcus pneumonia is not associated with any 2 oxo-acid dehydrogenase complexes (Håkansson \& Smith, 2007). In any case, recombinant SucB, PDHB and LpdA presented disulfide reductase activity (Fig. 2a).

Then, we tested whether these lipoyl-dependent reducing systems were capable of supporting Ohr peroxidase activity. Both SucB and PDHB promoted Ohr-dependent peroxide removal in the presence of 
Lpd. Besides that, LpdA alone or in combination with SucB or PDHB also supported Ohr peroxidase activity (Fig. 3a). Therefore, we have reconstituted three possible pathways involved in the decomposition of organic hydroperoxides. Traditionally, protein-associated lipoyl groups are viewed as electron acceptors in oxidative pathways, but they can also act in reductive processes (Bunik, 2003). For instance, lipoylated E2 from Mycobacterium tuberculosis reduces a thioredoxin-like protein (AhpD), thereby indirectly supporting the peroxidase activity of a peroxiredoxin (AhpC) (Bryk et al, 2002). Besides, it was also proposed that the reduced form of lipoylated enzymes could donate electrons to ribonucleotide reductase via Grx1(Beckwith, 2009). Interestingly, the redox state of the complex-bound lipoate is an indicator of the availability of the reaction substrates (2-oxo acid, CoA and NAD ${ }^{+}$) and thioldisulfide status of the medium(Bunik, 2003).

We also investigated whether other classical thiol-containing systems, well known reductants for other Cys-based thiol peroxidases (peroxiredoxins and glutathione peroxidases), could act as alternative electron donors to Ohr. Recombinant thioredoxin and thioredoxin reductase from $X$. fastidiosa (TSNC and TRR, respectively) were obtained, and they presented disulfide reductase activity (Fig. 3b). However, Ohr presented no peroxidase activity, even with the use of high concentrations of thioredoxin and thioredoxin reductase (Fig. 3c). Under the same conditions, PrxQ from X. fastidiosa was active (Fig. 3c). In fact, taking into account data from the literature, it is evident that the concentrations of thioredoxin and thioredoxin reductase employed here were high enough to support the enzymatic activity of other Cysbased peroxidases. (Munhoz \& Netto, 2004). Some Cys-based peroxidases display peroxidase activity supported by glutathione or glutaredoxin (Rouhier et al, 2002; Bréhelin et al, 2003). Therefore, it was relevant to investigate whether Ohr would present such activities. We previously observed that GSH does not support Ohr activity, even at very high concentrations (Cussiol et al, 2003). We have now verified that glutaredoxin 1 and glutaredoxin 2 from Saccharomyces cerevisiae and glutaredoxin 1 from E. coli in the presence of GSH and glutathione reductase (GR) do not support Ohr peroxidase activity. We did not observe any NADPH consumption even using millimolar concentrations of GSH. Given the fact that 2 $\mu \mathrm{M}$ of lipoamide is sufficient to support Ohr peroxidase activity (Fig. 3a), the glutathione system is probably not its physiological reductant. In conclusion, Ohr is highly specific for lipoylated enzymes among other biological reducing systems. 
To gain further insight into the physiological relevance of the interactions of Ohr with lipoylated enzymes, we performed bi-substrate kinetic analysis (Supplementary Fig. 2). The catalytic parameters of Ohr that were determined relative to SucB and PDHB were similar in comparison with free lipoamide (Table 1, Supplementary Fig. 2). Moreover, using saturating concentrations of $t$-BHP, we were able to analyze the dependence of the reaction on LpdA concentration (Fig. 3d). The $K_{m}$ value for LpdA (13.5 \pm $1.9 \mu \mathrm{M}$ ) was also very similar to that obtained for SucB and PDHB (Table 1). Comparison of $K_{m}$ values is difficult because the parameters for SucB and PDHB (Table 1) were calculated in a fixed concentration of flavoenzyme ( $\operatorname{Lpd}=1 \mu \mathrm{M})$, whereas for LpdA, the concentration of flavoenzyme present in the reaction mixture varies according to the value indicated on the x-axis (Fig. 2d) because this enzyme possesses both an Lpd and a lipoyl binding domain (Håkansson \& Smith, 2007). To test whether the increase in peroxidase activity could also be influenced by an increase in Lpd concentration, we performed the assay in the presence of SucB and various concentrations of Lpd (Supplementary Fig.4). Increasing concentrations of Lpd did not influence the activity of the system, showing that the concentration of Lpd used in these assays was not rate-limiting.

Finally, to determine whether lipoylated enzymes are present in the cell at concentrations that make Ohrdependent hydroperoxide reduction kinetically favorable, we employed semi-quantitative western blot analysis using anti-LA. SucB was the most abundant lipoyl protein, present at micromolar concentrations $(0.9 \mu \mathrm{M})$. LpdA and PDHB could also be detected, although at lower concentrations $(0.07 \mu \mathrm{M}$ and 0.13 $\mu \mathrm{M}$, respectively) (Fig. 1c). Therefore, we determined that lipoylated enzymes are present at concentrations capable of efficiently supporting Ohr peroxidase activity in vivo since these concentrations were in the range of the $K_{m}$. values determined by bi-substrate kinetic analyses. In fact, in another bacteria (E. coli), whose cells were grown in minimal media, E1, E2 and E3 were identified as three out of the nineteen proteins most induced by aerobic growth after anaerobiosis (Pedersen et al, 1978; Smith \& Neidhardt, 1983). Levels of lipoic acid in bacterial cytosols are also abundant (Noll, K.M. \& Barber, 1988; Reed, K.E. \& Cronan, 1993), making their ability to support Ohr peroxidase activity feasible.

The results presented here indicate that lipoylated proteins (SucB, PDHB and/or LpdA) are the biological reducing agents for Ohr (Fig. 1). This is the first description of a protein endowed with lipoyl-dependent peroxidase activity. The ability of Ohr to utilize reducing equivalents from lipoyl sulfhydryls, its unique 
structure and the fact that it is exclusively present in many types of pathogenic bacteria might represent an unexplored microbial niche for new molecular scaffolds. This finding is relevant since antibiotic-resistant strains of pathogenic bacteria are increasingly prevalent (Fischbach \& Walsh, 2009) and several major classes of bactericidal antibiotics operate through the production of highly deleterious hydroxyl radicals in both Gram-negative and Gram-positive bacteria (Kohanski et al, 2007). Remarkably, lipoyl groups are essential for parasite survival in host cells (O'Riordan et al, 2003; Allary et al, 2007) and for virulence (Smith et al, 2002). Indeed, the utilization of lipoylated proteins for Ohr reduction represents an emerging area of investigation (Bunik, 2003) into the likelihood that specific proteins perform multiple catalytic functions to provide a means to regulate divergent processes with a single molecular switch.

\section{METHODS}

Disulfide reductase activity assay

The disulfide reductase activities of the reducing systems were determined using the DTNB [5, 5'dithiobis-(2-nitrobenzoic acid), Elman's reagent] assay (Luthman \& Holmgren, 1982). The reaction mixtures contained $50 \mathrm{mM}$ sodium phosphate $(\mathrm{pH} 7.4), 1 \mathrm{mM}$ diethylenetriamine pentaacetic acid (DTPA), $0.5 \mathrm{mM}$ DTNB and $0.2 \mathrm{mM} \mathrm{NAD}(\mathrm{P}) \mathrm{H}$ and were carried out at $37^{\circ} \mathrm{C}$ and were initiated by the addition of NADH.

Ohr peroxidase-coupled lipoamide system assay

Using recombinant Lpd or LpdA from X. fastidiosa, lipoamide or recombinant E2 enzymes from $X$. fastidiosa (PDHB or SucB), decay due to NADH consumption was measured by $\mathrm{A}_{340}\left(\varepsilon=6290 \mathrm{M}^{-1} \cdot \mathrm{cm}^{-1}\right)$. The reaction mixtures contained $50 \mathrm{mM}$ sodium phosphate (pH 7.4), $50 \mathrm{mM} \mathrm{NaCl}, 1 \mathrm{mM}$ DTPA (pH 7.4) and $0.2 \mathrm{mM}$ NADH. All reactions were performed at $37^{\circ} \mathrm{C}$ and were initiated by the addition of peroxide at various concentrations. 
Immunoprecipitation of lipoic acid

Immunoprecipitation was performed as follows: $1 \mathrm{mg}$ of $X$. fastidiosa lysate (previously incubated for $30 \mathrm{~min}$ with Protein A Sepharose) were incubated with an anti-LA antibody (1:50) overnight at $4^{\circ} \mathrm{C}$. Immune complexes were then incubated with Protein A Sepharose for $4 \mathrm{~h}$ at $4^{\circ} \mathrm{C}$ followed by centrifugation. The immunoprecipitate was washed five times with Tris-HCl buffer (20 mM), $\mathrm{NaCl}(300 \mathrm{mM})$ and boiled with $40 \mu \mathrm{L}$ of sample buffer containing DTT (10 mM). Electrophoresis and transfer were performed. Blotted membranes were incubated with an anti-Ohr antibody (1:1000 in PBST) overnight at $4^{\circ} \mathrm{C}$. The membrane was subsequently incubated with an anti-phosphatase rabbit antibody for one hour and proteins were detected following incubation with the BCIP/NBT phosphatase substrate (Kirkegaard and Perry laboratories).

Supplementary information is available at $E M B O$ reports online.

\section{ACKNOWLEDGMENTS}

We are grateful to A.M. Silva (IQ - University of Sao Paulo); José FS Netto (ICB - University of Sao Paulo); B. B. Horta, K. F. Discola and Dr. M. Vainzof (IB - University of Sao Paulo); and Dr. J. R. K. Júnior (FMVZ - University of Sao Paulo) for providing material for this work. This work was supported by FAPESP (Grant 07/58147-6) and CNPq under the National Institute of Science and Technology (INCT) for Redox Processes in Biomedicine (Redoxome).

\section{REFERENCES}

Allary M, Lu JZ, Zhu L \& Prigge ST (2007) Scavenging of the cofactor lipoate is essential for the survival of the malaria parasite. Plasmodium falciparum Mol Microbiol 63: 1331-1344 
Atichartpongkul S, Loprasert S, Vattanaviboon P, Whangsuk W, Helmann JD \& Mongkolsuk S (2001) Bacterial OHR and OsmC paralogues define two protein families with distinct functions and patterns of expression. Microbiology 147: 1775-1782

Barr DP, Mason JP (1995) Mechanism of radical production from the reaction of cytochrome c with organic hydroperoxides. An ESR spin trapping investigation. J Biol Chem 270: 12709-12716

Bréhelin C, Meyer EH, de Souris J, Bonnard G \& Meyer Y (2003) Resemblance and dissemblance of Arabidopsis type II peroxiredoxins: similar sequences for divergent gene expression, protein localization, and activity. Plant Physiol 132: 2045-2057

Bryk R, Lima CD, Erdjument-Bromage H \& Nathan C (2002) Metabolic enzymes of Mycobacteria linked to antioxidant defense by a thioredoxin-like protein. Science 295: 1073-1077

Bunik VI (2003) 2-Oxo acid dehydrogenase complexes in redox regulation. Eur J Biochem 270: 10361042

Beckwith J (2009) Genetic suppressors and recovery of repressed biochemical memory. J. Biol. Chem. 284: 12585-12592

Cussiol JRR, Alves SV, Oliveira MA \& Netto LES (2003) Organic Hydroperoxide resistance gene encodes a thiol-dependent peroxidase. J Biol Chem 278: 11570-11578

Fischbach MA \& Walsh CT (2009) Antibiotics for emerging pathogens. Science 325: 1089-1093

Fourquet $\mathrm{S}$ et al (2008) The dual functions of thiol-based peroxidases in $\mathrm{H}_{2} \mathrm{O}_{2}$ scavenging and signaling. Antioxid Redox Signal 10: 1565-1576 
Gobel C, Feussner I \& Rosahl S (2003) Lipid peroxidation during the hypersensitive response in potato in the absence of 9-lipoxygenases. J Biol Chem 278: 52834-52840

Håkansson AP \& Smith AW (2007) Enzymatic characterization of dihydrolipoamide dehydrogenase from Streptococcus pneumoniae harboring its own substrate. J Biol Chem 282: 29521-29530

Huang J, Canadien V, Lam GY, Steinberg BE, Dinauer MC, Magalhães MA, Glogauer M, Grinstein S \& Brumell JH (2009) Activation of antibacterial autophagy by NADPH oxidases. Proc Natl Acad Sci USA 106: $6226-31$

Jalloul A et al (2002) Lipid peroxidation in cotton: Xanthomonas interactions and the role of lipoxygenases during the hypersensitive reaction. Plant J 32: 1-12

Janssen R, van der Straaten T, van Diepen A \& van Dissel JT (2003) Responses to reactive oxygen intermediates and virulence of Salmonella typhimurium. Microbes Infect 5: 527-34

Jiang ZY, Hunt JV \& Wolff SP (1992) Ferrous ion oxidation in the presence of xylenol orange for detection of lipid hydroperoxide in low density lipoprotein. Anal Biochem 202: 384-389

Lesniak J, Barton WA \& Nikolov DB (2002) Structural and functional characterization of the Pseudomonas hydroperoxide resistance protein OHR. The EMBO J 21: 6649-6659

Kohanski MA, Dwyer DJ, Hayete B, Lawrence CA \& Collins JJ (2007) A common mechanism of cellular death induced by bactericidal antibiotics. Cell 130: 797-810

Luthman M \& Holmgren (1982) A Rat liver thioredoxin and thioredoxin reductase: purification and characterization. Biochemistry 21: 6628-6633

10 
Maeng J, Sakay Y, Tani Y \& Kato N (1996) Isolation and Characterization of a Novel Oxygenase That Catalyzes the First Step of n-Alkane Oxidation in Acinetobacter sp. Strain M-1. J Bacteriol 178: 36953700

Meunier-Jamin C, Kapp U, Leonard GA \& McSweeney S (2004) The structure of the hydroperoxide resistance protein from Deinococcus radiodurans. Do conformational changes facilitate recycling of the redox disulfide? J Biol Chem 279: 25830-25837

Moini H, Packer L \& Saris NE (2002) Antioxidant and prooxidant activities of alpha-lipoic acid and dihydrolipoic acid. Toxicol Appl Pharmacol 182: 84-90

Montillet J-L, Agnel J-P, Ponchet M, Vailleau F, Roby D \&Triantaphylidès C (2002) Lipoxygenasemediated production of fatty acid hydroperoxides is a specific signature of the hypersensitive reaction in plants. Plant Physiol. Biochem. 40: 633-639

Munhoz DC \& Netto LES (2004) Cytosolic Thioredoxin peroxidase I and II are important defenses of yeast against organic hydroperoxide insult. J Biol Chem 279: 35219-35227

Noll KM \& Barber TS (1988) Vitamin contents of archaebacteria. J Bacteriol 170 4315-4321

Oliveira MA, Guimarães BG, Cussiol JRR, Medrano FJ, Gozzo FC \& Netto LES (2006) Structural insights into enzyme-substrate interaction and characterization of enzymatic intermediates of Organic hydroperoxide resistance protein from Xylella fastidiosa. J Mol Biol 359: 433-445

O'Riordan M, Moors MA \& Portnoy DA (2003) Listeria intracellular growth and virulence require hostderived lipoic acid. Science 302: 462-464 
Pedersen S, Bloch PL, Reeh S \& Neidhardt FC (1978) Patterns of protein synthesis in E. coli: a catalog of the amount of 140 individual proteins at different growth rates. Cell 14: 179-190

Poole LB (2005) Bacterial defenses against oxidants: mechanistic features of cysteine-based peroxidases and their flavoprotein reductases. Arch Biochem Biophys 433: 240-254

Reed KE \& Cronan JE Jr (1993) Lipoic acid metabolism in Escherichia coli: sequencing and functional characterization of the lipA and lipB genes. J Bacteriol 175: 1325-1336

Reed LJ (2001) A trail of research from lipoic acid to $\alpha$-keto acid dehydrogenase complexes. J Biol Chem 276: $38329-38336$

Rouhier N, Gelhaye E \& Jacquot JP (2002) Glutaredoxindependent peroxiredoxin from poplar: proteinprotein interaction and catalytic mechanism. J Biol Chem 277: 13609-13614

Schupke H et al (2001)New metabolic pathways of $\alpha$-lipoic acid. Drug Metab Dispos 29: 855-862

Segel, HI (1993) Enzyme Kinetics - Behavior and Analysis of Rapid Equilibrium and Steady-State Enzyme Systems pp 606-612. Wiley Interscience, New York, USA.

Smith AW, Roche H, Trombe M-C, Briles DE \& Håkansson (2002) A Characterization of the dihydrolipoamide dehydrogenase from Streptococcus pneumoniae and its role in pneumococcal infection. Mol Microbiol 44: 431-448

Smith MW \& Neidhardt FC (1983) Proteins induced by aerobiosis in Escherichia coli. J Bacteriol 154: 344-350 
Smolka MB et al (2003) Proteome analysis of the plant pathogen Xylella fastidiosa reveals major cellular and extracellular proteins and a peculiar codon bias distribution. Proteomics 3: 224-237

Tenhaken R, Levine A, Brisson LF, Dixon RA \& Lamb C (1995) Function of the oxidative burst in hypersensitive disease resistance. Proc Natl Acad Sci USA 92: 4158-41

Tosatto SC, Bosello V, Fogolari F, Mauri P, Roveri A, Toppo S, Flohé L, Ursini F \& Maiorino M (2008) The catalytic site of glutathione peroxidases. Antioxid Redox Signal 10: 1515-26

Trujillo M, Ferrer-Sueta G, Thomson L, Flohé L \& Radi R (2007) Kinetics of peroxiredoxins and their role in the decomposition of peroxynitrite. Subcell Biochem 44: 83-113

Wang G, Alamuri P \& Maier RJ (2006) The diverse antioxidant systems of Helicobacter pylori. Mol Microbiol 61, 847-60

Winterbourn CC \& Hampton MB (2008) Thiol chemistry and specificity in redox signaling. Free Radic Biol Med 45: 549-561

\section{FIGURE LEGENDS}

Figure 1 In vivo interaction of $\mathrm{Ohr}$ with lipoylated proteins. (a) Ohr co-immunoprecipitated with lipoylated enzymes. Proteins were precipitated with anti-LA and analyzed by western blot with anti-Ohr. Lane 1, immunoprecipitated proteins on beads $(30 \mu \mathrm{L})$ and lane 2, recombinant $\mathrm{Ohr}(0.1 \mu \mathrm{g})$. (b) Fractions containing extracellular proteins were obtained by washing cells twice with Tris buffer. Lanes 1-4 correspond to anti-Ohr (1:1000), and lanes 6-10 correspond to anti-lipoic acid (1:5000). Lane 1, Ohr $(0.1 \mu \mathrm{g})$; lane 2, X. fastidiosa lysate; lane 3, supernatant first wash; lane 4, supernatant second wash; lane 5, Rainbow ${ }^{\mathrm{TM}}$ MWM; lane 6, LpdA $(0.1 \mu \mathrm{g})$; lane 7, SucB $(0.1 \mu \mathrm{g})$; lane 8, X. fastidiosa lysate; lane 9, supernatant first wash; lane 10, supernatant second wash. (c) Immunodetection of lipoate enzymes in $X$. fastidiosa lysates. Lane 1, Rainbow ${ }^{\mathrm{TM}}$ MWM; lane 2, PDHB (0.1 $\left.\mu \mathrm{g}\right)$; lane 3, SucB (0.1 $\left.\mu \mathrm{g}\right)$; lane 4, 
LpdA $(0.1 \mu \mathrm{g})$; lanes 5-7, X. fastidiosa lysates $(15,10$ and $5 \mu \mathrm{g}$, respectively). (d) Ability of immunodepleted E. coli (Ec) and X. fastidiosa (Xf) lysates to support Ohr peroxidase activity. Bacterial lysates $(0.5 \mathrm{mg} / \mathrm{ml})$ were incubated with NADH $(0.2 \mathrm{mM}), \mathrm{Ohr}(1 \mu \mathrm{M}), \mathrm{Lpd}(2.5 \mu \mathrm{M})$ and $t$-BHP $(0.2$ $\mathrm{mM}$ ).

Figure 2 Characterization of lipoyl-dependent peroxidase activity. (a) Disulfide reductase activity of lipoamide systems. • (1 $\mu \mathrm{M} \mathrm{LpdA}+0.5 \mu \mathrm{M}$ PDHB $), \diamond(1 \mu \mathrm{M} \mathrm{Lpd}+1 \mu \mathrm{M}$ SucB $), \boldsymbol{\square}(1 \mu \mathrm{M}$ lipoamide $+1 \mu \mathrm{M} \mathrm{Lpd}), \boldsymbol{\Delta}(1 \mu \mathrm{M}$ LpdA $), \square\left(1 \mu \mathrm{M} \mathrm{LpdA}^{-\mathrm{LA}}\right), \Delta\left(1 \mu \mathrm{M} \mathrm{Lpd}+1 \mu \mathrm{M} \mathrm{SucB}^{-\mathrm{LA}}\right)$. $-\mathrm{LA}$ denotes proteins whose expression was not enriched with lipoic acid. (b) Lipoamide-dependent peroxidase activity of Cys-based thiol dependent peroxidases $(0.1 \mu \mathrm{M})$ in the presence of free lipoamide $(0.2 \mathrm{mM})$, Lpd $(0.5 \mu \mathrm{M})$ and $t$-BHP $(0.2 \mathrm{mM}) . \nabla(\mathrm{Ohr}), \boldsymbol{\Delta}(\mathrm{AhpC}), \boldsymbol{\nabla}$ (PrxQ), $\boldsymbol{\nabla}$ (no further addition). (c) Lineweaver-Burk plot of the lipoamide-dependent peroxidase activity of Ohr. Lipoamide concentrations: $\boldsymbol{\square}(7.5 \mu \mathrm{M}), \boldsymbol{\Delta}(10 \mu \mathrm{M})$ and $\boldsymbol{\nabla}(15 \mu \mathrm{M})$. (d) Henri-Michaelis-Menten plot for Ohr catalysis in reactions containing Ohr $(1 \mu \mathrm{M})$, Lpd $(5 \mu \mathrm{M})$ and lipoamide $(0.1 \mathrm{mM})$. The result is the average of three independent experiments. Data are means \pm s.d.

Figure 3 Reconstitution of the Ohr physiological reducing system. (a) Ohr peroxidase activity measured in the presence of lipoylated recombinant proteins [LpdA $(2 \mu \mathrm{M})$, SucB $(2 \mu \mathrm{M}), \operatorname{PDHB}(1 \mu \mathrm{M})]$ or free lipoamide $(2 \mu \mathrm{M})]$. Reaction mixtures contained NADH $(0.2 \mathrm{mM})$, Lpd $(2 \mu \mathrm{M})$, Ohr $(0.1 \mu \mathrm{M})$. (b) Disulfide reductase activity of the thioredoxin system from X. fastidiosa. $\bullet(5 \mu \mathrm{M}$ TSNC), $\bullet(5 \mu \mathrm{M}$ TRR), $\boldsymbol{\Delta}(5 \mu \mathrm{M}$ TRR $+5 \mu \mathrm{M}$ TSNC). (c) Peroxidase activity of Ohr and PrxQ in the presence of the thioredoxin system from $X$. fastidiosa. $\nabla(5 \mu \mathrm{M}$ TRR $+5 \mu \mathrm{M}$ TSNC $+5 \mu \mathrm{M}$ PrxQ $), \diamond(5 \mu \mathrm{M}$ TRR +5 $\mu \mathrm{M}$ TSNC $+10 \mu \mathrm{M}$ Ohr). (d) Dependence of Ohr activity on LpdA concentration. Reaction mixtures as described in "Methods" section contained Ohr $(0.1 \mu \mathrm{M})$. The results presented in (a) and (d) are the average of three independent experiments. Data are means \pm s.d. 
Figure 4 Proposed scheme for the Ohr reduction pathways. (a) The Ohr disulfide is reduced by a lipoylated protein (LP). (b) Ohr reduction by lipoylated proteins. The arrows represent the flow of electrons coming from NADH. 
Figure 1.

A

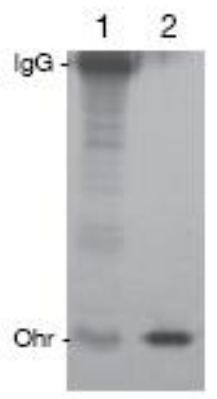

B

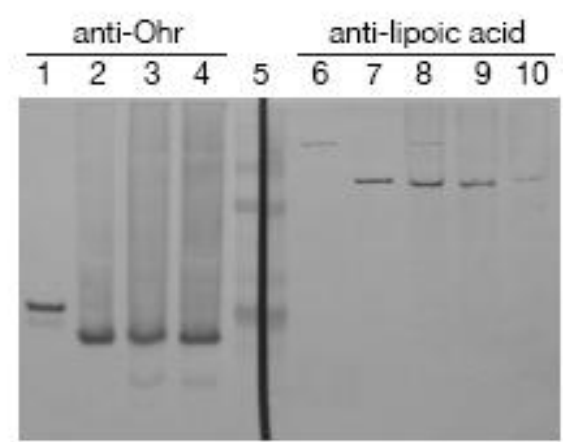

C

D

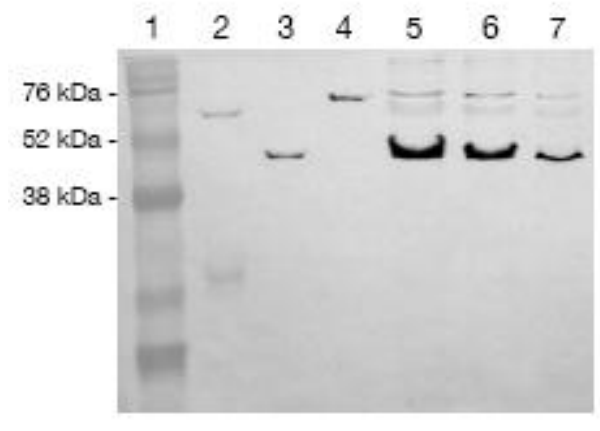


Figure 2.
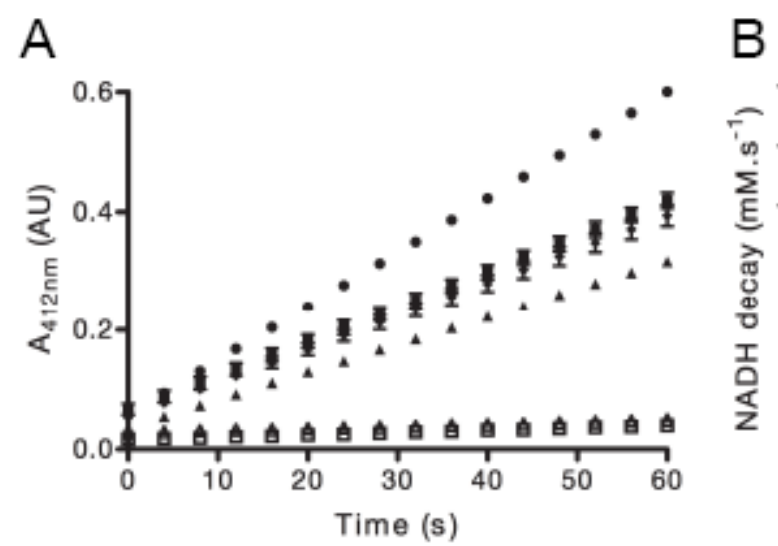

C
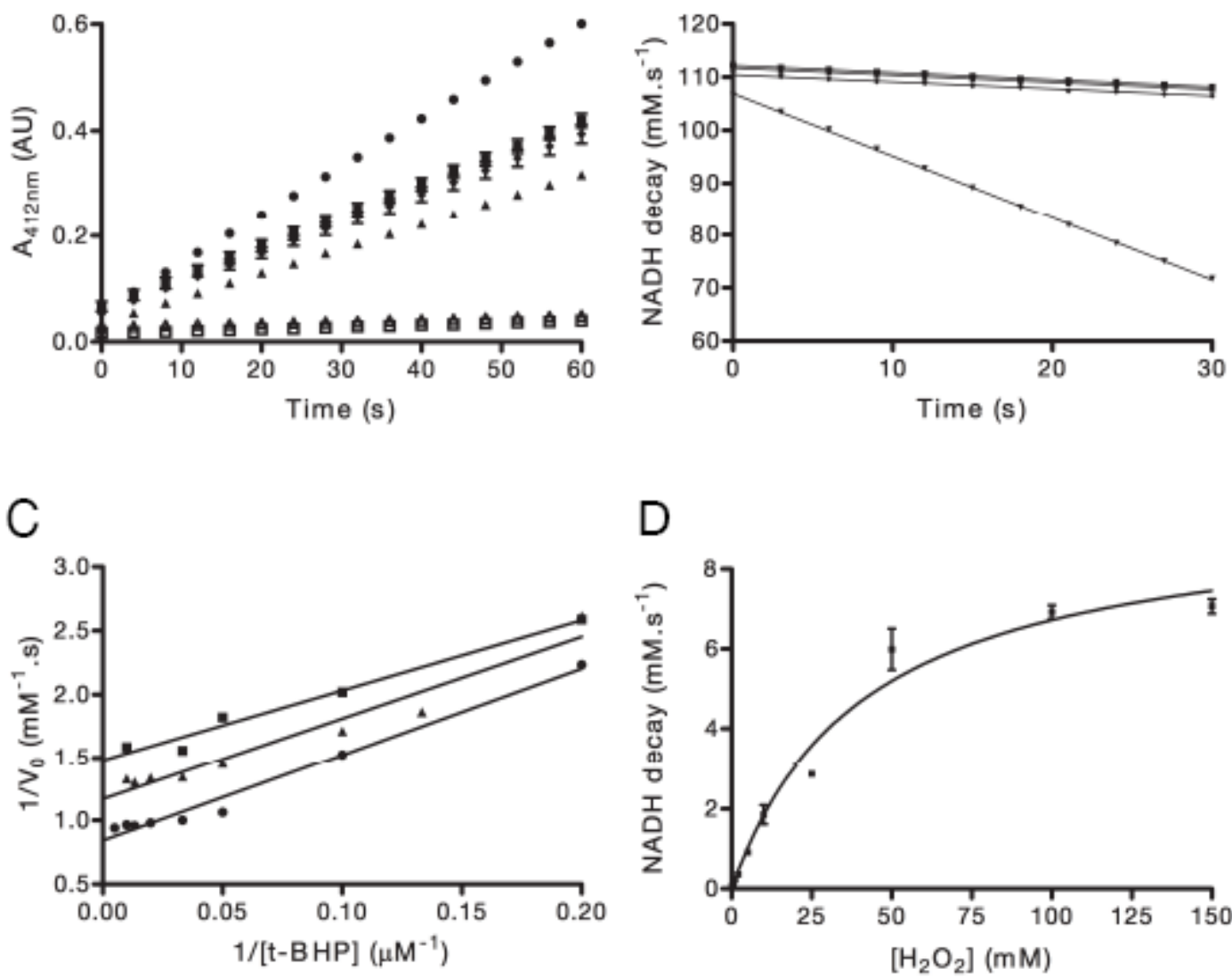

D

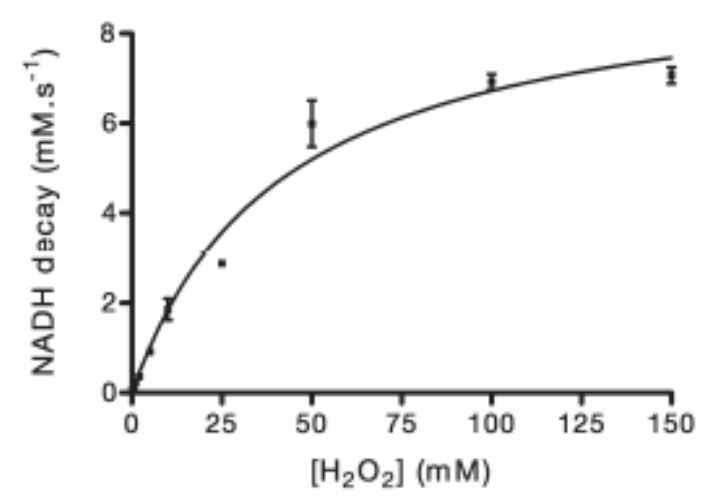


Figure 3.

A

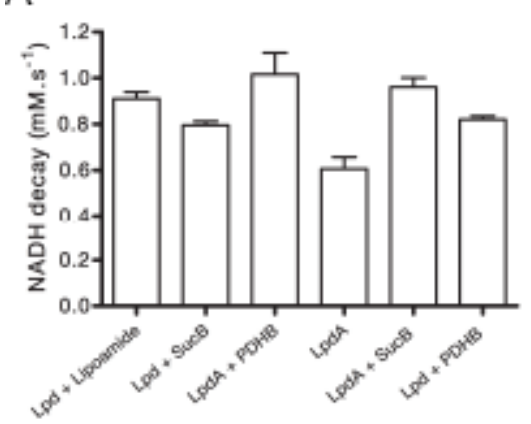

C

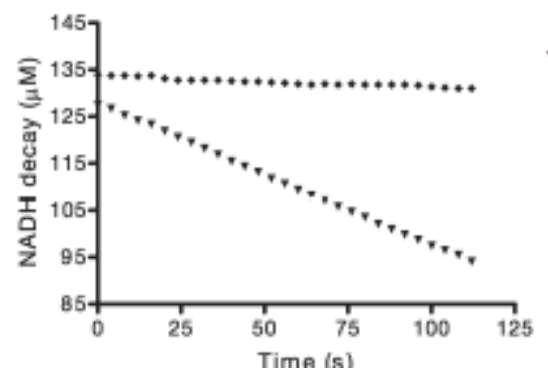

B

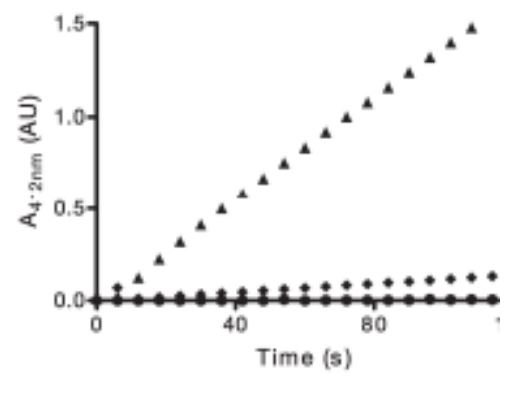

D

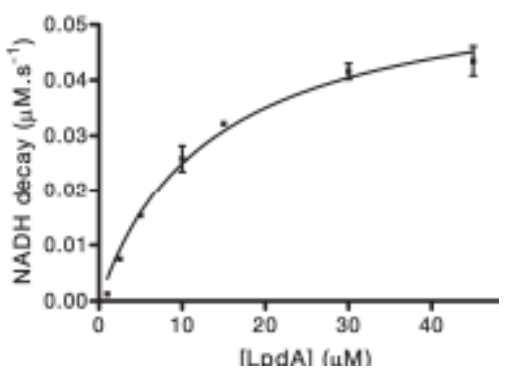


Figure 4.

A

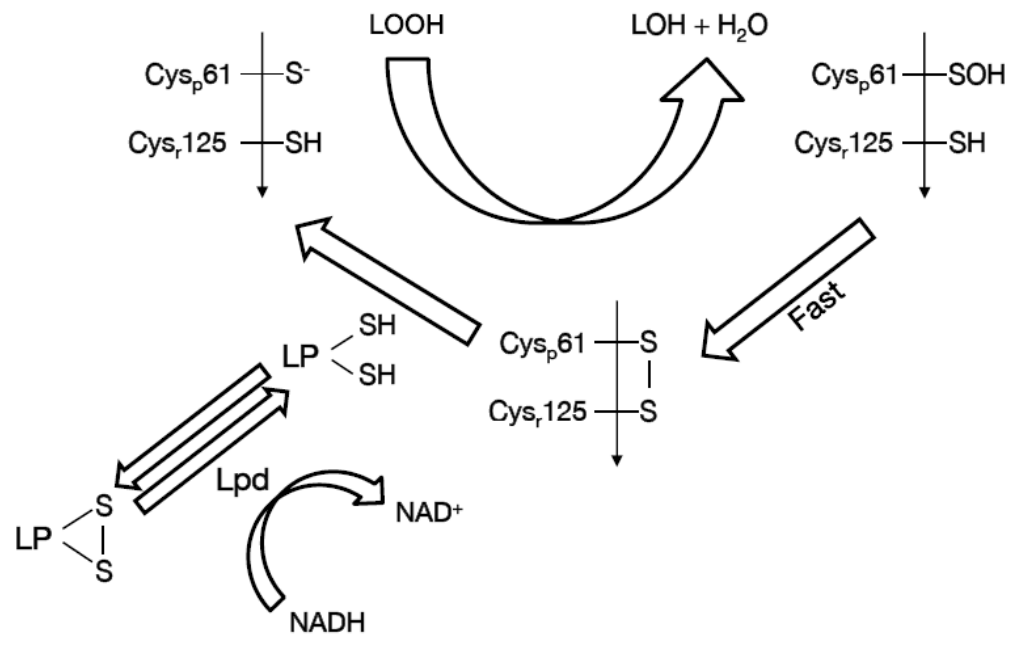

B

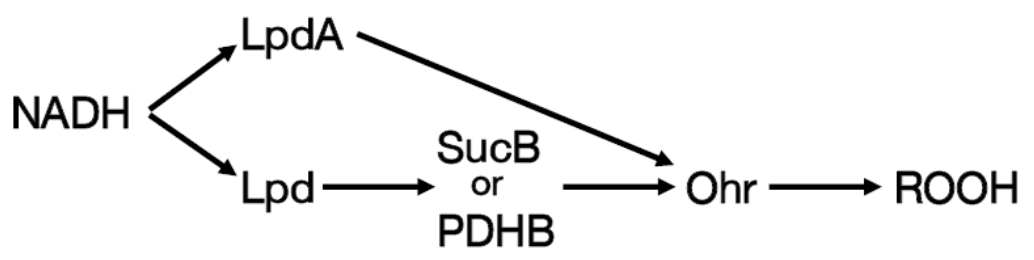


Table 1 Kinetic constant for different Ohr substrates.

\begin{tabular}{lccc}
\hline Substrate & $\boldsymbol{K}_{\boldsymbol{m}}(\boldsymbol{\mu M})$ & $\boldsymbol{k}_{\text {cat }}\left(\mathbf{s}^{-\mathbf{1}}\right)$ & $\boldsymbol{k}_{\text {cat }} \boldsymbol{K}_{\boldsymbol{m}}\left(\mathbf{M}^{-1} \cdot \mathbf{s}^{-1}\right)$ \\
\hline $\boldsymbol{t}-\mathrm{BHP}^{*}$ & $14.51 \pm 0.15$ & $17.95 \pm 7.25$ & $2.06 \times 10^{6} \pm 0.08$ \\
$\mathrm{H}_{\mathbf{2}} \mathrm{O}_{2}{ }^{*}$ & $41720.00 \pm 6530.00$ & $9.53 \pm 0.56$ & $2.30 \times 10^{2} \pm 0.20$ \\
\hline Lipoamide & $44.46 \pm 0.98$ & $90.9 \pm 4.70$ & $2.06 \times 10^{6} \pm 0.08$ \\
PDHB & $10.93 \pm 0.15$ & $9.5 \pm 0.20$ & $0.87 \times 10^{6} \pm 0.01$ \\
SucB & $38.51 \pm 14.12$ & $17.95 \pm 7.25$ & $0.46 \times 10^{6} \pm 0.02$
\end{tabular}

Parameters for $\mathrm{H}_{2} \mathrm{O}_{2}$ were obtained through a non-linear regression fit using saturating concentrations of lipoamide. Parameters for all other substrates were obtained with the secondary plots of $1 / \operatorname{Vmax}_{\text {qpp }}$ and $1 / K m_{a p p}$ versus 1/[LA]. In the case of lipoylated enzymes SucB and PDHB, LA represents the lipoic acid covalently attached to the enzyme (1 mol of LA: 1 mol of SucB and 2 moles of LA: 1 mol of PDHB). * indicates that parameters for $t$ - $\mathrm{BHP}$ and $\mathrm{H}_{2} \mathrm{O}_{2}$ were calculated using free lipoamide. The results are the average of three independent experiments and represent mean \pm standard deviation (SD). 